
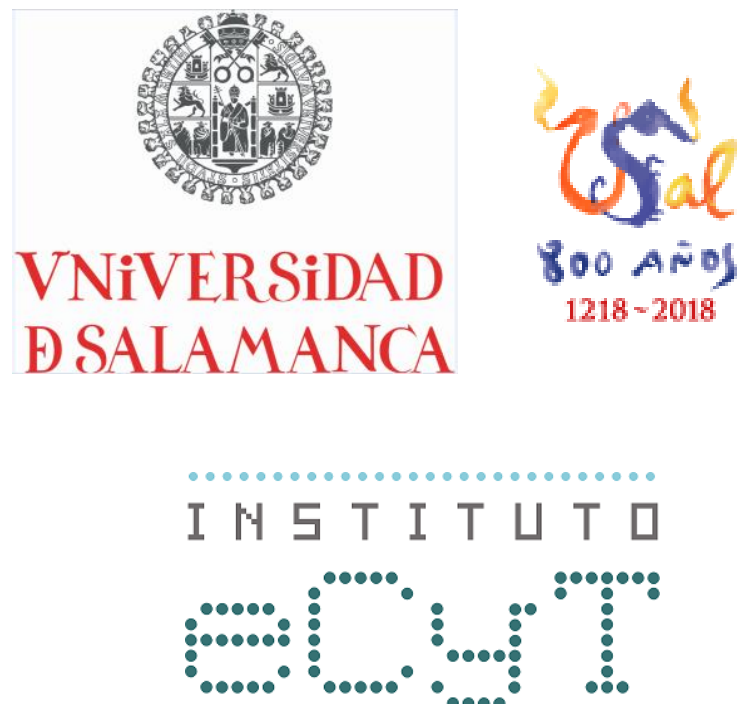

TESE

Para obtencão do grau de Doutoramento

Lúcia Susana Peixoto dos Santos Oliveira

$\underline{\text { Pela }}$

Universidad de Salamanca

$\underline{\text { Instituto de Estudios para la Ciencia y la Tecnología (ECYT) }}$

\title{
Titulo
}

\section{O papel dos Atores nas parcerias entre universidades europeias e subsahariana no desenvolvimento em contexto do século XXI}

Diretores da Tese

Santiago M. López, Ph.D, Universidad de Salamanca, Espanha Carlos Eduardo M. Sangreman Proença, Ph.D, Universidade de Aveiro, Portugal 
VNIVERSIDAD

DSALAMANCA 


\section{O Sumário}

O objeto de estudo desta investigação passa por compreender de que forma o Ensino Superior contribui para o progresso económico nos países em desenvolvimento, facilitando a igualdade de oportunidades num mercado cada vez mais internacionalizado. Ao nível da Cooperação para o Desenvolvimento, tem-se vindo a dar maior enfâse ao ensino primário e secundário acreditando que o combate à pobreza e o consequente crescimento económico passaria por este tipo de educação. De facto, o Ensino Superior em África, e em particular na África Subsariana, tem vindo a ser negligenciado ao longo de várias décadas, não sendo considerado com um fator de relevância para o desenvolvimento económico e, consequentemente, como um agente de mitigação da pobreza. A tese defende a hipótese de que o sistema de educação deve ser equilibrado e não se pode injuriar o nível superior contra o secundário e primário. O objectivo é contrastar este ponto de partida com a opinião dos Atores, internos e externos, no sentido de compreender qual o ponto de vista dos mesmos em relação à tese que defendemos. Para o efeito foi efetuado um inquérito aos diferentes tipos de Atores com o intuito de recolher informação que nos permita inferir se existe correspondência entre as ações esperadas e efetivas deste grupo de Atores e a sua opinião quanto às questões da Cooperação Internacional ao nível da educação assim como o seu efeito no progresso das economias locais e da possível melhoria da qualidade de vida da população dai resultante. Para a análise da informação recolhida através de 30 entrevistas/pesquisas foi efetuada a caracterização do Modelo Conceptual CATWOE no âmbito do Ensino Superior tendo em conta os diferentes Atores, e a representação da relação das diferentes etapas do sistema de ensino superior, no contexto da África Subsariana. Concluímos, que os Atores têm pesos diferentes na tomada de decisão e ao nível de formação de políticas públicas, contudo a sua ação é de extrema importância na edificação de um sistema de ensino superior com qualidade e mais abrangente. No entanto, a sua opinião confirma que o modelo educacional deve ser equilibrado e que as suas acções, nesse sentido, são cruciais na construção de um sistema de ensino universitário de qualidade e mais completo para a África, dada a dependência que o ensino superior tem da ajuda externa. Optámos pelo caso da África sub-saariana, por ser, possivelmente, a parte do mundo onde o desenvolvimento económico é mais complicado e, ao mesmo tempo, pelo facto de que a importância dada à universidade como uma opção de desenvolvimento tem sido reduzida. 


\section{Resumen}

El objeto de estudio de esta investigación consiste en entender cómo la educación universitaria contribuye al progreso económico en los países en desarrollo facilitando la igualdad de oportunidades en un mercado cada vez más internacionalizado. La cooperación al desarrollo ha dado mayor énfasis a la educación primaria y secundaria partiendo de la base de que el crecimiento económico y la lucha contra la pobreza derivan de fomentar este tipo de educación. De hecho, la educación universitaria en África, y sobre todo en el África subsahariana, se ha descuidado durante varios decenios al no ser considerada como un factor relevante para el desarrollo económico y como un agente de reducción de la pobreza. La tesis defiende la hipótesis de que el sistema de educación debe ser equilibrado y no se puede denostar el nivel superior frente al secundario y primario. El objetivo es contrastar este punto de partida con la perspectiva de los actores, internos y externos, para entender su punto de vista en relación a la tesis que defendemos. Para ello se ha realizado un estudio de los diferentes tipos de actores, con el fin de recopilar la información que nos permite deducir la correspondencia entre las acciones previstas y las ya tomadas (efectivas) de este grupo y su perspectiva sobre los temas de la cooperación internacional en el ámbito de la educación, así como su efecto sobre el progreso de las economías locales y la posible mejora de la calidad de vida de la población resultante de las mismas. Para el análisis de la información recogida a través de 30 entrevistas/encuestas se ha realizado su caracterización con el Modelo Conceptual CATWOE. Se ha aplicado en el ámbito de la educación universitaria, teniendo en cuenta a los diferentes actores, y su presencia e importancia en relación a las distintas etapas del sistema de educación universitario en el ámbito del África subsahariana. Llegamos a la conclusión de que los actores tienen diferentes pesos en la toma de decisiones, así como en el nivel de formulación de las políticas públicas en el que pueden operar. Sin embargo, su dictamen confirma que el modelo educativo debe ser equilibrado. En este sentido, sus acciones son cruciales en la construcción de un sistema de educación universitario de calidad y más completo para África dada la dependencia que la educación superior tiene de la ayuda exterior. Se ha tomado el caso del África subsahariana por ser posiblemente la parte del mundo donde el desarrollo económico es más complicado y, a la vez, la importancia concedida a la universidad como opción de desarrollo ha sido mínima. 


\begin{abstract}
The object of study of this research is to understand how higher education contributes to economic progress in developing countries by providing equal opportunities in an increasingly international market. Development cooperation has given greater emphasis to primary and secondary education on the basis of economic growth and poverty reduction derived from promoting this type of education. In fact, university education in Africa, especially in sub-Saharan Africa, has been neglected for several decades to not be considered as an important factor for economic development and as an agent of poverty reduction. The thesis defends the hypothesis that the education system should be balanced and cannot revile the upper level against the secondary and primary. The aim is to contrast this starting point with the view of stakeholders, internal and external, to understand their point of view in relation to the thesis we defend. To this end, we have conducted a study of different types of actors, to gather information that allows us to deduce the correspondence between the actions planned and those already taken (effective) of this group and their opinion on the issues of international cooperation in the field of education and its effect on the progress of local economies and possible improvement of the quality of life of the population resulting therefrom. For the analysis of the information gathered through 30 interviews / surveys were performed the characterization with the Conceptual Model CATWOE in the field of higher education taking into consideration the different actors and the representation of the relationship of the various stages of university education system in the context of sub-Saharan Africa. We conclude that the actors have different weights in decision-making process, as well as in the level of public policy formulation in which they can operate. However, their opinions confirm that the educational model must be balanced and that their actions, in this regard, are crucial in building a university education system of quality and more complete for Africa due to the influence of the international aid in the development of African university system. The case of sub-Saharan Africa is essential because it is the part of the world where economic development is more complicated and, at the same time, the importance given to the university as a development option has been minimal.
\end{abstract}


VNIVERSIDAD

DSALAMANCA 


\section{A dedicatória}

Dedico este trabalho à minha família, em especial aos meus filhos, a quem este projeto mais tempo subtraiu às suas vidas. A eles espero retribuir os frutos do tempo perdido, especialmente em termos de exemplo de como a educação é importante nas nossas vidas e de como a perseverança e a resiliência é importante para atingirmos os nossos objetivos.

Deixo uma dedicação especial ao meu pai que faleceu recentemente e à minha mãe pela "grande" mulher que sempre foi tendo sido um exemplo pela forma como ultrapassou grandes desafios durante toda a sua vida. 
VNIVERSIDAD

DSALAMANCA 


\section{Os agradecimentos}

Em primeiro lugar não posso deixar de agradecer ao meu orientador $\mathrm{e}$ coorientados, Prof. Doutor Santiago M. López García e Prof. Doutor Carlos Sangreman, pela orientação, apoio, paciência e tempo despendido. Agradeço especialmente a compreensão que sempre demonstraram, durante todo o processo de execução da dissertação, devido a vários contratempos que foram surgindo ao nível pessoal e que, de alguma forma foram retardando o término da mesma, assim como nunca permitiram que desistisse por falta de motivação.

Agradeço, igualmente, à minha família e amigos, que contribuíram indiretamente para o êxito do trabalho produzido

A todos os funcionários da Universidade de Salamanca que permitiram, apesar da distância, que toda a informação e todos os trabalhos fluíssem da melhor forma possível, o meu muito obrigada.

Por fim, agradeço a todas as pessoas que responderam ao inquérito e despenderam do seu tempo e que permitiram que este projeto se concretizasse, assim como às Instituições Europeias que forneceram dados estatísticos. 
VNIVERSIDAD

DSALAMANCA 


\section{A Lista de Abreviaturas / Acrónimos}

Inglês

AAU

$\mathrm{ACP}$

AfDB

ARAPKE

AUC

CAAST-Net

CEMAC

CPA

CSIR

CSO

DCI

DUDH

EAC

ECA

ECOSOCC AU

ECOWAS

EDF

EESC

EFA

ENPI

EP

EPAs

FAO

FP6
Association of African Universities

Africa/Caribbean/Pacific countries

African Development Bank

African Regional Action Plan for Knowledge Economy (AU initiative)

African Union Commission

Network for the Coordination and Advancement of Africa $=$ EU Science and Technology Cooperation

Economic and Monetary Community of Central Africa

Africa's Science and Technology Consolidated Plan of Action

Council for Scientific and Industrial Research

Civil Society Organisation

Development Cooperation Instrument

Universal Declaration of Human Rights

East African Community

Economic Commission for Africa

Economic, Social and Cultural Council

Economic Community of East African States

European Development Fund

European Economic and Social Committee

Education for All

European Neighbourhood Policy Instrument

European Parliament

Economic Partnership Agreements

Food and Agriculture Organisation

Framework Programme 6 
FP7

GED

IGAD

INCO

IOM

MDGs

MEAs

NEPAD

NRF

OECD

PAIPO

PAU

PPPs

PRSPs

PSC

RECs

SADC

SICAs

UN

UNCTAD

UNECA

UNESCO
Framework Programme 7

General Educational Development

Intergovernmental Authority on Development

Instruments for Cooperation

International Organization for Migration

Millennium Development Goals

Multilateral Environmental Agreements

New Partnership for Africa's Development

National Research Foundation, South Africa

Organisation for Economic Co-operation and Development

Pan African Intellectual Property Organisation

Pan African University

Public-Private Partnerships

Poverty Reduction Strategy Papers

Partnership Steering Committee

Regional Economic Communities

South African Development Community

Specific International Cooperation Actions

United Nations

United Nations Conference on Trade and Development

United Nations Economic Commission for Africa

United Nations Educational, Scientific and Cultural Organization 
Português

PIB

UE

$\mathrm{BM}$

ONG

ASS

FMI

Francês

CEPES
Produto Interno Bruto

União Europeia

Banco Mundial

Organizações Não-governamentais

África Subsariana

Fundo Monetário Internacional

Centre Européen pour l'Enseignement Supérieur 
VNIVERSIDAD

DSALAMANCA 
1.1.1. O conhecimento e a sua transmissão como bens públicos.............................83

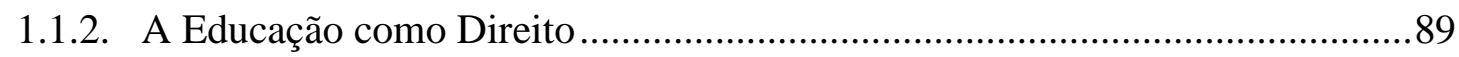

1.2. O sistema de educação em África ..............................................................93

1.2.1. Acesso ao ensino superior e igualdade de oportunidades.........................103

1.3. A reforma no Ensino Superior em África: Autonomia e legislação ...............110

1.4. A missão das universidades e a dicotomia entre público e privado................113

1.5. A profissão académica em África ..............................................................119

1.6. A Educação enquanto fomento da economia................................................122

1.6.1. O crescimento económico em África e a sua relação com o capital humano. 
2.1. Evolução histórica das Universidades Africanas: do pré-nacionalismo à globalização e internacionalização

2.1.1. O ensino superior em África durante a fase pré-colonial

2.1.2. O Ensino Superior em África durante o período colonial.

2.1.3. O Ensino Superior em África durante o período do Nacionalismo

2.1.4. O período de Modernização - Internacionalização e Globalização.

\subsection{0 desenvolvimento e a missão das Instituições de Ensino Superior no} contexto Africano

2.2.1. Uma nova parceria estratégia educacional para o desenvolvimento em África 153

2.2.2. Desafios para o Ensino Superior em África.

Capítulo 3 161

Financiamento do Ensino Superior em África 161

\subsection{O sistema de financiamento das Instituições de Ensino Superior em África163}

3.1.1. Transformação e aspirações do ensino 163

3.1.2. O sistema de financiamento das instituições de ensino 164

3.1.2.1.Financiamento Público do Ensino Superior. 167

3.1.3. Os constrangimentos financeiros e o acesso ao ensino superior 173 
3.2.2. A visão da Perspetiva Internacional Realista e do Internacionalismo Humano.

3.2.3. A internacionalização do Ensino Superior em África.

Capítulo 4

$\overline{\text { O Desenvolvimento Tecnológico e a Capacitação Humana.... } 191}$

\subsection{O Desenvolvimento Tecnológico em África.}

4.1.1. Aspetos culturais africanos que contribuem para o desenvolvimento tecnológico 196

4.1.2. O desenvolvimento das Novas Tecnologias de Informação e Comunicação em África

4.1.2.1.As Infraestruturas e a sua evolução.

4.1.2.2.O desenvolvimento das Tecnologias de Informação e Comunicação em

África e o compromisso Internacional.

4.1.2.3.África e o acesso à Informação .210

4.1.2.4 Redefinição das politicas governamentais e sua implementação.

4.1.3. Iniciativas internacionais para melhorar o acesso à Internet em África

\subsection{As instituições científicas e a sociedade do conhecimento em África como} promotores do desenvolvimento económico.

4.2.1. As políticas governamentais de apoio ao desenvolvimento tecnológico em África 221 
$\overline{\text { A Cooperação Internacional e o Desenvolvimento Humano... } 227}$

\subsection{A Cooperação Internacional para o Desenvolvimento}

5.1.1. A Cooperação Académica Europa - África.

5.1.1.1.Apoio às Instituições de Ensino Superior

5.1.1.2.Evolução da Procura pelo Ensino Superior

5.1.1.3.O papel estratégico das Universidades e a Cooperação Académica EU África 264

5.1.2. A Cooperação Académica e Científica enquanto promotor do desenvolvimento em África

5.1.2.1.O papel das parcerias internacionais, os diferentes tipos de Atores e a sua relação com a educação 
6.1.A Metodologia Científica.........................................................................................301

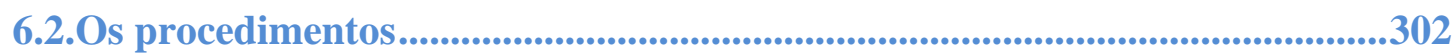

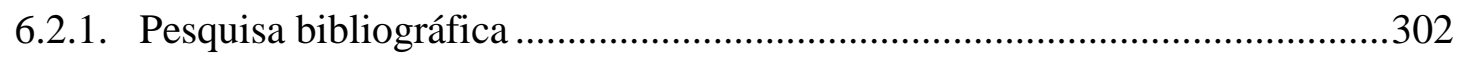

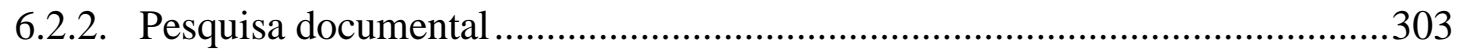

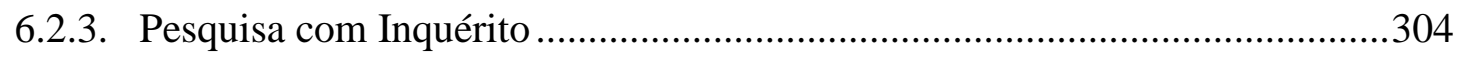

6.3.Instrumentos de análise ......................................................................308

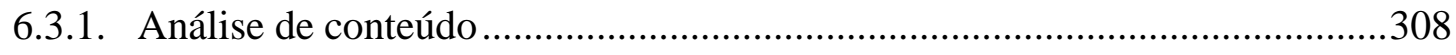

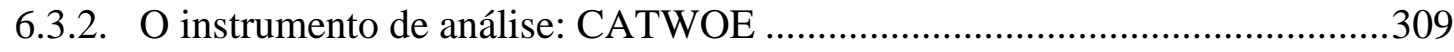

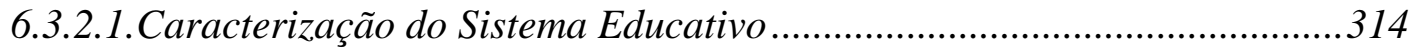

6.3.2.2.A definição da rota ao nível do Ensino Superior........................................315

6.3.3. Identificação dos Atores Externos - Cooperação Internacional ......................320

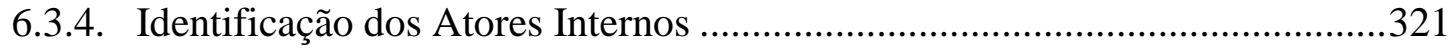

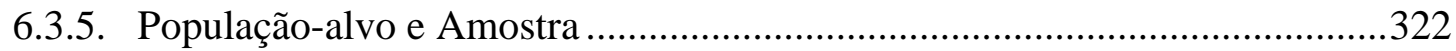

6.4.Hipóteses da Investigação .............................................................. 325

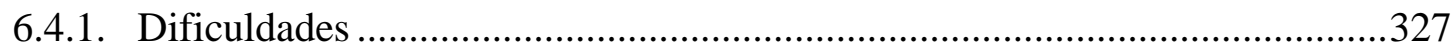

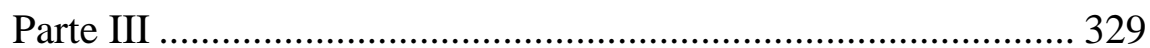

Análise de Dados ......................................................................... 329

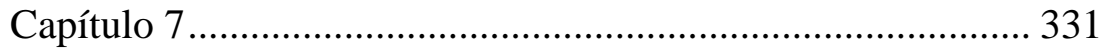

$\overline{\text { Aplicação do Modelo CATWOE mediante a análise dos dados }}$ obtidos de acordo com a sua caracterização no âmbito do ensino superior 
7.1.1. Política Pública Educacional

7.1.2. O Ensino Superior em África.

7.1.3. O sistema de financiamento das Instituições de Ensino Superior em Africa 355

7.1.4. A Cooperação Académica EU - África.

7.2.Implicações na caracterização do modelo CATWOE no âmbito do Ensino Superior tendo em conta o impacto dos diferentes Atores (internos e externos), no contexto da ASS.....................................................................................401

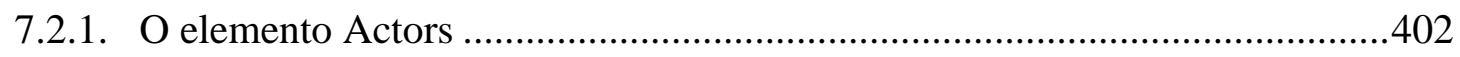

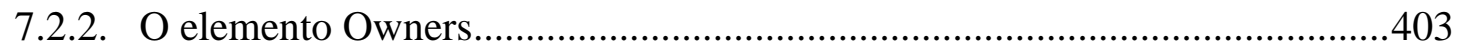

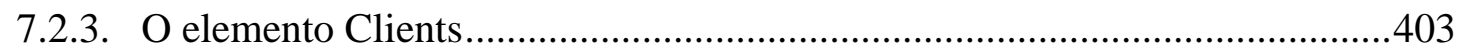

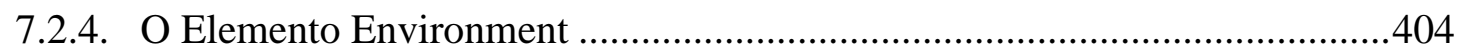

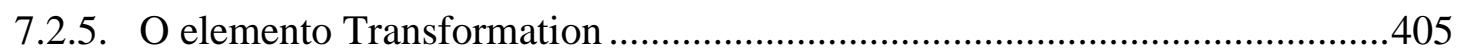

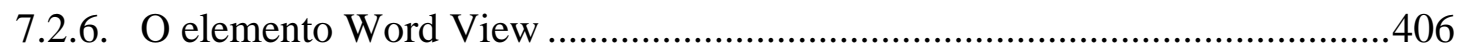

7.3.O papel dos diferentes Atores no processo de transformação .........................406

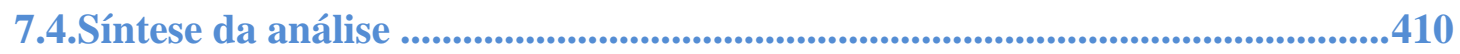

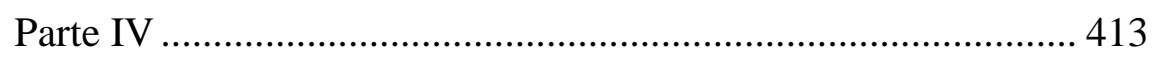

Conclusión .............................................................................. 413

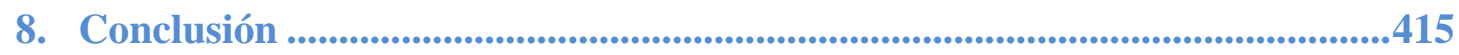

9. Bibliografia ......................................................................................................425 


\section{Índice de Figuras}

Figura 1 - Países que componen el África subsahariana .................................. 45

Figura 2 - Lista de Estados y economías frágiles ............................................ 52

Figura 3- Mapa das Liberdades Económicas, por País da África Subsariana, Index 2014. 208

Figura 4 - Correlação entre Educação e Crescimento Económico 292

Figura 5 - Conceptualização dos objetivos de uma nova parceria integrada...... 293

Figura 6 - Objetivos de Desenvolvimento sustentável aprovados na Cimeira de 2015 pelos Acordada pelos 193 Estados-membros da ONU. 294

Figura 7 - Caracterização do Modelo CATWOE para o Sistema de Ensino Superior. 316

Figura 8 - Papel dos "Atores" internos 317

Figura 9- Caracterização do Modelo Conceptual CATWOE no âmbito do Ensino Superior tendo em conta os diferentes atores (internos e externos), e a representação da relação das diferentes etapas do sistema, no contexto da África Subsariana 319

Figura 10 - Principais áreas de orientação universitária mencionadas pelos Atores inquiridos para fazer frente aos problemas socioeconómicos regionais e nacionais, por ordem de relevância. 347 
VNIVERSIDAD

DSALAMANCA 


\section{Índice de Tabelas}

Tabela 1 - Datos relativos a las circunstancias nacionales y locales, África subsahariana (2008/2009) 49

Tabela 2 - Estudos que demonstram que níveis superiores de capital humano implicam uma maior taxa de desenvolvimento 124

Tabela 3 - Número de Instituições de Ensino Superior, Públicas e Privadas, por País 147

Tabela 4 - Fontes de financiamento e a sua aplicação . 165

Tabela 5 - Comparação das Médias Regionais com as Médias Globais, em cada um dos indicadores da Liberdade Económica, Index de 2014. 207

Tabela 6 - Países da África Subsariana com e sem Centros de Investigação classificados no Ranking "Web of World Research Centers"* de acordo com os Princípios das Instituições de Ensino Superior ............................................... 218

Tabela 7 - ODM Vs Direitos Humanos ........................................................ 235

Tabela 8 - Príncipais desenvolvimentos na história da Ajuda no período pósguerra 245

Tabela 9 - Interação entre os diferentes atores para o desenvolvimento - área de atuação e instrumentos de ligação. 254

Tabela 10 - Ajuda para a educação, pelos principais doadores, 2002-2014 ...... 261

Tabela 11 - Contribuição dos Dadores da Parceria Global para a Educação, até 31 de Dezembro de 2013 (USD) 268 
Tabela 12 - Atores, o seu papel no desenvolvimento e a correlação com sua

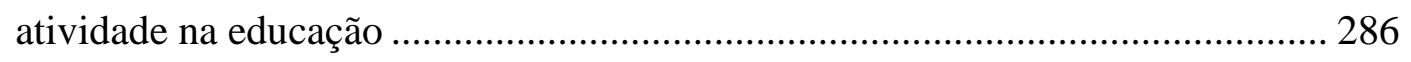

Tabela 13 - Amostra Populacional .................................................................. 322

Tabela 14 - Papel dos Atores Vs. Processo de Transformação............................ 409 


\section{Índice de Gráficos}

Gráfico 1 - Taxa líquida de matrícula no ensino primário................................. 94

Gráfico 2 - Taxa líquida de matrícula no ensino primário - por sexo ................... 95

Gráfico 3 - Taxa de alfabetização dos 15 aos 24 anos de idade, mulheres e homens 96

Gráfico 4 - Taxa de alfabetização dos 15 aos 24 anos de idade, por sexo.............. 97

Gráfico 5 - Número total de professores necessários para se alcançar a educação

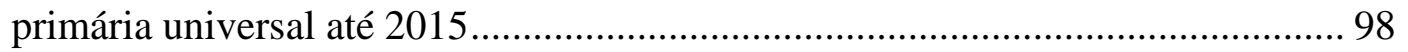

Gráfico 6 - Rácios de raparigas e rapazes no ensino primário, secundário e terciário, taxas de escolarização bruta, 1990 - 2011 .......................................... 104

Gráfico 7 - Rácio de literacia por sexo e região, 1990 - 2011 (percentagem) ..... 105

Gráfico 8 - Paridade do Género Vs. Tipo de educação, 2011 ............................ 106

Gráfico 9 - Relação Género Vs. Qualidade de Vida Vs. Nível de Estudos, 20052011. 107

Gráfico 10 - Relação entre as idades no ensino primário e secundário e a localização dos estudantes - rural e urbano ................................................... 108

Gráfico11 - Correlação entre Educação e Emprego Seguro ............................... 125

Gráfico 12 - Rácio de graduação no ensino superior de acordo com a área de

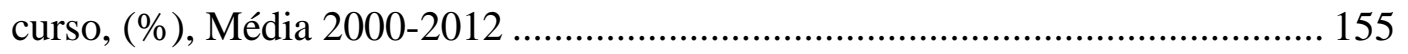

Gráfico 13 - Rácio da primeira graduação no ensino superior de acordo com a área de curso (\%), Média por país 2000-2012 _..................................................... 156

Gráfico 14 - Graduação no ensino superior por país e ano, 2000 a 2011 (\%) ..... 157 
Gráfico 15 - Média - Rácio bruto de graduação, ISCED 5A $1 .^{\circ}$ Curso (\%); por país de 2000-2012 158

Gráfico 16 - Financiamento do Estado para o Ensino Superior como percentagem do PIB, 1995-2007 168

Gráfico 17 - Financiamento do Estado para o Ensino Superior como uma percentagem da despesa total do Estado, 1995-2007. 168

Gráfico 18 - Despesa corrente em \% do total das despesas com instituições públicas de ensino superior, África Subsariana, por ano, 1999-2013. 170

Gráfico 19 - Despesa corrente em \% do total das despesas com instituições públicas de ensino superior, África Subsariana, por países, 1999-2013. 171

Gráfico 20 - Despesa do Governo com IES como \% do PIB (\%), África Subsariana, 1999-2013. 172

Gráfico 21 - Despesa do Governo com IES como \% do PIB (\%), por país, 19992013 172

Gráfico 22 - Liberdade Económica, Média Mundial comparada com diferentes regiões, 1995-2008 206

Gráfico 23 - Despesa Pública em Educação, por região e nível de rendimentos, 1999 e 2011 259

Gráfico 24 - Per Capita (ensino primário) (PPP constante 2010 - US\$) 259

Gráfico 25 - Total da ajuda financeira para a educação e para o ensino básico, por região e de acordo com o rendimento, 2002-2011. 260 
Gráfico 26 - Os principais doadores reduziram a sua ajuda financeira para o ensino básico, especialmente para os países de baixos rendimentos entre 2010 e 2011. 261

Gráfico 27- Rácio bruto de graduação, ISCED 5A 1. ${ }^{\circ}$ Curso (\%) ...................... 264

Gráfico 28 - Mobilidade Estudantes Africanos, por Região de destino, 1999-2012

Gráfico 29 - Mobilidade de Estudantes Africanos para países Europeus, 19992012. 283

Gráfico 30 - Mobilização de alunos africanos por ano, 1999-2012 284

Gráfico 31 - Resultado das respostas e percentagens / população alvo 323

Gráfico 32 - Percentagem de Homens e Mulheres que participaram no inquérito 323

Gráfico 33 - Percentagem de participantes no inquérito por tipo de Ator para o Desenvolvimento 324

Gráfico 34 - Países Europeus e Africanos que participaram no inquérito 324 Gráfico 35 - Opinião dos Atores quanto à educação como um bem público universal. 333

Gráfico 36 - Opinião dos Atores quanto ao nível de educação que deve ser fornecido pelos governos de forma gratuita. 335

Gráfico 37 - Opinião, por Tipo de Ator, quanto ao nível de educação que deve ser fornecido pelos governos de forma gratuita. 335

Gráfico 38 - Opinião dos Atores quanto ao apoio a ser dado a instituições de ensino publicas e/ou privadas 
Gráfico 39 - Opinião por tipo de Ator quanto ao apoio a instituições de ensino públicas e/ou privadas 338

Gráfico 40 - Opinião quanto ao nível de educação que poderá favorecer o desenvolvimento 340

Gráfico 41 - Opinião, por tipo de Ator, quanto ao nível de educação que poderá favorecer o desenvolvimento 340

Gráfico 42 - Opinião dos Atores quanto ao fato de um nível de ensino superior de educação favorecer melhores condições de vida 341

Gráfico 43 - Opinião por tipo de Ator quanto ao fato de um nível de ensino superior de educação favorecer melhores condições de vida 342

Gráfico 44 - Opinião dos Atores, no contexto da ASS, no sentido de perceber se o ensino superior ocupa um lugar primordial no desenvolvimento destes países .. 344 Gráfico 45 - Opinião por tipo de Ator, no contexto da ASS, no sentido de perceber se o ensino superior ocupa um lugar primordial no desenvolvimento destes países 345

Gráfico 46 - Opinião dos Atores em relação ao papel que o ensino superior deverá ocupar na Nova Agenda para o desenvolvimento pós-2015. 348

Gráfico 47 - Opinião por tipo de Ator em relação ao papel que o ensino superior deverá ocupar na Nova Agenda para o desenvolvimento pós-2015 349

Gráfico 48 - Opinião dos Atores quanto às dificuldades que as universidades enfrentam nos países em desenvolvimento 352

Gráfico 49 - Opinião, por tipo de Ator, quanto às dificuldades que as universidades enfrentam nos países em desenvolvimento 
Gráfico 50 - Opinião dos Atores quanto ao tipo de financiamento que deve ser fornecido, para as instituições de ensino superior de acordo com as suas necessidades, nos países em desenvolvimento 358

Gráfico 51 - Opinião, por tipo de Ator, quanto ao tipo de financiamento que deve ser fornecido para as instituições de ensino superior de acordo com as suas necessidades, nos países em desenvolvimento 358

Gráfico 52 - Opinião dos Atores quanto ao tipo de Apoio Financeiro a ser fornecido 360

Gráfico 53 - Opinião, por tipo de Ator, quanto ao tipo de Apoio Financeiro a ser fornecido 361

Gráfico 54 - Opinião dos Atores quanto ao suporte financeiro existente atualmente 362

Gráfico 55 - Opinião por tipo de Ator quanto ao suporte financeiro existente atualmente 363

Gráfico 56 - Opinião dos Atores quanto às medidas existentes / ou não de avaliação da sua execução, nos países em desenvolvimento 367

Gráfico 57 - Opinião, por tipo de Ator, quanto ao suporte financeiro atual e as medidas existentes / ou não de avaliação da sua execução, nos países em desenvolvimento 367

Gráfico 58 - Opinião dos Atores quanto ao fato da Cooperação Académica EU África constituir um importante fator no desenvolvimento de recursos humanos qualificados 375 
Gráfico 59 - Opinião, por tipo de Ator, quanto ao fato da Cooperação Académica EU - África constituir um importante fator no desenvolvimento de recursos humanos qualificados 376

Gráfico 60 - Opinião dos Atores quanto ao fato das universidades terem um papel estratégico no progresso das economias em desenvolvimento 377 Gráfico 61 - Opinião, por tipo de Ator, quanto ao fato das universidades terem um papel estratégico no progresso das economias em desenvolvimento 378 Gráfico 62 - Opinião dos Atores quanto à dependência do desenvolvimento tecnológico em Africa da cooperação académica 380 Gráfico 63 - Opinião, por tipo de Ator, quanto à dependência do desenvolvimento tecnológico em Africa da cooperação académica.... 381

Gráfico 64 - Opinião dos Atores quanto ao desenvolvimento tecnológico através das políticas governamentais 383

Gráfico 65 - Opinião dos Atores quanto ao desenvolvimento tecnológico através das políticas governamentais 384 Gráfico 66 - Opinião dos Atores quanto ao desenvolvimento tecnológico através das políticas governamentais nos diferentes níveis: regional, nacional e internacional... 385

Gráfico 67 - Opinião por tipo de Ator quanto ao desenvolvimento tecnológico através das políticas governamentais nos diferentes níveis: regional, nacional e internacional 386

Gráfico 68 - Opinião dos Atores quanto à promoção de melhores condições para os estudantes através cooperação EU-Africa. 387 
Gráfico 69 - Opinião, por tipo de Ator, quanto à promoção de melhores condições para os estudantes através cooperação EU-África 388

Gráfico 70 - Opinião dos Atores quanto à promoção de melhores condições para a população em geral através cooperação EU-Africa. 390

Gráfico 71 - Opinião por tipo de Ator quanto à promoção de melhores condições para a população em geral através cooperação EU-África 390

Gráfico 72 - Opinião dos Atores quanto ao fato da Cooperação poder aumentar o número de estudantes universitários em África 392 Gráfico 73 - Opinião, por tipo de Ator, quanto ao fato da Cooperação poder aumentar o número de estudantes universitários em África. 392 Gráfico 74 - Opinião dos Atores no sentido de perceber se a cooperação académica favorece a migração de estudantes. 394

Gráfico 75 - Opinião, por tipo de Ator, no sentido de perceber se a cooperação académica favorece a migração de estudantes 394

Gráfico 76 - Opinião dos Atores no sentido de perceber quais as principais consequências / vantagens que podem advir da cooperação académica. 396

Gráfico 77 - Opinião, por tipo de Ator, no sentido de perceber quais as principais consequências / vantagens que podem advir da cooperação académica. 396

Gráfico 78 - Opinião dos Atores no sentido de perceber se a Nova Agenda do Desenvolvimento deva ter um foco especial no ensino superior 397 Gráfico 79 - Opinião dos Atores no sentido de perceber se a Nova Agenda do Desenvolvimento deva ter um foco especial no ensino superior. 398 
Gráfico 80 - Opinião dos Atores quanto ao impacto positivo da educação na redução da pobreza, na melhoria da qualidade de vida e na promoção de sociedades mais justas, nos países em desenvolvimento 400

Gráfico 81 - Opinião por tipo de Ator quanto ao impacto positivo da educação na redução da pobreza, na melhoria da qualidade de vida e na promoção de sociedades mais justas, nos países em desenvolvimento....... 400 


\section{Índice de Anexos}

Anexo 1 - África: Lista de países por data de independência ou criação 457

Anexo 2 - Documentos políticos europeus relacionados com os ODM - 2002 2011 463

Anexo 3 - Despesa Publica em Educação, por região e nível de rendimentos, 1999 e 2011 467

Anexo 4 - Rendimento, várias Regiões do Mundo, 1999 e 2011 468

Anexo 5 - Total da ajuda financeira para a educação e para o ensino básico, por região e de acordo com o rendimento, $2002-2011$ 469

Anexo 6 - Instituições de Ensino Superior, públicas e privadas, atualmente em funcionamento 470

Anexo 7 - Total de Matriculas no ensino superior. Público e privado. Full e part time. Total - $2000-2011$

Anexo 8 - Rácio de graduação no ensino superior de acordo com a area de curso, ISCED 5A 1. Curso (\%), Média 2000-2012 500

Anexo 9- Matriculas em todos os programas do ensino superior. Total - $2000-$ 2012 502

Anexo 10 - Centros de Investigação na Africa Subsariana classificados no ranking mundial 504

Anexo 11 - Despesa corrente como \% do total da despesa em instituições públicas de ensino superior (\%), por país - ASS - 1999-2013 513

Anexo 12 - Despesa do Governo com IES como \% do PIB (\%), por país, ASS 515 Anexo 13 - Liberdade Económica, por país da ASS, 2014 516 
Anexo 14 - Lista de países Recetores da APD - DAC, 2008, 2009, 2010 519

Anexo 15 - Mobilização de Alunos Africanos por local de destino, 1999-2012 520

Anexo 16 - Inquérito 


\section{O prefácio}

Esta dissertação foi um projeto que marcou diferentes etapas da minha vida. Foram vários os obstáculos a ultrapassar não só em termos pessoais mas, igualmente, ao nível da execução da dissertação.

Compreender de que forma o Ensino Superior contribui para o progresso económico nos países em desenvolvimento constitui um tema da atualidade, bastante documentado, o que de certa forma implica um trabalho de pesquiza afinado, no sentido de limitar a informação produzida e fornecida por todas as instituições e Atores relacionados com a área, assim como selecionar apenas documentação com caracter de novidade no seu conteúdo.

Por outro lado, a recolha de dados revelou-se bastante morosa e trabalhosa, no sentido em que que os Atores inquiridos, visto tratar-se de pessoas em cargos essencialmente públicos, os quais, ainda que a informação solicitada fosse confidencial e devidamente agregada de acordo com os indicadores previamente definidos, não se quiseram expor a um possível escrutínio em termos de análise qualitativa das suas respostas.

Não obstante as dificuldades descritas, o fato de trabalhar para umas das maiores Instituições que contribuem para a Cooperação Internacional, em termos gerais, e em específico para a educação, permitiu as condições necessárias para a recolha dos dados para a execução e consecução da dissertação.

A este respeito quero sublinhar que este argumento tem muito do meu trabalho diário na Comissão Europeia o que determina a perspetiva e o conhecimento na matéria em causa. $\mathrm{O}$ objetivo da tese é mostrar o estado da situação e a coerência, ou não, entre o que pensam os atores, que têm a cargo as decisões políticas de apoio ao desenvolvimento do ensino superior em África subsahariana, e o que é realmente feito. Os dados apresentados referem-se, essencialmente, à Africa 
Subsariana, de forma a delimitar o campo de investigação, muito embora existam diferenças regionais, a temática em causa permite uma análise generalizada.

No entanto, enquanto apreciação critica foi com alguma deceção que verificámos que numa lista bastante extensiva na ordem das 560 pessoas que foram identificadas e as quais trabalhavam, especificamente, na área da Cooperação Internacional não quiseram participar. Apenas $5.6 \%$ dos inquiridos aceitaram participar no estudo em causa. As restantes afirmaram não ser da sua competência as questões colocadas e até mesmo o desinteresse demonstrado não só em contribuir para a investigação mas também no fato de terem demonstrado pouco aprofundamento das áreas com as quais trabalham e em alguns casos há bastante tempo.

Trata-se, portanto, de uma tese com fontes de informação de documentos oficiais, assim como, de contactos informais das instituicoes internacionais dedicadas ao desenvolvimento humano e em especial ao educativo relacionado com o ensino superior universitário nos países em desenvolvimento. Os dados foram completados com entrevistas a responsáveis das mesmas áreas, no caso particular da África subsahariana.

Por último, desejo assinalar que esta investigação teve como motivação o meu profundo interesse na área do desenvolvimento humano numa zona muito pobre do planeta e a firme convicção de que as universidades locais podem e devem ter um papel crucial no desenvolvimento económico moderno. Espero que a presente tese sirva para que as autoridades tenham um novo argumento para tomar decisões mais adequadas e pertinentes no que respeita a ajuda externa para a educação, a partir da minha capacidade para influenciar a área em causa.

Com esta tese pretendo obter o título de Doutor Internacional. Para o efeito a introdução e a conclusão são apresentadas em língua castelhana, no sentido de se fazer entender: não só as linhas orientadoras desta tese e os objectivos a serem 
atingidos, nomeadamente, apresentar as características económico-sociais dos países da Africa Subsariana, o percurso do ensino superior nestes países e a influência que esta representa para o desenvolvimento humano, assim como a importância do papel da cooperação internacional, em especial da União Europeia, para a efectivação do progresso destas regiões; mas também, as conclusões e reflexões onde se apresentam os principais desafios a serem superados, no âmbito do ensino superior nos países da Africa Subsariaana, de acordo com a opinião dos Atores relevantes para a tomada de decisão e possíveis caminhos futuros para o desenvolvimento destas instituições. 
VNIVERSIDAD

DSALAMANCA 
The MDGs have proven that focused global development objectives can make a profound difference. Success in the next 1,000 days will not only improve the lives of millions, it will add momentum as we plan for beyond 2015 and the challenges of sustainable development

UN Secretary-General Ban Ki-Moon Published in United Nations, New York 13-26318-June 2013-10 000 Sales No. E.13.I.9 USD 15 
VNIVERSIDAD

DSALAMANCA 


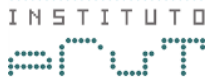

:.................

Introducción 
VNIVERSIDAD

DSALAMANCA 


\section{Introducción}

En esta introducción dedicamos las primeras páginas a dar un panorama económico y social objeto de nuestro análisis, que es a educación superior en el África Subsariana (SSA) y su relación con la ayuda al desarrollo de este segmento de la educación por parte de la colaboración internacional, especialmente de la UE. A continuación dedicamos dos secciones (encuadramiento y contribución) al tema elegido desde la perspectiva de los estudios sociales de la ciencia y la tecnología, con especial atención a la línea interpretativa que instituciones como la NESTA y las Naciones Unidas tienen del papel de la enseñanza superior en el desarrollo moderno de los países. Terminamos la introducción con una breve explicación de la estructura de la presente investigación.

\section{Objeto de estudio y preocupación}

La presunción de esta investigación se basa en el siguiente presupuesto:

- En un sistema económico post-industrial el sistema de educación debe ser equilibrado y no se puede dejar de lado al nivel superior y centrarse sólo en el secundario y primario.

Los cinco primeros capítulos sirven para apoyar esta presunción. A continuación nos serviremos de entrevistas a los responsables de las políticas de apoyo a la colaboración el desarrollo en materia de enseñanza superior para contrastar la importancia que ellos mismos le dan a esta cooperación. Esto nos conduce a la pregunta clave de la presente investigación:

- ¿Cuál es la perspectiva de los actores de las asociaciones entre universidades europeas y africanas sobre la relación entre el desarrollo económico en el contexto del siglo XXI y la cooperación internacional en la enseñanza superior? 
Esta cuestión se resuelve en los capítulos 6 y 7. En consecuencia, el objetivo de la investigación es:

- Contrastar el dictamen de los Actores, internos y externos, en el sentido de comprender cuál es el punto de vista de los mismos en relación a la presunción que defendemos: el apoyo al sistema de educación debe ser equilibrado y cubrir los tres niveles..

Para ello se efectuó una encuesta/entrevista a los diferentes tipos de Actores con el fin de recoger información que nos permitiera inferir si existe correspondencia entre las acciones esperadas y las efectivas de este grupo de Actores y su perspectiva en cuanto a las cuestiones de la Cooperación Internacional en lo que se refiere a la educación, así como su efecto en el progreso de las economías locales y de la posible mejora de la calidad de vida de la población resultante.

La Enseñanza Superior Africana, al inicio del nuevo Milenio, enfrenta nuevos desafíos, ya que pasa a ser reconocida como un factor clave para el desarrollo económico-social. Por otro lado, es importante mencionar que este tipo de enseñanza tiene un papel central, en un mundo cada vez más globalizado e internacionalizado, donde el conocimiento y la innovación forman parte de las sociedades más desarrolladas y más competitivas. Sin embargo, generalizar sobre un continente tan vasto y diverso como África no es una tarea fácil, teniendo en cuenta que las tendencias de la enseñanza superior en el Norte de África son considerablemente diferentes de las del África subsahariana ${ }^{1}$ (Figura 1):

\footnotetext{
${ }^{1}$ A El África subsahariana corresponde a la región del continente africano al sur del desierto del Sahara, es decir, a los países que no forman parte del norte de África. La palabra subsariana deriva de la convención geográfica euro centrista, según la cual el Norte estaría arriba y el Sur abajo (de ahí el prefijo latino sub). En efecto, el desierto del Sahara, con sus cerca de 9 millones de kilómetros cuadrados, forma una especie de barrera natural que divide el continente africano en dos partes muy distintas tanto en el aspecto humano como en el económico. Al norte encontramos una organización socioeconómica muy similar a la de Oriente Medio, formando un mundo islamizado. Al sur tenemos la llamada África Negra, así denominada por la predominancia en esa región de pueblos de piel oscura y ojos castaños (Wagner de Cerqueira, 2016).
} 
Com extensão territorial de aproximadamente 30,2 milhões de quilômetros quadrados, a África é o terceiro maior continente do planeta. Esse grande território, habitado por mais de um bilhão de pessoas, apresenta grande diversidade física, étnica, cultural e econômica. Todos esses elementos contribuíram para uma subdivisão regional, que estabeleceu a África Mediterrânea (também chamada de África Islâmica ou Setentrional) e a África Subsaariana. Wagner De Cerqueira (2016)

\section{Figura 1 - Países que componen el África subsahariana}

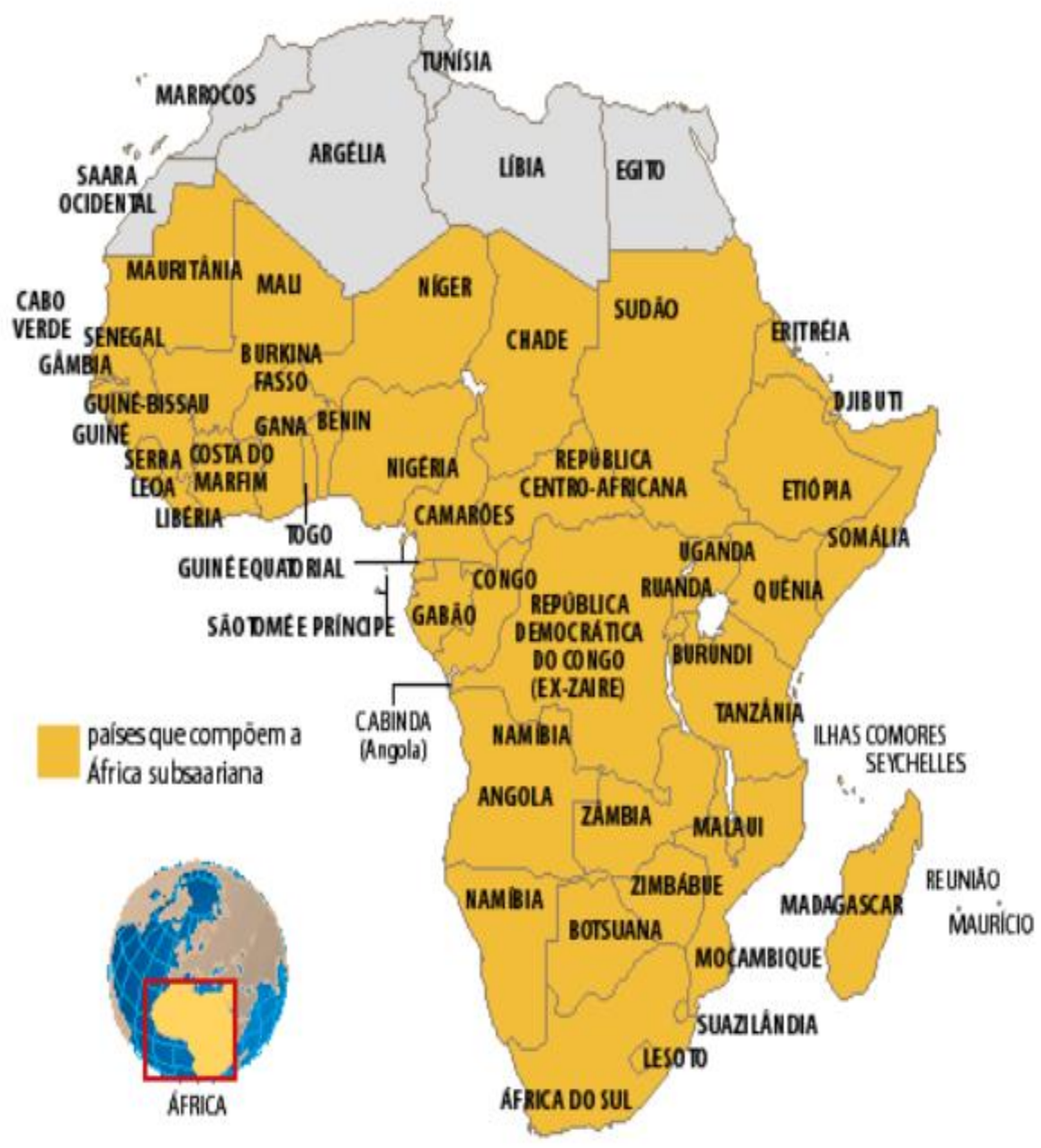


Sin embargo, es posible encontrar elementos comunes, aunque se haya optado por analizar el África subsahariana, con el fin de delimitar el campo de análisis, y consecuentemente, esas mismas diferencias. Esta delimitación pasa, además, por el hecho de que a pesar de un crecimiento en las matrículas de la educación terciaria en África, en las últimas dos décadas, con una media anual del 8,7\% (comparada con la media global del 5,1\%), el acceso a este nivel de enseñanza es desigual en las subregiones de África (Banco Mundial, 2010).

De acuerdo con datos de la UNESCO (1999) de los 82 millones de estudiantes de enseñanza superior en el mundo (en 1995) sólo 1.926 .000 eran del África subsahariana, datos que a juicio de la misma institución prácticamente no se han alterarado en términos relativos. De esta forma, comparada con las demás subregiones africanas, el África subsahariana sigue registrando un menor acceso a pesar de haber registrado una mayor tasa de crecimiento en las dos últimas décadas, superando el $100 \%$ y ha apostado en forma creciente en la enseñanza superior (Varela, 2015: 10).

No obstante, también los países del África subsahariana difieren considerablemente entre sí, sin embargo, consideramos que la temática en cuestión permite este mismo análisis, habida cuenta del hecho de que, a nivel del desarrollo, existen países que van a diferentes velocidades, como es el caso de Cabo Verde y Ghana en comparación con Guinea Bissau, Sudán y la República Centroafricana. Esta diversidad se observa, fundamentalmente, en el funcionamiento, orientación, apoyo financiero, pero también en lo que se refiere a las circunstancias nacionales y locales. La diversidad cultural, étnica, lingüística, religiosa, económica, política y social de África se produce dentro de los cincuenta y cinco Estados africanos, pero también a nivel de las subregiones del continente, así como a través de las diversas diásporas africanas esparcidas por el mundo (Varela, 2015). 
Esta diversidad, como hemos indicado, representa una división regional que se basa en dos criterios: el geográfico y el étnico-cultural. El primero se manifiesta a través de cuatro subregiones: África Occidental, África Central, África Oriental, África Meridional o del Sur. El segundo criterio destaca dos grandes grupos: la África blanca o septentrional (formada por los ocho países de África del Norte, Norte, más Mauritania y el Sahara Occidental) y África Negra o Subsahariana (los demás países de los continentes). Como se mencionó anteriormente, las circunstancias regionales y nacionales de cada uno de los países difieren bastante, sin embargo, la diversidad de los países africanos es "lo que más une África, enfrentada a la necesidad de hacer frente a los desafíos de afirmación de las soberanías nacionales, y la consolidación de los sistemas políticos, el desarrollo sostenible, la competitividad y la afirmación como continente en el contexto internacional" (Varela, 2015: 4).

Por lo que se refiere a la enseñanza superior africana, podemos considerar que la diversidad es una característica común, ya que las universidades enfrentan dificultades y perspectivas de desarrollo similares en comparación con los desafíos de la enseñanza superior universales (Varela, 2015). Así, a pesar del crecimiento de la enseñanza superior en África en las últimas décadas su acceso sigue siendo todavía restringido, la producción del conocimiento es limitada, las condiciones de funcionamiento son precarias y las débiles condiciones laborales incitan a la fuga de cerebros.

Las políticas inadecuadas están en el origen de estos problemas en conjunto con la crisis económica mundial y con la incredulidad y el recelo, por parte de los actores internacionales, del papel que las universidades desempeñan en el desarrollo de los países, a pesar de identificar en sus discursos e informes la creciente necesidad de este nivel de educación para el desarrollo de los países africanos. En este sentido, es necesario crear sinergias conjuntas, a nivel nacional e internacional, a través de alianzas entre Estados y universidades, que deben asumir el compromiso de 
promover una enseñanza superior de calidad y con objetivos de procurar la equidad en la sociedad más que de excelencia ${ }^{2}$.

En lo que se refiere a la economía africana se observa, de manera idéntica, que las tasas de crecimiento y persuasión de crecimiento no son homogéneas, a pesar de que se ha resistido a la crisis económica financiera global. Sin embargo, el PIB total de África es de sólo el 1,9\% del PIB mundial (Varela, 2015). Los países más pobres del mundo están en gran parte en este continente (21 países africanos de un total de 30 del mundo). El PIB per cápita en el África subsahariana representa sólo 7\% de la media de la OCDE (2013) y según las previsiones del Banco Mundial (2015) hasta el 2030 un porcentaje sustancial - 19\% - de la población africana todavía vivirá en la pobreza.

Esta situación se acentúa por el hecho de que en África subsahariana predomina el sector de la economía informal, que es fruto de una débil estructura institucional de los países en lo qu se refiere a la inversiones, las reglas del mercado y la gestión de la ayuda internacional, lo que da como resultado débiles estrategias para el desarrollo y la dificultad de "modernizar"el continente. En la siguiente tabla (Tabla 1 - Datos relativos a las circunstancias nacionales y locales, África subsahariana 2008/2009) podemos constatar estas diversidades entre los países del África Subsahariana de acuerdo con diferentes indicadores, donde podemos verificar que en referencia a la alfabetización existen discrepancias acentuadas, siendo pocos los países cuya alfabetización ha superado el 90\% (M - En 2006/2009, en particular Guinea Ecuatorial, la República del Congo, la región de Santo Tomé y Príncipe, las islas Seychelles y Zimbabue).

\footnotetext{
2 En este sentido, el modelo de las universidades interculturales de México es un buen ejemplo de cómo puede una universidad tener una función de integración social e igualación social de una comunidad, como por ejemplo sucede con los totonakos en el Estado de Puebla..
} 


\section{Tabela 1 - Datos relativos a las circunstancias nacionales y locales, África} subsahariana $(2008 / 2009)$

\begin{tabular}{|c|c|c|c|c|c|c|c|c|c|}
\hline País & Populación & Área & $\frac{\text { Literacia }}{\underline{(\mathrm{M} / \mathrm{F})}}$ & $\begin{array}{l}\frac{\text { PIB }}{\text { per }} \\
\text { Capita }\end{array}$ & $\begin{array}{l}\text { Trans } \\
\text { (Rank/ } \\
\text { Score) }\end{array}$ & $\frac{\frac{\text { Life }}{\text { Exp.) }}}{[68]}$ & $\underline{\text { HDI }}$ & $\begin{array}{c}\text { EODB } \\
\text { R } \\
\text { /SAB }\end{array}$ & $\frac{(\mathrm{RANK} / \mathrm{MA}}{\underline{\mathrm{RK}})}$ \\
\hline Angola & $18,498,000$ & $1,246,700$ & $82.9 \% / 54.2 \%$ & 9,000 & $168 / 2$ & 42.4 & 0.486 & $172 / 171$ & $132 / 58,43$ \\
\hline$\underline{\text { Benim }}$ & $8,791,832$ & 112,620 & $47.9 \% / 42.3 \%$ & 323 & $106 / 2.9$ & 56.2 & 0.427 & $172 / 155$ & $97 / 26,75$ \\
\hline Botswana & $1,990,876$ & 600,370 & $80.4 \% / 81.8 \%$ & 8,532 & $37 / 5.6$ & 49.8 & 0.633 & $45 / 83$ & $62 / 15,50$ \\
\hline$\underline{\text { Burkina Faso }}$ & $15,730,977$ & 274,200 & $25.30 \%$ & 1,360 & $79 / 3.6$ & 51 & 0.331 & $150 / 116$ & N/A \\
\hline Burundi & $8,988,091$ & 27,830 & $67.3 \% / 52.2 \%$ & 101 & $168 / 1.8$ & 49 & 0.316 & $176 / 130$ & $103 / 29,00$ \\
\hline$\underline{\text { Cabo Verde }}$ & 499,000 & 322,462 & & & & & & & \\
\hline Cameron & $18,879,301$ & 475,440 & $77 \% / 59.8 \%$ & 687 & $146 / 2.2$ & 50.3 & 0.482 & $171 / 174$ & $109 / 30,50$ \\
\hline Chade & $10,329,208$ & $1,284,000$ & $40.8 \% / 12.8 \%$ & 266 & 175/1.6 & 50.6 & 0.328 & $178 / 182$ & $132 / 44,50$ \\
\hline Cômoros & 752,438 & 2,170 & N/A & 382 & $143 / 2.3$ & 63.2 & 0.433 & $162 / 168$ & $82 / 19,00$ \\
\hline$\underline{\text { Cote d'Ivoire }}$ & $20,617,068$ & 322,463 & & & & & & & \\
\hline Djibouti & 516,055 & 23,000 & N/A & 817 & $111 / 2.8$ & 54.5 & 0.43 & $163 / 177$ & $110 / 31,00$ \\
\hline Eritreia & $5,647,168$ & 121,320 & N/A & 160 & $126 / 2.6$ & 57.3 & 0.349 & $175 / 181$ & $175 / 115,50$ \\
\hline Etiópia & $85,237,338$ & $1,127,127$ & $50 \% / 28.8 \%$ & 161 & $120 / 2.7$ & 52.5 & 0.363 & $107 / 93$ & $140 / 49,00$ \\
\hline Gabón & $1,514,993$ & 267,667 & $88.5 \% / 79.7 \%$ & 4,263 & $106 / 2.9$ & 56.7 & 0.674 & $158 / 152$ & $129 / 43,50$ \\
\hline$\underline{\text { Gambia }}$ & $1,782,893$ & 11,295 & & & & & & & \\
\hline Ghana & $24,200,000$ & 238,535 & & & & & & & \\
\hline Guiné & $10,057,975$ & 245,857 & & & & & & & \\
\hline $\begin{array}{l}\text { Guiné } \\
\text { Ecuatorial }\end{array}$ & 633,441 & 28,051 & $93.4 \% / 80.3 \%$ & 7,470 & $168 / 1.8$ & 51.1 & 0.537 & $170 / 178$ & $158 / 65,50$ \\
\hline Guiné-Bissau & $1,647,000$ & 36,125 & & & & & & & \\
\hline$\underline{\text { Lesotho }}$ & $2,130,819$ & 30,355 & $73.7 \% / 90.3 \%$ & 528 & $89 / 3.3$ & 42.9 & 0.45 & $130 / 131$ & $99 / 27,50$ \\
\hline Libéria & $4,128,572$ & 111,369 & & & & & & & \\
\hline Madagáscar & $19,625,000$ & 587,041 & $76.5 \% / 65.3 \%$ & 238 & $99 / 3.0$ & 59 & 0.48 & $134 / 12$ & $134 / 45,83$ \\
\hline$\underline{\text { Malawi }}$ & $14,268,711$ & 118,480 & N/A & 145 & $89 / 3.3$ & 47.6 & 0.4 & $132 / 128$ & $62 / 15,50$ \\
\hline Mali & $12,666,987$ & $1,240,000$ & $32.7 \% / 15.9 \%$ & 290 & $111 / 2.8$ & 53.8 & 0.359 & $156 / 139$ & $38 / 8,00$ \\
\hline$\underline{\text { Maurícia }}$ & $1,284,264$ & 2,040 & $88.2 \% / 80.5 \%$ & 4,522 & $42 / 5.4$ & 73.2 & 0.728 & 17-Oct & $51 / 14,00$ \\
\hline Mauritânia & $3,359,185$ & $1,030,700$ & & & & & & & \\
\hline Mozambique & $21,669,278$ & 801,590 & N/A & 330 & $130 / 2.5$ & 42.5 & 0.322 & $135 / 96$ & $82 / 19,00$ \\
\hline Namíbia & $2,108,665$ & 825,418 & $86.8 \% / 83.6 \%$ & 2,166 & $56 / 4.5$ & 52.5 & 0.625 & $66 / 123$ & $35 / 9,00$ \\
\hline Níger & $17,129,076$ & $1,267,000$ & & & & & & & \\
\hline Nigéria & $174,507,539$ & 923,768 & & & & & & & \\
\hline$\underline{\text { Kenia }}$ & $39,002,772$ & 582,650 & $77.7 \% / 70.2$ & 976 & $146 / 2.2$ & 57.8 & 0.519 & $95 / 124$ & $96 / 25,00$ \\
\hline $\begin{array}{l}\text { República } \\
\text { Centroáfrica }\end{array}$ & $4,511,488$ & 622,984 & $64.8 \% / 33.5 \%$ & 22 & $158 / 2.8$ & 44.4 & 0.343 & $183 / 159$ & $80 / 17,75$ \\
\hline
\end{tabular}




\begin{tabular}{|c|c|c|c|c|c|c|c|c|c|}
\hline $\begin{array}{l}\text { República } \\
\text { Democrática } \\
\underline{\text { del Congo }}\end{array}$ & $68,692,542$ & $2,345,410$ & $80.9 \% / 54.1 \%$ & 91 & $162 / 11.9$ & 46.1 & 0.286 & $182 / 152$ & $146 / 53,50$ \\
\hline $\begin{array}{l}\text { República del } \\
\underline{\text { Congo }}\end{array}$ & $3,700,000$ & 342,000 & $90.5 \% / 79.0 \%$ & 1,145 & $162 / 1.9$ & 54.8 & 0.533 & N/A & $116 / 34,25$ \\
\hline$\underline{\text { Ruanda }}$ & $10,473,282$ & 26,338 & $71.4 \% / 59.8 \%$ & 263 & $89 / 3.3$ & 46.8 & 0.429 & $67 / 11$ & $157 / 64,67$ \\
\hline $\begin{array}{l}\text { San Tomé y } \\
\underline{\text { Príncipe }}\end{array}$ & 212,679 & 1,001 & $92.2 \% / 77.9 \%$ & N/A & $111 / 2.8$ & 65.2 & 0.509 & $180 / 140$ & NA \\
\hline$\underline{\text { Senegal }}$ & $12,855,153$ & 196,712 & & & & & & & \\
\hline$\underline{\text { Sierra Leone }}$ & $6,190,280$ & 71,740 & & & & & & & \\
\hline Seychelles & 87,476 & 455 & $91.4 \% / 92.3 \%$ & 7,005 & $54 / 4.8$ & 72.2 & 0.773 & $111 / 81$ & $72 / 16,00$ \\
\hline$\underline{\text { Somália }}$ & $9,832,017$ & 637,657 & N/A & N/A & $180 / 1.1$ & 47.7 & N/A & N/A & $164 / 77,50$ \\
\hline$\underline{\text { Sudan }}$ & $31,894,000$ & $1,886,068$ & $79.6 \% / 60.8 \%$ & 2,500 & $176 / 1.5$ & 62.57 & 0.408 & $154 / 118$ & $148 / 54,00$ \\
\hline$\underline{\text { Sur de África }}$ & $49,052,489$ & $1,219,912$ & N/A & 3,562 & $55 / 4.7$ & 50.7 & 0.619 & $34 / 67$ & $33 / 8,50$ \\
\hline$\underline{\text { Sur do Sudão }}$ & $8,260,490$ & 619,745 & & & & & & & \\
\hline$\underline{\text { Swazilândia }}$ & $1,123,913$ & 17,363 & $80.9 \% / 78.3 \%$ & 1,297 & $79 / 3.6$ & 40.8 & 0.522 & $115 / 158$ & $144 / 52,50$ \\
\hline Tanzânia & $41,048,532$ & 945,087 & $77.5 \% / 62.2 \%$ & 339 & $126 / 2.6$ & 51.9 & 0.466 & $131 / 120$ & NA/15,50 \\
\hline$\underline{\text { Togo }}$ & $7,154,237$ & 56,785 & & & & & & & \\
\hline Uganda & $32,369,558$ & 236,040 & $76.8 \% / 57.7$ & 274 & $130 / 2.5$ & 50.7 & 0.446 & $112 / 129$ & $86 / 21,50$ \\
\hline Zâmbia & $11,862,740$ & 752,614 & N/A & 371 & $99 / 3.0$ & 41.7 & 0.43 & $90 / 94$ & $97 / 26,75$ \\
\hline Zimbabue & $11,392,629$ & 390,580 & $92.7 \% / 86.2 \%$ & N/A & $146 / 2.2$ & 42.7 & 0.376 & $159 / 155$ & $136 / 46,50$ \\
\hline
\end{tabular}

Leyenda: PIB per capita (2006 en dólares (\$)), Life (Exp.), (Expectativa de Vida 2006), Alfabetización (M / F - masculina / Femenina - 2006), Trans (Transparencia 2009 - Score = posición en la fila), HDI (Índice de

Desarrollo Humano), EODBR (Ease of Doing Business Rank - Junio de 2008 a mayo de 2009), SAB (Starting a Business - Junio de 2008 a mayo de 2009), PFI (Press Freedom Index 2009) Los datos no mostrados no están disponibles. Fonte: Africa Development Indicators 2008/2009: From the World Bank Africa Database AFRICAN DEVELOPMENT INDICATORS. World Bank Publications

Además, el desarrollo en África está correlacionado con esta economía informal. Entre la década de 1960 y la primera mitad de la década de 1970, los modelos económicos de desarrollo se basaban en la sustitución de importaciones y en el papel motor del Estado (Frieden, 2007). La crisis de la deuda externa de la década de 1970, iniciada en América Latina pero que rápidamente se extendió por los países africanos, llevó a los programas de ajuste estructural (PAE) y a una 
desvalorización del papel del Estado en el proceso de desarrollo en favor de la sociedad civil y el mercado.

Estos programas (PAE), desarrollados desde los años setenta, en casi todos los países de la OCDE, deberían haber contribuido a la reducción de la economía informal pero debido a las constantes inestabilidades políticas y guerras civiles los programas fracasaron y sus efectos no fueron los esperados. Por otro lado, los países del África subsahariana son países en desarrollo con una economía volátil y con Estados frágiles e inestables. De acuerdo con el reciente estudio de la OCDE (2016), la mayoría de las personas que viven en la pobreza residen en uno de los cincuenta países listados como Estados frágiles en el año 2015:

Aujourd'hui, $43 \%$ des personnes qui ne disposent pas de 1.25 USD par jour pour vivre se trouvent dans les 50 pays et économies figurant sur la liste des États fragiles de 2015 ... cette part pourrait passer à $62 \%$ d'ici à 2030 (OCDE, 2016:15)

De acuerdo con el mismo estudio estos estados frágiles se definen de acuerdo con cinco dimensiones: violencia (si son sociedades pacíficas o no); el acceso a la justicia para todos; la existencia de instituciones eficaces, responsables y abiertas; bases económicas de mercado aceptables; y capacidad para adaptarse a los choques y desastres de orden social, económico y ambiental. Sin embargo, los Estados frágiles tienen varias oportunidades para ir al encuentro del desarrollo. Desde esta perspectiva la apropiación por el país, el compromiso internacional y la innovación aparecen como factores cruciales para este desarrollo. Sin embargo, a los ojos de los analistas de la OCDE son necesarios esfuerzos multisectoriales para reducir la violencia, para reforzar la confianza en los gobiernos y para mejorar la calidad de los servicios públicos, lo que será fundamental para alcanzar la meta de los objetivos del milenio, del establecimiento de sociedades pacíficas y abiertas (OCDE, 2016 17). 
De acuerdo con los criterios descritos son varios los países del África Subsahariana inscritos en las listas de Estados frágiles (Figura 2). No obstante, casi una quinta parte de los Estados y economías frágiles se considera que están en el camino correcto para alcanzar la meta de la universalidad en la enseñanza primaria, en comparación con los países en desarrollo con Estados no frágiles, los cuales la mitad de ellos ya lo han logrado (OCDE, 2016: 40).

Figura 2 - Lista de Estados y economías frágiles

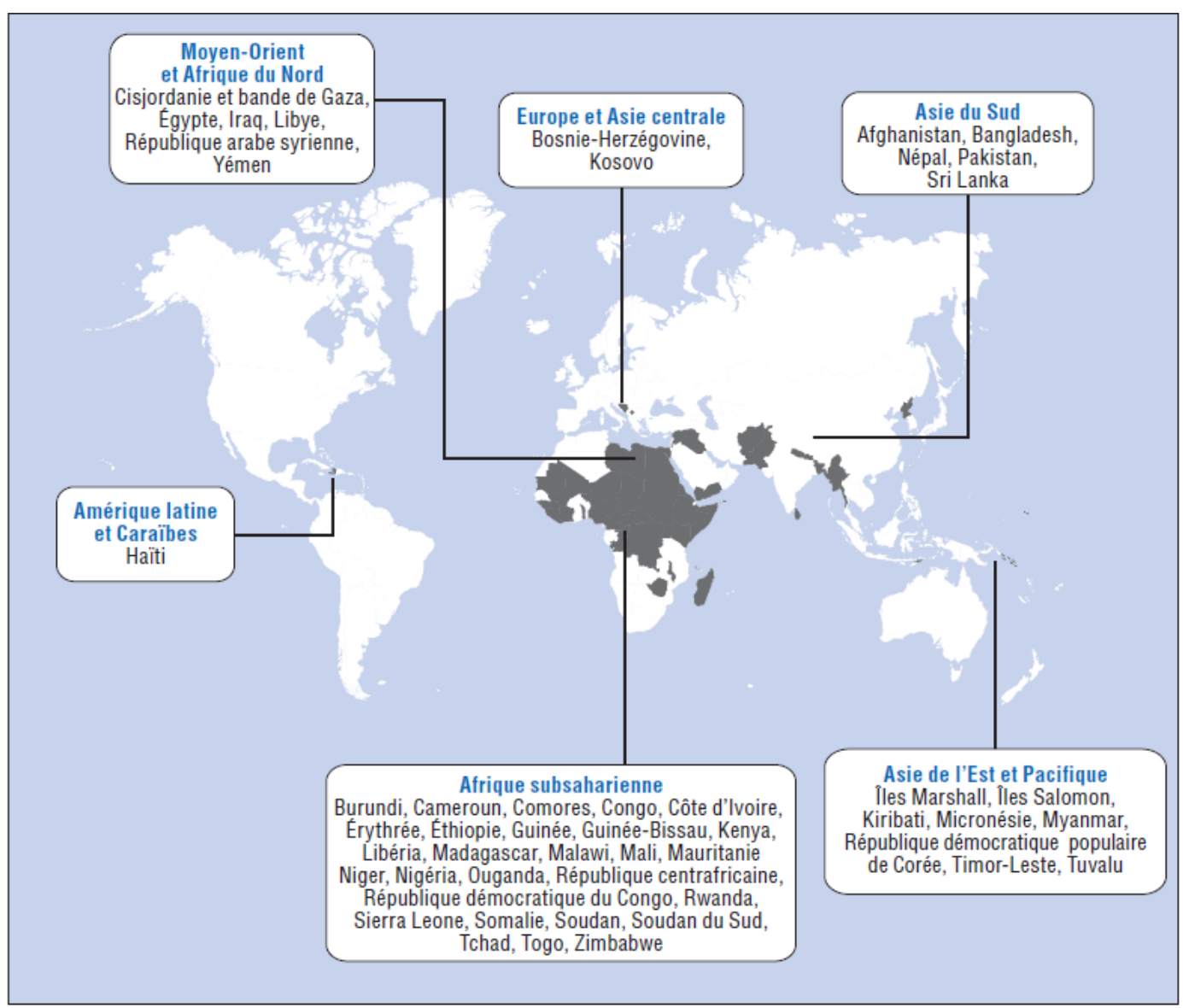

Fuente: OCDE, 2016:18

\footnotetext{
${ }^{3}$ La lista de estados y economías frágiles establecidos por la OCDE para este informe es el resultado de la compilación de dos listas: hay los países presentes en la lista armonizada de situaciones de fragilidad del Banco Mundial, el Banco Africano de Desarrollo y el Banco asiático de desarrollo, y Los países del índice de Estados frágiles (frágil de los Estados del Índice) del Fondo para la Paz, que se encuentran en "alerta" (índice superior a 90).
} 
La realidad de los países frágiles promueve la economía informal que daña la formación y educación de la población. La economía informal surge como una consecuencia de la incapacidad del poder gobernante para controlar la situación económica, social y política al distorsionarse los incentivos. "La existencia de la economía informal refleja un desajuste entre los intereses colectivos de la sociedad, entendidos por el Estado, y los incentivos individuales" (OIT, 2002). Por lo tanto, en los países del África subsahariana, el sector informal tiene un papel significativo en la creación de empleo y la generación de ingresos, así como en el desarrollo económico y social que distrae a parte de la población en la consecución de su educación. Por otra parte, la economía en el África subsahariana, se basa en tres elementos caracterizadores, en particular, de las familias, las empresas y el Estado. Sin embargo, la forma en que se articulan define el tipo de economía existente, es decir, el predominio de una economía informal. En esta economía la familia es el núcleo central de estas sociedades pues proporciona la mano de obra y asegura la producción de subsistencia, acciones ambas que pueden entorpecer la formación y educación de los más jóvenes.

La división de trabajo en el mundo rural y en el urbano, menos desarrollado, puede ser diferente en el centro y en la periferia, lo que implica que la mujer tiene que suministrar los productos frescos como hortícolas y, en algunas sociedades, el pescado también. Por otro lado, el hombre proporciona los bienes de base, como el arroz o el maíz, así como la carne.. Por lo que se refiere al tejido empresarial, éste está aún en expansión y utiliza tecnologías aún poco desarrolladas y rudimentarias y cuyos modelos de gestión están determinados por las formas de proximidad social. A su vez, las empresas estatales siguen siendo predominantes en la mayoría de las economías de los países africanos. Siguen desempeñando el papel que asumían después de la independencia de estos países, es decir, tienen el cometido de acelerar el desarrollo económico. Este cometido está en relación al hecho de

Fuentes: lista armonizada de situaciones de fragilidad 2014 establecidas por el Banco Mundial, el Banco Asiático de Desarrollo y el Banco Africano de Desarrollo, disponible en la siguiente dirección: http://siteresources.worldbank.org/EXTLICUS/Resources/511777-1269623894864/

HarmonizedlistoffragilestatesFY14.pdf; El Fondo para la Paz (2014), "Fragile Índice Unidos 2014", el Fondo para la Paz, Washington, disponible en la siguiente dirección: http://ffp.statesindex.org . 
que ante las situaciones sociales y económicas depresivas, como las que prevalecen en estos países, las empresas estatales constituyen un medio de transferencia y redistribución de los bienes del Estado, dejando en un segundo plano la lógica de la rentabilidad y de la acumulación. Son estas empresas, que absorben la mano de obra calificada y desempleada y crean ayudas, las que por el contrario están a menudo más expuestas a las crisis de liquidez y de gestión, así como a situaciones de ineficiencia (Hugon, 1999).

Por el contrario, las empresas multinacionales pueden instalarse y obtener beneficios sustanciales sin entrar en mayores valoraciones sociales. Se suelen instalar en el sector energético, agrícola y en el sector terciario (transportes, comercio, banca). Aunque se enfrentan a un ambiente institucional burocrático y con grandes deficiencias, disfrutan de relaciones de clientelismo, debido a las relaciones cercanas que tienen con los poderes políticos. Por otro lado, intentan crear un medio ambiente beneficioso para su propio funcionamiento, adaptándose a las condiciones socioeconómicas y políticas, al asumir el papel, que es tradicionalmente estatal, de suministro de bienes y servicios colectivos como la energía, las infraestructuras básicas, escuelas, hospitales, etc. y los medios de transporte.

Con los Programas de Ajuste Estructural, anteriormente denominados de estabilización económica, se creó la lógica de "menos y mejor Estado" reduciendo, efectivamente, el papel de las empresas de propiedad estatal, creando así otros tipos de empresas privadas o con presencia accionarial del Estado. En este contexto de reducción de empresas estatales y expansión de multinacionales, las empresas del sector informal del mercado han proliferado en los últimos años, pues son mucho más flexibles frente a las constantes situaciones de crisis e inestabilidad socioeconómica. Estas empresas, que quedan al margen de la política industrial del Estado, normalmente se integran en grupos que implican alguna relación de pertenencia que condicionan su funcionamiento, al basarse en reglas consuetudinarias, jerárquicas y paternalistas. 
En el contexto de la guerra fría muchos de los países de la zona que analizamos asumieron el compromiso del grupo de los denominados países "no alineaados", procurando sacar dividendos de la propia situación en el plano de la cooperación internacional, reforzando al mismo tiempo su papel en el sector social (educación, salud, etc.) y de creación de infraestructuras físicas. Pero los Estados en estos países acaban por no asumir sus funciones par garantizar tanto una seguridad social eficaz, como una eficiente actividad administrativa, de modo que terminan delegando en la economía informal estas funciones. Esta situación condiciona el mercado de trabajo, ya que en muchas naciones africanas, una parte considerable de la fuerza laboral trabaja en el sector informal en diferente grado,así por ejemplo en Sudáfrica representa el 31\% del total de empleos, pero en el Benín llega al 95\% (Walther, 2006).

El sector informal representa una proporción considerable del Producto Interior Bruto (PIB), aunque existen variaciones de país a país. Según Walther, Sudáfrica representa 1/3 de su PIB, en Benín, Camerún y Senegal representa entre el 50\% a $60 \%$ del PIB (Walther, 2006). Independientemente de que no esté regularizado el sector informal representa un importante papel en las economías de los países del África subsahariana.

Para entender la situación actual hay que partir de que a principios de los años setenta el modo de producción capitalista atravesó una crisis que afectó profundamente el mundo de trabajo. Esto fue porque el sistema capitalista de producción sufrió una fuerte desestructuración y, concluyentemente, se vio obligado a aplicar medidas para mantener su ciclo de reproducción, afectando tanto la forma de ser de la clase trabajadora, como a las acciones y prácticas de la misma (Antunes, 2000). El resultado fue un aumento de la precarización de las relaciones y condiciones de trabajo y un crecimiento de los índices de desempleo.

En este escenario, desde el inicio del milenio se están buscando nuevas formas de creación de empleo y mejora del rendimiento del trabajo. Esta perspectiva puede 
verse reflejada en la nueva Recomendación 195 de la OIT (2002), en la que se establece que "los miembros deberían definir políticas de desarrollo de los recursos humanos, de educación, de formación y de aprendizaje permanente para transformar las actividades de la economía Informal en trabajos aceptables plenamente integrados en la vida económica; Las políticas y los programas deberían elaborarse con el fin de crear puestos de trabajo adecuados y ofrecer oportunidades de educación y formación, así como la validación de los conocimientos y las competencias adquiridas para ayudar a los trabajadores y los empresarios en la economía informal."4

El sector informal tiene, de esta forma en África, una importancia de carácter estructural en el desarrollo económico, debido a su carácter masivo. Este tipo de economía tiene raíces profundas en la historia de África, lo que ayuda a explicar la gran importancia en la actualidad y las consecuencias para el desarrollo humano a través de la cualificación de la mano de obra. Para resolver el problema del sector informal es necesario desarrollar los recursos humanos cualificados, para que sean más conscientes de sus derechos y que contribuyan al desarrollo de prácticas empresariales más competitivas e internacionalmente aceptadas. En este sentido, el papel de la educación adquiere una importancia muy significativa, y no se puede obviar que se hace necesario el desarrollo de una educación más especializada y más técnica, por tanto basada en el nivel de la enseñanza superior.

En un mundo globalizado la necesidad de formar técnicos en el nivel de la enseñanza superior es mayor, ya que tienen que competir con profesionales calificados del mismo nivel en el mercado internacional. Antes de los años setenta, esta mano de obra cualificada no era tan necesaria para hacer frente a los desafíos económico-sociales, regionales y globales. La elección del tipo de desarrollo económico se efectuaba, esencialmente, siguiendo un modelo de desarrollo autárquico o de sustitución de importaciones, pero, desde el final del siglo XX, existe una mayor necesidad de políticas de desarrollo en función de la

\footnotetext{
${ }^{4}$ Recomendación 195 da OIT (art. 3, d).
} 
globalización. Ahora bien, teniendo en cuenta las condiciones específicas mencionadas, son varios los desafíos a los que la educación superior africana se enfrenta a la hora de constituir instituciones más eficientes y eficaces. Para ello, es necesario que evolucionen en lo que se refiere a su gestión económica, así como deben actuar para gestionar mejor sus herencias culturales y políticas.

De esta forma, se hace imprescindible una mayor inversión en el sector postsecundario y el verdadero reconocimiento por parte de los distintos Actores, que la enseñanza terciaria es crucial para el desarrollo actual en África. En realidad, durante un período de tiempo considerable las principales instituciones financieras internacionales consideraron que la educación superior en África era innecesaria y, por consiguiente, era tratada como una formación no prioritaria. El Banco Mundial consideraba este tipo de enseñanza como un servicio público costoso y competidor con los demás niveles de enseñanza en el acceso a los recursos presupuestarios, por lo que, a principios del siglo XX, se constataba una notable resistencia al financiamiento de proyectos en el ámbito de la enseñanza superior.

En los últimos años se ha dado a un cambio gradual de la posición de las organizaciones internacionales en relación con la prioridad que debe darse a la enseñanza superior. Existe una creciente bibliografía en la literaria académica, señalando que la enseñanza superior es un factor crítico en el crecimiento económico y la competitividad de un país (Bloom, Canning, y Chan, 2006, Douglass, 2009; Johnson, 2002; Lin, 2009; Marshall, 1995; Mazzoleni;, 2008, Banco Mundial, 2002, en Nyangau, 2014). La evidencia empírica indica que las recientes economías industrializadas, como Brasil, China, India, Corea, Singapur y Taiwán, también se enfrentaban a problemas similares a los del África subsahariana, en particular los altos porcentajes de analfabetismo, el bajo PIB, la falta de financiación para la I+D y la fuga de cerebros (Johnson, 2002; Marshall, 1995; Mazzoleni, 2008; MOE, 2008; MOE, 2012; MoS \& T, 2008; Zweig \& Rosen, 2003, in Nyangau 2014). En todos ellos el desarrollo de políticas que 
favorecen la enseñanza superior y una mayor inversión, por parte de los gobiernos y el sector privado, en la educación ha permitido crear las condiciones ideales que desempeñaron un papel central en el crecimiento económico liderado por la innovación (Bloom, Canning, y Chan , 2006, Johnson, 2002, Lin, 2009, Mazzoleni, 2008, in Nyangau, 2014).

De acuerdo con el estudio efectuado por Bloom et all (2006), financiado por el Banco Mundial a la Universidad de Harvard, se concluye que la competencia económica es más eficiente cuando es promovida por sociedades basadas en el conocimiento y en el contexto de una economía globalizada. Ello llevó a la reconsideración del papel de la enseñanza superior en el crecimiento económico. De esta forma, el Banco Mundial reconoce el importante papel de la enseñanza superior en el crecimiento económico (Bloom et all, 2006), recomendando la posibilidad de facilitar el acceso a este tipo de enseñanza a través de los presupuestos del Estado.

No obstante, defiende el principio de la competencia entre las universidades públicas y privadas con respecto a la financiación pública, aunque no equilibra sus diferencias cuando se consideran factores como la naturaleza de su misión y el público objetivo. El investigador del Banco Mundial, Donald R. Winkler (1993), corrobora con esta posición considerando que esta competencia debe medirse a través de políticas públicas y mecanismos que promuevan el incentivo a la productividad intelectual y la calidad de la enseñanza:

... no existe justificación alguna desde el punto de vista de la economía para tratar en forma diferente a las universidades públicas de las privadas en lo relativo al financiamiento. (Winkler, 1993:106).

Por lo tanto, un enfoque de reconocimiento de la educación terciaria como promotora del desarrollo en África, a pesar de que se sigue dando prioridad a la 
educación primaria universal y a la enseñanza secundaria, cada vez es tenido más en cuenta por los expertos como un carácter importante en el progreso de los países en Desarrollo. Un reciente informe del Banco Mundial corrobora esta idea demostrando que "descuidar la educación terciaria podría perjudicar seriamente las perspectivas de desarrollo a largo plazo de los países de la AS" (Banco Mundial, 2010: 24), afectando al mismo tiempo el progreso en la consecución de los Objetivos del Desarrollo del Milenio, muchos de los cuales requieren, para su implementación, formación de nivel superior. Este estudio "estableció, de forma convincente, la relación entre la acumulación de capital físico y la productividad total de los factores (el crecimiento combinado de la productividad del capital y de la fuerza de trabajo), que están interconectados" (Banco Mundial, 2010: 23), evidenciando que los retornos privados y sociales resultantes de la inversión en educación terciaria se han ido incrementando notablemente en los países de bajos ingresos, junto a los que se han registrado en la educación primaria.

El mismo estudio avanza además que "cada año más de educación puede producir retornos de 10 a 15 por ciento en forma de retornos salariales más elevados" (Banco Mundial, 2010: 23). En suma, al aumentar el nivel y la calidad de la educación, los países de la AS crean condiciones para estimular la innovación, promover y diversificar la creación de productos y servicios, maximizando los retornos de bienes de capital a través de una asignación y gestión más eficientes de los recursos públicos.

Más recientemente, la visión de los Estados Miembros, reportada en la Conferencia de las Naciones Unidas en 2014, coincide con esta perspectiva, concluyendo que la educación es un derecho de todos los niños y adolescentes así como el hecho de que el tipo de desarrollo humano que implica respeta especialmente los derechos humanos:

All children and adolescents have a right to education and must have a safe environment in which to learn. Human 
development also means respect for human rights. (UN Report, 2014:21)

Por otra parte, estas capacidades se consideran preponderantes para el desarrollo de un entorno global de trabajo seguro basado en la tecnología:

It is essential that young people receive relevant skills and quality education and lifelong learning, from early childhood development to post-primary schooling, including life skills and vocational education and training, as well as science, sports and culture. Teachers must be given the means to deliver learning and knowledge in response to a safe global workplace, driven by technology. (UN Report, 2014:21)

Existe, claramente, el reconocimiento de que debe existir una mayor inversión en la calidad de la enseñanza, así como en la garantía de acceso universal y equitativo para todos los niños y adolescentes a la escuela. Sin embargo, es necesario evaluar, con mayor precisión, si las competencias adquiridas en la escuela corresponden a las necesidades locales, no descuidando un mundo cada vez más globalizado e internacionalizado haciendo, de esta forma, frente a las necesidades del siglo veintiuno:

Investing in the quality of education and ensuring a sustainable source of funding are also essential. Stagnation in education progress has profound consequences for the children and adolescents who cannot go to school. As the world looks beyond 2015, it is crucial to reflect on and address the root causes of limited progress in youth literacy in some parts of the world. It is also necessary to explore new approaches to directly assess whether children have mastered the skills they are taught and whether they are being taught the skills they need in the twenty-first century. (United Nations (2015). The Millennium Development Goals Report. New York ) 
Al igual que la calidad es importante mencionar que es necesario una mayor inversión en investigación, ya que la innovación y la tecnología permiten el desarrollo empresarial en países que por su estructura de las pequeñas y medianas empresas, donde la contratación de trabajadores altamente formados es la manera de acceder a la tecnología. Un aumento de la inversión en tecnología generara nuevos empleos y condiciones favorables al desarrollo económico sostenible y mejora las condiciones de vida de la población:

Innovation and investments in sustainable and resilient infrastructure, settlement, industrialization, small and medium enterprises, energy and technology can both generate employment, and remedy negative environmental trends. An enabled, properly regulated, responsible and profitable private sector is critical for employment, living wages, growth, and revenues for public programmes. Transforming business models for creating shared value is vital for growing inclusive and sustainable economies. (UN Report, 2014:22)

En efecto, un desarrollo inclusivo, que implica una educación creciente en todos los niveles, se considera un factor primordial para la prosperidad de los países en desarrollo, para crear condiciones favorables para el desarrollo de economías fuertes, inclusivas y transformadoras. $\mathrm{Na}$ verdad, el crecimiento económico debería conducir a la prosperidad compartida. Como tal, la fortaleza de una economía debe medirse por el grado en que satisface las necesidades de las personas, y en la forma sostenible y equitativa de hacerlo. Es necesario un crecimiento inclusivo, basado en empleos decentes, medios de vida e ingresos reales crecientes para todos y medido de maneras que vayan más allá del PIB y respondan por el bienestar humano, la sostenibilidad y la equidad. Garantizar que todas las personas, incluidas las mujeres, las personas con discapacidad, los jóvenes, las personas de edad y los migrantes tengan un empleo decente, protección social y acceso a servicios financieros, será un sello distintivo del éxito económico (UN Report, 2014:22). 
De acuerdo con Nelson Mandela (2005) "Las instituciones de educación superior tienen la obligación de abancar sus puertas. Las que ofrecen la educación más rigurosa es que tienen la mayor obligación. Usted tiene la calidad, la habilidad, el apoyo necesario para presionar por ello "(discurso en la universidad norteamericana de Amherst). De hecho, la universidad tiene la misión transecular de generar, conservar, transmitir y ritualizar una herencia cultural de saberes, ideas y valores que promueven el desarrollo de la sociedad (Silveira, L. et al, 2005).

Teniendo en cuenta el reconocimiento de la importante función de la enseñanza superior, en las diversas dimensiones de las sociedades y en una economía globalizada, la nueva agenda de desarrollo apunta a la necesidad de crear orientaciones políticas coherentes en todos los niveles mediante la reforma de los mecanismos globales de gobernanza y una asociación global renovada y efectiva para un desarrollo sostenible basado en los principios de solidaridad, cooperación, responsabilidad mutua, así como en la participación de todos los gobiernos y stakeholders, lo que implica un papel reforzado de los Actores de la Cooperación Internacional, que a la fecha, han venido a devaluar el relevante papel de la enseñanza terciaria, tal como indican las Naciones Unidas:

\begin{abstract}
All inputs have underscored the need to integrate economic, social and environmental dimensions across the new agenda. To make this happen, they want normbased policy coherence at all levels, corresponding reform of global governance mechanisms, and a renewed effective global partnership for sustainable development. These, they tell us, should be based on solidarity, cooperation, mutual accountability, and the participation of governments and all stakeholders. (UN Report, 2014:16)
\end{abstract}

De acuerdo con las premisas anteriormente presentadas y teniendo en cuenta las más recientes preocupaciones en el desarrollo de las capacidades humanas, el presente proyecto de investigación quiere averiguar si existe la percepción de la necesidad de reforzar la Cooperación Internacional en el área de la Enseñanza Superior como respuesta a los desafíos globales y regionales, en el sentido de 
contribuir al desarrollo en África, con especial enfoque en el África Subsahariana, como ya se ha explicado. Sin embargo, ¿podríamos cuestionar hasta qué punto este discurso oficial tiene un verdadero reflejo en la actividad cotidiana de las instituciones internacionales, o si, tal vez, se trata de un discurso meramente oficial? En la presente investigación tuvimos el cuidado de conocer la perspectiva de los agentes que toman las decisiones, con el fin de percibir cuál es su percepción a este respecto una vez repasada la literatura que las organizaciones internacionales y las europeas ha generado.

El debate en cuestión no se refiere al hecho de tener que elegir entre invertir en la enseñanza superior o en educación primaria y secundaria. El debate pasa por percibir cuánto se debe invertir en la enseñanza superior en un país en desarrollo con carencias en casi todas las esferas de la vida cotidiana. Sin embargo, en ninguno de los países objeto del estudio, una población, por pequeña que sea, tendrá suficiente formación para ir a la Universidad y deseará ir a la universidad. La respuesta de las autoridades nacionales de educación pasa por la creación de un sistema nacional de enseñanza superior o por la creación de ayudas que permitan que las personas puedan proseguir sus estudios en universidades propias o de otros países. Si existen universidades nacionales los académicos expatriados podrán volver y formar un sistema propio de enseñanza superior. Una vez más queremos indicar que la formación de ese sistema es inevitable, siendo que la clave saber cómo y cuánto invertir en la enseñanza superior. Sin embargo, la precariedad de estos sistemas es tan grande, en el África subsahariana, que la primera cuestión es percibir si los actores nacionales e internacionales están determinados a realizar y mantener esta inversión y el grado de inversión mínimo necesario.

En conclusión, en la investigación se discuten las teorías de desarrollo, especialmente en lo que concierne al desarrollo de políticas que apunte a la necesidad de una mayor inversión en la evolución del sistema de enseñanza superior en los países subdesarrollados. Este tema es actualmente un debate de gran relevancia para las autoridades europeas. A este respecto, uno de los 
objetivos fundamentales es mostrar las iniciativas realizadas y, especialmente, los argumentos que los propios agentes tienen sobre el tema en cuestión. En este sentido, se realizaron encuestas / entrevistas a los agentes responsables de la ayuda a la cooperación con universidades subsaharianas en relación al juego de la enseñanza superior y la cooperación en este ámbito..

\section{Directrices y objetivos para una agenda política de cooperación}

La finalidad del estudio consiste en reunir información de las instituciones y los diversos actores para el desarrollo, a nivel regional, nacional e internacional del apoyo al desarrollo de la educación superior. El objetivo es averiguar de qué forma se podrá actuar en proyectos futuros de cooperación, no sólo para colmar las necesidades que se ven, sino también para unir y formar proyectos de colaboración con mayor cohesión entre los responsables políticos, entre las agencias donantes y las universidades africanas. Con el presente trabajo se tiene el propósito de contribuir a un mejor entendimiento de lo que se está haciendo para crear nuevos programas y políticas de desarrollo en el ámbito de la investigación y la educación, trascendiendo así la creencia de que la enseñanza superior no contribuye al desarrollo del desarrollo capital social, cultural y económico y, por consiguiente, que no contribuye a la reducción de la pobreza.

Se espera contribuir a nuevos debates e inspirar los responsables políticos, los donantes y a la comunidad académica para decidir acciones concretas, así como a debatir los Objetivos del Desarrollo Sostenible globales para 2030 (ODS) que han tenido éxito en los Objetivos del Milenio para el Desarrollo (ODM) y, en particular, en lo que concierne a la Educación y la Enseñanza Superior, una vez que de acuerdo con el Objetivo cuatro los Actores Internacionales se comprometen a: 
.... asegurar la educación inclusiva y equitativa y de calidad, y promover oportunidades de aprendizaje a lo largo de la vida para todos, así como reconocen que es necesario aumentar sustancialmente el contingente de profesores cualificados, incluso a través de la cooperación internacional para la formación de profesores, en los países en desarrollo, especialmente los países menos desarrollados y los pequeños Estados insulares en desarrollo. (Naciones Unidas, 2015: 24).

Es crucial que se desarrolle una nueva actitud que encare la enseñanza superior como una herramienta necesaria para formar capital humano, especialmente a través de la formación de profesores a todos los niveles, incluso para la enseñanza primaria y secundaria, que generarán profesionales cualificados, así como una nueva generación de gestores y líderes que conducirán las trayectorias de desarrollo de estos países.

De acuerdo con los datos publicados por la UNESCO (Instituto para la Educación - Higher Education Data) el porcentaje actual de la tasa de inscripción en la enseñanza superior en el África Subsahariana (que se estima en 6\%) es todavía muy baja (la más baja del mundo) cuando se compara con la media global (26\%), lo que indica que habrá un largo período a recorrer y cuyos esfuerzos invertidos tendrán que ser redoblados para que el desafío de desarrollo sea verdaderamente alcanzado (UN, 2010).

Para ello es necesario superar algunos de los problemas con los que se enfrentan las universidades africanas, en particular la creciente demanda de enseñanza terciaria, la falta de inversión pública, la retención de estudiantes cualificados en el territorio nacional mediante la creación de oportunidades de trabajo con mejores condiciones y una enseñanza de mayor calidad.

Las acciones de colaboración universitarias se presentan como una forma estratégica para el desarrollo de estas capacidades. Si su estructura es eficiente y 
sostenible, estas alianzas pueden contribuir a generar capital intelectual, capaz de desarrollar innovación e investigación, colocando a las universidades en el centro del desarrollo económico regional, nacional e internacional como agentes de transferencia de conocimiento.

De acuerdo con el informe de NESTA (Kitson et all, 2009), las universidades deben considerarse como poderosos actores económicos, ya que: la forma en que las universidades interactúan con las empresas está evolucionando y mejorando el proceso de transferencia formal del conocimiento. En este sentido nos encontramoscon las siguientes realidades: a) el desarrollo de empresas spin-out basadas en el beneficio mutuo a través de patentes y licencias, b) que las universidades se ven obligadas a demostrar el beneficio público y económico de los gastos en ciencia, tecnología e investigación, c) que los gobiernos locales deben repensar cómo aplicar las regulaciones de planificación para las universidades, dando prioridad a las solicitudes para desarrollar lugares donde las empresas y las universidades puedan interactuar, y d) por último, el sistema de financiación debe tener en cuenta la importancia de la interacción universidadempresa.

El mismo informe concluye que las universidades tienen una contribución multifacética en la economía, destacando su importancia como fuente de conocimiento, de funcionarios cualificados y como centros de agrupaciones económicas regionales. Por lo tanto, surgen tres preguntas a las que queremos responder en esta tesis. La primera pasa por percibir la razón por la que África todavía permanece 20 puntos porcentuales por debajo de la tasa media mundial al nivel de la inscripción de estudiantes de enseñanza superior? La segunda pasa por entender si esta diferencia de 20 puntos puede compensarse con las colaboraciones y ayudas al desarrollo para la enseñanza superior procedente de los países desarrollados, en particular en Europa. Por último, si las asociaciones para la colaboración para apoyar el desarrollo de la enseñanza superior en África pueden considerarse un mecanismo que desencadene el desarrollo económico 
La clave para entender la importancia de la existencia de sistemas nacionales de enseñanza superior de una cierta dimensión pasa por comprender que son vitales para el desarrollo de la clase media y, a su vez, para contribuir a una sociedad informada y modernizada, cuya población se vuelve más exigente, y a la vez que solicita en mayor medida una educación superior de calidad en su país para garantizar su ascenso y mejores condiciones de vida. En un estudio efectuado a los países de América Latina, se constató que el crecimiento de la clase media estaba estrechamente vinculado al nivel educativo de esta población, en la medida en que los niveles de pobreza de la población más habilitada bajan, mejoran sus condiciones de vida a través de empleos más estables en el sector formal de la sociedad, pasando a tener 1 capacidad financiera suficiente para habitar en zonas urbanas (Ventura, 2013). Esta urbanización tiene, a su vez, un impacto positivo en el crecimiento económico debido al proceso de aglomeración que se traduce en una mayor demanda por servicios y productos fomentando las industrias y las empresas, así como promueve la modernización de las infraestructuras:

\footnotetext{
Existe una relación directa entre la urbanización y el crecimiento económico. Son dos procesos que se retroalimentan. Debido a los beneficios de la aglomeración y las economías de escala, las empresas de las ciudades son generalmente más productivas. Además, gracias al mejor acceso a las infraestructuras básicas, los residentes urbanos tienen más facilidades para realizar actividades económicas. Finalmente, la urbanización está propiciando la inversión en carreteras, edificios, sistemas de canalización de agua y otras infraestructuras. Con el $40 \%$ de su población viviendo en ciudades, África tiene una tasa de urbanización mayor que la India (30\%) y muy cercana a la de China (45\%). Ventura (2013: 5)
}

Por lo que se refiere a las cuestiones de género, también las mujeres con más educación consiguen mejorar sus condiciones de vida y obtener una mayor conciencia cívica de sus derechos, integrándose con mayor facilidad en el mercado laboral, tal y como se indica en el el estudio de Ferreira et. al (2013). Se tata de un trabajo que pone el énfasis en el hecho de que el mantenimiento de la clase media 
está interconectado con la educación, en la medida en que el conocimiento pasa de generación en generación, especialmente cuando las madres están educadas, y que los hijos de países con mayor grado de escolaridad proseguir los estudios, principalmente aquellos cuyos de padres cuentan con estudios superiores, garantizando, de esta forma, la cadena generacional educativa. Dicho estudio contribuye, en términos comparados, al reconocimiento y debates más recientes en torno al papel de la educación en el buen funcionamiento de la economía a través de la actuación de las instituciones democráticas, tanto a la hora de dar la prioridad a las políticas educativas y como por su contribución a la creación de sociedades más equitativas y justas:

...las personas que pasan a formar parte de la clase media tienen un nivel educativo superior al de los que han dejado atrás. También es más probable que vivan en zonas urbanas y tengan un empleo en el sector formal. En el caso de las mujeres de clase media, es probable que tengan menos hijos y que estén más integradas en la fuerza laboral que las mujeres de los grupos pobres o vulnerables. Sin duda este informe alimentará los debates en torno a las implicaciones de estas nuevas tendencias para el funcionamiento de la economía, para las prioridades de las políticas y para la actuación de las instituciones democráticas. Hasan Tuluy, Vicepresidente, Región de América Latina y el Caribe en Ferreira et al (2013: xii)

Existe una correlación positiva entre una clase media sólida, el capital humano calificado y la competitividad de una economía. Una mano de obra cualificada permite la integración de los países en desarrollo en el mercado intencional a través de la maximización de la utilización de los recursos tecnológicos. Ello, a su vez, contribuye a la competitividad de la economía y a la exportación de productos. Martín Arnaiz matiza estos aspectos en el sentido contrario:

La reducida dotación de capital humano limita las ventajas que se derivan de la integración en los mercados, ya que supone un obstáculo para el proceso de difusión tecnológica al ser muy amplia la brecha entre el 
conocimiento incorporado en los artículos importados y el disponible en la sociedad. Se ven mermadas las posibilidades de incorporar tecnología y mejorar el producto, lo que resta atractivo a los productos exportados. Martin Arnaiz (2011:109).

Ahora bien, ante los países en desarrollo todo este proceso depende de las ayudas exteriores a través de la cooperación internacional, que desempeñan un papel preponderante en todos los procesos hasta ahora descritos, esencialmente, en lo que se refiere al cumplimiento de los ODM. Específicamente, al desarrollo de un sistema educativo equitativo y universal, así como el hecho de reforzar el reconocimiento de la importancia de la enseñanza superior como generador de sociedades más estables, más desarrolladas que hacen frente a la globalización y a la internacionalización de los mercados.

Una vez explicitadas las relaciones de causalidad entre capital humano cualificado y crecimiento económico, nos proponemos identificar a continuación el objeto y la contribución de la presente tesis a los debates actuales sobre la materia.

\section{Contribución de la investigación}

Ningún análisis reciente duda de que la enseñanza superior y las universidades, en particular, son esenciales para el desarrollo económico de las sociedades del conocimiento propias de un mundo desarrollado y por ello deben formar parte de la agenda de los responsables políticos de los países en desarrollo y de los actores internacionales para la cooperación y el desarrollo. Según Goddard (2009) todas las universidades financiadas a través de fondos públicos tienen un compromiso cívico con la sociedad a nivel local, nacional y global, en el sentido de vincular la esfera social a la económica. Las directrices políticas y de las agencias de cooperación indican que este compromiso debe existir a nivel institucional y debe comprender a todos los actores implicados. De esta forma la educación superior 
proporciona nuevas oportunidades a la sociedad y a todos los que forman parte de ella:

The engaged civic university which I propose is one which provides opportunities for the society of which it forms part. It engages as a whole with its surroundings, not piecemeal; it partners with other universities and colleges; and it is managed in a way that ensures it participates fully in the region of which it forms part. While it operates on a global scale, it realises that its location helps form its identity and provides opportunities for it to grow and help others, including individual learners, businesses and public institutions, to do so too. Goddard (2009: 5)

Este compromiso cívico de la universidad debe tener en cuenta las necesidades locales y nacionales para crear nuevas oportunidades, tal como menciona Goddard (2009: 5): "La evolución de las redes de las colaboraciones corresponde a las necesidades y la oportunidad de cada economía en las diferentes zonas de un país y responderá a las necesidades de las naciones". Por otro lado, el apoyo público a las universidades tiene en cuenta los esfuerzos para educar a los ciudadanos y para la transferencia y producción del conocimiento, que debe estar articulado con las necesidades públicas, en particular con el desarrollo económico que requiere capacidades técnicas y ciudadanos bien formados:

Public support for universities is based on the effort to educate citizens in general, to share knowledge and to produce it in accord with publically articulated purposes... including economic development which requires technical expertise and the general education of participants. Goddard $(2009,9)$

En resumen, el autor concluye que existe una misión nacional y global llevada a cabo conjunto con las universidades, pero se considera también a las universidades importantes instituciones regionales que contribuyen al desarrollo de las regiones donde se insertan. Sin embargo, este progreso para ser eficiente debe contar 
también con el apoyo de las empresas, los gobiernos locales, las organizaciones de desarrollo, las ONG y la población en general:

Universities inherently have a national and global role, but their status as important regional bodies with a uniquely broad remit is vital and needs to be developed. This is not solely a matter for universities. Companies, local government, development organisations, NGOs and the public have much to gain from thinking about how to interact more effectively with local universities. Goddard (2009:35)

Las universidades constituyen un importante vector de la sociedad económica global a través del intercambio de conocimiento a nivel internacional de recursos humanos altamente cualificados que crean y atraen negocios de valor añadido y son actores indispensables en las redes regionales que desarrollan las estrategias económicas de desarrollo. Teniendo en cuenta las características propias de cada región para maximizar sus recursos endógenos uno de los estudios de NESTA indica:

Universities increasingly provide important national and regional links into the global knowledge economy. They exchange knowledge, gather intelligence and facilitate international flows of highly-skilled people. They are also important actors in regional networks, and help lead the design and delivery of economic development strategies. NESTA (2007:1)

La creación de políticas, por parte de los gobiernos que promueven estas interacciones, es necesaria para que las universidades desempeñen todos sus papeles, desde los más tradicionales a los más modernos, es decir, la creación de recursos humanos capaces de innovar y de ir al encuentro de las necesidades sociales y económicas propias del siglo veinte y uno: 
Government should encourage greater interaction between universities and the wider economy and society, and ensure that research funding encourages innovation. Universities have traditionally had three main missions: undertaking research; teaching; and transferring knowledge. NESTA (2007:1).

Pero la posición de partida de muchos analistas pasa por la persuasión de que fortalecer la enseñanza superior en países en desarrollo tiene un costo de oportunidad en comparación con la enseñanza primaria y la enseñanza secundaria. El objetivo de este estudio no es dilucidar esta cuestión, sino antes percibir si las instituciones y los actores europeos e internacionales responsables de los apoyos y estrategias para la colaboración al desarrollo de los sistemas de enseñanza superior en África creen que esta ayuda contribuye efectivamente al desarrollo económico, así como la noción de su real contribución al crecimiento del sistema de educación superior en África y el potencial efecto sobre el crecimiento económico de estos países en desarrollo. De esta forma, el objeto de estudio de esta investigación pasa por comprender de qué forma las alianzas entre las universidades europeas con las africanas permiten el crecimiento económico en los países en desarrollo, a través del incremento de la educación al nivel superior, así como percibir si los actores tienen una percepción de que este objetivo se está alcanzando o no.

En primer lugar nos proponemos hacer un estudio teórico de este proceso de alianzas y ayudas al desarrollo. Se tiene la intención de detectar cuáles son los factores que contribuyeron al desarrollo de las instituciones de enseñanza superior a lo largo de las varias etapas históricas de la evolución de la enseñanza superior en África. Para ello, se pretende analizar cada una de estas fases dando especial enfoque a la fase de la internacionalización y modernización a la luz de los conceptos propios del siglo XXI. Nos proponemos, idénticamente, aplicar el modelo CATWOE con el fin de entender y analizar los preceptos anteriormente descritos, describiendo y caracterizando el modelo conceptual en el ámbito de la enseñanza superior teniendo en cuenta los diferentes actores (internos y externos) 
y la relación con las diferentes etapas del sistema de colaboración al desarrollo en el contexto del África subsahariana. El modelo CATWOE permite hacer una lista exhaustiva para comprobar e identificar todos los agentes del sistema. Una vez concluida esta fase iniciaremos la identificación de las relaciones y flujos de información. Por último, los agentes serán entrevistados para obtener la información esencial del sistema descrito, es decir, el sistema de alianzas entre las universidades africanas y las autoridades europeas e internacionales.

Se tiene la el objetivo de que este trabajo pueda contribuir a comprender y explorar el papel de los acuerdos de colaboración en los países en desarrollo, especialmente en el África subsahariana. En particular, se espera poder contribuir al debate sobre la importancia del papel de estas acciones de colaboración europeas con estos países, teniendo en cuenta que, desde el inicio del siglo XXI, la pobreza es uno de los principales problemas que afecta a gran parte de su población que tiene carencias en la alimentación, el agua potable, la energía, la asistencia médica y el alojamiento, y no pueden beneficiarse de una vida decente. De igual manera, estas carencias impiden la posibilidad de participar activamente en el proceso de expansión y disfrute de las libertades. En este contexto la cooperación internacional y la inversión extranjera se convierten en los principales pilares de desarrollo en países como los del África Subsahariana. Es posible considerar que la educación en general y la enseñanza superior en particular, han contribuido bastante favorablemente a la formación de clases medias y de una élite nacional, es decir, han contribuido a la afirmación de una identidad que permite una transformación social y el desarrollo humano. Para la realización de esta investigación se utilizarán datos cuantitativos y cualitativos, en un enfoque multidisciplinar, haciendo referencia naturalmente la economía (economía del desarrollo), pero también otras áreas complementarias en el análisis, como son la sociología, los estudios sociales en ciencia y tecnología (Social Studies in Science and Tecnology). 
En términos cualitativos este estudio recurrirá a la recogida y consulta de diversas bibliografías teóricas básicas en las áreas en cuestión, en particular en el ámbito de las instituciones de enseñanza superior en los países en desarrollo, especialmente en el África Subsahariana. Algunos estudios ya realizados por diferentes autores en cuanto a la viabilidad de la aplicación de los acuerdos de colaboración también se tendrán en cuenta y se utilizarán a efectos comparativos. Se consultarán datos estadísticos, esencialmente los relativos a la economía, las finanzas, el desarrollo en el ámbito de la educación, el mercado de trabajo y los datos demográficos. Con respecto al análisis cualitativo de la tesis la misma se basa en entrevistas con los responsables europeos e internacionales en las áreas relevantes para el estudio. Estas entrevistas son una parte importante de la tesis. Nuestro objetivo pasa por comprender el sistema de colaboración al desarrollo de la educación superior a través de sus actores que representan las diferentes partes del sistema. A través de ellos ha sido posible reunir la información necesaria para analizar ese mismo sistema.

Por último, queremos señalar que la presente tesis está escrita en un lenguaje que en algunas ocasiones no se corresponde con el puramente académico, ya que en ocasiones se acercar al discurso utilizado por las instituciones internacionales para el desarrollo. Esto es porque nuestra intención es que la tesis no sea sólo una reflexión teórica, sino que tenga un impacto directo en las instituciones europeas y sea un argumento para usarse en documentos que apoyan la enseñanza superior como una herramienta de desarrollo. Esta investigación es también en cierta medida un ejercicio de auto-reflexión por parte de la Administración Europea, ya que en diferentes ocasiones hemos detectado que las organizaciones para desarrollo no han hecho una auténtica reflexión sobre el papel de la enseñanza superior en el desarrollo. Este trabajo en última instancia es una cuestión abierta: ¿qué piensan realmente los actores para el desarrollo de la enseñanza superior como el núcleo del desarrollo social de una comunidad, un país o una región como el África Subsahariana? 


\section{Estructura de la Disertación}

En lo que concierne a la estructura de la disertación la misma se divide en tres partes. La primera contiene la introducción teórica al tema propuesto, en la segunda se describen los métodos y las técnicas utilizados para el estudio, de acuerdo con las reglas de investigación científica y, en la última, se presentan los datos recogidos de acuerdo con las técnicas anteriormente descritas, así como se propone el análisis de los mismos. De forma sistemática la estructura de la disertación se presenta de la siguiente forma:

\section{$\underline{\text { Parte I - Marco teórico de referencia }}$}

\section{Capítulo 1}

La política educativa como política pública

\section{Capítulo 2}

Evolución histórica de las Universidades africanas: del pre-nacionalismo a la globalización e internacionalización;

El desarrollo y la misión de las instituciones de enseñanza superior en el contexto africano.

\section{Capítulo 3}

El sistema de financiación de las instituciones de enseñanza superior en África

La internacionalización y la globalización de la enseñanza superior

\section{Capítulo 4}

Desarrollo tecnológico en África

Las instituciones científicas y la sociedad del conocimiento en África como promotores del desarrollo económico 


\section{Capítulo 5}

La cooperación internacional para el desarrollo

\section{$\underline{\text { Parte II - Metodología }}$}

Capítulo 6

La Metodología científica

\section{$\underline{\text { Parte III - Análisis de datos }}$}

\section{Capítulo 7}

Del análisis de datos a la aplicación del modelo de análisis CATWOE Implicaciones en la caracterización del modelo CATWOE en el ámbito de la Enseñanza Superior teniendo en cuenta los diferentes actores (internos y externos)

\section{$\underline{\text { Parte IV - Conclusión }}$}




\section{PARTE I}

\section{ENQUADRAMENTO}

TEÓRICO DE REFERÊNCIA 
VNIVERSIDAD

DSALAMANCA 
ESET

Capítulo 1

Política Educacional 
VNIVERSIDAD

DSALAMANCA 
IN 5 TITUT

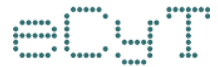

Education is the most powerful weapon which you can use to change the world.

Nelson Mandela 
VNIVERSIDAD

DSALAMANCA 


\subsection{A Política Educacional como Política Pública}

\subsubsection{O conhecimento e a sua transmissão como bens públicos}

Um bem privado é aquele que é concebido exclusivamente para ser consumido, estando desta forma, associado ao direito de propriedade, ou seja, os seus proprietários são livres de utilizarem esse mesmo bem de acordo com a sua vontade. Pelo contrário, um bem público é aquele que deve estar no domínio público significando que estão disponíveis para todos o consumirem, de forma justa e equitativa. Os bens públicos globais são bens com benefícios, os quais se estendem através de países e regiões, a todos os grupos sociais (Kaul, 2003). Desta forma os bens públicos globais tornam-se um produto da globalização. Contudo, na perspetiva da globalização podem ser considerados como um paradoxo, uma vez que, por um lado, desenvolve um sentimento de "perda de autonomia" (Mahbubani, 2001; Kaul, 2003), em particular nos países desenvolvidos, por outro lado, para vários povos, pode ser significado de "um mundo de oportunidades" (Giddens, 2000). Alguns destes bens são naturalmente globais (atmosfera, proteção do ozono, etc.), mas existem outros que atravessam um processo de globalização, onde todos os países seguem estratégias nacionais com políticas públicas orientadas na mesma direção, coordenadas com o sistema de cooperação internacional, o qual pode ser integrado de quatro formas diferentes (Kaul e Le Goulven (2003):

1. Cooperação Externa - visa a cooperação com outros e é considerada necessária para o bem de todos (ex.: serviço nacional de saúde - a procura de um bom serviço de saúde nacional tem consequências no controlo de doenças ao nível internacional, sendo por isso do interesse de todos; o Sistema Educacional enquanto promotor de uma consciência cívica global de interação entre vários povos permitindo a promoção da paz e dos direitos humanos numa sociedade democrática); 
2. Cooperação Interna - as exigências globais requerem políticas nacionais ajustadas às regras impostas internacionalmente (ex.: taxas financeiras estandardizadas);

3. Produção Intergovernamental - produção de um bem contratado com uma organização internacional cuja missão pode estar relacionada com a ajuda humanitária a qual terá melhores resultados quando os custos são partilhados (ex.: acordos efetuados com as Nações Unidas; Fundo Monetário Internacional; Banco Mundial);

4. Redes de Cooperação - ajustamento das políticas nacionais de forma a aceder a uma determinada rede cujo intuito passa por obter benefícios.

A cooperação no que concerne os bens públicos implica, assim, um acordo entre as partes que expressam a sua preocupação e estabelecem a intenção de agirem de forma concertada num determinado assunto (Kaul, 2003). De acordo com Sabastián (2004) ao nível das universidades a cooperação internacional implica a complementaridade das suas capacidades para realizar atividades conjuntas, de acordo com duas dimensões: a cooperação propriamente dita - sensu stricto -, ou a interuniversitária que visa a complementaridade de interesses e capacidades das instituições envolvidas as quais partilham objectivos académicos e científicos. Geram benefícios para ambas as partes implicando uma maior qualidade académica e fortalecimento institucional. Por outro lado, o autor considera que a cooperação universitária para o desenvolvimento põe em causa o principio da solidariedade e o papel social inerente à missão das universidades através da criação de capacidades e a transferência do conhecimento e de tecnologias que contribuam para o desenvolvimento humano e para o bem estar social:

La cooperación internacional de las universidades se basa en la complementariedad de sus capacidades para realizar actividades conjuntamente y en su asociación para el beneficio mutuo. Esta cooperación tiene a su vez dos dimensiones: la cooperación sensu stricto o 
interuniversitaria que se caracteriza por la complementariedad de intereses y capacidades de las instituciones involucradas que comparten principalmente objetivos académicos y científicos. Ello genera beneficios para ambas partes que se traducen en una mejor calidad académica y en un mayor fortalecimiento institucional. Por su parte, la cooperación universitaria para el desarrollo pone en juego el principio de solidaridad y el rol social que juegan las universidades a través de la creación de capacidades y la transferencia de conocimientos y tecnologías para contribuir al desarrollo humano y al bienestar social. Sabastán (2004:2)

A produção de um bem público global, enquanto soma de um bem público nacional com a cooperação internacional, requer uma visão entre as nações em vários níveis e de forma multissectorial, sendo um processo onde interagem vários atores. Esta interação implica definir objetivos e determinar responsabilidades uma vez que este processo de produção incorpora várias fases (Kaul, 2003):

Fase I - A tomada de decisão política - os stakeholders decidem quais os bens a produzir, de que forma e em que quantidades, assim como de que forma deverão ser distribuídos os seus benefícios;

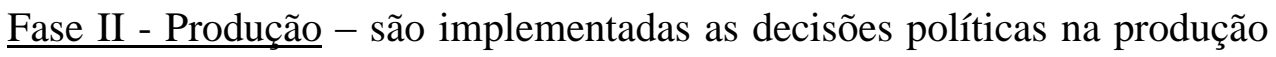
dos bens o que implica:

a. Financiamentos - são efetuados esforços para alocar os recursos de forma eficaz - privados e públicos - nos bens públicos globais; e

b. Gestão - é efetuada uma gestão estratégica dos bens para que sejam distribuídos de forma fracionada, eficiente e eficaz. 
Esta cooperação pode, ainda, ser correlacionada com o estudo efetuado por Elinor Ostrom (1990) no âmbito da ação coletiva e a cooperação no âmbito dos recursos comuns ou comunais. Ostrom estudou situações nas quais os indivíduos, em vez de se apropriarem dos seus recursos, estão presos num processo inflexível de destruição dos mesmos, tendo em comum o fato de que "não se pode separar a estratégia de uma das escolhas adotadas pelos demais". Ostrom observa que estes problemas geram a necessidade de mudar a forma pela qual os individuos de uma sociedade se comportam.

Aponta que o comportamento de cada membro está essencialmente ligado ao comportamente dos restamtes membros da sociedade, sendo, por isso mesmo, difícil de prever como se comportarão os outros ou como responderão à introdução de uma nova norma. Acresce que os membros de uma comunidade com um recurso comunal contam com certas vantagens. Estes possuem um conhecimento tanto do terreno como das pessoas que lhes servem como apoio. É um conhecimento "de tempo e lugar" na perspectiva de Ostrom. É o "conhecimento pessoal" de que fala Michael Polanyi ou o conhecimento subjetivo e disperso de que fala Friedrich Hayek. Esse conhecimento, combinado com a razão, leva a elaboração de normas que serão testadas pela experiência e vão sendo melhoradas, num processo de tentativa e erro, até se converterem num acordo comum, num conjunto de instituições, que guardam uma inteligência sútil na resolução de conflitos e levam a comunidade a explorar eficazmente o recurso em questão. Desta forma, a autora chega a "uma teoria da ação coletiva auto-organizada" na qual "no lugar de supor que uns indivíduos são incompetentes, malvados ou irracionais e outros são oniscientes" se presume que os indivíduos possuem "capacidades limitadas muito similares para raciocinar e pensar em estruturas de ambientes ou entornos complexos". Demonstra, ainda, que o motivo que leva as pessoas a agirem de uma certa maneira é por benefício económico, ou seja, de acordo com um determinado incentivo e uma série de mecanismos ou processos sociais, que os levam a uma boa solução. Ostrom expõe alguns casos paradigmáticos de boa gestão de bens comunais, derivados de acordos que se 
parecem com a privatização do recurso. A cientista política expõe igualmente exemplos de gestões fracassadas de recursos comuns os quais explicita através da falta de comunicação entre os participantes ou o peso dos interesses envolvidos. Um elemento comum nos dois casos é a ação do Estado, da qual é geralmente crítica: "sem uma informação válida e de confiança, uma agência central pode cometer numerosos erros" se não há um mecanismo, como o do "mercado concorrente" que exerça "uma pressão no governante para que projete instituições eficientes". Ostrom demonstra que há formas de gerir os recursos que não são do Estado nem de propriedade privada, mas que estão dentro do âmbito privado e que beneficiam da incorporação de um entorno com mercados concorrentes. No artigo "Understanding Knowledge as a Commons: From Theory to Practice", Ostrom identifica vários tipos de recursos (os quais devem ser partilhados por um grupo de pessoas) nomeadamente, aqueles que devem ser partilhados ao nível internacional e global, como é o caso do conhecimento cientifico:

Commons is a general term that refers to a resource shared by a group of people. In a commons, the resource can be small and serve a tiny group (the family refrigerator), it can be community-level (sidewalks, playgrounds, libraries, and so on), or it can extend to international and global levels (deep seas, the atmosphere, the Internet, and scientific knowledge). Hess, C. \& Ostrom, E. (2007:2).

Este conhecimento, apesar de ser um bem intangível, é considerado como um bem público, na medida em que não deve excluir ninguém de o adquirir e de o utilizar.

Knowledge, in its intangible form, fell into the category of a public good since it was difficult to exclude people from knowledge once someone had made a discovery. One person's use of knowledge (such as Einstein's theory of relativity) did not subtract from another person's capacity to use it. This example refers to the ideas, thoughts, and wisdom found in the reading of a booknot to the book itself, which would be classified as a private good. Hess, C. \& Ostrom, E. (2007:9). 
As autoras consideram o conhecimento cientifico como um bem público, pois deve estar ao serviço de todos sem excluir ninguém, quer seja ao nível local quer seja ao nível global. Ainda assim, identifica utilizações diferentes destes recursos de acordo com os grupos de interesse, ou seja, se por um lado se limita o acesso à informação, por parte de determinadas organizações, por outro se tenta assegurar que este acesso seja libre e sem custos associados. As universidades por sua vez, deparam-se com o dilema de uma sociedade empreendedora o que as leva à procura de financiamento alternativo ao público, o qual é cada vez mais racionalizado, para os seus projetos de investigação. No entanto, o seu sucesso está, de certa forma, determinado pela utilização generalizada da sua investigação e dos produtos gerados pela mesma, pelo que disponibiliza, de forma livre, os mesmos através de repositórios - open access - digitais:

Some knowledge commons reside at the local level, others at the global level or somewhere in between clearly multiple uses and competing interests in these commons. Corporations have supported increased patents and copyright terms, while many scientists, scholars, and practitioners take actions to ensure free access to information. Universities find themselves on both sides of the commons fence, increasing their number of patents and relying more and more on corporate funding of research, while at the same time encouraging open access and establishing digital repositories for their faculty's research products. Hess, C. \& Ostrom, E. (2007:9).

Nesta ordem de ideias e tendo em conta a Declaração Universal dos Direitos do Homem (DUDH), a educação deve ser tida em conta como um bem público o qual deve ser promovido pelo Estado, através de políticas que visem o acesso a todos, de forma equitativa e gratuita. A educação primária e secundária são, todavía, direitos diferentes da educação superior. Neste último caso, as sociedades não podem impedir o livre acesso ao conhecimento. Portanto, os governos devem proporcionar um sistema que forneça facilidades de acesso. Esse sistema deve, necessariamente, ser parcialmente público, uma vez que haverá sempre uma parte 
da população com capacidade intelectual para prosseguir o ensino superior sem capacidade económica. Por outro lado, parte do sistema deve ser promovido localmente. Não é possivel desenvolver um sistema de ensino superior apenas com programas de bolsas de estudo provenientes do estrangeiro. No entanto, apesar das universidades públicas prevalecerem em África, existem instituições de ensino superiores privadas, as quais se têm vindo a desenvolver cada vez mais, confrontando-se com dificuldades financeiras e governamentais como se poderá verificar mais adiante.

\subsubsection{A Educação como Direito}

Se o conhecimento é um bem público e a universidade é uma estrutura de acesso ao mesmo que deve de ser promovida pelas autoridades publicas estatais, então a educação, independentemente do seu nível, pode ser considerada como um direito do cidadão.

Tal como mencionado a DUDH estabelece o direito à educação como um meio de desenvolvimento humano, uma vez que "a educação é um direito que garante direitos". Desta forma, a necessidade de universalização da educação com qualidade deflagra-se como um dos principais desafios que implicam um Estado Social Democrático. Esta visão é reforçada por Sobrinho (2013) que defende a educação como um bem público e social na medida em que forma sujeitos e os transforma em cidadãos mais conscientes compondo uma sociedade moralmente democratizada, cujos interesses vão ao encontro da primordial dignidade humana como um todo e que tem como finalidade o bem comum:

Educação é um bem público e direito social, pois tem como finalidade essencial a formação de sujeitos e, por consequência, o aprofundamento da cidadania e da democratização da sociedade. O conceito de bem público é aqui entendido como um princípio, isto é, como um imperativo moral que sobrepõe a dignidade humana aos 
interesses, inclinações e circunstâncias individuais. Sobrinho (2013:109)

Verifica-se que a educação deve ser considerada como um bem público na medida em que é essencial para a formação de cidadãos conscientes mas também de profissionais qualificados. Esta capacitação profissional torna os cidadãos ética e técnicamente responsáveis, assim como os transforma nos principais atores do fortalecimento económico e, consequentemente, do desenvolvimento da nação. A economia assume uma dimensão essencial da vida humana onde a sociedade deve ser guiada pelo valor moral do bem comum (Sobrinho, 2013).

A evidência empirica tem demonstrado que a educação tem um papel determinante no nível das remunerações e nas oportunidades de emprego de uma população (Woessmann, 2006), sendo que os diferentes níveis educativos explicam a distribuição dos rendimentos e da pobreza (Psacharopoulos, 2007). A equidade em educação deve ser entendida como um instrumento fundamental da equidade social e onde a desigualdade de resultados escolares tem custos sociais e económicos. Isto porque o insucesso escolar e o abandono aumentam os riscos de desemprego, de delinquência juvenil e de criminalidade com os correspondentes impactos para a sociedade (The Prince's Trust, 2007). Esta visão é defendida pelas instâncias internacionais - OCDE (2007) e da União Europeia (CEC, 2006) - as quais consideram a equidade em educação como um fim em si mesmo, porque o direito ao desenvolvimento das capacidades de cada pessoa e a sua participação na sociedade faz parte dos direitos inscritos na maioria das leis fundamentais dos diferentes países, assim como consideram que é uma condição indispensável à consecução de outros fins, quer sociais quer económicos, e portanto à formulação das políticas públicas. Depreende-se, assim, a educação como um bem público, ou seja, um direito humano fundamental que implica o dever do Estado de realizar políticas com o objetivo da sua efetivação. Esta conceção de educação como um serviço público, de titularidade estatal, é entendido da mesma forma quando o serviço é prestado por entidades privadas, tal como aponta Sundfeld (2001:84) “a 
prestação de tais serviços não é um dever afastável do Estado, tendo os indivíduos o direito subjetivo de usufrui-los". A educação é um direito de todos e, por conseguinte, é um dever do poder público, onde o Estado é a entidade responsável pela titularidade do serviço a garantia do direito, o que implica uma atividade regulatória compatível com a identificação da educação como um bem público.

Esta ideia é reforçada por Petrella (2005:158) que considera que um bem público é da responsabilidade de todos, fazendo parte de um capital comum e imprescindível para a existência humana individual e coletiva. Sendo a educação e o conhecimento direitos humanos e sociais insubstituíveis e primordiais para a vida humana, onde somente os poderes públicos podem ser responsáveis por eles, em relação à regulamentação, à legislação, à supervisão, ao controle, à proteção e à avaliação. Os bens públicos, por serem parte essencial do direito que todos têm à vida digna e saudável, precisam ser universalmente acessíveis e não podem ser tomados como mercadoria. Reforça-se a ideia de que ao Estado cumpre, entre outras responsabilidades, proteger e promover a educação e o conhecimento como bens públicos.

Mas até que ponto podemos considerar que a educação em geral, e o ensino superior em especifico, constituem um direito? Esta perspectiva de educação enquanto bem público e direito social, leva ao reconhecimento da responsabilidade que as Instituições de Educação Superior (IES) têm no que toca à formação ética, científica e técnica dos cidadãos no marco da construção da sociedade, em termos locais e nacionais, mas também em termos universais e no que respeita à dignificação da humanidade. No entanto, esta lógica não "se coaduna com a lógica da mercantilização da vida humana, em geral, nem da mercadorização da educação, em particular” (Sobrinho, 2013). Esta perspectiva contraria as mais recentes visões do ensino superior como sendo meios para atingir fins comerciais, ou seja, as chamadas universidades empreendedoras. Esta nova missão do ensino terciário coaduna-se, essencialmente, com os sistemas de educação superior que procuram meios de financiamento alternativos ao público, levando à privatização 
das mesmas mas cujos objetivos podem ser discutidos na esfera do seu reconhecimento enquanto bem público. Não obstante, este tipo de ensino tem o seu valor desde que cumpra com a sua missão de educação, visto que as “instituições educativas privadas, nos termos amparados e exigidos pela Constituição Nacional, são legítimas e necessárias, desde que, sob a autoridade superior do Estado, cumpram com qualidade os objetivos públicos que são da essência da educação" (Sobrinho, 2013:110). Esta afirmação baseia-se na premissa de que os bens privados implicam competitividade e exclusão enquanto que os bens públicos visam os princípios de equidade, solidariedade e inclusão.

As instituições educativas em geral, e as universidades em particular, são referências e centros fundamentais para a produção, para o avanço e para a elevação da vida intelectual da nação e da sua sociedade. Elas contribuem efetivamente com os esforços coletivos de construção dos bens públicos e comuns, por meio de conhecimentos. Portanto, a questão não deve ser atribuída à instituição, neste caso a universidade, uma vez que o que cria um bem público é o conhecimento por natureza. Isto porque as instituições de ensino superior são, normalmente, instituições que visam o bem comum, embora nas últimas décadas se tenha assistido à mercadorização de algumas, principalmente as de caracter privado, tal como mencionado anteriormente. Baseadas no princípio da equidade, as instituições educativas deveriam ter como finalidade essencial de contribuir para a diminuição dos desequilíbrios sociais, sendo esta uma responsabilidade civica: A democratização da educação superior deve fazer parte
da democratização da sociedade e da promoção da justiça
social; não se restringe à ampliação do acesso, mas tem a
ver com qualidade, pertinência e relevância social; além
disso, a melhora da qualidade da educação superior está
vinculada à ampliação e à elevação qualitative de todo o
sistema educativo e, mais amplamente, de transformações
estruturais da sociedade. Portanto, é de responsabilidade
coletiva. Sobrinho (2013:9) 
A promoção do conhecimento, em todos os níveis, incluindo o superior, constitui as bases de uma sociedade democrática, estável e competitiva, sendo por isso do interesse comum, competindo às entidades governamentais, nacionais e internacionais, a garantia do seu bom funcionamente, incluindo o acesso equitativo o que contribui para a capacitação profissional a qual permitirá elevar os níveis de qualidade de vida de uma população através de uma economia fortalecida e sustentável. No mundo da revolução industrial e da divisão internacional do trabalho, alguns países consideravam a contribuição do trabalho como um aspeto primordial do desenvolvimento económico e, portanto, somente o ensino primário era considerado como um objetivo fundamental e optimizador de recursos públicos escassos. Contudo, num mundo globalizado esta perspetiva já não faz sentido ainda que, neste estudo, se considerem sociedades em desenvolvimento com condições especificicas como se poderá verificar de seguida.

\subsection{O sistema de educação em África}

A educação é globalmente aceite como um instrumento de promoção do crescimento económico, especialmente em África (e em particular na ÁfricaSubsariana), onde pode ter efeitos diretos na redução da pobreza. Com efeito, o baixo capital humano subjuga a capacidade de transformação estrutural, sendo critico o fato da mão-de-obra não ser qualificada devido aos baixos níveis de educação e à sua fraca qualidade. Por outro lado, o acesso à educação contínua a ser limitado (FAO et al, 2010; in UNECA, 2013), apesar dos progressos efetuados no sentido de permitir que todas as crianças possam frequentar pelo menos a escola primária (60.2\% em 2000 > 77.2\% em 2011), muito embora alguns países (18) ainda estejam a $10 \%$ de atingir a frequência primária global de acordo com os Objeticos Do Milénio ${ }^{5}$ até à data inicialmente proposta de 2015 (Gráfico $1^{6}$ ). O

\footnotetext{
${ }^{5}$ Objetivos do Desenvolvimento do Milênio - meta 2.A - Garantir que até 2015, todas as crianças, de ambos os sexos, tenham a oportunidade de completar um plano de estudos de escolaridade primária completo.
} 
mesmo acontece com as taxas líquidas de matrículas no ensino primário por sexo, onde se verifica um aumento das matrículas quer dos rapazes quer das raparigas (64.2\% nos rapazes e $56.2 \%$ nas raparigas em $2000>79.2 \%$ nos rapazes e $75.2 \%$ nas raparigas em 2011). Por outro lado, verifica-se que a percentagem de matricula entre os dois sexos é idêntica o que demontra que as desigualdades de género estão a desaparecer (Gráfico 2).

\section{Gráfico 1 - Taxa líquida de matrícula no ensino primário}

\begin{tabular}{|r|r|r|c|c|}
\hline \multicolumn{2}{|c|}{ ODM 2 - Taxa líquida de matrícula no ensino primário } \\
\hline \\
\hline
\end{tabular}

Fonte: Dados obtidos e adaptados de UN (2013)

a) As médias regionais apresentados nesta tabela são calculados usando uma média ponderada do último ponto de dados observados disponíveis para cada país ou território para o período de referência.UNESCO Institute for Statistics utiliza estimativas para os países com dados em falta. b) Amputação parcial devido à cobertura incompleta dos países (de 33 por cento a 60 por cento da população).

\footnotetext{
${ }^{6}$ Definida como o número de alunos em idade escolar oficial para frequentarem o ensino primário, matriculados quer na escola primária como secundária, expressa como a percentagem da população total nesse grupo etário.
} 
Gráfico 2 - Taxa líquida de matrícula no ensino primário - por sexo

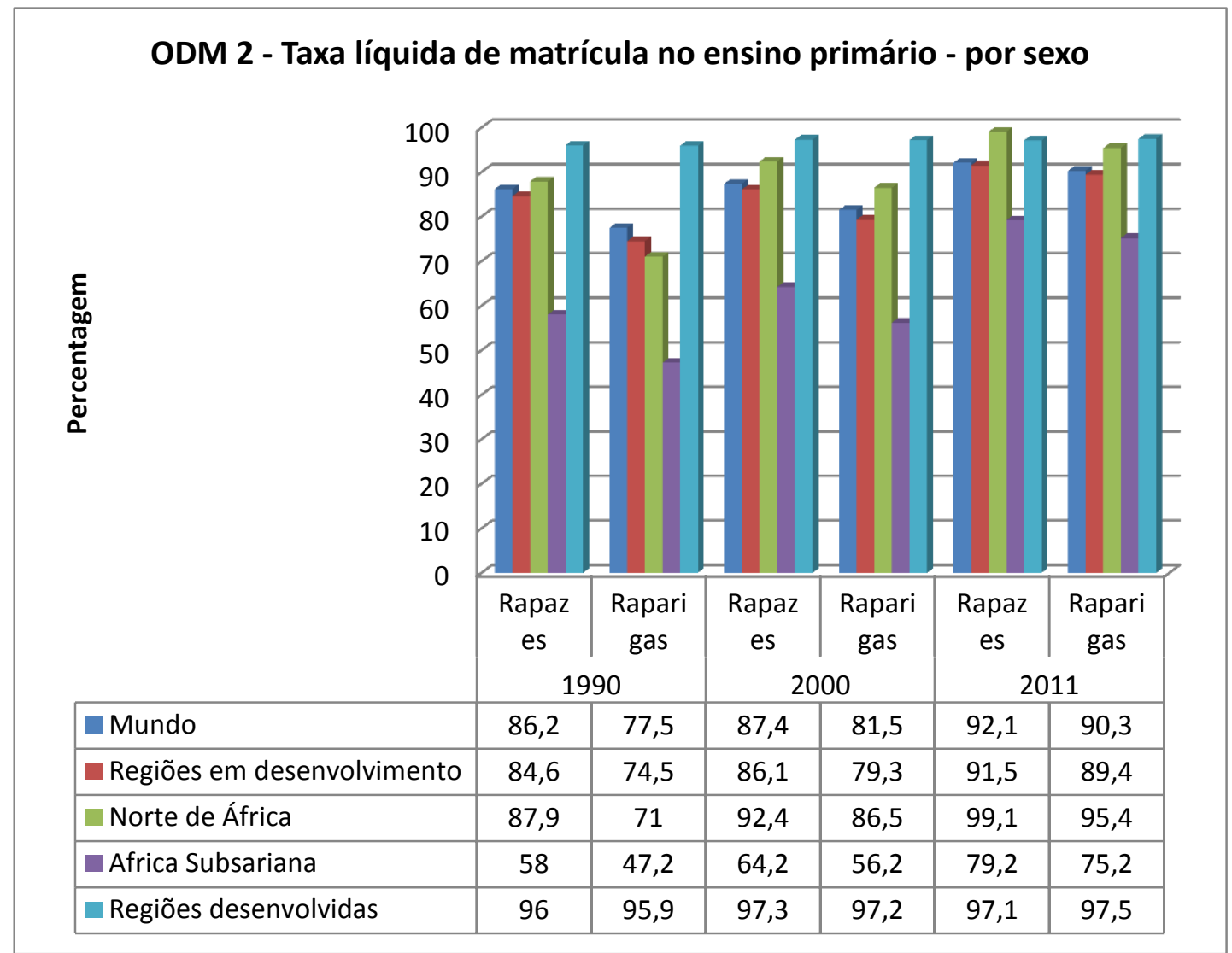

Fonte: Dados obtidos e adaptados de UN (2013)

b) As médias regionais apresentados nesta tabela são calculados usando uma média ponderada do último ponto de dados observados disponíveis para cada país ou território para o período de referência.UNESCO Institute for Statistics utiliza estimativas para os países com dados em falta. b) Amputação parcial devido à cobertura incompleta dos países (de 33 por cento a 60 por cento da população).

Por outro lado, as taxas de finalização do ensino primário são ainda baixas, derivadas de um grande número de desistências, o que resulta numa percentagem da população com idade entre os 15-24 anos que conseguem ler e escrever identicamente baixa em ambos os sexos (Gráfico 3 ). Constata-se que esta iliteracia é maior nas raparigas com uma diferença de $11.9 \%$ (apenas 6 países atingiram a taxa de 90\% de escola primária completa em 2009 (Gráfico 4 ). No ensino secundário e terciário o progresso é, equitativamente, lento. O ensino técnico e vocacional, de acordo com as necessidades de emprego do país, carece 
de maior regulamentação e deve ser assumido como uma das áreas a serem priorizadas pelo governo $(U N, 2013)$.

Gráfico 3 - Taxa de alfabetização dos 15 aos 24 anos de idade, mulheres e homens

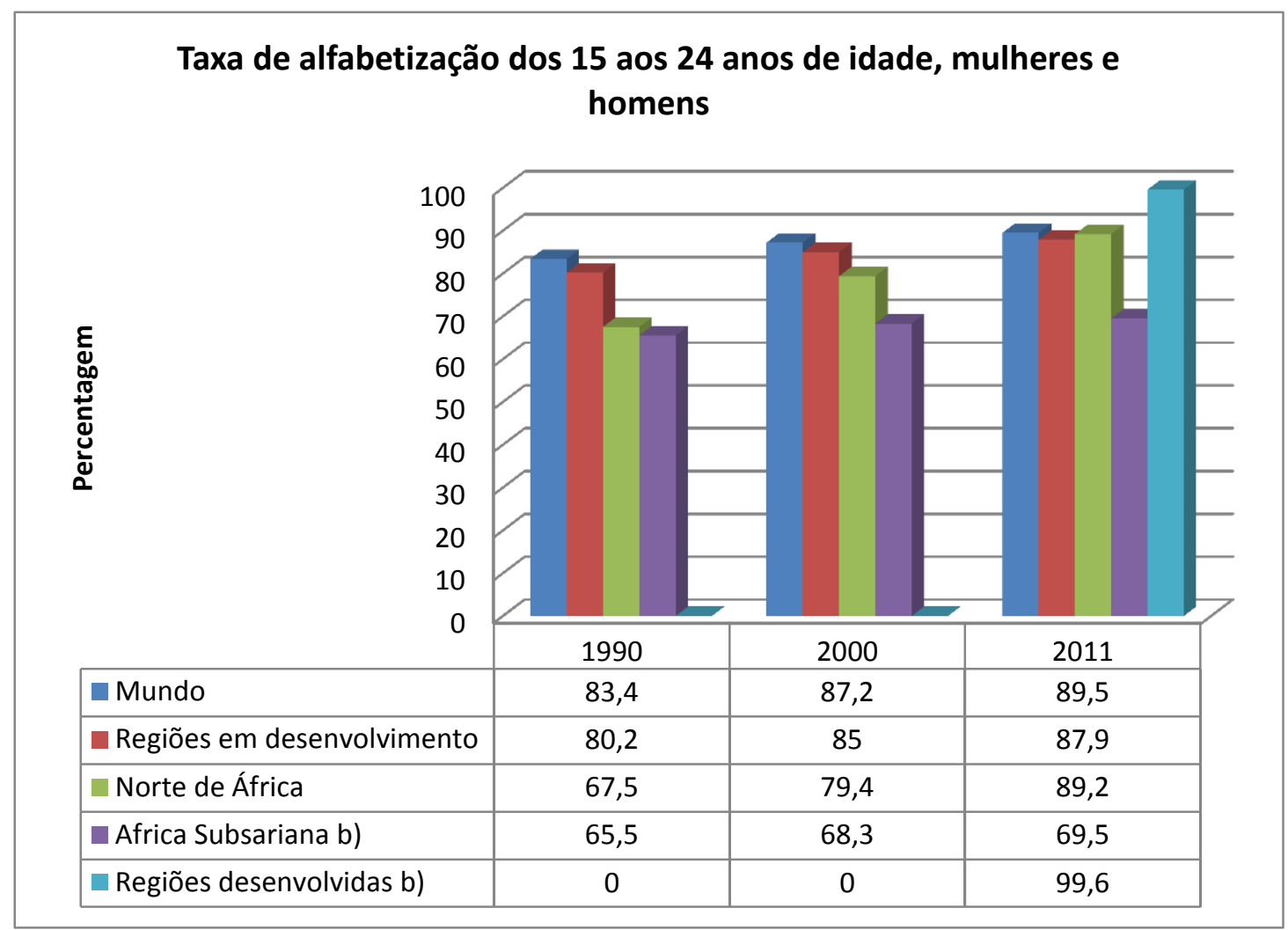

Fonte: Dados obtidos e adaptados de UN (2013)

a) As médias regionais apresentados nesta tabela são calculados usando uma média ponderada do último ponto de dados observados disponíveis para cada país ou território para o período de referência.UNESCO Institute for Statistics utiliza estimativas para os países com dados em falta. b) Amputação parcial devido à cobertura incompleta dos países (de 33 por cento a 60 por cento da população). 
Gráfico 4 - Taxa de alfabetização dos 15 aos 24 anos de idade, por sexo

\begin{tabular}{l} 
Taxa de alfabetização dos $\mathbf{1 5}$ aos 24 anos de idade, por sexo \\
\hline \multicolumn{1}{|l|}{100} \\
\hline
\end{tabular}

a)

Dados obtidos e adaptados de UN (2013) As médias regionais apresentados nesta tabela são calculados usando uma média ponderada do último ponto de dados observados disponíveis para cada país ou território para o período de referência.UNESCO Institute for Statistics utiliza estimativas para os países com dados em falta. b) Amputação parcial devido à cobertura incompleta dos países (de 33 por cento a 60 por cento da população).

Outro fator a ter em consideração é a falta de professores, mas também uma melhor formação para os professores já existentes:

Em muitos dos países mais pobres, a qualidade da educação é comprometida pela falta de professores, o que acarreta, frequentemente, salas de aula lotadas, nas séries iniciais e nas regiões mais pobres. As necessidades futuras de contratação de professores são determinadas por: déficits correntes, demografia, tendências de matrícula e número de crianças fora da escola. Análises do Instituto de Estatísticas da UNESCO (IEU/UIS) mostram que, entre 2001 e 2015, precisam ser contratados 5,2 milhões de professores - inclusive substitutos e extras - para garantir professores suficientes para se alcançar a educação primária universal. Isso significa 1 milhão de professores por ano, o que equivale a aproximadamente $5 \%$ da força de trabalho atual da educação primária. UNESCO (2014). 
De acordo com o recente estudo da UNESCO (2014a) a região que enfrenta os maiores desafios é a África Subsaariana, que necessita de mais da metade (63\%) dos professores atualmente existentes para alcançar o ensino primário universal até 2015 ou de dois terços (67\%) em 2030. O Relatório de Monitoramento Global de EPT (2013/14 ) determina que entre 2011 e 2015, seriam necessários 3,7 milhões de professores para substituir os que se vão aposentar, mudar de profissão ou deixar o trabalho, em função de doença ou morte. Por esta razão a necessidade de professores no sistema de ensino superior se justifica em qualquer país, por mais subdesenvolvido que seja. O restante 1,6 milhão corresponde a professores adicionais necessários para compensar o déficit existente e o aumento das matrículas, bem como garantir a qualidade de modo que não se tenha mais do que 40 alunos por professor (Gráfico 5 ).

\section{Gráfico 5 - Número total de professores necessários para se alcançar a educação primária universal até 2015}

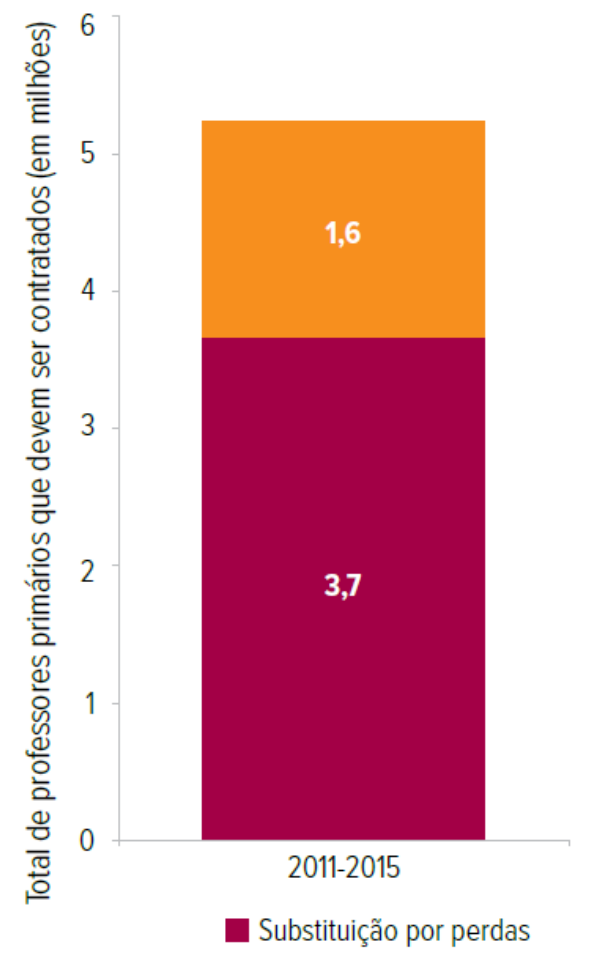

Professores adicionais necessários

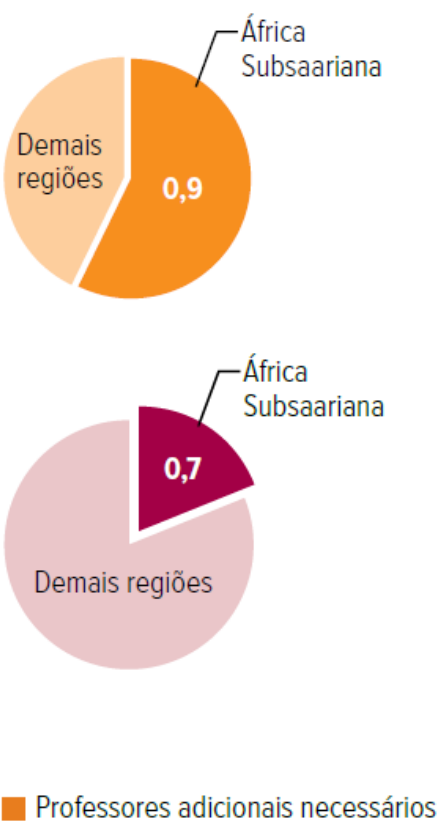

Fonte: UN (2014) 
Em toda a região, mais de 7 em cada 10 países enfrentam uma aguda escassez de professores. Esta situação pode deteriorar-se em muitos países tendo em conta que os governos enfrentam salas de aula superlotadas e a crescente procura por educação pela população em idade escolar: para cada 100 crianças em 2012 haverá 147 crianças em idade escolar em 2030. A África Subsariana terá de criar 2,3 milhões de novos postos de ensino em 2030 ao preencher cerca de 3,9 milhões de postos vagos devido ao atrito de novos alunos. De acordo com o mesmo estudo a maioria dos países terá de aumentar o orçamento para a educação, presumivelmente, com o apoio de doadores, de forma a aumentarem os indicadores. A situação mais extrema é encontrada na República Central Africana onde apenas $72 \%$ das crianças, em idade escolar primária, estão matriculadas na escola e a relação professor-aluno é o mais alto do mundo com o rácio de 80:1. Para contratar professores suficientes até 2020 o país teria de ter o triplo dos gastos públicos na educação primária. O Governo de Mali terá, por exemplo, de ajustar o seu orçamento para a educação a fim de aumentar os gastos de 1,8\% para $2,5 \%$ por ano (em percentagem do PIB), seguido pelo Chad (1,1\% para $1,6 \%$ ) e Malawi $(1,7 \%$ a $1,9 \%)$. Ter professores suficientes é uma condição necessária, mas não uma condição suficiente para melhorar a qualidade da educação uma vez que professores recém-contratados também precisam de ser motivados, bem treinados e dispostos a modernizar as ferramentas pedagógicas. Os sistemas de educação primária expandiram-se rapidamente o que implicou a contratação de professores sem a formação adequada. De acordo com dados da UNESCO (2014), em 30 dos 91 países com dados disponíveis, menos de $75 \%$ dos professores do ensino primário eram treinados de acordo com as normas nacionais em 2012. Mais do que metade (17 em 30) desses países pertencem à África Subsaariana, com o percentual de professores formados ao nível primário abaixo de 50\% em Angola, Benim, Guiné Equatorial, Guiné-Bissau, Senegal e Sudão do Sul.

Desde 2000, os decisores políticos têm respondido à necessidade de expandir os sistemas de educação através do recrutamento de professores com contratos temporários e com pouca formação. Os dados mais recentes (UNESCO, 2014) 
indicam que existem mais professores com contratos temporários do que em contratos da função pública chegando a quase $80 \%$ no Mali e no Níger e mais de $60 \%$ no Benim e Camarões. Aumentar a oferta de professores contratados permitiu alguns países com maiores carências de professores reduzir significativamente os seus rácios professor / aluno. No entanto, esta resposta política suscita questões importantes de qualidade pois a maioria dos professores contratados não estão totalmente formados.

De acordo com dados recentes da UNESCO (2014) a proporção de alunos por professor formado não deve ultrapassar 40:1. Contudo, no ritmo atual de recrutamento, alguns dos países - como os Camarões, o Congo, a Guiné-Bissau e o Senegal - aparecem no caminho certo para ter professores suficientes para alcançar o ensino primário universal até 2020. O Senegal tem recrutado professores a uma taxa de $9 \%$ ao ano na última década o que ajudou a reduzir o número de alunos por professor de 49 em 1999 para 32 em 2012. Ainda assim, o recrutamento de professores formados foi menor, em cerca de 6\% (em média 1.000 por ano) entre 2001 e 2010 (UNESCO, 2014). Como resultado, mais de metade dos professores do ensino primário senegaleses permanecem sem formação e o rácio de alunos por professor formado ronda os 70:1. Com base nestes dados, será uma meta improvável para o Senegal atingir o rácio de 40 alunos por professor formado até 2030. A obtenção do grau ao nível do ensino secundário é um requisito obrigatório para a entrada na carreira docente, sendo que devem ter um bom conhecimento da matéria a lecionar e das estratégias pedagógicas. No entanto, nos países mais subdesenvolvidos, aqueles que completaram o ensino secundário são escassos e são projetados para permanecer assim no imediato futuro. A análise do Relatório de Monitoramento Global de Educação para Todos (UN, 2014) demonstra que seria necessário destinar pelo menos $5 \%$ dos graduados do ensino secundário a programas de formação de professores primários para alcançar o ensino primário universal em 2020. No Níger, quase $25 \%$ de todos os concluíntes do ensino médio e superior teriam de se formar professores para preencher a lacuna de docentes. 
Muitos países pobres não conseguirão suprir a demanda, simplesmente por não terem estudantes suficientes que concluíram o segundo nível da educação secundária qualificação mínima para professores primários. Em 8, de 14 países da África Subsaariana, pelo menos $5 \%$ de todos os formados na educação secundária, em 2020, deveriam se tornar professores para suprir o déficit, taxa que aumenta para quase $25 \%$ no Níger. No entanto, apenas $3 \%$ da força de trabalho que completou a educação secundária atuam como professores da escola primária, em países de renda média.( UN, 2014:37)

Considerando os fatores atrás explicitados, os principais dadores internacionais têm colocado maior enfâse na educação primária e secundária, considerando que esta é promotora do crescimento económico e, consequentemente, da redução da pobreza, negligenciando a educação terciária. De acordo, com os últimos dados da UNESCO (2014), as taxas de participação no ensino superior são, efetivamente, as mais baixas do mundo. A crença por parte da comunidade internacional para o desenvolvimento de que o ensino superior não contribui para o crescimento económico, nem para a redução da pobreza, tem implicado um menor investimento nesta área (Tilak, 2003; UNESCO, 2014). No entanto, a evidência empírica mais recente, demonstra que o ensino superior produz benefícios públicos e privados (Bloom et al, 2006; OECD, 2012).

Os benefícios privados implicam uma perspetiva de melhor emprego, salários mais elevados e uma maior propensão para poupar e para investir, conduzindo a uma sociedade mais empreendedora e mais cívica (Bloom et al; 2006; UNESCO, 2014) podendo, ainda, ter impacto na saúde e na qualidade de vida. Por outro lado, os benefícios públicos estão relacionados com o desenvolvimento tecnológico permitindo colocar África ao nível da economia do conhecimento global e das sociedades tecnológicas mais desenvolvidas onde a mão-de-obra qualificada desempenha um importante papel. De acordo com o estudo efetuado por Bloom et al (2006) e da OECD (2012) o investimento na educação terciária pode promover um maior desenvolvimento tecnológico assim como pode melhorar a capacidade 
de maximizar os resultados económicos. Desta forma, um maior investimento na educação terciária implicaria um maior desenvolvimento tecnológico o que, por sua vez, permite o crescimento económico e, naturalmente, a redução da pobreza. Tendo em conta esta evidência e correlação, o Banco Mundial e os principais dadores mundiais começam a reconsiderar a importância deste tipo de educação e os seus efeitos positivos ajustando a sua estratégia e apoio.

Não obstante esta correlação positiva, a presente recessão global tem levado vários organismos a questionar a possibilidade de um maior investimento na educação superior. Por outro lado, o investimento público tem vindo a diminuir devido à complicada conjuntura financeira. No entanto, os estudos mais recentes, efetuados pela OECD (2012:4), demonstram que "a decisão de abandonar os investimentos na educação superior hoje, pode impedir melhores retornos económicos amanhã tanto no sector público como no privado". Esta análise demonstra que existem vários benefícios económicos na obtenção de diploma de nível superior, especialmente a longo prazo, indicando que desta forma é possível alcançar níveis salariais superiores no mercado de trabalho do seu país. O estudo indica que o valor líquido atual da educação superior calcula-se através da "estimativa do benefício económico para a vida profissional do individuo que completa a educação superior". Este benefício considera os seguintes aspetos:

- Salários mais altos para os detentores de grau superior;

- A menor probabilidade de ficar desempregado; e

- A possibilidade de obter subsídios pagos pelo Estado para prosseguir os estudos superiores.

Por outro lado, é considerado como custo as despesas relacionadas com a educação, os salários a que os alunos renunciam enquanto estudam, o aumento do imposto salarial e a contribuição social que as pessoas com educação superior 
pagam ao governo. O investimento efetuado na educação superior contribui, da mesma forma, para o sector público na medida em que, a longo prazo, os países vão recuperar os seus investimentos por meio do aumento da receita fiscal, pagas pelas pessoas com estudos superiores, assim como, normalmente, estas implicam um menor gasto com a assistência social. Apesar das evidências do benefício do ensino no crescimento económico e na melhoria das condições de vida são vários os aspetos de nível cultural que têm que ser colmatados, nomeadamente no que concerne à frequência do ensino pelas mulheres o qual necessita de ser estimulado através da criação de regulamentação de acesso e de igualdade de oportunidades, ainda que a tendência se esteja a inverter como se pode verificar de seguida.

\subsubsection{Acesso ao ensino superior e igualdade de oportunidades}

África tem o menor acesso per capita ao ensino superior do mundo (100 estudantes por cada 100.000 habitantes, comparado com 5.000 estudantes por 100.000 habitantes nos Estados Unidos). De forma a colmatar esta situação, e de acordo com vários autores e organizações (Seddoh, 2003; OECD, 2012; UNESCO, 2014; UNCTAD, 2014), o ensino deveria ser adaptado à procura do mercado, assim como consideram que seria importante melhorar a qualidade do ensino para que os detentores dos graus académicos possam assumir maiores responsabilidades. No que concerne às taxas de participação nas questões do género verifica-se que a taxa de frequência da escola pelas mulheres é cada vez maior, as quais têm vindo a ganhar importância, não só na educação, mas também na economia e na política. Desta forma, contribuem para o aumento do capital humano e para a melhoria das capacidades contribuindo para o aumento da produtividade. $\mathrm{O}$ índice de paridade do género tem melhorado bastante em todos os níveis da educação indo ao encontro do ODM 3 - Promover a igualdade entre os sexos e a autonomia das mulheres -, ou seja, verifica-se que o número de raparigas a frequentar o ensino equivale ao número de rapazes a frequentar o mesmo nível de ensino, quer ao nível do ensino primário quer secundário. Ao nível do terciário, 
identifica-se que esta igualdade aumenta de 1990 para 2000, na África Subsariana, no entanto, hà uma ligeira descida nos dados de 2000 para 2011. Por outro lado constata-se, igualmente, que ao nível terciário, a região da África Subsariana se encontra muito abaixo do indíce de paridade dos países desenvolvidos (Gráfico $6)$.

\section{Gráfico 6 - Rácios de raparigas e rapazes no ensino primário, secundário e terciário, taxas de escolarização bruta, 1990 - 2011}

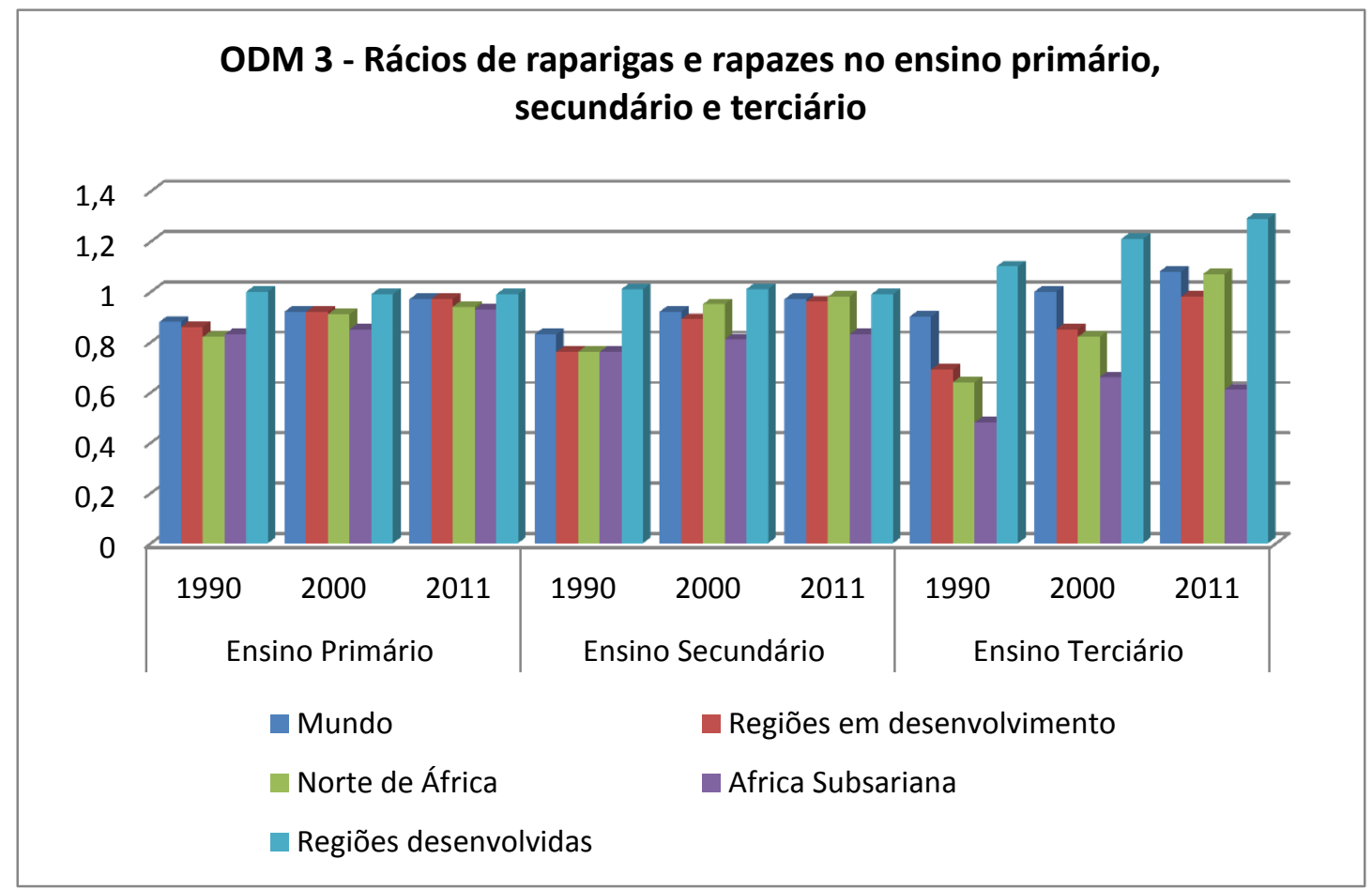

Dados obtidos e adaptados de UN (2013)

Na escola primária, em 2009, por cada 100 rapazes a frequentar a escola havia 90 raparigas. Na escola secundária o acesso das raparigas aumentou sendo o seu desempenho melhor do que a dos rapazes. No ensino terciário a participação feminina aumentou para o dobro em relação à participação masculina (AUC et al, 2012). Desta forma, o rácio de literacia, ou seja, a relação entre homens e mulheres que sabem ler e escrever, tem vindo a aumentar (de 1990 para 2011), contudo, existe ainda um hiato na região da ASS quando comparada com as outras 
regiões (Gráfico 7). Uma maior taxa de participação feminina na educação tem implicações diretas na sua qualidade de vida, pois passam a ter acesso ao mercado de trabalho, não só no emprego indiferenciado mas, essencialmente, no emprego qualificado, deixando de estar subjugadas ao trabalho no sector primário (agricultura) ou apenas trabalho doméstico. De acordo com o relatório das Nações Unidas (2013) na maior parte dos países, 62\% das mulheres têm um maior envolvimento no ensino terciário. Em 33\% dos países existe uma maior participação dos homens e em apenas $5 \%$ dos países existe paridade do género quanto à participação no ensino superior (Gráfico 8).

\section{Gráfico 7 - Rácio de literacia por sexo e região, 1990 - 2011 (percentagem)}

As taxas de alfabetização entre os adultos e os jovens estão em ascensão, e os hiatos de gênero estão a diminuir

Taxas de alfabetização dos jovens por região e por sexo, 1990 e 2011 (Percentagem)

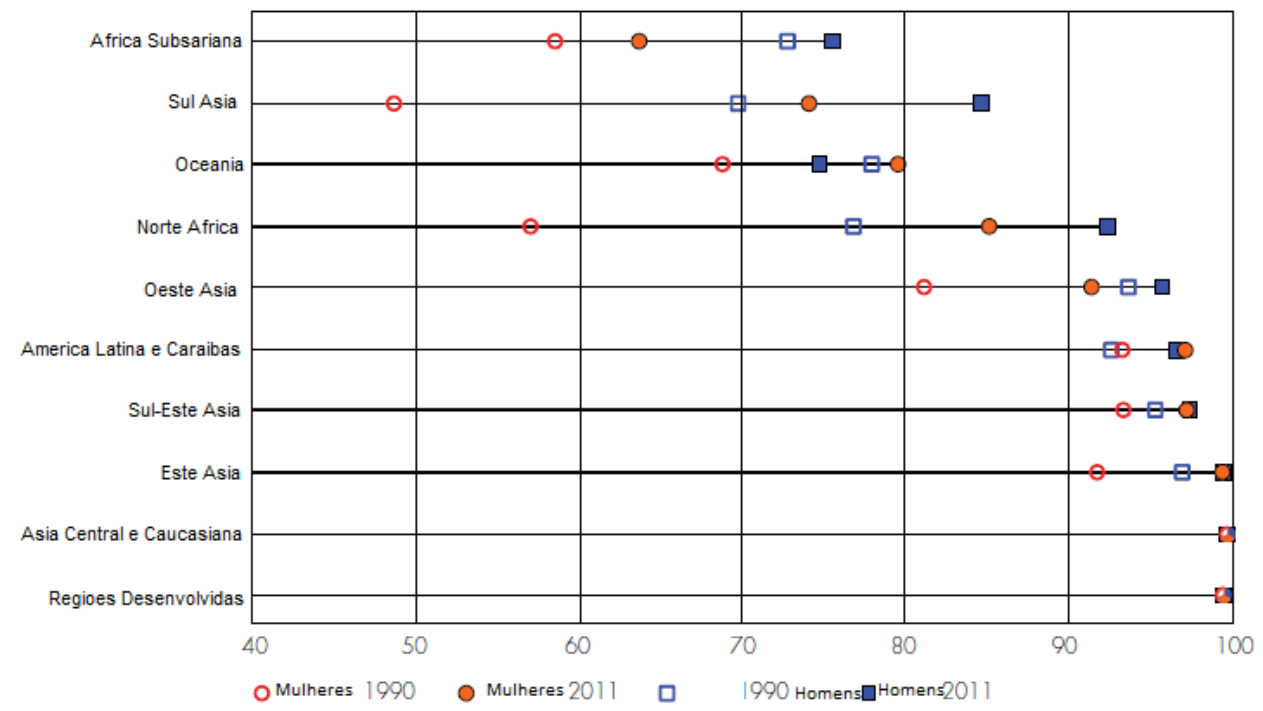

| Nota: Os dados de 1990 referem-se ao de período de 1985 a 1994. Os dados para 2011 referem-se ao período de 2005 a 2011. 
Gráfico 8 - Paridade do Género Vs. Tipo de educação, 2011

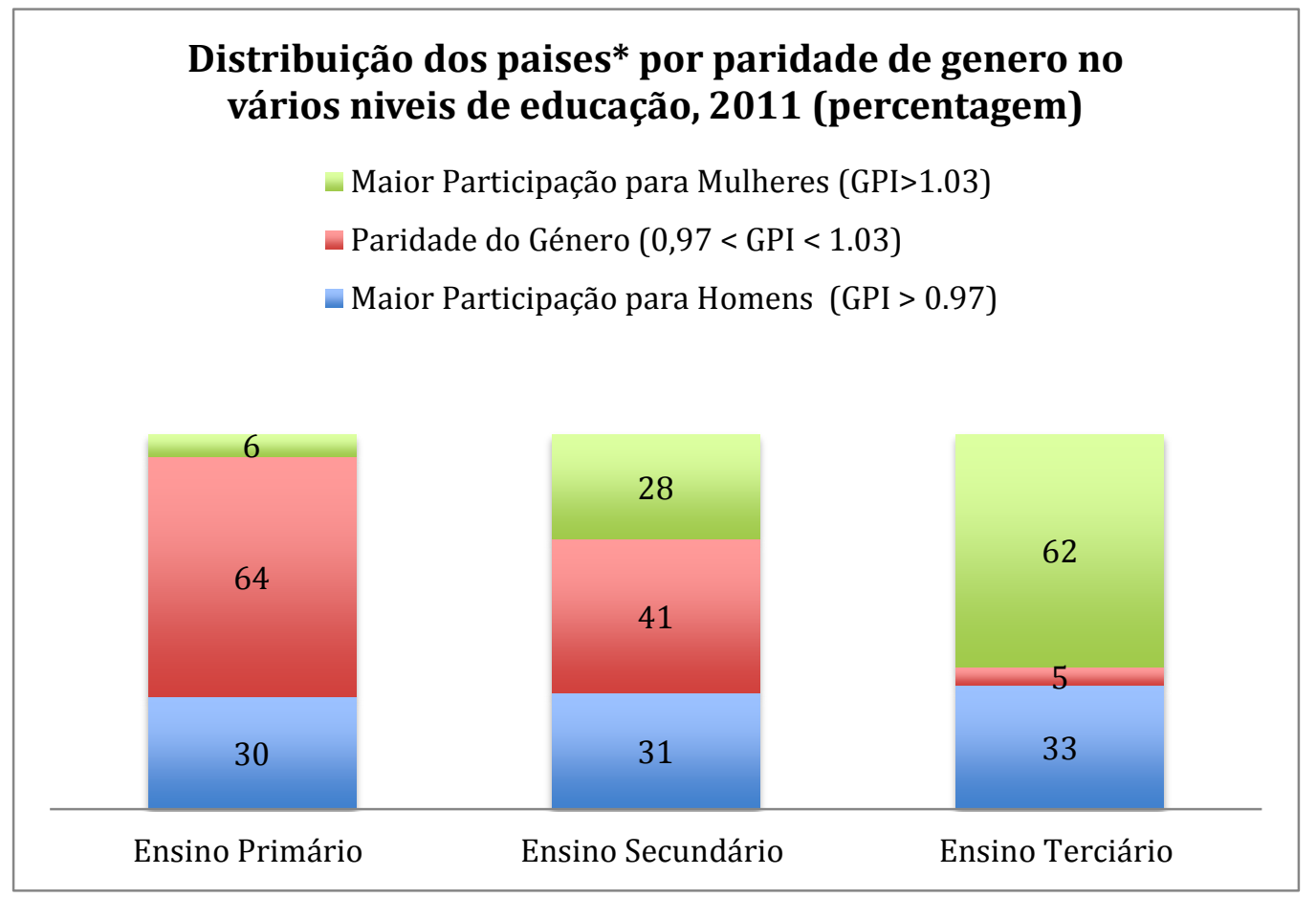

*Baseado em dados disponíveis para 175 países para a educação primária, 160 para a educação secundária e 141 países para a educação terciária. Na falta de dados para o ano de 2011 foi utilizada a ultima informação no período 2009-2011. GPI - Gender Parity Index ${ }^{7}$

Fonte: UN ( 2013)

Não obstante os progressos evidenciados anteriormente é relevante mencionar que a participação na educação contínua subordinada aos níveis sociais de vida, sendo que esta paridade de género verifica-se, essencialmente, nas crianças de classe social mais elevada de acordo com o estudo das Nações Unidas (2013) o qual demonstra que $20 \%$ dos alunos mais pobres permanecem no ensino primário até à

\footnotetext{
${ }^{7} \mathrm{O}$ rácio de meninas e meninos (índice de paridade de género) na educação primária, secundária e terciária é a razão entre o número de estudantes do sexo feminino matriculados nos níveis primário, secundário e terciário para o número de estudantes do sexo masculino em cada nível. Para padronizar os efeitos da estrutura da população dos grupos etários adequados é utilizado o Índice de Paridade de Gênero (GPI) da Relação de matrícula bruta (GER) para cada nível de ensino. A GPI de 1 indica paridade entre os sexos; quando o GPI varia entre 0 e 1 , tipicamente, uma disparidade em favor dos machos; enquanto um GPI maior do que 1 indica uma disparidade em favor das fêmeas. $\mathrm{O}$ indicador é uma medida imperfeita da acessibilidade na educação das raparigas, porque não permite determinar se as melhorias no rácio refletem os aumentos matrícula de meninas na escola (desejáveis) ou se representa uma diminuição de inscrição dos meninos (indesejável). Também não demonstra se o nível global de participação na educação é baixo ou alto. http://mdgs.un.org/unsd/mdg/Metadata.aspx? IndicatorId=9
} 
idade de 31 e 28 anos, raparigas e rapazes, respectivamente, enquanto que $20 \%$ dos estudantes de uma classe social mais abastada, concluem o ensino primário até à idade dos 9 e 8 anos, raparigas e rapazes, respectivamente. $\mathrm{O}$ mesmo se verifica no ensino secundário, onde os alunos das camadas sociais menos abastadas permanecem até aos 35 e 30 anos, raparigas e rapazes, respectivamente, e os estudantes das classes sociais altas, acabam o ensino secundário com 13 e 9, raparigas e rapazes, respectivamente (Gráfico 9). Por outro lado, os impedimentos culturais, sociológicos, económicos, psicológicos, históricos e políticos reduzem o acesso das mulheres ao mercado de trabalho e aumentam as desigualdades mencionadas, principalmente em áreas relacionadas com as ciências e a tecnologia, onde a população feminina continua a estar em menor percentagem quando comparada com a população masculina. A localização dos estudantes condiciona, de forma semelhante, a permanência dos estudantes na escola, na medida em que nas regiões rurais os alunos apenas acabam o ensino primário, em média, aos 22 anos enquanto que nas zonas urbanas, acabam em média aos 9 anos. O mesmo acontece no ensino secundário, onde os alunos das zonas rurais apenas acabam aos 24 anos compados com os 15 anos das zonas urbanas (Gráfico 10).

\section{Gráfico 9 - Relação Género Vs. Qualidade de Vida Vs. Nível de Estudos, 2005-2011}

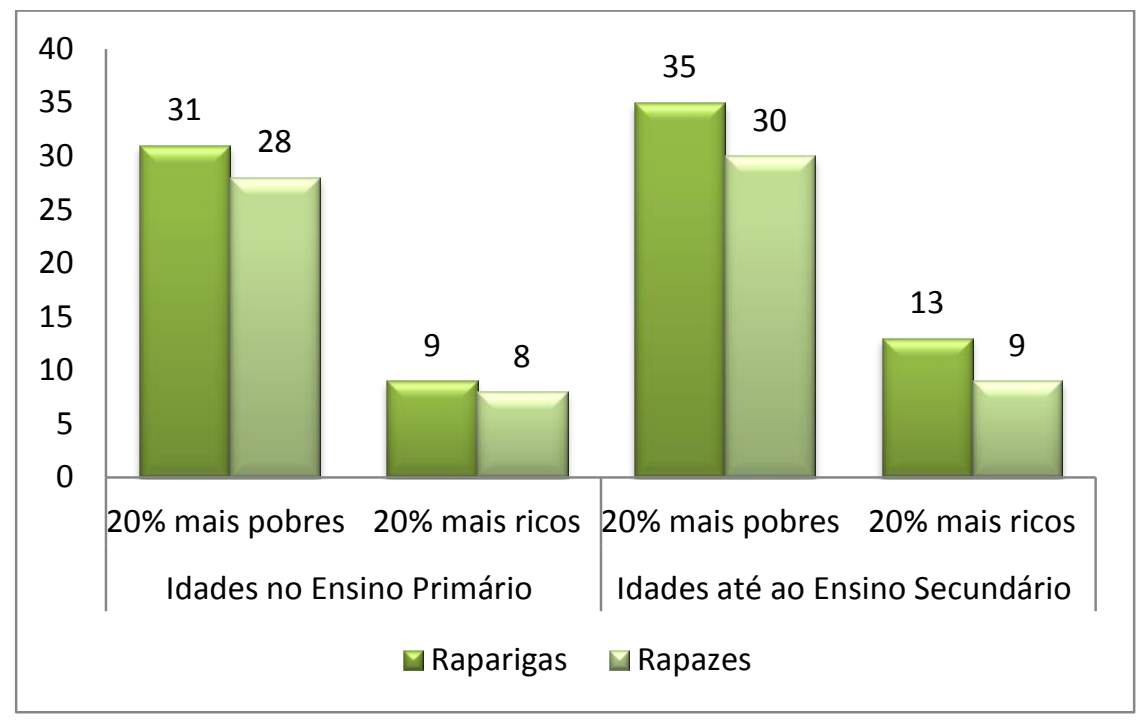

Fonte: UN (2013) 


\section{Gráfico 10 - Relação entre as idades no ensino primário e secundário e a localização dos estudantes - rural e urbano}

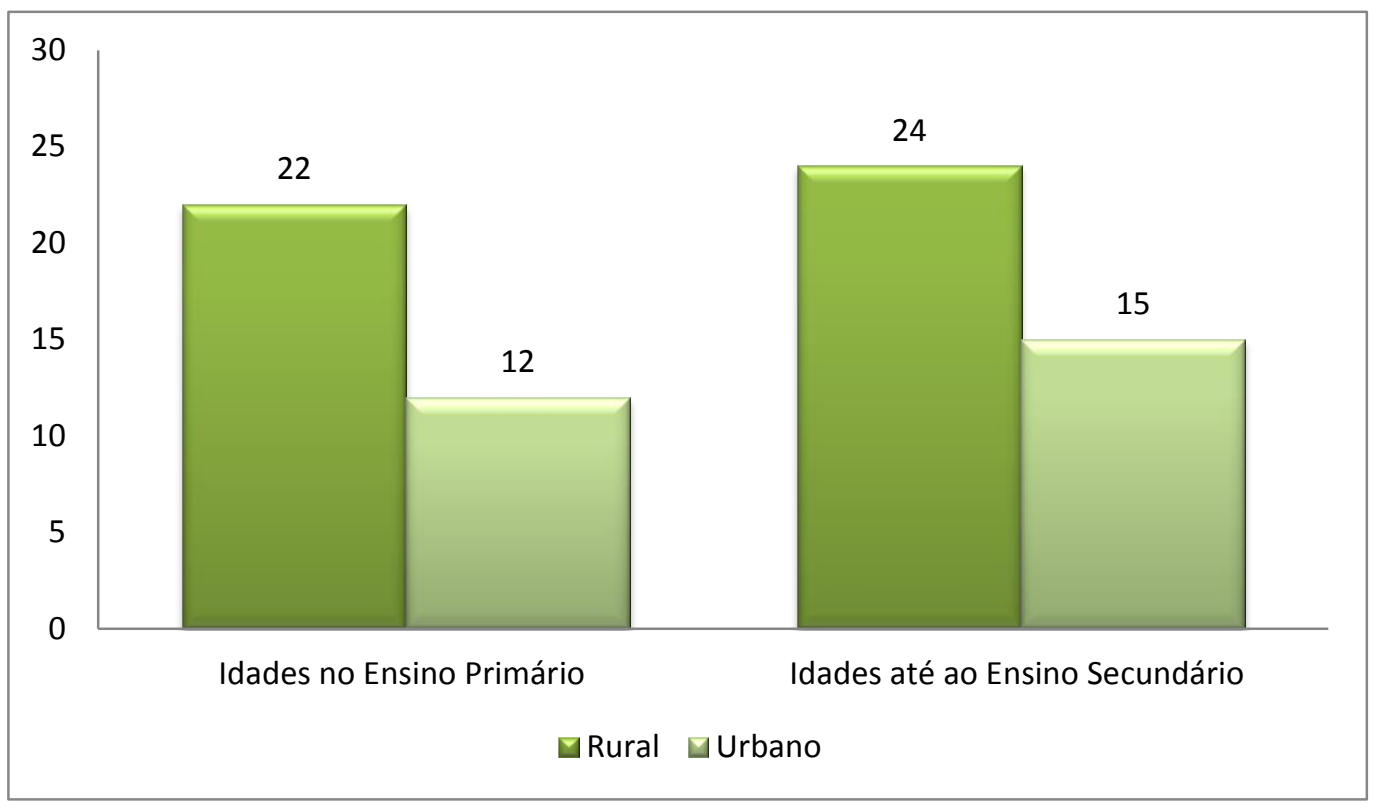

Fonte: UN (2013)

O fator mencionado está fortemente relacionado com as disparidades ao nível do emprego, uma vez que existe uma diferença de $24.8 \%$ de desemprego entre as mulheres e os homens em 2012. De acordo com o último relatório dos ODM, efetuado pelas Nações Unidas (UN, 2013:9), esta diferença é mais acentuada no Norte de África, onde a percentagem de mulheres sem emprego é maior e onde o rácio entre homens e mulheres com emprego se aproxima dos 50 \% em 2012. Importa mencionar que a taxa de participação no ensino superior encontra-se, de certa forma, subjugada às diretivas existentes no cerne destas instituições as quais limitam a autonomia dos seus dirigentes e a forma de organização destas instituições no sentido de promover uma maior taxa de inscrições das populações envolventes. 
Como refexão final concluímos que os fatores culturais e éticos próprios da sociedade subsariana tendem a se alterar, na medida em que a se assiste à transformação de uma sociedade machista, onde apenas o homem tinha direito a estudar e a trabalhar, para uma sociedade onde a mulher ganha direitos e maior autonomia, visto que os dados apresentados demostram uma paridade cada vez maior no acesso aos estudos por ambos os géneros. Não obstante, observamos a uma lenta transformação no que se respeita à metamorfose de uma sociedade de classes, ou seja, verifica-se que as classes sociais mais altas acabam o ensino primário mais cedo e os rapazes começam o ensino secundário de seguida e as raparigas algum tempo depois (fruto de uma herança cultural onde as mulheres devem ficar em casa) enquanto que as classes sociais menos abastados permacem até à idade de adultos para terminarem o ensino primário ingressando, a posteriori, de forma semelhante no ensino secundário. Esta situação acentua-se quando comparadas as zonas rurais com as urbanas. Estes dados influenciam a falta de desenvolvimento do sistema de educação superior enquanto consequência direta de um sistema educativo primário e secundário que perpectua com sociedades machistas e classistas, tal como demostrado anteriormente. A mudança de atitude por parte dos Atores, nacionais e internacionais, e o reconhecimento de que um sistema de ensino superior mais equitativo e acessível a todos os grupos etários e classes sociais, independentemente de se tratar da perifieria ou não, poderá constituir um factor primordial na transformação das sociedades e nas organizações socias com importantes impactos nas estruturas de poder em Africa, como seria o caso do empoderamento das mulheres e o acesso das mesmas aos lugares políticos. Para tal é necessário a reinvenção do sistema educativo, a todos os níveis, e em especial do ensino superior, no sentido de fazer frente aos desafios locais dos países da Africa Subsariana. 


\subsection{A reforma no Ensino Superior em África: Autonomia e legislação}

Apesar das Instituições de Ensino Superior contribuírem para um desenvolvimento sustentável e para uma sociedade mais democrática, como anteriormente verificado, a legislação existente no âmbito destas instituições, impede o desenvolvimento de esforços no sentido de promover uma maior taxa de participação no ensino superior assim como para melhorar a qualidade do ensino em África (Bloom et al, 2006). Na maior parte dos países as políticas de tomada de decisão são demasiado centralizadas restringindo a autonomia das instituições de ensino superior as quais respondem, em grande parte, aos objetivos políticos regionais e nacionais. Esta centralização política impede as universidades de serem responsáveis por mudanças ao nível do conhecimento, no mercado laboral e no desenvolvimento económico. Por outro lado, em alguns países, verifica-se precisamente o contrário, ou seja, a falta de unidade e de centralização dos sistemas, o que permite ao sector privado operar de forma a atrair estudantes e onde a qualidade da educação é, por conseguinte, muito baixa e com um custo bastante elevado não existindo, por isso, retorno do investimento (Bloom et al, 2006). São poucos os casos em que o governo dá autonomia total às universidades no que respeita à tomada de decisão, assim como encoraja o estabelecimento de instituições de ensino superior privadas (como por exemplo Angola). As condições legais para o ensino superior diferem de país para país, podendo as mesmas serem públicas e estar na alçada do governo, enquanto que as instituições privadas podem ter liberdade de gestão e governo. Isto porque em alguns países é permitido o estabelecimento de universidades privadas, existindo alguns casos onde ainda não existe regulamentação para este tipo de instituições. Facilmente se depreende a necessidade da ajuda e cooperação de atores externos no sentido de melhor coordenar e orientar os objetivos destas instituições e de regulamentar a sua estrutura, organização e gestão no sentido de se obterem instituições de maior qualidade, que promovam a igualdade de oportunidades e que estejam alinhadas com as necessidades do tecido empresarial. Por exemplo, no Egipto a universidade 
privada mais importante é a Arb Academy for Science, Technology \& Maritime Transport. Trata-se de uma instituição moderna com um número de professores bastante aceitável e conectada com as atividades portuárias do porto de Alexandria. Contudo, no último golpe de Estado Abdelfatah Al-Sisi tomou o poder e entre os seus direitos estava a nomeação dos reitores, incluindo as universidades privadas. Uma vez designado, o novo reitor desactivou o planos de formação de novos profissionais em áreas empresariais o que delimita o seu alinhamento com as necessidades das empresas locais.

A falta de autonomia das universidades africanas está estreitamente relacionada com a liberdade académica, a qual é percecionada como um fator crucial para a criação de novas ideias, para o desenvolvimento de novas investigações e de novas opiniões. A liberdade académica garante que os professores ensinem de forma livre comunicando sem receio as suas opiniões e as suas pesquisas sem medo de retaliações contribuindo, desta forma, para o desenvolvimento da sociedade. No entanto, tal como demonstrado, os governos africanos controlam a autonomia das universidades e, concludentemente, a liberdade de expressão académica, essencialmente nos casos em que se trata de ideias controversas e inconvenientes ao governo (Teferra e Altbach, 2004:40). Esta perspectiva é corroborada por Charles Ngome (2004) e Wondimu (2003, in Teferra e Altbach, 2004:40) o qual afirma que o governo interfere e abusa da liberdade académica tendo erodido a autonomia e a qualidade das instituições de ensino superior. Neste sentido, a comunidade académica tem sido cuidadosa para não ofender os decisores políticos o que poderá constringir a procura da verdade nas suas investigações e nos relacionamentos de cooperação que poderiam desenvolver com o sector empresarial para promoção de ideias inovadoras, assim como, no seu envolvimento para a prossecução da missão das universidades. No entanto, tem-se vindo a verificar melhorias nesta área, no contexto político pós-colonial ainda que se verifique uma dicotomia entre a missão das universidades públicas e privadas. Por outro lado, a influência ocidental continua a sustentar a ideia de que os países em desenvolvimento devem investir, principalmente, em educação secundária em 
prol da educação superior. Esta tendência deriva do facto de se acreditar que o ensino terciário serve, fundamentalmente, para reproduzir uma elite social poderosa. No entanto, esta poderá ser uma perspectiva retrogada própria de países colonialistas, os quais depreciam a educação superior como um meio de transformação das sociedades. Esta visão poderia ser aceitável no contexto da revolução indústrial e da produção em massa a qual permitiu avanços económicos e cujos requesitos ao nível de capital humano eram satisfeitos ao nível da educação secundária. Esta tese é defendida por Schofield (1973) e Sanderson (1983) que concluiem nos seus estudos que, no período da revolução indústrial, as fábricas não necessitavam de trabalhadores qualificados, mas sim de uma elite reduzida de trabalhadores alfabetizados, capazes de desenvolver tarefas mecanizadas e que na maior parte dos casos, as tarefas de produção fabris poderiam ser efectuadas por trabalhadores analfabetos. Esta visão é ainda defendida por Núñez e Tortella (1993) uma vez que se pode inferir dos seus estudos que a fase inicial de escolarização tem uma relação mais estreita com o inicio de um processso sustentável de crescimento de renda por habitante do que outros níveis mais elevados do sistema educativo. Mirónov no mesmo estudo corrobora com esta posição destacando que "en los países en vías de desarrollo, debido al nivel educativo relativamente bajo de la población y a la mentalidad tradicional, la contribución neta de la educación al desarrollo económico del país es comparativamente pequeño" (Núñez e Tortella, 1933:296).

A partir da Segunda Revolução Indústrial esta ideia de "homem prático" que se formava e adquiria experiência no posto de trabalho (Coleman e Macleod, 1986) deixa de fazer sentido sendo substituída pelas bases da formação cientifica e técnica com potencialidade para impulsionar o crescimento da indústria química, eléctrica e da engenharia mecânica (Mayoral, 2006). Esta perspectiva é enfatizada num mundo de inovação e desenvolvimento tecnológico constante, globalizado e internacionalizado. É necessário desenvolver capacidades de acesso às inovações cientificas, técnicas e institucionais desenvolvidas nos países mais avançados o que pode representar o acesso a mercados internacionais contribuindo para um 
desenvolvimento significativo nos recursos dos países em desenvolvimento permitindo a criação de capital humano o qual contribui para a sustentabilidade destes países e inverter o atrasado relativo em relação aos países desenvolvidos tal como descrito por Mayoral (2006). Esta perspectiva reinforça a missão da universidade e o seu contributo para sociedades desenvolvidas, modernizadas e autossustentáveis.

\subsection{A missão das universidades e a dicotomia entre público e privado}

A universidade, desde a Idade Média, tem a missão de diligenciar o saber e formar elites para servir o Estado e a Igreja. Evoluiu ao longo dos anos acabando por ser designada, na década de sessenta, por Clark Kerr (1963) como uma instituição de multidiversidade. De acordo com Pedrosa et al (2005:51), esta evolução implicou que o ensino superior desenvolvesse determinadas funções, nomeadamente:

- Educação e formação superior de distinta natureza e vocação;

- Estudo erudito, busca e criação de conhecimento;

- Investigação fundamental inserta em redes internacionais de excelência;

- Investigação aplicada e serviço à comunidade, com transferência de conhecimento.

Por outro lado, tem a missão de ser sede de criação e difusão do conhecimento livre e comprometido com a transparência e a busca da verdade legitimada pela ciência. À universidade pública caberá salvaguardar princípios e valores que são património da nação, prever riscos, estudar e debater questões fundamentais para o desenvolvimento assim como assegurar a educação superior e a investigação para sustentar a capacidade nacional de proporcionar conhecimento e saber em áreas não necessariamente atraentes do ponto de vista estritamente económico. Esta 
perspetiva é consistente com a Declaração Mundial sobre Educação Superior no Século XXI: Visão e Ação (1998) ${ }^{8}$. A visão e ação, adotada em 1998, sob os auspícios da UNESCO, cujo artigo $1 .^{\circ}$ sobre a educação, a formação e a investigação sintetiza nos seguintes termos as funções da universidade:

- Desenvolver, criar e disseminar o conhecimento através da investigação científica e tecnológica, assim como nas áreas das Ciências Sociais, Humanidades e Artes;

- Expandir as oportunidades de ensino superior ao longo da vida, formando para a cidadania e a participação na sociedade;

- Ajudar a entender, interpretar, preservar, reforçar, promover e disseminar a cultura nacional, regional e internacional, o pluralismo e a diversidade; e

- Identificar e debater questões que afetam a comunidade nacional e a sociedade global.

A UNESCO, a OCDE e a UE indicam, igualmente, os critérios necessários para distinguir o ensino superior privado do público, nomeadamente:

- O poder de definir as orientações gerais e as atividades principais das Instituições de Ensino Superior;

- O poder de nomear a direção da instituição;

- A percentagem do financiamento público; e

- A remuneração do corpo docente.

\footnotetext{
${ }^{8}$ Conferência Mundial sobre Educação Superior - UNESCO, Paris, 9 de outubro de 1998
} 
Assim, são consideradas instituições privadas, aquelas que têm o poder de orientação, nomeação e quando menos de $50 \%$ do seu orçamento é proveniente de entidades públicas e tem corpo docente e de investigação próprio. Pelo contrário, são públicas as instituições financiadas em mais de $50 \%$ por intermédio de entidades públicas e onde o poder final de aprovação de políticas e atividades gerais, de nomeação da direção e/ou remuneração do corpo docente pertencem direta ou indiretamente ao Estado. O ensino superior público, tal como o conceito acaba de ser definido, é o que predomina à escala mundial, embora com acentuadas diferenças de região para região. Segundo o Relatório GED (UN, 2006), publicado pela UNESCO, a média mundial da oferta de ensino superior privado não ultrapassa os $18 \%$ do total. Apenas em três países de África ao Sul do Sara, a oferta do ensino universitário privado é maior do que a oferta pública: no Botswana, em Cabo Verde e na Namíbia.

A abordagem relativa ao financiamento do ensino superior público e ensino superior privado deve ter em conta os príncipais critérios delimitados por organizações como a UNESCO, a OCDE, a União Europeia e o Banco Mundial que consideram os seguintes critérios interligados para distinguir estes dois tipos de ensino:

(i) o poder de definição das políticas, orientações gerais e atividades principais dos estabelecimentos, em particular as universidades; e

(ii) o poder de nomear a direção, assim como o corpo docente e de investigação; a percentagem do financiamento com origem em entidades públicas.

No entanto, o que predominou em África, até ao início do presente século, foi o ensino superior público, cujo envolvimento do governo está subjacente à gestão das mesmas (Teferra \& Altbach, 2004). Isto porque, a estrutura de gestão mais comum nas universidades africanas está estreitamente interligada com os 
governadores do Estado os quais assumem a presidência das universidades - com poder executivo -, assim como indicam os restantes gestores e diretores com possibilidade de tomada de decisão. Nesta linha de decisão administrativa os profissionais académico detém pouco poder quando comparados com outros profissionais pares de universidades internacionais. Como consequência, a estrutura de gestão, alinha-se com um sistema de gestão "hard", ineficiente, pobre e burocrático suportado por pessoal não qualificado e com falta de formação. Trata-se de uma "gestão ineficiente, inefetiva e desajustada" com "funcionários mal remunerados" (Teferra \& Altbach, 2004:31). Não obstante, o crescimento das instituições de ensino superior privadas é uma realidade. Este deve-se a vários fatores (Teferra \& Altbach, 2004), designadamente:

- O aumento da procura deste serviço por parte dos alunos;

- O declínio da capacidade das universidades públicas;

- A redução do serviço público;

- A pressão por parte das agências externas para cortar no serviço público;

- A necessidade de mão-de-obra qualificada de forma a ir ao encontro das necessidades do mercado local; e

- O interesse de fornecedores externos.

Ainda assim, estas instituições privadas são, por norma, mais pequenas e especializam-se em determinadas áreas estando situadas nas principais capitais onde a procura de estudantes é maior e cujas infraestruturas são de relativa boa qualidade. O principal rendimento destas instituições é proveniente de taxas e propinas pagas pelos estudantes o que encarece o custo deste tipo de educação, uma vez que, na maioria dos países africanos, os governos não financiam estas instituições privadas (podendo existir algumas exceções como é o caso da Libéria) cujo governo apoia os estudantes através de subsídios para pagar as propinas e material necessário no normal decurso dos estudos, essencialmente livros (Seyon 2003, in Teferra e Altbach, 2004). 
Estas instituições estão livres das obrigações a que, normalmente, as universidades públicas estão sujeitas, no sentido em que incumbe ao Estado a criação de uma rede de instituições que satisfaça as necessidades do país e que se comprometam com a criação, transmissão e difusão da cultura, do saber e da ciência e tecnologia, através da articulação do estudo, do ensino, da investigação, do desenvolvimento experimental e da sua difusão. Estas gozam de autonomia estatutária, pedagógica, científica e cultural, administrativa, financeira, patrimonial e disciplinar face ao Estado. As universidades privadas são impulsionadas pelas leis de mercado, ou seja, pelo lucro, pela escassez de profissionais, funcionam de acordo com as vontades partidárias, pela implementação de políticas de ação afirmativa, são flexíveis e inovadoras "para acomodar os marginalizados por razões de género, classe, região, étnia e religião" (Olukoshi e Zeleza 2004:603). Contudo, estão sujeitas a um maior escrutínio, visto serem consideradas instituições cujo ensino é de menor qualidade, como é o exemplo a África do Sul. No entanto, os cursos lecionados vão mais ao encontro das necessidades do mercado local, estando relacionados com áreas como a ciência e a tecnologia, contabilidade, gestão, finanças, marketing e secretariado (Teferra e Altbach, 2004). No que respeita ao corpo docente, são contratados professores do ensino público, os quais mantém contratos a termo parcial nas instituições públicas. Desta forma, arrecadam uma importante fonte de rendimento extra. Em alguns casos, os salários oferecidos pelo privado são de tal forma significativos que abandonam por completo o ensino público, essencialmente quando se tratam de áreas académicas mais atrativas. No entanto, persiste a ideia de que o ensino superior público tem melhor qualidade ainda que as instituições privadas contratem os melhores professores e ofereçam melhores infraestruturas e equipamentos (Teferra e Altbach, 2004:34). Esta crença advém do fato de que, devido ao crescente escalonamento da procura de vagas nas universidades públicas, apenas entram os que têm melhores resultados. Como consequência, as instituições privadas vão absorver os restantes, pelo que serão sempre considerados como graduados inferiores e de menor qualidade. 
Em suma, o ensino superior privado emerge numa perspetiva de negócio privado o que coloca em evidência o seu estatuto legal, a sua qualidade e os custos a si associados (Teferra e Altbach, 2004:34). Por outro lado, tal como indica Tolentino (2006) assiste-se à evolução e a novas tendências do ensino superior o qual está subjacentes à análise e às propostas relativas à criação de uma Universidade Pública Empreendedora, a qual se caracteriza pelas seguintes tendências:

- A globalização das economias, comércio, finanças, serviços, trabalho e outros domínios, tais como a educação, a cultura e a comunicação;

- O papel crescente da produção, aperfeiçoamento, disseminação e aplicação do conhecimento enquanto força propulsora do desenvolvimento;

- O progresso acelerado e a função impulsionadora das TIC na sociedade do conhecimento;

- A relação entre o ensino superior, o Estado, o mercado e a sociedade, centrada na partilha dos custos, benefícios e responsabilidades, incluindo a abertura das Instituições de Ensino Superior e dos mecanismos de prestação de contas à sociedade;

- A constante transformação social e política, caracterizada pelos movimentos contraditórios de afirmação da transparência democrática, por um lado, e da permanência da pobreza, insegurança e instabilidade, por outro;

- As grandes mudanças na evolução demográfica mundial;

- A recuperação da importância estratégica dos pequenos Estados Insulares para a sociedade global; e

- A importância crescente dos valores imateriais e não transacionáveis para os pequenos Estados Insulares. 
Tal como mencionado, existe um vasto leque de condições que propulsionaram o aparecimento das universidades privadas. Contudo, os constrangimentos financeiros e a falta de financiamento das universidades públicas, tendo em conta a crescente procura, impulsionou o seu rápido desenvolvimento com todas as implicações a si associadas. Não obstante, o contributo destas instituições, públicas e privadas, para o desenvolvimento é de relevante importância como se constatará de seguida, no entanto, é necessário repensar a carreira dos docentes académicos em países em desenvolvimento, considerando as especificades dos mesmos e dos desafios que enfrentam.

\subsection{A profissão académica em África}

De acordo com dados do Banco Mundial (2006) em 2005, numa amostra de cerca de 400 docentes do ensino superior público e privado, aproximadamente 275 (70\%) eram docentes em regime de tempo integral (ETI). Destes, 5,65\% eram Doutorados, 23,25\% Mestrados, $70 \%$ Licenciados e 1,1\% Bacharéis. Estes números deixam transparecer um ensino superior cuja qualidade pode ser dúbia. A função primordial das instituições universitárias nos países em desenvolvimento é precisamente a criação, a fixação e a atração de competências, lutando contra a escassez, o desperdício e a fuga de cérebros. Num país profundamente influenciado pela emigração a missão da universidade é crucial e tem características peculiares.

Com base em números relativos a 2000, o estudo efetuado pelo Banco Mundial (2006) demonstra que $67 \%$ dos cabo-verdianos qualificados, com cursos superiores ou técnicos, trabalham no estrangeiro constituindo a maior taxa africana de exportação de competências. Segundo o mesmo estudo, Moçambique e Angola deixam fugir para os países ricos, respetivamente, 45 e 33\% da sua mão-de-obra qualificada. De facto, um dos maiores desafios dos países africanos passa pelo afastamento dos investigadores e dos profissionais académicos das universidades. 
Este processo de migração, regional, nacional e internacional, é reconhecido na literatura como "brain drain" descrito, mais precisamente, como o movimento de peritos reconhecidos dos países em desenvolvimento para países industrializados, o que poderá refletir consequências negativas ao nível da sua capacidade de desenvolvimento (Teferra e Altbach, 2004; IOM, 2005). Este movimento deve-se, essencialmente, à procura de melhores condições por parte destes profissionais, os quais são atraídos por agências privadas através de salários mais competitivos (UNESCO, 2014). Os especialistas académicos com mais experiência são atraídos por universidades estrangeiras como por exemplo a Austrália, a Inglaterra, o Canadá e os EUA. Verifica-se uma evidente ineficácia das medidas administrativas para inverter esta tendência e estancar a hemorragia dos países mais pobres em benefício dos países mais ricos. No sentido de colmatar estas falhas, a UNESCO (2014) indica quatro estratégias complementares de recrutamento e formação acelerada de cientistas e professores:

- Negociar com universidades de excelência programas de formação de professores em regime de ocupação exclusiva;

- Negociar com universidades ou grupos de universidades estrangeiras pacotes de formação de professores em regime alternado, o qual permite aos candidatos manter parte da sua atividade pedagógica e de pesquisa e atrair competências do exterior, enquanto se enriquecem científica e profissionalmente no exterior;

- Adotar programas específicos de atração e recrutamento de mão-de-obra altamente qualificada que trabalha no estrangeiro podendo, em alguns casos, haver entendimento entre governos interessados;

- Recrutar a prazo competências estrangeiras para as áreas estratégicas de ensino, de investigação, de extensão e desenvolvimento organizacional. 
Atualmente, o universo de professores e cientistas reformados com experiência, motivação e energia para este tipo de projetos, constitui uma grande oportunidade de capacitação de jovens talentos e instituições. Existe, no entanto, uma grande desproporcionalidade entre os profissionais académicos e o pessoal não académico, na medida em que a percentagem destes últimos ultrapassa os primeiros na maior parte das instituições de ensino superior africanas. De acordo com Teferra e Altbach (2004) esta tendência deve-se à elevada taxa de procedimentos administrativos burocráticos. Os mesmos autores indicam que os recursos alocados a este sector são desproporcionais e elevados tendo em conta a qualidade do desempenho dos quadros administrativos. Se por um lado o papel dos funcionários não académicos é crucial, por outro a sua desproporcionalidade implica uma fraca alocação de recursos os quais poderiam ser utilizados para funções básicas e prioritárias da universidade como o ensino e a investigação, uma vez que estamos perante países cujos recursos são limitados, muito embora se verifiquem algumas melhorias ao longo da evolução destas instituições, como se poderá constatar no capítulo seguinte.

A fraca alocação destes recursos contribui para que a investigação e as publicações estejam numa condição critica. Por um lado, devido à falta de condições materiais para fazer investigação, como bibliotecas com pouco material de estudo, falta de laboratórios e respetivo equipamento. Por outro lado, a falta de fundos, o fenómeno de brain drain e o baixo número de especialistas para conduzir as investigações são ainda uma preocupação. É, ainda, relevante o fato de que a promoção dos profissionais académicos depende da investigação que estes realizam e das publicações que efetuam o que poderá conduzir a resultados académicos de menor qualidade.

Tal como indicado, o ambiente existente não tende a promover e a suportar as investigações e as publicações, apesar destas atividades constituírem uma ferramenta de medida da produção científica destes profissionais (Teferra, 2002; Teferra e Altbach, 2004). Trata-se de uma situação controversa já que, na maioria 
das instituições de ensino superior, a investigação e a publicação de artigos não tem qualquer tipo de apoio financeiro dificultando a ascensão e a visão dos investigadores africanos em termos internacionais. Nos casos em que se verifica uma maior produção de material científico e de investigação existe um investimento superior por parte das agências externas, tais como agências bilaterais e multilaterais, Organizações Não Governamentais (ONG) e fundações, muito embora a gestão destes fundos seja feita pelas próprias agências. As estruturas locais de publicação são normalmente fracas devido à falta de investigadores e aos fracos apoios financeiros, como referido, mas também devido à falta de editores com qualidade e à falta de liberdade académica e consequente compromisso por parte dos administradores das universidades.

Em suma, a fuga de cérebros - brain drain -, é um fenómeno que sempre existiu em regiões onde a taxa de crescimento económica é menor (sendo que as expectativas são piores para o futuro) e onde os salários reais são mais baixos (cuja situação se verifica presentemente). Acrece o facto de que o fenómeno é consubstancial à globalização. Neste sentido, a única forma de o abrandar é com fortes ações de inversão estrangeiras em setores de ponta que sejam muito atrativos para a mão-de-obra altamente qualificada e cujas condições de trabalho sejam competitivas de forma a permitir que estes recursos humanos não necessitem de procurar esta oferta de trabalho noutros países, tal como assinala a UNESCO (2014), assim como garantir a sua permanência nas universidades através de planos de cooperação com as universidades dos países desenvolvidos com as da Europa, correspondendo aos primeiros pontos dos quatro que assinala a UNESCO (2014).

\subsection{A Educação enquanto fomento da economia}

De acordo com a evidência empírica o avanço no desenvolvimento está estreitamente relacionado com a cooperação académica e científica internacional, 
o que contribui para a circulação do conhecimento (Tejada, 2008; OECD, 2013; UNESCO, 2014). Enquanto fator de desenvolvimento o fluxo de conhecimento tem suporte na interação entre os domínios técnicos, institucional e empresarial. O conhecimento na forma de educação e investigação científica ou tecnológica adquiridas e/ou produzidas pelos estudantes qualificados é um catalisador importante do desenvolvimento. Este capital humano pode ser definido como os efeitos económicos sobre o emprego e os rendimentos resultantes do investimento em formação e educação (Becker, 1993). Com efeito, a teoria do capital humano assenta na premissa de que a educação aumenta a eficiência e, portanto, os rendimentos ao longo da vida (Nakabashi e Figueiredo, 2008). Verifica-se, assim, uma correlação entre o capital humano e o crescimento económico, implicando que níveis mais elevados de educação podem conduzir a maiores ganhos (Altinok, 2007; Becker, 1993; Desjardins, 2003; Monks, 2000; Perna, 2003; Sudmant, 2002; Rosan, 2002).

Apesar de África ser um dos continentes com maior taxa de pobreza, uma das principais características dos fluxos migratórios, internos e externos, é a mobilidade internacional dos indivíduos qualificados, vindos dos países de África a sul do Sahara para os países desenvolvidos (IOM, 2005). Por outro lado, os estudantes e os cientistas que vivem na Europa constituem uma fonte de conhecimento, de ideias e de competências de grande valor para os seus países de origem (Tejada, 2008), tendo um importante papel no debate sobre a cooperação académica Europa-África. De acordo com o Instituto de Estatística da UNESCO (UN, 2003) os países industrializados têm em média dez vezes mais investigadores por cada milhão de habitantes que os países em vias de desenvolvimento. Nos países mais industrializados, 4.400 indivíduos em cada milhão são investigadores. Esta densidade é 68 vezes superior à de África.

Os desafios e as oportunidades de migração qualificada na cooperação académica e científica entre África e a Europa têm uma importância significativa uma vez que esta cooperação tem como objetivo global contribuir para o avanço do 
desenvolvimento em África, através da disseminação do conhecimento e contributo para a criação de capital intelectual e, consequente, para a valorização dos recursos humanos os quais refletem, em vários níveis, uma sociedade com capacidade de se autossustentar. Em termos de evidência empírica, são vários os estudos que relacionam o ensino superior com o seu impacto positivo no crescimento económico (Tabela 2), assim como existe uma correlação positiva entre educação e empregos mais seguros (Gráfico11). Esta correlação deve ser aplicada aos países em desenvolvimento da Africa Subsariana no sentido de contribuir para a mudança de atitude dos decisores políticos os quais tendem a desvalorizar o ensino terciário e cuja tendência deve ser alterada.

Tabela 2 - Estudos que demonstram que níveis superiores de capital humano implicam uma maior taxa de desenvolvimento

\section{Autores}

Principais Conclusões

\begin{tabular}{|c|c|}
\hline $\begin{array}{l}\text { Robert J Barro e Xavier } \\
\text { Sala-i-Martin (1995) }\end{array}$ & $\begin{array}{l}\text { Níveis Superiores de capital humano implicam uma taxa de } \\
\text { desenvolvimento. }\end{array}$ \\
\hline H Jenkins (1995) & Níveis de qualificação superiores aumentam a produtividade. \\
\hline T-C Lin (2004) & O ES tem um importante papel no crescimento económico. \\
\hline $\begin{array}{l}\text { EN Wolff e M Gittleman } \\
(1993)\end{array}$ & $\begin{array}{l}\text { As taxas de participação no ES estão relacionadas com o } \\
\text { crescimento da produtividade. }\end{array}$ \\
\hline $\begin{array}{l}\text { Jean-Luc de Meulemeester e } \\
\text { Denis Rochat (1995) }\end{array}$ & $\begin{array}{l}\text { Demonstram que o ES tem um impacto causal no crescimento } \\
\text { económico em alguns países (em conjunto com outros fatores } \\
\text { estruturais). }\end{array}$ \\
\hline $\begin{array}{l}\text { De Bloom, M Hartley, e H } \\
\text { Rosovsky (2006) }\end{array}$ & Existe uma correlação positiva entre o ES e o empreendedorismo. \\
\hline $\begin{array}{l}\text { D Lederman e WF Maloney } \\
\text { (2003) }\end{array}$ & $\begin{array}{l}\text { A investigação e o desenvolvimento contribuem para o } \\
\text { crescimento económico e para o aumento da produtividade. }\end{array}$ \\
\hline
\end{tabular}




\section{Gráfico11 - Correlação entre Educação e Emprego Seguro}

Educação conduz a emprego mais seguro Percentagem de trabalhadores pagos entre a idade de 15 e 64 anos em mercados urbanos com contrato de trabalho, por nível de educação, nos países selecionados, 2007-2011

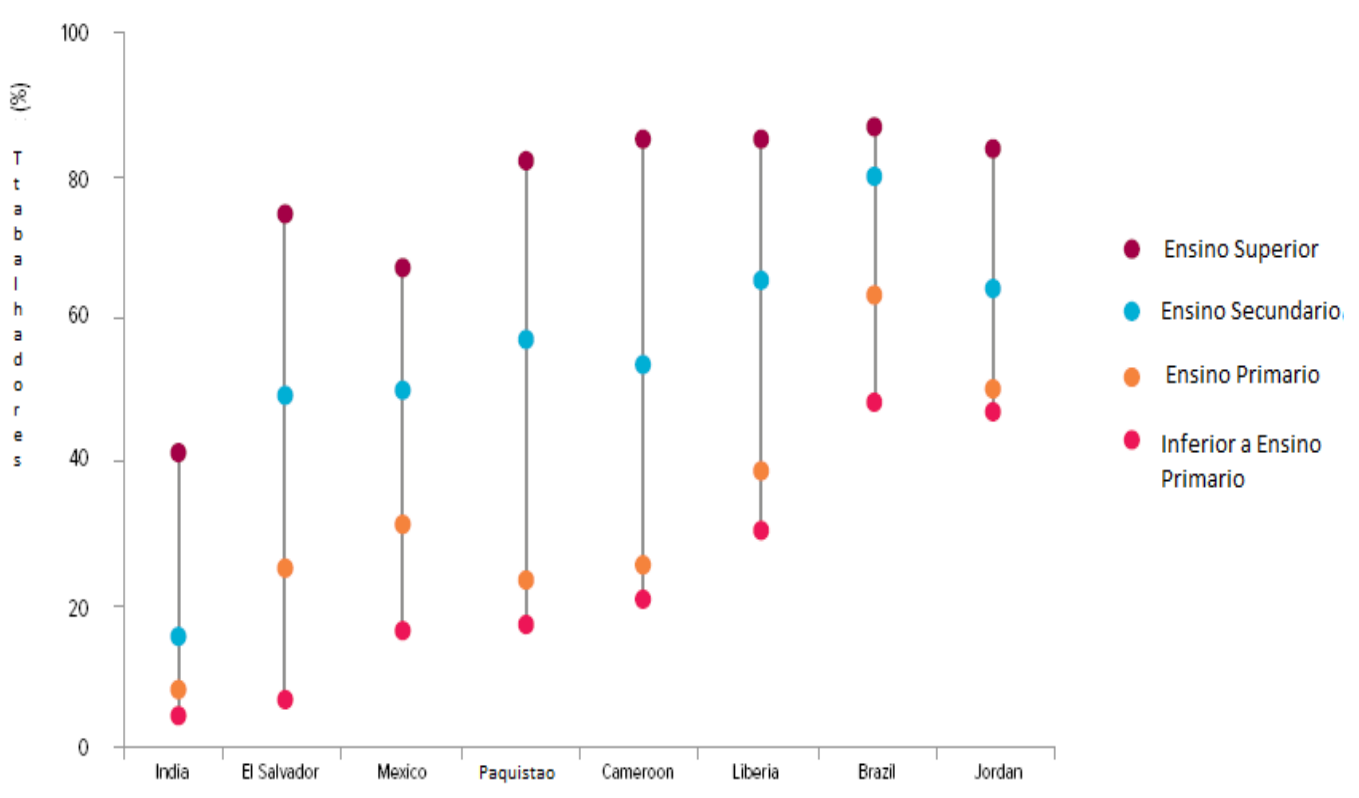

Fonte: Understanding children's work (2013)

Os sinais de progresso no ensino superior em África começam a ser visíveis (principalmente na África Subsariana), o que leva a comunidade internacional para o desenvolvimento a reconhecer a importância do ensino terciário e o seu impacto positivo no desenvolvimento e crescimento da economia, através da melhoria das condições de vida da população, a qual está correlacionada com melhores empregos e salários mais atrativos, tal como já mencionado, mas também através do desenvolvimento de tecnologias que satisfaçam as necessidades industriais, o que por sua vez irá contribuir para uma maior produtividade e, concludentemente, para a criação de mais emprego e de melhores oportunidades, inferindo-se que contribui para a redução da pobreza como se poderá constatar de seguida. 
Não obstante, é reforçada a ideia de que a educação secundária se adaptava às sociedades da época da revolução industrial, onde a força de trabalho era mecanizada e repetitiva. Com os avanços tecnológicos e com sociedades conectadas globalmente as exigências ao nível de capital humano aumentam substancialmente pelo que é necessários criar infraestruturas de conhecimento que acompanhem as novas necessidades empresariais e industriais dos países em desenvolvimento para um maior alinhamento com as economias globais desenvolvidas de forma a contribuir para o seu crescimento. Nesta ordem de ideias sustentasse a tese de que o sistema de ensino superior assume um importante fator no desenvolvimento de formação que satisfaça estes critérios a um nível avançado em áreas primordiais como as tecnologias de informação e comunicação, a robótica e a informática. Salienta-se que formação técnica e profissional, nas áreas mencionadas, pode ser dada ao nível secundário, no entanto, o desenvolvimento de capacidades inovadoras e criativas é efetuado ao nível do ensino superior muito embora se verifiquem alguns exemplos, como os Tecnoparques em Colômbia, onde existem sistemas de formação profissional nos quais a inovação e a investigação no campo das TIC são já uma realidade. Esta tendência não está, no entanto, generalizada pelo que as universidades assumem esta missão de formar capital humano para fazer face a um mundo globalizado e interconectado, especialmente os países em desenvolvimento.

\subsubsection{O crescimento económico em África e a sua relação com o capital humano}

A economia Africana demonstra grande resiliência quando comparada à economia global. No entanto, o seu crescimento tem sido facilitado pelos países com maior ligação aos mercados globais. O Produto Interno Bruto (PIB) do continente subiu, em média, 6,6 \%, em 2012 (African Economic Outlook, 2013) e aumentou $4 \%$, em 2013 (African Economic Outlook, 2014). Este crescimento deve-se sobretudo 
ao comércio tradicional pois as atividades de exportação continuam subjugadas ao clima político e socioeconómico destes países. A procura interna tem sido impulsionada, basicamente, pelo consumo e investimento privado. Por outro lado, a economia global debilitada restringiu os volumes de exportação provenientes de África (African Economic Outlook, 2013 e 2014), apesar de que, de uma forma geral, o preço das mercadorias mantém-se favorável aos exportadores africanos. Por outro lado, o norte de África constitui uma exceção, tendo em conta os constrangimentos políticos e as questões relacionadas com a segurança pública. De acordo com os dados estatísticos do $A D B / O C D E / U N$ (2014) o crescimento na África Subsariana foi de 5\% em 2013 estimando-se que seja de 5.8\% em 2014. Excluindo a África do Sul os dados passam para $6.1 \%$ e $6.8 \%$, respetivamente. O Este e o Oeste de África apresentaram o maior crescimento em 2013, tendo sido superior a 6\%. Os fluxos financeiros externos e a receita tributária são importantes fatores do desenvolvimento em África, contudo beneficiam principalmente os países mais ricos.

No que respeita à oferta, os principais impulsionadores do crescimento económico concentram-se no sector primário, nomeadamente na agricultura, e no sector terciário, ou seja, nos serviços. Os países ricos em recursos aumentaram a sua produção de petróleo e a atividade mineira, no entanto, a atividade industrial desempenha um papel pouco relevante. Em síntese, alguns países africanos (mais especificamente os países da África-Subsariana) têm vindo a desenvolver medidas no sentido de diversificar a sua economia. Mas, de uma forma geral, o progresso tem sido lento, o qual se depara com alguns obstáculos de carácter cultural e histórico, como já indicado. Estes fatores têm contribuído para o aumento da taxa de inflação - 7\% em 2010> 8.5\% em 2011> 9\% em 2012 -, (UNECA, 2013). Os principais fatores deste aumento devem-se, basicamente, ao incremento do preço da comida e do combustível, assim como pela desvalorização da moeda, o que tem consequências diretas nos consumidores, nomeadamente nos pobres urbanos (UNECA,2013; UNECA, 2014). De acordo com os estudos efetuados, o panorama 
manteve-se no período 2013 a 2014, muito embora possa sofrer uma pequena baixa, tendo em conta as fracas colheitas nacionais e internacionais mas também devido aos conflitos políticos nos principais países produtores de petróleo (UNECA, 2013 e 2014; UNCTAD, 2014). Neste sentido, as políticas monetárias procuram encontrar um equilíbrio entre o controlo da inflação e possibilidade de impulsionar o crescimento económico. São, também, relevantes as políticas de redução das taxas de juro de forma a facilitar o investimento privado. Neste campo a política fiscal depende das condições económicas de cada um dos países, podendo ser caracterizada como restritiva ou moderada (UNECA, 2013; UNECA, 2014; UNCTAD, 2014). Ou seja, alguns países (Algéria, Burkina Faso, República do Congo, Cameron, África do Sul, Namíbia e Zâmbia) desenvolvem políticas fiscais expansionistas enquanto nos países em risco de sobre-endividamento desenvolvem-se estratégias fiscais consolidadas de forma a garantirem a sustentabilidade das dívidas. (Egito, Gana, Etiópia, Botsuana, Ruanda, Malawi e Zimbabwe).

Em termos gerais, África tem vindo a desenvolver mecanismos de crescimento nos últimos anos, tendo como principal objetivo, a curto prazo, a consolidação das suas condições macroeconómicas, numa perspetiva económica global (UNECA,2013; UNECA,2014; UNCTAD,2014). Para tal, é necessário desenvolver políticas públicas de regulação do sector privado e das instituições, assim como promover um maior acesso aos serviços públicos essenciais tais como a educação, a saúde e a segurança. Desta forma, seria possível colocar os países africanos no caminho do desenvolvimento e, consequentemente, reduzir a pobreza e as desigualdades. Salienta-se a importância do ensino, com especial enfoque para o ensino superior, uma vez que este pode desempenhar um papel preponderante para atingir estes objetivos como já explicitado. De facto, tem-se vindo a verificar uma tendência generalizada para reduzir as despesas públicas e, por conseguinte, o financiamento do ensino superior através do orçamento do Estado, mesmo nos países mais ricos o que, de acordo com Tolentino (2006), cria um impasse uma 
vez que pode aumentar a responsabilidade pública da universidade e, por outro, diminuir o seu financiamento pela generalidade dos contribuintes. $\mathrm{O}$ autor indica ainda que a alternativa a este dilema poderá passar pela intensificação das funções empresariais da universidade, passando, desta forma, a ter "funções de interesse geral, de serviço público, para garantir a eficácia do Estado democrático de bemestar e as funções que encerram atividades com valor de mercado e para as quais há procura solvente" (p.79). A função de serviço público, que integra objetivos económicos e sociais, pode ser desempenhada por uma universidade totalmente pública, financiada pela coletividade nacional, exclusivamente através do orçamento do Estado, ou por uma universidade mista, estabelecida no quadro de parcerias entre o Estado e sectores da sociedade. A função de mercado é caracterizada pela vertente empresarial da universidade entendida como uma organização que produz serviços para vender a indivíduos, empresas e organizações que deles precisem, sem comprometer a função essencial de criar, difundir, adaptar e aplicar o conhecimento. Como enfatiza António Sáenz de Miera (1998:25, in Tolentino, 2006), a universidade mista é pós industrial, empreendedora e bicéfala porque tem de ser, ao mesmo tempo, altruísta e egoísta, pública e privada, solidária e competitiva. Trata-se de um novo paradigma de universidade com variadas implicações para os Estados em desenvolvimento, destacando-se aqueles onde a pequena escala e a hegemonia de modelos pesados tendem a opor radicalmente o bem público ao negócio privado como se tivessem de ser sempre incompatíveis (Tolentino, 2006).

As questões relacionadas com o financiamento destas instituições dependem, em grande parte, das condições económicas, dos sectores estratégicos e da missão e natureza da entidade instituidora. Esta lógica incorpora o entendimento do ensino superior como um fator-chave do desenvolvimento local e nacional, bem público e sistema produtor de capital intelectual e de serviços (Tolentino, 2006). A universidade deve agir ao nível regional de forma a transformar em vantagem as adjacências geográficas e culturais, a transnacionalização da população e o nicho 
de oportunidades que uma emigração qualificada representa. Nesta perpectiva, e para que exista uma relação de reciprocidade entre ganho e custos, existem várias formas possíveis de financiamento das universidades (Tolentino, 2006:394), nomeadamente:

- Através de propinas e venda de serviços, tais como consultoria, aluguer de espaços e equipamentos, produção editorial e cultural e recolha sistemática de fundos;

- Através de transferências do orçamento do Estado, incluindo projetos de investimento; bolsas e empréstimos a estudantes; fundos da cooperação internacional; perdão e reconversão da dívida pública externa;

- Através de investimento de entidades públicas, privadas e sociais, nacionais e estrangeiras, em conformidade com a natureza da entidade instituidora;

- Através da Cooperação Internacional direta nos domínios do ensino, ciência, tecnologia e artes.

Uma vez explicitada a função da educação em geral, e em particular do ensino superior na Africa Subsariana propomos-nos a decifrar, no capitulo seguinte, as várias fases da evolução das universidades em África desde o pré-nacionalismo até aos dias de hoje, na sua fase de modernização no sentido de se perceber os obstáculos ultrapassados e os desafios que ainda enfrenta. 
Capitulo 2

Evolução Histórica do Ensino Superior em África 
VNIVERSIDAD

DSALAMANCA 
"Education is neither eastern nor western. Education is education and it's the right of every human being."

Malala Yousafzai Nobel Peace Prize, 2014 
VNIVERSIDAD

DSALAMANCA 


\subsection{Evolução histórica das Universidades Africanas: do pré- nacionalismo à globalização e internacionalização}

Desde a segunda guerra mundial a maioria dos países africanos obteve a sua independência (cf. Anexo I). Contudo, no que respeita ao progresso e à expansão do ensino superior verificou-se que o seu desenvolvimento e organização foram lentos. Mais recentemente estes países procuram um sistema educacional relevante para o ambiente sociocultural, mas também que permita uma maior competição ao nível global (Arnove, 1999; Ajayi, Goma e Johnson, 1996; Lulat, 2005; Teferra e Altbach, 2003; Coker-Kolo e William, 2013), como poderemos verificar nas várias fases históricas a seguir identificadas. O sistema de ensino superior em África (e mais especificamente na Africa Subsariana) está relacionado com o sistema político, social e económico do continente em termos de evolução, transição e transformação através das suas quatro principais fases históricas: 1) o período antes do colonialismo, cuja informação na literatura é muito escassa; 2) o período do colonialismo que teve um impacto duradouro no continente e no seu sistema de educação; 3) o período do nacionalismo; 4) e o período da modernização.

\subsubsection{O ensino superior em África durante a fase pré-colonial}

Não existe muita informação na literatura sobre este período no que respeita ao ensino superior em África, devido à falta de uma escrita formal própria da época, assim como pela forma informal como a educação era tratada, ou seja, não existia propriamente uma metodologia de ensino nem profissionais adequadamente preparados e treinados. Por outro lado, os primeiros escritores, essencialmente europeus, negligenciaram o legado africano, sugerindo que os africanos não eram "educáveis" o que não permitiria criar um sistema de educação formal. Esta ideia é corroborada por Jack Trevor que sugere que "talvez no futuro próximo seja possível ensinar a história de África. Mas no presente não existe. Apenas existe a história de europeus em África, o resto é escuridão, tal como a história dos pré 
europeus e dos pré-colombianos na América " (in Lulat, 2005:2). Todavia, são vários os autores (Ajayi, Goma e Johnson, 1996; Marah, 2006) que reportam que a educação dos africanos tinha uma avançada forma, ou seja, o sistema educativo abrangia todos os cidadãos, desde os mais novos aos adultos (Marah, 2006). Não se tratava de um sistema perfeito mas sim de um sistema que deveria ser avaliado no sentido de perceber se de facto atingia, ou não, as necessidades dos cidadãos no período temporal em causa. No caso da educação mais avançada, no contexto da África tradicional, a mesma consistia na preparação dos jovens para uma carreira militar, para a família e para a agricultura. De facto, o ensino superior em África, a norte do deserto do Sahara, é considerado como um dos mais antigos, pois a universidade mais antiga do mundo é a universidade Al-Azhar do Egito, a qual continua a ser um dos maiores centros de ensino Islâmicos organizado de acordo com o modelo de ensino Islâmico. Todas as outras universidades africanas e do resto do mundo adotaram o modelo ocidental de organização académico. Desta forma, África pode reclamar uma tradição académica antiga muito embora a maioria dos centros de ensino superior tenham sido destruídos pelo colonialismo e passaram a ser organizados de acordo com o modelo Europeu, ou seja, "o ensino superior em África é um artefacto das políticas coloniais (Altbach \& Selvaratnam 1989; Lulat 2003; in Teferra \& Albach, 2004:22). Os principais orientadores desta colonização europeia, no sentido do desenvolvimento, foram países como a França, a Bélgica, a Grã-Bretanha, a Alemanha, a Itália, Portugal, a Holanda e a Espanha, muito embora seja de salientar que estes dois últimos países tiveram uma presença e influência bastante inferior na África Subsariana. Este legado deixou marcas ao nível da organização da academia mas também no que respeita à linguagem de instrução e à comunicação (Teferra \& Albach, 2004:23) tendo, identicamente, influência noutros pontos como se poderá constatar de seguida. 


\subsubsection{O Ensino Superior em África durante o período colonial}

A difusão da educação constituiu um importante marco na era do colonialismo estando estreitamente ligado à propagação do cristianismo. Esta educação de carácter ocidental teve efeitos sociais bastante visíveis, nomeadamente no crescente número dos membros da elite africana "educados à europeia" a qual constitui, nos dias de hoje, a oligarquia reinante e o essencial da administração dos Estados Africanos (UNESCO, 2010:935). A educação, de uma forma geral, oferecida nesta época demonstrou-se inadequada, com uma distribuição desigual e mal orientada, em cada um dos cinco tipos de instituições existentes: escolas primárias, secundárias, escolas normais, escolas técnicas e universidades. Só depois da Segunda Guerra Mundial, ou seja, no fim do período colonial, apareceram algumas escolas técnicas e colégios universitários por toda a África, sendo significativo o fato de se ter criado uma universidade em cada um dos seguintes países: em 1947 na Costa do Douro; em 1948 na Nigéria; em 1950 em Uganda, Madagáscar, Léopoldville e Senegal; em 1953 em Salisbury; e em 1957 em Elisabethville (UNESCO, 2010:935). Por outro lado, o financiamento das instituições de ensino, por parte do governo, era bastante reduzido. De acordo com Loyd (1972:79 in UNESCO, 2010) a despesa do governo atingiu em 1935 apenas $4 \%$ da receita da Nigéria e dos territórios franceses e $7 \%$ da receita do Gana. As instalações eram insuficientes e inadequadas pois o seu objetivo, tal como menciona Kabwegyere (1974:179 in UNESCO, 2010), não passava pelo desenvolvimento da educação para os africanos mas sim para "produzir africanos que fossem mais produtivos para o sistema [colonial]". O próprio curriculum oferecido era determinado pelas autoridades e em consonância com os programas metropolitanos. Não reproduzia, portanto, as verdadeiras necessidades do continente.

O ensino superior durante esta fase foi, idênticamente, considerado como inadequado em termos de oferta, objetivo, formato e legado (Coker-Kolo e William, 2013). As instituições foram estabelecidas na erige do patronato dos 
poderes coloniais e desenhado de acordo com as contrapartidas da colonização. $\mathrm{O}$ principal objetivo passava pela formação de administradores dos quadros mais baixos para o governo colonial ou de professores para as escolas missionárias. Alguns países africanos não tinham médicos, advogados ou engenheiros durante o período colonial. Muitos países não tinham instituições de ensino pós secundário a não ser depois da independência. As que se estabeleceram foram regionalizadas e tinham estreitos laços com a Europa. Eram financiadas por instituições externas o que comprometia a sua autonomia em termos de desenvolvimento do seu currículo, de políticas e de gestão. Mesmo depois da independência algumas universidades não eram verdadeiramente independentes, pois os diplomas eram emitidos por algumas universidades europeias. Os críticos do sistema educacional do colonialismo argumentam que a educação desenvolvida não foi liberalizada. Consideram que era controlada pelo poder económico e político e pelas classes dominantes de cada um dos países. Focava-se no capitalismo e não na equidade ou no socialismo.

Em suma, e de acordo com Teferra \& Albach (2004:23), a política do ensino superior no período colonial deparava-se com grandes desafios na medida em que:

- O acesso a este tipo de ensino se mantinha limitado - número limitado de vagas para nacionais;

- Havia dificuldades na línguagem do ensino - a língua utilizada era a do país colonizador;

- A liberdade era limitada - eram colocados limites na liberdade académica bem como na autonomia das instituições académicas;

- O Curriculum era limitado - os cursos das Universidades em África eram restritos. Existia preferência pelas áreas de direito e disciplinas relacionadas. As áreas científicas eram raramente lecionadas. 
Denota-se, portanto, que o legado do colonialismo mantem-se evidente no ensino superior africano, podendo-se constatar que a literacia lecionada no ensino superior permanece na língua original do país de colonização, assim como se verificam os poderes exercidos por uma "elite culta e alienada que reverenciava a cultura e a civilização europeias e menosprezava a cultura africana" (UNESCO, 2010:941). De fato, o ensino técnico e industrial foi negligenciado em prol do ensino das letras e da preparação para os empregos burocráticos. Esta situação leva a que as famílias de maiores posses enviem os seus filhos para estudar nas metrópoles ou para os Estados Unidos. São estes que irão, mais tarde, dirigir os movimentos anticolonialistas e nacionalistas.

\subsubsection{O Ensino Superior em África durante o período do Nacionalismo}

A maioria dos países africanos obteve a sua independência nos anos sessenta. A década seguinte caracterizou-se pela afluência, pela reconstrução de currículos e pelo nacionalismo. Existia a crença de que a expansão do ensino superior iria contribuir para o processo de reconstrução da nação, para promover a democratização e reforçar a educação nos níveis mais baixos. O ensino superior era, desta forma, considerado como uma alavanca para o desenvolvimento económico aumentando assim o financiamento, investigação e desenvolvimento de políticas nesta área (Sall e Ndiaye, 2007).

A la fin des années 1980, les pouvoirs publics ont commencé à réorienter les financements de l'enseignement supérieur vers l'enseignement primaire, en partie sur l'instance des bailleurs de fonds internationaux, qui soutenaient, peutêtre avec raison, qu'avec des niveaux élevés d'analphabétisme en Afrique, l'argent dépensé pour l'enseignement de base contribuerait davantage à la réduction de la pauvreté. Au même moment, bon nombre de bailleurs de fonds ont réduit l'appui à l'enseignement supérieur, notamment les bourses aux étudiants qui représentaient des coûts élevés, et ont supprimé graduellement les subventions destinées 
aux membres du corps enseignant dans les universités africaines (Bollag $2004: 4$ in Sall e Ndiaye, 2007).

Por outro lado, os políticos passam a ser a elite da tomada de decisão, assumindo as mais altas posições ao nível da administração das universidades. Esta situação demonstra que não existe uma verdadeira autonomia no ensino superior uma vez que a sua administração é proveniente de uma gestão ativa dos políticos nas instituições de educação em África (Coker-Kolo e William, 2013). Esta reforma educacional esteve interligada com a reconstrução da nação e na redefinição dos seus objetivos. Assistiu-se a um aumento na área da investigação com foco no continente Africano. Surgem nesta altura algumas publicações sobre a educação africana e incute-se nos programas de educação a cultura e a língua africana.

O ensino superior passa a ser considerado como um investimento e as instituições africanas tomam consciência da necessidade de desenvolver programas que correlacionem a educação com o desenvolvimento económico, assim como a criação de uma identidade nacional. Porém, estes objetivos foram dificultados devido ao baixo financiamento, à fraca autonomia e às políticas desfavoráveis. As suas principais responsabilidades passam por fornecer funcionários para a sociedade civil, continuando a se verificar que existem vários desafios (Teferra $\&$ Albach, 2004:24), nomeadamente:

- Ao nível do acesso - o acesso ao ensino superior cresceu limitando os recursos destas instituições, uma vez que as mesmas foram projetadas para poucos alunos não existindo condições físicas e financeiras que acompanhem a tendência;

- Ao nível do governo - predominam essencialmente, instituições públicas, as quais são limitadas por políticas governamentais;

- Ao nível do papel da investigação e na publicação de artigos; 
- Ao nível das tecnologias de educação;

- Ao nível da profissão académica;

- Ao nível da fuga de cérebros - brain drain;

- Na migração do talento.

Em síntese, o ensino superior contribuiu, nesta altura, para o processo de modernização de África. Depois da independência política dos vários Estados Africanos foram fundadas cerca de 80 instituições de ensino superior, assim como instituições de ensino profissionalizante, de formação superior pedagógica ou de ensino politécnico e institutos de tecnologia ${ }^{9}$. Este constitui um passo importante desde o século XVI, tendo em conta a fraca presença destas instituições no continente africano contando apenas com quatro Instituições de Ensino Superior (Teferra \& Albach, 2004:24) e cujo curriculum era muito limitado:

1. Universidade de Sankoné, em Tombouctou, na área de Direito, Filosofia e Teologia;

2. Universidade de al-Azhar, no Cairo, na área da Teologia e do Direito Islâmico;

3. Centro de Ensino Superior, na Etiópia, na área do Direito Canónico; e

4. Fourah Bay College, na Serra Leoa, na área dos Estudos Religiosos (Universidade Estatal fundada pela Church Missionary Society de Londres em 1927).

Na conferência de Addis-Abeba (1961) e Antananarivo (1962) discutiu-se qual o papel destas instituições, os seus objetivos e finalidades. Concluíram que as universidades africanas devem ter como objetivo expandir as fronteiras do saber, através do ensino e da pesquisa, de acordo com os ideais da objetividade e da

\footnotetext{
${ }^{9}$ A lista atual completa das universidades, públicas e privadas, existentes em cada um dos países da ASS, pode ser consultada no Anexo 6.
} 
busca da verdade (UNESCO, 2010). São estabelecidas de acordo com o modelo da Europa Ocidental ou da América do Norte, não deixando de se inspirar nos problemas locais. Porém, o seu progresso foi desigual pelos vários países africanos devido a constrangimentos políticos, sociais e económicos. A procura é crescente na medida em que permitiria o acesso a melhores empregos e, consequentemente, à melhoria da qualidade de vida. Não obstante, são ainda escassas as ofertas de emprego e um fraco mercado de trabalho virado para áreas mais técnicas e científicas, assim como se verificou um número insuficiente de profissionais académicos qualificados. A sub-representação feminina no ensino superior é, ainda, uma realidade fruto de uma pesada herança cultural.

No caminho do progresso, e após a década de sessenta, os países africanos constatam que a educação é um meio para o desenvolvimento individual em todos os níveis: físico, intelectual, social, moral e espiritual. Contribui, de igual forma, para o redescobrimento, para o fortalecimento e promoção de culturas e do desenvolvimento autóctone (UNESCO, 1982, in UNESCO, 2010). Apesar dos vários constrangimentos o ensino superior apresenta-se melhor organizado e cujo objetivo passa por acelerar o desenvolvimento social, na medida em que os estudos são reconhecidos como agentes para a mudança social, tornando os cidadãos mais conscientes, trabalhadores mais dinâmicos e produtivos exigindo, para tal, uma perspetiva mais inovadora e criativa de acordo com a realidade económico-social e em consonância com as linhas internacionais para se tornarem sociedades globalmente mais competitivas e modernas.

\subsubsection{O período de Modernização - Internacionalização e Globalização}

O sistema educacional africano tem vindo a ser bastante influenciado pela internacionalização e globalização. Depois da independência contínua a tendência de governos estrangeiros, agências multilaterais, sociedades escolares exteriores de financiarem e fazerem parte da direção do ensino superior (Teferra e Altbach, 
2003:25). De acordo com De Wit e Wit (2011) a internacionalização passou por três etapas: 1) a primeira ocorreu durante o período colonial, sendo nesta altura considerada como um incidente e não como organizada. Esta fase demonstra a importância do ensino superior do oeste e um movimento massivo de estudantes para instituições estrangeiras; 2) a segunda fase da internacionalização iniciou-se nos Estados Unidos no século vinte quando, por motivos de evitar o etnocentrismo e aumentar as relações externas, o país introduziu a educação internacional no panorama educacional e encorajou o aumento das inter-relações com estrangeiros nas suas instituições de ensino superior; 3) a terceira fase é mais recente e está relacionada com o período depois da Guerra Fria. Está rotulada como "a internacionalização do ensino superior” e ligada à globalização e regionalização das sociedades com impacto no ensino superior (De Wit e Wit, 2011).

Algumas das instituições de ensino superior em África adotaram esta última fase no sentido de aplicarem as melhores práticas definindo a sua forma de trabalhar. Quando comparado com o período do nacionalismo, a tendência do ensino superior altera a sua enfâse política para a económica para que as instituições terciárias em África possam competir globalmente na arena económica e académica. A resposta à globalização forçou, igualmente, uma mudança filosófica do socialismo durante a era do nacionalismo para o capitalismo. Por outro lado, verificou-se uma influência considerável das organizações internacionais (Banco Mundial, o FMI, as Nações Unidas, etc.) nas políticas e na implementação de um sistema educacional contemporâneo em África. Na perspetiva de De Wit (2011) a internacionalização deveria estar relacionada com objetivos tradicionais e originais da universidade, os quais devem garantir a qualidade do ensino e da investigação, assim como devem contribuir para o bem comum.

Resumidamente, poderemos considerar a internacionalização como uma ferramenta para a globalização, ou seja, os seus objetivos estão orientados para o mercado, o que não está totalmente oposto aos objetivos tradicionais, exceto no fato de que o seu âmbito é maior e os padrões são diferentes. Existem forças, 
externas e internas, que empurram África para a internacionalização. Ao nível externo as organizações multilaterais proporcionam empréstimos e pressionam os países africanos para uniformizar os programas, para privatizar as instituições e para simplificar os serviços sociais. Ao nível interno, as universidades africanas são confrontadas com maiores desafios, incluindo a falta de infraestruturas básicas de educação, assim como competem por verbas públicas. A investigação não é eficiente nem eficaz não existindo níveis de equidade entre as universidades (Banco Mundial, 2000:7).

O aumento da utilização das tecnologias de informação e as mudanças no mundo da economia despoletaram o conhecimento como fonte do bem-estar público. Desta forma, à medida que o conhecimento se torna mais importante também o ensino superior ganha maior relevância. Os cursos superiores passam a ser um requisito na procura de emprego no sentido de criar mais oportunidades e maior competitividade.

Ao analisar o processo de Bolonha, enquanto ferramenta para reestruturar o ensino superior, Shawa (2008, in Munene, 2009) verificou as suas implicações para o desenvolvimento de África. Afirma que algumas universidades africanas escolheram o Processo de Bolonha como um caminho para a globalização e para a internacionalização, contudo, não examina as implicações que poderá trazer para a sua situação em particular e para as suas necessidades, assim como não determina os parâmetros necessários para avaliar a qualidade do ensino. $\mathrm{O}$ processo de Bolonha, estabelecido em 1999, visava facilitar a comparação e a compatibilidade das estruturas e dos cursos do ensino superior na europa e melhorar a sua qualidade. As três dimensões de qualidade do acordo de Bolonha que incluem a distinção, a excelência e o comprometimento com vários requisitos estandardizados, podem não ser funcionais para as universidades africanas uma vez que serão julgadas de acordo com o paradigma europeu (Shawa, 2008 in Munene, 2009), deixando de parte as especificidades próprias dos países em desenvolvimento e das necessidades locais. $\mathrm{Na}$ verdade, as universidades 
africanas não dispõem dos mesmos recursos para atingir e manter os requisitos estandardizados. Considera-se relevante o facto de que o alinhamento do sistema de ensino em África com o Europeu conduz à retenção de talentos levando à perda de profissionais com capacidades em África os quais se dirigem para os países mais desenvolvidos, esgotando os recursos humanos necessários para sustentar o desenvolvimento em África. É neste sentido que o Comunicado da Conferencia Europeia de Ministros Responsável pelo Ensino Superior, através do apendium "International Openness", evidência a necessidade de alargar o âmbito do Processo de Bolonha para a comunidade internacional:

We call upon European higher education institutions to further internationalize their activities and to engage in global collaboration for sustainable development. The attractiveness and openness of European higher education will be highlighted by joint European actions. Competition on a global scale will be complemented by enhanced policy dialogue and cooperation based on partnership with other regions of the world, in particular through the organization of Bologna Policy Fora, involving a variety of stakeholders (Leuven \& Louvainla-Neuve, 28-29 April, 2009, p. 4).

Efetivamente, a missão do Ensino Superior passa por educar uma maior percentagem da população, criar novas oportunidades para estudantes não tradicionais, desenvolver investigação e inovação, responder aos desafios económicos locais e regionais e atuar na melhoria da qualidade e da eficiência em todos os aspetos (Crosier \& Parveva, 2013:19 in Gebremeskel, 2014) o que requer um maior alinhamento com o sistema de ensino superior global.

Atualmente, os esforços efetuados pelos países africanos para internacionalizarem as suas instituições como estratégia para o seu desenvolvimento têm várias implicações. A influência das forças internacionais, como por exemplo doadores multinacionais como o Banco Mundial, o Fundo Monetário Internacional e as Organizações de Comércio Mundiais, podem requerer ajustes estruturais nos seus 
serviços sociais, exigindo que os mesmos sejam redefinidos, principalmente ao nível da saúde e da educação. Nos anos oitenta os fundos foram redirecionados do ensino superior uma vez que os doadores multilaterais acreditavam que o problema da alta iliteracia poderia ser melhor resolvido nos níveis mais baixos de escolaridade (Terrefera e Altbach, 2003:26). A internacionalização poderá contribuir para a evolução do ensino superior permitindo aos países africanos avançarem economicamente.

Em termos gerais a educação é um fator central e crítico para o sucesso da economia de um país numa economia globalizada (Reich, 1992). Desta forma, para ser possível ter sucesso ao nível da competição global é necessário produzir uma força de trabalho com estudos superiores. Esta força de trabalho deve ser versátil e flexível para responder às rápidas transformações económicas resultado de mudanças abruptas ao nível tecnológico (Halsey, Lauder, Brown e Wells, 1997; Reich, 1992). A educação pode promover a igualdade de oportunidades e reduzir as desigualdades promovendo, de igual forma, a justiça social (Dewey, 1953, in Romo e Nubiola, 2005). Mas, nem sempre as políticas vão ao encontro destes preceitos, ou seja, tendem a promover o crescimento económico e não a igualdade de oportunidades (Harvey, 2007; Klein, 2008; Ferri e Stiglitz, 2003; Stiglitz, 2007). O que verdadeiramente conta numa economia globalizada é o custo da força de trabalho e a relação entre as capacidades, a qualidade das capacidades e a procura da economia global. De acordo com Reich (1992) quem tiver as capacidades mais procuradas terá uma maior recompensa enquanto quem não tem essas capacidades ficará para trás, resultando num sistema de desigualdades. Desta forma, torna-se numa missão complexa, para o Governo Africano, reformular o ensino superior no sentido de promover um maior acesso, equidade e igualdade de oportunidades. A globalização determina a capacidade do Estado para agir coerentemente e promover o bem-estar de todos os cidadãos.

Uma reforma educacional só por si não terá necessariamente repercussões na redução das desigualdades e na igualdade de oportunidades, principalmente tendo 
em conta a estrutura social da sociedade se esta não acompanhar as mudanças (Zalanga, 2009). O acesso ao ensino superior é mediado de acordo com vários fatores como o espacial e o regional, as condições socioeconómicas, as raciais e as desigualdades étnicas, de género e de religião. Um maior investimento no ensino superior depende do facto da economia se expandir e criar emprego (Blinder, 2006). Na perspetiva de Zalanga (2009) o sistema de ensino superior em África é bastante pesado no que concerne ao consumo de recursos. Por outro lado, os principais beneficiários do ensino superior público usam o seu poder para obterem posições de destaque na sociedade, assim como para se apoderarem de fundos públicos.

No seguimento das várias fases de evolução mencionadas, o ensino superior em África foi-se desenvolvendo de acordo com um clima político rígido e em circunstâncias socioculturais específicas. Não obstante, este fato são vários os países que apresentam um aumento significativo do número de instituições de ensino superior, quer de âmbito público quer privado como se pode averiguar no quadro abaixo (Tabela 3$)^{10}$.

Tabela 3 - Número de Instituições de Ensino Superior, Públicas e Privadas, por País

\begin{tabular}{|c|c|c|}
\hline País / Independência & $\begin{array}{l}\text { IES } \\
\text { Públicas }\end{array}$ & $\begin{array}{l}\text { IES } \\
\text { Privadas }\end{array}$ \\
\hline $\begin{array}{l}\text { Angola - } 11 \text { de novembro de } 1975 \text { (36 anos) - Independência } \\
\text { de Portugal }\end{array}$ & 8 & 17 \\
\hline $\begin{array}{l}\text { Benim - } 1 \text { de agosto de } 1960 \text { (51 anos) - Independência de } \\
\text { França }\end{array}$ & 3 & 23 \\
\hline Botswana - 30 de setembro de 1966 (45 anos) - Reino Unido & 0 & 12 \\
\hline Burkina Faso - 5 de agosto de 1960 (51 anos) - França & 0 & 2 \\
\hline Burundi - 1 de julho de 1962 (49 anos) - Bélgica & 0 & 6 \\
\hline Cabo Verde - 5 de julho de 1975 (36 anos) - Portugal & 7 & 4 \\
\hline Camarões - 1 de janeiro de 1960 (52 anos) - França & 8 & 22 \\
\hline Chade - 11 de agosto de 1960 (51 anos) - França & 0 & 2 \\
\hline Cômoros - 6 de julho de 1975 (36 anos) & 0 & 1 \\
\hline $\begin{array}{l}\text { Côte d'Ivoire (Costa do Marfim) - } 4 \text { de dezembro de } 1958 \\
\text { (53 anos) - França }\end{array}$ & 0 & 25 \\
\hline
\end{tabular}


Djibouti - 27 de julho de 1977 (34 anos) - França Eritreia - 24 de março de 1993 (18 anos) - Etiópia $0 \quad 1$

Etiópia - 5 de março de 1941 (71 anos) - Haile

Selassie restaurou-o, terminando com a ocupação italiana.

Gabão - 17 de agosto de 1960 (51 anos) - França

Gana - 6 de março de 1957 (54 anos) - Reino Unido

Guiné - 2 de outubro de 1958 (53 anos) - França

Guiné Equatorial - 12 de outubro de 1968 (43 anos) -

Espanha

Guiné-Bissau - 10 de setembro de 1974 (37 anos) - Portugal

Gâmbia - 18 de fevereiro de 1960 (52 anos) - Reino Unido

Lesoto - 4 de setembro de 1966 (45 anos) - Reino Unido

Libéria - 26 de julho de 1847 (164 anos) - Estados Unidos

Líbia - 24 de dezembro de 1951 (60 anos) - Reino

Unido, França (Abandonada pela Itália)

Madagáscar - 26 de junho de 1960 (51 anos) - França

Malawi - 6 de julho de 1964 (47 anos) - Reino Unido

Mali - 22 de setembro de 1960 (51 anos) - França

Mauritânia - 28 de novembro de 1960 (51 anos) - França

Maurícia - 12 de março de 1968 (43 anos) - Reino Unido

Moçambique - 25 de julho de 1975 (36 anos) - Portugal

Namíbia - 21 de março de 1990 (21 anos) - África do Sul

Nigéria - 1 de janeiro de 1960 (52 anos) - Reino Unido

Níger - 3 de agosto de 1960 (51 anos) - França

Quênia - 12 de dezembro de 1963 (48 anos) - Reino Unido

República Centro-Africana - 13 de agosto de 1958 (53 anos) - 0

França0

República Democrática do Congo - 30 de

junho de 1960 (51 anos) - Bélgica

República do Congo - 15 de agosto de 1960 (51 anos) - França

Ruanda - 1 de julho de 1962 (49 anos) - Bélgica

Senegal - 20 de agosto de 1960 (51 anos) + França

Serra Leoa - 27 de abril de 1961 (50 anos) - Reino Unido

Seychelles - 29 de julho de 1976 (35 anos) - Reino Unido

Somália - 26 de junho de 1960 (51 anos) 1 de

julho de 1960 (51 anos) - Reino Unido / Itália

Suazilândia - 6 de setembro de 1968 (43 anos) - Reino Unido

Sudão - 1 de janeiro de 1956 (56 anos) - Egito / Reino Unido

Sudão do Sul - 9 de julho de 2011 (7 meses) - Sudão

São Tomé e Príncipe - 12 de julho de 1975 (36 anos) -

Portugal

Tanzânia - 9 de dezembro de 1961 (50 anos) - Reino Unido

Togo - 27 de abril de 1960 (51 anos) - França

Uganda - 9 de outubro de 1962 (49 anos) - Reino Unido

Zimbabwe - 18 de abril de 1980 (31 anos) - Rodésia do

Sul, Reino Unido

Zâmbia - 24 de outubro de 1964 (47 anos) - Reino Unido

África do Sul - 31 de março de 1910 (101 anos) (Criação da

União da África do Sul) 31 de março de 1961 (50 anos)(deixa

de ser um domínio) - Reino Unido 
Considerando as diferentes etapas da evolução destas instituições considera-se importante descodificar a sua missão, como se poderá constatar de seguida.

\subsection{O desenvolvimento e a missão das Instituições de Ensino Superior no contexto Africano}

As universidades, em África, contribuem para o desenvolvimento e para a modernização de todas as áreas, apesar do ensino superior estar pouco desenvolvido e se confrontar com sérios problemas. São várias as iniciativas para contrariar a situação, incluindo as ações levadas a cabo pelo NEPAD ${ }^{11}$. O processo de globalização económica está constantemente a crescer, no entanto, revoluciona sectores de produção de bens, assim como contribui para a revolução da produção, da distribuição, da gestão de padrões e de uma maior fluidez de capital, de informação e da livre migração de pessoas. Depois da primeira geração de universidades do período colonial, apenas nos anos setenta, a maioria dos países africanos expressou a sua vontade para desenvolver as universidades. O número de instituições cresceu rapidamente, tendo passado de 20 em 1960 para 120 em 1997. Têm vindo a desenvolver capacidades de forma a gerar novo conhecimento através da investigação, contribuindo significativamente para o desenvolvimento nacional (Seddoh, 2003). O ensino superior em África tem, desta forma, a responsabilidade de criar um desenvolvimento sustentável e a democratização do saber. O principal fator que demarca a pobreza está determinado pela capacidade de apropriação de capital humano para produzir valor acrescentado e para fazer uso da tecnologia de forma a atrair investimento (Seddoh, 2003).

\footnotetext{
${ }^{11}$ New Partnership for Africa's Development - Quadro estratégico da União Africana para o desenvolvimento socioeconómico pan-Africano, é ao mesmo tempo uma visão e um quadro político para a África no século XXI. NEPAD é uma nova intervenção, encabeçada por líderes africanos, para enfrentar os desafios críticos que enfrentam o continente: a pobreza, o desenvolvimento e a marginalização de África em termos internacionais. NEPAD oferece oportunidades únicas para os países africanos assumirem o controle total da sua agenda de desenvolvimento, para trabalhar de forma mais estreita e cooperar de forma mais eficaz com os parceiros internacionais. - http://www.nepad.org/about
} 
O ensino superior em África tem vindo a contribuir para o desenvolvimento e para a modernização de todas as áreas, apesar do seu lento desenvolvimento e se confrontar com sérios problemas, tal como indicado anteriormente. No entanto, são várias as iniciativas para contrariar a situação, incluindo as ações levadas a cabo pelo NEPAD e pela UNESCO. Por outro lado, o processo de globalização económica está constantemente a crescer promovendo a revolução em vários sectores contribuindo para o aumento da produção de bens e da sua distribuição e gestão de acordo com padrões internacionais o que conduz a uma maior fluidez de capital, informação e livre migração de pessoas. A internacionalização tem sido uma condição única para as Instituições de ensino superior desempenharem o seu papel, assim como constitui uma parte integrante na procura de qualidade e de relevância no que respeita ao ensino, à investigação, à formação e aos serviços que a universidade presta à sociedade (Seddoh, 2003). Emergem novos apoios como a UNESCO-CEPES $^{12}$ e Apoios Regionais, os quais têm um papel preponderante na promoção e na reflecção de ideias acerca do ensino superior como um todo.

Não obstante estes fatores, o ensino superior deve ser analisado tendo em conta o ambiente externo em que está inserido (Seddoh, 2003). Na maioria dos casos os programas de ensino não têm em conta as prioridades do ambiente que as rodeia, apesar das disciplinas base serem universais. Não olham aos problemas que as sociedades africanas enfrentam os quais têm características bem peculiares. A eficiência externa é, portanto, bastante relevante na definição da sua missão e das prioridades. Deve ser dada especial atenção ao ensino, bem como ao número de graduados, com e sem emprego, tendo em conta que se verifica um fraco crescimento laboral, apontando como principais razões (Economic Report on Africa, 2013):

\footnotetext{
${ }^{12}$ UNESCO-CEPES (Centro Europeu de Educação Superior - CEPES) foi criada em 1972 em Bucareste, Roménia, como um escritório descentralizado para o Centro Europeu de Ensino Superior. O Centro fechou em 2011 devido à falta de financiamento. O centro promoveu a cooperação internacional no domínio do Ensino Superior entre os Estados membros da UNESCO no Sudeste da Europa Central, Oriental e serviu também o Canadá, EUA e Israel. O jornal oficial da UNESCO-CEPES inicidia sobre o Ensino Superior na Europa, incluindo os principais problemas e tendências no ensino superior. O CEPES tinha a sua sede no Palácio Kretzulescu em Bucareste.
} 
i. A falta de coerência entre os cursos escolares / formação profissional e as reais competências requeridas pelos empregadores;

ii. A procura crónica e insuficiente pelo trabalho;

iii. As principais fontes de rendimento focam-se na indústria mineira e na extração de petróleo e gás; e

iv. A fraca rede de cooperação entre estes sectores e os outros sectores da economia.

Desta forma, o sector informal e rural constituem os principais vetores de criação de emprego, implicando um maior apoio por parte do governo no desenvolvimento de políticas que permitam a inversão da situação, que visem uma maior produtividade e que reduzam a informalidade. A população jovem africana constitui uma importante fonte de mão-de-obra na produção de riqueza, muito embora careça de um maior investimento no que concerne à sua qualificação e consequente criação de trabalho com melhores condições o qual contribuirá para uma economia e desenvolvimento sustentável.

Em tempo de crise e recursos escassos as instituições africanas devem ser efetivas e eficientes mas devem, igualmente, considerar a sua qualidade. A falta de eficiência coloca em causa a otimização de recursos, favorecendo politicas que dividem os recursos em várias rubricas não os otimizando. Assim, cresce a procura por fundos, para além do financiamento público, tendo em conta que as instituições de ensino superior promovem capital humano com um elevado nível de competência o qual deveria ser utilizado em parcerias com instituições privadas e públicas. São vários os exemplos na literatura que demonstram que os laboratórios de investigação podem ter um impacto considerável no financiamento, provenientes de parcerias com empresas externas que têm grande experiência na gestão de recursos financeiros através de acordos que estipulam os direitos e obrigações de cada um dos parceiros. O mesmo acontece com as atividades educacionais de longa duração as quais poderão atrair fundos 
substanciais que revertem a favor do orçamento da universidade (Seddoh, 2003). A eficiência é percecionada como um procedimento que se foca nos resultados expectáveis e definidos na missão das universidades, procurando indicadores quantitativos e qualitativos da efetividade do sistema de ensino e do orçamento, com implicações ao nível das infraestruturas, do equipamento e dos recursos humanos (Seddoh, 2003). Estas instituições não devem ser consideradas, por si só, como instrumentos para a paz, para a democracia e para os direitos humanos muito embora possam ser entendidas como ferramentas para o desenvolvimento sustentável, enquanto instituições eficientes e efetivas, que têm por base a equidade, a igualdade de oportunidades no acesso e nas condições educacionais (Deketele, 1997:83-111).

No seguimento das ideias apresentadas definir a missão das instituições de ensino superior é uma tarefa complicada, pois deve ser analisada tendo em conta o ambiente externo em que está inserido, os seus programas de ensino, a forma como são administradas, mas também de acordo com as exigências externas ao nível da internacionalização e globalização destas entidades. A sua missão passa por perceber as necessidades do mercado de trabalho de forma a correlacionar os seus programas de ensino e investigação às necessidades da indústria e da população local.

Em súmula, o ensino superior constitui um fator importante no desenvolvimento das sociedades do conhecimento (EUA, 2010). Têm como objetivo treinar futuros professores e profissionais, gestores e líderes. As instituições de ensino superior são consideradas centros de investigação geradores de conhecimento e inovação. Neste sentido, o desenvolvimento e a modernização destas instituições deverá ser um dos objetivos dos governos locais e dos atores internacionais. Trata-se de uma meta ambiciosa na medida em que requer um maior investimento no desenvolvimento de capacidades e de capital humano. Estes atores devem unir esforços para ir ao encontro destes preceitos e criar parcerias estratégicas que permitam um desenvolvimento económico sustentável o que, por sua vez, 
contribuirá para a melhoria da qualidade de vida da população na África Subsariana como se poderá verificar de seguida.

\subsubsection{Uma nova parceria estratégia educacional para o desenvolvimento em África}

$\mathrm{Na}$ última metade do século vinte notou-se uma nova atitude dos africanos, os quais se vêm como ativistas para a mudança, reclamando o seu lugar na humanidade como iguais, confiantes das suas capacidades para o autodesenvolvimento. Esta confiança emerge fora da conceção de África que se move para a independência e para a democracia, onde se têm vindo a desenvolver esforços para acabar com os conflitos e para se manter a paz e a estabilidade (Seddoh, 2003). Existe a consciência de que o desenvolvimento da economia e do estado social dependem da unidade do país e do seu povo e dos países que trabalham em conjunto para se fortificarem e para se introduzirem na economia mundial (NEPAD, 2002:21).

As principais ações desta iniciativa têm como foco promover a estabilidade das Instituições de Ensino Superior e dos centros regionais de excelência e desenvolvimento através da colaboração institucional. É dada prioridade à utilização das experiências existentes, no sentido de se obter uma maior coerência, coordenação e colaboração através destas iniciativas (Seddoh, 2003). Estas têm como objetivo atrair recursos financeiros de instituições multilaterais e bilaterais, de fundações privadas e de organizações regionais. Para tal o NEPAD desenvolveu e promoveu projetos que procuravam desenvolver um quadro favorável no que respeita ao desenvolvimento das Instituições de Ensino Superior os quais estão atualmente em curso. Não obstante, são vários os esforços efetuados por parte dos atores internos e externos que contribuem para o desenvolvimento destas instituições, e dos progressos que se têm vindo a verificar, assim como são vários os indicadores da existência de diferentes desafios. 


\subsubsection{Desafios para o Ensino Superior em África}

O ensino superior em África tem vindo a melhorar nas últimas décadas, no entanto, tem-se vindo a deparar com alguns desafios. Uma das principais dificuldades está relacionada com o declínio significativo da sua qualidade. A principal causa deste declínio deve-se à diminuição de recursos durante os períodos em que houve um crescimento de matrículas e, consequentemente, devido ao insuficiente investimento público, como já explicitado anteriormente. Por outro lado, a retenção de estudantes e assegurar que os alunos acabam os estudos com sucesso é uma tarefa com que as universidades se deparam. Ao nível dos funcionários é necessário garantir melhores condições de trabalho e de prospeção de carreira (EUA, 2010).

A qualidade e relevância do ensino e da investigação são, assim, desafios e preocupações do ensino superior. A criação de estruturas governamentais inapropriadas e o fraco desempenho na economia nacional não criam condições saudáveis para a criação de emprego (Seddoh, 2003). Tem-se vindo a constatar que África tem o menor acesso per capita ao ensino superior do mundo. (100 estudantes por cada 100.000 habitantes, comparado com 5.000 estudantes por 100.000 habitantes nos Estados Unidos). De forma a colmatar esta situação, e de acordo com Seddoh (2003), o ensino deveria ser adaptado à procura do mercado, assim como considera que seria importante melhorar a qualidade do ensino para que os detentores dos graus académicos pudessem assumir maiores responsabilidades. Um dos mais recentes desafios passa pela utilização das novas tecnologias em África, a qual é ainda bastante remota no âmbito das universidades. África utiliza apenas dois por cento de ligações por telefone no mundo. O mesmo acontece ao nível da internet. Ainda assim, e apesar das adversidades, tem-se vindo a constatar um gradual aumento da frequência de cursos universitários na África Subsariana, embora as áreas ligadas às tecnologias estejam bastante desfavorecidas. As matrículas verificam-se, essencialmente, nas áreas de programas gerais $(50 \%)$ e de saúde (11\%) seguido da área de 
Humanidades, Artes e Ciências (10\% cada). As áreas de serviços, agricultura, ciências sociais, gestão e direito são as que têm um menor peso (2\% e 5\% respetivamente) no rácio calculado de graduação no ensino superior. As Engenharias $(8 \%)$ começam a tomar alguma proporção contudo têm ainda um grande percurso pela frente, estando estas áreas mais correlacionadas com o mercado de trabalho e com o sector privado, pelo que estarão dependentes de verbas e financiamento provenientes de fontes privadas que impulsionem as investigações (Gráfico 12). Existem algumas nuances de país para país, sendo que o rácio bruto de graduação, no mesmo período, difere, principalmente, na República Democrática do Congo, que se destaca com um maior rácio de graduação no ensino superior $^{13}$ na área das ciências sociais e da saúde, e o Gana que se destaca na área das ciências sociais (Gráfico 13; Gráfico 14; Gráfico 15) ${ }^{14}$.

\section{Gráfico 12 - Rácio de graduação no ensino superior de acordo com a área de curso, (\%), Média 2000-2012}

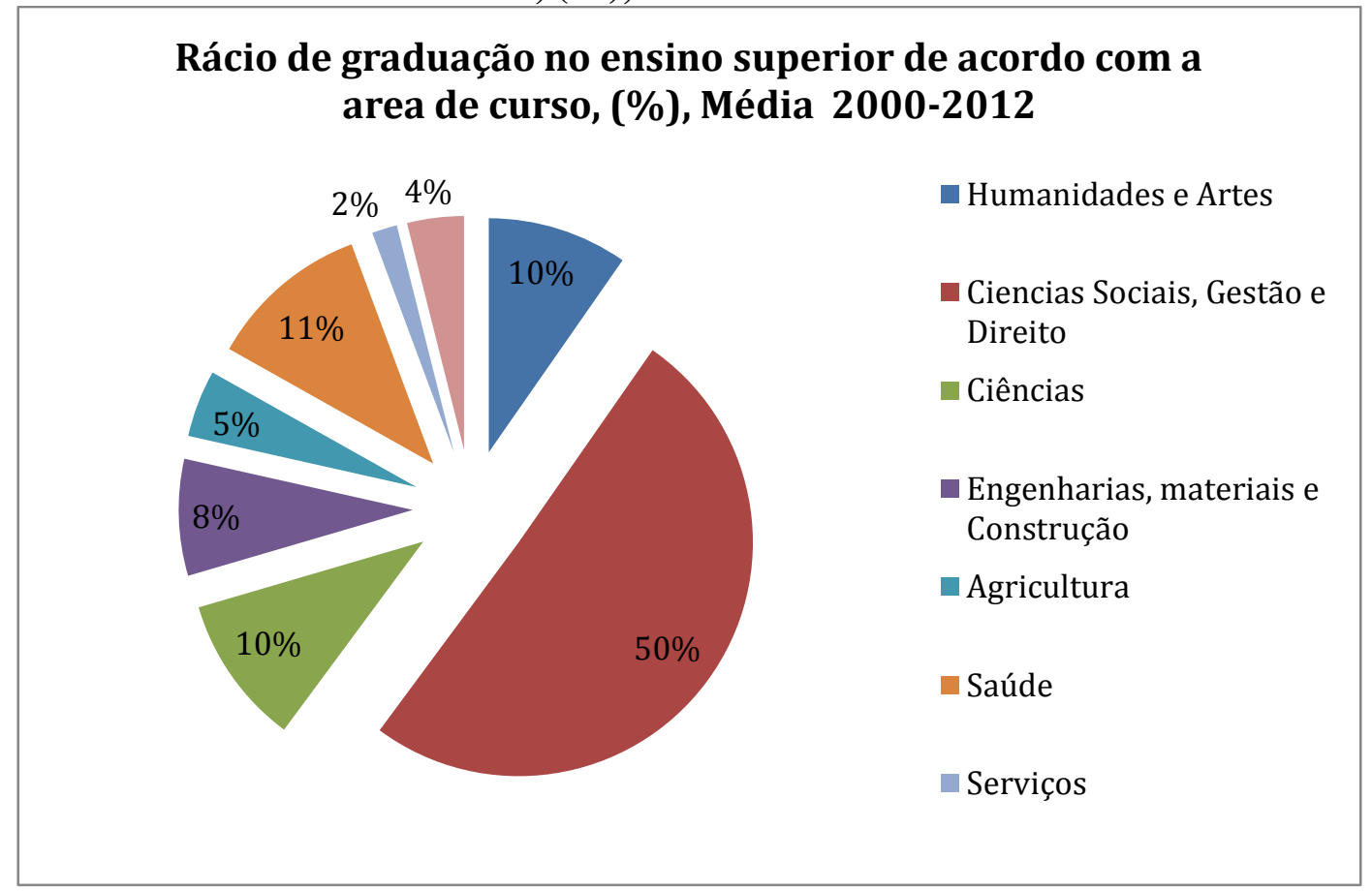

Fonte: Dados obtidos e adaptados em UNESCO Institute for Statistics, Higher Education Data

\footnotetext{
13 Anexo 8 - Rácio de graduação no ensino superior de acordo com a area de curso, ISCED 5A 1. Curso (\%), Média 2000-2012 e Anexo 9- Matriculas em todos os programas do ensino superior. Total - 2000- 2012 14 Existem países onde a informação não está disponível.
} 
Gráfico 13 - Rácio da primeira graduação no ensino superior de acordo com a área de curso (\%), Média por país $2000-2012$

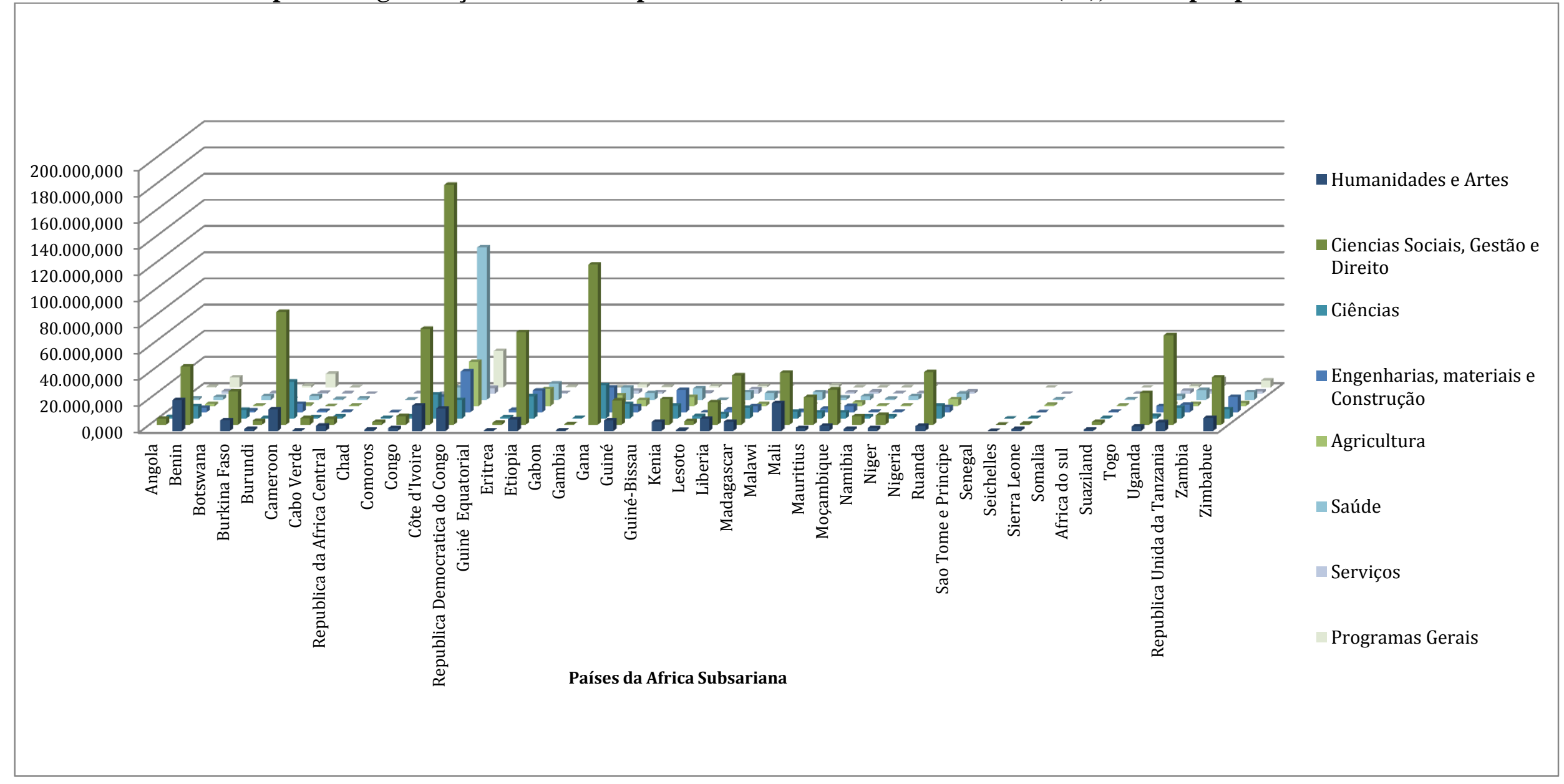

Fonte: Dados obtidos e adaptados em Unesco Institute for Statistics, Higher Education Data Não existem dados disponíveis para os países que não estão listados 


\section{IN 5 T IT T T O

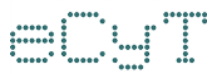

Gráfico 14 - Graduação no ensino superior por país e ano, 2000 a 2011 (\%)

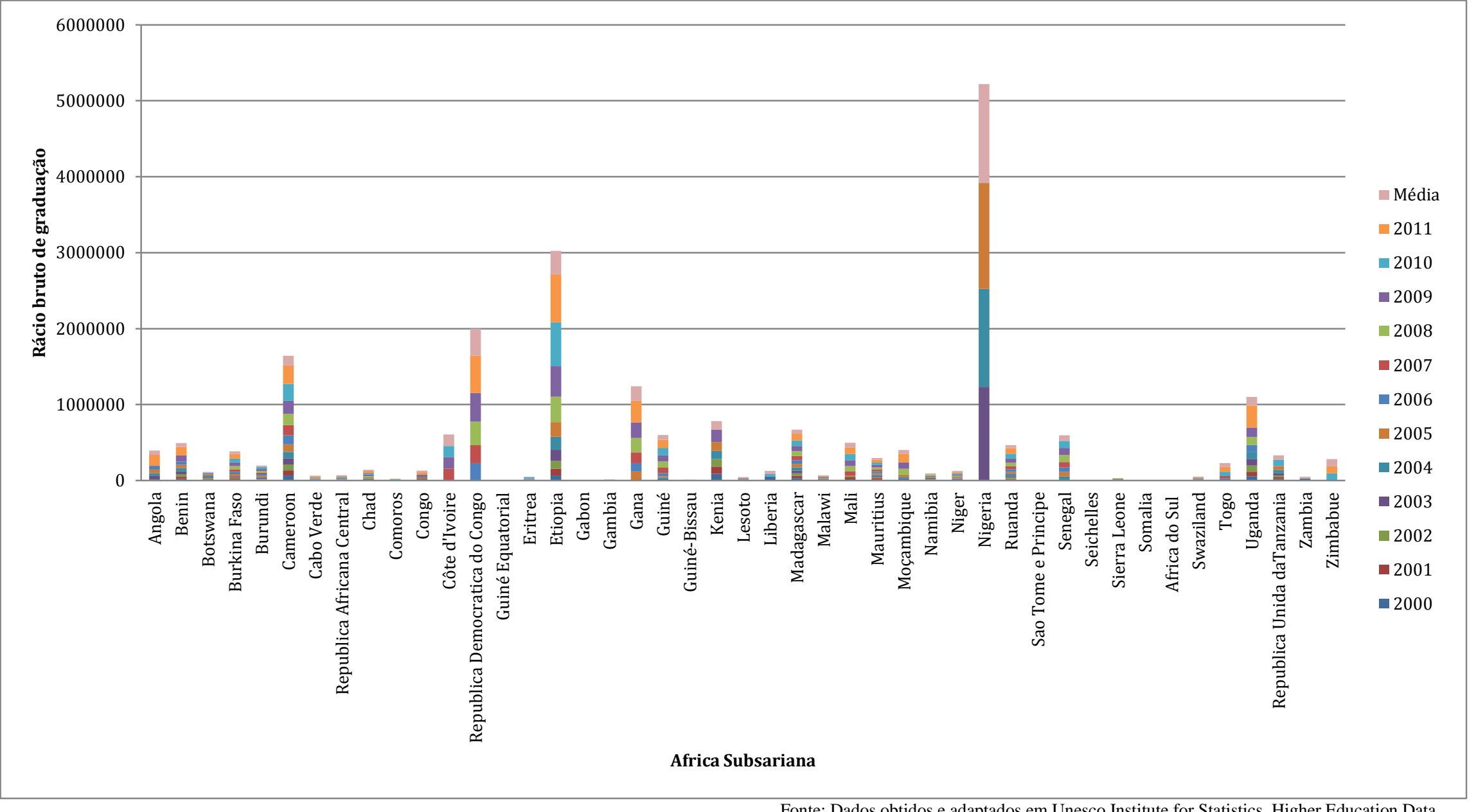

Fonte: Dados obtidos e adaptados em Unesco Institute for Statistics, Higher Education Data Não existem dados disponíveis para os países que não estão listados 
Gráfico 15 - Média - Rácio bruto de graduação, ISCED 5A $1 .^{\circ}$ Curso (\%); por país de 2000-2012

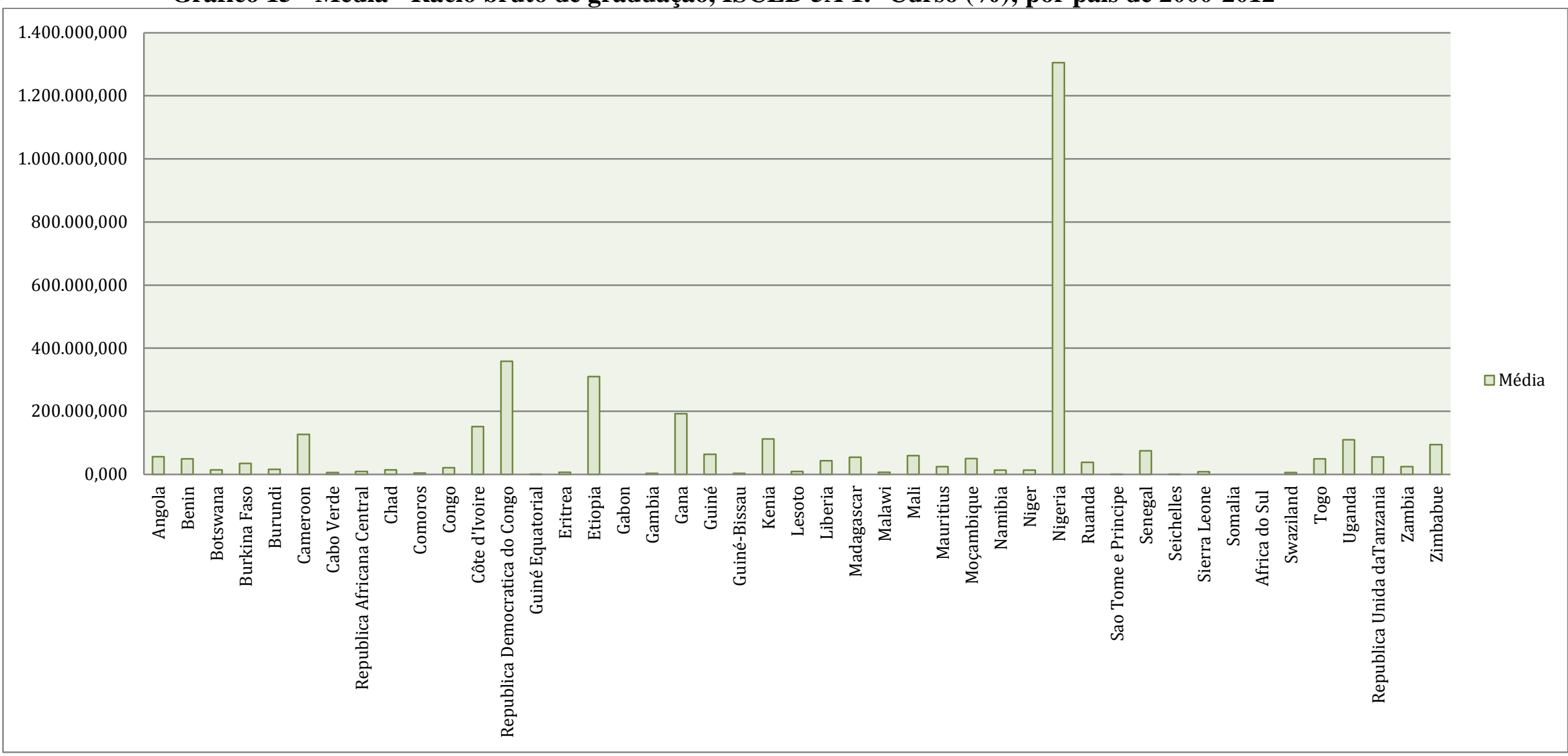

Fonte: Dados obtidos e adaptados em Unesco Institute for Statistics, Higher Education Data Não existem dados disponíveis para os países que não estão listados 
Não obstante todo um percurso de adversidades e constantes provações emergem novas oportunidades no contexto africano. A distância entre a noção de "desenvolvimento" e a de "academia" é cada vez menor passando a estarem ambas nas agendas internacionais (EUA, 2010) $)^{\circ}$ Os governos, os doadores e as universidades passam a reconsiderar o seu papel enquanto atores para o desenvolvimento alinhados com os objetivos internacionais. Tem-se vindo a verificar o reconhecimento da importância do ensino em geral, e do ensino superior, em particular, para o desenvolvimento económico e, subsequentemente, para se atingirem os objetivos do Millennium os quais, têm como principal meta a irradicação da pobreza e a construção de sociedades mais livres, mais democráticas e mais humanas. Esta nova perspetiva tem implicações ao nível do apoio fornecido às Instituições de Ensino Superior, designadamente, no que concerne aos diferentes tipos de financiamento de que dispõe, como se poderá constatar de seguida. 
VNIVERSIDAD

DSALAMANCA 
Financiamento do Ensino Superior em África

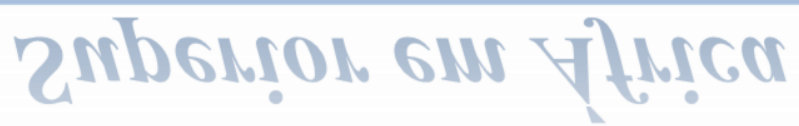


VNIVERSIDAD

DSALAMANCA 
3.1. O sistema de financiamento das Instituições de Ensino Superior em África

\subsubsection{Transformação e aspirações do ensino}

De acordo com o que se tem vindo a constatar a transformação do ensino superior agrupa aspirações relacionadas com aspetos sociais, económicos e políticos. Uma das principais transformações a ter em conta no ensino superior prende-se com aspetos de cariz racial e de exclusividade étnica, embora também fosse considerado como um sector fragmentado e descoordenado com baixas taxas de participação de estudantes negros (Nche, 1996 in Bunting, 2006). Com o início da democracia em 1994, o sistema de ensino superior era caraterizado por várias deficiências, identificadas por Nche (1996:1 - 2 in Bunting, 2006), tais como:

- A disseminação de uma distribuição desigual no acesso e nas oportunidades para os estudantes de acordo com a raça, com o género, com a classe e com a origem geográfica; e

- A disparidade crónica entre os resultados do ensino superior e as necessidades de uma economia moderna, de práticas discriminatórias que limitam o acesso de estudantes negros e da fraca participação de mulheres em áreas como ciências, engenharia, tecnologia e comércio.

Estas deficiências tiveram que ser objeto de transformação tendo em conta a promoção de um acesso mais equitativo, ao mesmo tempo que deveria estabelecer programas para desenvolvimento da capacidade de orientação por objetivos, de um sistema de financiamento relacionado com o desempenho e um esquema de alunos ao nível nacional (Nche, 1996 in Bunting, 2006; Cloete e Bunting, 2000; Bunting e Cloete, 2009; DoE, 1997). Isto porque o financiamento (público e privado) do 
ensino superior está estreitamente ligado com a acessibilidade (Teixeira et al. 2006).

\subsubsection{O sistema de financiamento das instituições de ensino}

Tal como mencionado no ponto anterior o sistema de educação superior africano, no início do século vinte e um, enfrentou uma severa crise financeira, a qual se a qual se deveu a vários fatores (Teferra \& Altbach, 2004), nomeadamente:

- A pressão de expansão e massificação - verificou-se o acesso de um grande número de estudantes ao ensino superior;

- Muitos países africanos enfrentam problemas económicos, o que constitui uma dificuldade acrescida no que concerne à disponibilidade de fundos para o ensino superior;

- O sistema fiscal é alterado por agências multilaterais como a Banco Mundial (BM) e o Fundo Monetário Internacional (FMI);

- A incapacidade dos estudantes para pagar taxas de matrícula; e

- A falta de priorização dos recursos financeiros disponíveis para subsidiar acomodação e alimentação aos estudantes.

O financiamento do ensino superior africano, proveniente essencialmente do Estado, quando comparado com o financiamento de universidades de países industrializados é bastante inferior e com recursos bastante limitados. Esta escassez tem como consequência: o baixo índice de publicações de livros e de artigos científicos; os fracos materiais de ensino disponíveis; a ausência de equipamento de laboratório; e, em último caso, o atraso no pagamento dos salários dos profissionais destas instituições (Teferra \& Altbach, 2004). Este financiamento público atinge, na maior parte dos casos, 90 a 95 por cento do orçamento das 
universidades. O percentual restante provém das taxas, dos serviços de consultoria e do aluguer dos alojamentos. Existe a crescente tendência de financiamento externo, principalmente, no que respeita ao financiamento da investigação, a qual é suportada essencialmente por agências externas, o que condiciona, em grande parte, as áreas de investigação as quais ficam restringidas aos interesses dos investidores. Desta forma, os investigadores têm vindo a observar um constante declínio no acesso a recursos, directos e indirectos, alocados ao ensino superior pelos governos (Tabela 4). Segundo Teferra \& Altbach (2004) esta tendência tem um impacto negativo na qualidade do ensino e da investigação, assim como na profissão académica.

Tabela 4 - Fontes de financiamento e a sua aplicação

\begin{tabular}{|c|c|c|}
\hline & $\begin{array}{lcc}\text { Despesa } & \text { com Instituições de } & \text { Ensino } \\
\text { (escolas, } & \text { universidades, } & \text { administração } \\
\text { escolar } & & \end{array}$ & $\begin{array}{l}\text { Despesa em Educação fora das } \\
\text { Instituições de Ensino }\end{array}$ \\
\hline \multirow[t]{2}{*}{ Despesa em serviços de educação } & $\begin{array}{l}\text { Despesa pública em serviços de instrução } \\
\text { em instituições de ensino }\end{array}$ & $\begin{array}{l}\text { Despesa subsidiada pelo privado em } \\
\text { livros }\end{array}$ \\
\hline & $\begin{array}{l}\text { Despesa subsidiada pelo privado em } \\
\text { serviços de instrução em instituições de } \\
\text { educação. } \\
\text { Despesa subsidiada pelo privado para taxas }\end{array}$ & $\begin{array}{l}\text { Despesa subsidiada pelo privado em } \\
\text { livros e em artigos escolares ou tutoria } \\
\text { privada }\end{array}$ \\
\hline $\begin{array}{l}\text { Despesa em Investigação } \quad \mathrm{e} \\
\text { desenvolvimento }\end{array}$ & $\begin{array}{l}\text { Despesa pública em investigação } \\
\text { universitária } \\
\text { Fundos provenientes da indústria privada } \\
\text { para investigação e desenvolvimento em } \\
\text { instituições de investigação }\end{array}$ & \\
\hline \multirow[t]{2}{*}{$\begin{array}{l}\text { Despesa em serviços de educação } \\
\text { sem contar o ensino / instrução }\end{array}$} & $\begin{array}{l}\text { Despesa pública para apoiar serviços como } \\
\text { refeições, transporte para escolas ou estadia } \\
\text { no campus }\end{array}$ & $\begin{array}{l}\text { Despesa subsidiada pelo privado para } \\
\text { a sobrevivência dos estudantes ou para } \\
\text { reduzir os preços do transporte }\end{array}$ \\
\hline & $\begin{array}{l}\text { Despesa privada em taxas para apoiar os } \\
\text { serviços }\end{array}$ & $\begin{array}{l}\text { Despesa privada para a sobrevivência } \\
\text { dos estudantes ou para os transportes }\end{array}$ \\
\hline
\end{tabular}

Fontes Publicas de financiamento

Fontes Privadas de financiamento

Fundos privados subsidiados publicamente 
Todavia, o financiamento governamental do ensino superior tem vindo a mudar. Inicialmente utilizava uma fórmula de financiamento cujos cálculos eram orientados de acordo com as inscrições de estudantes para a posteriori o financiamento ser calculado de acordo com objetivos de igualdade (WangengeOuma, 2010). Este financiamento era planeado de acordo com um mecanismo de orientação por objetivos para a atribuição de verbas governamentais para cada uma das instituições, tendo ainda em conta as prioridades políticas nacionais, os fundos disponíveis para o ensino superior e os planos de estudos aprovados de cada uma das instituições (MoE, 2004).

A nova agenda de financiamento constitui um importante mecanismo para atingir as prioridades políticas estabelecidas. Por sua vez o orçamento nacional para as Instituições de Ensino Superior está dividido em três componentes: subvenções globais, os fundos atribuídos e os fundos de reestruturação institucional. As subvenções globais são constituídas por quatro componentes: subsídios para o ensino, subsídios para os resultados do ensino, bolsas de pesquisa e bolsas institucionais.

O sistema de financiamento do ensino superior quando confrontado com as transformações é desenhado de forma a atingir objetivos políticos particulares, não sendo guiado de acordo com os custos atuais do ensino superior mas sim de acordo com o montante de financiamento disponível no orçamento de estado para este sector (Wangenge-Ouma, 2010). De acordo com Steyn e De Villiers (2006:56) o funcionamento das universidades implica custos avultados e para que estas instituições sejam eficientes a despesa orçamental destinada ao seu funcionamento deveria estar relacionada, de uma forma geral, com a despesa racional do orçamento de estado. Porém, o financiamento serve como um mecanismo predeterminado de atribuição de convenções (Steyn e de Villiers, 2006:56). Como consequência verifica-se que o ensino superior não tem fundos suficientes, para o seu desenvolvimento, assim como para a prestação de um serviço com qualidade. Le Roux e Breier (2007) criticam este sistema de 
financiamento afirmando que existe uma influência significativa do seu trabalho no comportamento institucional das universidades públicas. Verifica-se uma obsessão com "subsídios", nomeadamente no que respeita aos estudantes que poderão ter acesso (em termos de raça, nacionalidade, etc.), e quais os tipos de programas de estudo que estão abrangidos, estando igualmente relacionados com o tipo de regime em que esses programas são fornecidos (part time ou full time). Em complemento, Bunting (2006) afirma que o quadro de financiamento atualmente utilizado é, normalmente, consistente com o financiamento internacional, através do qual o governo financia e implementa as políticas nacionais do ensino superior (Ziderman \& Albrecht, 1995; Merisotis \& Gilleland, 2000). Ao contrário do que acontecia anteriormente, os quadros de financiamento rejeitavam o princípio da igualdade e da transformação, partindo da ideia de que não compete ao ensino superior colmatar as desigualdades sociais, as quais afetavam não só os indivíduos mas também as instituições (Bunting, 2006:84). Esta situação tem-se vindo a alterar razão pela qual, atualmente, o quadro de financiamento está alinhado com as políticas governamentais de igualdade, de transformação e de desenvolvimento.

\subsubsection{Financiamento Público do Ensino Superior}

Na perspetiva de Wangenge-Ouma (2010) existem indicadores que demonstram que o financiamento público do ensino superior tem diminuído (no período de 1995-2007), passando a ser uma percentagem da despesa total do Estado, assim como tem sido ajustado à inflação (Gráfico 16 e Gráfico 17). O autor indica que ambos gráficos demonstram um declínio tendencial do financiamento do Estado para o ensino superior. Enquanto percentagem do PIB o financiamento do Estado para o ensino superior diminui de 0,82\% em 1996 para 0,67\% em 2000. Como percentagem da despesa total do Estado passou de 3,08\%, em 1999 para 2,45\% em 2007. 


\section{Gráfico 16 - Financiamento do Estado para o Ensino Superior como} percentagem do PIB, 1995-2007

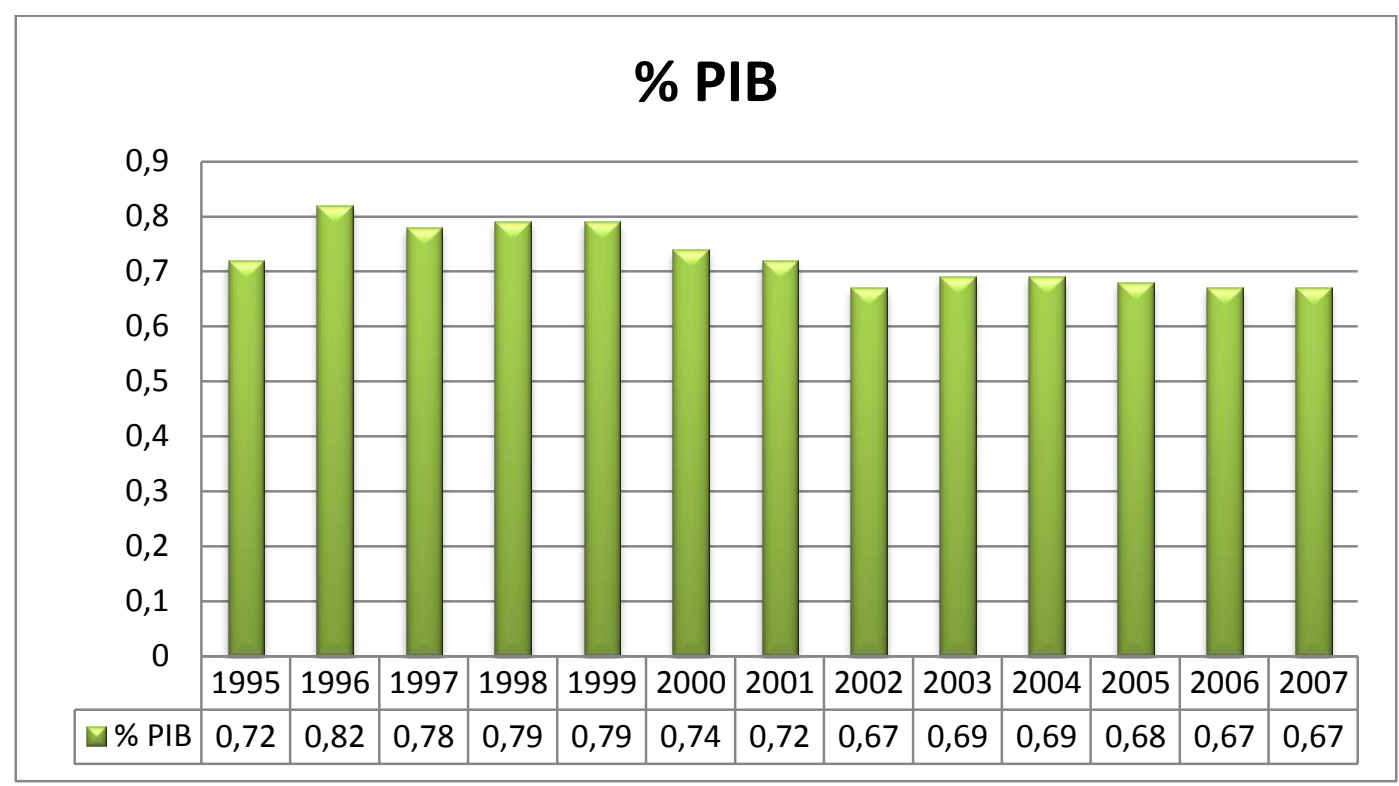

Fonte: $\operatorname{DoE}\left(2007^{\mathrm{a}}, \mathrm{A} 6\right)$

Gráfico 17 - Financiamento do Estado para o Ensino Superior como uma percentagem da despesa total do Estado, 1995-2007

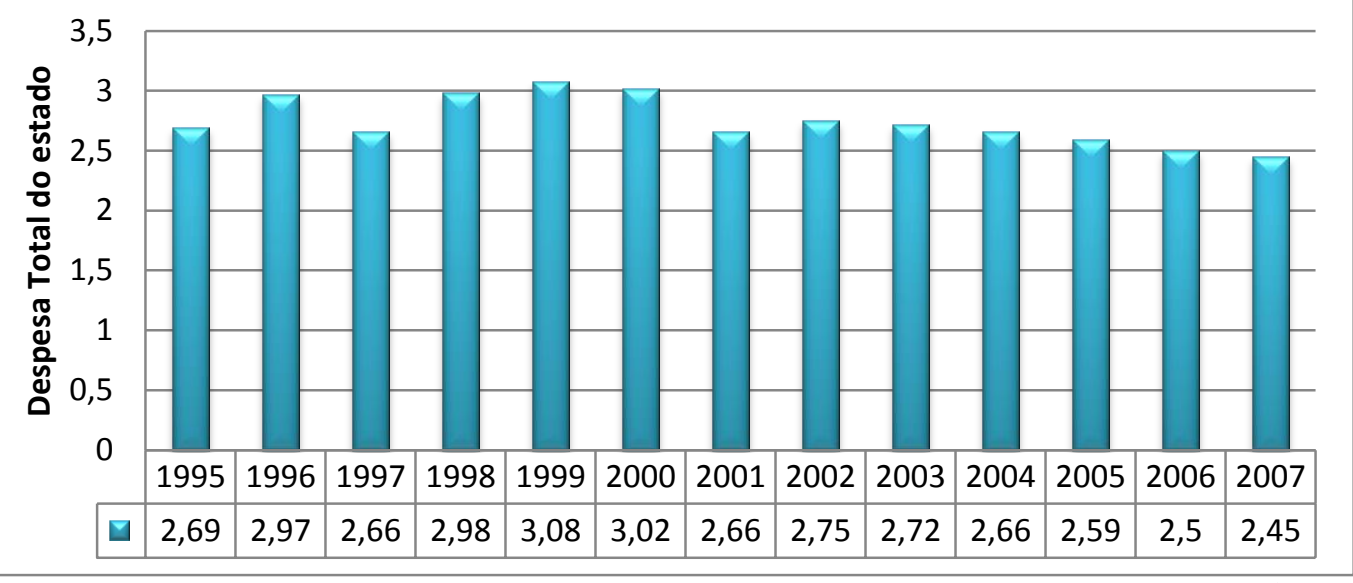

Fonte: $\operatorname{DoE}\left(2007^{\mathrm{a}}, \mathrm{A} 6\right)$ 
Uma análise mais recente demonstra que, entre 2000 e 2004, o financiamento do Estado para o ensino superior diminui 3,1\% em termos reais (DoE, 2007b). O financiamento para despesas capitais tem sido inadequado o que levou muitas universidades a financiarem-se através dos seus orçamentos operacionais ou através de créditos (Wangenge-Ouma e Cloete, 2008). Esta situação tem consequências ao nível das propinas, as quais sofrem aumentos constantes de forma a irem ao encontro das necessidades financeiras da universidade. As pressões financeiras resultaram num recuo do Estado em relação aos objetivos de transformação do ensino superior (Wangenge-Ouma, 2010). Os alunos subsidiados constituem uma indicação de que o governo está a 'lutar' para financiar adequadamente o ensino superior para rapidamente atingir as metas de transformação. A tendência de redução do financiamento do ensino superior é global (Clark, 1998; Johnstone, 2006a; Ouma, 2007). Um pouco por todo o mundo as universidades enfrentam momentos difíceis os quais são descritos por Johnstone $\left(2006^{\mathrm{a}}: 34\right)$ como uma austeridade assustadora, principalmente para as que estão dependentes do financiamento do Estado. Este financiamento do Estado sofre desequilíbrios com o défice tornando-se vulnerável o que requer que a universidade seja responsável na prossecução da sua missão, no sentido de sobreviver enquanto organização (Wangenge-Ouma, 2010). Esta situação vai ao encontro da teoria de dependência de recursos (Pfeffer e Salancik, 1978) uma vez que as empresas com recursos escassos terão dificuldades em sobreviver procurando fontes de rendimento continuas. No caso das universidades esta procura passa pela implementação de várias estratégias, incluindo o aumento das propinas, a comercialização e a procura de donativos através de antigos estudantes. Esta situação tem implicações para os estudantes com maiores carências, assim como tem contribuído para que o ensino superior acentue as disparidades sociais e as desigualdades (Teixeira et al., 2006). 
Os dados mais recentes demonstram que a despesa corrente com as instituições de ensino superior aumentou, no período de 2008 a 2010, voltando a decrescer a partir de 2011 até 2013, onde a percentagem da despesa diminui significativamente (Gráfico 18), pois apenas Ruanda apresenta despesas com as Instituições de Ensino Superior. Podemos verificar que muitos países não apresentam despesas nesta área ou é uma percentagem bastante baixa. A África do Sul, o Burundi e o Gana são os países que mais gastos apresentam com despesas nestas instituições ( Gráfico 19$)^{\mathbf{1 5}}$.

\section{Gráfico 18 - Despesa corrente em \% do total das despesas com instituições públicas de ensino superior, África Subsariana, por ano, 1999-2013}

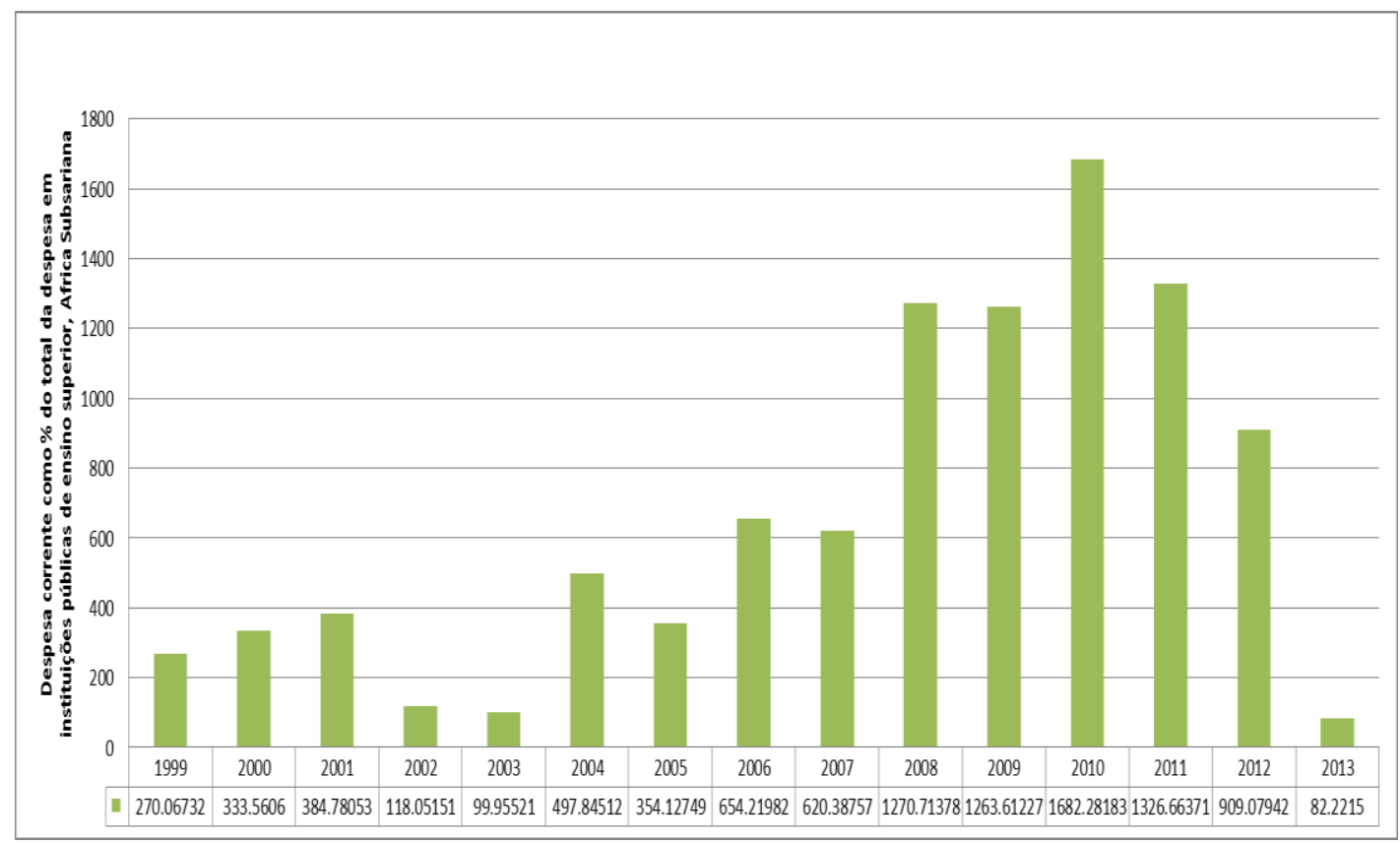

Fonte: Dados Adaptados de UIS/ISU

\footnotetext{
15 Anexo 11 - Despesa corrente como \% do total da despesa em instituições públicas de ensino superior (\%), por país - ASS - 1999-2013
} 
Gráfico 19 - Despesa corrente em \% do total das despesas com instituições públicas de ensino superior, África Subsariana, por países, 1999-2013

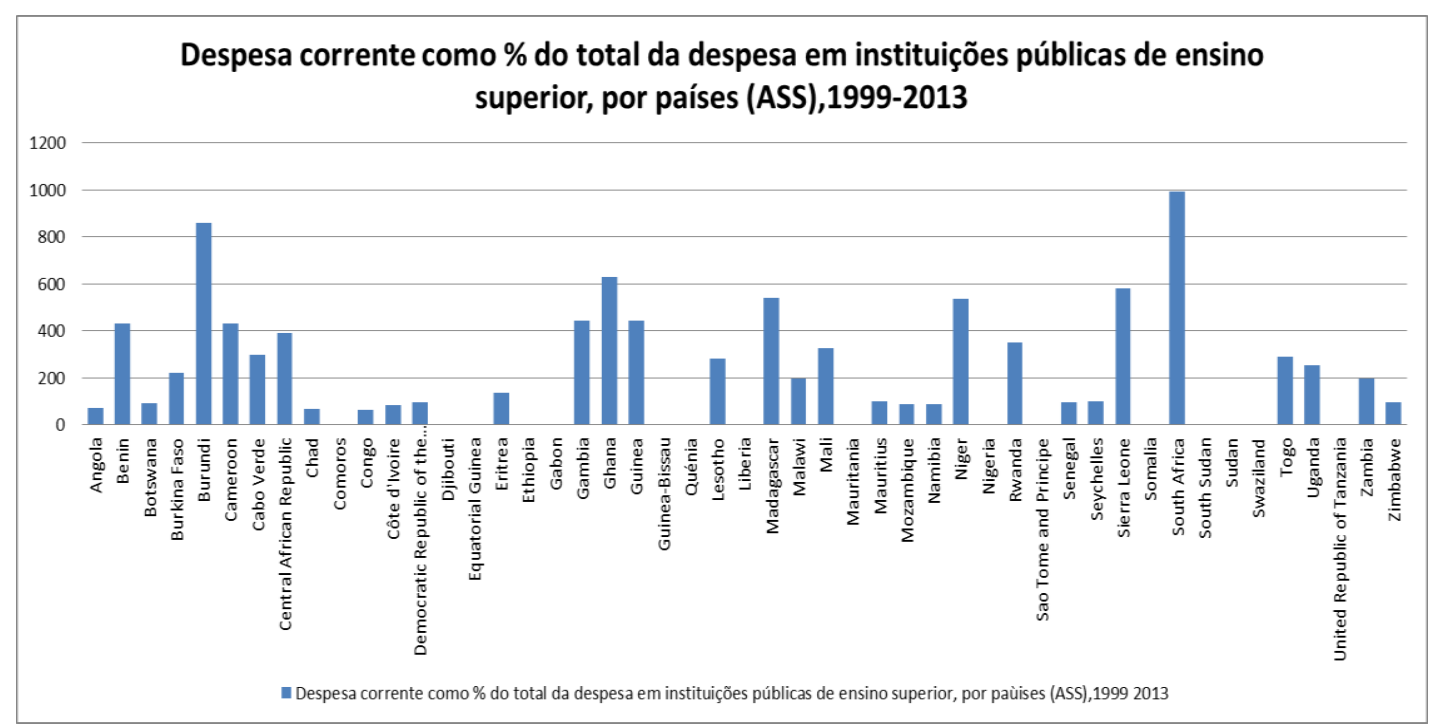

Fonte: Dados Adaptados de UIS/ISU

O decréscimo da despesa com as universidades está diretamente correlacionado com a diminuição do financiamento externo para o ensino superior uma vez que os principais dadores são confrontados com a crise financeira, económica e social a qual se vai estendendo e alcançando cada vez mais países. Verifica-se, consequentemente, uma diminuição da despesa do Governo com as Instituições de Ensino Superior a partir de 2010 (Gráfico 20). Aqui, distingue-se o Gana, cuja despesa com o ensino superior ronda quase os $12 \%$ do PIB, assim como o Lesoto e a África do Sul, com $7.5 \%$ e $6.6 \%$, respetivamente (Gráfico 21$)^{16}$.

${ }^{16}$ Anexo 12 - Despesa do Governo com IES como \% do PIB (\%), por país, ASS 
Gráfico 20 - Despesa do Governo com IES como \% do PIB (\%), África Subsariana, 1999-2013

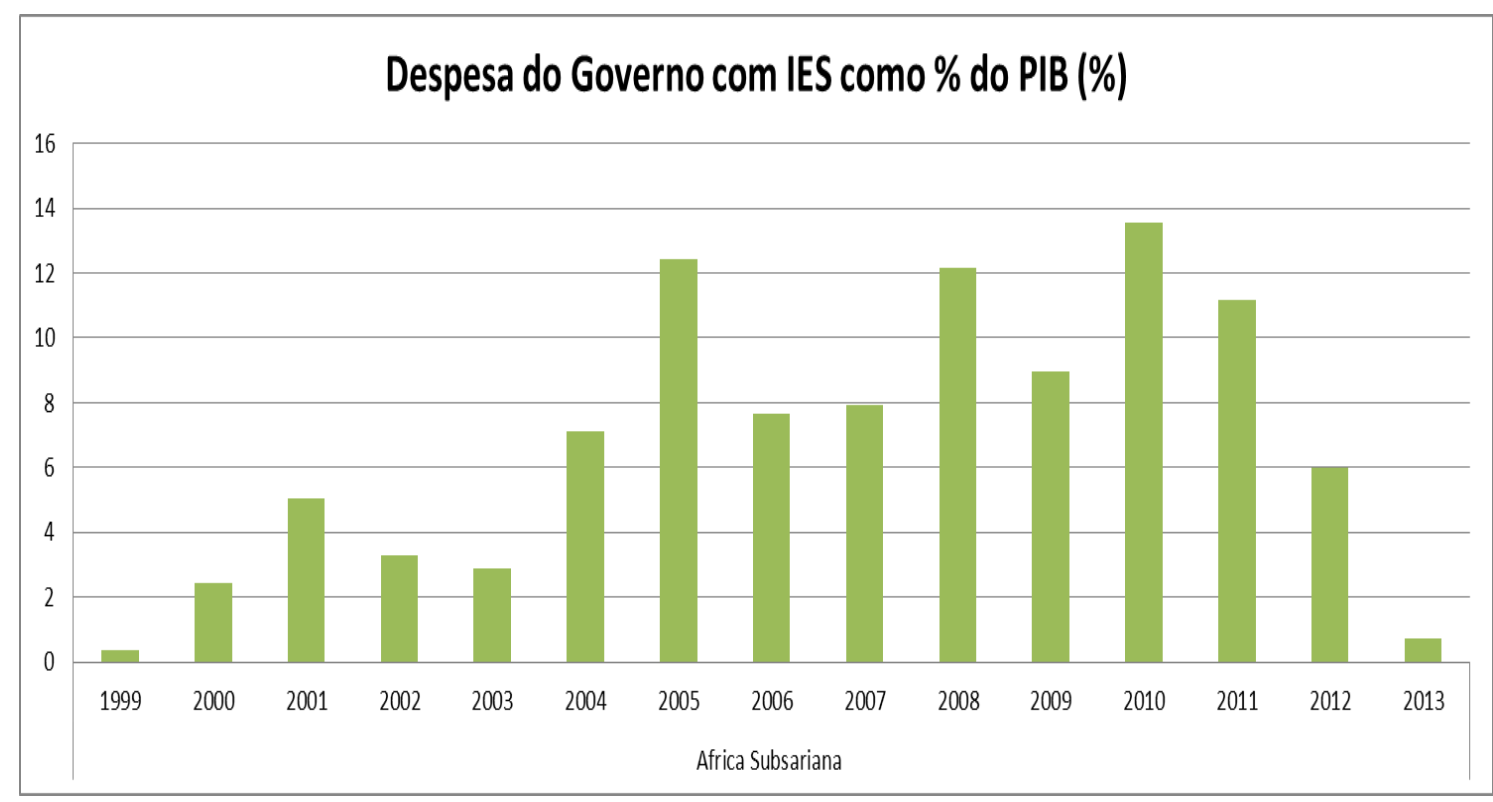

Fonte: Dados Adaptados de UIS/ISU

Gráfico 21 - Despesa do Governo com IES como \% do PIB (\%), por país, 1999-2013

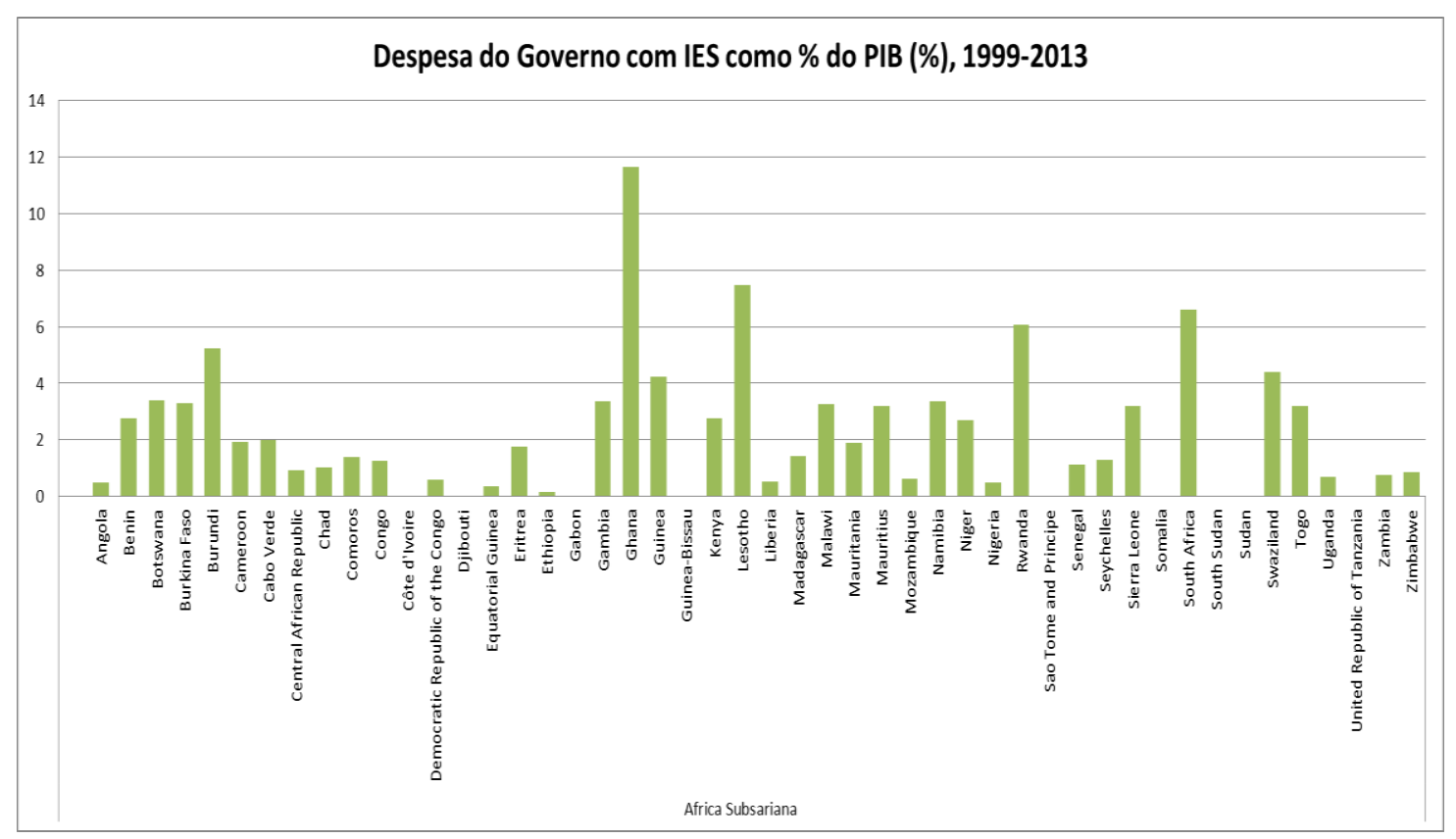

Fonte: Dados Adaptados de UIS/ISU 
No seguimento das várias dificuldades relacionadas com o financiamento do ensino superior, surgem várias reformas no sentido de apoiar os estudantes neste nível ensino e de promover uma maior igualdade no que concerne ao acesso do ensino terciário.

\subsubsection{Os constrangimentos financeiros e o acesso ao ensino superior}

São sugeridas várias reformas ao Esquema de Financiamento Nacional para Estudantes (NSFAS) as quais visão os seguintes aspetos: a possibilidade do acesso ao ensino superior para os pobres; rever as taxas de propinas tendo em vista uma maior equidade; e a igualdade e a acessibilidade no acesso. Contudo, são identificados vários fatores que não permitem atingir estes objetivos (Steyn e de Villiers, 2006), tais como:

- O financiamento inadequado - o financiamento do NSFAS não é suficiente para todos os estudantes, assim como as suas bolsas, quer a máxima como a mínima, não cobrem todos os custos dos estudantes; a alocação do financiamento do NSFAS é baseada na percentagem de custos dos programas de estudo e não no custo atual; a forma de cálculo não tem em consideração as manifestações de necessidade;

- A fórmula é baseada na raça - o financiamento das instituições baseiam-se na alocação anual de acordo com a sua avaliação e de uma fórmula, a qual tem em conta o número de estudantes em maior desvantagem, o seu perfil demográfico e a percentagem de todos os custos do estudo da respectiva instituição.

A formula baseada na raça tem sido alvo de algumas criticas uma vez que o financiamento não está relacionado com as necessidades dos estudantes, mas sim na sua raça, o que é irónico pois históricamente as universidades mais avançadas atraíam estudantes negros com algum estatuto os quais detinham algumas 
vantagens (Le Roux e Breier, 2007). Estas instituições, de acordo com Le Roux e Breier (2007), recebiam grandes financiamentos face aos poucos estudantes com necessidades comparado com as universidades que eram desfavorecidas as quais admitiam estudantes negros de baixos recursos e que careciam de maiores financiamentos. Na perspetiva de Wangenge-Ouma (2010) é necessário repensar a fórmula de alocação de financiamento baseada na raça, de forma a atingir os objetivos de transformação pretendidos. Neste sentido, as universidades com maior número de estudantes com necessidades deverão receber uma maior percentagem de financiamento para cobrir as despesas dos estudos destes estudantes reduzindo, assim, os custos dos estudantes mais pobres (WangengeOuma e Cloete, 2008). Por outro lado, o sector privado tem sido motivado a interagir com as universidades através de regalias fiscais, tais como: uma menor pressão do fisco (redução de taxas) para contribuir para o NSFAS ou através de esquemas de financiamento e apoios próprios. Estes apoios têm como destinatários estudantes pobres, os quais desenvolvem estudos em áreas relevantes para as empresas. Está em causa a necessidade das empresas, enquanto consumidoreschave das competências de alto nível, de contribuírem ativamente para a formação de capital humano (Wangenge-Ouma, 2010). Esta relação pode ser considerada como uma forma de serviço comunitário ou de responsabilidade social corporativa.

Normalmente, para se criar um impacto considerável no aumento do acesso ao ensino superior é necessário ter uma abordagem multifacetada, ou seja, de acordo com uma multiplicidade de mecanismos. Deve-se enfatizar o fato de que, apesar de se reduzirem os custos privados do ensino superior, é importante encorajar o acesso de estudantes pobres e marginalizados. O autor Wangenge-Ouma (2010) sugere que se deve adotar uma estratégia em que os custos não sejam reduzidos, como por exemplo, uma estratégia em que os estudantes pobres possam ser informados da disponibilidade dos vários mecanismos de apoio financeiro. 
Tendo em conta o fraco desempenho do sistema escolar em África, que afeta essencialmente os mais pobres, poderemos inferir que são poucos os estudantes que se qualificam para o ensino superior (Wangenge-Ouma, 2010). Neste sentido, para encorajar a participação no ensino superior de estudantes negros, de baixos recursos, seria necessário que os mesmos beneficiassem de apoios e bolsas académicas.

Apesar da nova fórmula de financiamento prever ir ao encontro das novas políticas do país com o objetivo da igualdade, o declínio do financiamento do ensino superior e o aumento constante da taxa de propinas constituem obstáculos para a transformação do ensino superior como já indicado. Estes fatores tendem a aumentar o custo privado do ensino superior não permitindo o acesso a todos, especialmente para os mais carenciados. É neste sentido que Wangenge-Ouma (2010) menciona que é importante proceder a algumas reformas orientadas para a sua transformação, uma vez que as questões de financiamento só por si não resolverão o problema. Esta transformação passa por uma aprendizagem contínua onde as universidades africanas beneficiam com as parcerias com outras instituições contribuindo para se tornarem mais eficientes através da aquisição e partilha de conhecimento tornando-se mais competitivas em termos globais.

\subsection{A internacionalização e a globalização do ensino superior}

\subsubsection{Internacionalização Vs. Globalização}

Apesar de interligados, a internacionalização e a globalização são fenómenos diferentes em vez de serem termos correlacionados (Scott, 2000). A Internacionalização está relacionada com a parceria entre países e "pressupõe o Estado nação como unidade essencial" (Marginson, 1999:19). Ou seja, na internacionalização cada país é percecionado como uma unidade autónoma que 
interage com outras unidades autónomas. Em contraste, a globalização implica "um sistema mundial que tem uma vida própria e que é distinta da vida local e nacional" (Marginson, 1999:19). Implica aumentar a interdependência e as intercomunicações entre nações com o mercado global com tendência para definir os limites das políticas locais e nacionais (Henry et al. , 1999 in Scott, 2000). Neste contexto, a universidade tem sido definida como uma instituição internacional (Scott, 2000). Durante o Renascimento, antes da Revolução Industrial, adquiriu a sua forma atual cuja função passa por "servir as necessidades profissionais e os requisitos ideológicos dos novos Estados nação da Europa, e posteriormente, do mundo" (Scott, 2000:5). Durante os últimos dois séculos a educação universitária tomou-se mais funcional e começou a alterar o seu principal foco que passava por preparar a elite da sociedade, para passar a preparar pessoas para o mercado de trabalho mundial assim como a sua manutenção (Jarvis, 2001).

Com o colonialismo, a internacionalização da Universidade adquiriu duas principais formas. A primeira estava associada com o imperialismo. Enquanto países como o Reino Unido, a França, a Espanha e outros estendiam a sua influência e domínio sobre outros países, as universidades foram uma das primeiras ações da colonização. Em segundo lugar, da internacionalização surgiu, no século XIX e XX, um novo foco na ciência e no método científico o qual foi percecionado como um objetivo inerente e, portanto, universal (Scott, 2000).

Tendo em conta que as relações entre os países ao nível científico, económico e político tem vindo a aumentar, fomentou-se uma confiança global para além da internacionalização na maior parte das universidades (Allen e Ogilvie, 2004). Esta atividade internacional é multifacetada, atuando desde o desenvolvimento de programas de intercâmbio em que através de um maior entendimento do mundo, é desenvolvida uma força de trabalho capaz de funcionar ao nível internacional, que lidera no sentido de aumentar o investimento de capital e do comércio (Chase 
Dunn, 2001). Em conjunto com a assunção de uma universidade orientada para a ciência legitima-se a noção de globalização.

\subsubsection{A visão da Perspetiva Internacional Realista e do Internacionalismo Humano}

A comunicação intercultural, a paz global e a segurança nacional são argumentos atuais para a internacionalização. Desta forma reconhece-se a interdependência dos países, havendo uma maior consciência de cidadãos do mundo (Allen e Ogilvie, 2004). Acredita-se que a educação e os seus ideais facilitam a paz mundial. Por sua vez, a cidadania global e as parcerias baseiam-se num maior entendimento do mundo e tendem a resolver problemas globais tais como a poluição e o terrorismo. Por outro lado, uma perspetiva de educação internacional facilita o sucesso profissional e as competências globais (Allen e Ogilvie, 2004).

O desejo do domínio nacional na arena global, política e económica está associado com a internacionalização. Pratt e Poole (2000) sugerem que existe demasiada competição ao nível mundial onde o realismo internacional e a internacionalização humana guiam as atuais abordagens da internacionalização. A perspetiva internacional realista sublinha a contribuição que a ajuda exterior trás para a segurança global comum. Argumenta-se que sem as iniciativas de desenvolvimento a paz mundial e a segurança nacional estariam ameaçadas (Allen e Ogilvie, 2004). Em contraste, o internacionalismo humano argumenta que, em termos éticos, existe uma necessidade de aceitação das obrigações para os que estão para além das fronteiras e que são severamente oprimidas ou vivem em condições de incessante pobreza. O objetivo é o desenvolvimento humano sustentável baseado em princípios de justiça e participação popular para atingir as necessidades humanas básicas, assim como outros objetivos de desenvolvimento para que sejam percecionados. Porém, a principal finalidade destas iniciativas 
internacionais é o humanitarismo e uma economia global saudável que seja do interesse de todos.

A educação seguiu um padrão similar à expansão da indústria e da influência política (Tikly, 2001). Com a chegada do colonialismo europeu, abriram-se portas a uma educação mais contemporânea. Esta educação tornou-se num mecanismo chave para o desenvolvimento de uma visão mais global, apesar do Eurocentrismo, o qual contribuiu para a criação de redes em todas as esferas da vida (Tikly, 2001). Nesta perspetiva a globalização da indústria e das profissões tem sido um objetivo bem articulado (King, 1997) desde há muito tempo (Chase Dunn, 2001). A globalização, desde o século XV e XIX, foi marcada pelos movimentos demográficos na Europa, na América e na Oceânia (Held et al. 1999), assim como pela expansão colonial em África e na Ásia. As redes internacionais económicas, politicas e militares foram percecionadas como importantes mesmo no século XIV, com grandes empresas internacionais que persistiram até ao século XVII (Chase Dunn, 2001).

Os períodos modernos de globalização (1850-1945) assistiram a uma expansão das parcerias globais, politicas e militares associadas a impérios globais do Oeste e a uma maior expansão do profissionalismo e dos investimentos (Held et al, 1999). O período contemporâneo de globalização (> 1945) tem sido marcado por impérios que dão lugar a "sistemas universais do estado-nação, baseado em sistemas multilaterais, regionais e globais de regulação e de governo" (Held et al., 1999). Mais recentemente, os avanços nas tecnologias de informação facilitaram o crescimento de um mercado global aumentando-se a velocidade com que o conhecimento pode ser transformado em algo útil (Marginson, 1999).

São apontadas três perspetivas diferentes sobre a globalização: a neoliberal, a transformação social e a liberal. Destas a visão dominante sobre a globalização na literatura é a neoliberal (Clyne et al., 2000). De acordo com a perspetiva neoliberal o Estado e a sua intervenção são visionados como obstáculos ao desenvolvimento 
económico e social (Navarro, 1998). Como consequência os recursos são provenientes de investimentos privados e alterados do sector público para o sector privado. O trabalho é considerado como uma comodidade com remunerações determinadas por forças internacionais ou pelos mercados nacionais. O estado social foi reduzido, passando a haver livre circulação de bens, serviços e de capitais de forma a garantir uma distribuição uniforme dos recursos (Navarro, 1998).

A maior parte dos países considera que é do seu interesse estarem envolvidos em transações internacionais, devido à enfâse que adquirem na expansão do mercado internacional. Streeck (1998) aponta que este aumento de interesse na expansão muda a noção de autonomia de cada um dos países. Como resultado, de acordo com o discurso neoliberal existe uma maior enfâse do mundo como uma comunidade global onde a interdependência económica é a norma. Para que as nações se tornem economicamente competitivas é imperativo o desenvolvimento dos recursos humanos na conjuntura internacional. Ainda neste contexto, a educação internacional, a globalização, as políticas educacionais e a gestão são vistas dentro de um único ciclo normativo onde a economia é dominante (Clyne et al, 2000). A internacionalização da educação tornou-se numa das expressões da globalização, em que a internacionalização das universidades é percecionada como o trabalho de "agentes autónomos a trabalharem em direção aos seus objetivos" (Clyne et al, 2000:6).

Em contraste ao ponto de vista neoliberal está a perspetiva de transformação social. Esta refere-se à forma como se mudam as sociedades e a cultura em resposta a fatores como o crescimento económico, à guerra ou distúrbios políticos (Castles, 2001). Existe o reconhecimento de que há inter-relacionamento entre os efeitos regionais, nacionais e locais. Os resultados destes efeitos não estão predefinidos nem não necessariamente positivos. É reconhecido que a atividade internacional pode criar novas formas de estratificação global onde algumas áreas podem ser integradas e outras marginalizadas. A chave para a transformação social 
reside na noção de redes como formas específicas de organização da sociedade global emergente. Esta perspetiva desafia a assunção ideológica de capital que se sobrepõe ao ponto de vista neoliberal. No modelo de transformação social as universidades colocam as suas prioridades nas associações partilhadas (Kerr, 1996 in Allen e Ogilvie, 2004) e em conjunto abraçarem o objetivo de benefícios mútuos.

O modelo liberal de internacionalização do ensino superior foi proposto por Warner (1992), o qual combina aspetos das duas visões da globalização. Do ponto de vista liberal perceciona o autodesenvolvimento das relações humanas e da cidadania. A internacionalização das universidades é vista como importante tendo em conta a troca de atitudes e o desmantelamento de perspetivas estereotipadas (Allen e Ogilvie, 2004). Ou seja, o contato com outros ajudará a colmatar o etnocentrismo e a aumentar a capacidade de funcionar com maior eficiência num sistema de países interdependentes e com múltiplas etnias. Fica, no entanto, por questionar a incongruência ideológica entre os modelos neoliberal e de transformação social. Os autores Allen e Ogilvie (2004) sugerem que poderá ser necessário um modelo de internacionalização de ensino superior que combine os debates que se têm vindo a conduzir sobre os modelos de globalização neoliberais e de transformação social. De fato, a globalização tem várias implicações ao nível das Instituições de Ensino Superior. Alguns autores defendem que a universidade poderá deixar de existir tal como a conhecemos se persistir a visão neoliberal da globalização. Acreditam que existe concertação entre as universidades a qual tende a ultrapassar o contexto nacional (Allen e Ogilvie, 2004).

Em oposição, outros argumentam que a globalização é uma forma superior de internacionalização que deve ser abraçada pelo ensino superior de forma a atingir novos objetivos e a liderar o conhecimento das instituições em termos globais. Uma das implicações desta mudança prende-se com a conceptualização da nação e da cultura uma vez que aumentam as pressões para a privatização, a transformação para instituições de mercado e a perda de normas culturais. Da mesma forma que 
emergiram as empresas transnacionais começam a surgir as universidades transnacionais. Ao privatizar e mercantilizar a educação tende a transformar-se num serviço (Henry et al, 1999). As universidades tornam-se mais competitivas na procura por estudantes assim como a publicitar os seus cursos / programas em termos globais através de iniciativas de intercâmbio. Desta forma, o mercado da educação internacional tende a tornar-se num grande negócio (Pratt e Poole, 1999; 2000). Este mercado resulta do fraco financiamento público, ao nível nacional e local, para as universidades e estudantes. Ao tornar-se a educação num mercado os estudantes tornam-se consumidores esperando, por isso, obter produtos tangíveis, tais como graus académicos e maior facilidade de entrada no mercado de trabalho (Pratt e Poole, 1999; 2000), em troca do seu pagamento. Estas pressões podem, facilmente, conduzir a universidade a negligenciar a qualidade do processo educativo e a aumentar o controlo corporativo.

A internacionalização do ensino superior de acordo com o modelo neoliberal ignora estas questões enquanto a adoção do modelo de transformação social garante a centralidade dessas ideias. Tradicionalmente, a universidade tinha como uma das suas funções a preservação e transmissão da cultura nacional (Alderman 2001). Marginson (1999) comenta que a globalização contemporânea (neoliberal) significa "colonialismo em larga escala" (p.23), associada à extensão da língua, das práticas económicas, formas culturais e das relações sociais.

$\mathrm{Na}$ perspetiva de Jarvis (2001) na sociedade neoliberal as corporações transnacionais estão a ser forçadas para criar mais conhecimento de forma a competir no mercado global o que resulta numa mudança radical do conhecimento em si. Existem corporações que patrocinam muitos centros de investigação para que estes se dediquem à investigação de tecnologias lucrativas (Macdonald's Corporate - Hamburger University, in Allen e Ogilvie, 2004) alterando a noção do que constitui a universidade. Por outro lado, as universidades são pressionadas para preparar os estudantes para o mercado de trabalho. Desta forma, a educação 
liberal torna-se obsoleta, desacreditando-se os cursos relacionados com as artes e com as ciências sociais.

De acordo com uma visão mais globalizada o conhecimento económico é caraterizado pelo mercado global o qual exige trabalhadores com maiores competências e com qualificações reconhecidas internacionalmente (McBurnie, 2001). É neste sentido que se afirma que a educação é uma propriedade intelectual valorizada ao nível internacional. Com a globalização as universidades sentem uma maior pressão para se reformarem a qual é considerada positiva no sentido de olharem para fora dos limites da sua região e nação. Com a globalização aumentaram, igualmente, as mudanças ao nível das tecnologias da informação. Com a utilização destas as universidades criam redes globais de trabalho, as quais contribuem para o avanço no conhecimento (Jarvis 2001:35). Por outro lado, o que sustenta a internacionalização das universidades é o objetivo de aumentar a competitividade de trabalhadores qualificados no mercado de trabalho e aumentar o acesso a empresas patrocinadas. Enquanto a perspetiva neoliberal assume que a globalização é benigna e natural a rede de transformação social sugere a necessidade de uma consciência crítica de possibilidades injustas e opressivas. Verifica-se que a perspetiva realista rejeita o modelo de transformação enquanto a perspetiva humanista rejeita o modelo neoliberal.

Uma perspetiva idealista sugere que o modelo liberal de globalização é a fusão de assunções ideológicas incompatíveis. Allen e Ogilvie (2004) concordam com esta perspetiva uma vez que acreditam que o modelo liberal de internacionalização do ensino superior é aceitável no contexto da globalização. São ambos pragmáticos e aceitáveis se o conceito de globalização e internacionalização forem claramente distinguidos e as contradições e tensões forem explícitas. A internacionalização do ensino superior não necessita de negar nenhum dos dois modelos de globalização neoliberal e transformação social. 
Tal como os indivíduos têm múltiplas identidades a globalização tem várias facetas. A internacionalização das universidades no contexto liberal requer uma avaliação crítica de diversas visões. Enquanto o modelo liberal do ensino superior prepara os graduados para ter acesso a posições que perpetuam o status quo, oferecendo oportunidades para criar cidadãos globais que desafiem a homogeneidade da estrutura mundial e reclamam a transformação social, a emancipação e a democracia social. Em vez de se rejeitar a globalização é necessário redefini-la de forma a incorporar o entendimento internacionalista de humanidade o qual se centra num discurso relacionado com os direitos humanos, justiça, paz e a sobrevivência do ecossistema global (Lfe, 1998:43 in Allen e Ogilvie, 2004).

Em suma a internacionalização tem permitido o desenvolvimento de currículos que aumentam o entendimento no que respeita às desigualdades locais, nacionais e internacionais. Por outro lado, as atividades internacionais e parcerias abrem possibilidades para a colaboração na investigação e nos esforços escolares principalmente ao nível do ensino superior.

\subsubsection{A internacionalização do Ensino Superior em África}

Knight afirma que "a internacionalização ao nível nacional, sectorial e institucional é definida como o processo de integração de uma dimensão internacional, intercultural ou global de acordo com objetivos e funções da educação pós-secundária (2003a:3). No estudo original da OCDE, efetuado por Knight e Wit, a definição de internacionalização do ensino superior é apresentada de acordo com uma "lógica académica, sociocultural, política e económica" (1997:9-14). Cada um dos segmentos implica diferentes meios e finalidades. No contexto de África os discursos da internacionalização estão diretamente relacionados com os currículos terciários e formação profissional, assim como a melhoria das qualificações do pessoal académico de acordo com os padrões 
internacionais. Por um lado, torna-se necessário colocar as universidades africanas ao nível da investigação e da inovação tecnológica internacional, assim como acarreta responsabilidades regionais e continentais. Por outro lado, torna-se imprescindível aumentar as receitas para fazer face aos desenvolvimentos necessários.

A razão pela qual a internacionalização do ensino superior se tem tornado tão popular está historicamente relacionada com um mercado credenciado de trabalho o que fazia com que o ensino superior já não se destinasse apenas a uma pequena elite mas sim a uma classe de massas nos anos sessenta e setenta. A procura pela educação terciária levou à criação de mais instituições de ensino superior. Nas décadas seguintes verificou-se uma rápida mudança ao nível tecnológico e as expectativas dos empregadores por competências qualificadas pressionaram as instituições de ensino superior para que se mantenham atualizadas de acordo com determinadas áreas e de forman a desenvolver melhores currículos em termos práticos e pedagógicos para atingirem estes objetivos.

Também em África as Instituições de Ensino Superior multiplicaram-se durante a década de setenta e oitenta, frequentemente patrocinadas. No entanto, o ensino superior estava dividido de acordo com a raça das pessoas, mas também de acordo com os recursos e em termos geográficos, pois apenas as instituições com menos recursos serviam a população negra. Desta forma, o sector do ensino superior sofreu pressões para se internacionalizar uma vez que está "historicamente provado que quando as universidades não se inserem nas economias sociais tornam-se moribundas e irrelevantes" (Altbach, 2004: 4).

De acordo com um discurso social e cultural da internacionalização, África tem-se envolvido internamente na reinvenção cultural assim como lida externamente com diversas circunstâncias da globalização (Edwards e Usher, 2000; Fasal e Lingard, 2000). A ideia de legitimar a academia de acordo com os padrões globais no ensino e na investigação foi fortemente aceite. Em 1997 a Associação 
Internacional de Educação foi convocada para "apoiar, promover e suportar a internacionalização do ensino superior de forma a promover alterações através de um fórum profissional para as instituições e indivíduos para desenvolver oportunidades na educação internacional. De acordo com Knight e Wit a internacionalização cultural do ensino superior tem como finalidade atingir uma identidade global sem deixar para trás a identidade nacional (1997:23-27). A lógica económica do discurso de internacionalização passa pelo desenvolvimento dos recursos humanos através do ensino superior de forma a estimular o crescimento económico em África. Contudo, esta prática pode ter como efeito a “intrusão de negócios na prática académica” (Zeleza, 2005:7). Significa que a introdução da internacionalização poderá ser um meio para gerar receitas numa economia cujo capital financeiro é limitado e onde as "universidades de todo o mundo comportam-se de forma a serem mais competitivas e a funcionarem numa lógica empresarial” (Yang, 2004:114) sendo que o ensino superior em África não é exceção muito embora se deva ter em consideração que estamos perante uma realidade com especificadades bastante vincadas as quais conduzem a uma situação de maior complexidade.

\subsubsection{Obstáculos à internacionalização do ensino superior}

Existem várias atividades que são levadas a cabo nas instituições de ensino superior africanas de âmbito internacional, porém, as mesmas não são planeadas nem coordenadas (Smout, 2003:10). De fato, a internacionalização não tem sido considerada como um problema mas sim como um fator que acrescenta valor de uma forma ou de outra à instituição. Na verdade, à medida que a dimensão internacional ganha maior atenção e reconhecimento as pessoas tentam usufruir dela da forma a atingirem os seus objetivos. Em termos retóricos a internacionalização deve ser entendida como um resultado positivo (Macgregor, 2005), num contexto onde a disciplina fiscal e o neoliberalismo, na maioria dos 
sectores públicos, têm tido resultados negativos. Na educação os outputs da internacionalização têm levado à "diminuição da despesa pública, levando a uma pior prestação em termos de qualidade e quantidade" (Akoojee e McGrath, 2004:27-30).

Tal como se tem vindo a demonstrar, em 2003 foram identificados vários problemas no sector do ensino superior, nomeadamente: a diminuição de fundos públicos; o aumento de dívidas por parte dos estudantes; baixas taxas de conclusão; baixas taxas de produção na investigação; falta de políticas acadêmicas e ineficiências ao nível do governo e da gestão (Ntshoe, 2004:206; Beebe, 2004:3). Esta situação não é sustentável do ponto de vista em que o sistema do ensino superior deve contribuir para o desenvolvimento da agenda nacional (Department of Education, 2005:3), assim como para a agenda regional. Num clima de estrangulamento financeiro do ensino superior, o insucesso e a desorganização institucional, os ideais académicos, culturais e sociopolíticos de internacionalização estão inevitavelmente comprometidos.

O ensino superior para ser bem-sucedido no que respeita à internacionalização, precisa de dar prioridade ao desenvolvimento dos recursos humanos internos, o que significa que deverá colocar em segundo plano a promoção do desenvolvimento social, cultural e filantrópico. As universidades em muitos países, incluindo países em desenvolvimento, têm demonstrado que o sector pode fornecer ganhos significativos através da internacionalização, não só através da educação mas também através de benefícios periféricos através de estudantes e da investigação. Parece existir consenso no fato de que os resultados financeiros gerados através das atividades relacionadas com a internacionalização devem ser reinvestidos em ações correlacionadas com a internacionalização, as quais são identificadas ao nível local, na própria instituição. No entanto, o debate prende-se com a entrada de financiamento privado e com base comercial nas instituições de ensino superior com o intuito de gerar lucro. De acordo com Knight e Wit (1997), a racionalidade económica da internacionalização do ensino superior justifica-se 
pela necessidade de criar uma mão-de-obra qualificada, moderna e global no sentido de criar uma economia sustentável. Por outro lado, indicam que a junção da investigação internacional aos projetos de desenvolvimento favorece a competição por novas tecnologias. Se definirmos a internacionalização da educação como o desenvolvimento e implementação de políticas, currículos, produtos, serviços e sistemas que oferecem uma experiencia educacional global através de interação cultural, assim como através da mobilização de estudantes entre fronteiras, estamos perante um processo que cria uma série de desafios para as instituições de ensino superior, o que implica algumas soluções criativas. Os fatores mais relevantes para o sucesso desta operação passam por uma estratégia efetiva, uma gestão planeada dos recursos e o estabelecimento de um balanço económico entre os custos e as receitas.

As políticas de internacionalização e os programas de governo para as universidades devem ser desenhadas no sentido de desenvolver atividades de acordo com as condições da globalização (Altbach, 2004:3). A oportunidade de ter fornecedores estrangeiros permite aumentar o acesso aos programas de ensino superior para adultos, assim como para investir em infraestruturas educacionais. Existe a crença de que o domínio estrangeiro ou exploração do sistema nacional e de cultura poderá constituir uma ameaça (Knight, 2002:13). Este cenário foi teoricamente facilitado pela introdução de um novo Acto de Imigração em $2003^{17}$, o qual permite a entrada de emigrantes com determinadas capacidades. Esta situação implica que se faça uma filtragem de "cérebros" e um trabalho árduo para atrair académicos qualificados e investigadores.

Planos futuros para a internacionalização no sector do ensino superior requerem o reconhecimento de que algumas iniciativas de internacionalização passadas que possam ter contribuído para aumentar as desigualdades no ensino. De acordo com Altbach (2004) as desigualdades entre os países desenvolvidos e os que estão em

\footnotetext{
${ }^{17} \mathrm{O}$ documento original pode ser consultado aqui - http://sistemas.mre.gov.br/kitweb/datafiles/Berlim/enus/file/RN\%20101.pdf
} 
vias de desenvolvimento podem ser aumentadas pela globalização da educação. De fato, existem diferenças entre as prioridades do desenvolvimento nacional e as estratégias implementadas através da internacionalização da educação (Turpin, 2004:12).

A UNESCO tem estado preocupada com o fenómeno de "fuga de cérebros" em alguns países em desenvolvimento para as comissões de investigação de forma a entender a mobilidade global de competências científicas e de conhecimento e o seu impacto nos países de origem (Turpin, 2004:12). Esta tendência é corroborada por Van Damme (2001:422) que afirma que em África, os investigadores e a emigração académica estão a criar um "grande problema de fuga de cérebros". A crescente mobilidade dos professores e dos investigadores tem tido implicações particularmente nos países desenvolvidos. Esta situação constitui maior desafio no progresso do sistema de ensino se os profissionais qualificados e graduados forem atraídos para outros países (Knight 2002: 13).

O sector do ensino superior tem um papel crítico a desempenhar no desenvolvimento futuro de África, dentro do que é cada vez mais uma "economia baseada no conhecimento mundial". Tal como o Banco Mundial admite - "sem um ensino superior com mais qualidade, os países desenvolvidos terão bastantes dificuldades em beneficiar de uma economia baseado no conhecimento mundial" (2000:9).

O discurso político para reinventar a identidade nacional e regional através de uma educação internacionalizada tem de ser cuidadosamente planeado em simultâneo com objetivos sociais e culturais e de acordo com um racionalidade económica tendo em conta os resultados de curto e longo prazo. Algumas estratégias atuais contribuem para a fuga de capitais das universidades africanas na atual crise de superlotação e subfinanciamento. Dunn (2007) concorda com esta visão concluindo que qualquer alteração no ensino superior deve estar centrada, por um lado, no contexto do impacto da globalização e do Novo Managerialismo (New 
Public Management - NPM) ${ }^{18}$ com todas as suas consequências, e por outro, nas necessidades da agenda social para a igualdade e inclusão (Ntshoe, 2004:218). Uma orientação no planeamento futuro poderia começar com os discursos de internacionalização da educação superior e garantir que o discurso corresponde a uma dada iniciativa.

Especificamente, o planeamento estratégico do ensino superior precisa de se mover além do conceito impreciso de internacionalização como um bem "intangível" e se concentrar em várias iniciativas que podem ser justificadas assim como devem ser financeiramente sustentáveis a longo prazo. Passa, ainda, pelo desenvolvimento e adoção das novas tecnologias de forma a se internacionalizar e colocar os países em desenvolvimento ao nível do conhecimento globalizado e transformar as sociedades de forma a irem ao encontro das necessidades locais contribuindo para uma maior capacitação humana e, consequentemente, desenvolver mercados mais competitivos como se poderá verificar no seguinte capítulo.

\footnotetext{
${ }^{18}$ Um termo adoptado no final dos anos 80 para designar uma nova (ou renovada) importância da gestão e 'engenharia de produção' - Nova Gestão Pública -, na prestação de serviços públicos, muitas vezes ligada a doutrinas de racionalismo económico (ver Hood, 1989 e Pollitt, 1993).
} 
VNIVERSIDAD

DSALAMANCA 


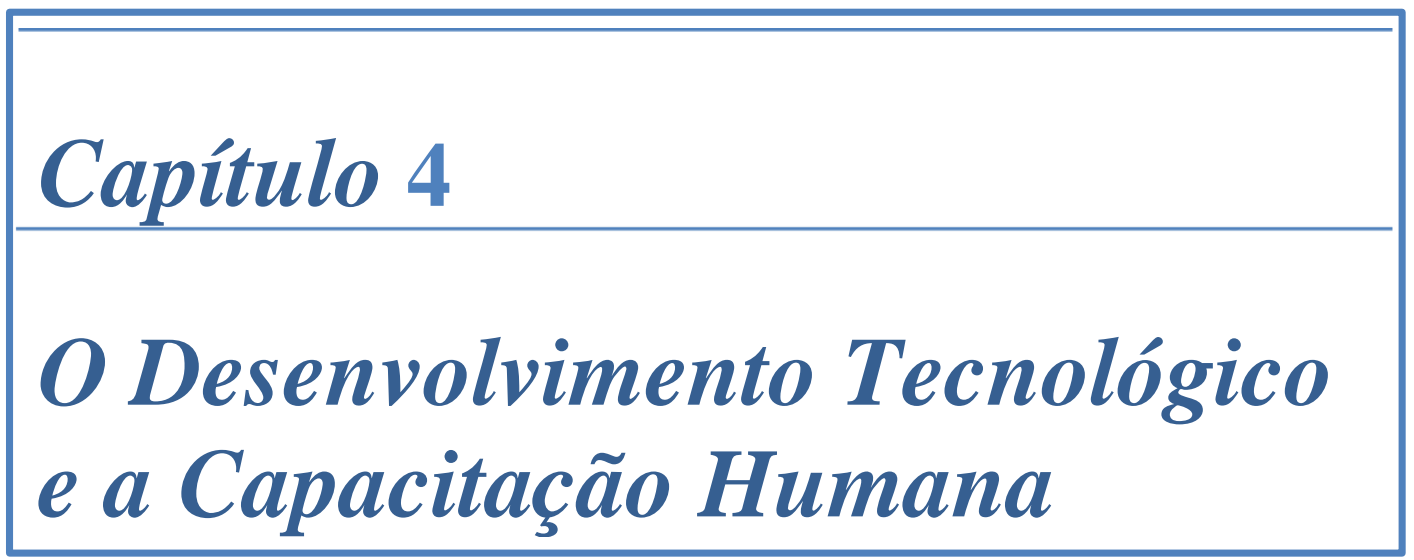

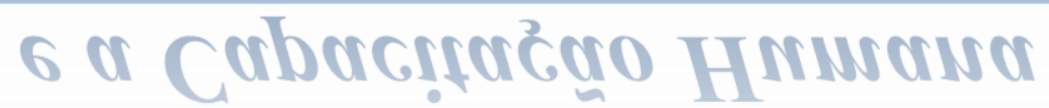


VNIVERSIDAD

DSALAMANCA 


\subsection{O Desenvolvimento Tecnológico em África}

Nenhuma nação consegue produzir toda a tecnologia que necessita para o progresso social independentemente do seu nível de civilização. Tendo em conta esta premissa, alguns críticos apontam que em África a inovação tecnológica não é dominante. Contudo, existem mudanças óbvias no que concerne às tecnologias mais modernas (Bright, 2010 in Ogungbure, 2011). São vários os autores que afirmam que a principal diferença entre os países desenvolvidos (América, Europa, Ásia e Extremo Oriente) e os países subdesenvolvidos de África reside nas suas capacidades tecnológicas (Ogungbure, 2011). Estas capacidades estão relacionadas com a forma como estas nações acedem, utilizam e exploram a ciência e a tecnologia de forma a resolverem os seus problemas socioeconómicos e humanos. Por outro lado, também se verifica algum desenvolvimento tecnológico em África, se tivermos em conta os aspetos culturais, os quais direcionaram a evolução e o domínio do conhecimento tecnológico no que respeita à indústria têxtil, arte e artesanato, música e comida em que a maioria das sociedades africanas, fizeram progressos significativos atraindo trocas e interação entre fronteiras. Esta ênfase na cultura é baseada na ideia de que os avanços tecnológicos sem a capacidade de exploração da cultura de um povo é impossível (Ogungbure, 2011). Isto porque a cultura é uma força orientadora que inspira os compromissos tecnológicos na sociedade humana. Qualquer tecnologia que se aplique na sociedade é um produto cultural, uma vez que a cultura é um fenómeno que incorpora todas as expressões materiais e não materiais de um povo. Afeta a forma como as pessoas interagem com a natureza e que varia de acordo com o ambiente que as envolve.

De forma a tirar partido da ciência e da tecnologia para o desenvolvimento as sociedades africanas devem reconciliar a sua cultura tradicional com as diferentes circunstâncias do ambiente internacional moderno o qual tem sido amplamente moldado pela ciência e pela tecnologia (Adegbola, 2003:124). É importante mencionar que a tecnologia não é apenas um catálogo de ferramentas e a 
demonstração especializada da sua utilização. É uma cultura de mentalidades que assegura a aquisição e a utilização de técnicas, métodos e aptidões adquiridas como uma parte integrante da sociedade (Ogungbure, 2011).

A filosofia da tecnologia compreende a capacidade de promover um pensamento científico crítico para explorar os recursos da natureza a favor da humanidade (Ogungbure, 2011). Trata-se de uma disposição cultural de um povo que expressa a forma como transcendem as limitações do ambiente que as rodeia através da modificação radical desse ambiente, moldando-o de forma a fazer sentido no mundo que os rodeia (Ogungbure, 2011).

A evidência empírica demonstra que a tecnologia tem contribuído largamente para os rápidos avanços a que assistimos nos dias de hoje. Contudo, este pensamento filosófico envolve o desafio de conquistar a natureza através da aplicação do conhecimento técnico para atingir um entendimento crítico da natureza conceptual e das consequências práticas da utilização dessas tecnologias e, consequentemente, providenciar as fundações conceptuais dos seus resultados e do desenvolvimento sustentável. Por outro lado, existem inúmeros benefícios provenientes do avanço da tecnologia ao nível mundial, cuja complexidade na dimensão global aumenta rapidamente, visto colocar de parte as nações subdesenvolvidas (Ogungbure, 2011). Nesta ordem de ideias a maior parte das nações africanas são consideradas, em termos tecnológicos, como retrogradas e incapazes de construir um pensamento crítico e válido não sendo, por isso, capazes de abraçar as fundações filosóficas da tecnologia (Ogungbure, 2011).

As capacidades tecnológicas nos países desenvolvidos diferem das do mundo desenvolvido, uma vez que as mesmas são frequentemente importadas uma vez que as empresas locais devem ter capacidade para as gerir, adaptar e melhorar de forma a terem um maior impacto socioeconómico. Os esforços internos devem compensar o fornecimento insuficiente de capital humano, de maquinaria 
avançada e de conhecimento tecnológico, os quais se encontram em abundância nos países desenvolvidos (Pietrobelli, 2006).

Os compromissos tecnológicos em África não acompanham as espectativas dos africanos apesar de transformar e melhorar as condições de vida, assim como existe uma crescente tendência para uma atitude com maior rigor técnico. Não obstante, o progresso que se atinge e o desenvolvimento tecnológico não é satisfatório, especialmente no que concerne a áreas relacionadas com a mecânica, com a hidráulica, com a metalurgia, etc.. A razão para esta situação pode estar relacionada com a experiência histórica de África (colonização, escravatura, recursos escassos, etc.), especialmente com processo de contato cultural com a comunidade global (Ogungbure, 2011). De acordo com Oladipo (2009:32) é claro o facto de que a opressão e a exploração, feita por terceiros, têm contribuído para o fraco desenvolvimento tecnológico em África, ou seja, a escravatura e o colonialismo deveu-se, em parte, ao subdesenvolvimento das capacidades tecnológicas de África. Entretanto, as nações africanas têm respondido aos desafios de crescimento sustentável e de desenvolvimento tecnológico através da criação de estratégias regionais e sub-regionais que têm como objetivo colocar África no caminho do crescimento tecnológico. Contudo, os resultados têm sido abismais e insatisfatórios (Obuah, 2010).

Em alguns países africanos as tentativas governamentais para ensinar ciência e tecnologia têm tido baixos resultados. Até nas instituições terciárias a investigação realizada, na área da ciência e tecnologia, tem pouco apoio do Estado, aliado ao fato de existir escassez de material e infraestruturas necessários para o avanço do conhecimento (Ogungbure, 2011). Todavia, não devemos menosprezar outros aspetos da cultura africana que contribuem para a aprendizagem social e para o dinamismo da mentalidade, os quais são crucias para qualquer exploração científica. O mais importante reside no que o povo pretende chegar de forma a criar novas tecnologias (Alozie, 2008). 


\subsubsection{Aspetos culturais africanos que contribuem para o desenvolvimento tecnológico}

Tal como demostrado no ponto anterior a cultura é uma condição necessária para o crescimento humano e para a sua adaptação na sociedade (Ogungbure, 2011). Uma vez que a cultura é um fenómeno dinâmico encoraja o progresso da investigação e da produção de tecnologias inovadoras. Não se deve deixar de salientar que todo o produto tecnológico tem como finalidade combater um problema social relacionado com a existência humana (Ogungbure, 2011). Antes da exploração do petróleo e da industrialização nos anos 70, África prosperava através dos ganhos na agricultura, a qual constituía a atividade principal da economia. Atualmente, a situação reverteu-se uma vez que a agricultura passou a ser uma atividade secundária (Ogungbure, 2011). Existe a necessidade dos governos e dos decisores políticos, em África, de olharem com maior atenção para a Conferência Mundial em Ciência ${ }^{19}$, de forma a reforçar as indústrias indígenas que utilizam matériaprima proveniente da agricultura, permitindo e contribuindo para a mudança social, uma vez que o desenvolvimento económico e social dos países africanos pode ser impulsionado através da adaptação, assimilação, internacionalização, inovação e invenção de novas tecnologias (Ogungbure, 2011). A internacionalização e adaptação de tecnologias originais na área da agrociência permitem assegurar a produção de comida, assim como previne a escassez dos produtos alimentares e da pobreza em África (Ogungbure, 2011). Neste sentido, as instituições de ensino superior focam as suas investigações em áreas relacionadas, sendo a biotecnologia uma das áreas com maior enfoque.

No caso da manufaturação de têxteis os países africanos descobriram e desenvolveram um conhecimento cultural bastante produtivo, o qual tem sido explorado e tem um impacto significativo nos avanços tecnológicos e socioeconómicos (Ogungbure, 2011). No entanto, apesar do desenvolvimento

\footnotetext{
${ }^{19}$ Conferência Mundial sobre a Ciência - "Ciência para o Século XXI: Um Novo Compromisso", patrocinada pela UNESCO e pela ICSU, Budapeste, 26 de junho - $1^{\circ}$ de julho 1999.
} 
destas capacidades em África, existe um constrangimento proveniente de más políticas governamentais e de fracas condições ao nível das infraestruturas como já ilustrado. Para além destas áreas tem-se verificado progressos tecnológicos na área da construção, onde se tem utilizado o bamboo, essencialmente na construção de casas, uma vez que este material tem como características a versatilidade, a durabilidade e a sustentabilidade.

Importa mencionar que, apesar de África não ter capacidade para produzir máquinas tecnológicas e equipamentos técnicos, tem competência para desenvolver a sua própria tecnologia de acordo com o seu conhecimento cultural e intelectual (Ogungbure, 2011). O principal foco africano reside na batalha para a sobrevivência (Alozie, 2008). Tal como se tem vindo a argumentar a tecnologia é um produto da cultura. Como tal, os africanos são capazes de produzir a sua própria tecnologia, a qual tem como finalidade resolver os problemas imediatos da existência social e do desafio da sobrevivência (Ogungbure, 2011). Ou seja, África tem capacidades para produzir toda a tecnologia de que necessita para a sua prosperidade de acordo com a sua realidade social e económica. De acordo com Ogungbure (2011) a cultura desempenha um papel crucial na transformação científica e tecnológica de qualquer sociedade. Qualquer criação intelectual ou ideológica de um cientista deriva essencialmente das heranças da sociedade a qual é gerada pela sua cultura (Iweriebor, 2004). Consequentemente, o povo não pode ter grandes progressos no que respeita aos avanços tecnológicos se o dinamismo cultural não for utilizado. Existe a necessidade de autorregeneração e reorientação que constituirão um valor acrescentado para os produtos tecnológicos das indústrias locais. Acresce o fato de que é necessário seguir uma agenda em África que encoraje a sofisticação das práticas culturais, a qual permitirá o desenvolvimento de uma cultura de tecnologia. Neste processo, os decisores políticos e o governo de África, devem promover uma cultura tecnológica através dos olhos da cultura africana, tendo como crucial o desenvolvimento tecnológico limitado das indústrias e, por conseguinte, adotar uma agenda centrada em África de forma a construir e reforçar as capacidades tecnológicas existentes, as quais 
podem conduzir a uma mudança social critica. Neste sentido, apresentam-se de seguida os principais desafios ao nível das novas tecnologias no contexto africano.

\subsubsection{O desenvolvimento das Novas Tecnologias de Informação e Comunicação em África}

Apesar do seu desenvolvimento ainda se encontrar em franca expansão, a utilização das tecnologias de informação e comunicação em África tem aplicação a vários níveis:

- Nas infraestruturas - em termos de acessibilidade, operacionalidade e manutenção, incluindo a utilização de transportes e de eletricidade;

- Nos acessos - caraterizado pelos serviços de acesso público, pela existência de conteúdos relevantes, de capacidade adequada aos vários níveis e novas experiências no que respeita à telefonia móvel;

- Suporte de ambientes favoráveis - inclui quadros de regulação e de políticas que promovam a boa governação económica e política.

Estes fatores devem ser abordados ao nível global, regional, nacional e local, assim como por todas as partes interessadas. Ao mesmo tempo, a panorâmica das tecnologias de informação e comunicação em África é formada por duas características estruturais que espelham o desenvolvimento das mesmas de uma forma mais ampla:

- As parcerias entre vários stakeholders tornaram-se numa característica da evolução e sucesso das tecnologias de informação e comunicação em todo o mundo. O DOT Force criado pelo G8 em 2000, juntou várias organizações internacionais, o governo, o sector privado e as ONG's numa aliança interativa e construtiva para a cooperação e desenvolvimento das 
tecnologias de informação e comunicação. Esta tarefa tem tido continuidade através da organização UN ICT Task Force, pelo Forum Governamental da Internet e pela aliança Global para o Desenvolvimento destas tecnologias (GAID);

- O aumento de convergências entre diferentes tecnologias, no qual a internet se tem tornado na plataforma comum para a aquisição de informação. Permite reduzir os custos da implantação da rede, juntamente com o fornecimento de novas sinergias, produtos e meios para a troca.

Estes fatores contribuem para diminuir os custos da implementação de uma rede de trabalho, para além de fornecer novas sinergias, produtos e meios para a mudança. A internet não só permite a disseminação de informação como é um sistema de transmissão, enquanto plataforma onde os indivíduos interagem e fazem negócios. Da mesma forma, os telefones móveis não são apenas utilizados para os serviços de voz, são igualmente usados para permitir o acesso a dados na internet assim como para serviços financeiros. Contudo, o acesso a estas infraestruturas não é igual para todas as camadas populacionais assim como é desigual em termos geográficos.

\subsubsection{As Infraestruturas e a sua evolução}

As infraestruturas de tecnologias de informação e comunicação referem-se a redes, cabos, redes sem fios (wireless) ou antenas parabólicas, mas também a outros elementos importantes como uma utilização otimizada destes dispositivos físicos (interligação das diferentes redes ou a gestão do espectro de frequências) e a sua manutenção (África Partnership Forum, 2008). Durante o ano de 2007 as infraestruturas de tecnologias de informação e comunicação em África aumentaram, apesar dos desafios da baixa densidade populacional, dos baixos salários e de uma população essencialmente rural. É particularmente notável a 
explosão de telefones móveis em muitos países africanos, tendo ultrapassado mais de 200 milhões de subscrições em 2007. Esta situação é, essencialmente, benéfica para as áreas rurais. Existe a estimativa de que existem 400.000 localidades na África Subsariana, das quais 99\% são vilas. Menos do que 3\% destas têm uma linha fixa de telefone, enquanto $7 \%$ dos habitantes rurais têm a subscrição de um serviço móvel em 2006 (ITU). Se por um lado estes números apontam para mudanças positivas, por outro mascaram grandes diferenças dentro e entre países. A maior parte das infraestruturas está concentrada em poucos centros urbanos. As áreas rurais (onde ainda vive a maioria da população africana) têm uma densidade de banda muito menor.

Há uma tendência geral em todo o continente para o uso de tecnologias sem fio o que explica o crescimento relativamente lento em linhas fixas, as quais permanecem praticamente estáticas - 28,5 milhões de linhas em 2006 -, pois a sua taxa é cerca de seis vezes menor que a média mundial (África Partnership Forum, 2008). Esta situação, junto com as altas tarifas relativas aos níveis salariais e uso de baixa taxa de utilização de computadores domésticos, tem levado a taxas de aceitação relativamente lentas de Internet e de banda larga em toda a África - até ao final de 2006 existiam apenas 44 milhões de usuários de Internet e 1 milhão de usuários de banda larga $(3,8 \%$ e $0,4 \%$ do total do mundo, respetivamente). No entanto, tem-se verificado uma mudança bastante rápida nas áreas urbanas com a recente introdução da banda larga sem fios 3G14 em muitos países, aumentando o acesso à internet através de telefones móveis (África Partnership Forum, 2008).

Uma série de iniciativas estão a ser levadas a cabo, no sentido de ajudar a acelerar a ampliação da utilização das tecnologias de informação e comunicação e a suavizar as variações no acesso às suas infraestruturas dentro e entre países. Uma das iniciativas mais notáveis está relacionada com projetos internacionais de fibra os quais irão melhorar significativamente a banda larga internacional disponível entre continentes nos próximos anos. Contratos, totalizando mais de EUA \$1 bilhão para pelo menos 30.000 quilômetros de fibra nacionais de transmissão de 
redes têm sido emitidos por operadores africanos durante os últimos meses, dois terços dos quais foram financiados pelo Banco Chinês de Exportação e Importação (África Partnership Forum, 2008). Juntamente com a implantação de redes de fibra nacionais têm surgido redes de transmissão por micro-ondas. Para tirar o máximo partido destes desenvolvimentos, a interconexão nacional entre redes ainda necessita de melhorias, juntamente com uma maior implantação das mesmas e promoção de tarifas mais acessíveis (África Partnership Forum, 2008). São necessários recursos e capacidades de suporte, a fim de beneficiar plenamente destas tecnologias. Para além do fornecimento de eletricidade - necessário para executar qualquer infraestrutura tecnológica - são necessárias redes de transporte, como estradas ou ferrovias, para suportar o aumento das atividades económicas e sociais.

Um estudo recente do Banco Mundial aponta que a capacidade de um país para beneficiar e absorver a nova tecnologia depende da disponibilidade de infraestruturas básicas. A capacidade humana pode constituir outro bloqueio ao uso das tecnologias em África. A iliteracia não só atrasa o desenvolvimento económico e social, como também é um obstáculo à difusão e utilização das TIC. A reduzida capacidade de promover a manutenção do hardware limita o potencial uso das tecnologias. É essencial o investimento na educação - básica, secundária e vocacional - para o desenvolvimento de África, não só para garantir que o público possa efetivamente utilizar as tecnologias mas também para criar um melhor ambiente propício para a inovação local e para a criação de riqueza. Neste sentido, têm-se verificado esforços para assegurar que as escolas e as Instituições de Ensino Superior estejam inteiramente relacionadas com o uso da Internet. Algumas iniciativas que vão ao encontro deste propósito incluem:

- A iniciativa da e-Escola promovida pelo NEPAD - tem como objetivo assegurar que 600.000 escolas do continente tenham internet; 
- A emergência da Investigação Nacional e de Redes de Educação - tem como finalidade estabelecer uma rede académica de fibra ótica para servir os membros da instituição.

Para a maioria da população, as facilidades de acesso público continuarão a ser uma parte importante da utilização das tecnologias de informação e comunicação. $\mathrm{O}$ acesso mais comum é feito através de cibercafés privados, centros telefónicos do Estado, em escolas ou em librarias. Existe uma consciência crescente de que tais instalações públicas podem fornecer vários serviços de baixo custo, que vão de telefonemas e correio eletrónico para o ensino à distância, multimédia e ecommerce. Estes acessos comunitários fornecem uma importante "ponte" que facilita o acesso às tecnologias para as empresas e para a população em África. A institucionalização das TIC tem sido vista como uma importante forma de atingir serviços universais, em áreas rurais e locais remotos e tem resultado em vários programas nacionais e projetos internacionais os quais testam diferentes modelos, meios de implementação e mecanismos para o desenvolvimento sustentável.

Algumas aplicações e conteúdos locais relevantes desempenham um papel crucial na ligação das pessoas com as tecnologias de informação e comunicação e que permitem que as infraestruturas ganhem vida. As aplicações incluem emails, transações eletrónicas, comunicações telefónicas através da internet e utilizações multimédia. O uso destas ferramentas em vários sectores permitiu a sua promoção, nomeadamente no que respeita ao e-comércio ou comércio eletrónico, à eagricultura, e-saúde, e-educação e e-governo. Contudo, apesar dos avanços, muitos dos conteúdos e serviços disponíveis continuam a não ser muito relevantes assim como não estão disponíveis na linguagem local. Acresce que as aplicações de internet e os conteúdos ainda estão pouco desenvolvidos nos sites de internet africanos. Contudo, o crescimento dos sites de internet em 2006 foi muito maior do que a média mundial, apesar dos domínios de internet africanos não serem vistos como fiáveis ou credíveis enquanto domínio internacional, assim como são 
mais dispendiosos. Além disso, as restrições de largura de banda locais também têm estimulado o uso de sites africanos "offshore" e a captação de redes internacionais. Os grupos de consumidores desempenham um papel crítico em particular no que respeita às infraestruturas e serviços das tecnologias. Eles tratam de questões de consciência do consumidor, direitos e voz. A pressão de tais grupos é necessária a fim de promover e proteger o interesse público, especialmente no longo prazo.

Atualmente, os maiores progressos das aplicações de internet locais, em África, foram implementados no sector dos meios de comunicação, dos negócios e da saúde. A UNECA e outras agências de desenvolvimento, têm levado a cabo várias atividades no sentido de promover o desenvolvimento e a utilização de aplicações do governo eletrónico, dos negócios eletrónicos, da saúde eletrónica, do e-learning e da ciência online. Foram, igualmente, desenvolvidas aplicações para telefones móveis que permitem fazer transferências bancárias, aceder a informação médica, a informação relacionada com a agricultura (preços de mercado, tempo, etc.) e a aceder a serviços de procura de empregos. Estas aplicações estão de tal forma desenvolvidas que, em África, os telefones móveis são, figurativamente, os computadores da maioria da população. Neste sentido, é essencial criar ambientes favoráveis ao investimento privado, sendo necessária a promoção de políticas e regulamentos, ao nível regional e nacional, para as tecnologias de informação e comunicação. A política nacional é um fator chave no desenvolvimento do seu uso eficaz e um número crescente de governos africanos começaram a adaptar os seus quadros regulamentares nacionais para ajudar a promover a utilização das tecnologias de informação e comunicação. O principal objetivo do processo de regulação é garantir a transparência e abertura, estabelecendo um limite à utilização abusiva do poder de mercado. Por outro lado, promovem e reforçam a previsibilidade, a estabilidade e a consistência para os operadores de telecomunicações, mas também para os investidores e utilizadores finais. Um quadro forte de regulamentação das tecnologias de informação e comunicação não deve ser arbitrário nem, necessariamente, intrusivo. Para atingir estes objetivos, as 
autoridades reguladoras independentes desempenham um papel central.

É usualmente aceite que a competição entre o sector das TIC seja mais eficiente para a provisão dos serviços do que o monopólio. No entanto, com vinte e seis (26) Estados titulares, em meados de 2007, África é o continente com a menor participação de operadores privados de telefonia fixa. A falta de um ambiente político competitivo liberalizado e o domínio de operadores estatais são os principais contribuintes para os acessos com preços altos e para a difusão de uma rede limitada.

A falta de concorrência faz com que os custos de telecomunicações e Internet estejam entre os mais altos do mundo para aqueles que menos podem pagar. Claramente, nestas circunstâncias, a possibilidade das tecnologias de informação e comunicação para contribuir para a diminuição da pobreza está altamente circunscrita. Não olhando à liberalização do sector das telecomunicações o quadro político mais amplo é influente para o desenvolvimento destas tecnologias. A fibra internacional apenas chega em 2008 a uma pequena minoria de países africanos. Todavia, os preços praticados pelos fornecedores eram demasiado altos quando comparados com outras regiões devido à falta de concorrência. Para o utilizador final significa que o acesso à internet mensal em África custa $170 \%$ do rendimento nacional bruto quando comparado com a média mundial de $62 \%{ }^{20}$.

Para fazer frente a esta situação, o NEPAD estabeleceu uma rede de banda larga NEPAD Broadband ICT Network (NBIN) -, a qual tem como objetivo assegurar que todos os países do continente tenham acesso a pelo menos duas ligações internacionais por cabo independentes. Uma política de tecnologias de informação e comunicação inclusiva aborda a visão de um país e da sua sociedade, inclui uma análise da situação, define objetivos e metas e descreve as iniciativas políticas destinadas a alcançar estes objetivos. Além disso, constitui uma fonte de financiamento para a execução destas políticas e desenvolve ferramentas para

\footnotetext{
${ }^{20}$ Africa Partnership Forum, 2008
} 
avaliar o progresso dos objetivos. Não obstante, estas políticas devem estar devidamente articuladas com outros objetivos como as políticas públicas, particularmente, no que respeita às estratégias de diminuição da pobreza (Poverty Reduction Strategy ${ }^{21}$ ). Ao mesmo tempo as políticas relacionadas com as TIC não são unicamente da responsabilidade do governo pois os contributos dos stakeholders são importantes. O acesso à informação para todos e para uma sociedade mais libre está na agenda da sociedade civil. O sector privado é primordial na medida em que pretende assegurar fatores como: condições de investimento favoráveis; a proteção dos direitos de propriedade intelectual; a transparência dos regulamentos; e a proteção da privacidade e dos dados pessoais. A este respeito ainda não existem grandes avanços deixando África para trás num contexto global. De acordo com o World Economic Freedom Index (2014) ${ }^{22}$ o nível de liberdade económica ${ }^{23}$ da África Subsariana continua mais fraco do que nas outras regiões do mundo (Gráfico 22 e Tabela 5), não obstante o fato de ter sido a segunda região que mais melhorou no mundo, ou seja, embora lento o progresso é contínuo ${ }^{24}$ estando a si inerente a ideia de que a liberdade económica traz mais prosperidade. O Índice de Liberdade Económica documenta a relação positiva entre liberdade económica e uma variedade de objetivos sociais e económicos positivos. Os ideais de liberdade económica estão fortemente associados com sociedades mais saudáveis, ambientes mais limpos, mais riqueza per capita, maior desenvolvimento humano, democracia e a erradicação da pobreza. Apesar do crescimento ser lento é importante mencionar que a sua competitividade melhorou em diversas áreas, e alguns países começam a implementar políticas fiscais sustentáveis, uma inflação passível de ser gerida e mercados mais eficientes. De acordo com as áreas analisadas pelo Index (Estado

\footnotetext{
${ }^{21}$ Poverty Reduction Strategy Papers (PRSPs) - são documentos exigidos pelo Fundo Monetário Internacional (IMF) e do Banco Mundial antes de um país ser considerado para alívio da dívida dentro do Países Pobres (PPAE) Altamente Endividados. Para mais informações: http://www.imf.org/external/np/prsp/prsp.aspx

${ }^{22}$ Publicado anualmente pelo The Wall Street Journal e The Heritage Foundation.

${ }^{23} \mathrm{O}$ Index define a liberdade económica - é o direito fundamental de todo ser humano de controlar o seu próprio trabalho e propriedade. Numa sociedade economicamente livre, as pessoas são livres para trabalhar, produzir, consumir e investir da forma que quiserem. Nas sociedades economicamente livres, os governos permitem que trabalho, capital e mercadorias circulem livremente, e não devem abster-se de coerção ou restrição da liberdade além do que é necessário para proteger e manter a própria liberdade.

${ }^{24} \mathrm{O}$ índice completo para o ano de 2014 referente a todos os países da ASS pode ser consultado no Anexo 12.
} 
de Direito; Eficiência Reguladora; Limitações do Governo e Mercado Aberto) a Maurícia é o único país da ASS que se encontra no rank das dez economias mais livres do mundo devido a uma regulação eficiente e transparente que sustenta um ambiente empreendedor dinâmico e que suporta o desenvolvimento de uma economia diversificada (Índice de Liberdade Económica). Botswana e Cabo Verde aumentaram o seu score em 1.4 e 2.4, respetivamente, em relação ao score do ano anterior. Os autores do relatório afirmam que as reformas nestes países têm permitido a expansão económica a longo termo e uma redução gradual da pobreza. Por outro lado, a África do Sul tem diminuído a sua liberdade económica na última década. Quanto aos outros países, onze estão nas categorias mais baixas (economia sem liberdade - reprimida) e os restantes na categoria seguinte (pouca liberdade económica - Figura $3^{25}$ ). Esta situação demonstra que é necessário investir no capital institucional, físico e humano para se obter um sector privado mais forte e competitivo.

\section{Gráfico 22 - Liberdade Económica, Média Mundial comparada com diferentes regiões, 1995-2008}

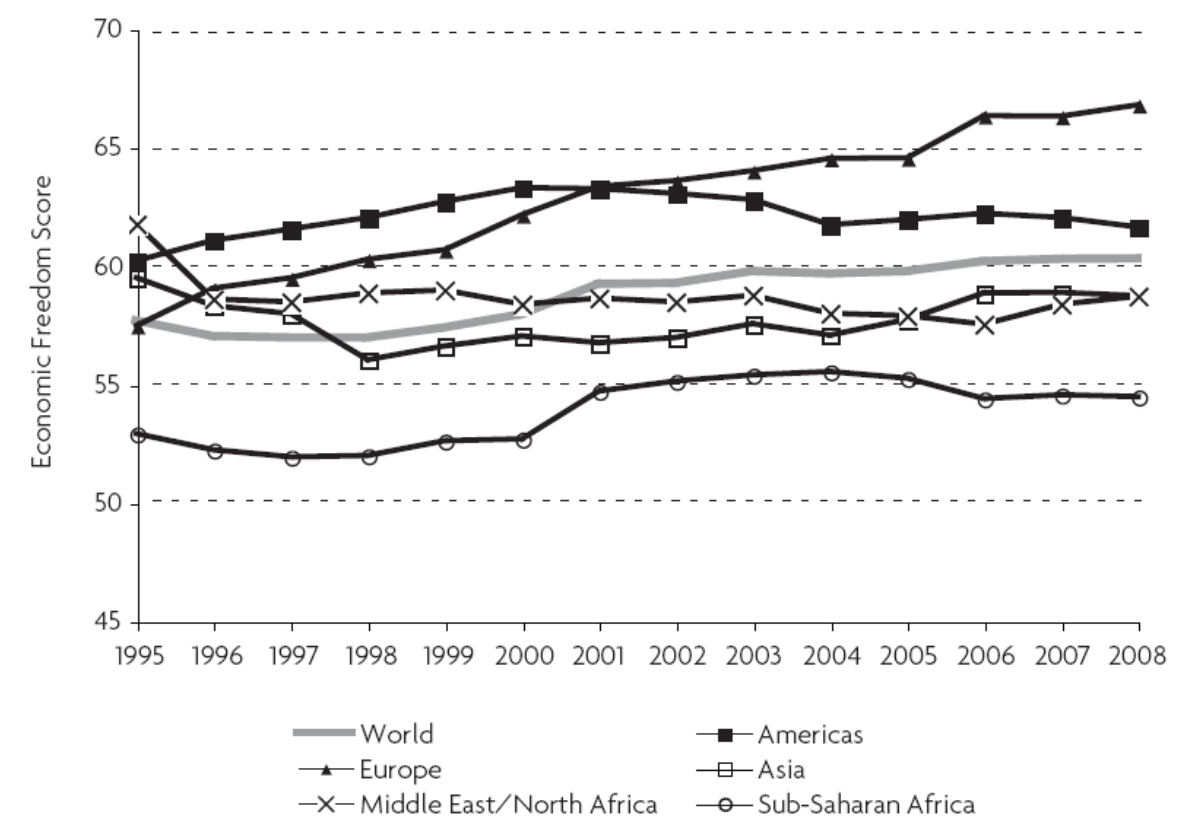

Fonte: http://www.heritage.org/research/features/index/chapters/pdf/index2008_execsum.pdf

\footnotetext{
${ }^{25}$ Anexo 13 - Liberdade Económica, por país da ASS, 2014.
} 
Tabela 5 - Comparação das Médias Regionais com as Médias Globais, em cada um dos indicadores da Liberdade Económica, Index de 2014

\section{Comparacão das Médias Regionais com as Médias Globais}

\begin{tabular}{|c|c|c|c|c|c|c|c|}
\hline & \multirow[b]{2}{*}{$\begin{array}{l}\text { América do } \\
\text { Norte }\end{array}$} & \multicolumn{3}{|c|}{ IMA OU IGUAL Á MÉDIA GLOBAL } & \multicolumn{2}{|c|}{$\begin{array}{l}\text { ABAIXO DA MÉDIA } \\
\text { GLOBAL }\end{array}$} & \\
\hline & & Europa & $\begin{array}{l}\text { Médio } \\
\text { Oriente I } \\
\text { Norte de } \\
\text { Africa }\end{array}$ & $\begin{array}{l}\text { América } \\
\text { Centrale } \\
\text { do Sull } I \\
\text { Caraibas }\end{array}$ & $\begin{array}{l}\text { Ásia- } \\
\text { Pacifico }\end{array}$ & $\begin{array}{l}\text { Africa } \\
\text { Subsariana }\end{array}$ & $\begin{array}{l}\text { Média } \\
\text { Global }\end{array}$ \\
\hline TOTAL & 74.1 & 67.1 & 61.5 & 59.7 & 58.5 & 54.6 & 60.3 \\
\hline DIREITOS DE PROPRIEDADE & 73.3 & 61.0 & 43.3 & 40.0 & 38.2 & 30.5 & 43.1 \\
\hline LIBERDADE E CORRUPCÃO & 63.2 & 55.5 & 41.7 & 38.3 & 35.8 & 29.3 & 40.3 \\
\hline LIBERDADE FISCAL & 75.5 & 71.8 & 88.3 & 78.3 & 80.2 & 75.3 & 77.3 \\
\hline DESPESA DO GOVERNO & 58.1 & 41.7 & 66.1 & 69.6 & 66.6 & 73.5 & 62.7 \\
\hline LIBERDADE DE NEGÓCIO & 85.1 & 78.1 & 67.6 & 61.6 & 65.5 & 51.8 & 64.9 \\
\hline LIBERDADE DE TRABALHO & 79.5 & 62.1 & 62.6 & 59.4 & 67.2 & 55.9 & 61.6 \\
\hline LIBERDADE MONETÁRIA & 76.4 & 77.2 & 72.5 & 74.5 & 72.6 & 72.7 & 74.2 \\
\hline LIBERDADE DE COMÉRCIO & 86.9 & 86.3 & 72.4 & 73.7 & 71.3 & 67.9 & 74.8 \\
\hline LIBERDADE DE INVESTIMENTO & 73.3 & 74.0 & 51.3 & 54.3 & 44.3 & 49.3 & 55.5 \\
\hline LIBERDADE FINANCEIRA & 70.0 & 63.0 & 48.7 & 47.2 & 43.3 & 40.2 & 48.9 \\
\hline
\end{tabular}

FONTE : Terry Miller, Anthony B. Kim, and Kim R. Holmes, 2014 Index of Economic Freedom (Washington, D.C.: The Heritage Foundation and Dow Jones \& Company, Inc., 2014), http://www.heritage.org/index. 
Figura 3 - Mapa das Liberdades Económicas, por País da África Subsariana, Index 2014

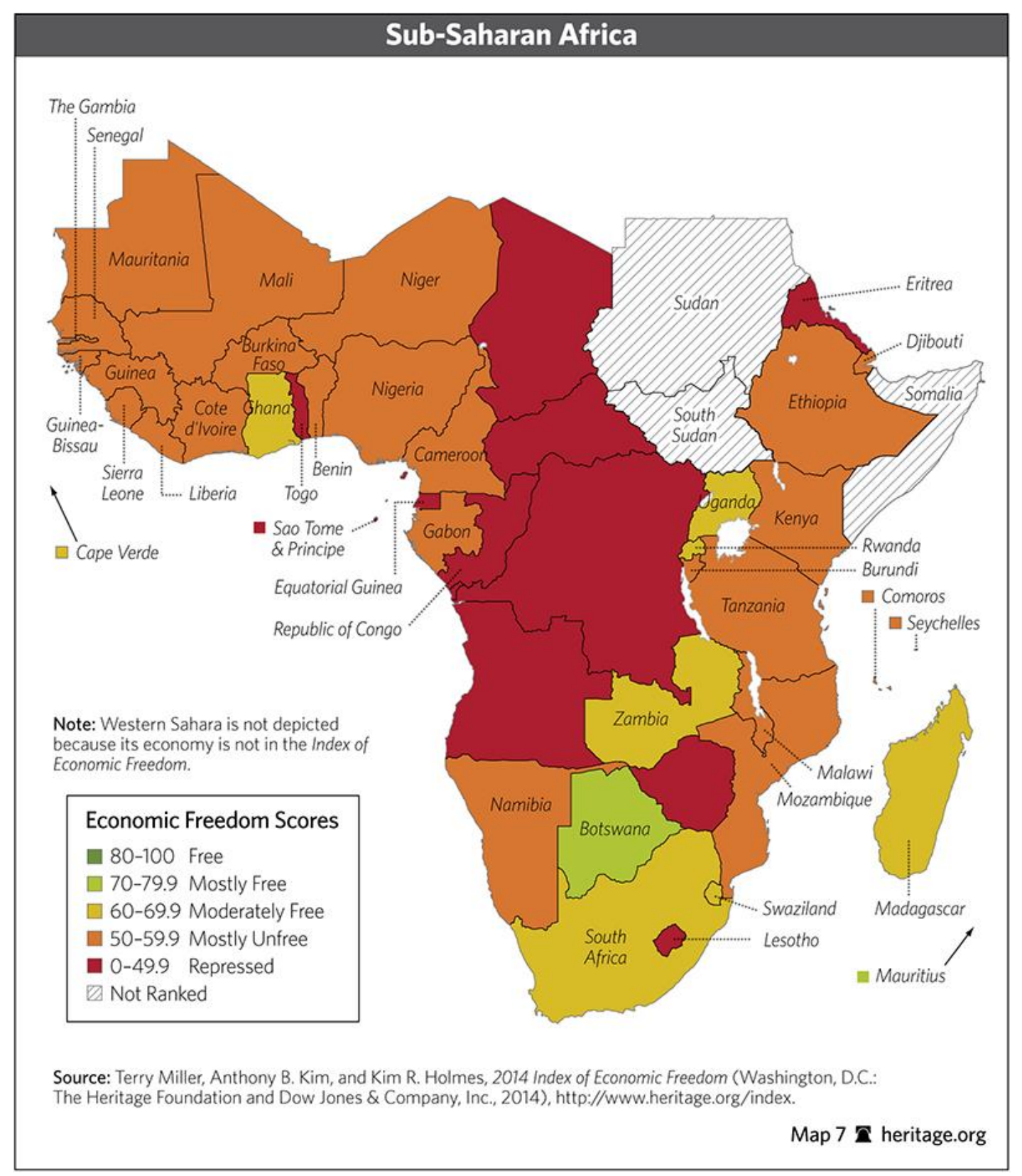

Fonte: World Economic Freedom Index (2014) 


\subsubsection{O desenvolvimento das Tecnologias de Informação e Comunicação em África e o compromisso Internacional}

Têm sido acordadas várias acções entre a comunidade internacional (UN Summits on the Information Society (WSIS); G8 África Action Plan e o NEPAD Founding Statement), referentes ao desenvolvimento das tecnologias de informação e comunicação e a sua utilização efetiva, assim como são vários os incentivos promovidos por esta Comunidade, nomeadamente:

- A Declaração do Milénio (Millennium Declaration) de 2000 - a Comunidade Internacional assegura que os benefícios das novas tecnologias - TIC - estejam disponíveis para todos e cujas preocupações se mantêm na declaração que sucedeu esta, a Declaração dos Objetivos de Desenvolvimento Sustentável, visto que se reconhece que " a disseminação da informação e das tecnologias da comunicação e inter conetividade global tem um grande potencial para acelerar o progresso humano, para eliminar o fosso digital e para o desenvolvimento de sociedades do conhecimento, assim como a inovação científica e tecnológica em áreas tão diversas como medicina e energia" (NU, 2015:6);

- A Conferência Mundial da Sociedade de Informação (World Summit of the Information Society (WSIS)) em 2003 - pretendeu estabelecer uma fundação de uma sociedade da informação para todos, assim como assume esforços no sentido de uma maior contratação de jovens e de mulheres;

- O G8 menciona as TIC no âmbito da DOT Force e de acordo com elementos específicos do Plano de Ação de África. A DOT Force teve um impacto positivo na sua estratégia de introduzir vários stakeholders nas atividades das TIC ao iniciar programas contínuos e efetivos em África. Por outro lado, estas atividades implicam esforços adicionais em termos de financiamento ao nível da educação. 
Estas iniciativas têm como principal objetivo promover ações que permitam um acesso mais uniforme a estas tecnologias sendo que, ao nível do ensino superior, pode ter um impacto significativo na medida em permite o acesso a um vasto leque de informação por parte dos estudantes académicos, os quais poderão prosseguir os seus estudos mais facilmente mas também fazer intercâmbios com os seus pares através destas ferramentas, abrindo as suas portas ao conhecimento globalizado.

\subsubsection{3. África e o acesso à Informação}

A União Africana identificou o acesso à informação e a liberdade de expressão como princípios fundamentais da Declaração da Democracia, da Política, da Economia e do Governo corporativo. Os governos africanos acordaram assegurar uma liberdade de expressão responsável, incluindo a liberdade de imprensa, mas também uma regulamentação independente das telecomunicações. A Declaração de financiamento do NEPAD situa as TIC no campo das infraestruturas, sendo um dos seus sectores principais para o desenvolvimento em África.

A UNECA é uma das instituições internacionais que mais tem trabalhado no desenvolvimento das TIC em África. O seu trabalho tem sido desenvolvido e coordenado na alçada da AISI, a qual se foca:

- Nas políticas e no planeamento nas áreas do comércio eletrónico e da saúde digital;

- No desenvolvimento da parceria PICTA, a parceria para as tecnologias de informação e comunicação em África, a qual se foca em parcerias enquanto grupo informal de doadores, criando agências onde a informação e experiências são trocadas;

- Na capacitação - apoio a decisores políticos, sociedade civil e do sector privado. A UNECA organiza palestras e formação, bem como inúmeros 
eventos sobre vários temas relacionados com a sociedade da informação.

Tem, igualmente, trabalhado com os governos nacionais e com as comunidades económicas (REC) no sentido de desenvolver o Plano de Ação Regional Africano no Conhecimento Económico (ARAPKE). É vital uma visão comum do papel crucial que as TIC desempenham no sentido de garantir economias globalmente competitivas baseadas no conhecimento e sociedades que tenham sido estabelecidas nas resoluções de 2003 e 2005 da WSIS e é compartilhada pelos líderes africanos e pelos seus parceiros de desenvolvimento.

As seguintes recomendações derivam de uma visão partilhada de como as TIC podem ter um papel importante na promoção do crescimento económico, na redução da pobreza e na concretização dos Objetivos de Desenvolvimento do Millennium (ODM):

- Um compromisso político sustentável para garantir uma regulação “amigável” das TIC e um maior investimento são pré-requisito para o crescimento eficaz e para a redução da pobreza. Um impulso político forte é crucial quando se trata de garantir mercados abertos e liberalizados e eficazmente regulado na área das tecnologias de informação e comunicação. No que concerne aos doadores, é necessário manter o compromisso político de sustentabilidade;

- Garantir o apoio financeiro adequado e parcerias entre diferentes stakeholders, de forma a promover o desenvolvimento e a difusão das TIC. Os fundos públicos escassos necessitam de ser complementados através de investimento privado. O licenciamento das novas tecnologias deveria suportar o acesso de regiões mais desfavorecidas e de pequenas e médias empresas (SME's). De acordo com a UNECA “têm sido aceites várias redes de stakeholders e de parcerias como promotoras do desenvolvimento 
em África, sendo essenciais para o seu renascimento". O capital privado contribui para o desenvolvimento de melhores infraestruturas, para um acesso mais amplo e um ambiente de apoio favorável.

Tendo em conta o importante carácter que as TIC têm vindo a desempenhar no progresso das sociedades, e visto ser uma ferramenta que deve ser apoiada através de fundos públicos e privados, é relevante criar e sustentar infraestruturas de apoio às mesmas, uma vez que se verifica grandes desfasamentos entre as regiões rurais e regionais. A disponibilidade, a operação e a manutenção das infraestruturas básicas (informática, eletricidade e transportes) para além das fronteiras, são fatores fundamentais para promover o crescimento económico. Neste sentido, os países africanos deveriam tomar medidas que permitam:

- Mobilizar fundos e investimentos para a implementação de quadros legais para avançar com a iniciativa de banda larga do NEPAD;

- Desenhar mecanismos e politicas que garantam infraestruturas adequadas de acesso universal, o que implicará um maior investimento do sector privado; e

- Garantir a coordenação regional através do planeamento de novas infraestruturas.

A ação dos parceiros internacionais constitui um apoio imprescindível no desenvolvimento destas infraestruturas, nomeadamente no que concerne ao apoio do projeto de banda larga do NEPAD com recursos financeiros. Apoiam ainda os parceiros regionais como o REC, associações de regulação e o governo nacional através de projetos a longo termo, os quais envolvem vários parceiros. Por último, implementam políticas de aumento do financiamento para infraestruturas (particularmente na área das TIC) e ao acesso a recursos financeiros como o microcrédito e "venture capital" para PME, para que as mesmas possam ser mais competitivas. 
O desenvolvimento de ferramentas e de infraestruturas tecnológicas implica recursos humanos qualificados capazes de lidar com os novos equipamentos e tirar o melhor partido dos mesmos, pelo que a educação ocupa aqui um lugar primordial no desenvolvimento de capacidades, principalmente ao nível do ensino superior. $\mathrm{O}$ acesso às novas tecnologias pela população requer capacidades individuais e institucionais, uma maior relevância nos conteúdos locais, preços acessíveis para o consumidor final e pontos de acesso físicos às tecnologias de informação e comunicação. Para tal é necessário que os países africanos apoiem ações que encorajem e promovam a criação de aplicações (do tipo open source) as quais são relevantes para a subsistência de determinados grupos populacionais (agricultores, técnicos de saúde e professores), devendo estar disponíveis na língua local e através dos dispositivos locais acessíveis (telefones móveis, etc.). A regulação nesta área deve permitir às empresas a possibilidade de efetuar vários serviços como por exemplo operações bancárias ou de serviços públicos os quais devem estar disponíveis através de suporte eletrónico. Por último, é importante que a utilização das TIC tenha uma maior difusão entre o sector educacional, criando potenciais oportunidades para o seu público-alvo. O papel dos parceiros internacionais é mais uma vez primordial, os quais deverão contribuir com formação ao nível das capacidades em todos os níveis de atividades de tecnologias de informação e comunicação, essencialmente no que respeita às infraestruturas, para garantir que as mesmas não só são utilizadas, mas também que garantam o seu uso de forma eficiente. Deverão ainda contribuir para o desenvolvimento de conteúdos locais assim como aplicações na língua local (através de software de tradução open source), contribuindo para um maior acesso a todos. O seu papel é relevante no sector da educação onde deverão promover a investigação independente, através da criação de plataformas que permita a troca de experiencias e de material científico e cuja informação poderá ser utilizada por instituições locais. 


\subsubsection{Redefinição das políticas governamentais e sua implementação}

Tendo em conta o já mencionado, torna-se evidente a necessidade de criar, em termos de políticas-chave, um ambiente favorável à competição, em termos empresariais, e que vise os mais desfavorecidos, que garanta que as tecnologias de informação e comunicação tenham um forte impacto no crescimento da economia e na redução da pobreza. Para que tal seja possível, os países africanos devem: assegurar uma competição efetiva através de preços mais baixos e do estabelecimento de mecanismo de regulação independentes; melhorar as políticas nacionais relacionando-as com estratégias de redução da pobreza; promover aplicações governamentais online para aumentar a administração efetiva, mais transparente e com uma maior participação do público; permitir a troca de informação dentro do país, incluindo a liberdade de expressão e apoio aos consumidores; e nos países em que já existem políticas relacionadas devem continuar a promover e a implementar políticas de tecnologias de informação e comunicação. Ao nível dos parceiros internacionais deve ser dada especial atenção à regulação independente através da troca de experiencias. Devem, ainda, apoiar a boa governação, incluindo a liberdade de expressão, e fornecer plataformas que permitam a troca de experiencia no sentido de reforçar a cooperação regional.

\subsubsection{Iniciativas internacionais para melhorar o acesso à Internet em África}

Entre as iniciativas Internacionais de apoio a África para melhorar o acesso à Internet e às Tecnologias de Informação e Comunicação (TIC), são mencionados alguns exemplos que visam o desenvolvimento das redes de trabalho entre as Instituições de Ensino Superior:

- Apoio da Fundação Carnegie para o desenvolvimento de bases de dados nas Universidade Africanas; 
- Apoio do Ministério da Holanda para a Cooperação (DGIS) para desenvolver aplicações TIC em sete universidades Africanas;

- Apoio da Associação Federação Internacional de Bibliotecas (IFLA) para o desenvolvimento de bases de dados de bibliotecas (em países africanos);

- Apoio da USAID através de Educação para o Desenvolvimento e Iniciativa Democrática (EDDI) que permitiu dar assistência a 100 universidades africanas no uso da tecnologia;

- A Rede da Sociedade Regional de Informação (Regional Information Society Network - para África (RINAF)) - uma iniciativa da UNESCO organizada em cooperação com o governo Italiano, envolvendo projetos na área do ensino à distância assim como como tinha como objetivo criar uma comunidade de multimédia - telecentros;

- A iniciativa UNESCO em Bibliotecas e laboratórios virtuais. Um projeto desenhado para promover o desenvolvimento de laboratórios virtuais para o ensino à distância para os investigadores africanos em países desenvolvidos;

- As Redes de Informação Cooperativas (Cooperative Information Network (COPINE) - colaboraram na área da informação para os cientistas, professores, e para a tomada de decisão - é uma iniciativa das NU a favor de 20 países Africanos ligados aos centros de investigação na europa.

- A Rede Informação Académica para Projetos (Network for Academic Information Projects (ICP/OAU) - desenhada para mostrar como a informação das tecnologias podem ser usadas para colmatar o isolamento dos investigadores;

- A iniciativa da Sociedade Africana de Informação (African Information Society Initiative (AISI)) - criada em 1996 pela conferência dos Ministérios Africanos para reforçar as TIC em África, assim como para reduzir a exclusão digital. 
As Instituições de Ensino Superior Africanas precisam de ir ao encontro de condições básicas de forma a atingir o desenvolvimento e para reduzir as falhas entre as suas regiões e as regiões mais industrializadas. Devem, desta forma, procurar (Seddoh, 2003):

1) Promover um ambiente onde os direitos políticos e fundamentais sejam respeitados através de uma democracia participativa e do desenvolvimento económico-social centrado no ser humano;

2) Desenvolver a educação numa perspetiva holística a qual deverá enfatizar uma relação sistémica vertical entre diferentes níveis de educação, assim como em termos horizontais, através de abordagens complementares no fornecimento da educação;

3) Promover a inovação, assegurar a qualidade e a cooperação funcional através da partilha de instalações e experiencias com países vizinhos, reforçando os mecanismos existentes para a cooperação e desenvolvimento de redes de trabalho com outras regiões do mundo.

É importante para África agir rapidamente no sentido de fazer parte do mesmo sistema educacional que outras regiões do mundo. Estas ações exigem medidas políticas de cooperação, e não apenas oportunidades que não são coordenadas através de estratégias globais (Seddoh, 2003). É relevante o fato de que cada uma das Instituições de Ensino Superior mantenha a coerência entre a missão e o plano estratégico estabelecendo ações prioritárias com qualidade crescente, de acordo com uma gestão prospetiva. Esta iniciativa permitirá identificar linhas de ação prioritárias no quadro nacional de cooperação. As possibilidades oferecidas pelas TIC alteraram o padrão dessa mesma cooperação. As instituições de ensino superior estabelecem redes de forma a organizar cursos de pós-graduação à distância, em que cada uma das instituições é responsável por um tipo de educação ou sector de educação, para o qual tem reconhecida competência. Na mesma 
ordem de ideias, algumas unidades orientadas para a qualidade - tais como departamentos com recurso pedagógico - necessitam de criar redes no sentido de trocarem, umas com as outras, experiências e formação adquiridas (Seddoh, 2003). Todas estas considerações sugerem um novo impacto para os programas de cooperação, tais como UNITWIN/UNESCO Chairs e Networks ${ }^{26}$. A criação destas redes constitui uma importante contribuição para o desenvolvimento de culturas de responsabilidade responsável e para manter a paz. É essencial para o ensino superior em África “ promover um padrão prospetivo de gestão de forma a fornecer produtos de qualidade para o desenvolvimento do país no espírito da equidade e solidariedade responsável" (World Conference on Higher Education ${ }^{27}$ ).

\subsection{As instituições científicas e a sociedade do conhecimento em África como promotores do desenvolvimento económico}

A maioria dos países Africanos tem desenvolvido esforços no sentido de utilizar a ciência e a tecnologia como motores do desenvolvimento económico. Durante os anos setenta são estabelecidas políticas nacionais nesta área surgindo Concelhos Nacionais de Investigação como resultado da partição de vários países na Conferencia dos Ministros de Gabinete responsável pela Aplicação da Ciência e da Tecnologia (CASTAFRICA I e II) ${ }^{28}$, a qual teve lugar no Dakar, Senegal em Janeiro de 1974 e a segunda em 1987. Entre estes encontros os países africanos

\footnotetext{
${ }^{26}$ Lançado em 1992, o Programa UNITWIN/UNESCO promove a cooperação inter-universitária internacional e rede para reforçar as capacidades institucionais através da partilha de conhecimento e trabalho colaborativo. O Programa apoia a criação de cadeiras UNESCO e UNITWIN Networks em áreas prioritárias relacionadas com os campos de competência da UNESCO - ou seja, na educação, as ciências naturais e sociais, cultura e comunicação - http://en.unesco.org/unitwin-unesco-chairs-programme

${ }^{27}$ A Conferência Mundial sobre Educação Superior de 2009 ofereceu à comunidade global do ensino superior uma oportunidade de marco para colocar em ação a responsabilidade colectiva e ambição de tornar o ensino superior em todas as regiões motor do desenvolvimento e da compreensão internacional na segunda década do século XXI. Para mais informações consultar: http://www.unesco.org/new/en/education/themes/strengtheningeducation-systems/higher-education/reform-and-innovation/world-conference-on-higher-education/

${ }^{28}$ Second Conference of Ministers Responsible for the Application of Science and Technology to Development in Africa. Arusha, United Republic of Tanzania, 6-15 . July 1987. http://unesdoc.unesco.org/images/0007/000795/079563eo.pdf
} 
com instituições de C\&T (Ciência e Tecnologia) cresceram de 4 para 28. Estas instituições de investigação e desenvolvimento são financiadas, basicamente, através de fundos públicos, focando a sua pesquiza em áreas como as ciências naturais, a agricultura, a medicina, a ciência nuclear, a industrial e a do ambiente (Adeboye, 2000; UNECA, 2010). De acordo com o grupo de investigação Cybermetrics Lab ${ }^{29}$ existem 96 Centros de Investigação em apenas 22 Países da África Subsariana (Tabela 6 - Ranking Web of World Research Centers that formally and explicitly adheres to the Berlin Principles of Higher Education

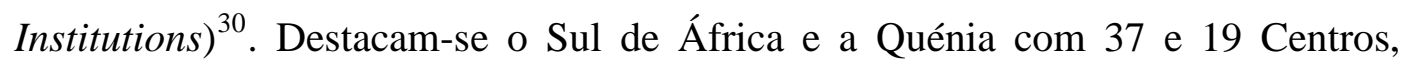
respetivamente, e cujas áreas de investigação se centram nas ciências da saúde e nos recursos naturais / agricultura (Anexo 10).

\section{Tabela 6 - Países da África Subsariana com e sem Centros de Investigação classificados no Ranking "Web of World Research Centers"* de acordo com os Princípios das Instituições de Ensino Superior}

\begin{tabular}{|c|c|c|}
\hline $\begin{array}{l}\text { País com Centros de Investigação } \\
\text { classificados no } \\
\text { Ranking "Web of World Research } \\
\text { Centers" }\end{array}$ & $\begin{array}{c}\text { Sub-Saharan } \\
\text { Africa Research } \\
\text { Centres }\end{array}$ & $\begin{array}{c}\text { Países sem Centros de } \\
\text { Investigação classificados no } \\
\text { Ranking "Web of World } \\
\text { Research Centers" }\end{array}$ \\
\hline Benim & 1 & Angola \\
\hline Botswana & 1 & Burundi \\
\hline Burkina Faso & 2 & Cape Verde \\
\hline Camarões & 2 & República Africana Central \\
\hline Djibouti & 1 & Chade \\
\hline Etiópia & 1 & Cômoros \\
\hline Gabão & 2 & $\begin{array}{c}\text { Côte d'Ivoire (Costa do } \\
\text { Marfim) }\end{array}$ \\
\hline Gambia & 2 & $\begin{array}{l}\text { República Democrática do } \\
\text { Congo }\end{array}$ \\
\hline
\end{tabular}

\footnotetext{
${ }^{29} \mathrm{O}$ "Ranking Web of World Research Centers" é uma iniciativa do Cybermetrics Lab, um grupo de pesquisa pertencente ao Consejo Superior de Investigaciones Científicas (CSIC), o maior organismo público de investigação em Espanha. CSIC está ligado ao Ministério da Educação e o seu principal objetivo é promover a pesquisa científica para melhorar o progresso do nível científico e tecnológico do país, o que contribuirá para aumentar o bem-estar dos cidadãos. A organização colabora com outras instituições do Sistema I\&D Espanhol e (universidades, regiões Autonomas, outros organismos de investigação públicos e privados) e com os agentes sociais, económicos, nacionais ou estrangeiras para o qual contribui com a sua capacidade de investigação e recursos humanos e materiais para o desenvolvimento de projectos de investigação ou sob a forma de consultoria e apoio científico e técnico. CSIC foi fundada em 1939 a partir de um corpo anterior, a Junta para la Ampliación de Estudios e Investigaciones Científicas criado em 1907 sob a liderança do Espanhol Prémio Nobel Prof. Ramón y Cajal. 30

Anexo 10 - Centros de Investigação na Africa Subsariana classificados no ranking mundial
} 


\begin{tabular}{ccc}
\hline Gana & 2 & Guiné Equatorial \\
\hline Quénia & 19 & Eritreia \\
Mali & 1 & Guiné \\
\hline Mauritânia & 1 & Guiné-Bissau \\
Maurícia & 1 & Lesotho \\
Namílbia & 3 & Libéria \\
\hline Níger & 1 & Madagáscar \\
\hline Nigéria & 4 & Malawi \\
\hline Ruanda & 1 & Moçambique \\
\hline Senegal & 5 & República do Congo \\
South África & 37 & São Tomé e Príncipe \\
\hline Tanzânia & 3 & Seychelles \\
\hline Uganda & 4 & Serra Leone \\
\hline Zâmbia & 2 & Somália \\
\hline Tonte: adaptado de http://research.webometrics.info/en/Ranking_africa/Sub_saharan_Africa &
\end{tabular}

O Ranking "Web of World Research Centers" adere formalmente e explicitamente aos Princípios de Berlim para as Instituições de Ensino Superior os quais têm como principal objetivo melhorar continuamente as metodologias de acordo com um conjunto de princípios de boas práticas mencionados previamente. ${ }^{31}$

Algumas organizações internacionais, tais como a UNESCO, a UNCTAD, a IRDC, a Swedish Agency for Research Cooperation with Developing Countries

\footnotetext{
${ }^{31}$ Metodologia utilizada para criar rankings. A unidade de análise é o domínio institucional, ou seja, apenas as universidades e centros de pesquisa com um domínio web independente são consideradas. Se uma instituição tiver mais de um domínio principal, duas ou mais entradas são usadas com os diferentes endereços. Cerca de 5-10\% das instituições não têm presença independente na web, a maioria delas localizadas em países em desenvolvimento. A melhor maneira de construir o ranking é a combinação de um conjunto de indicadores que medem diferentes aspetos. Almind \& Ingwersen propôs o primeiro indicador de Web - Fator de Impacto Web (WIF) -, com base na análise de ligação que combina o número de inlinks externos e o número de páginas do website, uma proporção de 1: 1 entre visibilidade e tamanho. Essa relação é utilizada para o ranking, mas a adição de dois novos indicadores para o componente tamanho: número de documentos, medidos a partir do número de arquivos num domínio web e número de publicações acedidas pelo banco de dados Google Scholar
} 
(SAREC) entre outras, desempenharam um papel significante no desenvolvimento de políticas nesta área, assim como contribuíram com o estabelecimento de redes de investigação multidisciplinares e estudos relacionados com a transferência de tecnologia. Em 2005 a Comissão da União Africana (AUC) e a Nova Parceria para o Desenvolvimento em África (NEPAD) adotaram o Plano de Ação Tecnológico (CPA, 2006 - 2010) e a consolidação da Ciência em África os quais pretendem criar um compromisso que permita o uso da ciência e da tecnologia no desenvolvimento socioeconómico dos países africanos e da sua integração na economia mundial. Este compromisso baseia-se em três pilares interrelacionados: capacidade de construção, produção do conhecimento e inovação tecnológica.

A Comissão Económica das Nações Unidas para África (UNECA) desenvolveu alguns programas no sentido de promover a utilização da ciência, da tecnologia e da inovação (STI) para atingir um desenvolvimento socioeconómico sustentável, através de estudos e de iniciativas que promovem o acesso à informação científica (para cientistas, estudantes, investigadores e para os que promovem a tomada de decisão), assim África, tais como: África Science Business Challenge (ASBC), cujo intuito passa por oferecer a oportunidade aos empreendedores Africanos de aprender como poderão transformar a sua ideia num negócio; African Science and Technology Endowment Fund (ASTIEF) - investe em resultados de I\&D com potencial comercial; e African Technology Development and Transfer Network apoia programas de formação e a partilha de experiências para novos inventores e para a formação de startups ${ }^{32}$ (UNECA/IST, 2010). Destas parcerias surge a criação do Observatório Africano de STI e a criação de parques de ciência em África.

Apesar de todos os esforços para o desenvolvimento da C\&T, os dados existentes continuam a demonstrar que África tem tido um fraco desempenho quando comparada com outras áreas do mundo, o que se deve, essencialmente, ao fato de

\footnotetext{
${ }^{32}$ Uma empresa startup é uma empresa, uma parceria ou organização temporária projetado para procurar um modelo de negócios repetível e escalável. Estas empresas, geralmente recém-criados, estão em fase de desenvolvimento e pesquisa para os mercados.
} 
que existe a necessidade de desenvolver os recursos humanos existentes para utilizar as tecnologias disponíveis (Bell e Cowie, 1999 e 2001). Daqui resulta um baixo desempenho ao nível de projetos tecnológicos e consequentes pedidos de patentes e de marcas concedidas (UNECA/IST, 2010). Alguns estudos demonstram que o número de publicações científicas em revistas técnicas é bastante baixo na maioria dos países africanos, com a exceção da África do Sul com um bom desempenho na publicação de artigos científicos.

\subsubsection{As políticas governamentais de apoio ao desenvolvimento tecnológico em África}

A análise da sociedade do conhecimento e o delineamento de planos estratégicos, nos países Africanos tem, inevitavelmente, que ter em consideração o significado de C\&T, no que concerne à educação e, naturalmente, no desenvolvimento de capacidades científicas e tecnológicas. É importante a capacidade de converter o investimento efetuado em Investigação e Desenvolvimento (I\&D) e o conhecimento tecnológico em produtos e serviços inovadores. Todavia, a esfera política não tem desenvolvido estratégias e politicas prioritárias que acompanhem esta tendência, muito embora se comece a reconhecer que a C\&T desempenha um importante papel no crescimento da economia e na redução da pobreza nos países em desenvolvimento. De acordo com o estudo efetuado pela GeSCI $^{33}$ são poucos os países que desenvolvem politicas que consideram a área de C\&T como prioritária, tal como a Zâmbia, Moçambique, a Tanzânia e a Uganda, embora cada um dos países tenha uma perspetiva diferente:

\footnotetext{
${ }^{33}$ Global e-Schools and Communities Initiative (GESCI) - é uma organização de assistência técnica internacional sem fins lucrativos com sede em Nairobi, no Quênia. GESCI foi fundada pelo grupo de trabalho das Nações Unidas no domínio das TIC em 2004, com um mandato para ajudar os governos no desenvolvimento socio-económico dos seus países através da integração generalizada da tecnologia para o desenvolvimento da sociedade do conhecimento.
} 
- Zâmbia - ciência, tecnologia, investigação e desenvolvimento para a expansão industrial adaptando as novas tecnologias à economia local;

- $\underline{\text { Uganda }}$ - desenvolve a sua investigação e tecnologias na área da agricultura no sentido de modernizar e melhorar a comercialização do sector;

- Malawi e Moçambique - consideram a C\&T como uma forma de diminuir a pobreza incluindo, por isso, nas suas políticas estratégicas de redução de pobreza (Poverty Reduction Strategy Papers);

- Tanzânia, Ruanda e Moçambique - estes são os países que focam explicitamente o desenvolvimento da ciência e da tecnologia, assim como, o conhecimento científico, nas suas prioridades politicas.

Como referido não existe uma verdadeira articulação entre as várias políticas sectoriais dos países e a implementação de planos estratégicos pelos governos nacionais, em especial no que respeita a políticas de C\&T (Hewitt e Gillson, 2003; Warren-Rodriguez, 2007), assim como uma previsão do seu real impacto no desenvolvimento da economia, apesar dos países Africanos se aperceberem que as iniciativas a este nível são necessárias e facilitadoras da sua integração numa economia mundial baseada no conhecimento. Ou seja, identificam a necessidade de desenvolver o capital humano e de transformar conhecimento e inovação em crescimento económico e desenvolvimento. Torna-se imprescindível considerar a educação como um elemento chave de uma economia orientada pela inovação e baseada no conhecimento afetando a procura e a oferta da inovação (Dahlman, 2007; UNECA, 2010). Neste sentido, o capital humano e a mão-de-obra qualificada complementam os avanços necessários a este nível. Porém, de acordo com dados do Banco Mundial (World Development Indicators, 2010), a África Subsariana tem baixas taxas de frequência do ensino superior quando comparada com outras regiões, tendo mesmo assim crescido 1.3 pontos percentuais entre 2000 
e 2008. Como consequência o número de investigadores em I\&D é baixo, colocando em causa a qualidade do ensino e a formação de capital humano qualificado o que, por sua vez, tem implicações diretas e indiretas na produção de novo conhecimento e nos resultados da C\&T, nomeadamente, na importação de bens, no licenciamento de tecnologias / produtos, na criação de novas empresas (Yusuf e Evenett, 2002), assim como no desenvolvimento de uma atitude mais empreendedora por parte deste capital humano qualificado, que constitui, em grande parte, a sociedade do conhecimento. Esta assunção é suportada por estatísticas que revelam que os países com maior frequência na educação terciária estão associados a níveis superiores de PIB per capita. Efectivamente, de acordo com as estatísticas do Banco Mundial, os países africanos parecem estar relativamente bem ao nível do ensino primário e secundário quando comparados com o ensino terciário, acrescido do fato de ter baixos resultados em termos tecnológicos e crescimento económico. Efetivamente, para que as economias africanas sejam competitivas na economia do conhecimento, o seu sistema de inovação deverá ter a capacidade de converter o seu investimento em I\&D e as suas capacidades educacionais em forças industriais e ter a capacidade de exportar para os grandes sectores tecnológicos (Dahlman, 2007). Os dados relativos à propriedade intelectual - número de patentes - e referentes aos artigos científicos publicados em revistas técnicas são significativamente baixos demonstrando as baixas taxas de produção científica e técnica quando comparado com outras regiões. Por outro lado, a integração na sociedade do conhecimento exige infraestruturas de informação modernas e adequadas as quais facilitam a comunicação, disseminação e processamento da informação e do conhecimento. Tal como já mencionado, as tecnologias de informação e comunicação desempenham um importante papel na medida em que permitem uma ligação direta com os mercados económicos, cria redes de conhecimento e permite explorar e partilhar o conhecimento produzido de forma a ganhar vantagem competitiva. 
O contributo da ciência e da tecnologia (C\&T) para o desenvolvimento da sociedade do conhecimento depende da proliferação de comunidades de conhecimento, as quais se caracterizam pela sua capacidade de produção de conhecimento, pela sua facilidade de apreender e trocar informação e conhecimento tecnológico, bem como o uso intensivo de tecnologia da informação (David e Foray, 2002). Neste sentido, o ensino superior e o desenvolvimento de competências, especialmente com a crescente consciência do papel da ciência, da tecnologia e da inovação no desenvolvimento econômico são considerados críticos (Juma, 2006). Neste contexto, e tendo em conta o declínio do sistema educacional em décadas anteriores, a maioria dos países Africanos tem tentado reestruturar a sua educação introduzindo uma política de ensino primário grátis o que implicou, em grande parte dos países, um aumento da frequência da escola neste nível exercendo uma pressão para a expansão do ensino secundário público e privado. Apesar dos progressos, a qualidade deste tipo de educação é pobre e as infraestruturas são fracas e mal equipadas, principalmente no que respeita a laboratórios e equipamento básico para o ensino das ciências. Por outo lado, o número de professores de ciências é baixo o que constitui um grande desafio para os objetivos em termos de políticas de C\&T para o país. Por sua vez, o aumento de matrículas no ensino primário e secundário pressiona o desenvolvimento do ensino terciário na medida em que as expectativas de acesso, destes estudantes, aumentam (Nampota et al., 2002).

As instituições de ensino superior e de investigação são consideradas como um recurso valioso para os negócios, para a indústria e para a sociedade. A maioria das universidades em África foram originalmente concebidas para apoiar a construção da nação, com ênfase nas humanidades. Os desafios de hoje passam por uma construção de uma comunidade que coloque especial ênfase na construção de competências empreendedoras, ou seja, estudantes que desenvolvam a capacidade de transformar ideias em propostas de negócios, bem como produtos e serviços existentes para os mercados locais e internacionais (Juma, 2006). Por outro lado, é importante mencionar que o ambiente sociocultural, por si só, tem 
impacto no desenvolvimento da ciência e tecnologia na medida em que envolve questões éticas como já mencionado. Algumas crenças poderão não sustentar a ideia de criação e aplicação das tecnologias emergentes. O sistema político dos países em desenvolvimento age em conformidade podendo criar barreiras à transferência do conhecimento tecnológico, através da não atribuição de fundos para a área de I\&D ou até criar taxas adicionais na transação de produtos tecnológicos o que aliado à instabilidade destes países e à dependência das exportações de matérias-primas e dos sectores primários tradicionais, como a agricultura, para o seu desenvolvimento económico, reflete a baixa produção de tecnologia de ponta nas economias africanas.

Os principais desafios destes países continuam virados para a resolução de problemas de saúde primários, bem como a luta para combater as fracas condições sanitárias e de habitação, não obstante o fato da população ser cada vez mais informada a qual procura novos desafios e oportunidades assim como contribui para o desenvolvimento de uma sociedade do conhecimento em constante mutação. Neste sentido as ações levadas a cabo pelos Atores Regionais, Nacionais ou Internacionais, constituem um importante marco no desenvolvimento destas sociedades. Estes últimos através da cooperação internacional têm um especial enfoque nesta ajuda e nas parcerias que se criam, utilizando diferentes ferramentas as quais apoiam o progresso dos países em desenvolvimento, em todas as suas vertentes como se poderá verificar de seguida. 
VNIVERSIDAD

DSALAMANCA 


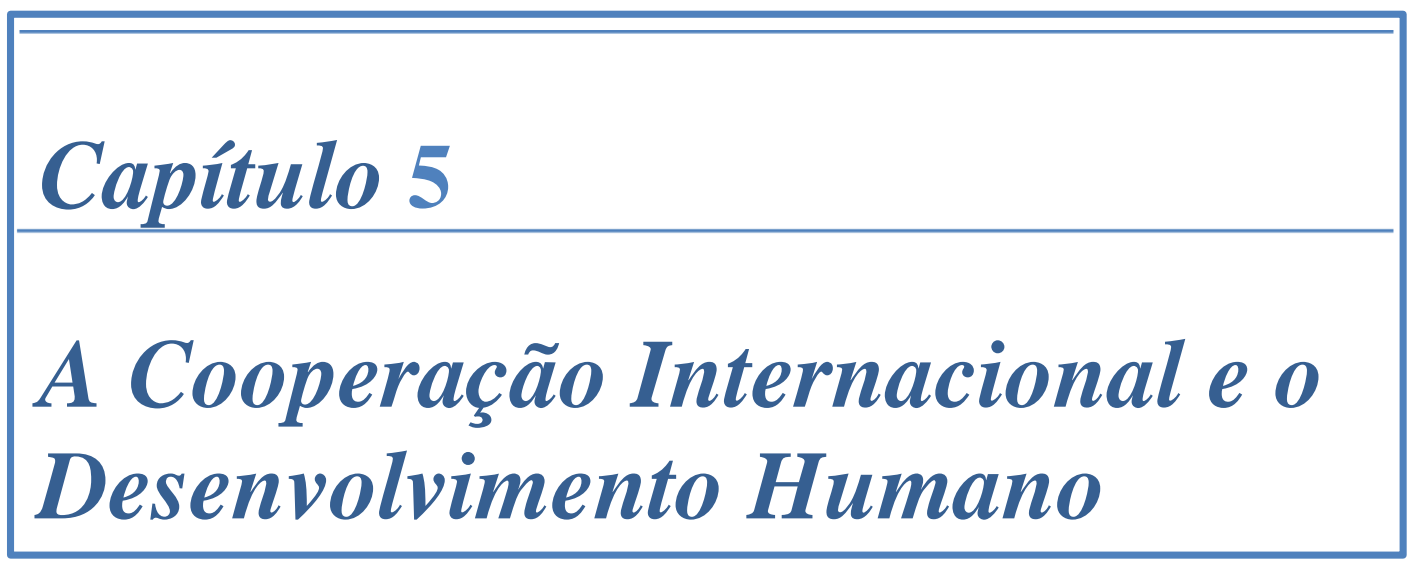

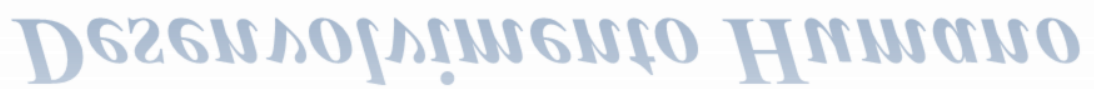


VNIVERSIDAD

DSALAMANCA 
Souviens-toi du futur! (...)

Se reppeler le futur, c'est ne pas oublier que nous sommes en chemin vers lui, en marche vers un avenir dont nous pensons qu'il sera meilleur.

Jean-Claude Guillebaud "Une autre vie est possible" 
VNIVERSIDAD

DSALAMANCA 


\subsection{A Cooperação Internacional para o Desenvolvimento}

A Cooperação para o Desenvolvimento na Europa e nos EUA despoletou-se no pós Segunda Guerra Mundial através do Plano Marshall ${ }^{34}$ (1947) com a finalidade de reconstruir os Estados soberanos, possibilitando a sua recuperação económica, nas décadas de 1950 e 1960, tendo como principais objetivos (René e Maurice, 1993): a) possibilitar a reconstrução material dos países capitalistas destruídos na Segunda Guerra Mundial; b) recuperar e reorganizar a economia dos países capitalistas, aumentando o vínculo deles com os Estados Unidos, principalmente através das relações comerciais; e c) fazer frente aos avanços do socialismo, no leste europeu liderado pela extinta União Soviética. No seguimento destas preocupações surge, na década de sessenta, o Paradigma dos Projetos Setoriais no âmbito da Cooperação para o Desenvolvimento. Este tem como principal objetivo o desenvolvimento dos diferentes setores de forma equilibrada, assim como controlar o endividamento dos países em desenvolvimento (Sangreman, 2009c). Os países doadores da Ajuda orientam o seu apoio para setores específicos dos países beneficiários (Ridell, 2007 in Faria, 2014). Estes consideram que o crescimento económico e as mudanças estruturais e institucionais não são fatores, por si só, suficientes para a erradicação da pobreza sendo necessário ajudar as populações mais desfavorecidas dos países em desenvolvimento. Este Paradigma considerava que o Estado deveria intervir criando as condições necessárias para a produção do capital necessário ao seu progresso, uma vez que o mesmo correspondeu a "teorias, politicas e modelos (...) da economia e do desenvolvimento articulado com a convicção de que o Estado era a única entidade interveniente dominante no campo da Cooperação" (Sangreman, 2009c). Para que tal progresso fosse possível era, igualmente, necessário a responsabilização por

\footnotetext{
${ }^{34}$ Com o final da Segunda Guerra Mundial, muitos países ficaram destruídos. Era necessário muito investimento financeiro para a reconstrução destes países. Neste contexto, foi criado nos Estados Unidos, pelo então secretário de Estado George Marshall, um plano econômico cujo principal objetivo era possibilitar a reconstrução dos países capitalistas. A ajuda foi feita, principalmente, através de empréstimos financeiros. O Plano Marshall deve ser entendido dentro do contexto histórico da Guerra Fria, pois foi uma forma de fortalecer o capitalismo e a hegemonia dos Estados Unidos. O Plano foi colocado em operação em 1947. «Le Plan Marshall et le Relèvement économique de l'Europe », Colloque tenu à Bercy les 21, 22, 23, mars 1991, Comité pour l'histoire économique et financière de la France, 1993.
} 
parte dos beneficiários da ajuda na medida em que os Estados deveriam ter "capital humano suficiente para tornar eficaz a planificação nacional e regional, dar prioridade à modernização das estruturas físicas, da agricultura e da indústria, da educação e da saúde" (Sangreman, 2009c). Contudo, no seguimento da crise económica e, consequente, crise da divida promovida pelo choque petrolífero, pela diminuição do preço das matérias-primas e pelo aumento das taxas de juro o que resultou na incapacidade de alguns países para pagar os empréstimos concedidos (Faria, 2014). Estas dificuldades levam a comunidade internacional a questionar o sistema económico instituído e a definir como prioridade a promoção da estabilidade macroeconómica e financeira. Para tal, fomentaram medidas de estabilização através de um conjunto de políticas que visa o ajustamento estrutural (na década de oitenta) assim como por um plano de boa governação (década de noventa). De facto, os elevados défices públicos e de inflação e a sobrevalorização da moeda levaram o FMI a recomendar "o fim do controle de preços e medidas de restrição de procura, através da redução das despesas públicas, da subida das taxas de juro e da abolição dos subsídios" (Alves, 2002:18 in Faria, 2014). Neste sentido, durante a década de oitenta, assiste-se a uma mudança de paradigmas levando ao aparecimento do Consenso de Washington. Contudo, este não correspondeu às expectativas pelo que surgiram, posteriormente, no século XXI, o Paradigma dos ODM, o Consenso de Monterrey e o Consenso Europeu. Este último Consenso teve como objetivo a análise das reformas económicas implementadas caraterizando-se, segundo Marangos (2009:197 in Faria, 2014) por um conjunto de políticas económicas para promover o desenvolvimento, incluindo os países fragilizados (principalmente a América Latina). O mesmo autor indica que os princípios orientadores destas reformas passavam por:

1. A estabilização macroeconómica através do controlo da inflação e da redução dos défices fiscais existentes;

2. Abertura das economias à globalização através da liberalização dos mercados e dos capitais; e 
3. Implementar políticas de liberalização através da privatização e da desregulamentação.

Estas reformas tiveram impacto direto na disciplina fiscal, na despesa nacional, na tributação, na liberalização do mercado financeiro, no câmbio, no Investimento direto Estrangeiro, na privatização, na desregulamentação e nos Direitos de propriedade. No entanto, a simplicidades destas medidas colocou em causa a sua eficácia sendo, por isso, alvo de críticas. De acordo com o vice-presidente e economista do BM existe uma preocupação com o desenvolvimento descurando-se o desenvolvimento social (Stiglitz, 1998:6-7 in Faria, 2014). Este cariz social está relacionados com os aspetos da empregabilidade, da saúde, da alimentação, do sistema de ensino das condições de vida e do desenvolvimento sustentável. Desta forma, verifica-se que os benefícios do livre comércio e da privatização não vão ao encontro das necessidades de investimento em capital humano. $\mathrm{O}$ reconhecimento destas falhas leva ao surgimento do Pós-Consenso de Washington, com o intuito de se criarem ferramentas que visam o crescimento económico e onde o papel do Estado surge como um complemento do setor privado. Os princípios orientadores foram identificados como (Stiglitz, 1998:6-7 in Faria, 2014):

1. Aumentar a qualidade de vida, incluindo a saúde e a educação;

2. O desenvolvimento sustentável através da utilização eficaz dos recursos naturais;

3. O progresso equitativo, onde existisse um benefício igual para todos resultante do crescimento económico; e

4. A promoção de uma sociedade mais democrática, com participação ativa de todos os cidadãos ao nível da tomada de decisão.

Apesar da revisão do pensamento relacionado com este Consenso, as críticas continuam visto que os níveis de pobreza e de segurança permanecem altos. Considera-se que o crescimento económico deve estar associado a melhores práticas institucionais e à abertura do comércio e dos fluxos de capitais (Marangos, 
2009:205 in Faria, 2014). Neste sentido surge uma segunda geração de reformas, denominadas como o Consenso de Washington Alargado, as quais focam os seguintes objetivos (Rodrik, 2003 in Faria, 2014):

- A cooperação governativa;

- A dminuição da corrupção;

- A criação de mercados de trabalho flexíveis;

- O desenvolvimento de acordos com a Organização Mundial do Comércio (OMC);

- Regras financeiras;

- Prudência na abertura de contas de capital;

- Regimes cambiais não intermediários;

- Bancos centrais independentes;

- Metas para a inflação;

- A criação de redes de segurança social e redução dos níveis de pobreza.

A preocupação com a redução da pobreza extrema reuniu, no início do século XXI, os Chefes dos Estados Membros da Assembleia Geral das Nações, os quais assinaram a Declaração do Milénio (Setembro de 2000) comprometendo-se a alcançar os Objetivos do Desenvolvimento Internacional até 2015 (ODM).. Esta declaração teve como principal meta a redução da pobreza e a melhoria das condições de vida das populações dos países em desenvolvimento assegurando o acesso a todos aos bens essenciais, à água potável, à saúde e ao ensino. Este novo Paradigma da Cooperação substitui o anterior Paradigma do Ajustamento Estrutural, focando-se em oito objetivos (United Nations, 2008):

1. Erradicar a pobreza extrema e a fome;

2. Alcançar o ensino primário universal;

3. Promover a igualdade de género;

4. Reduzir a mortalidade infantil;

5. Melhorar a saúde materna; 
6. Combater o VIH/SIDA, a malária e outras doenças mortíferas;

7. Assegurar a gestão ambiental sustentável;

8. Promover uma parceria global para o desenvolvimento.

Dentro de cada um dos objetivos foram, ainda, identificados diferentes indicadores de forma a avaliar a execução dos mesmos, assim como medir os seus efeitos nos diferentes países. No que respeita à educação apenas o Objetivo 2 visa metas específicas. No entanto, só o ensino primário figura como essencial, ou seja, visa assegurar que até 2015 todas as crianças podessem concluir o ensino primário completo.

Existe uma correspondência de todos os objetivos com os princípios da Declaração dos Direitos do Homem, uma vez que ambos têm como prioridade "preservar e proteger a dignidade humana através da realização de um vasto leque de direitos civis, culturais, económicos, políticos e sociais". De fato, a cada Objetivo correspondem obrigações, critérios ou normas de Direitos Humanos" (Objetivo 2015:6-11 - Tabela 7). Verifica-se uma relação de complementaridade mas também de sustentabilidade visto que o desenvolvimento é um direito de todos, na medida em que favorece toda a população sendo por isso que as metas dos ODM deveriam ser cumpridas e respeitadas.

\section{Tabela 7 - ODM Vs Direitos Humanos}

\begin{tabular}{|ccc|}
\hline ODM & Direito a... & Convenções \\
\hline $\begin{array}{c}\text { Erradicar a pobreza } \\
\text { extrema e a fome }\end{array}$ & $\begin{array}{c}\text { Melhores condições de vida }- \\
\text { alimentação; saúde; serviços } \\
\text { sociais; habitação }\end{array}$ & $\begin{array}{c}\text { DUDH - Art. 25 (1) } \\
\text { ICESCR - Art. 1 }\end{array}$ \\
& $\begin{array}{c}\text { Segurança social - desemprego; } \\
\text { velhice; viuvez; etc. }\end{array}$ & DM - Art. 11 e 19 \\
\hline & & DUDH - Art. 25 (1) \\
Alcançar o ensino & & ICESCR - Art. 13 e 14 \\
primário universal & Educação & CEDAW - Art. 28 (1.a) \\
& & CERD - Art. 5 (e; v) \\
\hline $\begin{array}{l}\text { Promover a igualdade } \\
\text { de género e dar poder }\end{array}$ & Não descriminação em função do & DM - Art. 19 \\
\hline
\end{tabular}




\begin{tabular}{|c|c|c|}
\hline às mulheres & & $\begin{array}{l}\text { CRC - Art. } 2 \\
\text { DM - Art. } 20\end{array}$ \\
\hline $\begin{array}{c}\text { Reduzir a mortalidade } \\
\text { infantil }\end{array}$ & $\begin{array}{l}\text { Vida e a condições de saúde } \\
\text { básicas de sobrevivências }\end{array}$ & $\begin{array}{c}\text { DUDH - Art. } 25 \\
\text { CRC - Art. 6, 24, 2.a } \\
\text { ICESCR - Art. 12 (2.a) } \\
\text { DM - Art. } 19\end{array}$ \\
\hline $\begin{array}{l}\text { Melhorar a saúde } \\
\text { materna }\end{array}$ & Saúde física e mental & $\begin{array}{c}\text { DUDH - Art. } 25 \\
\text { CEDAW - Art. 10.b; } 11 . f ; 12 ; 14 . b \\
\text { ICESCR - Art. } 12 \\
\text { CRS - Art. 24, 2.d } \\
\text { CERD - Art. 5.e (IV) } \\
\text { DM - Art. } 19\end{array}$ \\
\hline $\begin{array}{c}\text { Combater o VIH/SIDA } \\
\text { a malária e outras } \\
\text { doenças graves }\end{array}$ & $\begin{array}{c}\text { Não descriminação e condições } \\
\text { de saúde básicas }\end{array}$ & $\begin{array}{l}\text { DUDH - Art. } 25 \\
\text { ICESCR - Art. } 12 \\
\text { CRC - Art. } 24 \\
\text { CEDAW - Art. } 12 \\
\text { CERD - Art. } 5 \text { (e; IV) } \\
\text { DM - Art. } 19\end{array}$ \\
\hline $\begin{array}{c}\text { Garantir a } \\
\text { sustentabilidade } \\
\text { ambiental }\end{array}$ & $\begin{array}{l}\text { Melhores condições de vida de } \\
\text { acordo com uma melhor } \\
\text { utilização dos recursos naturais } \\
\text { existentes e respeito pelos } \\
\text { mesmos }\end{array}$ & $\begin{array}{c}\text { DUDH - Art. 25.1 } \\
\text { ICESCR - Art. 11.1; } 12 \\
\text { CEDAW - Art. 14.2.b } \\
\text { CRC - Art. } 24 \\
\text { DM - Secção IV }\end{array}$ \\
\hline $\begin{array}{c}\text { Fortalecer uma } \\
\text { parceria global para o } \\
\text { desenvolvimento }\end{array}$ & $\begin{array}{l}\text { Reforço regional, nacional e } \\
\text { internacional para a } \\
\text { concretização dos Direitos } \\
\text { Humanos ao nível social, } \\
\text { económico e cultural }\end{array}$ & $\begin{array}{c}\text { CNU - Art. 1(3); } 55 \text { e } 56 \\
\text { DUDH - Art. 22; } 28 \\
\text { ICESCR - Art. 2(1); } 11(1) ; 15(4) ; \\
22 ; 23 \\
\text { CRC - Art. 4; } 24(4) ; 28(3) \\
\text { DM - Art. 12; 15; Seção V }\end{array}$ \\
\hline
\end{tabular}

\begin{tabular}{c|l}
\hline DUDH & Declaração Universal dos Direitos Humanos \\
\hline ICESCR & $\begin{array}{l}\text { Pacto Internacional de Direitos Económicos, sociais e Culturais } \\
\text { Convenção sobre os direitos das crianças } \\
\text { Concenção internacional para a eliminação de todas as formas de discriminação } \\
\text { CEDA W } \\
\text { contra a mulher }\end{array}$ \\
Cenvenção internacional para a eliminação de todas as formas de discriminação \\
racial \\
Declaração do Milénio \\
CNU & Carta das nações Unidas \\
\hline
\end{tabular}

Os esforços Internacionais para o desenvolvimento são reforçados em 2002, através do Consenso de Monterrey ${ }^{35}$, em que todos os países participantes assumiram o compromisso de promover ações específicas no sentido de ajudar os

\footnotetext{
${ }^{35}$ Conferencia Internacional sobre o Financiamento do Desenvolvimento, em Monterrey, Assembleia Geral das Nações Unidas (UN) - texto integral disponível em http://www.un.org/esa/ffd/monterrey/MonterreyConsensus.pdf
} 
países menos avançados a alcançar os Objetivos do Milénio. Esta cooperação internacional incide em seis áreas consideradas primordiais para o desenvolvimento destas economias (Afonso e Fernandes, 2005:10), nomeadamente:

1. Amplificar a mobilização dos recursos financeiros no interior dos países;

2. Aumentar os fluxos de investimento privado ao nível internacional e ampliar a sua distribuição geográfica;

3. Alargar o acesso aos mercados e assegurar regimes comerciais justos e equitativos;

4. Reforçar a ajuda pública ao desenvolvimento (APD);

5. Contribuir para a resolução do problema da divida dos países em desenvolvimento;

6. Promover a coerência das estruturas financeiras mundiais e regionais, assim como a justa representação dos países em desenvolvimento no processo de tomada de decisão ao nível internacional.

Para que estas ações sejam bem-sucedidas é necessário que o governo de cada um dos países, destinatários da ajuda, seja responsável pela aplicação de políticas adequadas nas áreas mencionadas. No sentido de harmonizar a gestão da Ajuda surge, em 2003, a Declaração de Roma ${ }^{36}$ sobre Harmonização. O seu principal objetivo passa pela adoção de sistemas e procedimentos comuns, planos de trabalho conjuntos, promover a tomada de decisão partilhada e a troca de informação para tornar a ajuda mais eficaz:

(...) reaffirm our commitment to eradicating poverty, achieving sustained economic growth, and promoting sustainable

\footnotetext{
${ }^{36}$ A declaração pode ser consultada em: http://d3f5055r2rwsy1.cloudfront.net/images/cooperacao/declaracao_roma.pdf
} 
development as we advance to an inclusive and equitable global economic system. Our deliberations are an important international effort to harmonize the operational policies, procedures, and practices of our institutions with those of partner country systems to improve the effectiveness of development assistance, and thereby contribute to meeting the Millennium Development Goals (MDGs). (Rome Declaration on Harmonization, 2003:1)

Pretende-se promover uma governação mais corporativa, parcerias públicoprivadas, acordos de investimento, assistência técnica e programas de capacitação que visem uma maior produtividade e competitividade. Torna-se necessário que as instituições internacionais e regionais trabalhem em conjunto de forma a serem mais competentes, assim como devem aumentar os seus apoios ao investimento para o desenvolvimento de infraestruturas e de tecnologias de forma a vitalizar as redes de comércio. Com efeito, a ajuda financeira para o desenvolvimento, por parte dos atores internacionais, constitui um importante fator para que os países menos desenvolvidos consigam atingir os objetivos do milénio. Estes fluxos monetários subdividem-se em três grupos (Afonso e Fernandes, 2005:10): i) Fluxos Públicos; ii) Donativos das Organizações Não Governamentais (ONG); e iii) Fluxos Privados.

O financiamento público inclui:

- A Ajuda Pública ao Desenvolvimento (APD) - a qual pode ser bilateral ou multilateral (ex.: cooperação técnica, ajuda alimentar, alivio da divida, apoio ao orçamento, etc.); e

- Outros Fluxos Oficiais - transações oficiais cujo objetivo não está diretamente correlacionado com o desenvolvimento tendo em consideração que os fluxos não são significativos (ex.: empréstimos, créditos para a exportação, participações, investimento em carteira, reescalonamento da divida, etc.). Trata-se de uma importante fonte de financiamento para o 
desenvolvimento, tendo sido definida nos anos setenta, no quadro do Comité de Ajuda ao Desenvolvimento (CAD) da Organização de Cooperação e Desenvolvimento Económico (OCDE) como fundos que devem:

- Ser canalisados pelo sector público;

- Contribuir para promover o desenvolvimento económico e melhorar a qualidade de vida da população dos países recetores;

- Constituir uma transferência de recursos na forma de donativo ou empréstimo com condições mais favoráveis do que as do mercado;

- O país recetor da ajuda deverá constar da lista de países em desenvolvimento do Comité de Ajuda ao Desenvolvimento.

Este tipo de ajuda destina-se a dois blocos de países devidamente listados e classificados pelo Comité de Ajuda ao Desenvolvimento (CAD) ${ }^{37}$, sendo que um se destina aos países mais subdesenvolvidos e o outro bloco aos países em transição (Europa Central e Oriental, Novos Estados Independentes da ex-URSS e países em desenvolvimento mais avançado ${ }^{38}$ ). Os donativos das Organizações Não Governamentais (ONG) são efetuados na forma de donativos privados, sem fins lucrativos e visam a promoção do desenvolvimento. Incluem contribuições em géneros para organizações multilaterais ou ONGD internacionais.

Os fluxos privados (FP) estão relacionados com as transações, de longo prazo, com empresas e indivíduos do país doador. Estes fundos, apesar da sua importância crescente, concentram-se num reduzido número de países. A cooperação para o desenvolvimento pode ainda ser categorizada de três formas:

\footnotetext{
${ }^{37}$ Consultar anexo 14 para ver lista completa dos países

${ }^{38} \mathrm{O}$ relatório completo dos países recetores da ajuda pode ser consultado em: http://www.oecdilibrary.org/docserver/download/4305012ec003.pdf?expires=1412694344\&id=id\&accname=guest\&checksum =0374505DFE6B5A2801EB1EF75B44ED92
} 
1. De acordo com a origem:

a. Pública - administração central, regiões, etc.;

b. Privada - Organizações Não Governamentais, empresas, associações;

2. De acordo com os canais de execução:

a. Bilaterais - os doadores canalizam os fluxos da ajuda diretamente para os recetores;

b. Multilaterais - os fundos são transferidos para organizações multilaterais no sentido de financiar as suas atividades de promoção do desenvolvimento. Este tipo de cooperação tende a ser mais eficaz no que concerne à resolução dos problemas locais dos países recetores da ajuda;

c. Descentralizada - constitui uma nova abordagem da cooperação realizada por entidades sub-estatais, que não fazem parte da administração central do Estado (municípios, regiões, instituições de ensino superior, etc.). Implica a inclusão de um grande número de atores da sociedade civil e da sua real e participação na promoção do desenvolvimento do seu país. Este tipo de cooperação tende a ter, cada vez mais, maior significância devido ao seu carácter de proximidade. 
3. De acordo com os instrumentos:

a. Este tipo de ajuda corresponde aos instrumentos e ferramentas utilizados para atingir os fins do desenvolvimento. Destacam-se as seguintes modalidades:

- Cooperação Técnica - destina-se ao desenvolvimento institucional através da capacitação humana contribuindo para a geração de know-how técnico e aptidões produtivas de um país em vias de desenvolvimento. Recursos humanos mais qualificados "são indispensáveis ao desenvolvimento sustentável através da gestão e funcionamento eficazes de uma economia e da sociedade em geral" (OCDE, 1992:61). Este tipo de ajuda efetiva-se de acordo com diferentes processos: donativos aos nativos dos países recetores no âmbito da formação, nacional ou internacional; e pagamento a consultores, professores e administradores.

- Cooperação Financeira - este tipo de ajuda destina-se ao desenvolvimento económico através de instrumentos financeiros tais como: subvenções e créditos (projetos e programas); financiamento de bens necessários ao desenvolvimento do país recetor o qual não tem capacidade para os importar; e financiamento de reformas estruturais como os apoios ao ajustamento e à anulação e/ou reescalonamento da divida.

- A Ajuda Projeto - este instrumento pressupõe uma intervenção precisa e finita no país beneficiário, assim como a definição dos objetivos, das atividades e das despesas a serem financiados de acordo com um sistema de gestão específico. Estes projetos destinavam-se ao desenvolvimento de infraestruturas (estradas, saneamento, autoestradas, telecomunicações, etc.) para a posteriori 
abrangerem mais áreas, o que levou à sua insustentabilidade (com a crise petrolífera nos anos oitenta). Em consequência este tipo de ajuda dá lugar a outros tipos de apoios: ajuda programa financeiro; operações de assistência técnica de criação reforço de capacidades; e projetos executados pelo sector privado ou pelas Organizações Não-governamentais. A gestão dos projetos pode ser efetuada a diferentes níveis: a) projeto gerido pelo Governo recetor controlam a gestão dos fundos do doador de acordo com determinados preceitos contabilísticos e regras de utilização utilizado pelos doadores multilaterais; b) projeto gerido pelos doadores $-\mathrm{o}$ doador tem o controlo de todas as atividades e da gestão dos recursos - utilizado pelos doadores bilaterais e pela Comissão Europeia; projetos geridos através de ONGD e entidades privadas - o doador concede uma subvenção ou contrato a uma ONG tendo por base uma proposta de um projeto específico com regras de execução financeira.

- A Ajuda Programa - engloba todas as contribuições efetuadas ao país beneficiário com o objetivo de desenvolvimento generalizado (balança de pagamentos, apoio ao Orçamento e apoio ao nível de produtos de base. (OECD, 1992:81). Distinguem-se quatro categorias: ajuda geral a programas de ajustamento estrutural (PAE) definidos pelo Banco Mundial e Fundo Monetário Internacional); ajuda sectorial a programas (transferência para um sector económico ou social especifico - agricultura, educação, transportes, etc.) estando associados a programas sectoriais definidos pelo PAE e BM; ajuda alimentar programa - promove a segurança alimentar através da transferência de alimentos ou recursos para a sua aquisição; alivio da divida - pode ser de carácter bilateral ou multilateral (OCDE, 1992:103) destinando-se 
ao apoio direto ao Orçamento de forma a atingir os compromissos assumidos pelo Governo recetor.

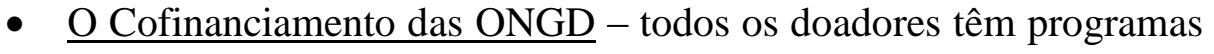
de cofinanciamento das ONGD (Afonso e Fernandes, 2005:86). Consiste no apoio, através de fundos públicos, à capacidade operativa destas organizações da sociedade civil mediante a apresentação e avaliação de projetos específicos.

- A Ajuda Humanitária - este tipo de ajuda visa dar resposta a situações de emergência, no sentido de salvar vidas através da distribuição de bens de primeira necessidade e promover os Direitos Humanos. Aqui, a ajuda humanitária integra diferentes tipos de ação: a ajuda de emergência; a ajuda a refugiados, repatriados e deslocados; e a ajuda a reabilitação e reconstrução; a prevenção de conflitos e de desastres naturais.

- $\quad$ A Ajuda Alimentar - a sua finalidade passa por reduzir a diferença entre a procura interna e a oferta de alimentos produzidos internamente e as importações comerciais (OCDE, 1992:95). Implica a transferência de recursos (alimentos, donativos monetários, bens doados ou vendidos com pelo menos $25 \%$ de concessionalidade) para um país ou região com graves problemas de fome como resultado de constrangimentos estruturais. Este tipo de ajuda é fornecido através de organizações internacionais, em particular através do Programa Alimentar Mundial (PAM) e ONGD. 
As entidades europeias reforçam a sua posição quanto ao apoio ao desenvolvimento através do Consenso Europeu ${ }^{39}$ em 2005, na forma de uma "declaração conjunta do conselho e dos representantes do Governo dos Estados Membros reunidos no Conselho do Parlamento Europeu e da Comissão sobre a política de desenvolvimento da \{EU\}" (Conselho da União Europeia, 2005:1). Os princípios orientadores desta declaração passam pela criação de políticas de desenvolvimento no âmbito da apropriação, das parcerias, do aprofundamento do diálogo politico, na participação da sociedade civil, na igualdade de género e da fragilidade dos Estados. Verifica-se, uma vez mais, a preocupação politicas alinhadas com os Direitos Humanos, com a promoção de sociedades mais democráticas, a boa governação e a erradicação da pobreza. Para que estes objetivos sejam atingidos, o Conselho Europeu menciona que é necessário investir em capital humano, assim como promover uma maior preocupação com os recursos naturais criando-se, desta forma, maior riqueza.

A Ajuda Financeira da Comunidade Internacional para o desenvolvimento continuam a ser um apoio relevante na prossecução destas metas pelo que a sua eficácia e coordenação deve ser reforçada. Neste sentido criou-se uma programação anual conjunta com base nas estratégias de redução da pobreza dos países parceiros e nos respetivos processos orçamentais, em mecanismos comuns de execução como a análise e as missões conjuntas ao nível dos doadores e o recurso a regimes de cofinanciamento (Conselho da União Europeia, 2005:11). A declaração conjunta do Conselho Europeu constitui um marco importante na história da Cooperação para o Desenvolvimento através das políticas e estratégias de apoio que se baseiam nos ODM. Considerando os preceitos anteriormente descritos apresentamos um quadro síntese da evolução histórica da Ajuda ao Desenvolvimento, até ao início do século XXI, nas suas diferentes vertentes (Tabela 8).

\footnotetext{
${ }^{39}$ Declaração conjunta do Conselho e dos Representantes dos Governos dos Estados-Membros reunidos no Conselho, do Parlamento Europeu e da Comissão sobre a política de desenvolvimento da União Europeia: "O Consenso Europeu" [Jornal Oficial C 46 de 24.2.2006].
} 
Tabela 8 - Príncipais desenvolvimentos na história da Ajuda no período pósguerra

\begin{tabular}{|c|c|c|c|c|}
\hline & $\begin{array}{c}\text { Instituições } \\
\text { dominantes ou em } \\
\text { Ascensão }\end{array}$ & $\begin{array}{l}\text { Ideologia dos } \\
\text { doadores }\end{array}$ & $\begin{array}{l}\text { Aspetos centrais } \\
\text { para os doadores }\end{array}$ & Tipo de Ajuda \\
\hline Década de 40 & $\begin{array}{c}\text { Plano Marshall }{ }^{40} \\
\text { Sistema das Nações } \\
\text { Unidas e do Banco } \\
\text { Mundial }\end{array}$ & Planeamento & Reconstrução & Ajuda Programa \\
\hline Década de 50 & $\begin{array}{l}\text { EUA e URSS } \\
(>1956)\end{array}$ & $\begin{array}{l}\text { Anticomunismo } \\
\text { Forte papel do Estado }\end{array}$ & $\begin{array}{c}\text { Movimento de } \\
\text { desenvolvimento da } \\
\text { comunidade }\end{array}$ & $\begin{array}{c}\text { Ajuda Projeto } \\
\text { Ajuda Alimentar }\end{array}$ \\
\hline Década de 60 & $\begin{array}{l}\text { Estabelecimento dos } \\
\text { programas bilaterais }\end{array}$ & $\begin{array}{l}\text { Apoio do Estado nos } \\
\text { sectores produtivos }\end{array}$ & $\begin{array}{l}\text { Sectores produtivos e } \\
\text { infraestruturas }\end{array}$ & $\begin{array}{c}\text { Doadores bilaterais: } \\
\text { assistência técnica e } \\
\text { apoio ao orçamento } \\
\text { Doadores } \\
\text { multilaterais: apoio a } \\
\text { projetos }\end{array}$ \\
\hline Década de 70 & $\begin{array}{l}\text { Expansão das } \\
\text { agências } \\
\text { multilaterais: BM, } \\
\text { FMI e agências } \\
\text { árabes }\end{array}$ & $\begin{array}{l}\text { Apoio às atividades } \\
\text { do Estado nos } \\
\text { sectores produtivos e } \\
\text { á satisfação das } \\
\text { necessidades básicas }\end{array}$ & $\begin{array}{c}\text { Pobreza } \\
\text { Agricultura } \\
\text { Necessidades básicas } \\
\text { / sociais }\end{array}$ & $\begin{array}{l}\text { Diminuição da ajuda } \\
\text { alimentar } \\
\text { Apoio às importações }\end{array}$ \\
\hline Década de 80 & $\begin{array}{l}\text { Crescimento das } \\
\text { ONG's }\end{array}$ & $\begin{array}{c}\text { Ajustamento } \\
\text { estrutural } \\
\text { Confiança no } \\
\text { mercado } \\
\text { Diminuição do papel } \\
\text { do Estado }\end{array}$ & $\begin{array}{c}\text { Reforma } \\
\text { macroeconómicas }\end{array}$ & $\begin{array}{c}\text { Programas de Ajuda } \\
\text { financeira } \\
\text { Alivio da divida }\end{array}$ \\
\hline Década de 90 & $\begin{array}{l}\text { Ex-URSS e países da } \\
\text { Europa Oriental } \\
\text { tornam-se recetores }\end{array}$ & $\begin{array}{l}\text { Regresso ao forte } \\
\text { papel do Estado }\end{array}$ & $\begin{array}{l}\text { Pobreza } \\
\text { Governação }\end{array}$ & Apoio Setorial \\
\hline $\begin{array}{l}\text { Década de } 2000 \text { - } \\
2010\end{array}$ & Londres e Madrid & $\begin{array}{l}\text { Segurança como um } \\
\text { aspeto primordial da } \\
\text { Agenda (depois de } 11 \\
\text { Setembro) }\end{array}$ & $\begin{array}{c}\text { ODM tornam-se no } \\
\text { centro dos interesses } \\
\text { dos doadores na área } \\
\text { social }\end{array}$ & $\begin{array}{l}\text { Ajuda Programa e } \\
\text { Apoio Setorial }\end{array}$ \\
\hline
\end{tabular}

Presentemente, o discurso da ajuda continua a refletir a evolução mencionada. O papel dos governos é preponderante e, cada vez mais, a sua participação deve ser ativa e transparente para ir ao encontro do desenvolvimento sustentável dos países recetores da ajuda. Quanto às preocupações a evidência empírica e as resoluções

\footnotetext{
${ }^{40}$ O Plano Marshall pode ser considerado como o primeiro projecto específico de cooperação entre um Estado Soberano e independente e um conjunto de Estados soberanos e independentes.
} 
políticas têm demonstrado que as questões do género e os aspetos ambientais são realçados para além da pobreza extrema. Os Bens Públicos Globais passam a constar na Agenda da Cooperação Internacional para o Desenvolvimento existindo uma real preocupação em desenvolver ferramentas que permitam que o acesso aos mesmos seja facilitado, de forma global e equitativa, na medida em que os mesmos podem permitir melhorar as condições de vida da população (como o caso da saúde e da educação) através de políticas globais, as quais promovem a estabilidade financeira, e que dependem dos esforços conjuntos de todos os países (IPAD 2003, in Afonso e Fernandes, 2005) e dos diferentes tipos de Atores da Cooperação para o Desenvolvimento. Estes são "entidades que se dedicam à promoção do desenvolvimento, ou seja, podem influenciar, financiar e implementar as políticas de cooperação que tenham por objetivo o desenvolvimento socioeconómico dos países, regiões e comunidades mais vulneráveis" (Afonso e Fernandes, 2005:43). Embora com objetivos semelhantes estes atores subdividem-se em entidades de natureza, orientação e funções distintas, utilizando instrumentos e ferramentas diferentes para promover o desenvolvimento como se demonstrará de seguida.

\section{Os Estados Doadores - Cooperação Bilateral e Multilateral}

São os principais doadores da Ajuda Pública ao Desenvolvimento através da cooperação bilateral (a ajuda é fornecida diretamente ao pais beneficiário) ou da cooperação multilateral (a ajuda é fornecida através de organizações multilaterais que consagram parte ou toda a sua atividade ao desenvolvimento dos países beneficiários). As principais responsabilidades dos Estados passam por criar reais oportunidades de acesso ao mercado internacional para os produtos dos países em desenvolvimento, através da Organização Mundial do Comércio (OMC), de forma a diminuir a dependência da Ajuda. Para tal contribuem para o desenvolvimento de políticas coerentes, ao nível do comércio, mas também no âmbito dos Direitos Humanos e da prevenção de conflitos. 
2. Os Municípios e as Regiões - Cooperação Descentralizada

Este tipo de cooperação é promovido por várias instituições internacionais (agências dos Estados, Autarquias dos países do Norte) de forma a contribuir para o reforço da sociedade civil, enquanto atores não estatais para o desenvolvimento (poderes locais e regionais dos países em desenvolvimento), os quais assumem uma maior responsabilidade na cooperação para o desenvolvimento. Caracteriza-se pela descentralização das iniciativas do poder central para as administrações locais no sentido promoverem o seu próprio desenvolvimento. A cooperação descentralizada pode ser efetuada entre municípios - intermunicipal - através de parcerias que podem tomar a forma de protocolos (projetos e assessorias), geminações (troca de conhecimentos) ou redes (promove a troca de experiências).

\section{O Governo dos Países em Desenvolvimento}

O progresso dos países em desenvolvimento depende do seu empenho e envolvimento de forma responsável no sentido de tornar as parcerias de cooperação eficientes e eficazes. Os governos destes países devem comprometer-se com a aplicação das normas e das medidas promovidas pela cooperação internacional na prossecução dos objetivos do milénio, nomeadamente: aplicar as medidas microeconómicas e de desenvolvimento social aprovadas; promover a igualdade de género; garantir a aplicação da lei e a responsabilização dos governantes; fortalecer a capacitação humana e institucional; criar condições para o crescimento do tecido empresarial através de uma gestão financeira transparente e a criação de um sistema de impostos coerente.

\section{As Organizações Multilaterais - Cooperação Multilateral}

São Instituições formadas por governos de países que canalizam as suas atividades, total ou parcialmente, a favor do desenvolvimento e da ajuda a países recetores (Comité da Ajuda ao Desenvolvimento da OCDE, in 
Afonso e Fernandes, 2005). Entre outras, destacam-se ao nível global: o Grupo Banco Mundial; o Fundo Monetário Internacional; as Nações Unidas; e a Organização para a Cooperação e Desenvolvimento Económico. Ao nível regional em África existe a South África Development Comunity (SADC).

\section{O Comité de Ajuda ao Desenvolvimento da OCDE}

Este comité constitui um centro de informação, documentação e assessoria, assim como define diretrizes de ajuda para os estados membros ${ }^{41}$. Tem como objetivo a harmonização dos procedimentos e práticas dos doares por forma a melhorar a eficácia da Ajuda e a coordenação de esforços e dos recursos internacionais a favor dos países recetores. Este fórum internacional, em que participam os principais doadores bilaterais, tem como observadores o BM, o FMI e o PNUD. As principais atividades passam pela formulação de políticas e orientações técnicas (embora a sua aplicação não seja obrigatória), no âmbito da proteção ambiental, nas questões do género, ao nível da boa governação ou da reconstrução pósbélica. Contribuem para a análise e avaliação da qualidade e eficácia dos Programas de Ajuda de cada um dos Estados-membros do $\mathrm{CAD}^{42}$, assim como para a sua gestão de acordo com a evolução dos compromissos financeiros. Como resultado da sua ação produzem relatórios e estatísticas sobre a ajuda para o desenvolvimento.

\section{A União Europeia}

A União Europeia é o principal interveniente mundial ao nível da ajuda para o desenvolvimento ${ }^{43}$. O seu objetivo passa pela redução e erradicação da pobreza. A política de desenvolvimento da União foi elaborada progressivamente. Inicialmente abrangia os países e territórios

\footnotetext{
${ }^{41}$ Para mais informações consultar o site oficial: http://www.oecd.org/dac/

${ }^{42}$ Presentemente o CAD é constítuido por 34 Estados - membros. Podem ser consultados aqui: http://www.oecd.org/about/membersandpartners/\#d.en.194378

43 Os fundamentos da cooperação para o desenvolvimento são estabelecidos pelo Tratado sobre o Funcionamento da União Europeia (Título III).
} 
ultramarinos associados à União e atualmente engloba o conjunto dos países em desenvolvimento. Constitui assim um dos pilares das relações externas da União, dando uma resposta adaptada às necessidades dos países em desenvolvimento. A ação da União Europeia em matéria de cooperação para o desenvolvimento tem por base os princípios da eficácia da ajuda, da coordenação com os Estados-Membros e outros intervenientes internacionais e da coerência das políticas europeias com os objetivos do desenvolvimento. O "Consenso Europeu sobre o Desenvolvimento" 44 define o quadro geral da ação da União e dos Estados-Membros nesta matéria. A União está empenhada na realização dos Objetivos de Desenvolvimento do Milénio (ODM) das Nações Unidas, tendo criado para tal diferentes instrumentos ${ }^{45}$ que servirão para reforçar o impacto da sua ação. Esta defende um desenvolvimento social e humano sustentável, igualitário e participativo dos países em desenvolvimento na economia mundial, assim como promove os Direitos Humanos, a boa Governação, a Democracia e o Estado de direito (Afonso e Fernandes, 2005). Em termos de financiamento a política de cooperação da União Europeia é financiada através do Orçamento Comunitário, do Fundo Europeu de Desenvolvimento e do Banco Europeu de Investimento. Quanto às Instituições responsáveis pela execução e definição das políticas de cooperação destacam-se: o Concelho da União Europeia responsável pela pelos assuntos gerais e das relações externas; o Parlamento Europeu responsável pela Comissão para o Desenvolvimento, Cooperação e Assembleia Parlamentar Paritária ACP-EU; e a Comissão Europeia cujas atividades envolvidas passam pela Direção-Geral das Relações Externas (EEAS), a Direção-Geral do Desenvolvimento (DEVCO), a EuropAid e a ECHO (Directorate-General For Humanitarian Aid).

\footnotetext{
${ }^{44}$ Declaração conjunta do Conselho e dos Representantes dos Governos dos Estados-Membros reunidos no Conselho, do Parlamento Europeu e da Comissão sobre a política de desenvolvimento da União Europeia: "O Consenso Europeu" [Jornal Oficial C 46 de 24.2.2006].

${ }^{45}$ Os diferentes instrumentos podem ser consultados aqui:

http://europa.eu/legislation_summaries/development/general_development_framework/index_pt.htm
} 


\section{As Organizações da Sociedade Civil}

i. As Organizações Não-Governamentais de Desenvolvimento são independentes do Estado e dos partidos políticos, sem fins lucrativos abrangendo várias áreas de atuação. Promovem a cooperação entre as sociedades civis de vários países, estando organizadas em redes nacionais e temáticas. A sua principal ação passa por promover a coordenação e aumentar o poder de pressão sobre os decisores políticos (Afonso e Fernandes, 2005). Os deveres e princípios regem-se pela Carta Europeia das $\mathrm{ONGD}^{46}$ a qual tem como princípios orientadores: a justiça social, a igualdade e respeito pelos Direitos Humanos; a participação das populações beneficiária na elaboração, implementação e avaliação dos projetos e programas; a participação da sociedade civil na definição de políticas de cooperação; e o desenvolvimento dos parceiros do Sul. Os seus recursos financeiros são provenientes do sector privado (donativos e campanhas de recolha de fundos) e do sector público (subvenções do Estado e/ou organizações internacionais). As ONGD agrupam-se em redes e plataformas sendo a sua coordenação feita pela Confederação Europeia de ONGD de Emergência e Desenvolvimento - CONCORD. ${ }^{47}$

ii. Organizações Locais e de Desenvolvimento Local

Estas associações desenvolvem projetos junto das suas comunidades, em diversas áreas como a educação, a saúde, o ambiente, entre outras.

\footnotetext{
${ }^{46}$ Pode ser consultada aqui:

http://www.plataformaongd.pt/conteudos/File/Plataforma/Carta das ONGD europeias.pdf

${ }^{47}$ CONCORD é a Confederação Europeia das ONG de Emergência e Desenvolvimento. Membros da organização: 28 associações nacionais, 18 redes internacionais e 2 membros associados, que representam mais de 1.800 ONGs, apoiadas por milhões de cidadãos em toda a Europa - http://www.concordeurope.org/aboutus
} 
iii. Organizações de Solidariedade Oriundas das Migrações

São organizações informais de solidariedade de imigrantes nos países do norte que visam a integração cultural e social desta população.

iv. As empresas

Começam a ter impacto enquanto Atores da Cooperação para o Desenvolvimento, enquanto promotores do capital humano e dos recursos tecnológicos nos países em desenvolvimento. Nestas economias, cada vez mais globalizadas, torna-se imprescindível a cooperação das empresas com as unidades de investigação, assim como com as instituições de ensino superior, no sentido de criar mais inovação e, consequentemente, promover mais emprego, transferência de tecnologia e conhecimento. Desta forma aumentam a sua competitividade em termos locais mas também ao nível internacional contribuindo para o crescimento económico sustentável. Esta cooperação pode ser efetuada de duas formas:

- Diretamente - através de incentivos e facilidades de investimento (apoios dos Governos Nacionais, da União Europeia, do Banco Mundial, dos Bancos Regionais, etc.);

- Indiretamente - através de parcerias com ONGD e patrocínios.

Todos os Atores mencionados participam de diferentes formas no desenvolvimento, através de atividades que compreendem as seguintes configurações (Afonso e Fernandes, 2005):

i. Cooperação Sul/Sul - criação de parcerias entre organizações da sociedade civil do Sul, no sentido de aumentar a sua capacidade de decisão e de 
influência nas políticas de cooperação internacional para o desenvolvimento;

ii. $\quad$ A Capacitação - promove a formação humana para um desempenho mais eficaz, eficiente e sustentável dentro das instituições públicas e das organizações da sociedade civil;

iii. $\quad$ O Comércio Justo - pretende dar ao comércio uma dimensão ética através de uma parceria comercial baseada no diálogo, na transparência e no respeito, procurando a equidade comercial ao nível internacional, contribuindo para o desenvolvimento sustentável;

iv. Os Direitos Humanos - a Declaração sobre os Direitos de Desenvolvimento (1986) confere a todos os povos o direito de participar, contribuir e usufruir do desenvolvimento económico, social, cultural e político. Implica todos os atores da cooperação para o desenvolvimento os quais devem implementar mecanismos de fiscalização das práticas e das instituições quanto aos direitos e deveres;

v. $\quad$ O Género - Como já mencionado em pontos anteriores as questões do género são um ponto fundamental no que toca ao desenvolvimento. Não só se colocam entraves de ordem cultural mas também refletem a sua condição socioeconómica e respetiva posição que ocupam nas sociedades onde habitam. Como verificado, o grau de desigualdades ainda permanece em níveis elevados, ainda que se verifiquem melhoras, essencialmente em países com maior grau de desenvolvimento, e onde, ao nível da educação, já se verifica maiores taxas de matrícula nos níveis mais baixos assim como ao nível do ensino superior.

vi. O Microcrédito - consiste em pequenos créditos concedidos a pessoas com baixo rendimento. Desta forma, não só os mais pobres mas também as 
mulheres, conseguem gerar rendimento para a sua sobrevivência e para melhorar a sua qualidade de vida.

vii. A Prevenção de Conflitos - trata-se de um enquadramento conceptual que prevê a criação de métodos e programas de carácter estrutural para as diferentes etapas do conflito: a prevenção, a resolução, e a reconstrução pós-conflito. Neste sentido, a comunidade internacional, os Estados e as Organizações têm vindo a trabalhar em conjunto no sentido de perceber as raízes do conflito e da sua prevenção, nomeadamente em áreas que impedem o desenvolvimento como a pobreza, a desigualdade, a depressão económica, os regimes não democráticos, a violação dos direitos humanos, dentro dos quais o acesso à saúde e à educação.

viii. A Segurança Alimentar - implica o acesso a uma quantidade de alimentos que permita uma vida saudável e ativa. $\mathrm{A} \mathrm{FAO}^{48}$ identifica quatro áreas de ação fundamentais: disponibilidade, acesso, estabilidade e qualidade. Estas estão correlacionadas com aspetos de ordem económica, nomeadamente, a produção, o consumo, a distribuição e a comercialização o que implica determinadas medidas políticas de regulação.

Como se tem vindo a verificar todos os atores da cooperação para o desenvolvimento interagem entre si de acordo com um sistema de interajuda e ferramentas próprias para a promoção do desenvolvimento (financiamento, parcerias, dialogo institucional, etc. - Tabela 9). O quadro abaixo sintetiza os diversos instrumentos de ligação formais entre os atores.

\footnotetext{
${ }^{48}$ Food and Agricultural Organisation of the United Nations - http://www.fao.org/home/en/
} 
Tabela 9 - Interação entre os diferentes atores para o desenvolvimento - área de atuação e instrumentos de ligação

\begin{tabular}{|c|c|c|c|c|c|c|}
\hline & Estados & $\begin{array}{c}\text { Apoios } \\
\text { Financeiros }\end{array}$ & $\begin{array}{l}\text { Apoios } \\
\text { Técnicos }\end{array}$ & UE & ONGD & Empresas \\
\hline Estados & $\begin{array}{c}\text { Cooperação Bilateral: } \\
\text { doações, créditos, alivio } \\
\text { da divida, assistência } \\
\text { técnica. } \\
\text { Coop. Sul-Sul: } \\
\text { assistência técnica, } \\
\text { partilha de despesas. } \\
\text { Coop. Descentralizada: } \\
\text { coop. técnica, social e } \\
\text { cultural. }\end{array}$ & $\begin{array}{c}\text { Quotas - } \\
\text { APD } \\
\text { Multilateral }\end{array}$ & $\begin{array}{c}\text { Quotas e } \\
\text { donativos } \\
\text { voluntários a } \\
\text { Fundos e } \\
\text { Programas - } \\
\text { APD } \\
\text { Multilateral }\end{array}$ & $\begin{array}{l}\text { Contribuiçõe } \\
\text { s para o } \\
\text { orçamento e } \\
\text { para o FED }\end{array}$ & $\begin{array}{c}\text { Cofinancia } \\
\text { mento } \\
\text { Parceria }\end{array}$ & $\begin{array}{l}\text { Apoios e } \\
\text { Incentivos }\end{array}$ \\
\hline $\begin{array}{c}\text { Apoio } \\
\text { Financeiro }\end{array}$ & $\begin{array}{l}\text { Assistência financeira } \\
\text { (créditos) e técnica } \\
\text { Alivio da divida }\end{array}$ & $\begin{array}{l}\text { Cooperação } \\
\text { e } \\
\text { coordenação } \\
\text { de políticas }\end{array}$ & Coordenação & Coordenação & $\begin{array}{c}\text { Cofinancia } \\
\text { mento }\end{array}$ & $\begin{array}{l}\text { Apoios e } \\
\text { incentivos }\end{array}$ \\
\hline $\begin{array}{l}\text { Apoio } \\
\text { Técnico }\end{array}$ & $\begin{array}{l}\text { Intermediários na } \\
\text { cooperação técnica } \\
\text { Donativos }\end{array}$ & Coordenação & Coordenação & Coordenação & $\begin{array}{c}\text { Cofinancia } \\
\text { mento e } \\
\text { atribuição } \\
\text { da execução } \\
\text { de alguns } \\
\text { programas }\end{array}$ & $\begin{array}{c}\text { Apoios e } \\
\text { incentivos } \\
\text { Cooperação } \\
\text { técnica }\end{array}$ \\
\hline EU & $\begin{array}{c}\text { Preferências comerciais } \\
\text { Cooperação técnica e } \\
\text { financeira }\end{array}$ & $\begin{array}{l}\text { Quotas dos } \\
\text { membros }\end{array}$ & $\begin{array}{c}\text { Quotas dos } \\
\text { membros }\end{array}$ & & $\begin{array}{c}\text { Cofinancia } \\
\text { mento }\end{array}$ & $\begin{array}{l}\text { Apoios e } \\
\text { incentivos }\end{array}$ \\
\hline ONGD & $\begin{array}{c}\text { Consultadoria } \\
\text { Parcerias } \\
\text { Assistência técnica } \\
\text { Lobby e advocacia }\end{array}$ & $\begin{array}{l}\text { Lobby e } \\
\text { advocacia }\end{array}$ & $\begin{array}{c}\text { Consultadori } \\
\text { a e parcerias } \\
\text { Coop. } \\
\text { técnica } \\
\text { Lobby e } \\
\text { advocacia }\end{array}$ & $\begin{array}{l}\text { Cofinanciam } \\
\text { ento e } \\
\text { parcerias } \\
\text { Lobby e } \\
\text { advocacia }\end{array}$ & $\begin{array}{c}\text { Parcerias } \\
\text { Troca de } \\
\text { conhecimen } \\
\text { tos } \\
\text { Redes } \\
\text { Donativos }\end{array}$ & $\begin{array}{l}\text { Parcerias } \\
\text { Troca de } \\
\text { conheciment } \\
\text { os }\end{array}$ \\
\hline Empresas & $\begin{array}{l}\text { Reconstrução do tecido } \\
\text { reprodutivo } \\
\text { Emprego e Tecnologia }\end{array}$ & $\begin{array}{c}\text { Cooperação } \\
\text { técnica }\end{array}$ & $\begin{array}{c}\text { Cooperação } \\
\text { técnica }\end{array}$ & $\begin{array}{c}\text { Cooperação } \\
\text { técnica }\end{array}$ & $\begin{array}{l}\text { Donativos } \\
\text { Parcerias }\end{array}$ & $\begin{array}{c}\text { Cooperação } \\
\text { técnica }\end{array}$ \\
\hline
\end{tabular}


No ponto seguinte incidiremos sobre as principais questões da cooperação ao nível da educação superior, enquanto um bem global (o qual pode ser considerado como um bem público) na medida em que permite a estabilidade financeira de um país, contribuindo, ao mesmo tempo, para a estabilização da comunidade económicofinanceira global estando, por isso, depende dos esforços conjuntos de todos países, pelo que se trata de uma cooperação internacional estratégica. Estes bens tendem a ser subfornecidos, em níveis diferentes de acordo com o tipo de Ator que os fornece ou criadas as condições para o seu fornecimento, devido à ausência de conjunturas político-económicas favoráveis, como é o caso de grande parte dos países da África Subsariana.

\subsubsection{A Cooperação Académica Europa - África}

Pretende-se identificar as principais questões com que se debatem as sociedades africanas relativamente aos desafios da sociedade do conhecimento, assim como reconhecer os problemas enfrentados pelo ensino superior africano, as suas potencialidades e os desafios que se colocam à cooperação, entre os continentes Africano e Europeu, no domínio do ensino superior, da ciência e da tecnologia. São identificados três eixos: a) a cooperação académica entre África e Europa; b) modelos de organização e financiamento sustentáveis; c) redes de conhecimento e criação de centros de excelência.

De acordo com a evidência empírica o sistema universitário africano tem-se, em grande parte, desenvolvido devido à cooperação académica entre Europa e África. Os primeiros académicos africanos formaram-se em universidades europeias. Por outro lado, os cientistas europeus têm vindo a lecionar e a investigar nas universidades africanas, desde a sua existência. Atualmente, as universidades estão a ser africanizadas no sentido de que os seus docentes são, cada vez mais, de nacionalidade africana. No entanto, encontram-se numa situação de superlotação, com bibliotecas ineficientes, com falta de equipamentos e edifícios degradados, 
com a exceção de algumas que funcionam melhor no sul de África. Existe, contudo, um número crescente de jovens que tem acesso ao ensino superior. Alguns destes graduados optam por lecionar em universidades europeias, em busca de maior qualidade (Herbert, 2008 in Lopes, 2008). Neste contexto, e de acordo com Herbert (2008 in Lopes, 2008) a cooperação entre universidades europeias e africanas serve vários propósitos: o ensino e a formação; a investigação; e o apoio ao desenvolvimento estrutural e organizacional das universidades africanas. Não obstante, são vários os desafios que a cooperação académica enfrenta, os quais segundo Lopes (2008) se apresentam como a tentativa de: perceber que tipo de apoio existe para as universidades africanas; entender quais são os vícios que já existem nas experiências de cooperação até ao momento; compreender qual é a evolução da procura nas universidades em africanas; e apreender qual o papel estratégico que as universidades devem ter em África. Apresenta-se de seguida uma breve caraterização de cada um destes desafios de acordo com o mesmo autor.

\subsubsection{Apoio às Instituições de Ensino Superior}

$\mathrm{O}$ processo de suporte às instituições de ensino superior foi evoluindo historicamente e carateriza-se por diferentes etapas. A primeira vaga de apoios surgiu de fundações americanas, as quais sustentavam projetos de consolidação das universidades africanas. Teve, nas décadas de sessenta e setenta, apoio de organizações como a UNESCO, influenciando países como a Suécia e o Canadá com instituições públicas voltadas para a cooperação académica (Agência Sueca para a Cooperação na Área da Pesquisa - SAREC; Centro Internacional para o Desenvolvimento da Pesquisa - IDRC do Canadá). Este período foi reconhecido como uma era de grandes apoios e onde a boa vontade se refletia em projetos de grande relevância, embora as ações fossem pontuais e específicas, e cuja intervenção não deixava grandes marcas. 
A segunda vaga foi caraterizada pela contestação do papel das universidades em África, onde os economistas tiveram um papel preponderante. Estes chegaram à conclusão de que a taxa de retorno não era suficiente quando comparada com o investimento na educação primária, visto que aqui o retorno era maior. Esta vaga teve consequências ao nível político pois as universidades conheceram, devido à sua situação económica, uma marginalização relativa aos sistemas políticos. Deixam de ser um fator prioritário no diálogo de cooperação dos governos com os seus interlocutores. Desta forma, deixam de receber verbas das agências internacionais, assim como deixam de ter um papel preponderante no orçamento governamental, no qual são diminuídas drasticamente as receitas públicas para as universidades (Lopes, 2008).

A terceira vaga começou no final dos anos noventa, durante os processos de paz, tendo sido eliminados a maioria dos conflitos que contribuíram para a pauperização do capital intelectual africano pois durante algumas décadas assistiuse a uma grande fuga de cérebros. A iniciativa das fundações americanas serviu de motor para uma maior reflecção nos organismos internacionais que normalmente financiavam as Instituições de Ensino Superior como o Banco Mundial. O apoio às universidades faz mais sentido se for concebido a longo prazo, pelo que devem ser concedidos não em função das influências em prol de aspetos económicos e de rentabilidade, mas sim de acordo com uma noção mais vasta de universidade, como a geminação entre instituições universitárias, uma vez que tem a si inerentes várias vantagens: as parcerias nos países do norte ou da OCDE continuam a lutar para que a geminação seja efetiva tentando, junto das suas instituições, o financiamento de que carecem; trata-se de uma cooperação mais transparente porque é feita entre pares, seguindo regras diferentes das que são utilizadas por outros protagonistas estando, por isso, resguardadas todas as boas vontades de agências de cooperação e desenvolvimento (Lopes, 2008). Outro aspeto relevante prende-se com o quadro institucional relacionado com a localização do saber promovendo-se vários debates sobre a africanização dos curricula. Isto porque em determinadas áreas e disciplinas específicas, onde a criatividade é um fator 
preponderante, é necessário criar sistemas que limitam a inovação. Na perspetiva de Lopes (2008) este processo de limitação da inovação não contribui para gerar o crescimento e a intervenção das universidades na sociedade, o que poderá traduzirse numa marginalização tecnológica.

De acordo com os estudos mais recentes, a ajuda financeira para o desenvolvimento da educação não tem sido suficiente, não só no que respeita ao financiamento governamental, mas também por parte dos doadores externos. Os países de baixos rendimentos, e em particular a África Subsariana, foram mais atingidos pela redução da ajuda no ensino básico por parte destes doadores. Por outro lado, os governos dos países mais pobres (rendimentos baixos e médios) aumentaram o seu compromisso na área da educação em mais de um ponto percentual do PIB entre 1999 e 2011 (Gráfico 23) ${ }^{49}$. De acordo com o estudo da EFA (UNESCO, 2013) a maioria dos países tem a oportunidade de expandir a sua base de impostos, nomeadamente os países de baixo e médios rendimentos, o que iria favorecer os fundos alocados à educação fazendo face à diminuição de $6 \%$ da ajuda ao ensino básico, entre 2010 e 2011, aumentando da mesma forma, o PIB (Gráfico 24. Existe, na literatura, a ideia partilhada de que depois de 2015 devem ser estabelecidos objetivos financeiros comuns, para que cada país possa alocar pelo menos $6 \%$ do PIB em educação.

${ }^{49}$ Dados completos no anexo 3. 
Gráfico 23 - Despesa Pública em Educação, por região e nível de rendimentos, 1999 e 2011

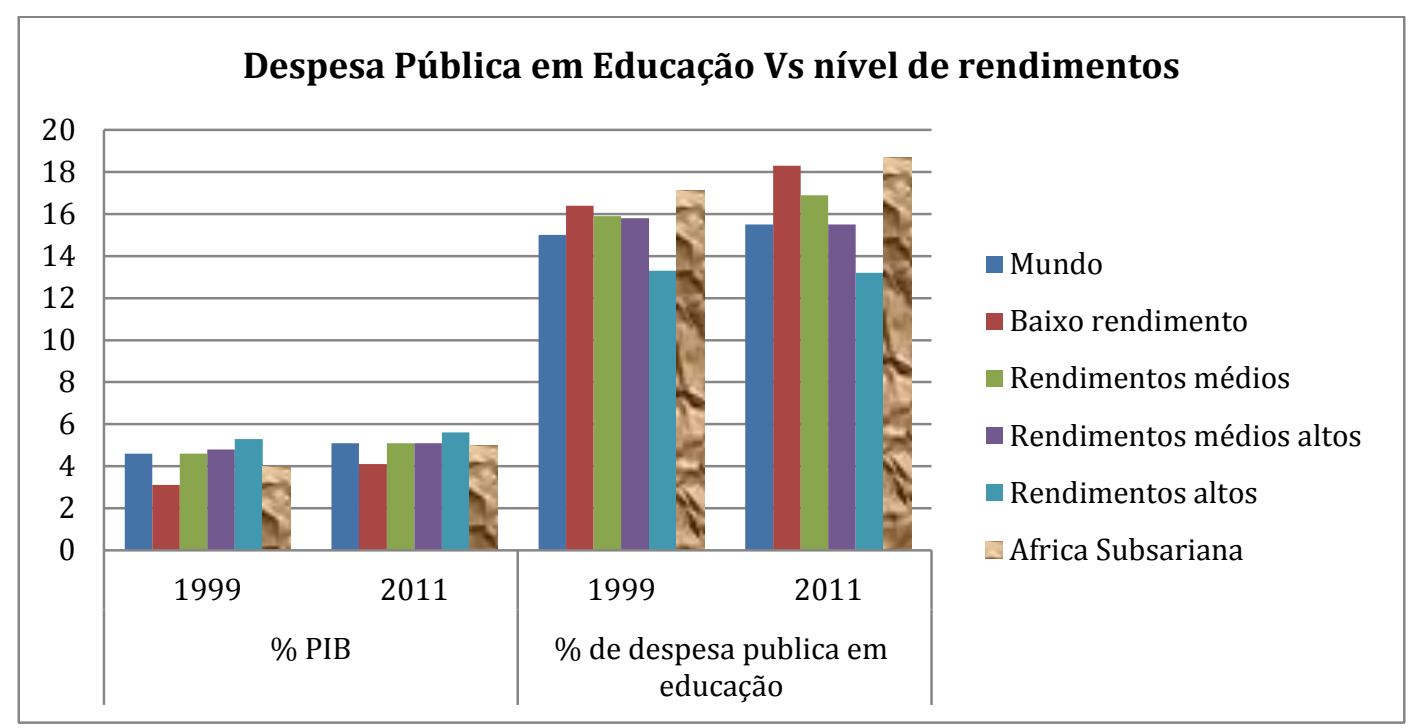

Fonte: Dados obtidos e adaptados em EFA Global Monitoring Report Team calculations (2013), based on UIS database

\section{Gráfico 24 - Per Capita (ensino primário) (PPP constante 2010 - US\$)}

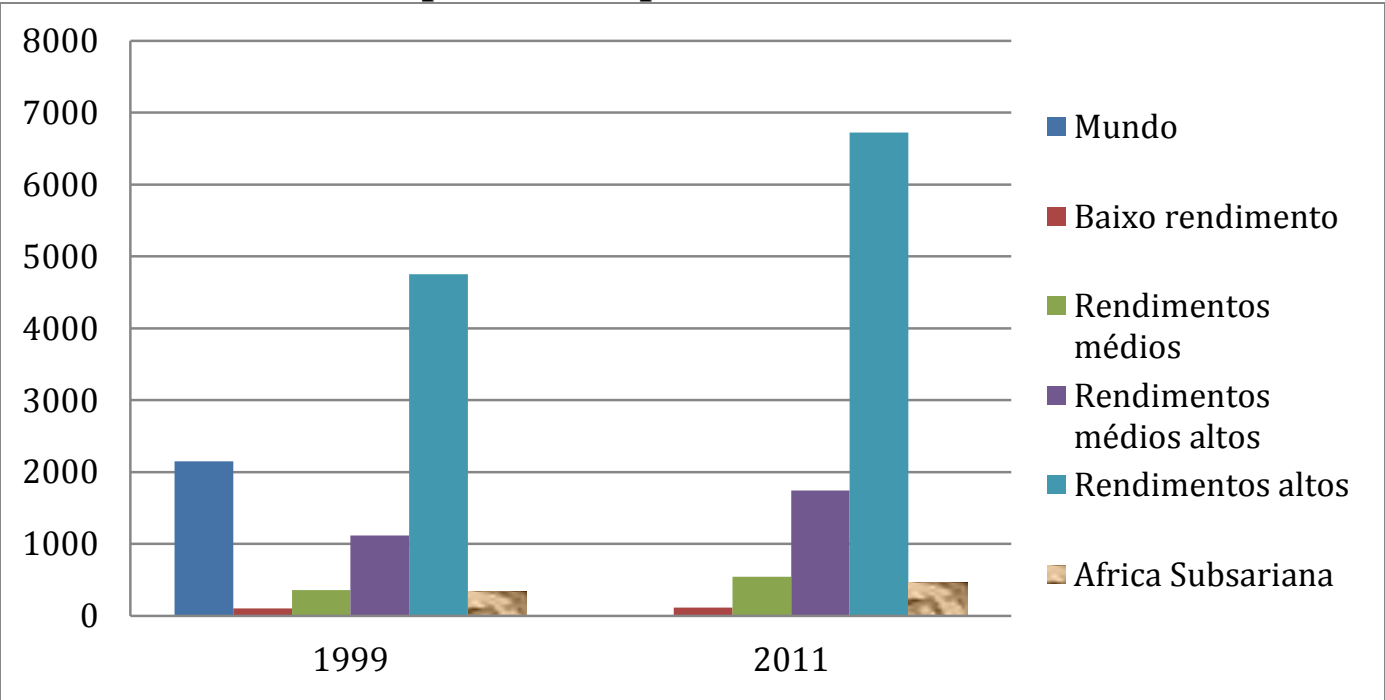

Fonte: Dados obtidos e adaptados em EFA Global Monitoring Report team calculations (2013), based on UIS database

A queda da ajuda para a educação reflete uma mudança significativa nos padrões da despesa financeira de acordo com os vários doadores. A ajuda direta para a 
educação diminui mais do que a ajuda noutros sectores entre 2010 e 2011, cujo declínio se situou entre os $12 \%$ e os $10 \%(\text { Gráfico } 25)^{50}$.

\section{Gráfico 25 - Total da ajuda financeira para a educação e para o ensino básico, por região e de acordo com o rendimento, 2002-2011}

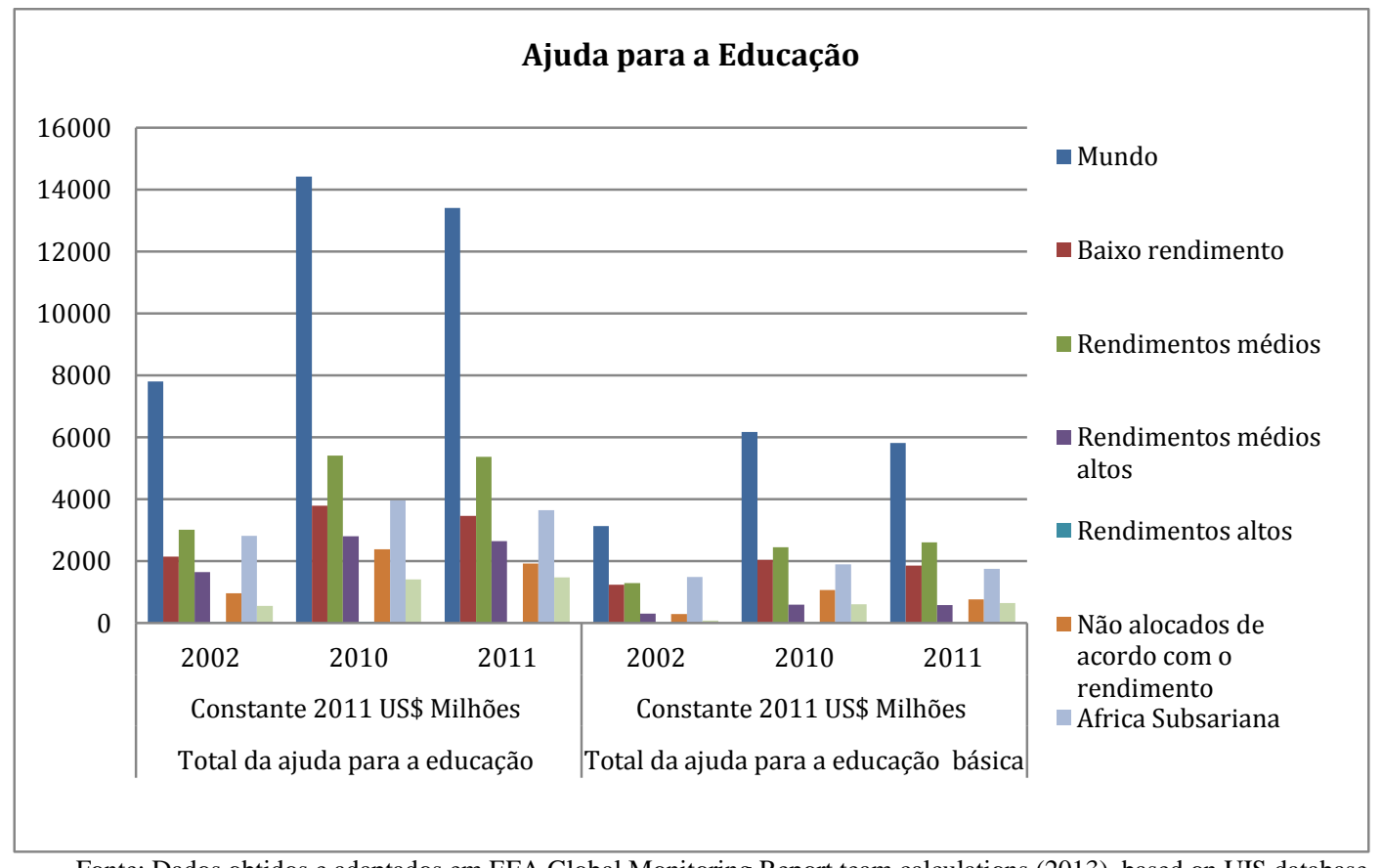

O Canadá, a França, a Holanda e os Estados Unidos em particular, cortaram na despesa da ajuda à educação em maiores proporções quando comparado com outros cortes. De facto, entre 2010 e 2011, vinte e um doadores bilaterais e multilaterais reduziram os apoios para a educação básica. Os doadores que mais cortaram em termos de volume foram o Canadá, a União Europeia, a França, o Japão, a Holanda, a Espanha e os Estados Unidos os quais em conjunto perfazem $90 \%$ da redução da ajuda à educação (Gráfico 26$)^{51}$. Muitos doadores esperam reduzir a ajuda para a educação ainda mais nos próximos anos (Tabela 10).

\footnotetext{
50 Dados completos podem ser consultados no anexo 4.

51 Dados completos podem ser consultados no anexo 5
} 
Gráfico 26 - Os principais doadores reduziram a sua ajuda financeira para o ensino básico, especialmente para os países de baixos rendimentos entre 2010

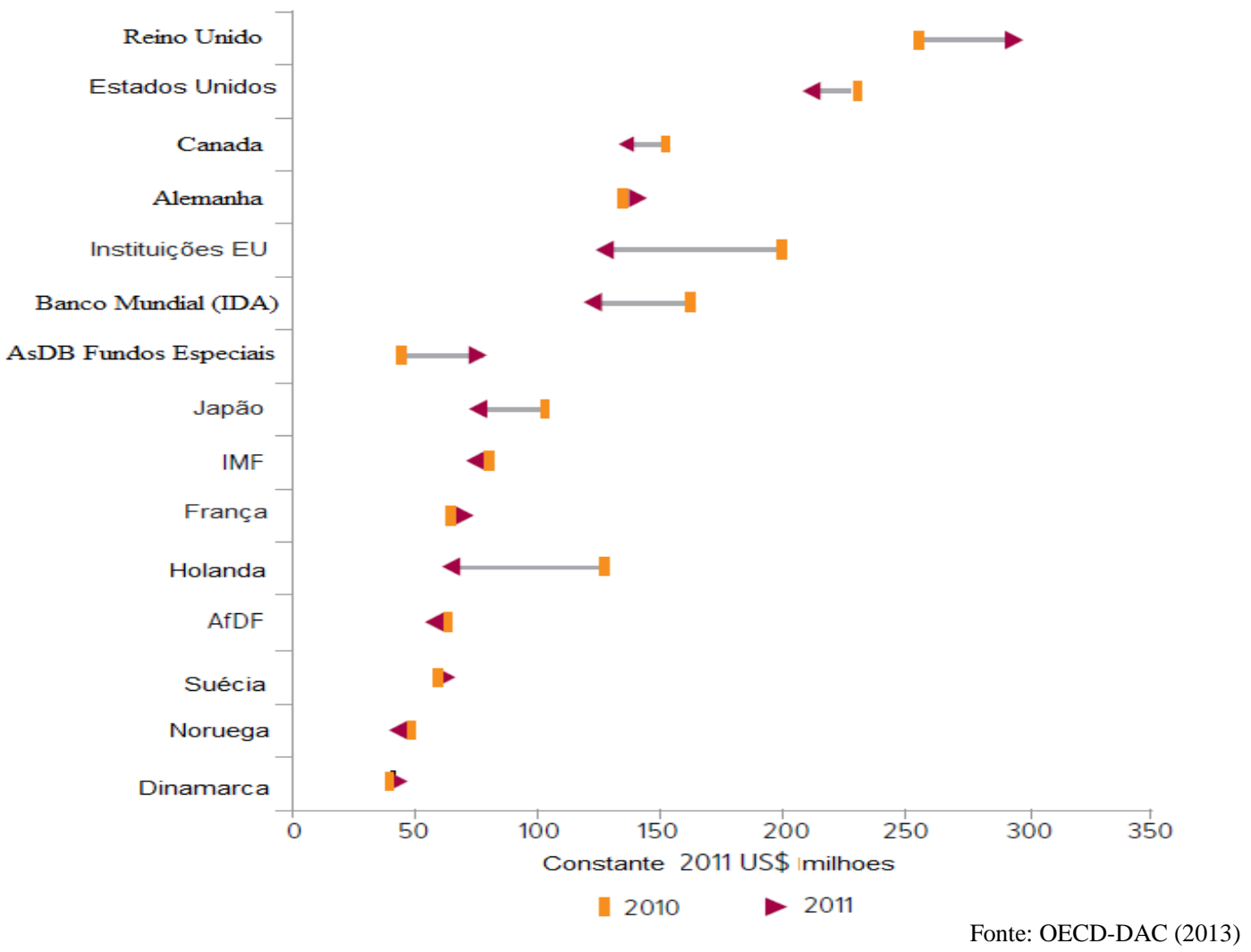

Tabela 10 - Ajuda para a educação, pelos principais doadores, 2002-2014

\begin{tabular}{|c|c|c|}
\hline Doador & $\begin{array}{c}\text { Ajuda para } \\
\text { a educação } \\
\text { básica \% }\end{array}$ & Ajuda \\
\hline $\begin{array}{c}\text { Banco } \\
\text { Mundial }\end{array}$ & 16 & $\begin{array}{l}\text { Os compromissos para a educação totalizaram EUA US } \$ 3 \text { bilhões no } \\
\text { exercício financeiro de } 2012 \text {. Este é um aumento acentuado tendo em conta } \\
\text { os US } \$ 1,8 \text { bilhão em 2011, em grande parte devido ao aumento do } \\
\text { investimento na educação primário e secundária. O Sul e Oeste da Ásia são } \\
\text { os principais beneficiários dos recursos adicionais. }\end{array}$ \\
\hline $\begin{array}{l}\text { Estados } \\
\text { Unidos }\end{array}$ & 10 & $\begin{array}{l}\text { O orçamento dos assuntos internacionais em } 2014 \text { permaneceu o mesmo que } \\
\text { em } 2013 \text {. No entanto, o programa de ajuda bilateral diminuiu em } 58 \text { dos } 100 \\
\text { países, incluindo } 17 \text { na África Subsaariana, com uma mudança para a Ásia } \\
\text { Oriental e no Pacífico. Além disso, o pedido para educação básica é de } 37 \% \\
\text { menor em } 2014 \text { do que em 2013; os recursos totais para a educação básica } \\
\text { foram cortados pela metade desde } 2010 \text {. }\end{array}$ \\
\hline
\end{tabular}




\begin{tabular}{|c|c|c|}
\hline Reino Unido & 9 & $\begin{array}{l}\text { Entre } 2011 \text { e } 2012 \text {, era esperado que a ajuda bilateral aumentasse de US } \$ 8.8 \\
\text { para US } \$ 8,9 \text { bilhões, mas a ajuda para a educação caiu de US } \$ 1,0 \text { bilhão para } \\
0,8 \text { bilhões de dólares. }\end{array}$ \\
\hline $\begin{array}{l}\text { União } \\
\text { Europeia }\end{array}$ & 8 & $\begin{array}{l}\text { O orçamento do Fundo Europeu de Desenvolvimento caiu } 4,3 \text { bilhões de } \\
\text { dólares entre } 2014 \text { e } 2020 \text { como parte dos cortes gerais do orçamento da EU. }\end{array}$ \\
\hline Holanda & 7 & $\begin{array}{l}\text { Estima-se uma queda de } 1.3 \text { bilhões de dólares entre } 2014 \text { e } 2017 \text {, de } 0,63 \% \\
\text { para } 0,55 \% \text { do RNB, visto que a ajuda à educação básica diminuiu de } 243 \\
\text { para US\$76 milhões entre } 2011 \text { e } 2014 \text {. }\end{array}$ \\
\hline Japão & 6 & Japão aumentou o financiamento para a educação básica, entre 2011 e 2014. \\
\hline Canada & 4 & $\begin{array}{l}\text { Após a decisão de cortar a ajuda, em } 2012 \text {, de } 7,5 \% \text { até } 2015 \text {, a ajuda caiu } \\
\text { US } \$ 650 \text { milhões em } 2013 / 14 \text { e estima-se uma queda de US } \$ 781 \text { em } 2015 / 16 \text {. } \\
\text { A Agência de Ajuda Internacional canadense irá fechar e a ajuda será gerida } \\
\text { pelo Departamento de Relações Exteriores e Comércio Internacional. }\end{array}$ \\
\hline Alemanha & 4 & $\begin{array}{l}\text { A ajuda em } 2013 \text { de US } \$ 159 \text { milhões foi inferior ao planeado e US } \$ 112 \\
\text { milhões menos do que em } 2012 \text {. Verificaram-se outros cortes em } 2014 \text {. A } \\
\text { Alemanha fez o compromisso de aumentar a ajuda para a educação básica, no } \\
\text { entanto, assim como se comprometeu a apoiar a educação em outros países } \\
\text { em } 2013 \text {. }\end{array}$ \\
\hline Austrália & 3 & $\begin{array}{l}\text { O governo tem deixado para trás o compromisso de alcançar os objetivos de } \\
\text { ajuda até } 2015 \text { de } 0,5 \% \text { os quais passam para um período indefinido. } \\
\text { Anunciou que, ao longo dos próximos quatro anos, o montante de } 4.2 \text { bilhões } \\
\text { de dólares será cortado do orçamento de ajuda externa. Implicou uma queda } \\
\text { da percentagem do RNB de } 0,37 \% \text { em } 2013 \text { para } 0,32 \% \text { em } 2016 / 17 \text {. }\end{array}$ \\
\hline Dinamarca & 1 & $\begin{array}{l}\text { A ajuda bilateral à educação está a ser eliminada, com } 11 \text { programas que que } \\
\text { fecharam desde } 2011 \text { até } 2015 \text {. Para manter a sua promessa de manter os } \\
\text { níveis de ajuda para a educação básica, a Dinamarca precisara de aumentar os } \\
\text { níveis de ajuda através de mecanismos multilaterais. }\end{array}$ \\
\hline
\end{tabular}

Fontes: Beckett (2013); Bernard Van Leer Foundation (2013); CIDA (2013); Deutsche Welle (2012); DFID (2013); Gavas (2013); Global Partnership for Education (2012); Piccio (2013); Robinson and Barder (2013); Taylor (2013); World Bank (2013a; 2014).

A falta de investimento na área da educação tem como consequência a falta de qualidade do mesmo, infraestruturas debilitadas e material escasso. Representa a falta de credibilidade que a comunidade internacional tem no que respeita ao contributo do ensino para o progresso das sociedades em desenvolvimento e na aposta de promover um capital intelectual produtivo cujas consequências ao nível da profissão académica se discutem de seguida. 


\subsubsection{Evolução da Procura pelo Ensino Superior}

Outro desafio que se perspetiva entender passa por perceber a evolução da procura por parte dos estudantes pelo ensino superior. A população africana tem, em termos relativos, o povo mais jovem do planeta. Este fato traduz-se numa procura elevada da aprendizagem, incluindo o ensino superior e em particular na África Subsariana, onde se pode constatar que o rácio bruto de graduação tem vindo a aumentar gradualmente desde 2000 até $2011^{52}$ (Gráfico 27). Contudo, as universidades africanas têm uma baixa contribuição para a mobilidade social do continente. Isto porque as universidades têm formado pessoas que acabam por ser recuperadas por universidades internacionais, sendo este processo reconhecido como "fuga de cérebros". Por outro lado, uma boa parte dos universitários formados acabam por ser reciclados em processos de produção que não estão relacionados com a sua formação universitária de base. A constituição da classe média africana tem sido um processo muito lento, embora se deva salvaguardar algumas diferenças grotescas que existem entre várias realidades africanas. O mercado de trabalho qualificado é global e não local. Neste sentido, é necessário adaptar as universidades como um bem público comum, com políticas bem especificas de incentivo.

\footnotetext{
${ }^{52}$ Informação adicional: Anexo 7.
} 
Gráfico 27- Rácio bruto de graduação, ISCED 5A $1 .^{\circ}$ Curso (\%)

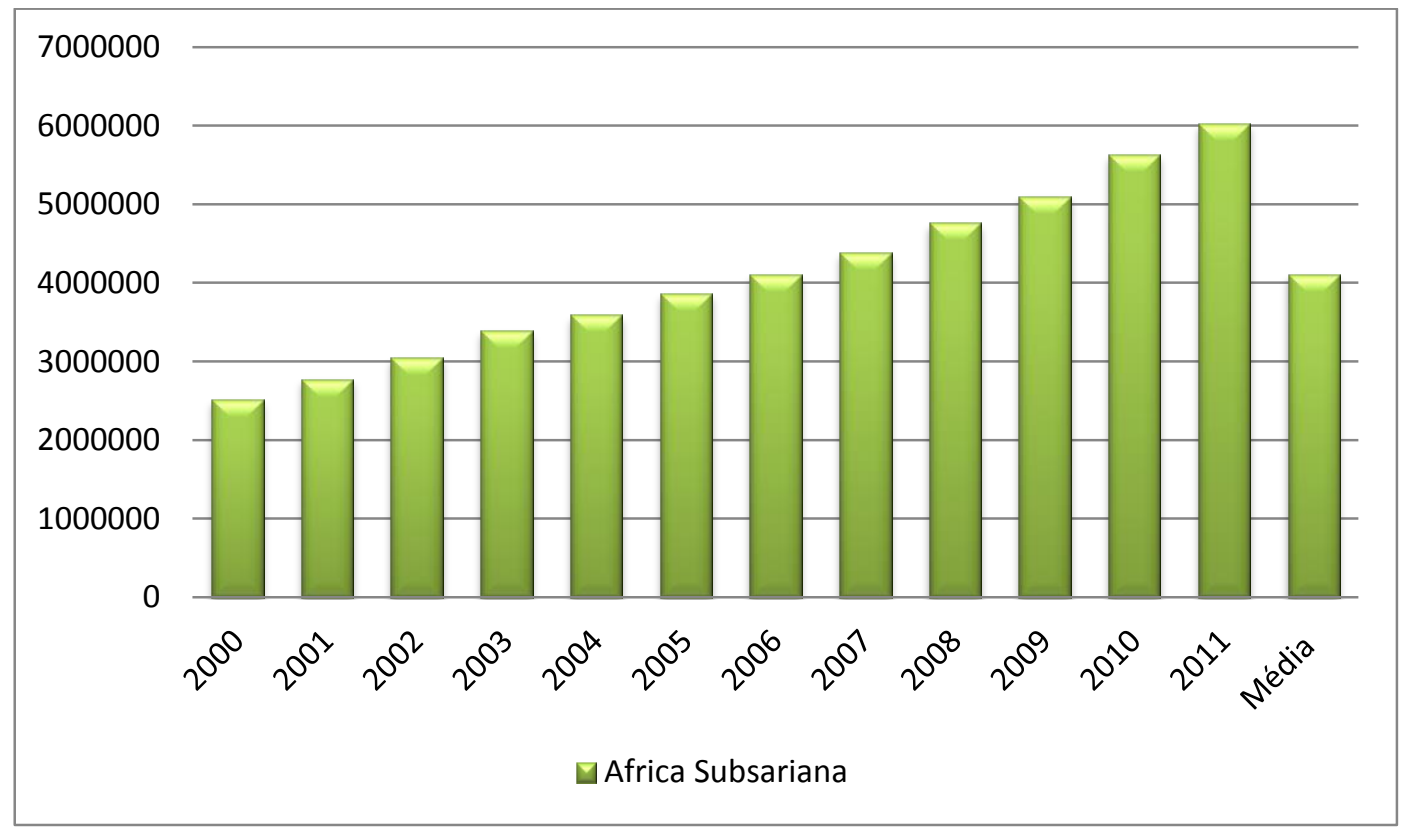

Fonte: Dados obtidos e adaptados em Unesco Institute for Statistics, Higher Education Data

\subsubsection{O papel estratégico das Universidades e a Cooperação Académica EU - África}

As universidades são centros de saber, servindo para a reprodução do capital intelectual. Devem, para além de ensinar, ter um papel ativo na sociedade, à semelhança das universidades europeias. Por outro lado, não só são centros de saber, como são, igualmente detentoras da missão de formar pessoas para que, dessa forma, a universidade tenha uma contribuição própria, interna e endógena na formulação de estratégias. Assim, as universidades têm como principal objetivo contribuir para a consolidação da capacidade individual, institucional e social. Tendo em conta um mundo cada vez mais interdependente e interrelacionado, África e a Europa necessitam de trabalhar em conjunto para atingir as metas globais tais como o desenvolvimento sustentável, energia, condições climatéricas, segurança e migração. A melhor forma de atingir estas metas e ultrapassar estes desafios é através do desenvolvimento do capital intelectual o que implica um 
maior investimento e reconhecimento do papel do ensino superior como um ator para o desenvolvimento sustentável e que contribui para a criação de sociedades mais competitivas. Neste sentido, é imprescindível aumentar e melhorar a cooperação entre as universidades africanas e as da Europa apoiando o desenvolvimento de capacidades mas também no desempenho académico. Quando estas parcerias são efetuadas de forma estruturada e sustentável permitem gerar capacidades ao nível do ensino e da investigação. As universidades são consideradas como alinhadoras da economia e agentes de transferência da tecnologia. A eficácia destas parcerias depende de programas específicos elaborados em conjunto com os stakeholders em ambos os continentes (EUA, $2010)^{53}$. Efetivamente, África está num processo de constante mutação fazendo parte de um sistema de integração política, económica e cultural. Com a criação da Nova Parceria para o Desenvolvimento de África (NEPAD) em 2001, e a União de África (UA) em 2002, este continente dotou-se de uma estratégia e de instituições, para a guiar na integração política e económica.

O quadro para o apoio comunitário a estes processos é constituído pelo Acordo de Cotonu $^{54}$, pelo Acordo de Comércio ${ }^{55}$, pelo Desenvolvimento e Cooperação (TCDA), pela Parceria Euro-Mediterrânica ${ }^{56}$ e pela Política Europeia de

\footnotetext{
${ }^{53}$ European University Association. Africa-Europe Higher Education Cooperation for Development: Meeting Regional and Global Challenges. White paper - Access to Success Project $(2008-2010)$.

${ }^{54} \mathrm{O}$ Acordo de Cotonu tem como principais objetivos a redução da pobreza e, a prazo, a sua erradicação e a integração progressiva dos Estados de África, das Caraíbas e do Pacífico (ACP) na economia mundial, em consonância com os objetivos de desenvolvimento sustentável. Acordo 2000/483/CE de parceria entre os Estados de África, das Caraíbas e do Pacífico e a Comunidade Europeia e os seus Estados-Membros assinado em Cotonu, em 23 de Junho de 2000.

${ }^{55}$ A presente decisão visa estabelecer um quadro multilateral de princípios e de normas para o comércio de serviços a fim de favorecer a expansão deste comércio e a sua liberalização progressiva pela via de negociações, assegurando simultaneamente uma regulamentação transparente e uma participação crescente dos países em desenvolvimento. Decisão 94/800/CE do Conselho, de 22 de Dezembro de 1994, relativa à celebração, em nome da Comunidade Europeia e em relação às matérias da sua competência, dos acordos resultantes das negociações multilaterais do Uruguay Round (1986/1994).

${ }^{56}$ A parceria euro-mediterrânica ou "União para o Mediterrâneo" constitui a política da União Europeia em relação aos países mediterrânicos. Destina-se a reforçar as relações entre a União e os países parceiros, favorecendo ao mesmo tempo o reforço das relações entre os próprios países mediterrânicos. Lançada em 1995 na sequência da Declaração de Barcelona, a parceria tem por objetivo favorecer a paz e a estabilidade na região, instaurando um diálogo político no respeito pelos valores comuns partilhados pelos parceiros, como a democracia e o Estado de direito. Tem igualmente por objetivo favorecer a prevenção e a resolução de
} 
Vizinhança $^{57}$. São, ainda, pilares deste processo de integração continental, ao nível da produção de crescimento económico, e da estabilidade política, as Comunidades Económicas Regionais ${ }^{58}$.

\author{
De acordo com Carvalho e Albernaz (2008) são várias as razões de carácter \\ institucional que fazem com que África se comece a destacar como ator político, \\ agindo em vários segmentos diferentes:
}

conflitos, bem como a prosperidade, nomeadamente pela criação de uma zona de comércio livre e o desenvolvimento de cooperações. Neste contexto, a parceria euro-mediterrânica agrupa os Estados-Membros da União e 16 países mediterrânicos em redor de um vasto programa que se articula em três vertentes: uma vertente política e de segurança, uma vertente económica e financeira, e uma vertente social e cultural. O reforço da cooperação em matéria de justiça, migração e integração social é igualmente um elemento importante do processo. A realização da parceria assenta em duas dimensões: uma dimensão bilateral e uma dimensão regional. Ao abrigo da dimensão bilateral, as relações são adaptadas às especificidades de cada país parceiro, cujos acordos de associação euro-mediterrânicos representam um aspeto importante. A assistência financeira comunitária assenta principalmente no Instrumento Europeu de Vizinhança e de Parceria (IEVP) e na Facilidade Euro-Mediterrânica de Investimento e de Parceria (FEMIP) do Banco Europeu de Investimento. A parceria foi reforçada pelo lançamento da União para o Mediterrâneo aquando da Cimeira para o Mediterrâneo que decorreu em Paris em Julho de 2008. Foi criada uma presidência rotativa entre os parceiros do Norte e do Sul, estabelecendo-se um secretariado permanente em Barcelona para assegurar a gestão dos projetos regionais, sub-regionais e transnacionais. http://europa.eu/legislation_summaries/glossary/barcelona_process_pt.htm

\begin{abstract}
${ }^{57}$ A política europeia de vizinhança (PEV) tem por objetivo estabelecer relações privilegiadas com os países vizinhos da Europa do Leste, do Sul do Mediterrâneo e do Cáucaso Meridional que não têm perspetivas de adesão. Desenvolvida desde 2003 para partilhar com os países vizinhos os benefícios do alargamento e evitar a emergência de novas divisões, a PEV inscreve-se no âmbito da estratégia europeia de segurança. A PEV incide essencialmente na promoção da democracia, das liberdades, da prosperidade, da segurança e da estabilidade, procurando simultaneamente alargar as relações já estabelecidas com cada país vizinho. No entanto, o estabelecimento destas relações privilegiadas está condicionado pelo interesse mútuo em respeitar valores comuns, a saber, a democracia, o Estado de direito, os direitos humanos, a boa governação, os princípios de uma economia de mercado e o desenvolvimento sustentável. A PEV é aplicada através de planos de ação bilaterais, baseados nas necessidades do país vizinho em causa e nos interesses recíprocos de cada país e da União. Os planos de ação estabelecem uma agenda de trabalho, para um período de três a cinco anos, considerando as reformas políticas e económicas, a aproximação das legislações nacionais em relação à legislação comunitária, a participação em certos programas comunitários e o desenvolvimento ou o reforço da cooperação e do diálogo. http://europa.eu/legislation_summaries/glossary/neighbourhood_policy_pt.htm Os acordos bilaterais anteriores à PEV servem de enquadramento para a aplicação desta política. Os países vizinhos beneficiam igualmente de uma assistência financeira e técnica, principalmente através do Instrumento Europeu de Vizinhança e Parceria (IEVP) para o período de 2007-2013 (que substitui os programas TACIS e MEDA aplicados de 2000 a 2006).
\end{abstract}

${ }^{58} \mathrm{O}$ objetivo final da Comissão Econômica para a África é criar um mercado comum africano, através do desenvolvimento das comunidades econômicas regionais já que observou-se que são o instrumento mais adequado para desenvolver o comércio exterior e a integração do mercado africano. As comunidades econômicas regionais são os principais clientes a nível sub-regional da Comissão Econômica para a África. Como tal, a Comissão e seus escritórios sub-regionais trabalham estreitamente com as comunidades econômicas regionais para harmonizar as políticas dos diferentes países e fortalecer a capacidade técnica para desenvolver a integração regional. A Ata Constitutiva da União Africana deixa claro que o principal objetivo da União é o de estabelecer uma Comunidade Econômica Africana e atribui às comunidades econômicas regionais a responsabilidade primordial de conseguir este objetivo. http://pt.reingex.com/Africa-Integracao$\underline{\text { Regional.asp }}$ 
- Na política: ao nível das reformas de democratização;

- $\mathrm{Na}$ economia: promovem o incremento das matérias-primas; as oportunidades de investimento criativas; e o crescimento económico sustentável no continente;

- Estrategicamente: contribui para o realinhamento de poderes globais e permite a participação de um grande número de intervenientes internacionais em África;

- Ao nível social: verifica-se a globalização das normas socioculturais e dos meios de comunicação social;

- Ao nível demográfico: apresenta um crescente número de habitantes; maior mobilidade e migração no interior de África e entre África e a União Europeia, cujo processo está estreitamente relacionado com a globalização e com a internacionalização.

Apesar dos progressos África tem ainda um longo caminho a percorrer no sentido de desenvolvimento sustentável. Uma grande parte dos africanos (40\%) sobrevive com menos de um dólar por dia. Apenas seis em cada dez crianças frequentam a escola primária. A Declaração do Milénio, adotada em 2000, pelos 189 Estados membros da Assembleia geral das Nações Unidas, lançou um processo decisivo de cooperação global no século XXI. Foi dada uma grande ênfase às questões do Desenvolvimento, onde se identificaram os principais desafios da Humanidade o que impulsionou a aprovação dos Objetivos do Desenvolvimento do Millennium $(\mathrm{ODM})$, pela comunidade internacional ${ }^{59}$. No entanto, para que estes sejam impulsionados e implementados são necessários compromissos políticos e financeiros suplementares (Carvalho e Albernaz, 2008) ${ }^{60}$.

Depois da estratégia comum dos Objetivos Do Milénio o ponto de viragem do diálogo Europa - África, deu-se com o lançamento, em 2001, da Nova Parceria

\footnotetext{
${ }^{59}$ Documentos políticos europeus relacionados com os ODM - anexo 2

${ }^{60}$ Relatório elaborado pela Global Partnership for Education Secretariat
} 
Para o Desenvolvimento de África (NEPAD) seguido da criação da União África (UA), no ano seguinte. Em 2003, o montante que a União Europeia concedeu a África para a ajuda ao desenvolvimento ascendeu aos 15 mil milhões de euros (em 1985 foram 5 mil milhões). A União Europeia é, assim, o maior dador de ajuda a este continente, constituindo um dos principais atores na cooperação internacional para o desenvolvimento, como se poderá verificar na tabela abaixo (Tabela 11) onde se apresentam as contribuições até 31 de Dezembro de 2013, de todos os dadores da Parceria Global para a Educação (PGE) relacionados com os Fundos de Investimento (Fundo PGE, Fundo GPE 2 (CE), Fundo de Investimento Catalítico (EC-ACP), Fundo de Investimento Catalítico 2, Programa de Parcerias do Banco Holandês (BNPP) e o Secretariado do Fundo de Investimento).

Tabela 11 - Contribuição dos Dadores da Parceria Global para a Educação, até 31 de Dezembro de 2013 (USD)

\begin{tabular}{cccc}
\hline & & A ser pago de acordo & \\
Pais Doador & Contribuição paga até à & com Acordo de & Total da \\
data (2013) & Contribuição já & assinado & contribuição \\
\hline Reino Unido & $773,672,981$ & 81.296 .847 & \\
\hline Holanda & $607,951,736$ & 41.266 .610 & 854.969 .828 \\
\hline Espanha & $353,318,740$ & & 649.218 .346 \\
\hline Noruega & $268,800,426$ & $16,261,220$ & $353,318,740$ \\
\hline Dinamarca & $237,941,315$ & & $285,061,646$ \\
\hline Suécia & $186,765,842$ & $30,445,571$ & $237,941,315$ \\
\hline Comissão & $151,664,734$ & $27,015,874$ & $217,211,413$ \\
\hline Europeia & $149,868,515$ & $151,623,261$ & $178,680,608$ \\
\hline Austrália & $101,093,058$ & & $301,491,776$ \\
\hline Canada & $97,597,640$ & & $101,093,058$ \\
\hline Franca & $67,128,422$ & & $97,597,640$ \\
\hline Irlanda & $48,117,417$ & & \\
\hline Bélgica & & & \\
\hline
\end{tabular}




\begin{tabular}{|c|c|c|c|}
\hline Alemanha & $44,827,093$ & & $44,827,093$ \\
\hline Itália & $37,210,180$ & & \\
\hline Estados Unidos & $23,275,000$ & & $23,275,000$ \\
\hline Suíça & $19,542,721$ & $14,645,412$ & $34,188,133$ \\
\hline Japão & $16,011,600$ & & $16,011,600$ \\
\hline Rússia & $15,200,000$ & & $15,200,000$ \\
\hline Luxemburgo & $6,484,282$ & & $6,484,282$ \\
\hline Roménia & 712,007 & & 712,007 \\
\hline Total & $3,207,183,708$ & $387,314,761$ & $3,594,498,469$ \\
\hline
\end{tabular}

Fonte: Report prepared by the Global Partnership for Education Secretariat

Os Objetivos de Desenvolvimento do Milênio (ODM), que produziram o mais bem-sucedido movimento anti pobreza da História, serve como um trampolim para a nova agenda de desenvolvimento sustentável que foi adotada pelos líderes mundiais em 2015 e cujos objetivos se explicitam mais à frente.. O ano 2005 tornou-se o ano internacional para África uma vez que foram lançadas iniciativas internacionais de grande relevância, tais como o compromisso de ajuda do G8, na sequência da Declaração de Paris ${ }^{61}$ sobre a eficácia da ajuda; a adoção pelo conselho de ministros da UE de um pacote de medidas para aumentar a Ajuda Pública ao Desenvolvimento e reforçar a eficácia da ajuda e a Coerência da Política para o Desenvolvimento (CPD), no sentido de ajudar África e os países em desenvolvimento a alcançar os Objetivos de Desenvolvimento do Milénio (ODM), até 2015. Desta forma, a estratégia Europa-África tem como principal objetivo a realização dos Objetivos do Desenvolvimento do Milénio (ODM) sendo, para isso, necessário colocar as pessoas no centro do desenvolvimento. Para que tal seja possível a União Europeia deve apoiar o acesso ao ensino das pessoas mais carenciadas em África, assim como às unidades de saúde e aos serviços sociais de base. Desta forma, a União Europeia deve reforçar o apoio orçamental

\footnotetext{
${ }^{61}$ Na Declaração de Paris (2005), doadores e parceiros identificaram 5 dimensões para uma ajuda mais eficaz: Harmonização, Alinhamento, Apropriação, Prestação de Contas/Responsabilização Mútua e Gestão para os Resultados. Em cada uma delas foram identificados compromissos com metas de concretização até 2010. : https://www.instituto-camoes.pt/eficacia-da-ajuda/root/cooperacao/cooperacao-paradesenvolvimento/eficacia-da-ajuda\#sthash.rvWh2puP.dpuf http://www.oecd.org/dac/effectiveness/38604403.pdf
} 
sectorial referente à educação, em especial ao ensino primário, mas também o acesso ao conhecimento, à transferência de competências e ao ensino superior (Carvalho e Albernaz, 2008).

A União Europeia tem vindo a apoiar a internacionalização do ensino superior tendo-se tornado uma área prioritária, na cooperação entre Europa e África, em 2005, colocando o ensino superior africano no contexto mundial. Esta iniciativa baseia-se na conexão em rede, das Instituições de Ensino Superior Africanas, na mobilidade dos estudantes e dos universitários, assim como no apoio à inovação institucional, através da utilização das Tecnologias da Informação e da Comunicação tendo como finalidade o estabelecimento de uma infraestrutura de comunicação para o sector da investigação e do desenvolvimento (Carvalho e Albernaz, 2008). A comparação e a concorrência a nível internacional contribuem significativamente para a melhoria da qualidade do ensino superior.

A estratégia da União Europeia para África passou pela criação de uma "Janela para África" que se inclui no programa Erasmus Mundus, numa vertente para as universidades, para professores e estudantes africanos de pós-graduação. Esta "janela" pretende promover a cooperação institucional do ensino superior entre a União Europeia e os países terceiros através de um programa de mobilidade que visa o intercâmbio estudantil e académico para fins de estudo, formação e investigação. Pretende estimular a criação de parcerias entre Instituições de Ensino Superior europeias e africanas que abranjam a mobilidade dos estudantes, investigadores e docentes.

No sentido de promover estas parcerias a Comissão lançou o programa Edulink ${ }^{62}$ cujo objetivo é contribuir para a promoção de capacidade institucional e da integração regional no domínio do ensino superior através de redes de instituições e apoiar um sistema de ensino superior de qualidade correlacionado com as

\footnotetext{
${ }^{62} \mathrm{O}$ site official do programa pode ser consultado aqui: http://www.acp-edulink.eu/pt-pt/content/o-programa
} 
necessidades do mercado de trabalho, e do desenvolvimento socioeconómico dos países ACP (Carvalho e Albernaz, 2008).

O objetivo geral do Programa EDULINK é o de promover a capacitação e a integração regional no domínio do ensino superior através de redes institucionais, bem como apoiar sistemas de ensino superior de qualidade, que sejam eficientes e relevantes para as necessidades do mercado de trabalho e, por conseguinte, consistentes com as prioridades de desenvolvimento socioeconómico dos países ACP. (ACP Secretariat, site oficial do programa)

O Edulink é um programa de cooperação no Ensino Superior financiado pelo Fundo Europeu de Desenvolvimento - FED - o qual está aberto a todos os países de África, Caraíbas e Pacifico (ACP) e aos 15 Estados membros da União Europeia signatários do 9. ${ }^{\circ}$ Fundo Europeu do Desenvolvimento (FED). Este programa visa melhorar a eficácia e o impacto da cooperação ACP-UE, ao nível do ensino superior, assim como promove a implementação dos programas financiados pela Comissão de apoio aos estudos ACP, no sentido de alcançar a meta do segundo Objetivo de Desenvolvimento do Milénio ao nível do ensino superior e os Objetivos de DAKAR relativos à educação para todos (Carvalho e Albernaz, 2008).

No 7. Programa Quadro de Investigação e Desenvolvimento Tecnológico, que entrou em vigor em 2007, a União Europeia facilita o estabelecimento de redes entre os investigadores de países terceiros que trabalham na União Europeia e os organismos de investigação dos países de origem. De acordo com Carvalho e Albernaz (2008) a mobilização das universidades e dos centros de investigação dos países africanos passa por uma maior cooperação com os centros europeus. 
O processo de Bolonha ${ }^{63}$ coloca o ensino superior europeu num contexto mundial uniformizando o mesmo em três ciclos (licenciatura, mestrado e doutoramento) de forma atingir uma maior qualidade do ensino superior. Permite o reconhecimento das habilitações e dos períodos de estudo. A sua estratégia visa melhorar a prestação da informação, promover a competitividade dos estabelecimentos de ensino superior na Europa e reforçar as parcerias, intensificar o diálogo político e melhorar os mecanismos de reconhecimento (Carvalho e Albernaz, 2008). Contudo, tendo em conta a globalização, a resposta às necessidades emergentes em matéria de ensino superior não se confinem à Europa. Os países africanos também se inserem nesta sinergia existindo uma maior abertura para o mundo. Similar ao processo de Bolonha, os ministros da CPLP, assinaram em 2004, a Declaração de Fortaleza ${ }^{64}$ onde decidem "renovar o apoio à cooperação no domínio do ensino superior e construir nos próximos 10 anos um espaço de ensino superior da CPLP”. Na mesma declaração são indicadas como prioridades:

1. O estímulo à qualidade das formações oferecidas no âmbito da CPLP e ao reconhecimento mútuo e internacional;

2. A promoção da mobilidade de estudantes, docentes, investigadores e técnicos;

3. A cooperação no domínio da estrutura das formações superiores;

4. O incentivo à participação das instituições da CPLP em programas relevantes de outras comunidades de países.

Desta forma, tenta-se construir um espaço de ensino superior coeso, mais competitivo e atrativo promovendo a empregabilidade (Carvalho e Albernaz, 2008). A estratégia Europa-África promove o desenvolvimento da ciência, da tecnologia e da inovação tendo em conta que contribui para o crescimento económico e para o desenvolvimento sustentável do continente africano (Carvalho e Albernaz, 2008). A competitividade na economia global está, em grande parte,

\footnotetext{
${ }^{63}$ Joint declaration of the European Ministers of Education, The Bologna Declaration of 19 June 1999 http://www.ond.vlaanderen.be/hogeronderwijs/bologna/documents/MDC/BOLOGNA_DECLARATION1.pdf ${ }^{64}$ Documento oficial pode ser consultado em: http://www.cplp.org/id-4179.aspx
} 
dependente do conhecimento, da aplicação de tecnologias modernas, em especial as tecnologias de informação e comunicação (TIC) como já demonstrado. As parcerias e investimentos que contribuem para as infraestruturas no domínio das TIC, permitem o desenvolvimento da ciência, da tecnologia e dos sistemas inovadores em África, os quais são cruciais para atingir os objetivos do Milénio (Carvalho e Albernaz, 2008). De fato, a parceria Europa-África adotada pelo conselho Europeu de 2005, permitiu colocar África na via do desenvolvimento sustentável e de atingir os ODM em 2015. Só desta forma, será possível proteger a subsistência das populações mais pobres, a médio e longo prazo.

Como temos vindo a verificar a parceria entre a Europa e África remonta a longa data, assentando em interesses comuns, sendo sólida e onde existe reconhecimento mútuo e responsabilidade. Esta parceria África-UE foi formalizada na Cimeira de Lisboa em 2007 e baseia-se na Estratégia Conjunta África-EU - Joint África-EU Strategy (JAES) ${ }^{65}$. Trata-se de um documento negociado e acordado conjuntamente pelas instituições da União Africana e da União Europeia, bem como pelos Estados Africanos e os Estados-Membros da UE. A parceria estendese para além das instituições políticas, incluindo intervenientes não estatais tais como organizações da sociedade civil, organizações de juventude, o sector privado e outros atores sociais. Nestes incluem-se as universidades as quais deverão ser percecionadas pelos governos e pelas agências internacionais como atores versáteis e flexíveis para o desenvolvimento, assim como conseguem mobilizar diferentes atores e agências ao nível das políticas, dos doadores e da comunidade académica. Este documento estabelece a visão, os valores e os princípios com os quais se comprometem a cumprir. De acordo com o documento oficial esta parceria tem uma visão partilhada visto que:

O objetivo desta estratégia conjunta é levar a relação África-UE a um novo nível estratégico, com uma parceria política reforçada e uma cooperação reforçada a todos os níveis. A

\footnotetext{
${ }^{65}$ Documento Oficial: "THE AFRICA-EU STRATEGIC PARTNERSHIP - A Joint Africa-EU Strategy" http://www.africa-eu-partnership.org/sites/default/files/documents/eas2007_joint_strategy_en.pdf
} 
parceria será baseada num consenso Euro-Africano de valores, interesses e objetivos estratégicos comuns. Essa parceria deve se esforçar para reduzir o fosso de desenvolvimento entre África e a Europa, através do reforço da cooperação económica e da promoção do desenvolvimento sustentável em ambos os continentes, vivendo lado a lado em paz, segurança, prosperidade, solidariedade e dignidade humana. (...) Esta Estratégia Conjunta pretende fornecer um quadro global de longo prazo para as relações UE-África, será implementada através de sucessivos Planos de Ação a curto prazo e através do reforço do diálogo político a todos os níveis, revertendo-se em resultados concretos e mensuráveis em todas as áreas da parceria. (The Africa - EU Srategic Partnership - A Joint África-EU Strategy)

O mesmo documento apresenta como objetivos principais desta parceria partilhada de longo termo os seguintes aspetos:

1. Reforçar e elevar a parceria política África-UE para tratar de questões de interesse comum. Inclui o fortalecimento dos laços institucionais e enfrentar desafios comuns, em especial a paz e a segurança, a migração e o desenvolvimento, e um ambiente saudável. Para este fim, os dois lados vão considerar a África como um todo e reforçar o diálogo político UE-África para permitir uma parceria forte e sustentável de continente a continente, com a UA e a UE no seu centro;

2. Fortalecer e promover a paz, a segurança, a governação democrática e os direitos humanos, as liberdades fundamentais, a igualdade de género, o desenvolvimento económico sustentável, incluindo a industrialização, a integração regional e continental em África, e para garantir que todos os Objetivos do Desenvolvimento do Milénio (ODM) sejam cumpridos em todos os países africanos até o ano de 2015;

3. Promover e manter um sistema de multilateralismo efetivo, com instituições fortes, representativas e legítimas; promover a reforma do 
sistema das Nações Unidas, em conjunto com outras organizações internacionais relevantes; enfrentar os desafios globais e as preocupações comuns, tais como os direitos humanos, incluindo os direitos das crianças e da igualdade de género, o comércio justo, a migração, os problemas de VIH / SIDA, a malária, a tuberculose e outras pandemias, mudanças climáticas, segurança energética e sustentabilidade, o terrorismo, a proliferação de armas de destruição maciça e ao tráfico ilícito de armas pequenas e armamentos leves, e as questões de sociedade baseada no conhecimento, como as TIC, a ciência, a tecnologia e a inovação;

4. Facilitar e promover uma parceria ampla e abrangente centrada nas pessoas; África e a UE irão capacitar atores não-estatais e criar condições que lhes permitam desempenhar um papel ativo no desenvolvimento, na construção da democracia, na prevenção de conflitos e no pós-conflitos e processos de reconstrução. Ambos os lados irão promover abordagens holísticas para os processos de desenvolvimento e fazer desta Estratégia Conjunta uma plataforma permanente de informação, participação e mobilização de um amplo espectro de atores da sociedade civil na UE, em África e noutros continentes. O diálogo permanente com a sociedade civil, com o sector privado e com os agentes locais sobre as questões abrangidas pela presente Estratégia Conjunta será um componente chave para garantir a sua execução.

No seguimento desta parceria foi efetuada uma nova Cimeira (2-3 Abril de 2014) - 4th EU-África Summit - Roadmap 2014-2017 66 -, a qual teve lugar em Bruxelas, tendo participado os Chefes de Estado e do Governo da União Europeia e de África, o Presidente do Concelho Europeu, o Presidente da Comissão Europeia, o Presidente da Comissão Africana (AU) e o Representante da Comissão da União Europeia (AUC). O tema desta Cimeira foi "Investir nas Pessoas, Prosperidade e

\footnotetext{
66 Documento oficial pode ser consultado em: http://www.africa-eupartnership.org/sites/default/files/documents/2014_04_01_4th_eu-africa_summit_roadmap_en.pdf
} 
Paz". Foi confirmado que os objetivos apresentados na Cimeira anterior permanecem a política estratégica de referência no que concerne às relações EUÁfrica, no entanto reconhecem-se que a implementação da Estratégia conjunta deverá ser melhorada e guiada de acordo com uma abordagem baseada em resultados para o período 2014-2017. O documento acordado estabelece as principais prioridades e áreas de interesse comum para as ações conjuntas ao nível inter-regional, continental e global, nomeadamente no que concerne a:

i. Paz e Segurança;

ii. Democracia, Boa Governação e Direitos Humanos: direito social e cultural, civil e político;

iii. Desenvolvimento Humano: ciência, tecnologia e inovação; ensino superior; Mobilidade, migração e emprego;

iv. Sustentabilidade e desenvolvimento e crescimento inclusivo e integração continental: investimento privado; infraestruturas; integração continental; agricultura, segurança alimentar; e

v. Questões Globais e Emergentes: alterações climatéricas e ambiente; Agendo do Desenvolvimento Pós-2015; proliferação de pequenas armas e de armas de fogo, armas de destruição em massa e transferência de armas convencionais; e a Reforma do sistema de governo internacional.

Para cada um destes objetivos foram identificadas as ações a serem implementadas ao nível regional, continental e global. Foi, ainda, acordado aumentar as sinergias entre o diálogo político, a cooperação e a promoção de uma maior participação do sector privado e da sociedade civil. No que concerne à área de Prioridade 3 Desenvolvimento Humano - foi delineado como objetivo estratégico a promoção do desenvolvimento do capital, das sociedades e das economias baseadas no conhecimento e nas qualificações. Para tal é necessário reforçar as relações entre a educação, a formação, a ciência e a inovação e uma melhor gestão da mobilidade 
das pessoas. Estas ações permitiram o acesso a melhor emprego e proteção social, assim como o acesso para todos à educação de qualidade, saneamento e a tratamentos de saúde.

De acordo com estas premissas as áreas chave de cooperação identificadas foram:

\section{Ciência, tecnologia e cooperação}

- Pretendem promover um maior investimento na ciência, na tecnologia e na inovação, reconhecendo-se que estas áreas são cruciais para o crescimento e para o emprego, melhoram a competitividade contribuindo para atingir todos os outros objetivos socioeconómicos. Neste sentido, perspetiva-se reforçar a cooperação entres as comunidades de investigação e a criação de programas conjuntos de investigação académica, com um foco especial na inovação e no sector produtivo.

- Será desenvolvida a longo-termo, gerida e financiada com fundos conjuntos uma parceria de investigação e de inovação, especialmente na área da segurança alimentar e da agricultura sustentável. Salienta-se a importância crescente da relação inovação / empreendedorismo, da investigação ao nível das infraestruturas e no desenvolvimento de competências técnicas em África e na Europa.

- O Diálogo Político de Alto Nível EU-África (EU-África High level Policy dialogue - $H L P D^{67}$ ) em ciência, tecnologia e inovação será a plataforma chave para desenhar e implementar um mapa detalhado

\footnotetext{
${ }^{67}$ The HLPD Expert Working Group - foi criado após a Cimeira UE-África de 2014, trabalha no sentido de criar um roteiro para uma Parceria UE-África financiada conjuntamente no âmbito da Investigação e da Inovação nas áreas da segurança alimentar e nutricional e agricultura sustentável. A reunião foi realizada back-to-back com uma reunião da UE-África e HLPD Bureau de decisores políticos, financiadores potenciais, bem como os projectos de apoio financiados FP7 / Horizon 2020. - http://www.africa-eupartnership.org/newsroom/events/third-meeting-eu-africa-high-level-policy-dialogue-expert-working-group
} 
com os objetivos e as etapas desta parceria. O financiamento será proveniente do Programa Europeu de Investigação e Inovação (European Research and Innovation Program), do Horizonte 2020 (Horizon $2020^{68}$ ) e de outras contribuições da União Europeia e de stakeholders africanos.

\section{Ensino Superior}

- O ensino superior desempenha um papel crucial no desenvolvimento socioeconómico e na catalisação do desenvolvimento sustentável através da produção de recursos humanos altamente qualificados e na disseminação de resultados da investigação científica e técnica. A mobilidade poderá implicar a melhoria da qualidade do ensino superior na medida em que acelera o uso da transparência e de ferramentas de reconhecimento, permitindo às instituições desenvolver melhores serviços para receber e enviar estudantes e investigadores estrangeiros.

- O programa Erasmus+ ${ }^{69} \mathrm{e}$ as Ações Marie Skłodowska-Curie $(\mathrm{MSCA})^{70}$ permitiram uma mobilidade de qualidade de estudantes, investigadores e profissionais através de ações centradas nos indivíduos, nas instituições e no sistema de ensino superior. $\mathrm{O}$

\footnotetext{
${ }^{68}$ Horizonte 2020 é o maior programa Europeu de financiamento de Investigação e Desenvolvimento, com fundos na ordem dos $€ 80$ bilhoes disponíveis no período de 2014 - 2020. Ele promete maiores avanços, descobertas e estreias mundiais, transformando grandes ideias do laboratório em planos de negócio aplicados ao mercado. - https://ec.europa.eu/programmes/horizon2020/en/what-horizon-2020

${ }^{69} \mathrm{O}$ programa Erasmus+ tem por objetivo reforçar as competências e a empregabilidade, bem como modernizar a educação, a formação e a animação de juventude. O programa, que abrange um período de sete anos, disporá de um orçamento de 14,7 mil milhões de euros, o que representa um aumento de $40 \%$ em relação aos níveis de despesa atuais, em consonância com o compromisso assumido pela UE de investir nesta área. - http://ec.europa.eu/programmes/erasmus-plus/discover/index_pt.htm

${ }^{70}$ Podem beneficiar de financiamento todos os investigadores, quaisquer que sejam os seus domínios de trabalho, desde a assistência sanitária de emergência à ciência fundamental. As MSCA também apoiam os doutoramentos industriais, que conciliam investigação académica com trabalho exercido em empresas, bem como outros tipos de formação inovadora que promovem a empregabilidade e o desenvolvimento das carreiras profissionais. - http://ec.europa.eu/research/mariecurieactions/index_pt.htm
} 
Programa de Mobilidade Nyerere ${ }^{71}$ irá providenciar bolsas de estudo para 500 estudantes no âmbito dos estudos de pós-graduação e permitirá a mobilidade de 70 académicos e profissionais dentro de África até 2017. Esta ação pretende promover a retenção de estudantes assim como aumentar a competitividade e a atratividade das próprias instituições.

- Serão financiados o desenvolvimento de centros de excelência em África, particularmente através da Universidade Pan-Africana ${ }^{72}$. Pretende-se expandir a iniciativa piloto de Harmonização e sintonia do Ensino Superior Africano (African Higher Education Harmonisation and Tuning ${ }^{73}$ ) com o incentivo de melhorar a relevância e a qualidade do curriculum, de melhorar os resultados do ensino e da aprendizagem, aumentar de 60 para 120 o número de universidades participativas através do continente africano. Pretende-se impulsionar iniciativas de boas praticas e de qualidade nas universidades no sentido de assegurar a sua qualidade e acreditação aumentado as parcerias alinhadas e a internacionalização do ensino superior. Promove-se o ensino, a formação vocacional e o empreendedorismo entre as mulheres e os mais jovens.

\footnotetext{
${ }^{71}$ Este programa fornece bolsas de estudo que facilitem o intercâmbio entre Universidades Africanas. Este programa é uma das ações concretas promovidas pela 7 parceria temática do JAES. http://www.africa-eupartnership.org/newsroom/all-news/nyerere-programme

${ }^{72}$ A declaração de missão da Universidade é: "formar profissionais competentes e comprometidos e incentiválos a servir com a iniciativa pessoal e de responsabilidade social na comunidade em que trabalham, ajudando assim a construir uma sociedade melhor, na Nigéria e na África em geral". http://www.pau.edu.ng/

73 Site oficial http://www.africa-eu-partnership.org/newsroom/all-news/african-higher-educationharmonization-tuning-workshop-joint-degrees
} 
III. Mobilidade, migração e emprego

- A Cimeira de Bruxelas (Fourth EU-África Summit) adotou a declaração conjunta em Migração e Mobilidade e acordou implementar um Plano de Ação para período 2014-2017. Serão promovidas sinergias entre a migração e o desenvolvimento incluindo a redução dos custos das transações. Pretende-se organizar melhor a mobilidade intra e inter-regional dos trabalhadores. Tem-se ainda o objetivo de melhorar a cooperação no âmbito do tráfico de seres humanos reforçando as ações de prevenção, proteção e prossecução. Pretende-se cooperar na migração irregular através de uma melhor gestão e da promoção de alternativas. Esta cooperação irá, no campo da proteção internacional e no asilo, promover o respeito dos direitos humanos dos migrantes.

Resumindo, a nova parceria EU-África traduz uma maior preocupação com a área da educação, nomeadamente com o ensino superior e, consequentemente, com a investigação e a inovação. Existe, claramente, o reconhecimento de que é necessário investir no desenvolvimento do capital humano para que seja possível promover sociedades mais competitivas e organizadas a todos os níveis. Para tal o papel das universidades torna-se cada vez mais evidente na promoção de recursos humanos qualificados e no desenvolvimento de tecnologias de forma a atingir os objetivos anteriormente identificados, mas também na qualidade do ensino e dos seus serviços. Existe uma maior preocupação no que concerne à mobilidade destes profissionais e na sua retenção promovendo ações que visem melhores condições de trabalho e garantia de estabilidade. 


\subsubsection{A Cooperação Académica e Científica enquanto promotor do desenvolvimento em África}

Como se tem vindo a verificar o avanço no desenvolvimento está estreitamente relacionado com a cooperação académica e científica internacional, o que contribui para a circulação do conhecimento (Tejada, 2008). Enquanto fator de desenvolvimento o fluxo de conhecimento tem suporte na interação entre os domínios técnicos, institucional e empresarial. O conhecimento na forma de educação e investigação científica ou tecnológica, adquiridas e/ou produzidas pelos migrantes qualificados, é um catalisador importante do desenvolvimento. Apesar de África ser um dos continentes com maior taxa de pobreza, uma das principais características dos fluxos migratórios, no interior e exterior de África, é a mobilidade internacional dos indivíduos qualificados, vindos dos países de África a sul do Sahara para os países desenvolvidos (OIM, 2005). Os estudantes e os cientistas que vivem na Europa, os quais constituem uma fonte de conhecimento, de ideias e de competências de grande valor para os seus países de origem (Tejada, 2008), têm um importante papel no debate sobre a cooperação académica Europa-África.

De acordo com o Instituto de Estatística da UNESCO (2003) os países industrializados têm em média dez vezes mais investigadores por cada milhão de habitantes que os países em vias de desenvolvimento e nos países mais industrializados. Neste sentido, os programas internacionais de cooperação académica e científica constituem fatores importantes que permitem a circulação de estudantes internacionais e de pessoas qualificadas entre o centro e a periferia. Desta forma, é necessário refletir sobre os seus papéis para encorajar uma estratégia de brain gain que seja benéfica para toda a África, para a Europa e para os migrantes qualificados (Tejada, 2008). De acordo com os dados da UNESCO $31 \%$ dos estudantes africanos mobilizam-se para países europeus. As migrações internas para outros países africanos ainda é uma realidade (34\%) e a maioria 
destes estudantes prefere deslocar-se para outros países internacionais $(35 \%)^{74}$ (Gráfico 28).

Gráfico 28 - Mobilidade Estudantes Africanos, por Região de destino, 19992012

\section{Mobilidade de Estudantes Africanos Total por Região de Destino, 1999-2012}

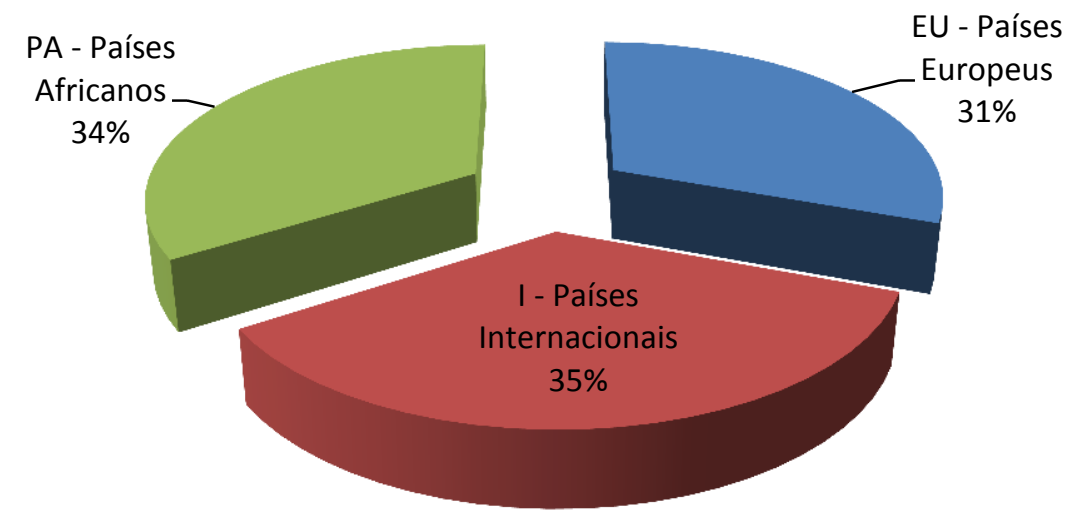

Fonte: dados extraidos e adaptados de UIS/ISU (2013)

Os desafios e as oportunidades de migração qualificada na cooperação académica e científica entre África e a Europa têm uma importância significativa. De fato, entre o período de 1999 a 2012 verificou-se uma mobilização total de 2.492.563,50 alunos (Gráfico 29) para países europeus de um global total de 4.120.840,33 (Gráfico 30). Os principais países de destino Europeus são a França, o Reino Unido, a Alemanha e Portugal.

${ }^{74}$ Anexo 15 - Mobilização de Alunos Africanos por local de destino, 1999-2012 
Gráfico 29 - Mobilidade de Estudantes Africanos para países Europeus, 1999-2012

\begin{tabular}{|c|c|c|}
\hline & TOTAL POR PAÍS & \\
\hline Reino Unido e Norte da Irlanda & $387.715,00$ & \\
\hline Antiga Republica da Juguslavia - Macedonia & 11,00 & \\
\hline Suiça & $29.852,00$ & \\
\hline Suécia & $11.932,00$ & \\
\hline Espanha & $54.268,00$ & \\
\hline Eslovenia & 119,00 & \\
\hline Eslovaquia & $1.332,00$ & \\
\hline Romania & $16.026,00$ & \\
\hline Portugal & $82.634,00$ & \\
\hline Polónia & $7.147,00$ & \\
\hline Noruega & $17.045,00$ & \\
\hline Holanda & $19.658,00$ & \\
\hline Malta & 655,00 & \\
\hline Luxemburgo & 397,00 & \\
\hline Lituania & 188,00 & \\
\hline Liechtenstein & 25,00 & \\
\hline Latvia & 216,00 & \\
\hline Italia & $69.262,00$ & \\
\hline Irlanda & $9.130,00$ & \\
\hline Hungria & $4.301,00$ & \\
\hline Grecia & $4.426,00$ & \\
\hline Alemanha & $265.430,00$ & \\
\hline França & & $1.397 .418,00$ \\
\hline Finlandia & $19.441,00$ & \\
\hline Estónia & 102,00 & \\
\hline Dinamarca & $5.050,00$ & \\
\hline Republica Checa & $5.098,00$ & \\
\hline Chipre & $4.515,00$ & \\
\hline Croacia & 57,00 & \\
\hline Bulgaria & $1.790,00$ & \\
\hline Belgica & $64.130,00$ & \\
\hline Belarus & $2.796,00$ & \\
\hline Austria & $10.397,50$ & \\
\hline
\end{tabular}

Fonte: dados extraidos e adaptados de UIS (2013) 
Gráfico 30 - Mobilização de alunos africanos por ano, 1999-2012

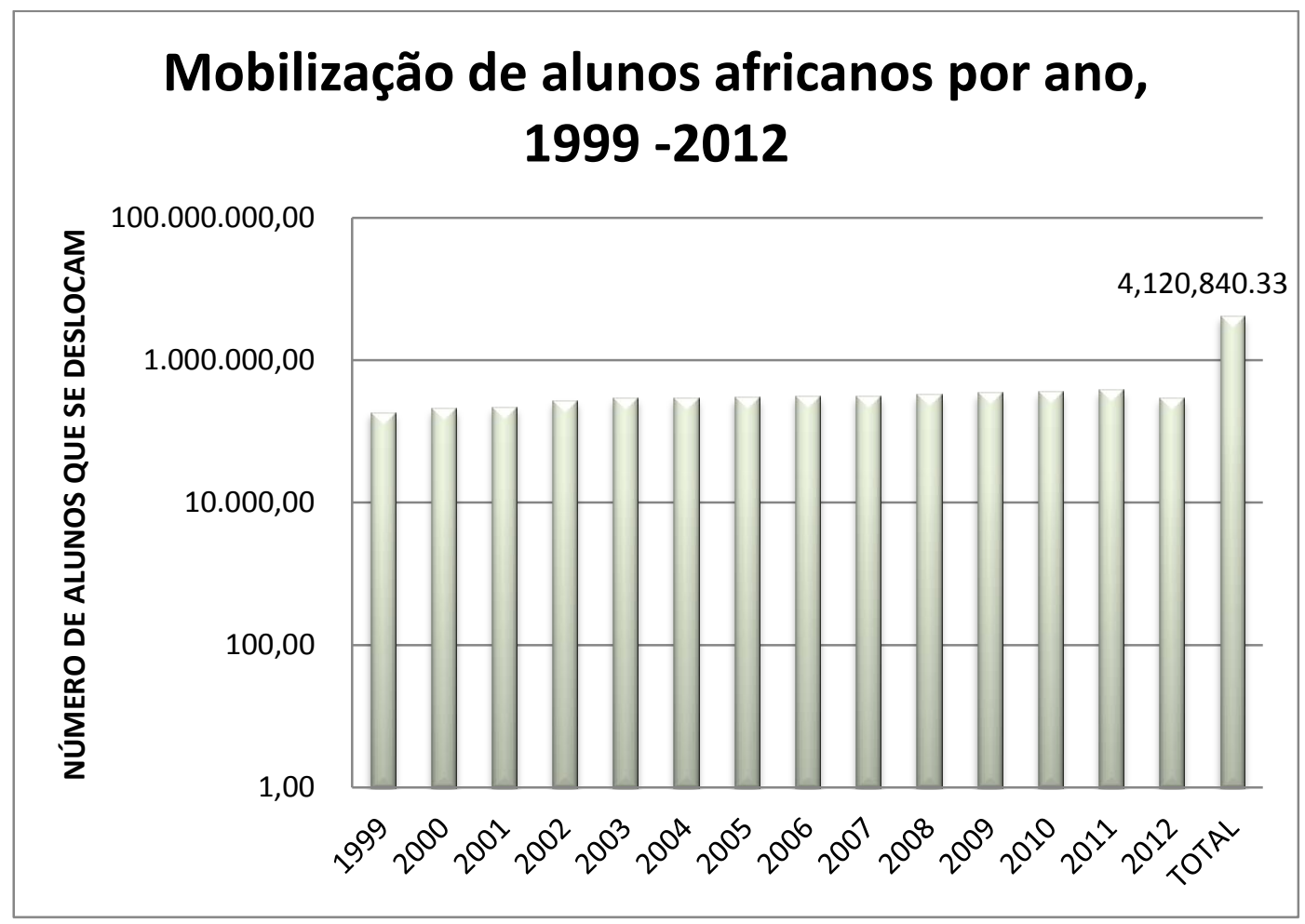

Fonte: Dados extraidos e adaptados de UIS/ISU (2013)

Esta cooperação tem como objetivo global contribuir para o avanço do desenvolvimento em África. De acordo com o relatório efetuado pelas Nações Unidas para a renovação da parceria global de desenvolvimento (pós-2015) a migração e as redes de conhecimento que proporciona são uma condição obrigatória para o século vinte e um. Indica que a migração e a mobilidade humana são conduzidas pelas oportunidades de desenvolvimento que produzem, assim como o desenvolvimento para a inovação e para a comercialização de novos produtos. Tendo em conta os prós e os contras desta mobilização a migração requere o apoio da cooperação a vários níveis, entre fronteiras e de vários Atores e Stakeholders (UN, 2013:15), destacando-se o sector privado, as organizações filantrópicas e as fundações, os quais desempenham um papel fundamental no desenvolvimento e em específico no que toca à saúde e à educação. Tem-se verificado que a cooperação para o desenvolvimento Sul-Sul tem desempenhado 
um importante papel enquanto complemento da cooperação Norte - Sul. Este tipo de ajuda tem um papel particular no que respeita à ajuda e contribuição em termos materiais (equipamento e produtos) mas também no que respeita a recursos humanos (voluntários, suporte técnico, troca de pessoal qualificado) uma vez que a troca de conhecimento, de experiências e de tecnologias contribui para promover o desenvolvimento de novas formas de parcerias (UN, 2013:16). Os novos atores da cooperação internacional, incluindo a cooperação Norte-Sul, Sul-Sul e Cooperação Triangular $^{75}$, em conjunto com a participação das organizações da sociedade civil, assim como as organizações da diáspora migratória, o sector privado e a filantropia, devem trabalhar em conjunto, de forma transparente e em colaboração com os beneficiários, apoiados por um sistema de monitorização e de responsabilidade mútua, de acordo com as capacidades de cada um dos atores e de acordo com o plano nacional de desenvolvimento.

\subsubsection{O papel das parcerias internacionais, os diferentes tipos de Atores e a sua relação com a educação}

Os Atores da cooperação internacional para o desenvolvimento e o Ensino Superior têm vindo a criar parcerias (bilaterais e multilaterais) desde longa data, constituindo um importante Ator externo de influência nas prioridades nacionais no desenvolvimento de recursos humanos (King, 2007), nos países em desenvolvimento, mas mais especificamente na África Subsariana. É, no entanto, relevante referir, tal como mencionado anteriormente, que existem diferentes níveis e tipos de Atores (desde departamentos governamentais e agências, organização não governamentais e semigovernamentais, fundações privadas e públicas, convenções e tratados, a instituições de educação e fornecedores), com diferentes missões (execução de políticas públicas, regulação, financiamento, advocacia e redes de trabalho) envolvidos na promoção, provisão e regulação da

\footnotetext{
${ }^{75}$ A Cooperação triangular é efetivada através de projetos planeados, financiados e implementados através de parcerias entre os países industrializados, potências emergentes e países em desenvolvimento. http://www.seer.ufrgs.br/austral/article/viewFile/40498/26974
} 
dimensão internacional do Ensino Superior (Tabela 12), o que comporta diversos tipos de programas e atividades (como por exemplo em atividades relacionadas com a mobilidade dos estudantes, investigação e desenvolvimento, currículo escolar, bolsas e qualidade da segurança, etc.) com implicações políticas e regulamentares ao nível internacional, regional e doméstico, muito embora a linha que separa estes níveis esteja cada vez mais ténue (Knight e Teffera, 2008), uma vez que todos os níveis de Atores se podem interrelacionar ou ter influência no desenvolvimento e na implementação de políticas, dos programas e da regulamentação na dimensão internacional. Estas redes de interação entre Atores tornam-se mais complexas quando analisadas num panorama nacional, bilateral, sub-regional, regional, inter-regional e internacional.

\section{Tabela 12 - Atores, o seu papel no desenvolvimento e a correlação com sua atividade na educação}

Tipo de Ator
Nível

Papel

Desempenhado

\begin{tabular}{c|ccc|}
\hline $\begin{array}{c}\text { Departamentos } \\
\text { Governamentais ou }\end{array}$ & Nacional & Elaboração de \\
Agências & & políticas & \\
ONG ou & Bilateral & Regulação & Mobilidade \\
Organizações & & & Académica \\
Semigovernamentais & & & Investigação \\
Associações & Sub-regional & Advocacia & Curriculum \\
Profissionais ou & Regional & Financiamento & Garantia de \\
Grupos de Interesse & & & qualidade \\
Fundações & Inter-regional & Programação & Ciência e \\
Instituições de & Internacional & Redes de Trabalho & Tecnologia \\
Educação e & & Disseminação da & \\
Fornecedores & & Informação & \\
& & \multicolumn{2}{c}{ Adaptado: Knight e Teffera (2008) }
\end{tabular}

Atividade 
Esta cooperação tem contribuído para que desde a última metade do século vinte se verifique, por parte da população africana, uma atitude mais ativista e voltada para a mudança, no sentido de obter uma maior equidade global, demonstrando maior confiança nas suas capacidades para o autodesenvolvimento. Esta confiança emerge fora da conceção de África que se move para a independência e para a democracia, onde se têm vindo a desenvolver esforços para acabar com os conflitos e para se manter a paz e a estabilidade (Seddoh, 2003). Cria-se a consciência de que o desenvolvimento da economia e do Estado social dependem da unidade do país, do seu povo e dos países que trabalham em conjunto para se fortificarem e para se introduzirem na economia mundial (NEPAD, 2002:21). As principais iniciativas, no âmbito da cooperação internacional, têm como foco promover a estabilidade das Instituições de Ensino Superior e criar centros regionais de excelência e desenvolvimento através da colaboração institucional.

É dada prioridade à utilização de experiências existentes, no sentido de obter maior coerência, coordenação e colaboração através destas iniciativas (Seddoh, 2003). As mesmas têm como objetivo atrair recursos financeiros de instituições multilaterais e bilaterais, de fundações privadas e de organizações regionais, de forma a colmatar um dos maiores problemas do Ensino Superior em África o qual está relacionado com o declínio significativo da sua qualidade. A principal causa deste declínio deve-se à diminuição de recursos durante os períodos em que houve um crescimento de matrículas como anteriormente verificado. Por outro lado, a criação de estruturas governamentais inapropriadas e o fraco desempenho na economia nacional não criam condições saudáveis para a criação de emprego (Seddoh, 2003). King (2007) acrescenta que um dos problemas do Ensino Superior Africano deve-se ao constante "estado de crise" impedindo que as mesmas contribuam para o desenvolvimento tendo em conta várias dimensões: falta de infraestruturas físicas e de comunicação (bibliotecas, laboratórios, salas de aula equipadas, equipamento informático e acesso às linhas de internet); fracos recursos humanos (desde professores a gestores e pessoal administrativo); financiamento insuficiente para atingir os objetivos estipulados no que respeita à expansão do 
Ensino Superior; e a diminuição da capacidade de efetuar investigação por estas instituições. De facto, como já identificado, a utilização das novas tecnologias, por parte das Instituições de Ensino Superior africanas, tem ainda um longo percurso a percorrer. É necessário estimular o crescimento tecnológico e um maior investimento na investigação e no desenvolvimento da inovação (Economic Report on África, 2013). Para tal é importante manter uma relação de cooperação entre as instituições de investigação e o sector empresarial de forma a adaptar o desenvolvimento tecnológico às reais necessidades locais, implicando um investimento no desenvolvimento do capital humano e intelectual.

Os programas internacionais de cooperação académica e científica constituem, assim, fatores importantes que permitem a circulação de estudantes internacionais e de pessoas qualificadas. Torna-se necessário refletir sobre os seus papéis para encorajar uma estratégia de brain gain que seja benéfica para toda a África, para a Europa e para os migrantes qualificados (Tejada, 2008), e não apenas no sentido apontado por King (2007) que identifica o processo de brain drain como negativo, interpretando o mesmo no sentido de fuga de profissionais qualificados para outros continentes, não obstante o facto de que esta situação também se possa verificar. Independentemente do fluxo de migração é relevante e preponderante repensar nas políticas públicas que promovem o acesso às Instituições de Ensino Superior, uma vez que as taxas de alunos, neste tipo de instituições, são ainda baixas não correspondendo às necessidades do mercado de trabalho, o que poderá refletir outro tipo de carências socioeconómicas e culturais. De acordo com esta perspetiva o papel do sector privado vislumbra-se cada vez mais importante.

\subsection{O papel do sector privado}

O papel do sector privado enquanto Ator para o desenvolvimento tem vindo a ser reconhecido de forma crescente. Por um lado porque cria emprego e fonte de rendimento o que, por sua vez, contribui para a redução da pobreza. Por outro 
lado, fornece bens e serviços para os mais pobres como por exemplo comida, telecomunicações e serviços financeiros e de saúde (European Union, 2013) ${ }^{76}$. Quanto maior for o dinamismo deste sector privado maior será o seu desenvolvimento em termos de inovação de forma a satisfazer a necessidade mais básicas da população mais carente. Este dinamismo permitirá a geração de taxas de imposto as quais permitem as autoridades públicas criar melhores condições ao nível da qualidade de vida, mas também ao nível das infraestruturas e ambiente comercial favorável a este sector. Desta forma, estão-se a criar e a reforçar as redes da sociedade civil as quais vão poder usufruir de melhores condições de vida promovendo um maior acesso à educação e aos serviços de saúde.

Tem-se verificado um apoio constante da União Europeia neste sector com especial enfoque nas pequenas e medias empresas, nomeadamente no que concerne ao reforço de políticas públicas (na áreas das marcas, inovação, competitividade e acesso a financiamento) de forma a construir melhores capacidades de negócio. Este apoio atingiu 2.4 bilhões de euros no período 20042010 (European Commission, 2013:44). O desenvolvimento do sector privado permite criar parcerias público - privadas as quais promovem o fornecimento de bens públicos em geral, e em particular sustenta a possibilidade de uma maior participação da população na educação não só nos níveis mais básicos, mas também ao nível do ensino superior, visto que as universidades podem criar programas científicos e de investigação que vão ao encontro das necessidades do sector empresarial favorecendo o seu desenvolvimento. Este sector constitui uma das áreas de preocupação na nova parceria global no pós-2015, uma vez que constitui uma fonte de rendimento doméstica, implicando a partilha de conhecimento e a inclusão.

\footnotetext{
${ }^{76}$ Annual Report (2013). Relatório sobre as políticas de desenvolvimento e de assistência externa da União Europeia e a sua implementação em 2012, elaborado pela Comissão Europeia, Direcção-Geral de Desenvolvimento e Cooperação - Europaid.
} 


\subsubsection{A Agenda do Desenvolvimento no pós-2015}

As principais recomendações efetuadas pelas agências internacionais no que concerne à Agenda de Desenvolvimento no pós-2015 estão relacionadas com os direitos humanos, a igualdade e a sustentabilidade, de forma a assegurar um desenvolvimento económico de inclusão, progresso social, sustentabilidade ambiental, paz e segurança. Esta agenda permite várias transformações de forma a responder às aspirações de todas as pessoas do mundo de forma livre, no entanto, inclui os objetivos do milénio ainda não terminados assim como a melhor forma de os finalizar. Num mundo cada vez mais globalizado existe a necessidade de renovar as parcerias globais para o desenvolvimento baseadas em fortes ações coletivas e compromissos transparentes dos países desenvolvidos (United Nations, 2013).

O sistema multilateral deve ser reforçado e deve compreender ações de monitorização dos compromissos no sentido de criar uma ligação entre as ações e os recursos com os resultados de desenvolvimento. Esta nova parceria tem como eixo prioritário o comprimento dos ODM não atingidos, mas também responder aos novos desafios globais. Os países com necessidades específicas requerem apoio especial dos parceiros globais. Para tal, é necessário uma melhor mobilização dos recursos - internos e externos - por parte da comunidade internacional, tendo em vista a implementação da agenda do desenvolvimento no pós-2015. Deve ser dada uma maior enfâse aos recursos internos - domésticos -, uma vez que os mesmos possibilitam a redução, a longo prazo, da dependência da ajuda e políticas externas. Assim, esta nova parceria global incentiva a efetiva colaboração entre a fonte da ajuda e os países destinatários, assim como adota um diálogo direcionado para a sustentabilidade da divida (United Nations, 2013).

Reconhece-se que o acesso à ciência, à tecnologia e à inovação sustenta o progresso em todas as dimensões do desenvolvimento, tendo como principal foco o crescimento económico (United Nations, 2013; UNESCO 2014). No entanto, na 
medida em que o conhecimento e a tecnologia são reconhecidos como um bem público, incorre na possibilidade de falta de investimento, o que pressupõe uma maior colaboração internacional de forma a suportar e apoiar a criação e a disseminação de tecnologias (United Nations, 2013). É necessário uma ligação e parcerias mais dinâmicas entre o público e o privado, não só no âmbito do financiamento, mas também na promoção da inovação, na catalisação internacional dos centros e das redes tecnológicos e na facilitação de atividades de I\&D.

Existe a preocupação de alinhar os interesses do sector privado com as investigações efetuadas pelos centros de investigação e instituições de ensino superior de forma a criar e a promover as tecnologias, produtos e serviços que melhor correspondem as necessidades do mercado. Para tal, é necessário formar recursos humanos com capacidades a este nível de desenvolvimento, mas também criar centros de transferência de tecnologia capazes de promover a propriedade intelectual e industrial. Esta abordagem deve ser considerada como central na parceria global pós-2015, tal como indicado pelas Nações Unidas e pela UNESCO, tendo implicações a vários níveis, uma vez que promove o crescimento económico e contribui para a prosperidade das sociedades e da vida humana ( Figura 4). 
Figura 4 - Correlação entre Educação e Crescimento Económico

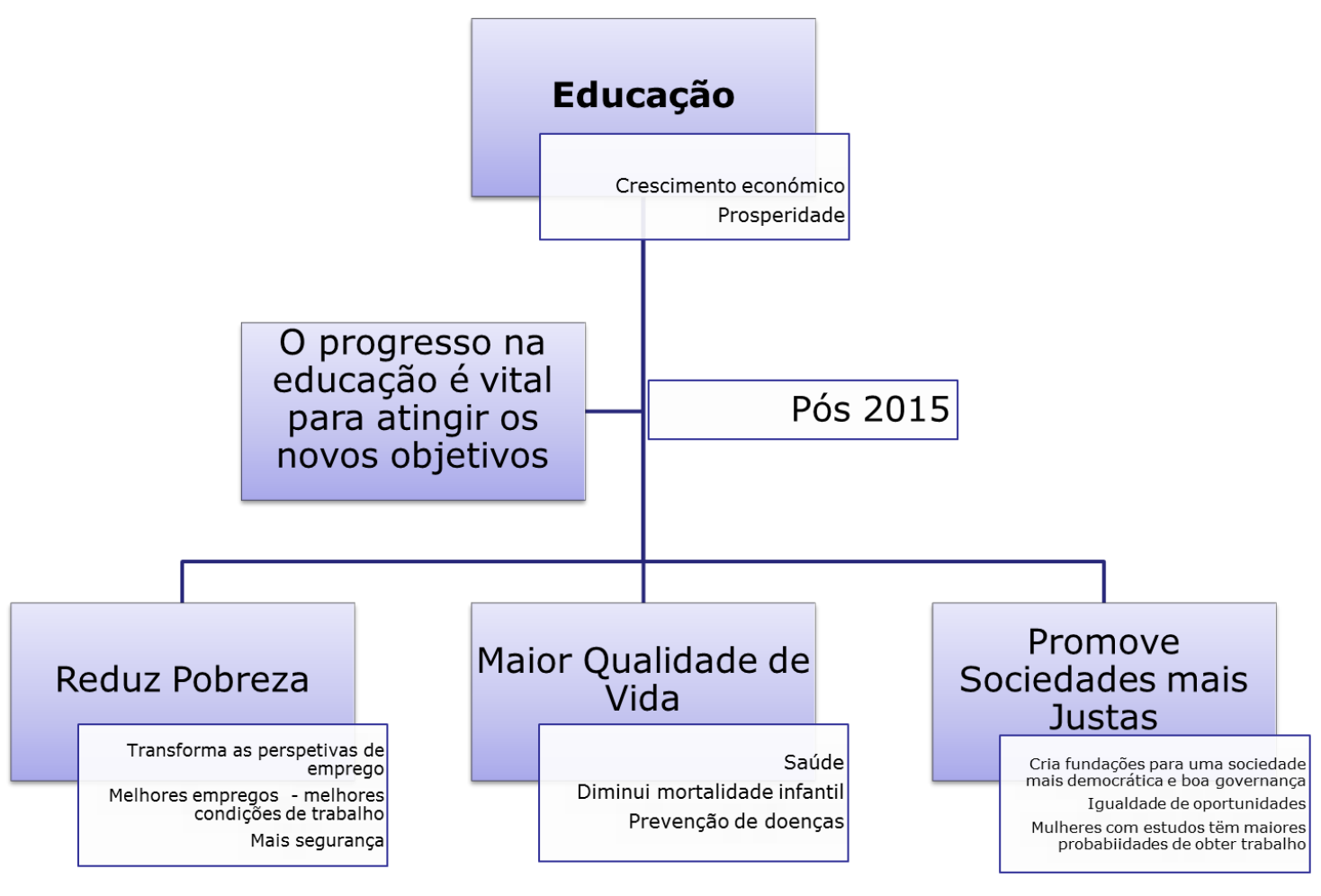

Adaptado de Nações Unidas (2013)

Esta nova parceria global para o desenvolvimento pretende ter em conta uma agenda universal, sustentada num quadro de responsabilidade possibilitando transformar promessas em compromissos efetivos. De acordo com o relatório das Nações Unidas (2013), a agenda global do desenvolvimento pós - 2015 tem três princípios: direitos humanos; igualdade e sustentabilidade. Indicam as quatro dimensões do desenvolvimento onde é necessários progressos: sustentabilidade ambiental; paz e segurança; desenvolvimento económico inclusivo e desenvolvimento humano (Figura 5). 
Figura 5 - Conceptualização dos objetivos de uma nova parceria integrada

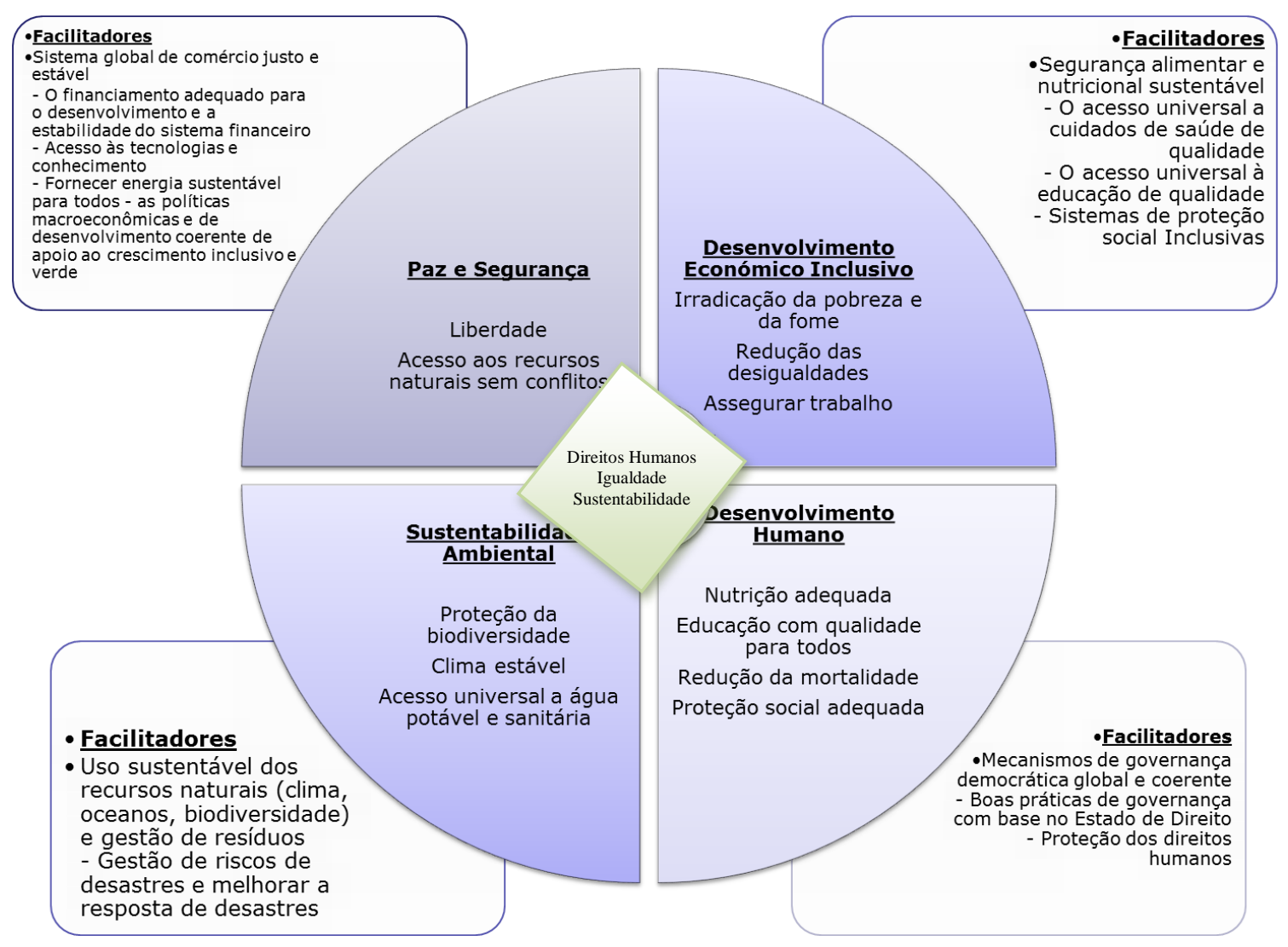

Adaptado de Nações Unidas (2013)

A nova agenda servirá como plataforma de ação da comunidade internacional e dos governos nacionais na promoção da prosperidade comum e do bem-estar para todos até 2030. Baseia-se no resultado da Cúpula Mundial sobre Desenvolvimento Sustentável de 2002, da Cúpula de 2010 sobre os ODM, o resultado da Conferência das Nações Unidas sobre Desenvolvimento Sustentável de 2012 (Rio+20) e os pontos de vista de pessoas em todo o mundo. Acordada pelos 193 Estados-membros da ONU, a agenda proposta, intitulada "Transformando Nosso Mundo: a Agenda 2030 para o Desenvolvimento Sustentável” , consiste numa Declaração, 17 Objetivos de Desenvolvimento Sustentável (Figura 6) e 169 metas, uma seção sobre meios de implementação e uma renovada parceria 
mundial, além de um mecanismo para avaliação e acompanhamento. Esta declaração reconhece que acabar com a pobreza deve caminhar lado a lado com um plano que promova o crescimento económico e responda a uma gama de necessidades sociais, incluindo educação, saúde, proteção social e oportunidades de trabalho, ao mesmo tempo em que aborda as mudanças climáticas e proteção ambiental, assim como prevê questões como desigualdade, infraestrutura, energia, consumo, biodiversidade, oceanos e industrialização.

\section{Figura 6 - Objetivos de Desenvolvimento sustentável aprovados na Cimeira} de 2015 pelos Acordada pelos 193 Estados-membros da ONU

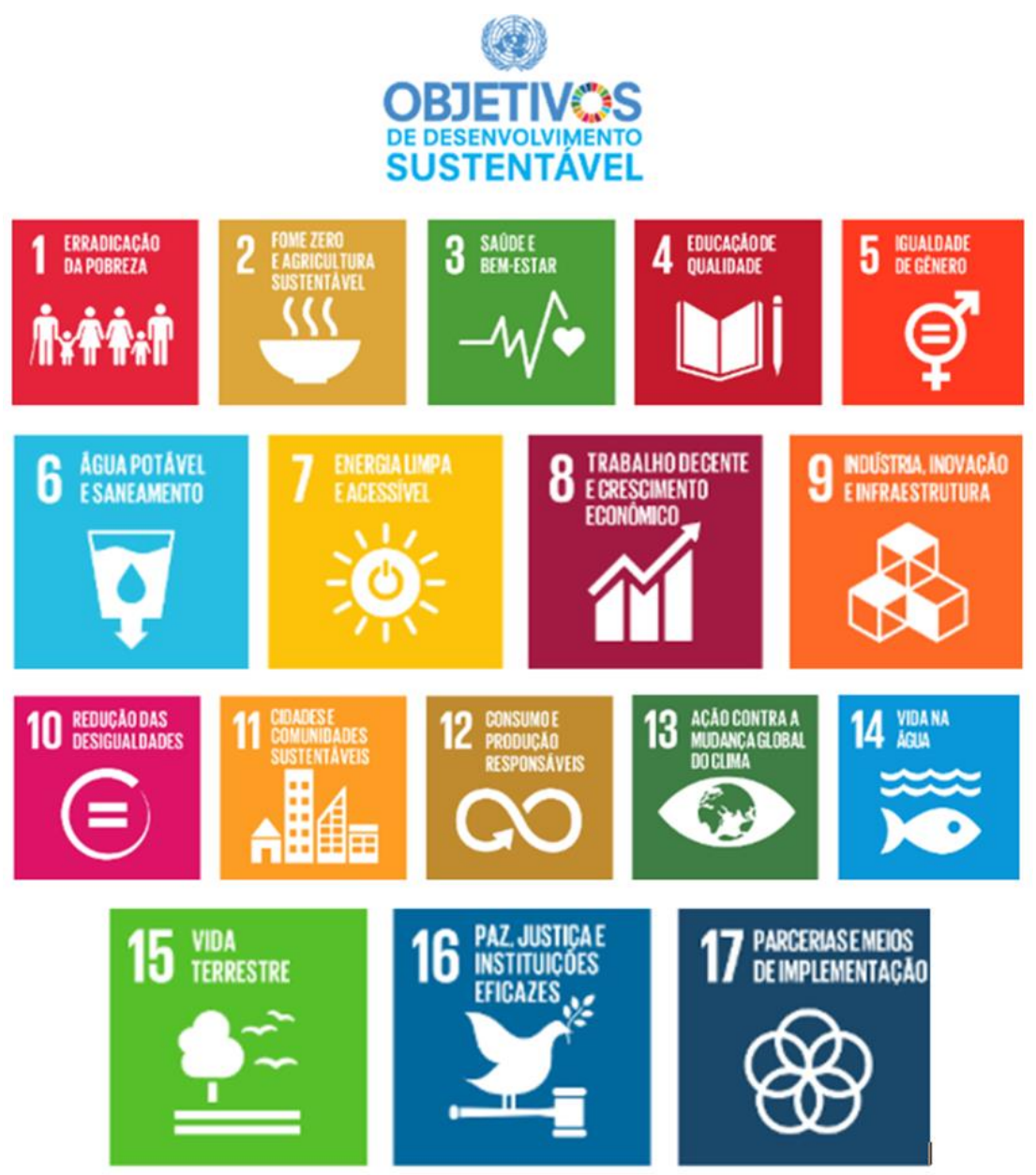


Nesta declaração os Atores Nacionais e Internacionais para o Desenvolvimento admitem a necessidade de mobilizar os meios necessários para implementar esta Agenda por meio de uma Parceria Global para o Desenvolvimento Sustentável revitalizada, com base num espírito de solidariedade global reforçada, concentrada em especial nas necessidades dos mais pobres e mais vulneráveis e com a participação de todos os países, todas as partes interessadas e todas as pessoas. Os vínculos e a natureza integrada dos Objetivos de Desenvolvimento Sustentável são de importância crucial para assegurar que o propósito da nova Agenda seja realizado. A efetivação desta Agenda implica a melhoria de vida de todos e de mundo melhor. A visão desta nova parceria reforçada implica um mundo com alfabetização universal, com acesso equitativo e universal à educação de qualidade em todos os níveis, aos cuidados de saúde e proteção social, onde o bem-estar físico, mental e social estão assegurados. Um mundo em que reafirmamos os nossos compromissos relativos ao direito humano à água potável e ao saneamento e onde há uma melhor higiene; e onde o alimento é suficiente, seguro, acessível e nutritivo. Um mundo onde habitats humanos são seguros, resilientes e sustentáveis, e onde existe acesso universal à energia acessível, confiável e sustentável. É, igualmente, reconhecido o papel essencial dos parlamentos nacionais através da promulgação de legislação e adoção de orçamentos, bem como seu papel na garantia da responsabilização para a implementação efetiva dos compromissos. Os Governos e as instituições públicas devem trabalhar em estreita colaboração na implementação com as autoridades regionais e locais, as instituições sub-regionais, instituições internacionais, universidades, organizações filantrópicas, grupos de voluntários e outros. De acordo com a evidência empírica demonstrada ao longo dos capítulos anteriores é possível constatar um papel cada vez mais importante e primordial dos Atores, externos e internos, no desenvolvimento de sociedades mais competitivas, inovadoras e numa economia sustentável com capacidade de desenvolver melhores condições de vida e de trabalho, para os seus cidadãos. É neste sentido que nos propomos a analisar o papel destes atores através da metodologia apresentada no capítulo seguinte. 
VNIVERSIDAD

DSALAMANCA 


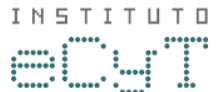

\section{PARTE II}

\section{METODOLOGIA}


VNIVERSIDAD

DSALAMANCA 
Capítulo 6

Metodologia Cientifica

Métodos e Técnicas

Wofogor 6 LGGingorr 
VNIVERSIDAD

DSALAMANCA 


\subsection{A Metodologia Científica}

A metodologia científica pode ser descrita como um caminho para atingir um fim na medida em que utiliza um determinado método que comporta regras e procedimentos adequados a uma pesquisa específica. Desta forma, o método científico baseia-se num “conjunto de dados iniciais e um sistema de operações ordenadas, adequado para a formulação de conclusões de acordo com certos objetivos predeterminados" (Gerhardt e Silveira, 2009). Para tal, é necessário a formulação da pergunta inicial a qual procura a resposta para uma dúvida ou problemática devidamente delimitada. Neste sentido, a metodologia agrega a teoria com os procedimentos, ou seja, utiliza os estudos já formulados e as conclusões obtidas com os métodos e as técnicas a serem utilizados na busca de resposta para a questão inicialmente proposta na pesquisa científica e na aferição das hipóteses.

$\mathrm{Na}$ pesquisa científica aqui proposta utiliza-se uma abordagem qualitativa na medida em que não é possível uma representação numérica dos dados propondo-se, sobretudo, o aprofundamento da compreensão de temática relacionada com a cooperação internacional em geral, e em especifico na área da educação, analisando diferentes grupos sociais identificados como os Atores, os quais são de difícil acesso devido as suas posições políticas o que dificulta a quantificar os dados analisados. $\mathrm{O}$ desenvolvimento da pesquisa é assim imprevisível. Neste sentido, tal como aponta Deslauriers (1991:58 in Gerhardt e Silveira, 2009) o objetivo da amostra é o de produzir informações aprofundadas e ilustrativas, a qual pode ser pequena ou grande dimensão, sendo que o mais importante é que produza novas informações.

Quanto à natureza podemos apontar que se trata de uma pesquisa de caráter aplicado na medida em que se pretendem gerar novos conhecimentos para aplicação prática, dirigidos à solução de problemas específicos, envolvendo verdades e interesses locais. 
Tendo em conta os objetivos podemos considerar que a pesquisa tem uma orientação exploratória, descritiva e explicativa. No primeiro caso porque se pretende a familiarização com o problema, no sentido de o tornar mais explícito para a construção das hipóteses. Para tal, irá proceder-se ao levantamento bibliográfico, ao contato com pessoas da área e à análise de exemplos que estimulem a compreensão do objeto de estudo. Na pesquisa descritiva iremos analisar informação que descreva os fatos e fenómenos da realidade em causa, nomeadamente no que concerne à evolução do ensino e, mais especificamente, do ensino superior na África Subsariana, assim como da descrição da situação económico-social das mesmas regiões. A análise documental será um complemento neste tipo de pesquisa. Por último, a pesquisa explicativa visa identificar os fatores que determinam ou contribuam para a ocorrência dos fenómenos identificados através dos resultados obtidos. Ou seja, pretende-se identificar qual o papel da cooperação internacional no que toca às parcerias entre as universidades europeias e africanas (com especial enfoque para a África Subsariana) no contexto do desenvolvimento. Implica, ainda, a identificação dos principais Atores do processo de cooperação, assim como perceber o verdadeiro impacto que o ensino superior poderá ter no progresso da economia e, consequentemente, na melhoria da qualidade de vida da população.

\subsection{Os procedimentos}

\subsubsection{Pesquisa bibliográfica}

Este tipo de pesquisa visa recolher informações e conhecimentos já existentes tendo em conta uma determinada problemática para a qual se pretende formular uma resposta tendo por base uma determinada hipótese. Esta pesquisa é feita através do levantamento de referências teóricas já analisadas, e publicadas por meios escritos e eletrónicos, com o objetivo de recolher informação de natureza teórica elaborada e 
tratada na produção científica existente sobre o problema em causa e para o qual se procura uma resposta (Fonseca, 2002:32), tal como demonstram Cervo e Bervian:

Explica um problema a partir de referenciais teóricos publicados em documentos. Pode ser realizada independentemente ou como parte da pesquiza descritiva ou experimental. Ambos os casos buscam conhecer $e$ analisar as contribuições culturais ou científicas do passado existente sobre um determinado assunto, tema ou problema (Cervo e Bervian, 1983:55).

Neste sentido, para o enquadramento teórico de base na presente investigação recorreu-se a pesquisa bibliográfica, ou seja todo o referencial já tornado público em relação ao tema de estudo, nomeadamente sobre a Cooperação Internacional em geral, e sobre a educação em específico, mas também sobre assuntos correlacionados ou bilaterais às áreas mencionadas. Entre a bibliografia consultada destacam-se os livros, os artigos científicos, as revistas, as monografias, as dissertações, as teses, as páginas de internet, entre outros.

\subsubsection{Pesquisa documental}

A pesquisa documental, embora facilmente confundida com a pesquisa bibliográfica, distingue-se pela análise de material que ainda não recebeu tratamento analítico ou que pode ser reelaborado de acordo com os objetivos da pesquisa. Visa organizar informações que se encontram dispersas conferindo-lhe uma nova dimensão. Para tal, os dados deverão ser selecionados, tratados e interpretados dando-lhes uma nova importância. Esta pesquisa recorre a fontes mais diversificadas e dispersas, sem tratamento analítico, tais como: tabelas estatísticas, jornais, revistas, relatórios, documentos oficiais, entre outros (Fonseca, 2002:32). Os documentos aqui retratados e analisados estão estreitamente relacionados com relatórios e documentos oficiais na 
área da cooperação internacional, nomeadamente relatórios de análise do comprimento dos ODM nos países em desenvolvimento objeto deste estudo, por parte dos Atores internacionais, assim como documentos relacionados com o atual panorama económico-financeiro, com a situação ao nível do ensino em geral e em especifico o ensino superior. Em termos quantitativos, serão analisados e adaptados ao estudo em causa os dados estatísticos já existentes em bases de dados de organizações internacionais, como: UNESCO Institute for Statistics; OECD; EFA; Nações Unidas; Banco Mundial; Entre outros.

\subsubsection{Pesquisa com Inquérito}

Esta pesquisa utiliza o questionário como instrumento de recolha de informação direta junto de um grupo de interesse, devidamente categorizado, previamente determinado de acordo com os dados que se pretendem obter. Este procedimento permitirá tirar conclusões e/ou induções relacionadas com a pesquisa exploratória e descritiva na medida que recolhe dados sobre as características e perspectivas deste grupo de pessoas representante de uma população-alvo e que aqui se identifica como Atores os quais são mapeados e apresentados através da caracterização do Modelo CATWOE para o Sistema de Ensino Superior em África. São considerados Atores relevantes as autoridades governamentais, as autoridades de instituições públicas, nomeadamente Universidades, bem como instituições privadas e da sociedade civil. Assim, os resultados obtidos através dos inquéritos (com questões predominantemente abertas) aplicados à população alvo, irão ser analisados (análise qualitativa de conteúdo) para obter outro tipo de elementos que não estão disponíveis nas estatísticas. $\mathrm{O}$ questionário foi testado antes da sua utilização definitiva pelos orientadores da pesquisa $^{77}$. Para o estudo e caracterização do sistema de parcerias entre universidades, ter-se-á por base o modelo CATWOE. Este consiste numa checklist para repensar nos problemas e nas soluções de acordo com os princípios que se apresentam mais adiante. Por fim será, naturalmente, levado em linha de conta o conhecimento real do

\footnotetext{
${ }^{77} \mathrm{O}$ Inquérito final poderá ser consultado no Anexo 16 - Inquérito.
} 
terreno e os diversos contactos e encontros, formais e informais, estabelecidas por ocasião de possíveis deslocações.

O inquérito utilizado foi construído através da operacionalização dos principais eixos temáticos do estudo em causa. Neste sentido, apresenta-se, em seguida, a relação entre estes eixos e as perguntas realizadas para uma melhor perceção da divisão do trabalho realizado e a sua posterior análise (Parte III - Análise de Dados) aquando da aplicação do modelo de CATWOE, assim como das conclusões inferidas.

\begin{tabular}{|c|c|}
\hline & $\begin{array}{c}\text { Part I } \\
\text { Public Educational Politics }\end{array}$ \\
\hline \multirow{9}{*}{$\begin{array}{c}\text { Capitulo } \\
1\end{array}$} & $\begin{array}{l}\text { 1. Do you consider education as a public good that should be given to } \\
\text { everybody? }\end{array}$ \\
\hline & $\begin{array}{l}\text { 1.1. In which level of education do you think that the States should } \\
\text { provide to the people for free? }\end{array}$ \\
\hline & $\begin{array}{l}\text { 1.2. At what level should International actors for development } \\
\text { interfere? }\end{array}$ \\
\hline & $\begin{array}{l}\text { 2. Having in mind the mission of education, and in your opinion, what } \\
\text { kind of institutions do you think that the countries in development } \\
\text { should create/support: private or public? }\end{array}$ \\
\hline & $\begin{array}{l}\text { 2.1. What kind of support should the international actors give to each } \\
\text { one of them? }\end{array}$ \\
\hline & $\begin{array}{l}\text { 2.2. In your opinion do you think that education contributes to the } \\
\text { development of the local economies as well for the national ones? }\end{array}$ \\
\hline & $\begin{array}{l}\text { 2.2.1. If yes, can you please identify the areas where it might have a } \\
\text { bigger impact? }\end{array}$ \\
\hline & $\begin{array}{l}\text { 2.2.2. Which level of education is more important for this } \\
\text { development? }\end{array}$ \\
\hline & $\begin{array}{l}\text { 3. In your opinion, does a higher level of education guarantee better } \\
\text { conditions of life? }\end{array}$ \\
\hline
\end{tabular}




\section{Part II \\ Higher Education in Africa}

1. Considering the particularity of the African continent, and in particular, the countries of Sub-Saharan Africa, do you think that higher education plays an important role in the development of these countries?

2. What areas do you think that higher education should provide courses in order to face regional and national socio-economic problems?

2.1. Considering the fact that the new development agenda is the successor of the Millennium Development Goals, do you think that higher education should be one of the preoccupations of this new development agenda post 2015?

3. What challenges do universities face in countries in development?

\begin{tabular}{|c|c|}
\hline & $\begin{array}{l}\text { Part III } \\
\text { Financial System in Africa Higher Education Institutions }\end{array}$ \\
\hline \multirow{5}{*}{$\begin{array}{l}\text { Capitulo } \\
3\end{array}$} & $\begin{array}{l}\text { 1. What kind of financial support do you believe that would fit better } \\
\text { the needs of higher institutions, in development countries? }\end{array}$ \\
\hline & $\begin{array}{l}\text { 2. What kind of financial contribution do the international agencies } \\
\text { for development should give to these institutions? }\end{array}$ \\
\hline & 3. In your opinion is it sufficient? \\
\hline & $\begin{array}{l}\text { 4. What kind of support do you think that the agencies could give to } \\
\text { universities? }\end{array}$ \\
\hline & $\begin{array}{l}\text { 5. Do you have an idea of how much your institution has been given } \\
\text { to support Africa sub-Saharan higher institutions? }\end{array}$ \\
\hline
\end{tabular}


6. This financial support comprises some measures to assess how it is spent by the countries in development?

7. Does this kind of support have in count the student's needs?

7.1. And what about inequalities and financial difficulties of the students?

\section{Part IV \\ Academic Cooperation EU - Africa}

1. In your opinion the academic cooperation between EU and Africa is important for the development of qualified human resources?

2. Do you think that universities have a strategic role on the progress of economies in development?

3. In your opinion the technological development in Africa is dependent of the academic cooperation?

4. Do you consider that government policies of the developing countries are supporting technological development? In what level: regional, national or international?

5. In your opinion the academic cooperation between EU and Africa has been promoting better conditions for students?

5.1. And for the population in general? Can you please explain your point of view?

6. Do you think that this cooperation might have increased the number of students in the universities in Africa?

7. In your opinion the academic cooperation favours the migration of students?

8. What kind of consequences / advantages you think are most prevalent? 


\subsection{Instrumentos de análise}

\subsubsection{Análise de conteúdo}

A análise de conteúdo é definida como um conjunto de técnicas de análise de comunicações que utiliza procedimentos sistemáticos e objetivos de descrição do conteúdo das mensagens (quantitativos ou não) que permitam a inferência do conhecimento relativos às condições de produção / receção (variáveis inferidas) dessas mensagens (Bardin, 1994; Silva, 2003). Tem uma função heurística na medida em que enriquece a tentativa exploratória e aumenta a propensão à descoberta, assim como se refere à administração da prova onde as hipóteses servem de diretrizes apelando para o método de análise de uma confirmação ou infirmação das mesmas. Trata-se de um método que pode ser aplicado tanto na pesquisa quantitativa como na qualitativa, embora com aplicações diferentes (Bardin, 1994; Silva, 2003). A análise de conteúdo constitui uma ferramenta para a compreensão do discurso de determinados Atores sociais permitindo entender as representações que o individuo apresenta em relação à realidade que se pretende estudar e a interpretação que faz dos significados à sua volta. Neste sentido, e tendo como foco o presente estudo, elaboraram-se questionários abertos os quais foram submetidos a uma população alvo previamente definida e categorizada, para obter a compreensão destes mesmos Atores em relação à realidade em causa - a cooperação internacional para o desenvolvimento. Após a recolha dos dados necessários procedeu-se à análise e interpretação das informações colhidas para, a posteriori, se passar à etapa da conclusão. Os dados obtidos carecem de tratamento com o intuito de inferir saber. Os dados numéricos foram tratados com a ajuda de instrumentos estatísticos, enquanto os dados de carácter literal foram objetivo de análise de conteúdo. Esta consistiu em três fases: a pré-análise onde se efetuou a exploração do material e tratamento de dados de acordo com procedimentos definidos; a exploração do material com o intuito de cumprir as decisões anteriormente delimitadas; e o tratamento dos resultados onde nos propomos a analisar os resultados e a torna-los significativos e válidos no que concerne à cooperação para o desenvolvimento em geral, e em especifico, no que 
respeita à cooperação académica entre a Europa e os países da África Subsariana e a consequente ação dos Atores, Internos e Externos, neste campo, como se demonstra mais adiante, complementando esta investigação através do instrumento de análise CATWOE, inferindo-se as respostas às hipóteses inicialmente propostas.

\subsubsection{O instrumento de análise: CATWOE}

A investigação baseia-se em dados quantitativos e qualitativos, numa abordagem multidisciplinar envolvendo sobretudo a economia mas também outras áreas complementares de análise, como já demonstrado. Em termos qualitativos, recorrerá à recolha e consulta de diversa bibliografia teórica de base nas áreas em causa, em particular no domínio das Instituições de Ensino Superior nos países em desenvolvimento - África Subsariana, bem como na Europa. Utiliza alguns estudos já realizados por diferentes autores, quanto à viabilidade de implementação de parcerias, assim como dados estatísticos. Procurando-se, no entanto, obter outro tipo de elementos que não estão disponíveis nos estudos e estatísticas, pelo que se procedeu à elaboração de um instrumento de recolha de dados, nomeadamente um inquérito de respostas abertas. A investigação utiliza os resultados destes e de entrevistas realizadas a diferentes camadas da população, incluindo Autoridades Internacionais e Governamentais, a Instituições Públicas (envolvendo dirigentes de Universidades), bem como instituições privadas e da sociedade civil os quais serão designados como os principais Atores. Para o estudo e caracterização do sistema de parcerias entre instituições de ensino superior, tem-se por base o modelo CATWOE. Este consiste numa checklist para pensar nos problemas e nas soluções de acordo com os princípios que se apresentam mais adiante. Esta metodologia consiste numa das técnicas de modelação mais conhecidas na perspetiva da Soft Systems Metodology (SSM). Tem como objetivo reconhecer o papel da imagem que os indivíduos têm do mundo e a influência do seu passado histórico na interpretação da realidade (Jayaratna, 1994:176). A SSM surgiu nos anos oitenta com Checkland, a qual derivada da Teoria Geral de Sistemas (também conhecida como T.G.S.) que surgiu com os trabalhos do 
biólogo austríaco Ludwig von Bertalanffy, publicados entre 1950 e 1968. Esta teoria não pretende solucionar problemas ou tentar soluções práticas, mas sim produzir teorias e formulações conceituais que possam criar condições de aplicação na realidade empírica. $\mathrm{O}$ seu pressuposto básico passa pela necessidade de se avaliar a organização como um todo e não somente em departamentos ou sectores. Identifica o maior número de variáveis possíveis, externas e internas que, de alguma forma, influenciam o processo existente na Organização. A Teoria dos Sistemas começou a ser aplicada na administração principalmente em função da necessidade de uma síntese e de uma maior integração das teorias anteriores (Científicas e Relações Humanas, Estruturalista e Comportamental oriundas das Ciências Sociais) e da intensificação do uso da cibernética e da tecnologia da informação nas empresas (Chiavenato, 1999). Permite repensar os fenômenos numa abordagem global, possibilitando a inter-relação e a integração de assuntos que são, na maioria das vezes, de natureza completamente diferentes. No seguimento desta abordagem global, a Soft Systems Metodology surge como um sistema de análise da atividade humana a qual pode ser percecionada de diferente formas baseando-se num sistema de aprendizagem continua e na participação sendo, por isso, considerado como um sistema na medida em que interrelacionada as diferentes partes de acordo com um determinado principio e causa gerando uma rota "simples" para a análise do paradigma. De um ponto de vista sistemático, o estabelecimento de metas no plano e a tomada de decisão são um pré-requisito para se estabelecerem ligações causais entre os meios e os fins (Khisty, 1995). Neste sentido, a Soft Systems Metodology de Checkland pode ser considerada como um exemplo concreto de uma metodologia sistémica para resolver problemas reais tentando delinear a rota do problema através de questões sucessivas, aprendendo sobre o mesmo através de perguntas e/ou de relações históricas, as quais são consecutivamente analisadas, no sentido de tomar ação sobre o mesmo. Esta ação não visa propriamente a sua resolução mas sim argumentar e debater sobre os problemas do mundo real.

De acordo com Checkland trata-se de uma ferramenta de aprendizagem que utiliza um sistema de ideias para organizar quatro processos mentais básicos: perceber; 
prever; comparar; e determinar mudanças e ações necessárias. O resultado deve ser encarado como o reconhecimento, a aprendizagem e a introspeção (Doumitt, 1990 in Khisty, 1995). Os elementos que compõe a estrutura da Soft Systems Metodology são conhecidos como CATWOE. Esta é a palavra mnemónica para os seguintes termos: Customer, Actor, Transformation, Weltanshauunh, Owner and Enviromental, ou seja, Cliente, Ator, Transformação, Visão do Mundo e Ambiente. Desta forma, tem como foco modelar perspetivas de acordo com um problema ou de acordo com questões ou assunções (Bergvall-Kareborn et al, 2004), para melhor compreender uma realidade social. Combina elementos como a intuição, a experiência no mundo real, assim como o sistema formal (Smyth e Checkland, 1976). Cada um dos seus elementos é essencial para uma análise fidedigna. Se um dos elementos não for tido em conta a análise final poderá sofrer alterações. De acordo com o estudo efetuado por Bergvall-Kareborn et al (2004) os elementos Ownership (O) e Actors (A) são omissos com frequência apesar do principal objetivo do CATWOE se relacionar com o processo de Transformation (T) e a Worldview (W). No entanto, ao longo dos tempos foi verificado que uma rota bem definida deveria seguir a seguinte forma (BergvallKareborn et al, 2004): um O - Owned e um A - sistema operacional afetam C, transformam $\mathrm{T}$ para um novo estado do $\mathrm{T}$ de acordo com alguns $\mathrm{W}$ dentro dos constrangimentos do E. Apesar deste sistema de modelagem pouco se ter alterado ao longo dos tempos (desde 1970), o que permite evidenciar a sua forte capacidade de análise da realidade bem como na tentativa de solucionar um problema ou questão, não está, contudo, isento de críticas, uma vez que Mingers (1992) aponta algumas falhas de análise teórica pois o seu mecanismo é dominado pelos input-output da Transformação, não tendo em conta o processo em si. Acresce o facto de que a estrutura dá a ideia de um processo estático e estabilizado, não incluindo aspetos de aprendizagem e de desenvolvimento (Bergvall-Kareborn et al, 2004), fazendo com que a distinção entre o mundo real e o mundo conceptual seja difícil de desenhar.

De acordo com o autor desta teoria a descrição dos elementos é apresentada da seguinte forma: 
- A Transformation - T - representa a atividade a ser modelada, expressa como o processo de transformação, formulado como input - output, ou seja, Input $\mathrm{T}$ - Output. Esta fórmula permite estabelecer conexões entre a situação atual (input) e uma possível situação futura (output). Desta forma, pretende-se traçar um mapa onde seja possível visualizar onde a Transformação poderá ter maior ou menor impacto. Mingers (1992) acredita que, desta forma, é possível verificar o que o sistema atualmente faz com precisão e consistência. Não deixa, no entanto, de ser alvo de críticas, uma vez que alguns autores consideram que constitui um erro comum de confundir o input, o qual foi transformado no output com os recursos necessários para levar a cabo o processo de transformação (Checkland \& Scholes, 1999). Um dos aspetos positivos desta análise prende-se com o facto de que enfatiza o elemento humano que tem e define as suas necessidades. Tendo em conta as fraquezas e forças da Transformation é necessário ter cautela na sua utilização de acordo com escolhas conscienciosas e com o contexto.

- O elemento Weltanschauung - W - está relacionado com a visão do mundo sobre a problemática tentando explicar o significado da ação do T, estando diretamente relacionado com a perspetiva dos participantes. Por outro lado, permite ser utilizado com vários sentidos durante o processo de construção do modelo de análise (Fairtlough, 1982). Para clarificar a sua utilização foram introduzidos três níveis: $\mathrm{W} 1, \mathrm{~W} 2$ e $\mathrm{W} 3$. O primeiro representa o $\mathrm{W}$ no CATWOE o qual indica o objetivo do sistema. O segundo está relacionado com o problema permitindo perceber a relevância do W1. O terceiro nível está relacionado com as nossas crenças e assunções sobre a realidade fazendo-nos perceber as representações sociais. Ainda assim, estes níveis podem não estar correlacionados com os problemas efetivos das pessoas. Para estas o $\mathrm{W}$ pode estar relacionado com as mudanças que se desejam e não as que de facto seriam necessárias. Numa tentativa de colmatar esta falha Bergvall-Kareborn (2002a) introduziu o conceito de "Qualificação de Funções" o qual deverá enriquecer o significado do W. Introduz aspetos relacionados com o espaço, 
físico, biológico, lógico, histórico, social, económico, jurídico e étnico. Estas dimensões permitem uma análise que enfatiza os aspetos mais relevantes, clarificando e relacionando os vários elementos de acordo com os papéis profissionais, responsabilidades e interesses (Bergvall-Kareborn et al, 2004).

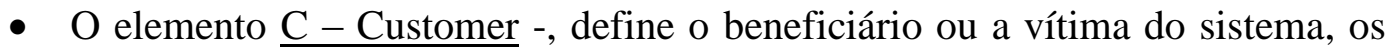
quais podem, no entanto, não ser os seus clientes diretos nem estar envolvidos nas suas atividades (Mingers, 1992).

- O $\underline{\text { Owner - }}$-, por outro lado, é definido como aquele que tem capacidade e poder para parar a Transformação (Checkland e Scholes, 1999), ou seja, aquele(s) que têm poder para "parar o sistema" . Este conceito aplica-se tanto às instituições privadas como públicas, incluindo as estruturas de poder formais e informais, e cujo poder pode balançar o sistema, o qual pode ser originário de vários níveis profissionais. Por sua vez o Ator é considerado como aquele que efetiva as transformações. Neste sentido, importa ter em conta que o impacto do Ator estará relacionado com os grupos com os quais se relaciona ao nível profissional e académico. Estes aspetos irão certamente afetar a forma como a transformação é levada a cabo.

- Por fim, os constrangimentos ambientais são considerados como aqueles que estão fora do sistema os quais são dados como adquiridos (Checkland \& Scholes, 1999). Alguns exemplos destes elementos podem ser considerados como o tempo, os recursos, as infraestruturas, normas, ética, tecnologia, objetivos da organização e definição do projeto. Estes aspetos podem ser de primordial importância uma vez que podem alterar em vários sentidos as linhas traçadas anteriormente para o sistema.

Tendo em conta estes elementos foi delineada a estratégia metodológica de acordo com uma modelagem apropriada ao estudo em causa definindo cada um dos elementos de forma adaptada para posterior análise e de acordo com o enquadramento 
teórico apresentado, referente à importância das universidades africanas no sistema de educação ao nível do ensino superior, essencialmente no que se refere ao impacto que têm no desenvolvimento, assim como qual o papel que a cooperação internacional tem no âmbito da ajuda ao desenvolvimento enquanto doadora de fundos aplicados nas Instituições de Ensino Superior.

\subsubsection{Caracterização do Sistema Educativo}

Tendo em conta o anteriormente exposto concluímos, resumidamente, que a Constituição do Modelo CATWOE passa pela abordagem dos seguintes fatores: 
$\mathrm{E}=\mathrm{ENVIRONMENT}$

- os limites / constrangimentos a que o sistema está sujeito tais como regulamentos, constrangimentos financeiros, fracos recursos, leis nacionais / internacionais, ética, etc.

$\mathrm{O}=$ OWNERS

- O sistema em si ou quem tem poder no sistema para instituir regras ou abolir as existentes

\section{Sistema}

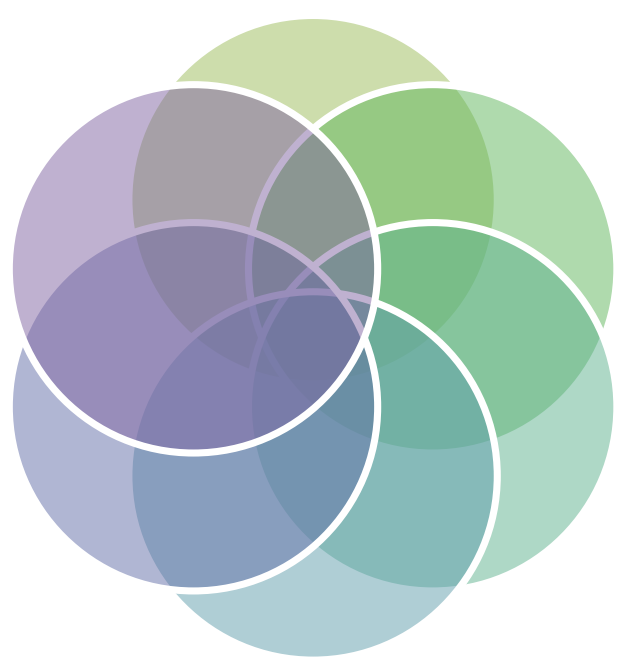

$\mathrm{A}=$ ACTORS OR AGENTS

-Atores que desenvolvem atividades / definem regras para transformar inputs em outputs

$\mathrm{T}=$ TRANSFORMATION PROCESS

- O que o sistema faz para levar a cabo as transformações

\section{$\mathrm{W}=\mathrm{WELTANSCHAUUNG}$ ou WORLD VIEW \\ - A visão que o exterior tem dos outputs e as suas consequências}

\subsubsection{A definição da rota ao nível do Ensino Superior}

O modelo CATWOE deve ter em conta todos os seus elementos na definição da estratégia a seguir, o que implica: um sistema que pertence a $\underline{\mathbf{O}}$ para fazer $\underline{\mathbf{W}}$ através de $\underline{\mathbf{A}}$ tendo em conta os constrangimentos de $\underline{\mathbf{E}}$ para atingir o objetivo $\underline{\mathbf{T}}$ para $\underline{\mathbf{C}}$. Assim, definição da estratégia implica o Sistema $\underline{\mathbf{T}}$ no qual $\underline{\mathbf{A}}$ faz $\underline{\mathbf{W}}$ para $\underline{\mathbf{C}}$. Logo, a caracterização do Modelo CATWOE para o Sistema de Ensino Superior Universidade ou Instituto Superior - deverá ser definido da seguinte forma ( Figura 7): 


\section{Figura 7 - Caracterização do Modelo CATWOE para o Sistema de Ensino Superior}

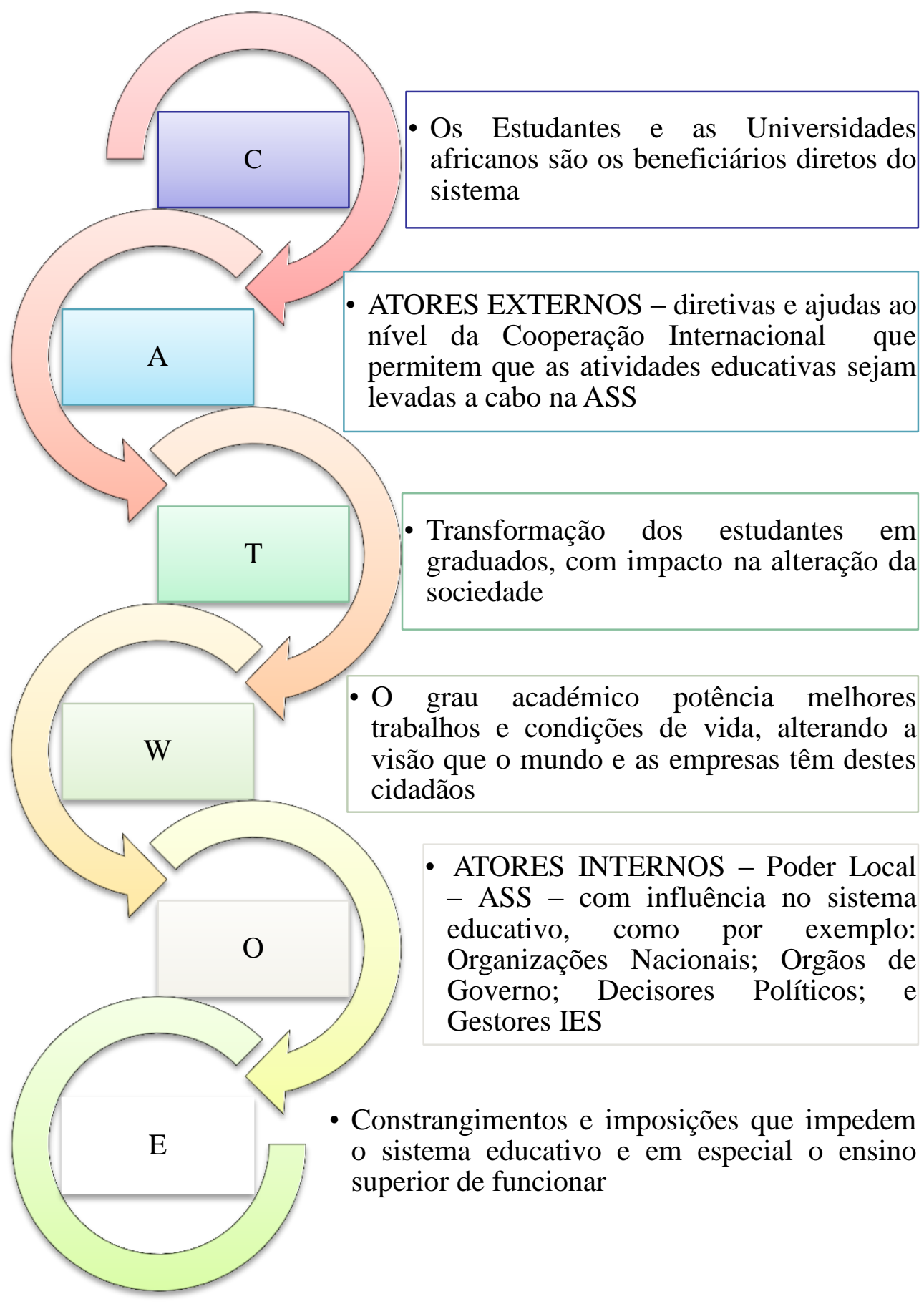

Desta forma a análise CATWOE segue uma rota bem definida onde as Instituições de Ensino Superior possuem um Sistema que concede graus académicos aos estudantes (X) que se qualificam com sucesso de acordo com uma determinada avaliação (Y) e 
de acordo com normas estabelecidas de forma a garantir uma certificação (Z) para potenciais empregadores assegurando que os estudantes possuam a proficiência, capacidades e qualificações requeridas. Estamos perante um sistema que faz $\mathrm{X}$, através de Y para atingir Z. Contudo, é necessário ter em consideração o papel dos "Atores" externos a este processo e o seu real impacto no contributo para o desenvolvimento das Instituições de Ensino Superior nos países em desenvolvimento, os quais foram identificados anteriormente da seguinte forma (Figura 8):

\section{Figura 8 - Papel dos "Atores" internos}

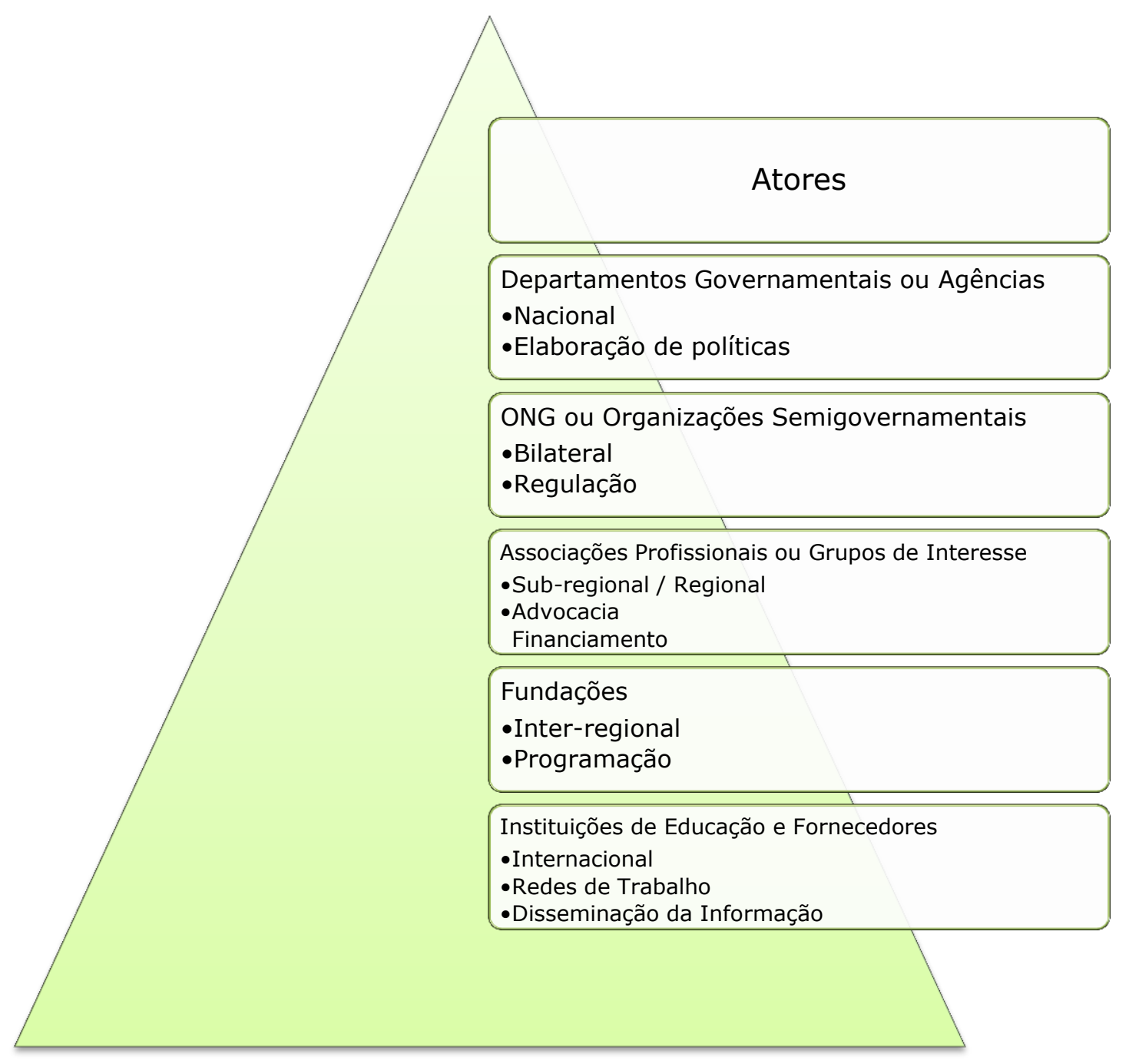


Por outro lado, torna-se conveniente analisar o efetivo contributo dos agentes externos, correlacionando o seu input com o output pretendido, ou seja, se as taxas de estudantes que finalizam os cursos superiores correspondem às necessidades do mercado envolvente, assim como estão adaptadas ao mercado de trabalho e às pretensões dos seus potenciais empregadores. Esta abordagem implicaria uma abordagem sistémica do ensino superior a qual incorpora a parceria com a indústria para atingir um resultado ótimo no que respeita ao desenvolvimento dos recursos humanos, especialmente nas áreas que estão confinadas com a ciência e a tecnologia, proporcionando a construção de uma ponte entre a indústria e o sistema educacional. De acordo com esta perspetiva desenhou-se a Caracterização do Modelo Conceptual CATWOE no âmbito do Ensino Superior tendo em conta os diferentes Atores (internos e externos), e a representação da relação das diferentes etapas do sistema, no contexto da África Subsariana (Figura 9). 
Figura 9- Caracterização do Modelo Conceptual CATWOE no âmbito do Ensino Superior tendo em conta os diferentes atores (internos e externos), e a representação da relação das diferentes etapas do sistema, no contexto da África Subsariana

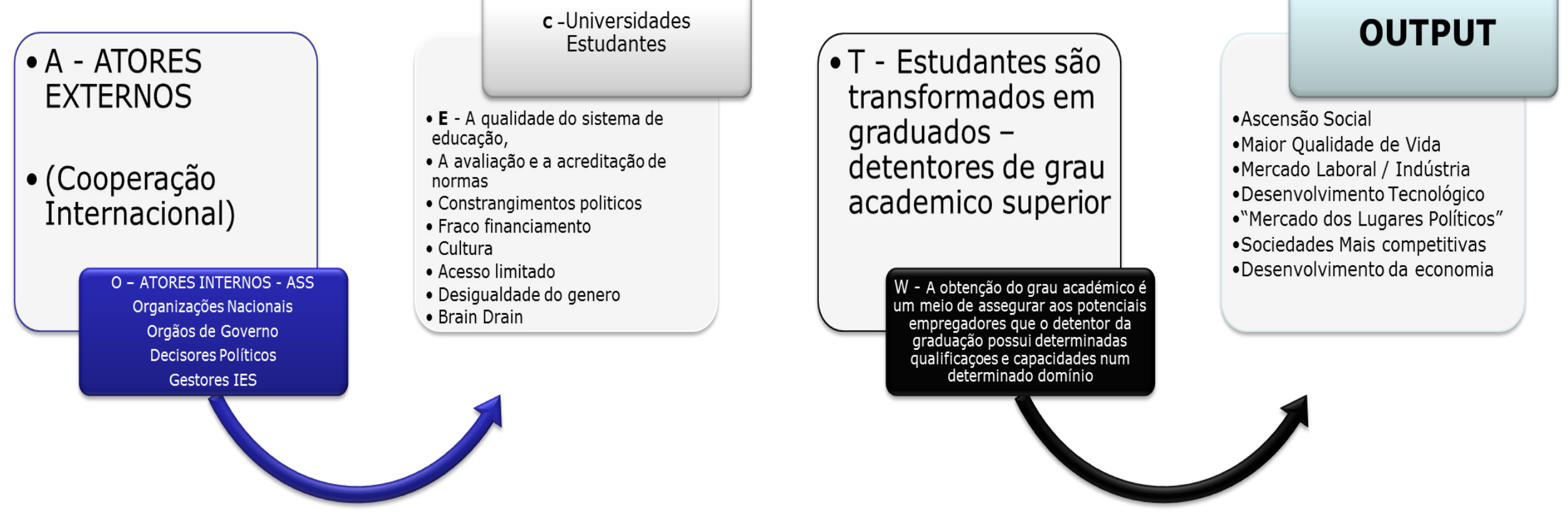




\subsubsection{Identificação dos Atores Externos - Cooperação Internacional}

Os atores externos apresentam-se no seguinte diagrama:

\section{Atores Externos}

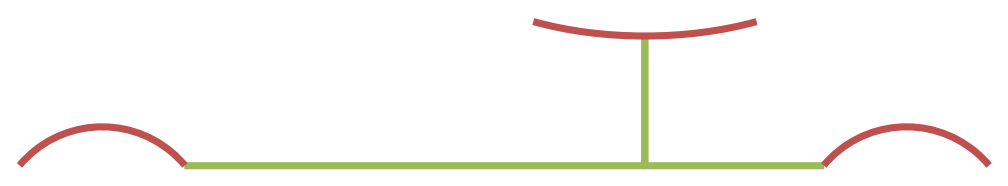

Atores Europeus

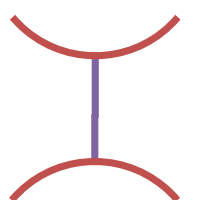

Estados Doadores

Principais doadores da

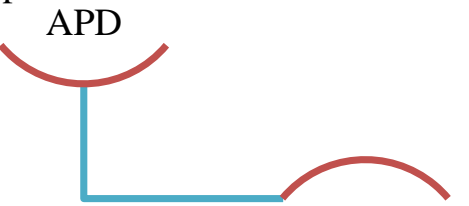

União Europeia
Atores Internacionais

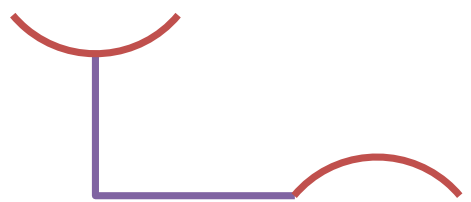

Organizações Multilaterais BM, FMI, NU, OCDE

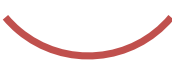


Os atores internos apresentam-se no seguinte diagrama:

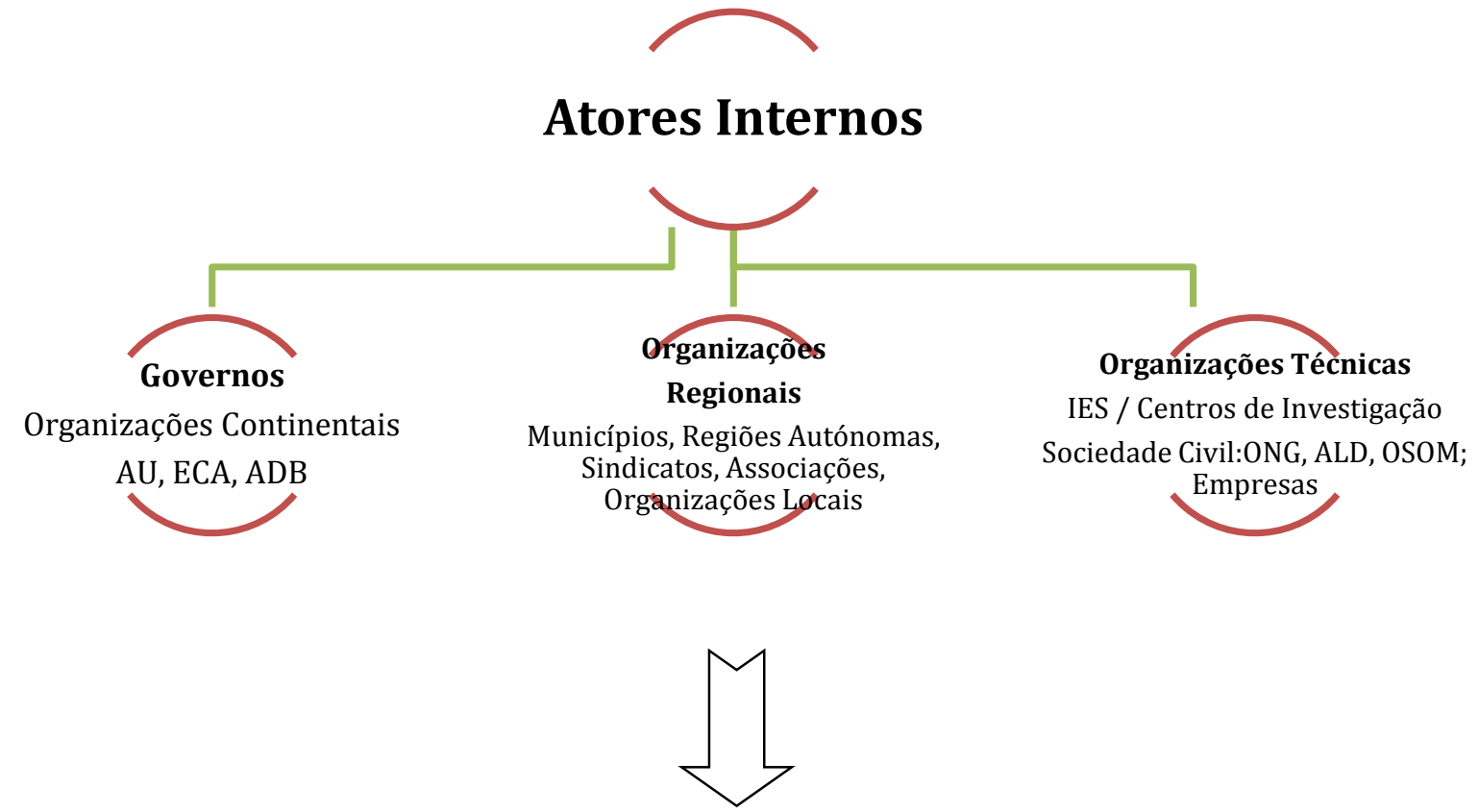

Atores Regionais

Communauté des États Sahélo-sahariens - Censad Common Market for Eastern and Southern Africa - Comesa

East African Community - Eac

Communauté Economique des Etats de l'Afrique Centrale - ECCAS

Economic Community Of West African States - ECOWAS

Intergovernmental Authority on Development IGAD

Southern African Development Community - SADC

UMA

Commission de la Communauté Économique et Monétaire de l'Afrique Centrale CEMAC

Intergovernmental Oceanographic Commission - IOC

Union Economic et Monetaire Ouest Africaine - UEMOA 


\subsubsection{População-alvo e Amostra}

De acordo com os pontos anteriores foram identificados como população alvo dois grupos de Atores da cooperação internacional para o desenvolvimento - os Atores Externos e os Atores Internos - os quais são compostos pelos atores cuja ação se define ao nível Internacional e Europeu, assim como aqueles que atuam ao nível local, respetivamente. Neste sentido, após a devida classificação e categorização destes atores foi efetuada uma lista composta por 560 indivíduos de acordo com a sua função (no âmbito da cooperação internacional para o desenvolvimento (em média os atores respondentes trabalham nesta área há 13 anos) e organização para a qual trabalha (Tabela 13). Por razões de confidencialidade apenas se apresentam os números relativos aos grupos categorizados e não as instituições para as quais trabalham nem o papel que cada um desempenha dentro das mesmas.

Tabela 13 - Amostra Populacional Categorização

\begin{tabular}{|c|c|c|}
\hline \multirow[t]{2}{*}{ Atores Externos } & Atores Internacionais & 176 \\
\hline & Atores Europeus & 202 \\
\hline \multirow[t]{4}{*}{ Atores Internos } & Organizações Regionais & 16 \\
\hline & $\begin{array}{c}\text { Organizações Técnicas - } \\
\text { ONG }\end{array}$ & 48 \\
\hline & $\begin{array}{c}\text { Organizações Técnicas - } \\
\text { Universidades }\end{array}$ & 21 \\
\hline & $\begin{array}{c}\text { Organizações Técnicas - } \\
\text { Sub-Saharan Africa } \\
\text { Research Centres }\end{array}$ & 97 \\
\hline Total & & 560 \\
\hline
\end{tabular}

De todos os contatos efetuados apenas $5.36 \%$ optou por responder ao questionário, sendo que $8 \%$ informou não querer dar o seu contributo para a investigação e $70 \%$ dos indivíduos selecionados não deu qualquer resposta (Gráfico 31). Dos indivíduos que responderam $56 \%$ corresponde ao sexo masculino e os restantes $44 \%$ ao sexo feminino (Gráfico 32). 
Gráfico 31 - Resultado das respostas e percentagens / população alvo

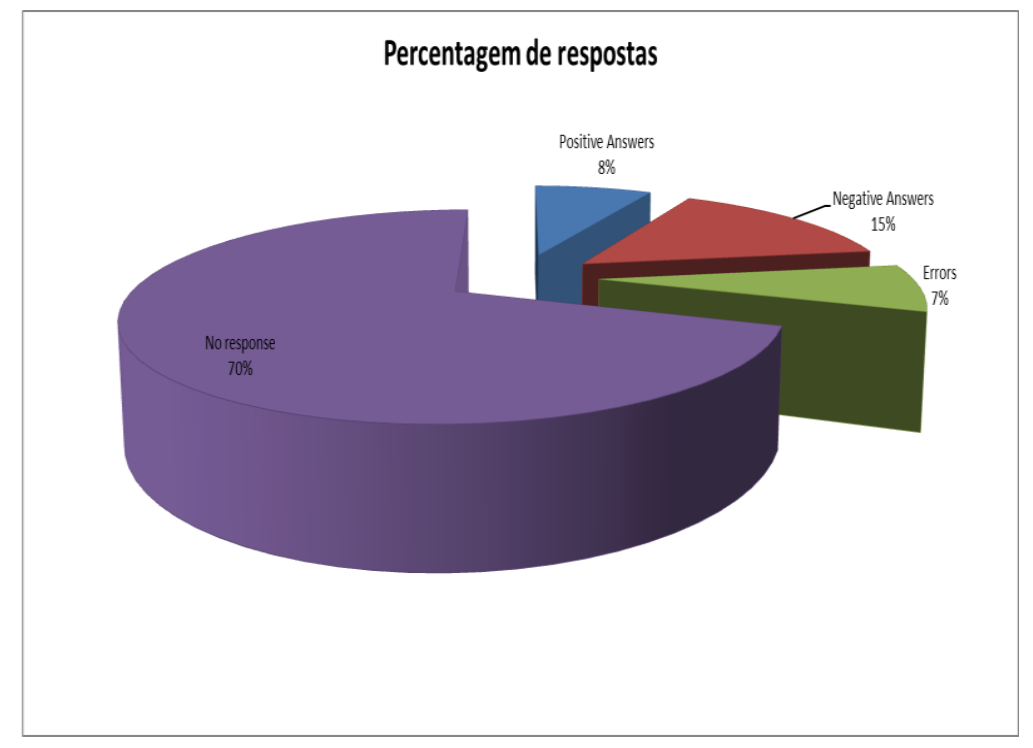

Gráfico 32 - Percentagem de Homens e Mulheres que participaram no inquérito

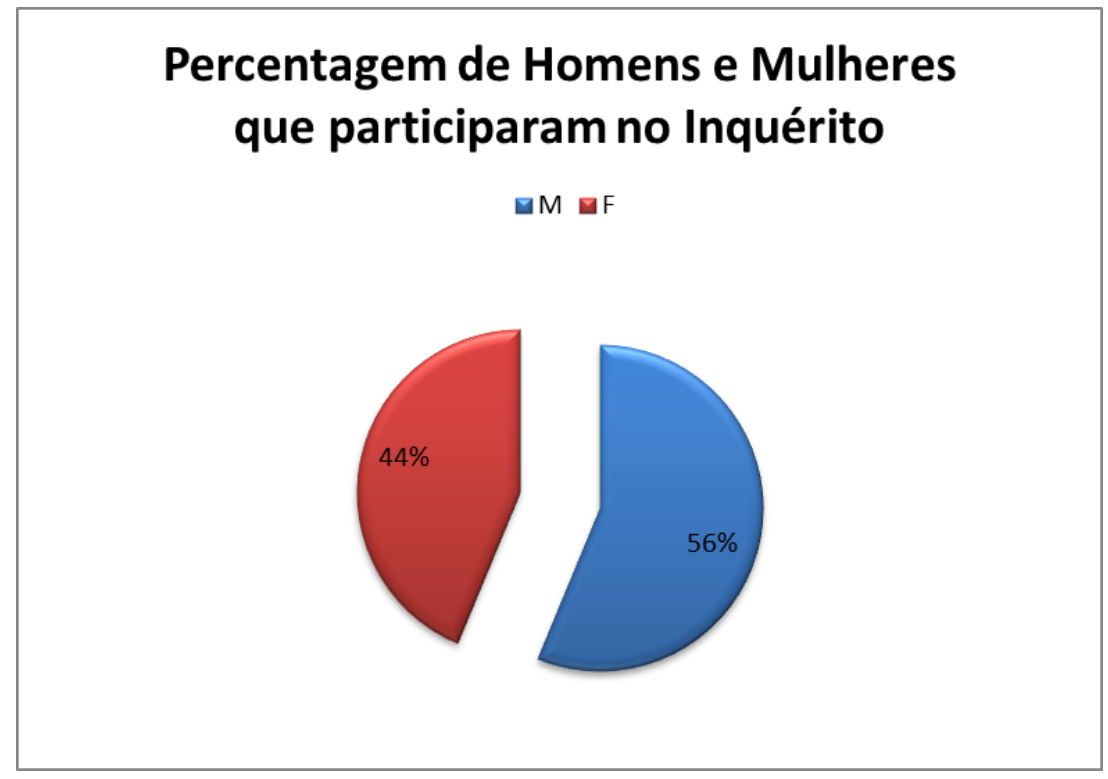

Das respostas obtidas, e de acordo com a categorização mencionada, a maioria corresponde aos Atores Internacionais (37\%) seguido pelos Atores Europeus (19\%) e Organizações Técnicas - Universidades e Centros de Investigação - (num total de $28 \%$ ). As organizações regionais são as que apresentam um menor grau de representatividade com apenas $16 \%$ de respostas (Gráfico 33). 
Gráfico 33 - Percentagem de participantes no inquérito por tipo de Ator para o Desenvolvimento

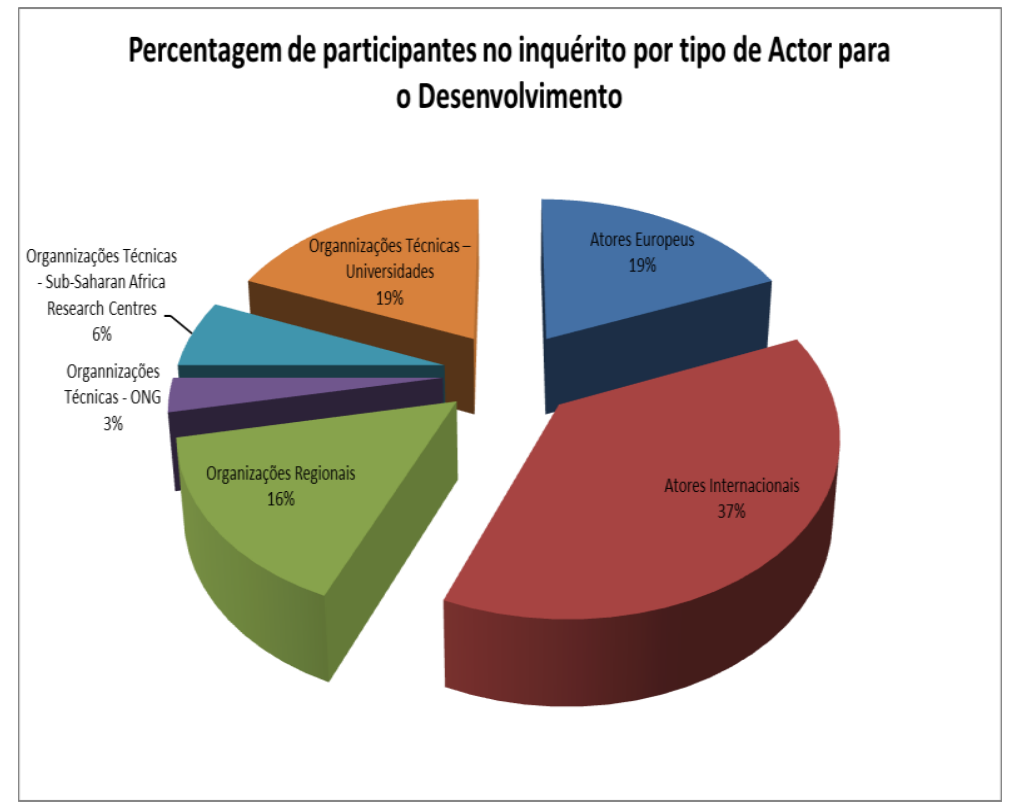

Quanto aos países que participaram obtivemos respostas de 9 países europeus e cinco países Africanos e cujas percentagens se apresentam no Gráfico 34 .

\section{Gráfico 34 - Países Europeus e Africanos que participaram no inquérito}

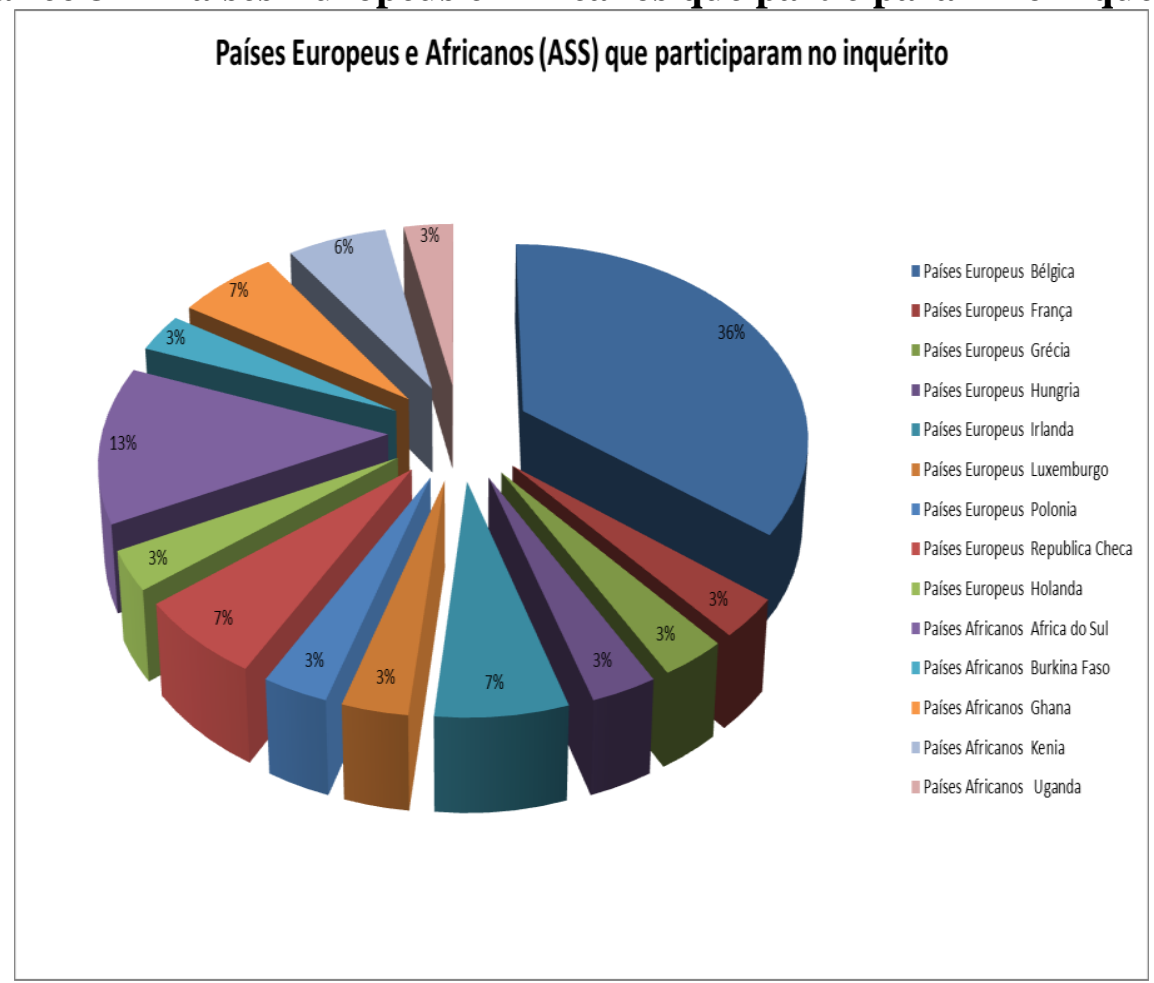


As questões efetuadas no questionário tiveram como principal intuito responder aos objetivos traçados e ao quadro teórico apresentado, segundo os quais foram formuladas as hipóteses de investigação que a seguir se apresentam.

\subsection{Hipóteses da Investigação}

Para que os objetivos traçados no projeto pudessem ser alcançados e tendo o quadro teórico-conceptual como elemento orientador da investigação, elaboraram-se as hipóteses, as quais serão confrontadas com a realidade empírica e cujos resultados serão descritos e analisados ao longo do trabalho.

No seguimento do explicitado, a presunção desta investigação baseia-se na seguinte questão:

- Num sistema econômico pós-industrial o sistema de educação deve ser equilibrado e não se pode injuriar o nível superior en prol do secundário e primário.

Neste sentido pretendemos saber:

- Qual é a opinião dos atores que promovem parcerias entre universidades europeias e africanas sobre a relação entre $o$ desenvolvimento econômico no contexto do século XXI e da cooperação internacional no ensino superior?

E o objetivo de pesquisa é:

- Contrastar a opinião dos Atores, internos e externos, no sentido de compreender qual o ponto de vista dos mesmos em relação à presunção que defendemos: o sistema de educação deve ser equilibrado. 
Para o efeito foi efetuado um inquérito aos diferentes tipos de Atores com o intuito de recolher informação que nos permita inferir se existe correspondência entre as ações esperadas e efetivas deste grupo de Atores e a sua opinião quanto às questões da Cooperação Internacional ao nível da educação assim como o seu efeito no progresso das economias locais e da possível melhoria da qualidade de vida da população dai resultante.

No entanto, outras questões complementares foram elaboradas, ao nível da influência dos Atores, inferindo-se que:

1 - O peso dos atores não é o mesmo, pelo que existem atores chave, que influenciam muito e são pouco dependentes;

2 - Os atores locais das Instituições de Ensino Superior partilham da lógica que se encontra subjacente à ação inovadora, ou seja, a lógica que faz o apelo à diversificação da atividade económica local;

3 - Embora haja uma concordância por parte dos atores envolvidos, quanto à diversidade da atividade económica local, os seus desafios estratégicos identificam-se mais com o desafio estratégico que preconiza a abertura do território local ao investimento exterior, contribuindo para o seu processo de industrialização.

Assim, e tendo em conta a questão central, surgiram as seguintes questões complementares:

- Existe aliança entre os atores?

- Existe uma hierarquização dos Atores nos seus vários níveis?

Existe um jogo de atores face ao desenvolvimento o qual se pretende compreender, assim como a sua influência direta e indireta que cada um deles poderá ter sobre o 
ensino superior, ao nível regional, nacional e internacional. Neste sentido, e após a obtenção dos dados, através da aplicação do inquérito, aos Atores mencionados, os quais foram devidamente categorizados e tratados, passámos a análise dos mesmos, através do modelo de análise apresentado, no sentido de dar resposta às hipóteses formuladas. Salienta-se o fato de que nos gráficos apresentados as perguntas foram deixadas em inglês para não se perder o sentido das mesmas.

\subsubsection{Dificuldades}

Tal como demonstrado toda a amostra é constituída por Atores que ocupam funções públicas de grande envergadura e de diferentes países, não só ao nível europeu mas também em África, o que constituiu um obstáculo no que concerne à obtenção dos seus testemunhos. Não obstante conseguiu-se um número de respostas significativo, tendo em conta o caráter aberto das questões, e que permitiu o avanço da investigação através da análise de conteúdo das mesmas. 
VNIVERSIDAD

ĐSALAMANCA 


\section{PARTE III}

\section{ANÁLISE DE DADOS}


VNIVERSIDAD

Đ SALAMANCA 


\section{Capítulo 7}

Aplicação do Modelo CATWOE mediante a análise dos dados obtidos de acordo com a sua caracterização no âmbito do ensino superior

GN2!NO 2MbGI0I

gomorgfomigoŕgoro no grmpifo ga 
VNIVERSIDAD

Đ SALAMANCA 
7.1.Da análise de dados à aplicação do modelo de análise CATWOE

\subsubsection{Política Pública Educacional}

De acordo com a informação recolhida existe consenso, entre os vários tipos de Atores, no que concerne a considerar a educação como um bem público, pois todas as respostas são positivas (Gráfico 35).

\section{Gráfico 35 - Opinião dos Atores quanto à educação como um bem público universal}

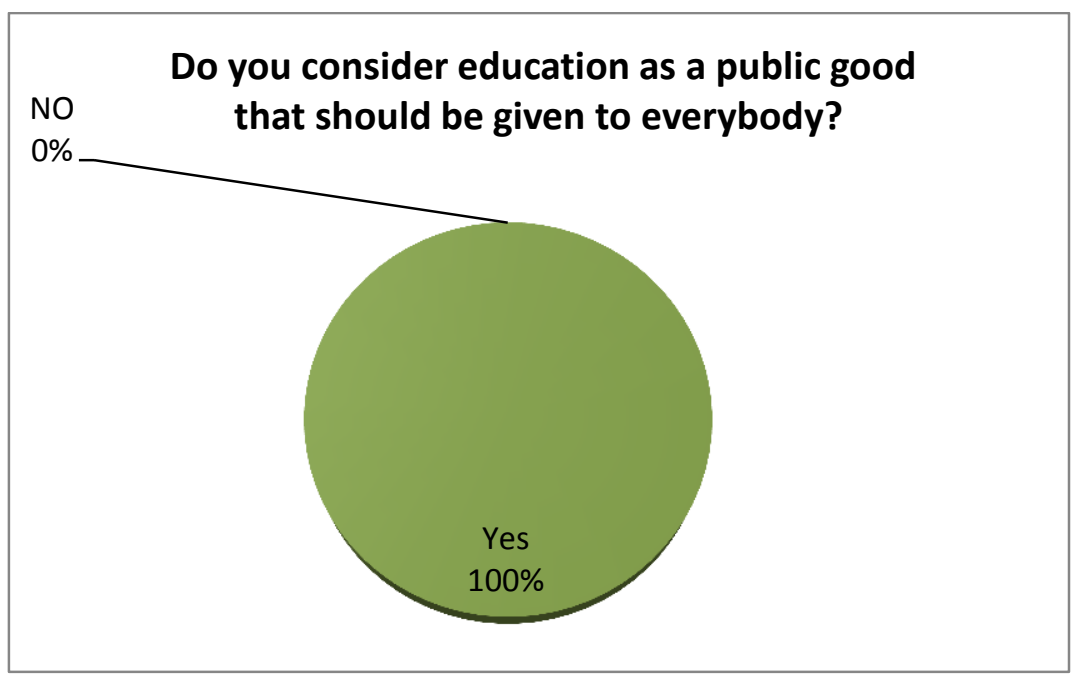

Na sua maioria os Atores responderam que a educação é, de fato, um direito humano fundamental e universal pelo que deverá englobar toda a população, sem qualquer tipo de descriminação, incluindo crianças, jovens e adultos de ambos os géneros. Consideram que a educação constitui um instrumento elementar para o desenvolvimento humano, o qual contribui não só para o desenvolvimento pessoal, mas também, como consequência, para o desenvolvimento das sociedades ao nível regional, nacional e global. Desta forma, a educação é percecionada como um instrumento para gerar conhecimento, mas também, para melhorar as condições de vida e criar sociedades mais equitativas e mais democráticas. A educação permite o 
crescimento económico das sociedades, criando mais e melhores oportunidades de trabalho, facilitando o desenvolvimento pessoal e profissional de todos os cidadãos. De acordo com a opinião dos diferentes Atores, a educação é um importante fator no que concerne à erradicação da pobreza existindo por isso uma estreita relação com o desenvolvimento económico, tal como verificamos anteriormente no enquadramento teórico e de acordo com os vários estudos realizados.

No entanto, no que concerne ao fornecimento da educação pelos Governos, de forma gratuita, as opiniões dividem-se sendo que apenas $25 \%$ da população inquirida considera que o ensino superior deva ser financiado em contrapartida do ensino primário e secundário (37\% e 38\% respetivamente - Gráfico 36). Os Atores Internacionais são os que dão maior enfâse ao fornecimento do ensino superior de forma gratuita (Gráfico 37). Estes resultados vão ao encontro da Nova Agenda para o Desenvolvimento promovida pelos Atores Internacionais na medida em que na mesma, tal como já demostrado, se reconhece que o acesso à ciência, à tecnologia e à inovação sustenta o progresso em todas as dimensões do desenvolvimento tendo como principal foco o crescimento económico (United Nations, 2013; UNESCO, 2014). Existe consenso quanto à classificação do conhecimento e da tecnologia como um bem público, muito embora o investimento nestas áreas seja reduzido o que pressupõe uma maior colaboração internacional de forma a suportar e apoiar a criação e a disseminação de tecnologias. 
Gráfico 36 - Opinião dos Atores quanto ao nível de educação que deve ser fornecido pelos governos de forma gratuita

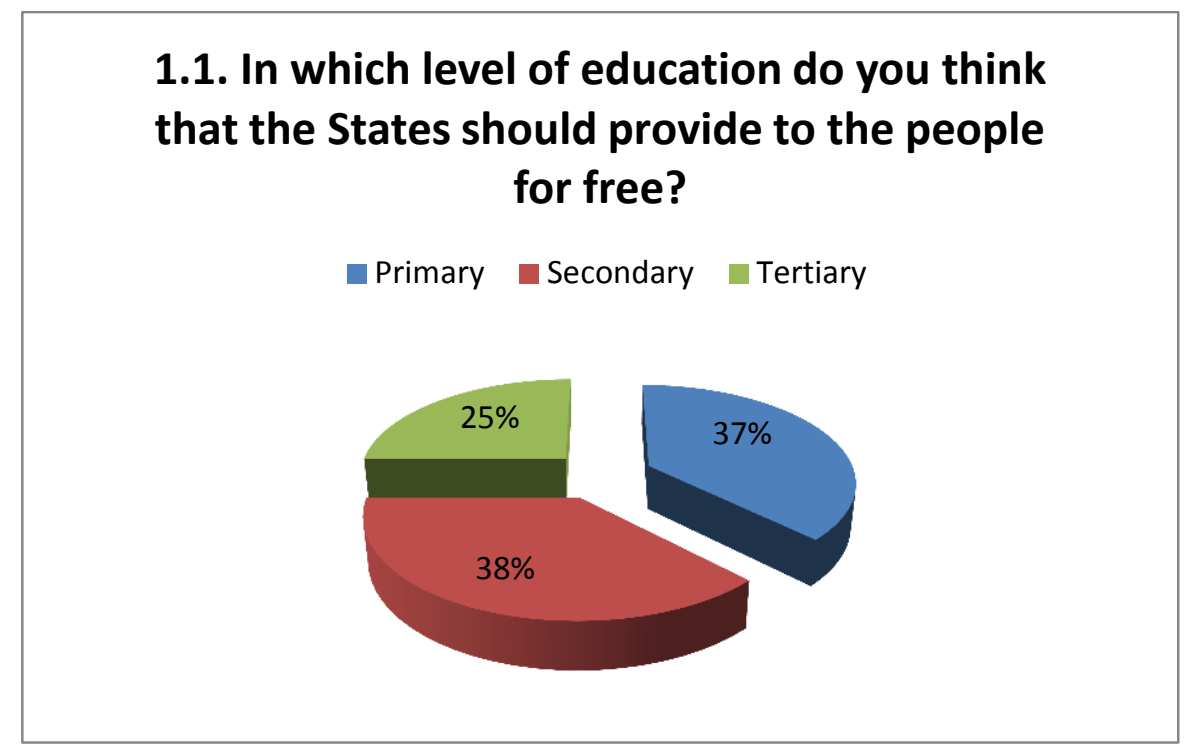

Gráfico 37 - Opinião, por Tipo de Ator, quanto ao nível de educação que deve ser fornecido pelos governos de forma gratuita

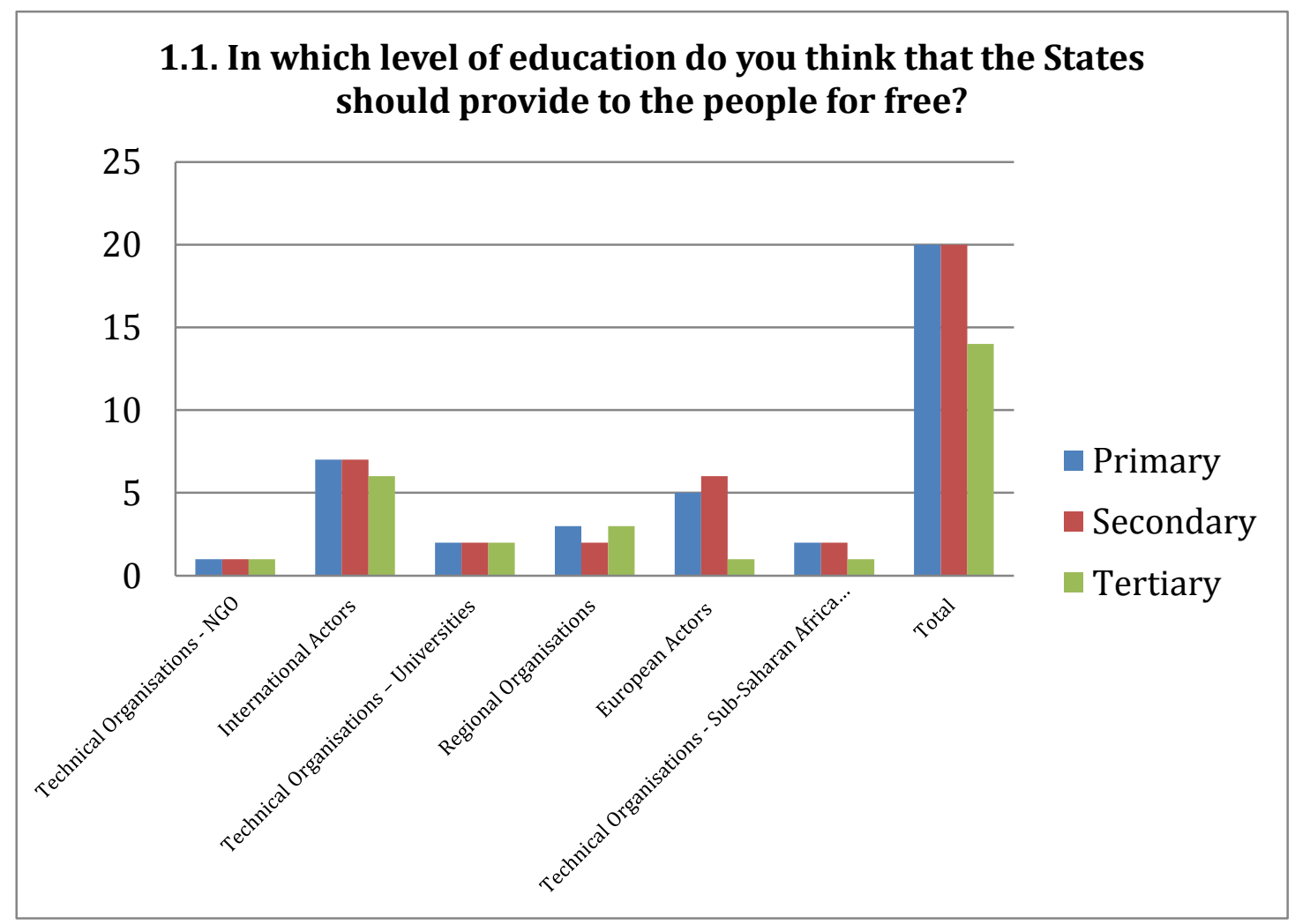


De uma forma geral, todos os outros Atores privilegiam o ensino primário e uma crescente enfâse no ensino secundário, na medida em que o ensino primário é essencial para a obtenção de competências básicas (i.e. ler e escrever, fazer contas, etc.) assim como aprender as regras básicas de convivência, de socialização (i.e. respeito pelo outro, democracia, etc.). Ao nível do ensino secundário consideram que os alunos adquirem conhecimento vocacional possibilitando a identificação de talentos particulares, assim como na sua preparação para o mercado laboral. No caso dos Atores que afirmam que o ensino superior deva ser gratuito, os mesmos consideram que os alunos devem ser selecionados de acordo com o seu desempenho (avaliações próprias), de forma a não desperdiçar os recursos envolvidos na sua graduação. Por outro lado, indicam que os Governos poderão cofinanciar o ensino superior de acordo com um sistema de subsidiariedade, onde cada estudante teria de pagar de acordo com os rendimentos da sua família, sendo relevante que esta percentagem varia de acordo com o nível de desenvolvimento de cada um dos países em causa. Outro tipo de suporte, mencionado pelos Atores inquiridos, passa por apoios privados, essencialmente ao nível do ensino superior, através de empresas locais as quais teriam interesse em financiar bolsas de estudo nas áreas com as quais trabalham para estudantes que poderiam, após terminar a sua graduação, ser uma mais-valia para as mesmas empresas uma vez adquirido o know-how necessário para desenvolver produtos e serviços inovadores os quais irão contribuir para o progresso da economia local.

Estamos perante um processo de desenvolvimento do conhecimento que valoriza todos os intervenientes incentivando, ao mesmo tempo, um nível de ensino superior com qualidade, o qual é defendido por todos os Atores inquiridos. Este ensino com qualidade tem vindo a ser uma preocupação por parte dos diferentes atores para o desenvolvimento, devido aos vários fatores já mencionados, tais como a falta de docentes qualificados e a massificação da procura pelo ensino. No que concerne ao apoio por parte dos Atores Internacionais, e de acordo com as respostas obtidas, este deverá incidir ao nível do ensino primário e secundário, pelas razões mencionadas. Todos os Atores consideram que, tendo em conta a missão da educação, os Governos 
devem apoiar e criar, essencialmente, escolas públicas (65\%), apenas 35\% dos Atores considera que o apoio deva ser dado a escolas privadas (Gráfico 38).

Gráfico 38 - Opinião dos Atores quanto ao apoio a ser dado a instituições de ensino publicas e/ou privadas

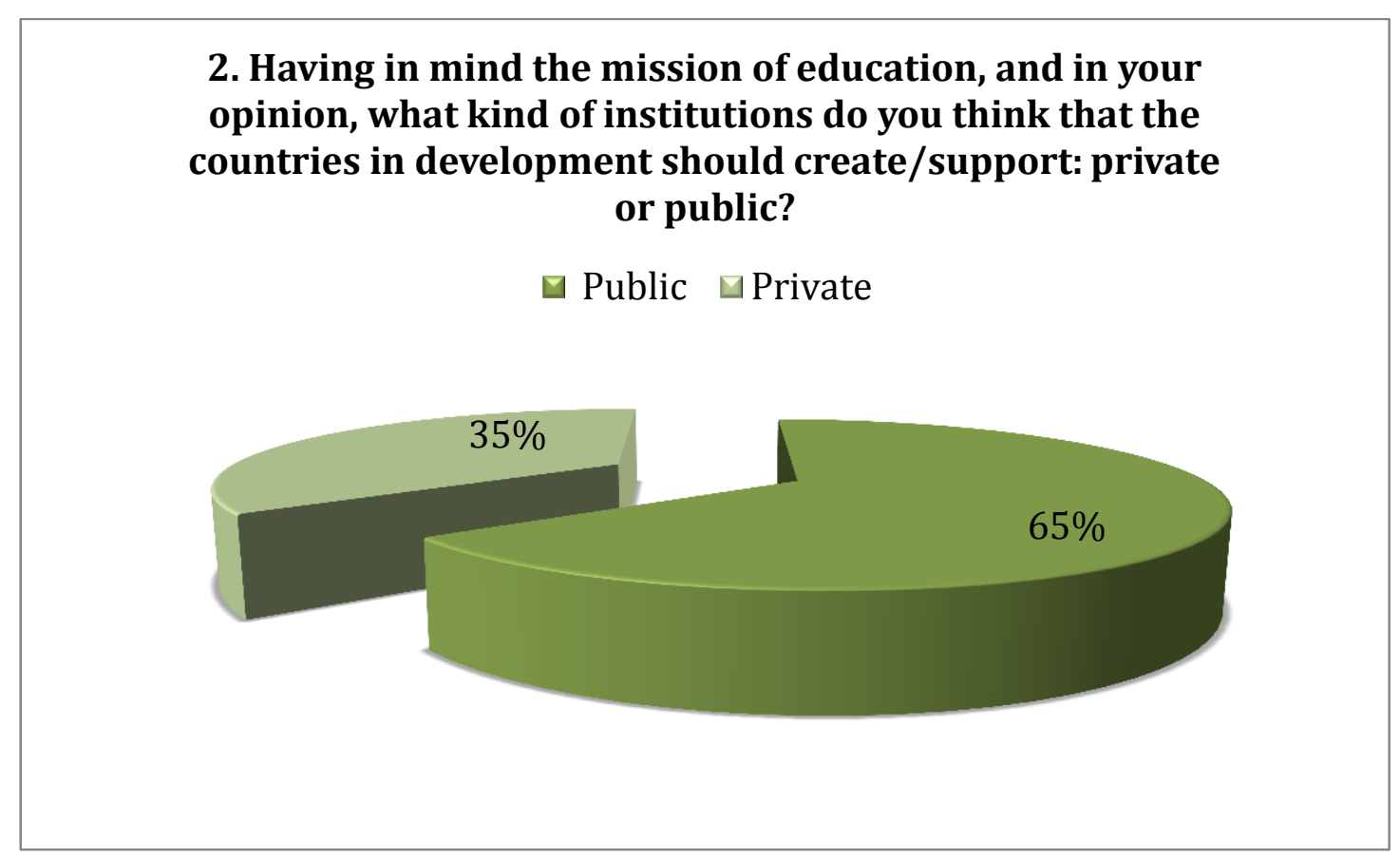

Os Atores Internacionais são os que consideram que este apoio deva ser equitativo entre as escolas públicas e as privadas. Os Atores Europeus e as Organizações Técnicas - Universidades dão uma maior enfâse ao ensino público (Gráfico 39). 
Gráfico 39 - Opinião por tipo de Ator quanto ao apoio a instituições de ensino públicas e/ou privadas

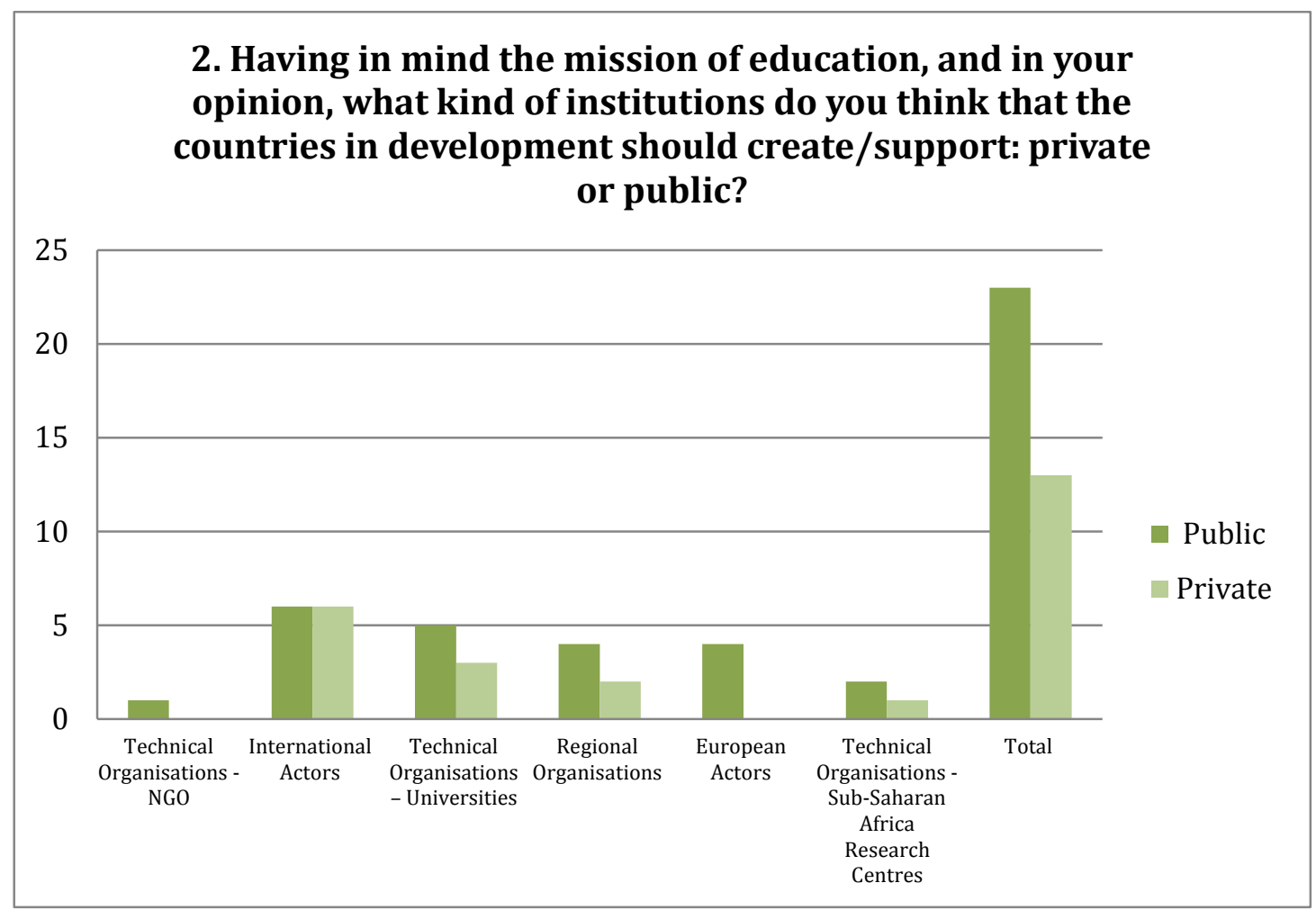

Os dados obtidos corroboram a preocupação de alinhar os interesses do sector privado com as investigações, efetuadas pelos centros de investigação e instituições de ensino superior, de forma a criar e a promover as tecnologias, produtos e serviços que melhor correspondem às necessidades dos mercados locais, contribuindo para o desenvolvimento económico-social. Para tal, é necessário formar recursos humanos com capacidades a este nível de desenvolvimento, tal como indicado pelas Nações Unidas e pela UNESCO, tendo implicações a vários níveis, uma vez que promove o crescimento económico e contribui para a prosperidade das sociedades e da vida humana (Figura 4 - Correlação entre Educação e Crescimento Económico). Não obstante, existe um percurso a ser delineado na medida em que o fenómeno de brain drain permanece um indicador constante, tal como anteriormente verificado. No sentido de colmatar esta carência de recursos humanos qualificados é necessário desenvolver linhas orientadoras estratégicas, por parte dos Atores Regionais, com 
incentivos Internacionais específicos e orientados para a melhoria das condições de trabalho das profissões qualificadas em geral, e para a profissão académica, em específico. Por outro lado, existe a crescente crença, por parte dos Atores para o Desenvolvimento, que o nível secundário - 36\% - e terciário - 35\% - de ensino são os que mais poderão favorecer o desenvolvimento económico (Gráfico 40). Existe, no entanto, a preocupação com o ensino primário na medida em que a percentagem de Atores que considera este nível é relevante para o desenvolvimento persiste elevada $(29 \%)$.

Os atores Internacionais e Europeus colocam uma maior enfâse no ensino secundário (Gráfico 41) uma vez que acreditam que é a este nível que os alunos adquirem as competências necessárias em sociedades em constante mudança, as quais tendem a passar de uma economia baseada na agricultura - sector primário - passando para uma sociedade industrial baseada numa economia industrial e de serviços - sector terciário -, colocando-se ao nível das sociedades globais, internacionalizando os seus produtos e serviços. O ensino superior tem aqui um papel primordial na preparação de cidadãos mais informados e especializados em diversos sectores, criando maiores e melhores oportunidades, assim como competências empreendedoras. Estes Atores consideram que níveis mais elevados de educação permitirão formar líderes mais críticos, com uma melhor planificação estratégica das suas regiões e voltados para uma sociedade aberta à mudança criando, desta forma, comunidades mais democráticas e de bemestar, contribuindo para gerar cidadãos responsáveis os quais poderão ter a sua independência económica. 
Gráfico 40 - Opinião quanto ao nível de educação que poderá favorecer o desenvolvimento

\subsubsection{Which level of education is more important}

for this development?

Primary $\square$ Secondary $\square$ Terciary

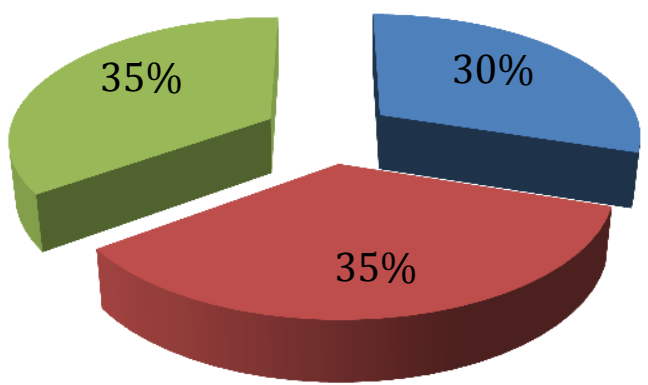

Gráfico 41 - Opinião, por tipo de Ator, quanto ao nível de educação que poderá favorecer o desenvolvimento

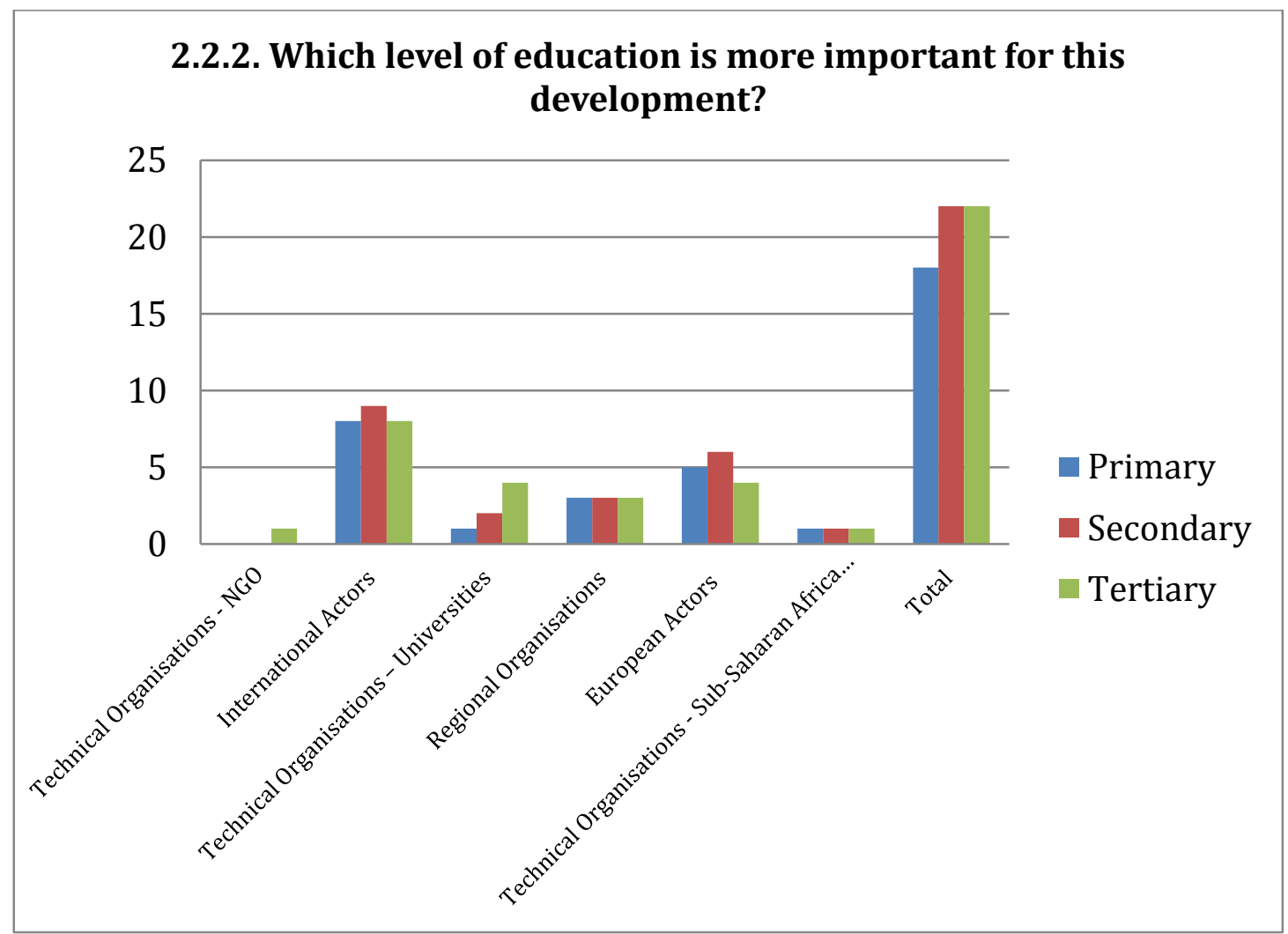


Como consequência, uma grande parte dos Atores $(81 \%)$ considera que um maior nível de educação garante melhores condições de vida (Gráfico 42). Os Atores Internacionais e as Organizações Técnicas - Universidades, são os que mais sustentam este fato (Gráfico 43). Mencionam que, efetivamente, um maior nível de educação conduz a melhores perspetivas de emprego (por conta de outrem ou até mesmo criação do próprio emprego). Esta situação permitirá conduzir a população a melhores condições de vida, não só por munir a sociedade de profissionais qualificados em varias áreas mas também porque permite o acesso, economicamente plausível, a estes profissionais, a melhores serviços como por exemplo na área saúde e da educação e até mesmo ao nível tecnológico. A educação tem aqui um importante papel na redução da exclusão, das desigualdades e da pobreza indo ao encontro dos vetores da nova parceria global para o desenvolvimento.

Gráfico 42 - Opinião dos Atores quanto ao fato de um nível de ensino superior de educação favorecer melhores condições de vida

\section{In your opinion, does a higher level of education guarantee better conditions of life?}

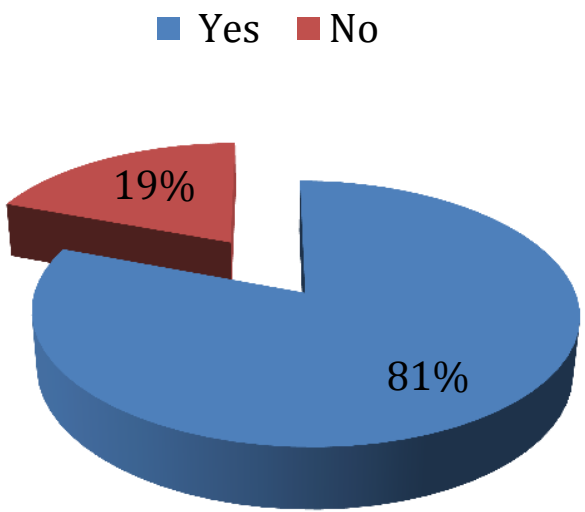


Gráfico 43 - Opinião por tipo de Ator quanto ao fato de um nível de ensino superior de educação favorecer melhores condições de vida

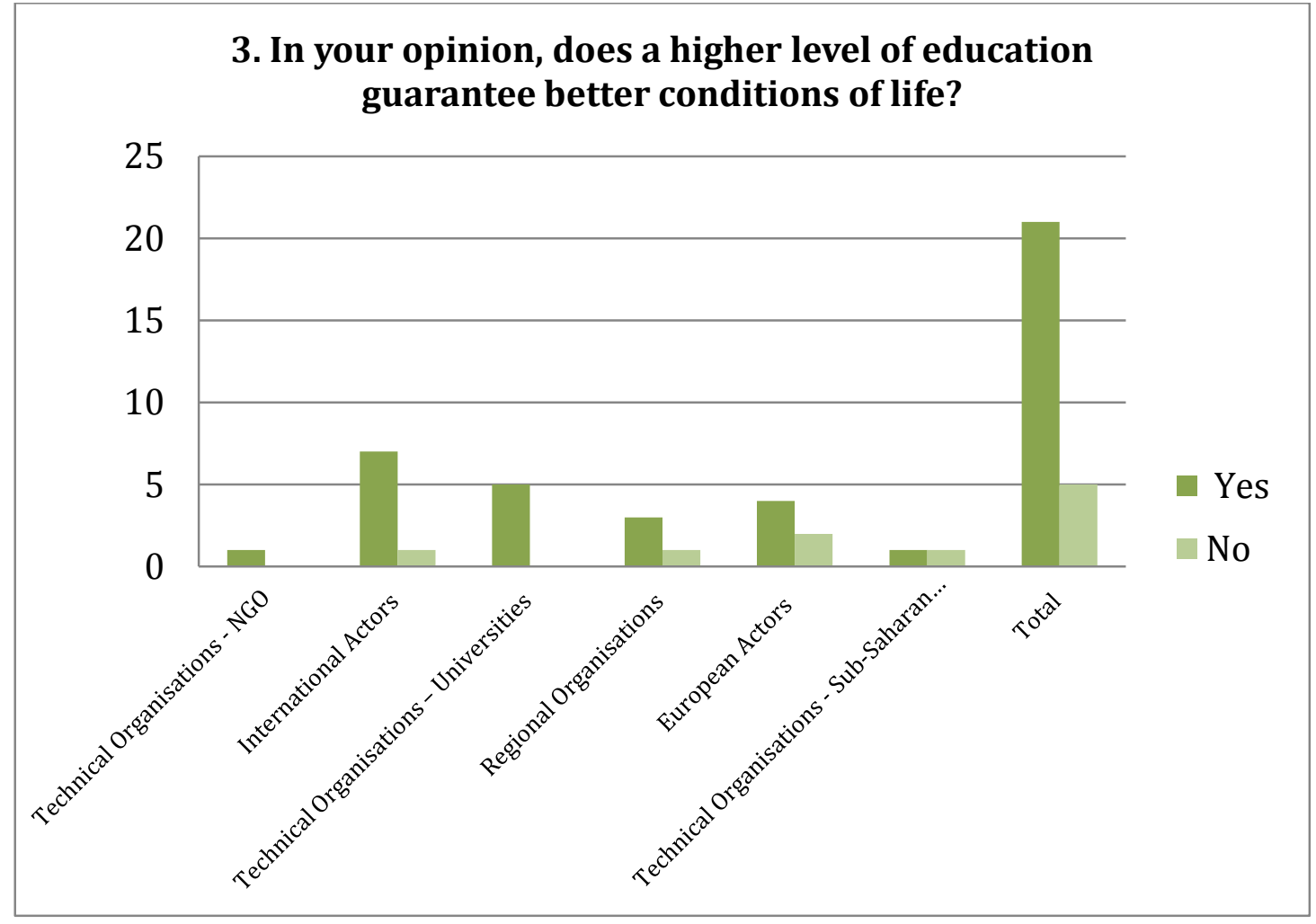

Esta nova parceria global para o desenvolvimento pós-2015, tal como já mencionado, sustenta uma maior vinculação com os direitos humanos, a promoção da igualdade e da sustentabilidade frisando a necessidade de se correlacionar estes valores com a educação (Figura 5 - Conceptualização dos objetivos de uma nova parceria integrada). Efetivamente existe, por parte dos Atores para o Desenvolvimento a crescente crença nesta relação, assim como que níveis mais elevados de educação são favoráveis a este desenvolvimento socioeconómico como se poderá verificar de seguida. 


\title{
7.1.2. O Ensino Superior em África
}

Com o intuito de verificar a consistência das respostas dadas anteriormente pelos diferentes Atores, e no sentido de perceber se efetivamente consideram que o ensino superior desempenha um importante papel no desenvolvimento dos países da África Subsariana, formularam-se novas questões aplicadas especificamente a estes países. Com efeito, $92 \%$ dos inquiridos consideram que o ensino superior desempenha um importante papel no desenvolvimento dos países da África Subsariana, considerando de uma forma geral as suas especificidades (Gráfico 44). Tal como menciona um dos Atores Regionais, as Universidades, no contexto da África Subsariana, são agentes chave na estratégia do desenvolvimento sustentável tendo como papel a promoção de valores morais, cívicos e ecológicos mas também no desenvolvimento de competências académicas e de investigação sustentável, de parcerias com o governo, com ONG’s, com a indústria e com a cooperação interuniversitária.

\begin{abstract}
Yes, Sub-Sahara African universities are key agents in any strategy for improving sustainable development in Africa. Yet, there are few studies or data available about the role and practices that the universities and other higher education institutions have adopted or may be developing to promote and contribute to sustainable development of the region. Higher education provides the following roles in the development of sub-Saharan Africa countries: moral obligation, public outreach, sustainable physical operations, ecological literacy, develop inter disciplinary curricula, encourage sustainable research, partnership with government, non-governmental organization and industry and inter university cooperation (Comentário de um Ator Regional).
\end{abstract}

Apenas $8 \%$ dos Atores mencionam não existir esta correlação. Todavia, justificam a sua resposta de uma forma bastante subtil e indicam que esta relação deveria existir assim como deveria ser suportada para aumentar as competências dos países em causa. Os Atores Internacionais e os Europeus são os que defendem com maior convicção o papel do ensino superior no desenvolvimento destes países (Gráfico 45). Apontam que um quadro intelectual superior contribui para o progresso das sociedades através de um quadro técnico especializado capaz de colaborar ao nível 
internacional e de desenvolver capacidades ao nível local de forma a contribuir para a melhoria da qualidade de vida da população. Indicam, ainda, que esta dinâmica permite a evolução de um sector financeiro mais dinâmico e cujas características vão ao encontro dos requisitos internacionais e de uma sociedade globalizada. Uma sociedade com quadros técnicos qualificados conduz à sua modernização e, consequentemente, a uma sociedade mais livre, sem violência, sem conflitos, com mais oportunidades e com uma economia mais resiliente.

In Africa, 15 countries have chosen education and/or training as a focal sector in their cooperation with the EU in the period 2014-2020. Higher education EU programs as Erasmus+ can play an important role as these will help our African partner countries build their higher education capacities and modernize their higher education systems so that they achieve their development objectives in an inclusive and sustainable way. In addition to specific, traditional capacity building actions, mobility itself and in particular credit mobility has a strong potential to improve the quality of higher education in developing countries: by accelerating the design of internationalization strategies and the use of transparency and recognition tools, and by helping institutions develop better services to send and receive foreign students or researchers, and promote the recognition of foreign diplomas.(Comentário de um Ator Internacional)

Gráfico 44 - Opinião dos Atores, no contexto da ASS, no sentido de perceber se o ensino superior ocupa um lugar primordial no desenvolvimento destes países

1. Considering the particularity of the African continent, and in particular, the countries of Sub-Saharan Africa, do you think that higher education plays an important role in the development of these countries?

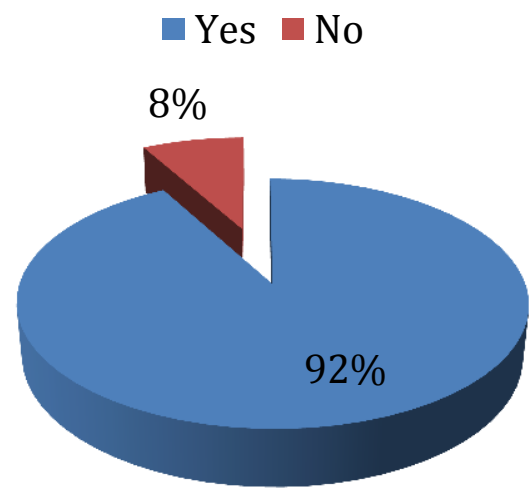


Gráfico 45 - Opinião por tipo de Ator, no contexto da ASS, no sentido de perceber se o ensino superior ocupa um lugar primordial no desenvolvimento destes países

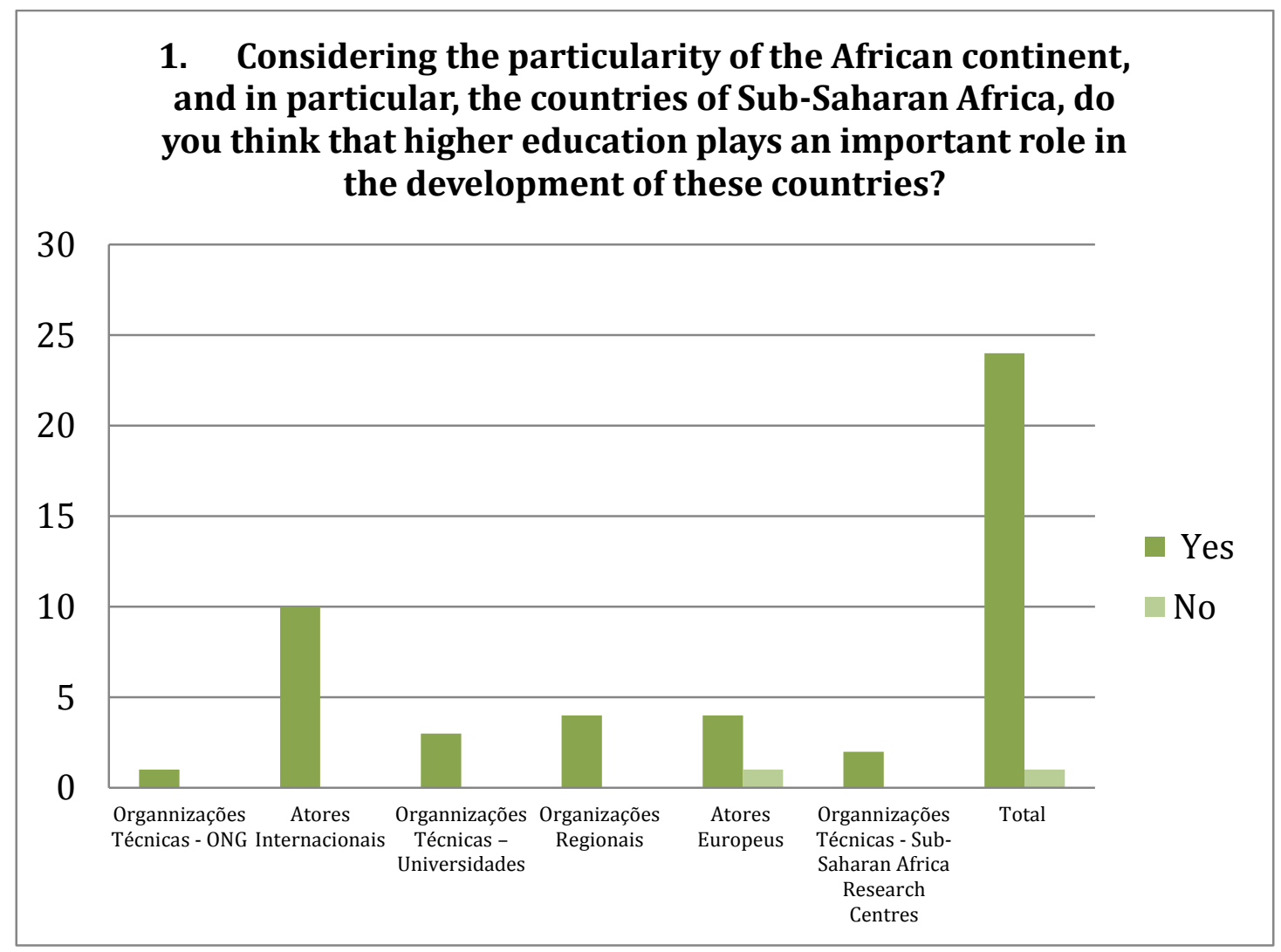

Em suma, o ensino superior pode ter um importante papel no desenvolvimento dos países da África Subsariana através da promoção de futuras elites com as qualificações e ferramentas necessárias para eleger o desenvolvimento político e socioeconómico de forma inclusiva e sustentável, considerando o contexto e especificidade de cada um dos países envolvidos. Este entendimento permitirá a criação de sistemas eficientes que possibilitem a partilha dos benefícios de um crescimento uniforme. $\mathrm{O}$ ensino superior permite treinar indivíduos os quais irão participar ativamente para um sector privado mais eficiente e competitivo, assim como irão contribuir para uma sociedade da informação, mais equitativa e democrática. Desta forma, criam-se condições capazes de reter os jovens talentos nos seus países de origem evitando o processo de brain drain já explicitado. Um ensino 
superior eficiente implica a criação transparente de ferramentas de reconhecimento de diplomas, um sistema de intercâmbio de estudantes e investigadores devidamente planeado e organizado, planos de investigação que visem a cooperação com o tecido empresarial regional e, concludentemente, a utilização dos recursos existentes localmente, respeitando as especificidades culturais e históricas de forma a promover um progresso sustentável. De acordo com os Atores inquiridos são atribuídos vários papéis ao ensino superior correlacionados com o desenvolvimento destas sociedades: obrigação moral, sensibilização pública, operações físicas sustentáveis, literacia ecológica, desenvolvimento de curricula interdisciplinar, encorajar investigações sustentáveis, cooperação interuniversitária e com a indústria. Todavia, este progresso deve ser coordenado e orientado de acordo com as necessidades específicas ao nível nacional e regional, pelo que a oferta formativa a este nível deverá ter em linha de conta as carências correlacionadas ao nível do capital intelectual. Os dados obtidos indicam que o ensino superior deveria fornecer, essencialmente, cursos nas áreas relacionadas com as engenharias, a gestão, a saúde e a agricultura de forma a fazer face aos problemas socioeconómicos regionais e nacionais (Figura 10). 
Figura 10 - Principais áreas de orientação universitária mencionadas pelos Atores inquiridos para fazer frente aos problemas socioeconómicos regionais e nacionais, por ordem de relevância

Educação - Línguas

Ciências Sociais

Administração, Gestão,

Economia, Comércio, Direito

Ciências da Vida -

Medicina / Saúde

Tecnologia -

ICT

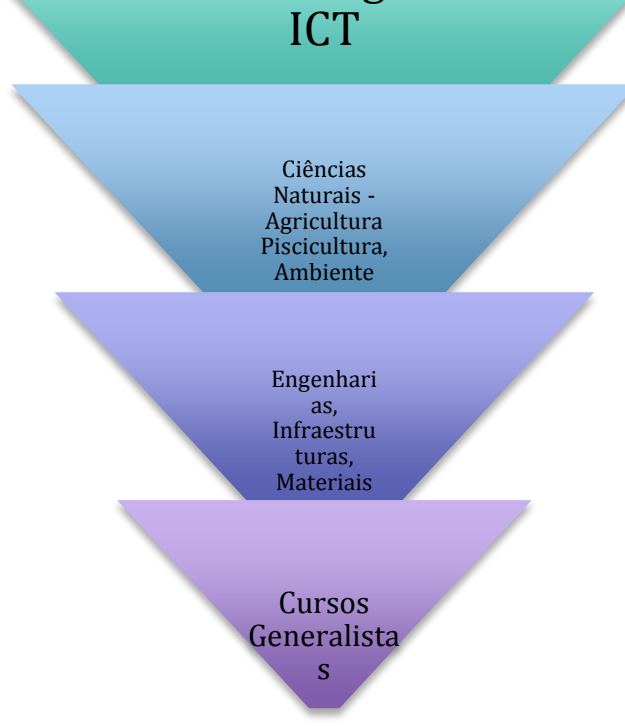

A investigação propriamente dita praticamente não é mencionada por todos os Atores inquiridos, pelo que nos leva a considerar que ainda não existe uma verdadeira sensibilização quanto ao desenvolvimento de infraestruturas que permitam impulsionar esta vertente do ensino superior. No entanto, foi sugerido pelos Atores, em outras questões a necessidade de uma maior cooperação entre as instituições do ensino superior e a indústria, o que implica um maior alinhamento do trabalho dos investigadores com as necessidades industriais locais e regionais e o desenvolvimento 
de tecnologias e produtos de acordo com essas mesmas necessidades. Não obstante este fato, verificamos que todos os Atores consideram que o ensino, em geral, constitui uma importante ferramenta no desenvolvimento dos países da África Subsariana, assim como o ensino superior, em específico, uma vez que contribui para a qualificação de mão-de-obra, que permitirá alcançar outros níveis de progresso, não só ao nível das sociedades mas também em termos de qualidade de vida dos indivíduos. Neste sentido, e tendo em conta a Nova Agenda pós-2015 enquanto sucessora dos Objetivos do Milénio, tentámos avaliar até que ponto os Atores inquiridos consideram que o ensino superior deveria ser umas das orientações desta nova agenda. De acordo com os dados obtidos $76 \%$ considera que sim contra $24 \%$ de respostas negativas (Gráfico 46). Estas são justificadas pelo fato de darem prioridade às necessidades imediatas e básicas, ao acesso universal e equitativo à educação primária e secundária de qualidade, assim como privilegiam o ensino técnico e vocacional.

\section{Gráfico 46 - Opinião dos Atores em relação ao papel que o ensino superior} deverá ocupar na Nova Agenda para o desenvolvimento pós-2015

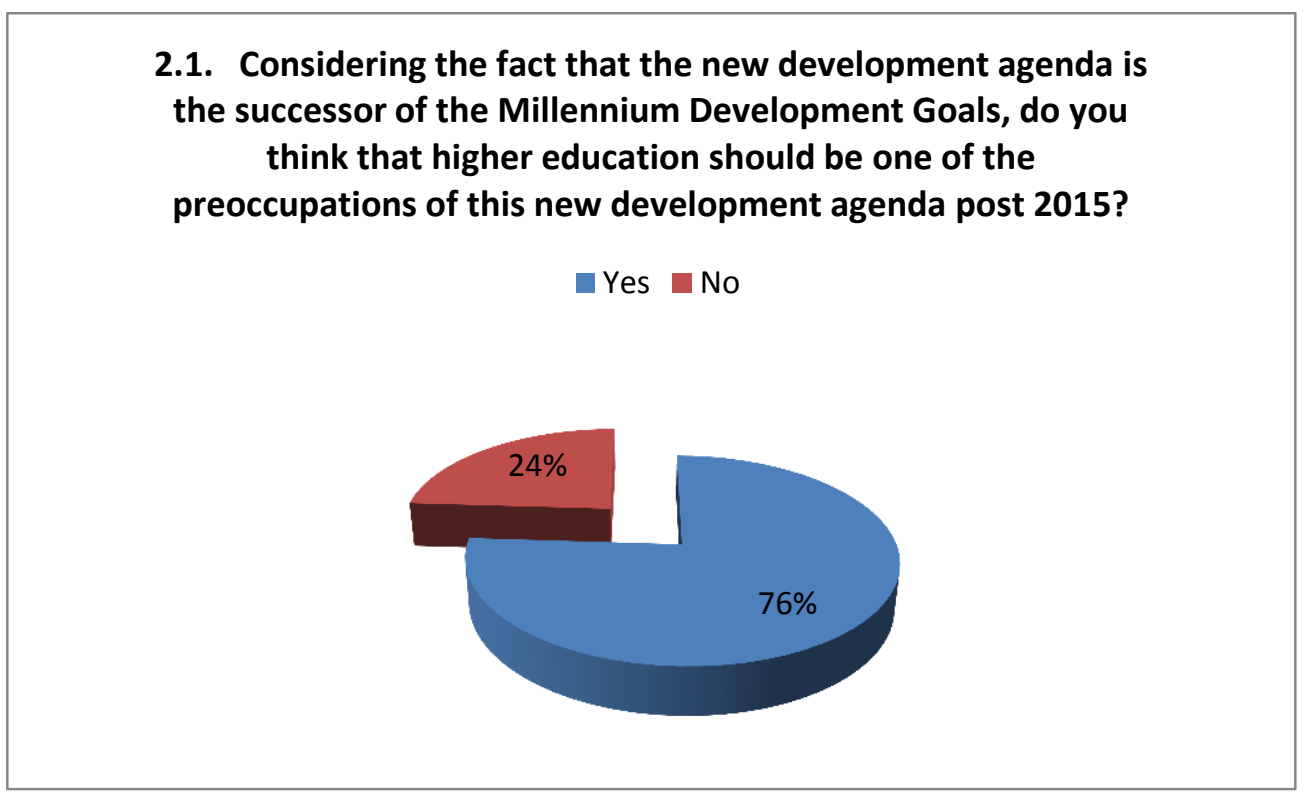


Gráfico 47 - Opinião por tipo de Ator em relação ao papel que o ensino superior deverá ocupar na Nova Agenda para o desenvolvimento pós-2015

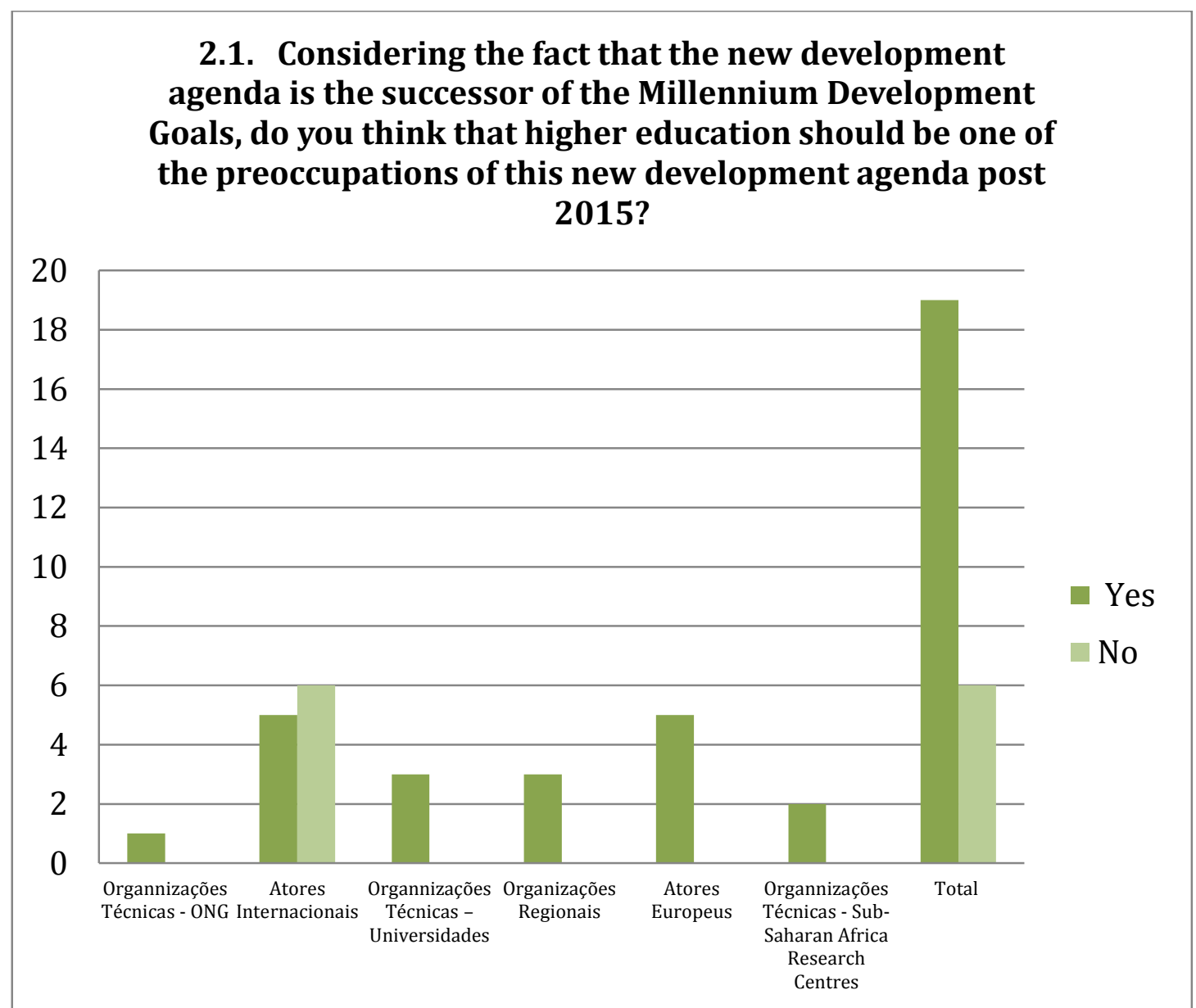

Os Atores Europeus seguidos dos Atores Internacionais são os que consideram, em maior percentagem, que o ensino superior deve constituir uma das preocupações da Nova Agenda pós-2015 (Gráfico 47). Defendem que o ensino superior constitui uma ferramenta chave no fornecimento do conhecimento o qual é uma condição necessária ao desenvolvimento através da criação de emprego, do aumento do empreendedorismo e da mobilidade inter-geracional, de uma sociedade civil fortificada e de um melhor governo. De fato, a recente comunicação da União Europeia EU Higher Education in the World ${ }^{78}$ sublinha a importância das parcerias estratégicas e da cooperação no ensino superior com os países parceiros e a

\footnotetext{
${ }^{78}$ Documento acessível em: http://eur-lex.europa.eu/legal-content/EN/TXT/?uri=CELEX:52013DC0499
} 
necessidade de assegurar coerência entre as estratégias de internacionalização e as políticas europeias de cooperação internacional as quais devem considerar os princípios da equidade e da apropriação pelos países terceiros, mas também devem considerar os investigadores, os estudantes e os trabalhadores dos países em desenvolvimento como vetores de cooperação com as suas Instituições de Ensino Superior.

For the EU, higher education is key to delivering the knowledge requirements for economic development: through job creation, better governance, increased entrepreneurship and intergenerational mobility, and a stronger civil society. The EU (...) outlines the importance of strategic partnerships and cooperation in higher education with partner countries and the need to ensure coherence between internationalisation strategies and EU development cooperation policies by considering the principles of equity and partner country ownership; use students, researchers and staff from non-EU countries as vectors of cooperation with HEIs in these countries. (Comentário de um Ator Internacional)

No entanto, os Atores quando confrontados com a pergunta relacionada com o nível de educação que poderá ter maior relevância para o desenvolvimento aparentam ter uma opinião um pouco diferente uma vez que os resultados demostram uma divisão, mais ou menos equitativa, entre os diferentes tipos de educação, considerando que o ensino secundário e terciário são igualmente importantes (36\% e 35\% respetivamente) e uma importância ligeiramente menor para o ensino primário (29\% - cf. Gráfico 40). A fundamentação passa pelo fato de que uma economia sustentável necessita de todos os níveis de educação. $\mathrm{O}$ acesso ao ensino primário e secundário deve ser universal, equitativo e de qualidade. O seguimento dos estudos deverá ser efetuado de acordo com as capacidades dos alunos, os mesmos devem seguir para o ensino superior, para o ensino vocacional ou para o mercado de trabalho. Não obstante, é importante mencionar que as taxas de iliteracia de cada um dos países deve ser tida em conta na medida em que nos países onde esta taxa é mais elevada terá de ser dada maior relevância aos níveis de educação mais baixos. De uma forma geral os Atores que suportam a ideia de que o ensino superior proporciona o desenvolvimento consideram que recursos humanos qualificados são essenciais para um sistema económico 
sustentável e independente de forma a fazer frente às regras internacionalmente impostas pelos mercados comerciais e industriais através de profissionais melhores preparados e informados. Por outro lado, contribui para cidadãos - profissionais e líderes - mais conscientes dos seus direitos os quais irão, certamente, fazer escolhas mais acertadas, contribuindo como agentes ativos e responsáveis para a mudança capazes de criticar os sistemas edificados. Para que a sua missão seja levada a cabo é indispensável colmatar os vários desafios que as universidades africanas enfrentam como já mencionado no quadro teórico, nomeadamente a instabilidade política, as desigualdades de género, a falta de académicos qualificados, as dificuldades financeiras, a procura pela qualidade de ensino, uma maior taxa de utilização das novas tecnologias, assim como a adaptação do ensino às necessidades locais do mercado de trabalho. No que respeita à opinião dos Atores a mesma vai ao encontro, de uma forma geral, das necessidades mencionadas com especial foco para as dificuldades que respeitam ao apoio financeiro e à falta de recursos humanos qualificados na área dos profissionais de ensino superior, i.e., professores com grau de doutoramento (Gráfico 48). Os Atores Internacionais são os que mais dificuldades apontam seguidos pelos Atores Europeus os quais corroboram as dificuldades já mencionadas, fundamentalmente, ao nível do apoio financeiro e de capital humano. Verifica-se alguma preocupação que começa a emergir com o fenómeno de brain drain (Gráfico 49). 
Gráfico 48 - Opinião dos Atores quanto às dificuldades que as universidades enfrentam nos países em desenvolvimento

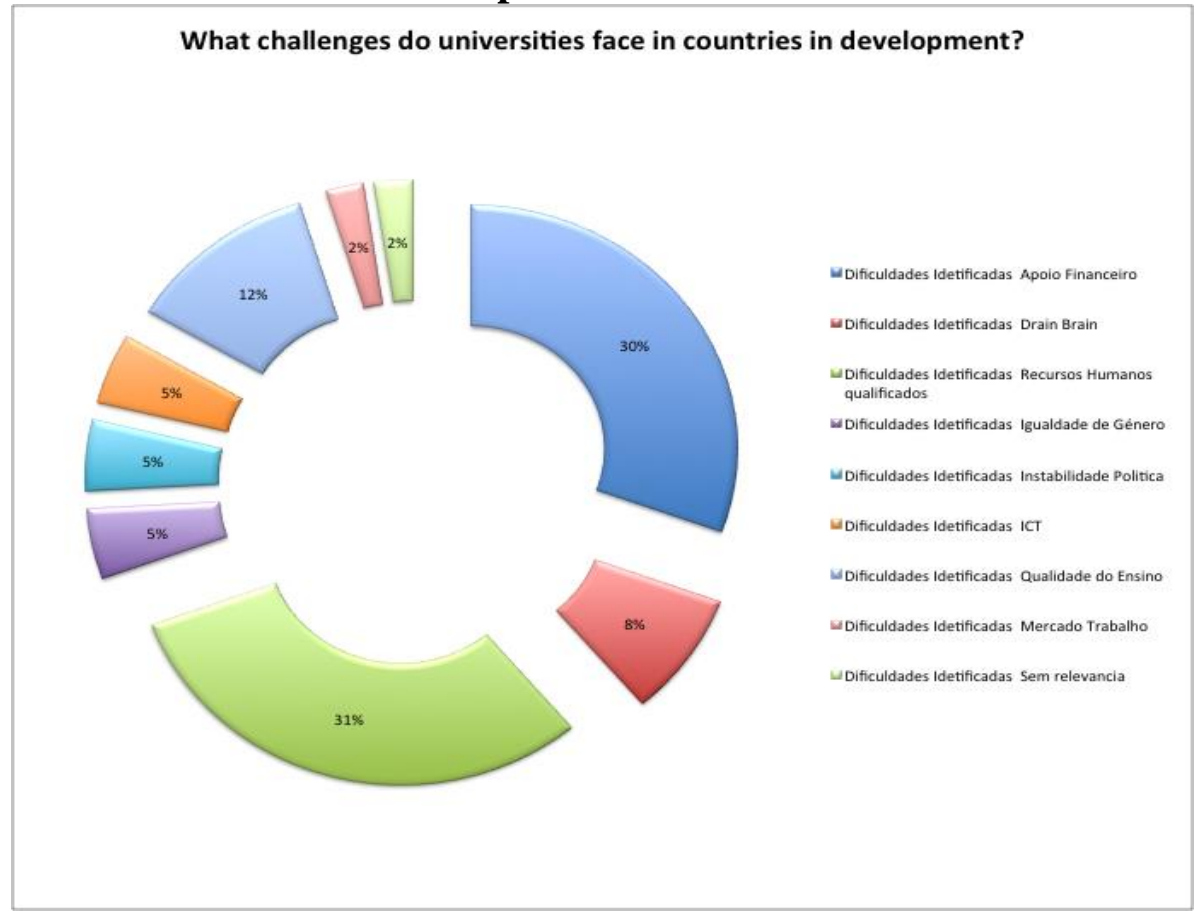

Gráfico 49 - Opinião, por tipo de Ator, quanto às dificuldades que as universidades enfrentam nos países em desenvolvimento

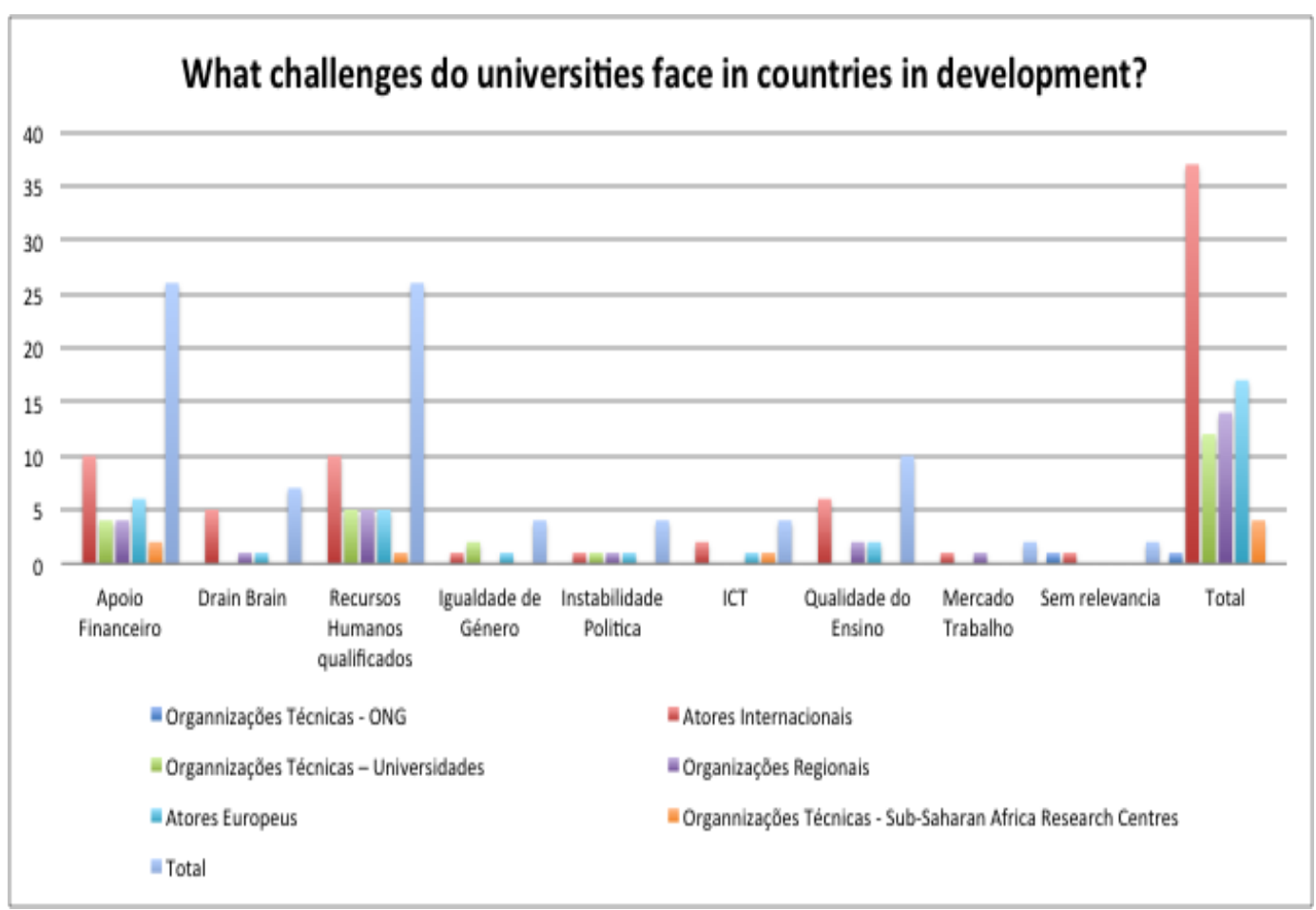


Um dos comentários dos Atores Internacionais vai ao encontro da situação mencionada descrevendo os desafios mais relevantes que as universidades dos países em desenvolvimento enfrentam, assim como descreve outros fatores identificados no enquadramento teórico nomeadamente a rápida expansão do ensino superior e consequente massificação com repercussão ao nível das infraestruturas. Refere, ainda, a necessidade de reforçar os sistemas de ensino superior, incluindo o financiamento, a retenção, a formação e qualificação dos professores, mas também a harmonização da estrutura educacional e a sua qualidade, o reconhecimento das qualificações e a capacitação ao nível da investigação. Considera que o surgimento das universidades privadas exerceu pressão ao nível das competências académicas forçando a uma maior preocupação por parte das universidades no que respeita à qualidade dos seus serviços, não só porque passa a competir num universo cada vez mais globalizado e internacionalizado, como já exposto, onde a economia do conhecimento tem um papel primordial. De forma a se tornarem competitivas é essencial que façam parte das redes académicas internacionais que produzem conhecimento, inovação e investigação. Para tal, torna-se primordial apostar na educação digital a qual permite oferecer novas oportunidades e um maior acesso à educação especialmente nas zonas rurais ou grupos desfavorecidos, mas também para chegar a potências alunos que não tenham possibilidades de viajar a ter acesso a outro tipo de informação. Desta forma, o papel social das IES também se altera, não só ao nível local, mas similarmente ao nível regional e nacional no sentido de criar capacidades em economias emergentes e na criação de parcerias internacionais. Esta ideia é expressa na recente comunicação da Comissão Europeia Opening up Education $(2013)^{79}$ a qual tem como intuito o "Ensino e a aprendizagem para todos de maneira inovadora graças às novas tecnologias e aos Recursos Educativos Abertos”. Este Ator Internacional manifesta a sua preocupação no que concerne à qualidade do ensino superior, pois considera que os alunos, cada vez mais, acabam a sua graduação sem os conhecimentos e as competências que se espera que tenham, para fazer face ao mercado trabalho. Menciona que o principal foco de trabalho da União Europeia com África, em matéria

\footnotetext{
${ }^{79}$ Documento official pode ser consultado aqui: http://eur-lex.europa.eu/legalcontent/PT/TXT/PDF/?uri=CELEX:52013DC0654\&from=EN
} 
de ensino superior, passa pela criação de políticas públicas que tenham em vista a melhoria da qualidade do ensino superior, visando também a harmonização dos programas de ensino para o reconhecimento das qualificações de forma a possibilitar a cooperação com Europa. São várias as iniciativas que estão a decorrer, por parte dos Estados Membros Europeus as quais foram identificadas no quadro teórico, na área do ensino superior, na medida em que se tem vindo a reconhecer o seu valor no desenvolvimento socioeconómico dos países.

Due to the extensive expansion of higher education participation and enrolment, tertiary education systems in many developing countries face pressures of massification and enormous challenges in infrastructure. The response needs to focus on strengthening the higher education systems, including financing, retention, training and retraining teachers, harmonisation of educational structures, quality assurance, recognition of qualifications and research capacity. Dramatic expansion and the rise of private institutions have heaped pressure on academic standards. This places developing countries at a significant disadvantage, and puts special strains on most academic systems facing the dilemma of expanded enrolment and the need to support top-quality universities. In a context of globalization in the university world, countries that are only weakly connected to the global knowledge economy find themselves increasingly at a disadvantage, as they are excluded from those international academic networks that produce knowledge, innovation and research. How education is delivered is also changing across the globe, and all levels. Digital education can offer new opportunities and in a number of countries can be an answer to a wider access especially in rural areas and for disadvantaged groups or to reach potential students who may not be able to travel or take a break from employment. It changes the social role of institutions as providers of knowledge and innovation and as contributors to development, putting new pressures on HEIs in Europe in particular to rethink their societal responsibilities in their local, national and regional context, including the responsibility to build capacity in emerging economies and developing countries of the world and engage in worldwide partnerships. This potential is addressed in the recent Commission Communication "Opening up Education" ${ }^{80}$. Quality in education is one of the most pressing issues, in Europe but also in the developing world where more and more students are graduating without the kind of profiles, knowledge, skills, competences and experience they need to succeed in the labour market. Quality in education is probably one of the areas that is

\footnotetext{
${ }^{80}$ Comunicação acessível em: http://europa.eu/rapid/press-release_IP-13-859_en.htm
} 
covered the most in recent policy dialogues with partner countries in the developing world. This is the main focus of the EU's work with Africa for instance in the field of higher education, in the framework of the Joint Africa-EU Strategy. The harmonisation of Higher Education in Africa is of the utmost importance to enhance the quality and relevance of graduates skills and qualifications, the harmonisation of degree programs and qualifications at continental level, and for cooperation with Europe. The Africa-EU Summit in April 2014 welcomed the planned extension of the Harmonisation and Tuning initiative to additional universities across the continent and the involvement of academics, students, graduates, employers, employers' associations and the councils for higher education and quality agencies in this initiative. EU Member States and UNESCO will be actively involved in the quality and accreditation measures undertaken in the initiative. Erasmus+ will address challenges in higher education by offering a balanced mix of actions addressing individuals, institutions and higher education systems. Programming is currently underway for the 2014-2020 period. Education is being chosen as a priority sector by a number of developing countries and the focus is changing towards a more holistic and comprehensive support to the education sector, with more focus on innovation, knowledge, quality and skills development. (Comentário de um Ator Internacional)

Tendo em conta o forte caráter do apoio financeiro no desenvolvimento e apoio às instituições de ensino superior nos países em desenvolvimento foram feitas questões aos diferentes tipos de Ator relacionadas com este item com o intuito de se verificar a sua opinião quanto aos apoios a serem fornecidos a estas instituições e a que nível.

\subsubsection{O sistema de financiamento das Instituições de Ensino Superior em Africa}

No seguimento das questões anteriormente colocadas onde se verificou que a cooperação internacional tem vindo a demonstrar o seu importante papel no progresso dos países em desenvolvimento, e em especifico, no que toca ao apoio ao sistema de educação, de acordo com os ODM, promovendo políticas de inclusão, ou seja, uma educação destinada a toda população e sem restrições de género, reconhecendo ao mesmo tempo a educação como um meio de erradicação da pobreza. Por outro lado, e de acordo com os mais recentes estudos, o reconhecimento do ensino superior como 
um fator de desenvolvimento de economias sustentáveis tem vindo a ser avidamente discutido entre as comunidades internacionais. Neste sentido, pretende-se compreender qual a opinião dos Atores inquiridos quanto ao tipo de apoio que consideram ser mais pertinente. A maioria dos Atores (42\%) considera que este apoio financeiro deve ser proveniente dos Governos Nacionais, seguido pelo Financiamento Internacional (31\%) e por último o Regional (27\%) - (Gráfico 50). Mencionam que para os países de rendimento médio o suporte financeiro através dos governos nacionais é essencial devendo coexistir com outros tipos de financiamento que funcionem como complemento a este e de forma coerente. Alguns dos Atores Regionais (Universidades) mencionam que a indústria local deveria considerar as universidades como parcerias de geração de conhecimento, assim como é necessário aumentar o apoio ao nível nacional, como por exemplo o apoio a estudantes através de bolsas e subsídios. $\mathrm{O}$ apoio internacional deveria servir de base à criação de redes de investigadores.

Local industry should consider universities as knowledge partners; national need to do more to support HEIs (for instance through input/enrolment and subsidies); international actors should donate smartly in collaborative efforts that will draw African researchers into networks with other Africans and with their counterparts in the bases of global science in the north. (Comentário de um Ator Regional, Organizações Técnicas, Universidades).

Estes Atores defendem que o apoio Regional favorece a proximidade, através da utilização de redes de centros regionais de excelência, enquanto o Internacional tende a favorecer a mobilidade entre estudantes, professores e investigadores. Consideram que os países menos desenvolvidos e com menores rendimentos deveriam poder contar com os fundos de programas de desenvolvimento propostos por organizações internacionais, muito embora este apoio deva ser sujeito a regras e controlo. Os Atores reconhecem que as Instituições de Ensino Superior em África dependem deste tipo de financiamento uma vez que os recursos locais não são suficientes para se tornarem independentes, contudo as parcerias com o sector privado devem ser estimuladas sendo este um desafios da comunidade Europeia tal como menciona um dos Atores Internacionais. 
Financing education is one of our big challenges. International financial support is necessary but we need to explore how to attract the international community attention again on education and also to reinvest interest not only of "traditional donors" but also of donors from emerging economies. We need also to more and better work with the private sector. We have to find the right angle. The Education for All Global Monitoring Report 2014 (GMR) highlights the importance of increased attribution of domestic funds (in addition to donors funds) to education (the 6\% a/o 20\%); the EU working in the same direction as the recommendations issued by the report (it is a chapter in all the national indicative programs (NIPs) and multiannual indicative programs (MIPs)). The GPE Replenishment conference hosted by the EU on 25-26 June in Brussels will aim at mobilizing increased domestic resources as well as external financing for education (Comentário de um Ator Internacional )

De fato, os Atores Internacionais são os que mais defendem que o apoio às Instituições de Ensino Superior deva ser efetuado através de verbas Nacionais (

Gráfico 51). Relembram que é necessário uma maior participação do sector privado, nomeadamente ao nível de parcerias com os centros de investigação de forma a desenvolver tecnologias que vão ao encontro das necessidades locais criando, ao mesmo tempo, recursos humanos qualificados que podem a posteriori ser absorvidos por este mercado industrial visto o seu potencial conhecimento das inovações desenvolvidas, criando-se espaço para a transferência de tecnologias e, consequentemente, contribuir para uma economia sustentável. 
Gráfico 50 - Opinião dos Atores quanto ao tipo de financiamento que deve ser fornecido, para as instituições de ensino superior de acordo com as suas necessidades, nos países em desenvolvimento

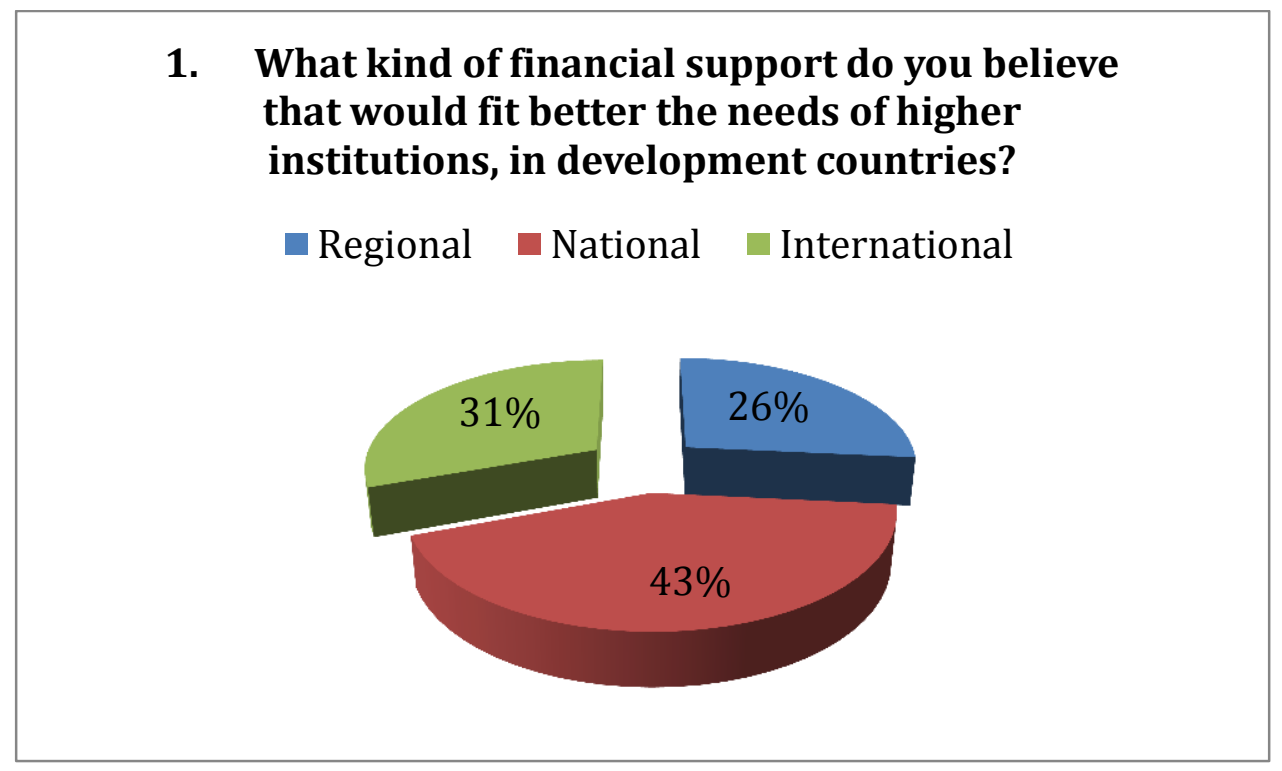

Gráfico 51 - Opinião, por tipo de Ator, quanto ao tipo de financiamento que deve ser fornecido para as instituições de ensino superior de acordo com as suas necessidades, nos países em desenvolvimento

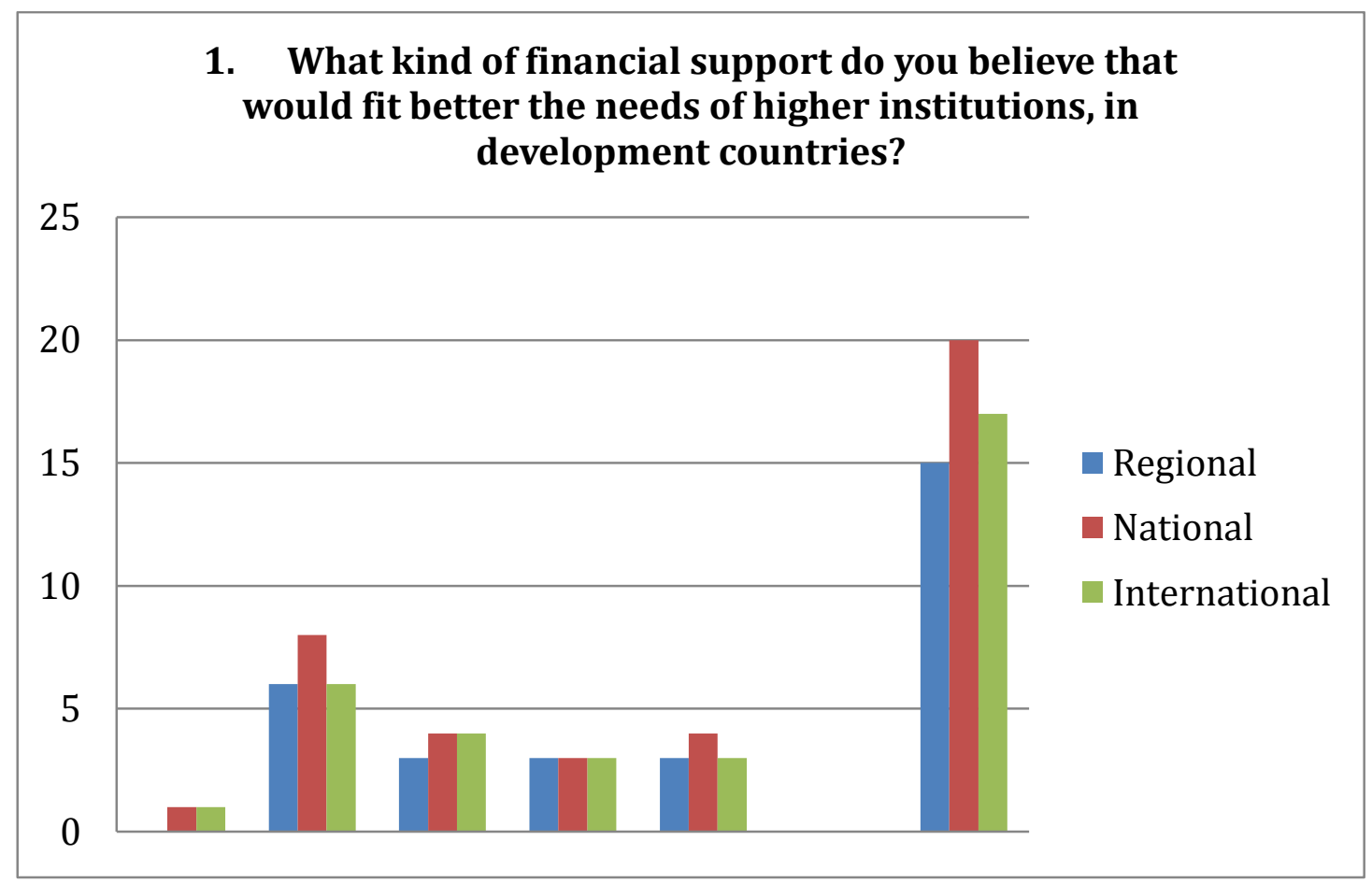


Quanto aos apoios financeiros propriamente ditos a maioria dos Atores considera que os mesmos devem ter como principal finalidade a formação de recursos humanos e o apoio a projetos de educação (Gráfico 52). Apontam que a formação constante de académicos, o intercâmbio de professores, de estudantes e os estágios nacionais e internacionais devem estar no topo da lista dos apoios. Alegam, ainda, que este suporte deve ser dado na forma de bolsas, para projetos de investigação e para a aquisição de material e melhoria das infraestruturas. Consideram ser de menor relevância os apoios internacionais na forma de créditos ou subvenção, ou seja, cujo apoio é dado para ser gerido diretamente pela instituição sem uma finalidade concreta. Contudo, tal como menciona um dos Atores Regionais, é importante procurar outros tipos de financiamento de forma a valorizar os resultados obtidos por parte dos estudantes.

Funding for collaborative efforts may include scholarships for shared postgraduate training, co-supervision, joint degrees, joint research, workshops / training to increase research skills, which will stimulate the formation of networks within the continent, and linking with academic networks in developed countries. The effect should be to reverse the marginalization of African scholarship by pooling it for greater critical mass and then engaging it with established scholarship communities. Too often African scholarship is treated as second-rate, whereas in reality there are excellent scholars but they need the correct platforms in which to develop their ideas with others and present it to the world as new knowledge. Within such collaborative consortiums the other needs for improved skills, capacity, infrastructure and so on can be supported according to the needs of the consortium; this includes scholarships for collaborative postgraduate training, funds for research, lab facilities, cost of travel to meetings and joint workshops/conferences, short courses in research skills, proposal development, academic writing, academic leadership, etc. But it is also good practice to seek co-funding of these initiatives from the institutions themselves or from the final beneficiaries as they will then value the outcomes more. (Comentário de um Ator Regional Organizações Técnicas Universidades)

Mais uma vez os Atores Internacionais são os que mais suportam o apoio à formação de recursos humanos, aos projetos de educação e de investigação (Gráfico 53). 
Consideram, no entanto, e em concordância com o ponto anterior, que o apoio nacional deve cobrir as necessidades ao nível das infraestruturas e de equipamento, de uma forma geral.

... as a whole, the support should be conditional (meaning that it should be provided for something particular that is identified as very important for the country's development), but also flexible to extend allowing the utilization of the support in the optimal way having in mind the local circumstances. The contributions could be used for exchange of students among countries, exchange of educators, scholarships, mainly something that would be lasting and could generate long-term effects. Equipment (unless very expensive technology which the country doesn't have access to) should be priority of the national government. The financial support of the international agencies should target building knowledge/skills, and providing opportunities for applying them later on (through paid traineeships for example). (Comentário de um Ator Internacional)

\section{Gráfico 52 - Opinião dos Atores quanto ao tipo de Apoio Financeiro a ser} fornecido

\section{What kind of financial contribution do the international} agencies for development should give to these institutions?

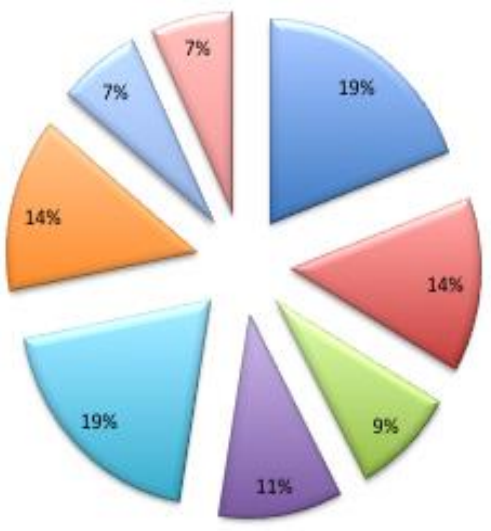

IFormaçăo RH

Molsas

MCréditos/Subvençōes

EEquipamento / Infraestruturas

WProjetos de Educaçăo / Inter Universidades

Mrojectos de investigaçăo

A Apoio Direto

$\cup N / A$ 
Gráfico 53 - Opinião, por tipo de Ator, quanto ao tipo de Apoio Financeiro a ser fornecido

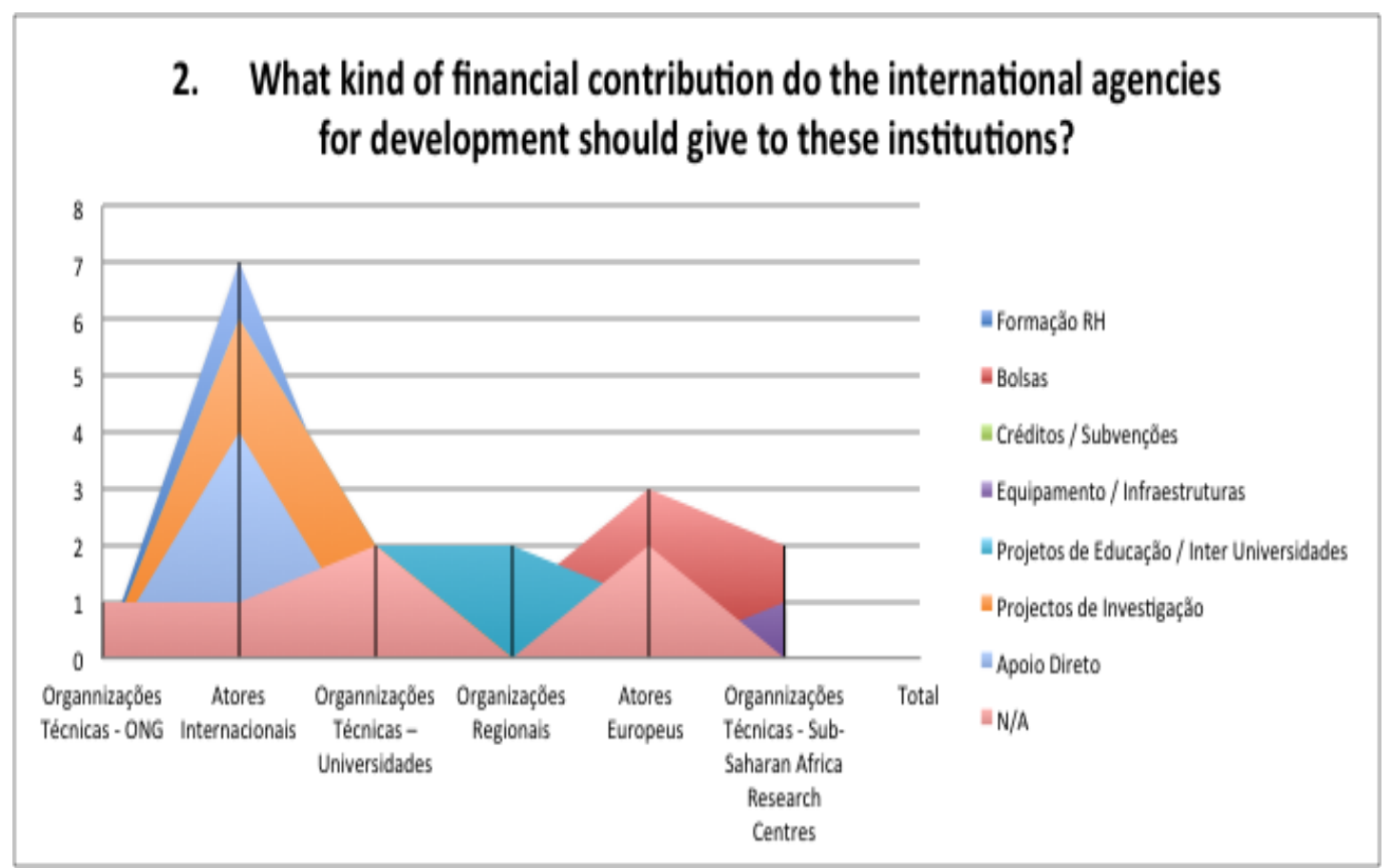

Quanto ao fato de considerarem o apoio financeiro suficiente, grande parte dos Atores (50\%) respondeu negativamente (Gráfico 54). Explicitam que o ensino é uma área que carece ainda de grandes mudanças, de acordo com o já mencionado, e que os programas educativos no âmbito da capacitação de recursos humanos e da mobilização de académicos, como por exemplo o programa Erasmus + , deveriam ser mais apoiados. Tal como menciona um dos Atores Internacionais o apoio financeiro externo seria suficiente no caso de as instituições funcionarem bem. Acresce que deve existir o compromisso, por parte dos representantes dos países africanos, de melhorar o sistema educativo de forma a ir ao encontro dos requisitos internacionalmente reconhecidos dentro da área.

External financial help can never be sufficient unless the local institutions function well. Therefore, financial help shoud not be the only way to help. In parallel with this, there should be engagement of the representatives of the African countries (governmental representatives, educators, non-profit organizations, students, etc.) in international endeavors for improving the educational system across the world - that could 
be attending conferences, seminars, taking part in international educational projects, etc. (Comentário de um Ator Internacional)

\section{Gráfico 54 - Opinião dos Atores quanto ao suporte financeiro existente atualmente}

3. In your opinion is it sufficient?

Os Atores Internacionais em conjunto com os Atores Europeus são os que mais identificam a necessidade de financiamento externo, ainda que a opinião dos primeiros esteja subdividida (Gráfico 55), tal como demostra o comentário abaixo.

More funds can always be spent but we operate in an environment with limited resources and politics is about making choices. Given the current circumstances and the current needs of Africa, it seems the level of support to higher education is relatively adequate. (Comentário de um Ator Internacional) 
Gráfico 55 - Opinião por tipo de Ator quanto ao suporte financeiro existente atualmente

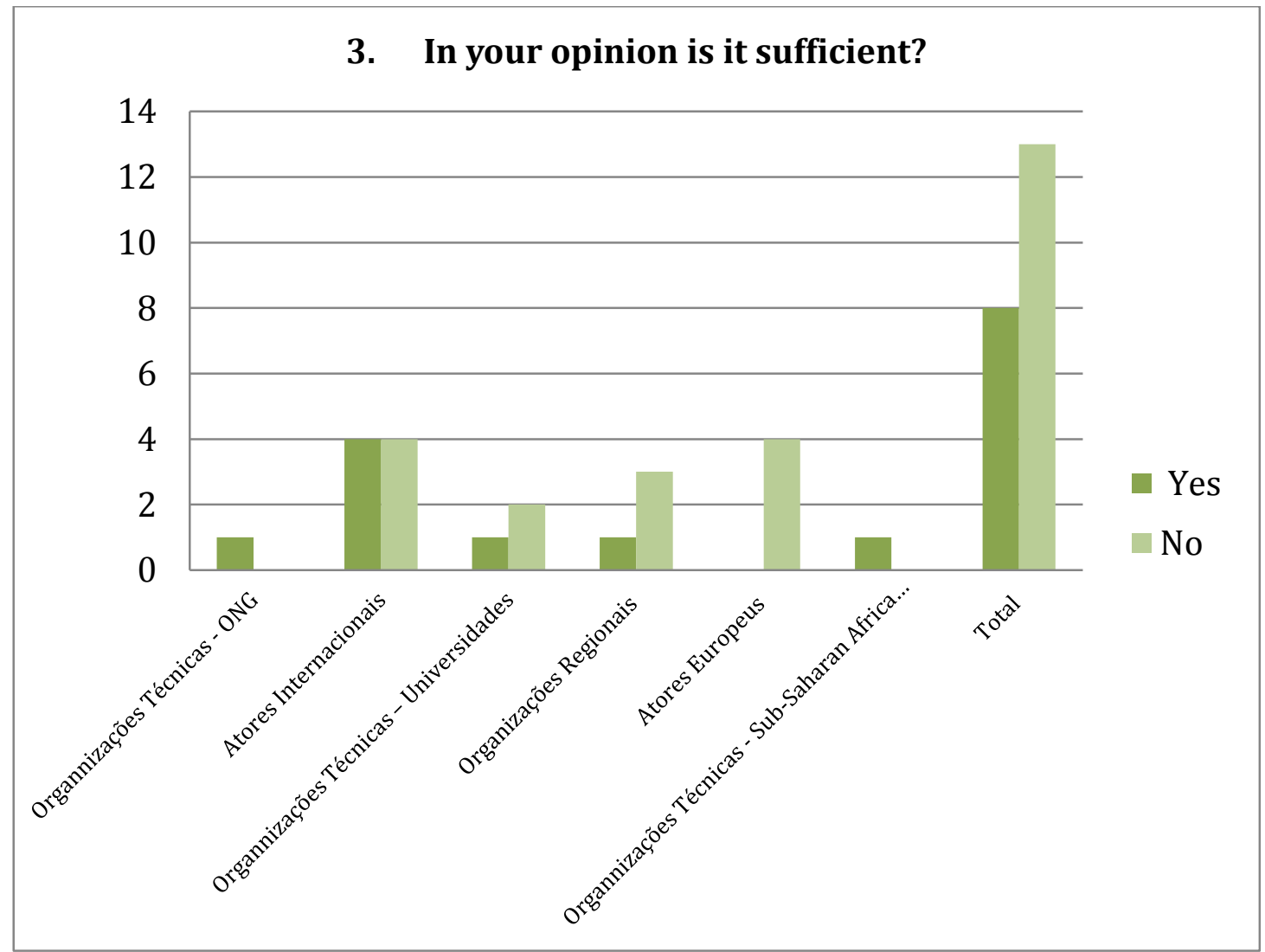

Este apoio, de acordo com o já mencionado, deve ir ao encontro das necessidades de criação de recursos humanos qualificados sendo, no entanto, importante promover as parcerias entre universidades através de programas de mobilidade e através de politicas educacionais que permitam contornar o fenómeno de brain drain, de forma a ser obrigatório para os estudantes africanos voltarem ao seu país de origem. A possibilidade de cooperação com o setor privado poderá ter aspetos significativamente positivos oferecendo, por exemplo, estágios após o retorno destes estudantes através dos quais irão adquirir competências práticas requeridas pela mercado de trabalho.

Capacity-building through twinning with universities in Europe and allow the African institutions to become sustainable. Mobility programmes should however take the problem of brain drain into consideration and it should therefore be mandatory 
for African students to return to their home country. I would also advise strong cooperation with the private sector to make sure the students obtain skills that are asked for in the jobmarket. These companies could also offer internship opportunities. (Comentário de um Ator Internacional).

O apoio das Agências Internacionais passa ainda pelo apoio descentralizado, na medida em que os apoios fornecidos são utilizados diretamente pelas universidades, mas de acordo com as medidas antes mencionadas. As Agências têm a seu cargo a promoção, a monitorização e a disseminação da informação relacionada com os programas existentes.

For Erasmus +, the action "credit mobility" is decentralized and managed by the network of E+ National Agencies located in Programme countries. It is up to universities from "Programme countries" to apply for funding to national Agencies, on behalf of their partners. Agencies are in charge of promoting, monitoring and dissipating information on erasmus+. Their role is to guide potential applicants on choosing relevant types of action, advise on administrative procedures and contractual issues, provide training and assistance on proposal writing, distribute documentation (forms, guidelines, manuals, etc) and assist in partner search. (Comentário de um Ator Internacional)

Quanto ao apoio financeiro que cada tipo de Ator tem vindo a dar para suportar as Instituições de Ensino Superior, na ASS, as respostas foram bastantes evasivas. A maior parte dos Atores respondeu que não tinha conhecimento sobre os valores em causa nem de que forma este apoio tem sido efetuado, com a exceção das seguintes respostas:

Comentários de Atores Internacionais

1) "The European seventh framework programme on research allocated 178 MEUR to researchers from Africa.

2) The Commission has invested $€ 4.2$ billion on education as a focal sector in 42 partner countries and in the EU Higher 
Education programs in the programming period 2007 - 2013. As you may know, many countries have graduated from EU ODA, but we still forecast around an estimated $€ 4.5$ billion in support of education in 2014-2020, i.e. an increase. Out this, the total of $€ 1.68$ billion will go to support the external dimension of the Erasmus+ program. 15 countries have chosen education and/or training as a focal sector in Africa, and we expect that this will bring an increase in EU support to education on the continent. Specific support to sub-Saharan Africa? Erasmus + for SA (2014-2017) : 21M

Comentário de um Ator Regional

1) The needs are so immense that budgets are not enough. Our committee is new and therefore it needs a strong support, and in diverse areas of its missions to ensure its growth. The support to be provided depends on the priorities of the institution, which are based on the major priorities of the government. For Burundi, we have the following areas as priorities: The budget depended, every time, of the Commission's various projects in relation to its mission and action plan. For the University of Burundi, (..) support allocated covered a set of projects (9 in all) that had been developed with the Belgian partners (CUD). Budgets were granted annually and projects extended over a period of 5 years renewable (for CUD, French Cooperation), 13 years (for VLIRUOS, Dutch cooperation).

Comentário de um Ator Regional - Organizações Técnicas - Universidades

1) My institution has invested in various collaborative efforts with SSA HEIs but the value is not known to me - perhaps 300,000-400,000 euros in the past five years. We have also received funding from various agencies for collaborative networks of the nature described above to the value of perhaps 2-3 million euros over the past five years.

Dos comentários expostos podemos concluir que a maioria dos Atores não tem perceção dos montantes atribuídos pelas suas instituições para o apoio de instituições de ensino superior na ASS. São poucos os que conseguem apontar com precisão qual o montante dos fundos e onde foram investidos. No entanto, quando se questiona 
quanto ao fato destes fundos estarem sujeitos a avaliações referentes à aplicação e execução de acordo com as regras estipuladas pelo projeto / programa a maioria dos Atores $(78 \%)$ respondeu que sim (Gráfico 56). Contudo, as justificações não são coerentes pois não sabem identificar quais as medidas de avaliação e monitorização que são utilizadas, com a exceção de um único Ator Internacional (apesar deste grupo de Atores ser o que mais concorda (Gráfico 57Gráfico 57) indicando que cada programa ou projeto Europeu tem de ser submetido a uma avaliação e respetiva monitorização. Indica, ainda, que o promotor do projeto tem uma estreita relação com outras instituições, assim como tem uma posição ativa na tomada de decisão estratégica e operacional. Menciona que no caso das ONG's são atribuidos fundos para ações específicas nos países parceiros, sendo necessário prestar contas de cada uma das etapas do programa.

Each EU programme/project is to be submitted to a monitoring and assessment. In addition to the EU collaboration and dialogue with partner countries, the EU maintains a close partnership and dialogue with international institutions and non-governmental organizations involved in the sector, including UNICEF, UNESCO and others. This partnership has various dimensions. With regard to international organizations, The EU is providing funds while at the same time being actively involved in strategic and/or operational decision making. Nongovernmental organizations obtain funds for specific actions in partner countries; at the same time, they are being consulted at various steps of the programming, both at headquarters and a country levels. (Comentário de um Ator Internacional) 
Gráfico 56 - Opinião dos Atores quanto às medidas existentes / ou não de avaliação da sua execução, nos países em desenvolvimento

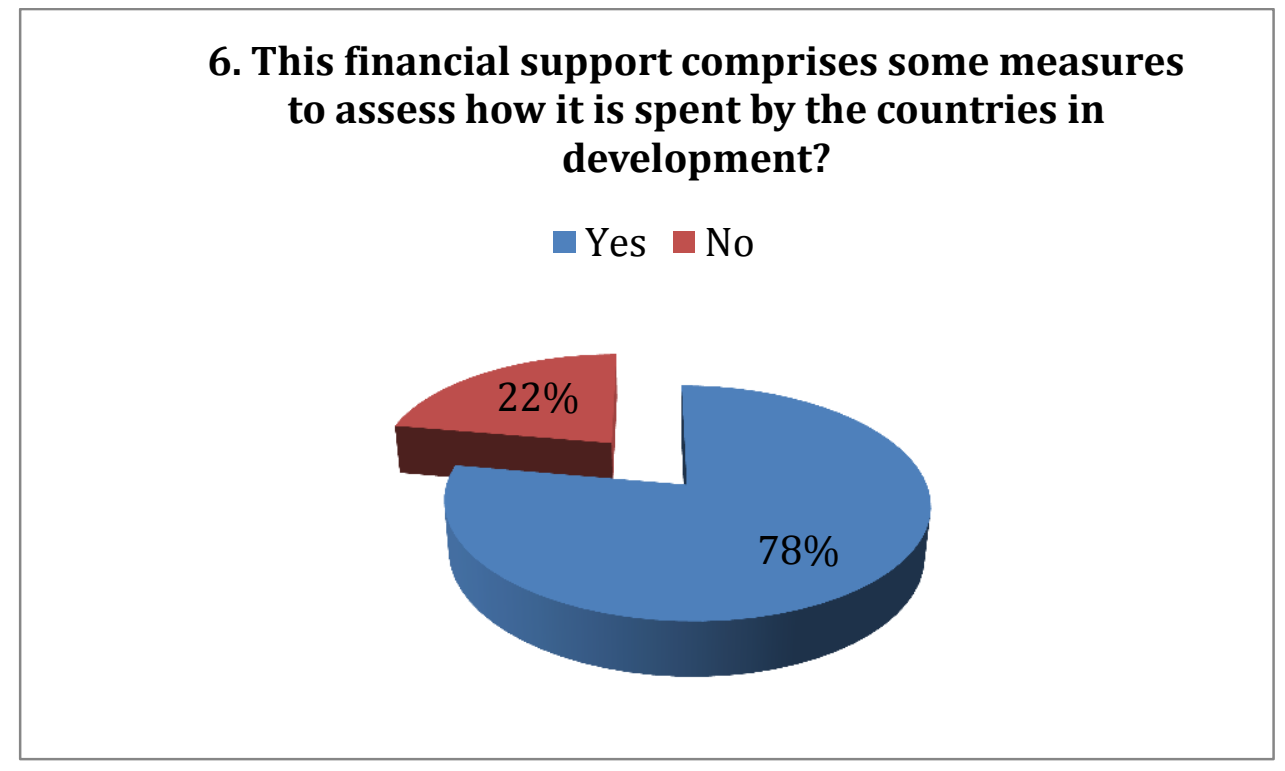

Gráfico 57 - Opinião, por tipo de Ator, quanto ao suporte financeiro atual e as medidas existentes / ou não de avaliação da sua execução, nos países em desenvolvimento

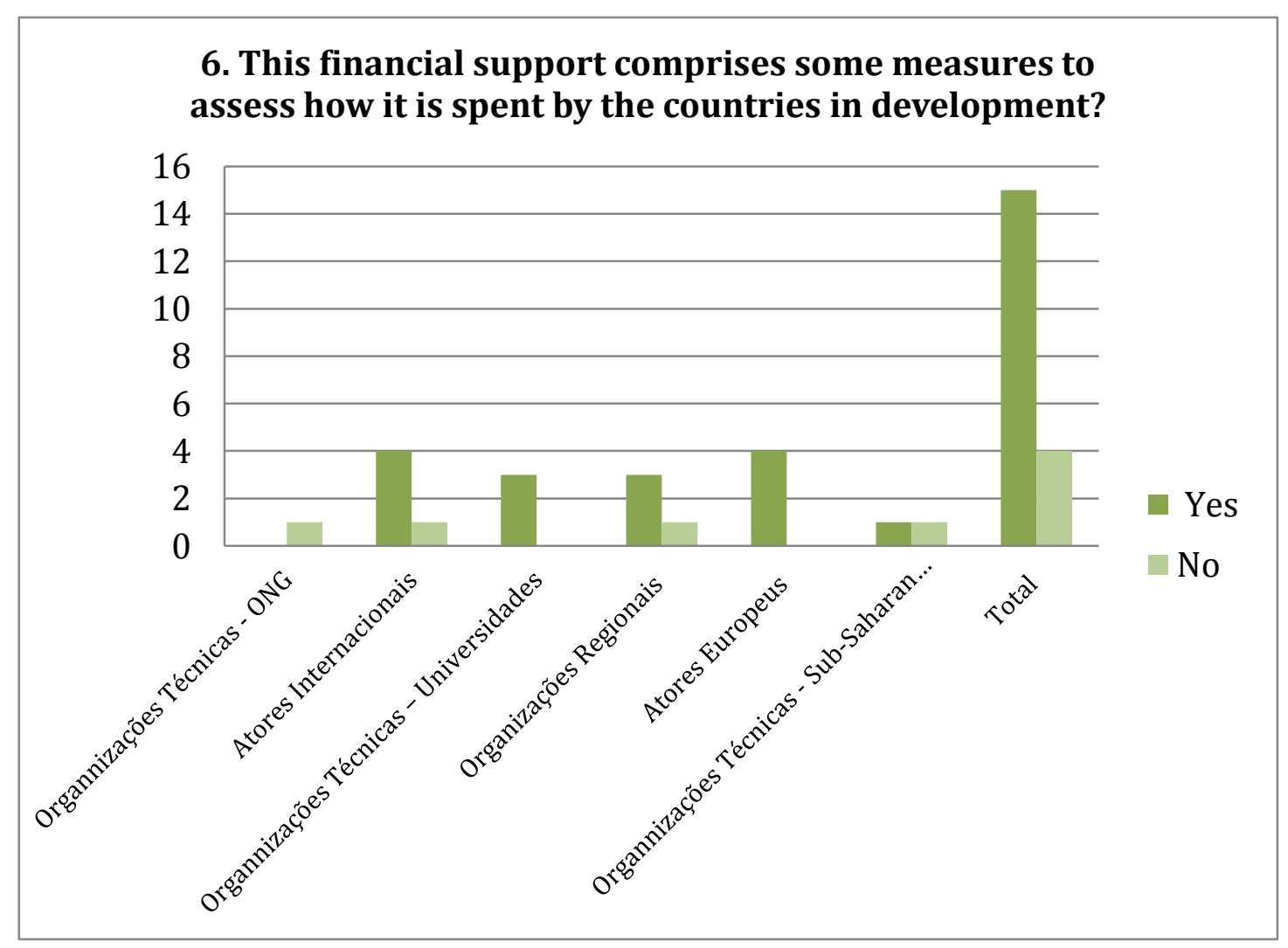


Quanto ao fato deste apoio financeiro ir ao encontro das necessidades dos estudantes, no sentido de possibilitar que os mesmos possam aceder ao ensino superior tendo em consideração os fracos rendimentos que por norma a sua família aufere, a maioria das respostas é muito vaga demonstrando que os Atores de uma forma geral não tem conhecimento da especificidade de cada projeto / programa de financiamento, ou seja, de que forma é aplicado o financiamento o que justifica o fato de também não saberem que tipo de avaliação é feita aos mesmos. Apenas um dos Atores Internacionais descreveu este processo de financiamento para um dos programas específicos e como são definidas as linhas prioritárias das necessidades. Explica que que são feitas consultas aos parceiros visto que, no caso do programa Erasmus + , o programa tem orientação "Bottom - up", ou seja, parte dos níveis mais baixos para os níveis mais elevados. Indica que esta orientação tem sido bem-sucedida em programas como "Tempus" e "Erasmus Mundus"demonstrando ser flexíveis ao ponto de permitir que a tomada de decisão seja tomada ao nível das universidades. Desta forma o apoio financeiro será aplicado de acordo com as necessidades locais de cada uma das universidades. Esclarece, ainda, que a consulta costuma ter lugar nos diálogos políticos com os parceiros através de encontros e/ou cimeiras onde todos os interessados - stakeholders - discutem os objetivos propostos para o programa baseados nos dados atuais do sector, orientações e prioridades no que respeita aos projetos de capacitação humana. A indicação destas prioridades será refletida nas propostas anuais de projetos de financiamento.

For Erasmus Plus - Yes. The priority orientations for the programme have been defined on the basis of a wide variety of consultations with the partner countries and regions. Erasmus+ is a demand driven and bottom up programme, targeting principally the higher education community in the partner countries (universities, associations, students, agencies, councils, etc.) so consultations are wider than just the partner country governments. The success of programmes such as Tempus and Erasmus Mundus is based on their bottom-up character and flexibility that allows universities to test new approaches and exchange with peers. Consultations have taken place in the framework of the various policy dialogues with Partner regions or countries, typically through platform meetings bringing together all stakeholders to discuss the proposed objectives of the programme and based on the current state of play of the sector, the main challenges for a given 
region or country and overall orientations. Senior Official Meetings with partner countries have also been an opportunity to discuss orientations and priorities. [...] discuss priority areas with the regions in the run up to the annual call for capacity building projects, whereby the authorities/regional associations in charge of higher education will indicate which are the preferred areas for cooperation in the given period. These priorities will be reflected where relevant in the annual calls for proposals. Therefore, we can assure you that countries, universities, civil society and beneficiary groups have been consulted and the Erasmus + priorities are based on the results of these consultations.(Comentário de um Ator Internacional )

No que toca à preocupação com as desigualdades e às dificuldades financeiras dos estudantes o tipo de respostas foi idêntico à questão anterior visto que estão correlacionadas. Um dos Atores Internacionais comentou que esta preocupação está patente nos projetos / programas de financiamento ao ensino superior. Indica que os projetos de Harmonisation of Higher Education e Erasmus + são exemplos desta preocupação e prioridade, uma vez que se pretende garantir o acesso a este tipo de ensino a grupos vulneráveis e desfavorecidos. Informa que neste momento estão a ser desenhados mecanismos de avaliação para as diferentes etapas dos projetos para assegurar medidas inclusivas, nomeadamente:

- Autonomização dos fundos para os países menos desenvolvidos;

- Tetos aplicadas a grandes países, como as economias emergentes e de países de renda média superior;

- Campanhas de informação a ser organizadas, tanto na UE como nos países parceiros, para promover o programa de forma a assegurar a participação de universidades menos avançadas e para incentivar as universidades europeias a iniciar novas parcerias e envolver instituições de regiões e áreas menos desenvolvidas.

They are considered highly and this issue is included in our programmes/projects of Higher education. This will be the case for the project "Harmonisation of Higher Education" or for Erasmus+. For instance, for Erasmus Plus: This is one of our main concerns and our development priority. We want to 
ensure the access for vulnerable groups and disavantaged populations in the programme. We will have mechanisms at different stages to guarantee an inclusive approach, and notably, at design stage:1) Ring-fencing of funds for least developed countries (LDCs); 2) Ceilings applied to large countries, such as emerging economies (BRICs) and upper middle-income countries (UMICs)). Information campaigns to be organized both in the EU and in Partner countries, will promote the programme to ensure participation of less advanced universities and to encourage European universities to start new partnerships and to involve institution from lessdeveloped regions and areas. (Comentário de um Ator Internacional)

Assinala que, similar ao projeto Erasmus, o Crédito Internacional para a ação de mobilidade será gerido por uma rede de Agências Internacionais que receberão instruções precisas de como alocar os fundos durante o procedimento de seleção. Uma das principais preocupações passará precisamente por assegurar a participação de grupos marginalizados e instituições em desvantagem. No caso dos grupos marginalizados a seleção de estudantes visará critérios de mérito académico assim como será dada prioridade, no caso de perfis idênticos, aos alunos provenientes de grupos desfavorecidos. A autonomização e os limites, ainda em estudo, serão complementados por outras medidas que só poderão ser introduzidas durante a sua implementação e serão um mecanismo adicional para assegurar que o programa possa atingir a população esperada. Este programa irá permitir desenvolver novos indicadores os quais serão analisados durante a sua implementação, de acordo com uma monitorização sistemática de forma a permitir a participação dos países menos desenvolvidos, dos grupos e instituições mais desfavorecidos. Desta forma, será possível fazer ajustamentos durante o próprio programa no sentido de ser possível aplicar medidas corretivas na fase de revisão anual.

Similar to the intra-EU Erasmus programme, the international credit mobility action will be managed by a network of National Agencies that will receive precise instructions (...) on how to allocate the funds during the selection procedures. These instructions will deal in particular with the issue of how to ensure proper participation of marginalized groups and 
disadvantaged institutions. For disadvantaged groups, the selection of students is based on a criterion of academic merit but for two identical academic profiles, priority will be given to the student coming from a disadvantaged group. Ring-fencing and ceilings at design stage will be complemented by other measures that can only be introduced during implementation and will be an additional mechanism to ensure that the programme is targeting its intended population. In particular, the programme will develop indicators that can be followed throughout the programme. Systematic monitoring will gauge the participation of the least developed countries, people from marginalized groups and disadvantaged institutions. This will allow for adjustments over the course of the programme life: indicators will be identified to measure to what extent the most vulnerable groups have been included in the programme. If the results are not satisfactory, corrective measures will be taken at the annual review stage (Comentário de um Ator Internacional).

Como se tem vindo a averiguar a relação de cooperação entre a Europa e os países da África Subsariana é bastante estreita, no sentido de se tratar de uma ligação estratégica, como se verificou anteriormente. No mesmo sentido, a cooperação académica tem um importante papel no que respeita à capacitação humana, através de mais e melhores cursos, mas também no sentido de se dar apoio à área de investigação a qual se deve desenvolver para fazer frente às necessidades locais reforçando a ligação com a indústria e promovendo a inovação e a transferência de tecnologia. Novas redes de networking devem emergir desta cooperação as quais contribuem para a criação de centros de excelência difundindo troca de experiências. É neste sentido que de seguida iremos analisar as respostas dos Atores quanto à sua opinião sobre o fato da Cooperação EU - África constituir um importante fator no desenvolvimento de recursos humanos qualificados.

\subsubsection{A Cooperação Académica EU - África}

Tal como verificado a cooperação entre universidades europeias e africanas proporciona progressos ao nível do ensino e formação, da investigação e apoia o desenvolvimento estrutural e organizacional das universidades africanas. 
Efetivamente, a maioria dos Atores corrobora a ideia de que a Cooperação Académica EU - África é importante para o desenvolvimento de recursos humanos qualificados (Gráfico 58). Consideram que as universidades preparam peritos em diferentes áreas, desenvolvendo competências as quais têm um impacto positivo no desenvolvimento da economia.

Yes. Universities are the focal points through which experts in different fields and disciplines that affect development of economies are prepared and trained. Yes, because the cooperation will facilitate the skill development of existing human resources (Organizações Regionais).

Mencionam que os programas de cooperação existentes como INTRA-ACP ${ }^{81}$ e o EDULINK representam um importante fator de suporte à mobilidade de académicos no continente. Na perspetiva de um dos Atores Regionais (Universidades) as Instituições Europeias deveriam encorajar os académicos africanos, professores e investigadores, a desenvolverem uma carreira internacional de forma a estabelecerem programas sustentáveis entre os seus países de origem e a Europa de forma a contribuírem para o desenvolvimento das capacidades humanas. Efetivamente, esta cooperação poderá ser vantajosa em termos de aprendizagem contínua, de benchmarketing das melhores práticas na área do ensino e da investigação, na criação de redes de trabalho para partilha de conhecimento e abertura das fronteiras culturais africanas aos ensinamentos europeus. Não obstante, e como já mencionado, ao longo do trabalho é necessário criar condições locais de reacolhimento destes académicos para que se verifiquem os outputs mencionados e de forma a solucionar o fenómeno de brain drain.

Yes, the value of the INTRA-ACP programmes and EDULINK initiatives of the EU is extremely important to support mobility within the continent. EU institutions should encourage academic from Africa teaching/researching in Europe to establish sustainable programmes with their countries of origin

\footnotetext{
${ }^{81} \mathrm{O}$ regime de mobilidade académica intra-ACP apoia a cooperação do ensino superior entre países da África, do Caribe e do Pacífico (ACP). O esquema visa promover o desenvolvimento sustentável e o alívio da pobreza, aumentando a disponibilidade de mão-de-obra profissional de alto nível treinada e qualificada nos países ACP.. $\underline{\text { Mais informações sobre o programa }}$
} 
to contribute towards capacity development (Organizações Técnicas - Universidades).

\section{Os Atores Internacionais (Gráfico 59}

Gráfico 59) são os que demostram em maior grau que acreditam que esta cooperação académica EU - África é benéfica para a constituição de recursos humanos qualificados. Defendem que contribui para o aumento de recursos humanos com estudos de qualidade e para a disseminação de resultados científicos e técnicos. A construção de redes internacionais entre a Europa e a África é essencial para promover o mútuo entendimento e para disponibilizar os mais recentes desenvolvimentos ao nível do conhecimento. Para tal as redes criadas pelas instituições de ensino superior constituem uma importante linha de orientação para o desenvolvimento de capacidades, técnicas e pessoais, com impacto positivo na empregabilidade dos estudantes mas também ao nível estrutural e organizacional das instituições de ensino superior. Mais uma vez são dados como exemplo o programa Erasmus + e o crédito para a mobilidade. Este tipo de projeto tem impacto não só nos indivíduos mas também nas instituições as quais necessitam de oferecer melhores serviços para enviar e receber estudantes estrangeiros, para comparar e melhorar o programa dos seus cursos e as técnicas de ensino, assim como para reforçar a liderança institucional e a sua gestão. Outros programas foram mencionados pelos Atores Internacionais, nomeadamente:

- O programa Erasmus Mundus alumni - a maioria dos alunos regressa com cursos de qualidade os quais têm vindo a dar importantes contribuições para a academia, para a gestão das universidades, para o desenvolvimento de capacidades, da investigação e dos negócios;

- Marie Skłodowska-Curie Actions (MSCA), dentro do Programa Europeu de Investigação Horizonte 2020 - este programa continuará a suportar os recursos humanos no âmbito da investigação e da inovação. Aponta que 65.000 investigadores de todo o mundo irão beneficiar de mobilidade internacional e intersectorial assim como condições de trabalho atrativas; 
- O Programa de Mobilidade Nyerere - irá providenciar bolsas de estudo para 500 estudantes ao nível de estudos de pós-graduação e permitirá a mobilidade de 70 académicos e administrativos dentro de África até 2017. Desta forma será possível reter os alunos ao mesmo tempo que se aumenta a competitividade e a atratividade das próprias instituições;

- A União Europeia irá, igualmente, apoiar o desenvolvimento de centros de excelência em África, particularmente através da Pan-African University ${ }^{82}$. Pretende-se expandir as iniciativas de harmonização do Ensino Superior em África (African Higher Education Harmonisation) e a iniciativa piloto Tuning ${ }^{83}$ com o intuito de realçar a relevância da qualidade do curricula, de introduzir medidas de avaliação dos resultados ao nível do ensino e da aprendizagem, de aumentar de 60 para 120 o número de universidades africanas que participam e aumentar o número de disciplinas lecionadas e os níveis de ensino.

Por fim indica que impulsionar as iniciativas African Union Higher Education Harmonization e Garantia de Qualidade (Quality Assurance) permitirá promover práticas de qualidade nas universidades e suportará a implementação de um quadro continental de garantia de qualidade e de acreditação, um aumento de parcerias alinhadas e a internacionalização do ensino superior. Todas as ações levadas a cabo terão em linha de conta a consulta e o intercâmbio de informação entre os parceiros no sentido de "promover a educação, a formação profissional e o empreendedorismo entre as mulheres e os jovens".

\footnotetext{
${ }^{82}$ A Universidade Pan-Atlética contribui para o desenvolvimento nacional através da provisão de programas acadêmicos relevantes para as necessidades do país. A universidade está aberta a todas as pessoas, independentemente da sua nacionalidade, raça, sexo, religião ou grupo étnico. As atividades curriculares da Universidade fazem parte de uma formação mais ampla que é fornecida na Universidade - mais informação disponível em: http://www.pau.edu.ng/about-us/mission

${ }^{83}$ Tuning é um processo colaborativo e consultivo que envolve acadêmicos que trabalham em grupos de sujeitos com empregadores e outras partes interessadas no desenvolvimento curricular para aprimorar as competências dos alunos. Os projetos de afinação no ensino superior foram concluídos com êxito em mais de sessenta países ao redor do mundo. http://eeas.europa.eu/delegations/african_union/press_corner/all_news/news/2011/20111102_01_en.htm
} 
Thanks to this cooperation in higher education, there is an increase of high quality human resources and a higher dissemination of the results of scientific and technical research. The building of international networks between EU and Africa is essential for fostering mutual understanding and giving access to up-to-date knowledge. It is in this context that the networks that link institutions become a shared vehicle for capacity building across the board. Erasmus + will have an impact on the personal development and employability of students but also a structured and sustainable impact on universities/institutions. This is particularly the case of the credit mobility that has an impact not only on individuals, but also on institutions which need to develop better services to send and receive foreign students, compare and upgrade curricula, improve teaching and strengthen their institutional leadership and management. (Comentário de um Ator Internacional).

\section{Gráfico 58 - Opinião dos Atores quanto ao fato da Cooperação Académica EU - África constituir um importante fator no desenvolvimento de recursos humanos qualificados}

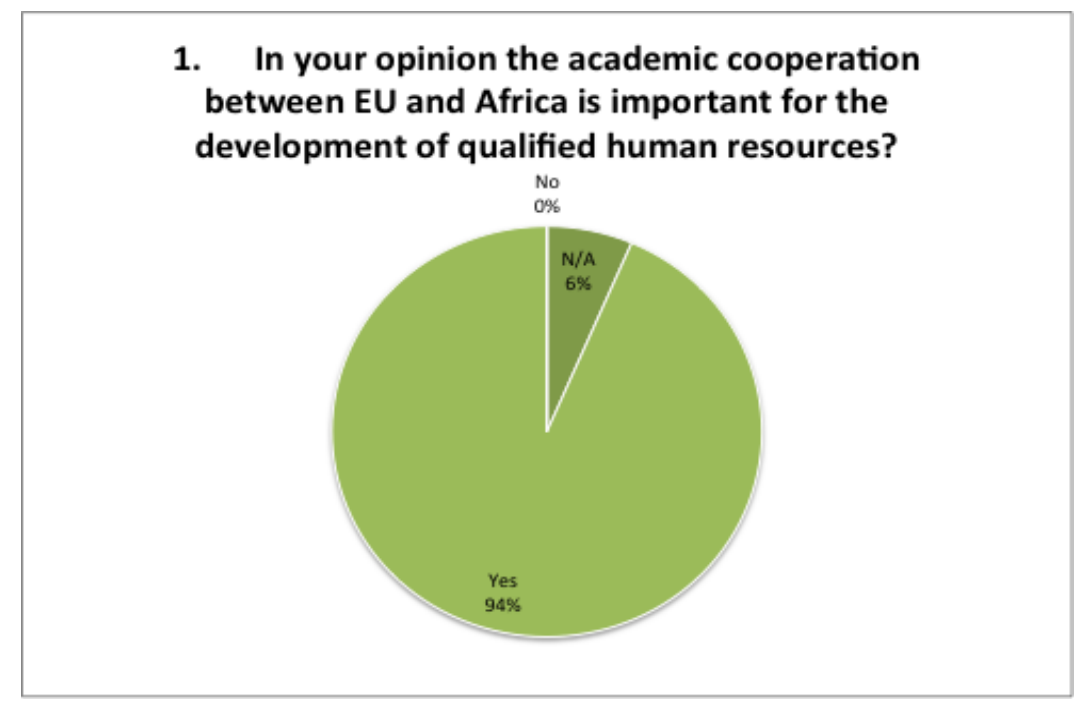




\section{Gráfico 59 - Opinião, por tipo de Ator, quanto ao fato da Cooperação Académica EU - África constituir um importante fator no desenvolvimento de recursos humanos qualificados}

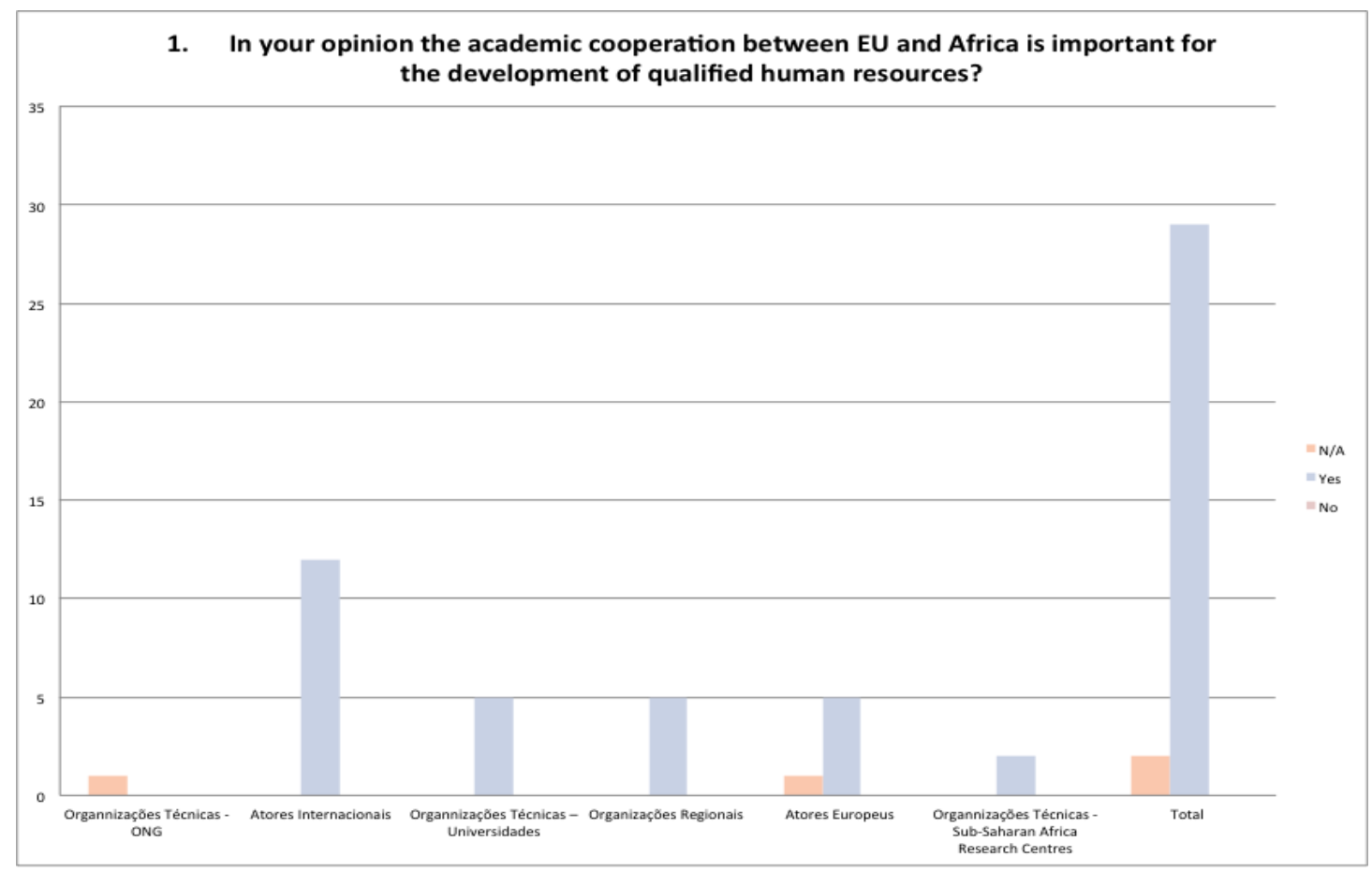

Na sequência da questão anterior a maioria dos Atores (Gráfico 60) consideram que as universidades têm um papel estratégico no progresso das economias em desenvolvimento, na medida em que contribuem para o crescimento económico e para a erradicação da pobreza, sendo que os Atores Internacionais são os que mais sustentam esta ideia (Gráfico 61). De fato, tem-se vindo a reconhecer, por parte da EU e dos seus parceiros, o importante papel do ensino superior para o desenvolvimento económico-social. Um dos Atores Internacionais menciona que o Processo de Bolonha e a Agenda Europeia para a Modernização do ensino superior forneceram um quadro comum de reformas nacionais. Esta foi completada a nível internacional por novos diálogos políticos (intercâmbio de melhores práticas em políticas de ensino superior), a nível regional e com os países parceiros estratégicos no âmbito dos programas de ensino superior internacionais como Erasmus Mundus, Tempus (para os países vizinhos), Alfa (América Latina ), e Edulink (países ACP) e agora com o programa Erasmus + . 
Yes, universities play a key role. Higher education institutions play a key role in society contributing to economic growth and the eradication of poverty. The focus on higher education complements the EU's development programmes for basic education. The European Union and its partners have long recognised the importance of higher education for economic and social development. The Bologna Process and the EU Agenda for the modernisation of higher education have provided a shared framework for national reforms. This has been supplemented at international level by new policy dialogues (exchanges of best practice in higher education policies) at regional level and with strategic partner countries under international higher education programmes like Erasmus Mundus, Tempus (for the neighbouring countries), Alfa (Latin America), and Edulink (ACP countries) and now with Erasmus+ (Comentário de um Ator Internacional).

Gráfico 60 - Opinião dos Atores quanto ao fato das universidades terem um papel estratégico no progresso das economias em desenvolvimento

\section{Do you think that universities have a strategic role on the progress of economies in development?}

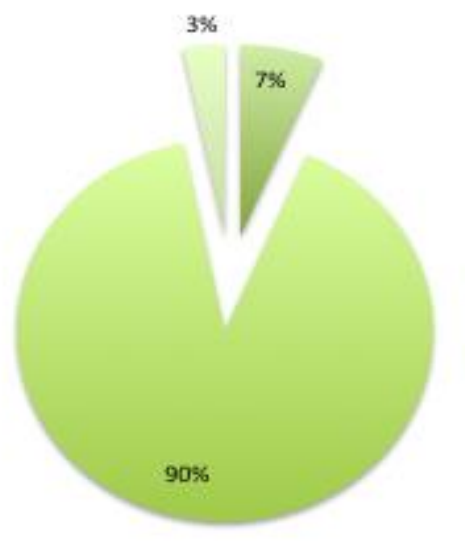


Gráfico 61 - Opinião, por tipo de Ator, quanto ao fato das universidades terem um papel estratégico no progresso das economias em desenvolvimento

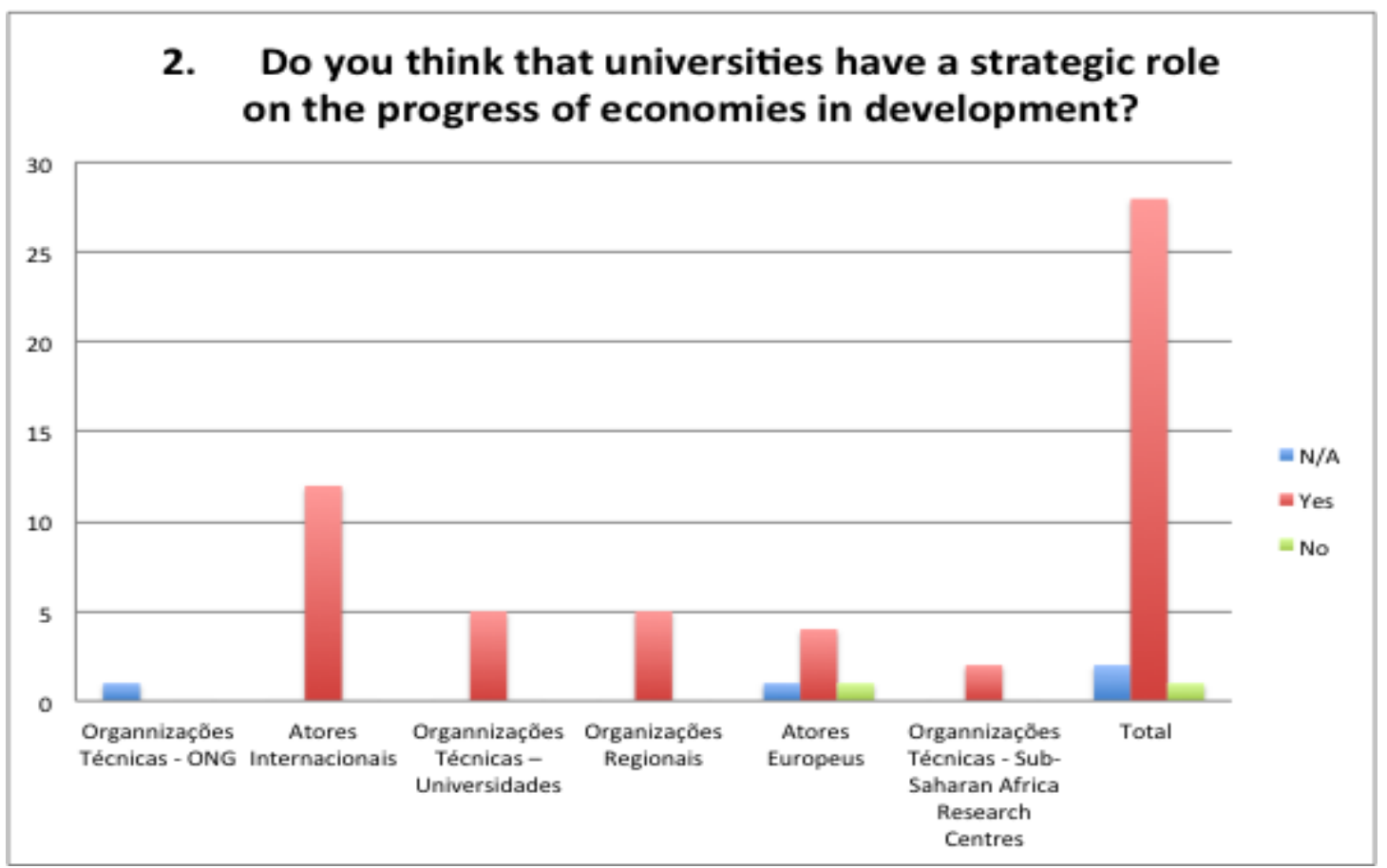

Muito embora se reconheça o importante papel da Cooperação Académica EU África para o desenvolvimento de recursos humanos qualificados e, concludentemente, para o progresso das economias dos países em desenvolvimento, assim como o papel da cooperação internacional ao nível das diferentes ajudas e ferramentas de apoio ao ensino superior, deparamo-nos com a pertinente questão de perceber se existe dependência do desenvolvimento tecnológico em África da cooperação académica. No que toca à opinião dos Atores (75\%) a maioria considera que sim (Gráfico 62). Os Atores Internacionais e os Atores Regionais ao nível das Universidades são os que mais corroboram esta ideia (Gráfico 63). A justificação consiste no fato de que é esta cooperação com a UE que tem vindo a permitir o desenvolvimento tecnológico em África. São os projetos conjuntos com base em parcerias multilaterais que financiam o desenvolvimento de currículos e modernização, novos diplomas, práticas atualizadas de ensino e de aprendizagem, melhoria das instalações e equipamentos, melhorando a gestão das universidades e 
permite criar melhores ligações entre o ensino superior e o mundo do trabalho. Esta cooperação financia projetos destinados a ter um impacto sobre os sistemas nacionais, através do envolvimento das autoridades nacionais em conjunto com instituições de ensino superior. O impacto verifica-se não só no desenvolvimento e empregabilidade dos indivíduos, mas também no desenvolvimento das capacidades das instituições.

The EU cooperation can support the countries and contribute to their technological development in Africa. For ex, with the capacity building action of E+, there will be joint projects based on multilateral partnerships to fund curriculum development and modernisation, new diploma, modern teaching and learning practices, upgrading of facilities and equipment, improving university governance and creating better links between higher education and the world of work. This action will also finance projects aiming to have an impact on national systems, through the involvement of national authorities, alongside HEIs. The Mobility action of the Erasmus+ programme will thus have an impact not only on the development and employability of individuals, but also on the development of the capacities of the institutions (Comentário de Ator Internacional)

Os Atores Regionais indicam que tendo em conta que a missão do ensino superior passa pelo ensino, pela pesquisa científica e pelo serviço à comunidade é imprescindível o uso das novas tecnologias de comunicação e informação, e cuja correlação foi já descrita no quadro teórico. Neste sentido, e uma vez que os parceiros europeus estão mais avançados, é necessário trabalhar em associação e intercâmbio com os mesmos para se verificarem os desenvolvimentos tecnológicos desejados.

Any institution of university higher education has, among other missions: teaching, scientific research and community service. With the use of increasingly require new communication technology and information, we know that our European partners are advanced in this area. Therefore, we can confirm that the missions of Universities, mainly in Africa, will be carried out satisfactorily in association and exchange with partners (Comentário de Ator Regional) 
Na perspetiva de um Ator Regional (Organizações Técnicas, Universidades) a cooperação garante que a marginalização da ciência em África seja revertida através da criação de comunidades de alunos em diferentes contextos Sul-Sul e redes de ligação com a ciência tradicional no norte. Estas redes devem garantir que os cientistas recebam apoio para o seu trabalho nos seus próprios contextos, para que não precisem de migrar para o norte. Em termos de carreira podem ser educadores, supervisores e mentores para os futuros profissionais e um modelo para os académicos futuros. Infere-se, neste caso, que a investigação científica e o desenvolvimento tecnológico devem ser efetuados utilizando os recursos locais existentes, no entanto, deve recorrer à partilha de informação e de conhecimentos através da cooperação e de parcerias académicas.

[...] cooperation ensures that the marginalisation of science in Africa is reversed by creating communities of scholars across different south-south contexts and linked into the traditional science base in the north. These networks ensure that scientists receive support for their work in their own contexts, so they do not need to migrate to the north for such support. In their own context they can be educators, supervisors and mentors for future professionals and a role model for future academics (Comentário de Ator Regional, Organizações Técnicas, Universidades).

\section{Gráfico 62 - Opinião dos Atores quanto à dependência do desenvolvimento tecnológico em Africa da cooperação académica}

3. In your opinion the technological development in Africa is dependent of the academic cooperation?

Yes $\quad$ No

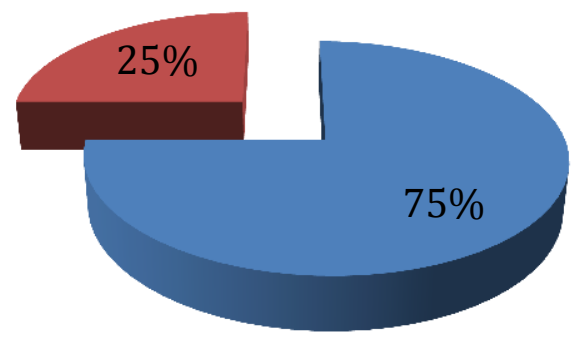


Gráfico 63 - Opinião, por tipo de Ator, quanto à dependência do desenvolvimento tecnológico em Africa da cooperação académica

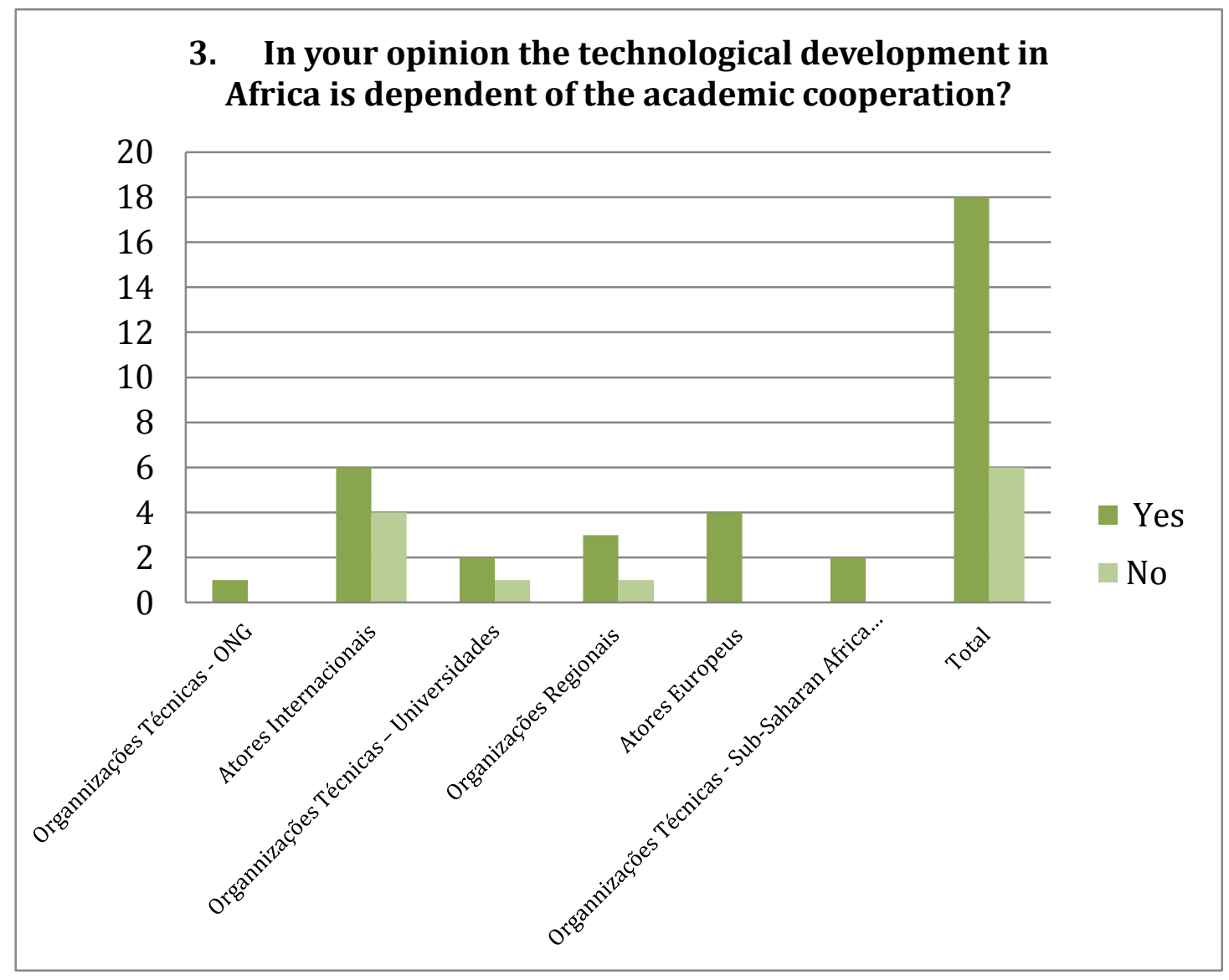

O incremento da cooperação académica poderá ser um ponto de partida para colmatar o fenómeno de brain drain em conjunto com as ferramentas de apoio ao nível da cooperação internacional como já demonstrado ao longo do trabalho. No entanto, as políticas governamentais deverão ir ao encontro destas iniciativas. A opinião dos Atores quanto ao desenvolvimento tecnológico através das políticas governamentais subdivide-se (Gráfico 64). Metade dos Atores considera que as políticas governamentais apoiam o desenvolvimento tecnológico e a outra metade não concorda. Os Atores Internacionais são os que menos concordam com esta afirmação. De uma forma geral, consideram que embora exista algum apoio não é o suficiente para suportar este crescimento. Um dos Atores Internacionais afirma que, em África, o crescimento vem principalmente da exportação de recursos naturais pelo que é necessário garantir a industrialização do continente para permitir que os recursos e os bens sejam processados localmente. Neste sentido, o desenvolvimento tecnológico 
será imprescindível para esse propósito, razão pela qual mais esforços devem ser desenvolvidos pelas políticas governamentais para esse fim. Infere-se que para que este desenvolvimento tecnológico e industrialização se verifiquem é imprescindível formar recursos humanos qualificados e, consequentemente, cursos superiores cujas áreas devem ir ao encontro das necessidades locais.

Probably not in a sufficient manner, so far. In Africa, growth mainly comes from the exportation of natural resources. The objective now is to ensure the industrialisation of the continent to allow for resources and goods to be processed on the ground. Technological development will be crucial in that regard and more should be done to that end (Comentário de um Ator Internacional).

Um outro Ator Internacional corrobora a ideia de que mais deve ser feito ao nível nacional. Contudo, menciona que os esforços devem ser conjuntos indicando que os Programas da UE no ensino superior, como Erasmus +, foram concebidos no âmbito dos vários diálogos políticos com regiões ou países parceiros e outros doadores. Os mesmos são efetuados através de reuniões plataforma que agrupa todas as partes interessadas para discutir os objetivos propostos dos programas com base no estado atual da situação do sector, nos principais desafios para uma dada região ou país e de acordo com orientações gerais. Assim, o programa indicativo plurianual da UE é o resultado desta consulta que deve incluir as prioridades acordadas da UE, das partes interessadas e do governo, as quais devem ser refletidas nas políticas do país e nos planos de ação.

EU programmes in Higher education, as Erasmust, are designed in the framework of the various policy dialogues with Partner regions or countries and other donors, typically through platform meetings bringing together all stakeholders to discuss the proposed objectives of the programmes and based on the current state of play of the sector, the main challenges for a given region or country and overall orientations. So, the EU multiannual indicative programme is the results of this consultation which should include the agreed EU and stakeholders and government priorities which should be reflected in the country policies and action plans (Comentário de um Ator Internacional). 
Os que concordam em maior grau são os Atores Europeus e as Universidades (Gráfico 65). Consideram que as políticas governamentais dos países em desenvolvimento vão ao encontro das suas necessidades, especialmente no que toca ao apoio para o desenvolvimento de infraestruturas e para os projetos que visam a capacitação humana através da educação. Ainda assim, mais ações são necessárias para sejam atingidos os fins pretendidos.

I) Yes, at national level, particularly through infrastructure projects (e.g. in the energy sector) and by investing in people (in education) (Comentário de um Ator Europeu).

II) Yes. At the national and regional levels. The policies can be enhanced further though. There is however some difficulties from policy to practice which governments in developing countries need to work consciously at to achieve much effective results (Comentário de um Ator Regional, Organizações Regionais).

\section{Gráfico 64 - Opinião dos Atores quanto ao desenvolvimento tecnológico através das políticas governamentais}

4. Do you consider that government policies of the developing countries are supporting technological development?

$\square$ Yes $\square$ No
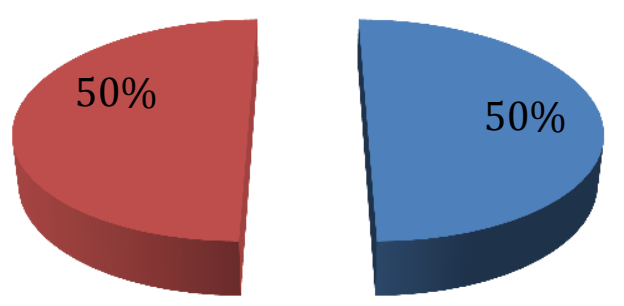


\section{Gráfico 65 - Opinião dos Atores quanto ao desenvolvimento tecnológico através das políticas governamentais}

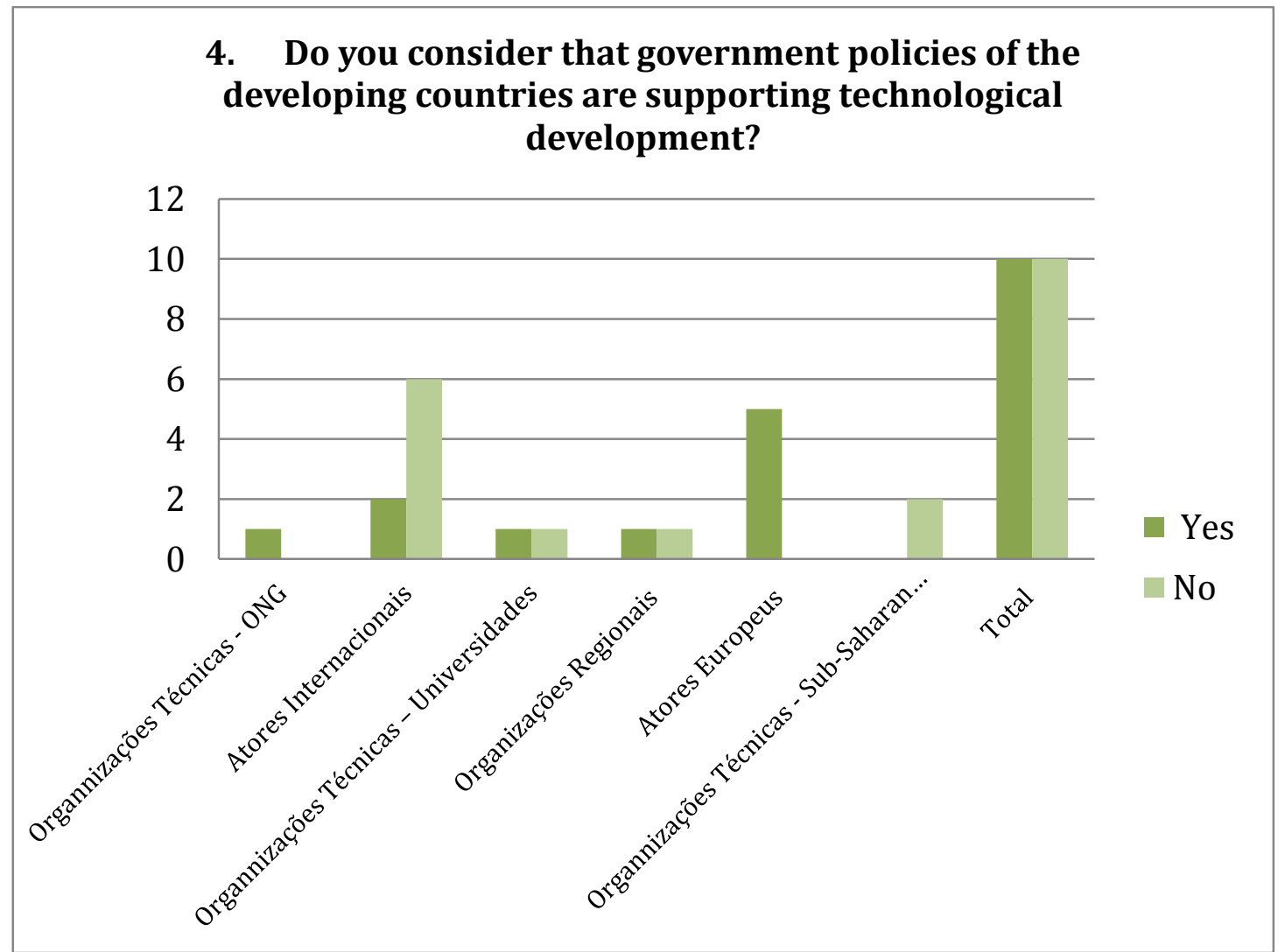

Efetivamente, a maior parte dos Atores (72\%) considera que deveria existir um maior apoio das entidades nacionais, principalmente os Atores Internacionais (Gráfico 66) e Gráfico 67Gráfico 67), visto que são poucos os governos que apoiam o desenvolvimento científico. Um dos Atores Regionais (Universidades) afirma que os Chefes de Estado comprometeram-se a aumentar a despesa pública em C\&T pelo menos 1\% do Produto Interno Bruto (PIB) em 2007 e como tal deveriam ser responsáveis pela aplicação desta medida de forma a se verificar um maior desenvolvimento regional e nacional. Este fato não inviabiliza a necessidade de continuar com outras medidas colaborativas de apoio ao nível internacional. Um outro Ator Regional reforça a ideia deste apoio afirmando que as políticas governamentais dos países em desenvolvimento suportam a transferência tecnológica ao nível nacional. 
1) Only a few governments support scientific development sufficiently, most do not. African heads of state committed to raising S\&T spending to at least 1\% of GDP in 2007; they need to be held accountable to this for regional and national development. At international level they must also support collaborative academic networks (Comentário de Ator Regional, Organizações Técnicas, Universidades).

2) Yes, government policies of developing countries support technological transfer at national level through development of blue prints where various polices are derived for technological development and research is carried out in various areas for policy development (Comentário de Ator Regional, Organizações Regionais).

Gráfico 66 - Opinião dos Atores quanto ao desenvolvimento tecnológico através das políticas governamentais nos diferentes níveis: regional, nacional e internacional

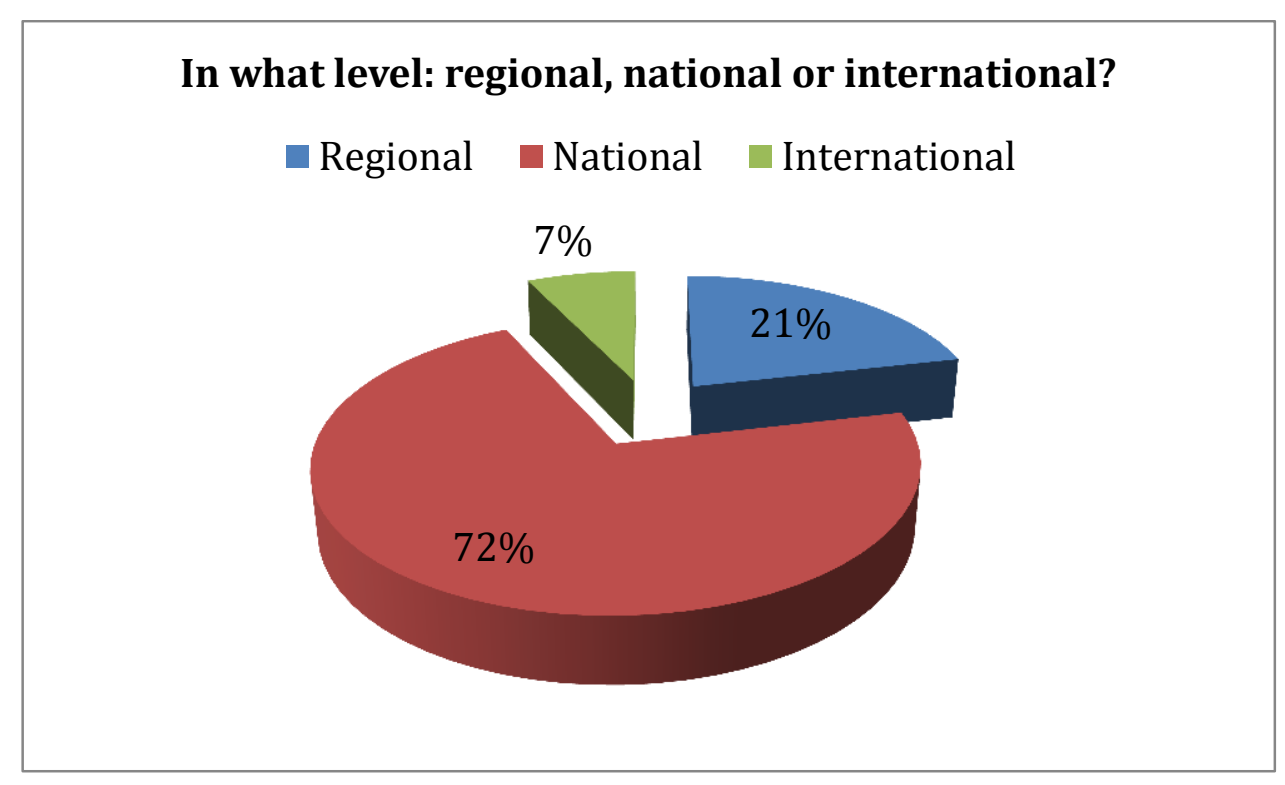


Gráfico 67 - Opinião por tipo de Ator quanto ao desenvolvimento tecnológico através das políticas governamentais nos diferentes níveis: regional, nacional e internacional

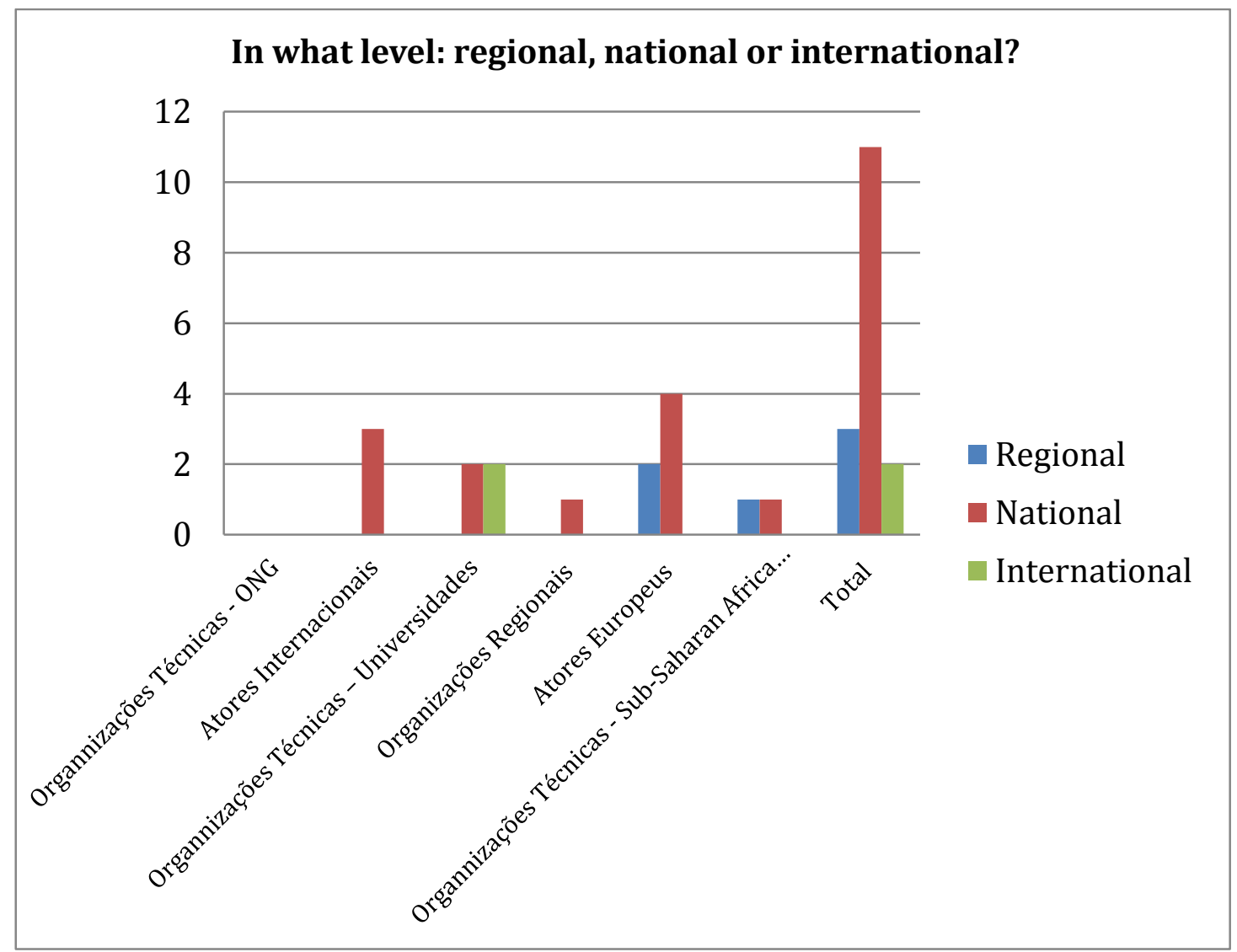

Tal como se tem vindo a verificar a cooperação entre parceiros é essencial para que o setor do ensino em geral, e do ensino superior em específico, se desenvolvam de forma constante, com qualidade e de acordo com as necessidades locais para fazer frente aos problemas regionais ainda que exista algum consenso no que concerne ao fato de se verificarem algumas medidas de apoio através dos governos locais. Neste sentido, pretendeu-se perceber se na opinião dos Atores a Cooperação Académica EU - África tem vindo a promover melhores condições para os estudantes. A maioria dos Atores afirma que, na sua opinião, esta relação existe e é positiva (Gráfico 68), nomeadamente os Atores Internacionais e os Atores Europeus em conjunto com as Organizações Regionais (Gráfico 69). Um dos Atores Internacionais afirma que nos países parceiros o programa Erasmus + permitirá melhorias de qualidade, de 
igualdade de acessos, melhor formação dos funcionários e acesso a redes internacionais. Na sua opinião esta oferta atingirá não só os indíviduos mas também as próprias instituições, assim como o sistema de ensino. Considera que o programa cooperação, no âmbito da capacitação humana e modernização das instituições de ensino superior, reúne as condições necessárias para melhorar as condições dos estudantes deste tipo de ensino.

In Partner Countries, Erasmus+ will address the challenges of quality, relevance, equity of access, staff development, access to international networks, by offering a balanced mix of actions addressing individuals, institutions and higher education systems. These challenges reflect the expected work to improve students conditions. Through programmes as Erasmus+, the EU supports partner countries in meeting the challenges in their higher education systems via a learning mobility component (Key Action 1) and through the funding of capacity building aimed at modernizing higher education institutions and systems in the partner countries (Key Action 2) that will provide better learning conditions for students (Comentário de um Ator Internacional).

Gráfico 68 - Opinião dos Atores quanto à promoção de melhores condições para os estudantes através cooperação EU-Africa

\section{In your opinion the academic cooperation between $\mathrm{EU}$ and Africa has been promoting better conditions for students?}

$\square$ Yes $\square$ NO

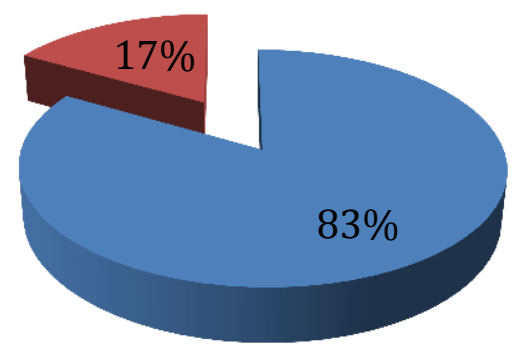


Gráfico 69 - Opinião, por tipo de Ator, quanto à promoção de melhores condições para os estudantes através cooperação EU-África

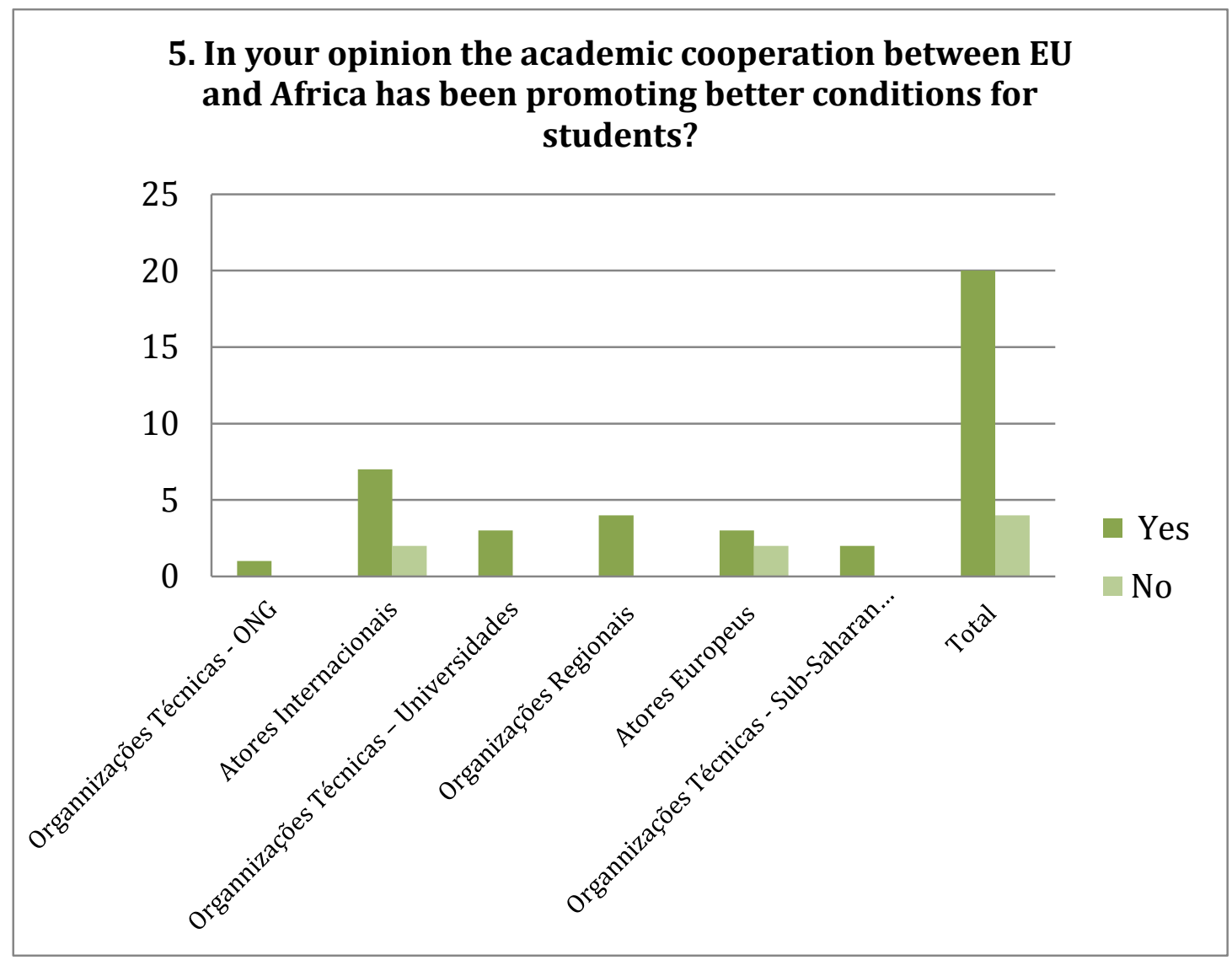

No seguimento da questão anterior pretende-se agora perceber se os Atores consideram que esta cooperação promove, igualmente, melhores condições para a população em geral, uma vez que, em questões anteriores, afirmaram que esta cooperação é primordial para a evolução dos países em desenvolvimento, visto que níveis de ensino superiores têm repercussões no desenvolvimento económico destas regiões desencadeando melhores condições de vida para a população em geral. Nesta ordem de ideias, as respostas dadas anteriormente são reconfirmadas pois a maioria dos Atores $(87 \%)$ considera que a cooperação EU-África promove melhores condições para a população em geral (Gráfico 70). Também em conformidade os Atores Internacionais, os Atores Europeus e as Organizações Regionais são os que mais corroboram esta ideia (Gráfico 71). Afirmam que pessoas mais instruídas, nos países em desenvolvimento, implicam um maior retorno para as suas regiões. Estas 
podem tornar-se a próxima geração de líderes, contribuindo de forma positiva para a melhoria das condições de vida da população como se poderá verificar em alguns dos seus comentários.

(1) [...] Highly educated people from developing countries upon returning might become the next generation of leaders, making a tremendous impact on the living conditions of the population. For example, in some African countries people educated in Hungary during the 1970s became ministers in their choosen profession (Comentário de um Ator Europeu).

(2) The academic cooperation ultimately improves in a long run the well-being of the population as it increases opportunities for education for more people but also improves the effectiveness of universities and their role in decision making processes - the universities can conduct better research and provide necessary information for developing better policies (Comentário de um Ator Internacional).

(3) Erasmus+ is a demand driven and bottom up programme, targeting principally the higher education community in the partner countries (universities, associations, students, agencies, councils, etc.) so consultations are wider than just the partner country governments.The external dimension of Erasmus + aims to support Partner Countries to address the challenges facing their higher education institutions and systems, including those of quality, relevance, equity of access, planning, delivery, management, governance and internationalisation by offering a balanced mix of actions addressing individuals, institutions and higher education systems. Objectives and principles underlying development cooperation will be ensured, including national ownership, social cohesion, equity, proper geographical balance and diversity. A special attention will be given to the least developed countries as well as to disadvantaged students from poor socio-economic backgrounds and to students with special needs (Comentário de um Ator Internacional). 
Gráfico 70 - Opinião dos Atores quanto à promoção de melhores condições para a população em geral através cooperação EU-Africa

\subsection{And for the population in general?}

$\square$ Yes No

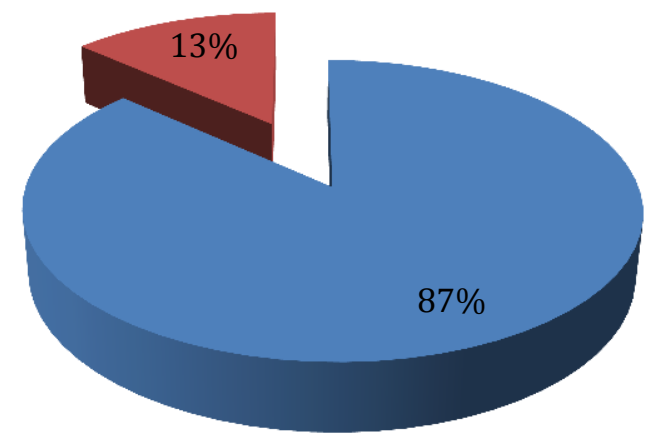

Gráfico 71 - Opinião por tipo de Ator quanto à promoção de melhores condições para a população em geral através cooperação EU-África

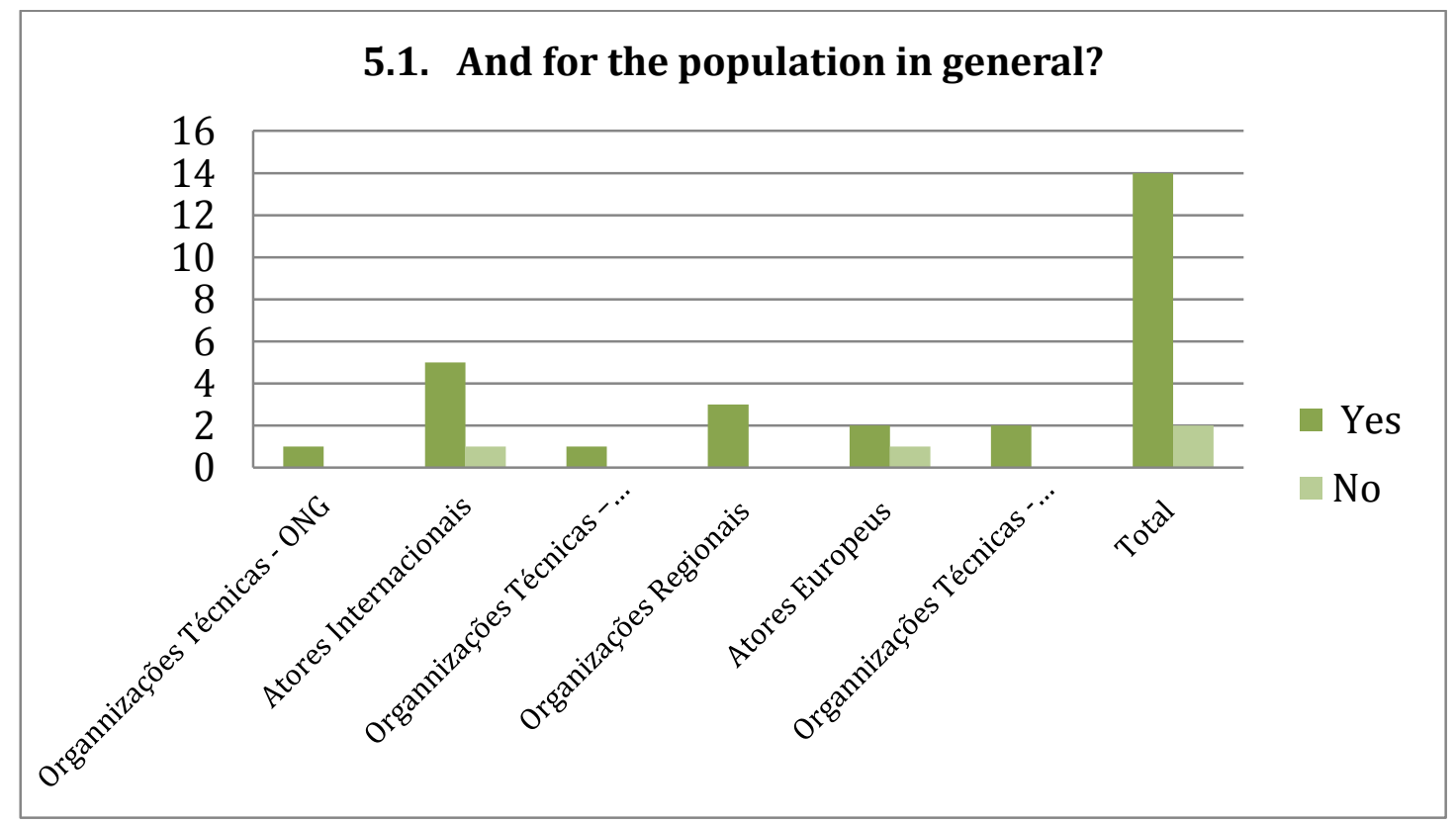


A Cooperação tem vindo a ser reconhecida, por parte dos Atores, como um motor de desenvolvimento das economias dos países em desenvolvimento, nomeadamente na África - Subsariana. Da mesma forma legitima-se o especial contributo da educação e do ensino superior como linhas orientadoras deste progresso através de recursos humanos qualificados apesar da necessidade de se promoverem parcerias com as indústrias locais. Esta capacitação humana permitirá a melhoria da condição de vida destes estudantes mas também a da população em geral pela presença de cidadãos mais informados e mais cientes dos seus direitos e obrigações. Neste sentido, é importante que as políticas públicas desenvolvidas pelos diferentes Atores, e de forma conjunta, visem o aumento das taxas de ingresso no ensino superior. A maior parte dos Atores (45\%) considera que a cooperação tem vindo a aumentar o número de estudantes no ensino superior em África (Gráfico 72). No entanto, uma percentagem significativa dos inquiridos optou por não responder a esta questão (39\%), inferindose que não terão conhecimento da realidade em causa. Dos Atores respondentes a maioria dos que concordam com esta afirmação são os Atores Internacionais e os Atores Regionais (Gráfico 73), muito embora também aqui uma grande percentagem de Atores Internacionais tenha optado por não responder. Ainda assim consideram, de uma forma geral, que a cooperação internacional tem contribuído para melhorar os resultados dos países africanos. De acordo com um dos Atores Internacionais a participação no ensino superior e as matrículas cresceram consideravelmente desde o final dos anos 1970. Informa que existe uma previsão do aumento do número de alunos matriculados no ensino superior para 2030 uma vez que se prevê um aumento de cerca de 100 em 2000 para 400 milhões em 2030, sendo que os maiores aumentos estão previstos para a Ásia, para a América Latina e para o Caribe. Os dados disponíveis para África são menos precisos, uma vez que se sabe que apenas dois quintos das crianças estão matriculadas no ensino básico na África Subsaariana (relatório GMR 2013/14) ${ }^{84}$.

The cooperation has probably contributed by the international support to the african countries to improve the results. From a global perspective, Higher education participation and enrolment has expanded considerably particularly since the late

\footnotetext{
${ }^{84}$ Documento pode ser consultado aqui: http://www.uis.unesco.org/Education/Pages/gmr-launch-2014.aspx
} 
1970's. The number of students enrolled in higher education by 2030 is forecast to rise from about 100 in 2000 to 400 million in 2030, with the largest increases in Asia, Latin America and the Caribbean. Have we more precise figures for Africa? Knowing that only two-fifths children are not learning the basic in subSaharan Africa. of children (...), if there is improvement, there are still challenges to. (Comentário de um Ator Internacional).

Gráfico 72 - Opinião dos Atores quanto ao fato da Cooperação poder aumentar o número de estudantes universitários em África

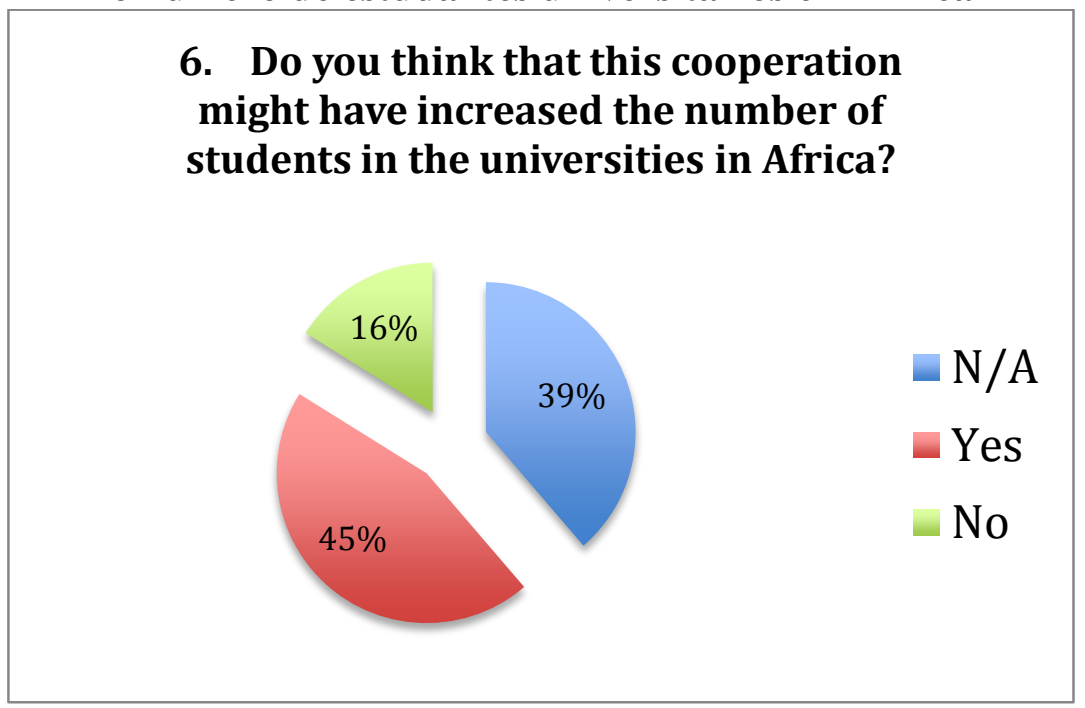

Gráfico 73 - Opinião, por tipo de Ator, quanto ao fato da Cooperação poder aumentar o número de estudantes universitários em África

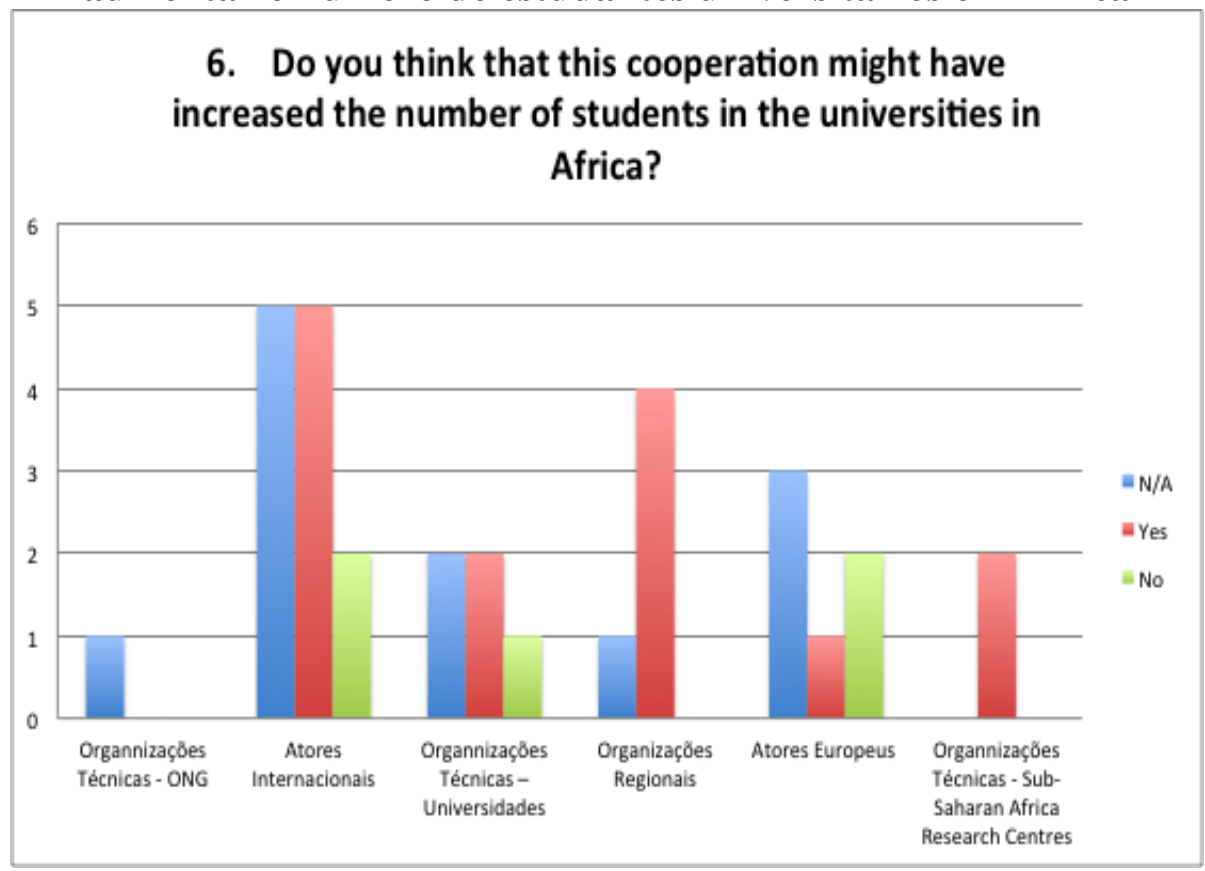


A maioria dos Atores considera, porém, que a cooperação académica favorece a migração de estudantes (Gráfico 74) principalmente os Atores Internacionais e as Atores Regionais (Gráfico 75). Um dos Atores Internacionais destaca os estudos da OCDE os quais referem a importância da mobilidade académica para os avanços no conhecimento. Afirma desta forma que se criam redes que interligam as instituições as quais se tornam um veículo comum para o reforço das capacidades e permitem a mobilidade mais organizada e estruturada. Menciona, que a prevenção da fuga de cérebros foi cuidadosamente levada em conta no planeamento do projeto de Erasmus + mobilidade. As ações de créditos do projeto de mobilidade deste programa contribuem para a circulação de cérebros por definição. O estudante móvel vai voltar para a sua universidade de origem, que lhe vai entregar o diploma, tendo em conta os créditos adquiridos durante a mobilidade na Europa. Para a ação "mobilidade grau" do programa Erasmus +, há indicadores positivos de alunos Erasmus Mundus (cf. Pesquisa de Impacto de Pós-Graduação). A maioria dos alunos retornou da Europa, com um grau de alta qualidade os quais estão a dar contribuições importantes para a academia, para a gestão universitária, para a capacitação, para a pesquisa e para os negócios. Na verdade, os dados relativos a estas afirmações são bastante escassos, não obstante, no relatório mencionado pelo Ator é possível verificar que de todos os beneficiários que participaram no programa e que responderam ao inquérito, o número de graduados que permanece na União Europeia após a graduação diminui ao longo dos tempos os quais retornam aos seus países de origem. Ainda assim, uma percentagem significativa $(32,06 \%)$ permanece na EU apontando como principais razões para a escolha da residência a perspetiva de melhor emprego, a possibilidade de carreira e por razões familiares (Graduate Impact Survey, 2013-2014).

The OECD studies have highlighted that student and scholar mobility facilitate the building of international networks that are essential for fostering mutual understanding and giving access to up-to-date knowledge. It is in this context that the networks that link institutions become a shared vehicle for capacity building across the board and allow for more organized and structured mobility. The issue of preventing brain drain has been carefully taken into account in the design of Erasmus+ mobility. Credit mobility actions of the E+ programme contribute to brain circulation by definition. The mobile student will go back to his/her university of origin which 
will deliver the diploma, taking into account the credits acquired during the mobility in Europe. For the action"degree mobility" of the Erasmus + programme, there are positive indicators from Erasmus Mundus alumni (cf. Graduate Impact Survey $)^{85}$. The majority of the alumni return from Europe with a high quality degree and we are seeing that they are giving important contributions to academia, university management, capacity building, research and business (Comentário de um Ator Internacional ).

\section{Gráfico 74 - Opinião dos Atores no sentido de perceber se a cooperação académica favorece a migração de estudantes}

\begin{tabular}{|l|l|}
$\begin{array}{c}\text { 7. In your opinion the academic } \\
\text { cooperation favours the migration of } \\
\text { students? }\end{array}$ \\
\hline $21 \% \quad 24 \%$ & $\mathrm{~N} / \mathrm{A}$ \\
$\mathrm{yes}$ & $\mathrm{No}$ \\
\hline $55 \%$ & \\
\hline
\end{tabular}

Gráfico 75 - Opinião, por tipo de Ator, no sentido de perceber se a cooperação académica favorece a migração de estudantes

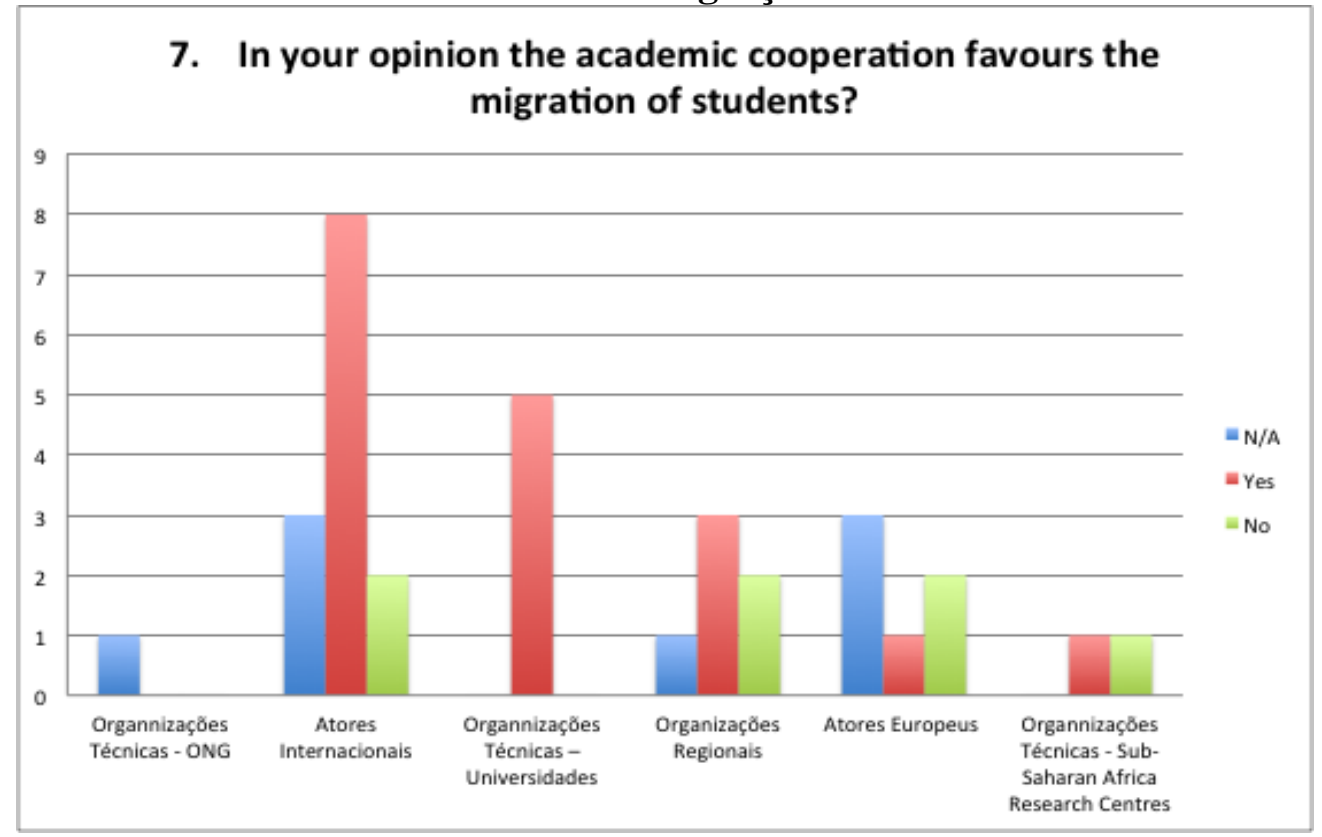

\footnotetext{
${ }^{85}$ Disponível em: Graduate Impact Survey - http://www.ema.eu/fileadmin/content/GIS/Graduate_Impact_Survey_2014.pdf
} 
Quanto às principais consequências e/ou vantagens que podem advir da cooperação académica a maioria dos Atores considera que as vantagens se sobrepõem principalmente no que respeita ao desenvolvimento de recursos humanos e ao nível da criação de redes de conhecimento e da internacionalização das instituições (Gráfico 76). Contudo, uma percentagem significativa optou por não responder (30\%) e os Atores Internacionais são os que mais referem estas vantagens acrescentando como vantagem a transferência de tecnologia. Todavia, consideram que uma das consequências negativas desta cooperação é o fenómeno de Brain Drain (Gráfico 77). Um dos Atores Internacionais refere, tal como já mencionada ao longo deste trabalho, que o ensino superior não é apenas um objetivo em si, mas um contribuidor chave para alcançar muitos outros objetivos de desenvolvimento, uma vez que a educação também reduz significativamente os riscos de conflito. Este tipo de ajuda aumenta as capacidades dos países parceiros para assumir a responsabilidade pelo seu próprio desenvolvimento.

Higher education is not only an objective in itself, but a key contributor to achieving many other development objectives. Education also significantly reduces the risks of conflicts. Therefore, education rightly plays a key role in international development efforts. Over the previous programming period, a significant part of the funding for education has been done through budget support. This aid modality increases the capacities of partner countries to take over responsibility for their own development. This modality increases the impact on the whole education system; on the other side, the specific contribution of each $€$ spent becomes more difficult to assess. (Comentário de um Ator Internacional). 
Gráfico 76 - Opinião dos Atores no sentido de perceber quais as principais consequências / vantagens que podem advir da cooperação académica

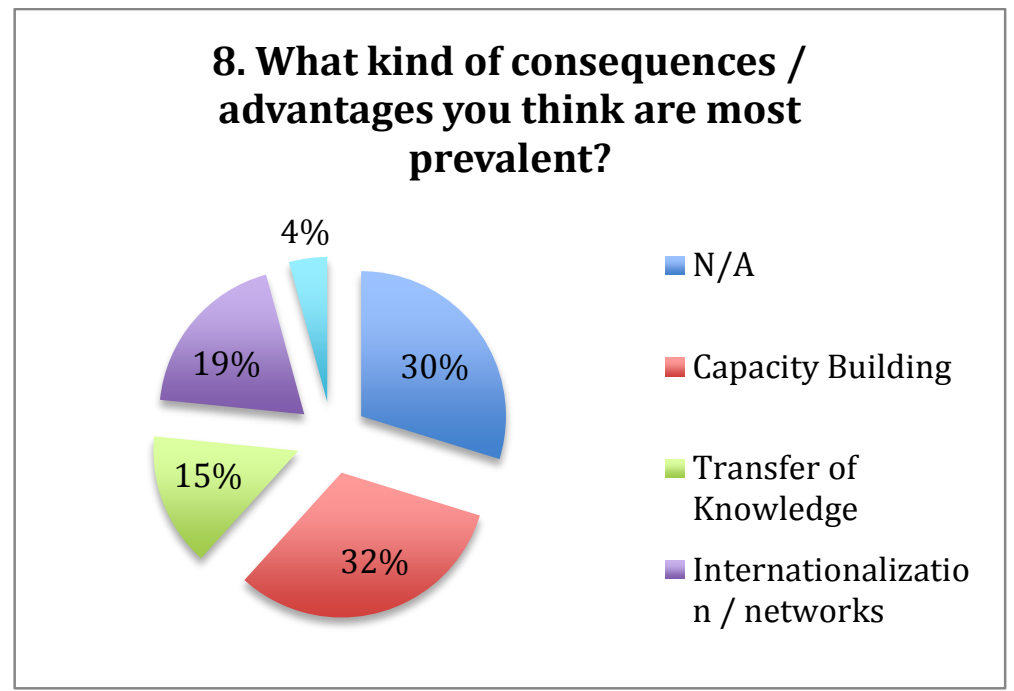

Gráfico 77 - Opinião, por tipo de Ator, no sentido de perceber quais as principais consequências / vantagens que podem advir da cooperação académica

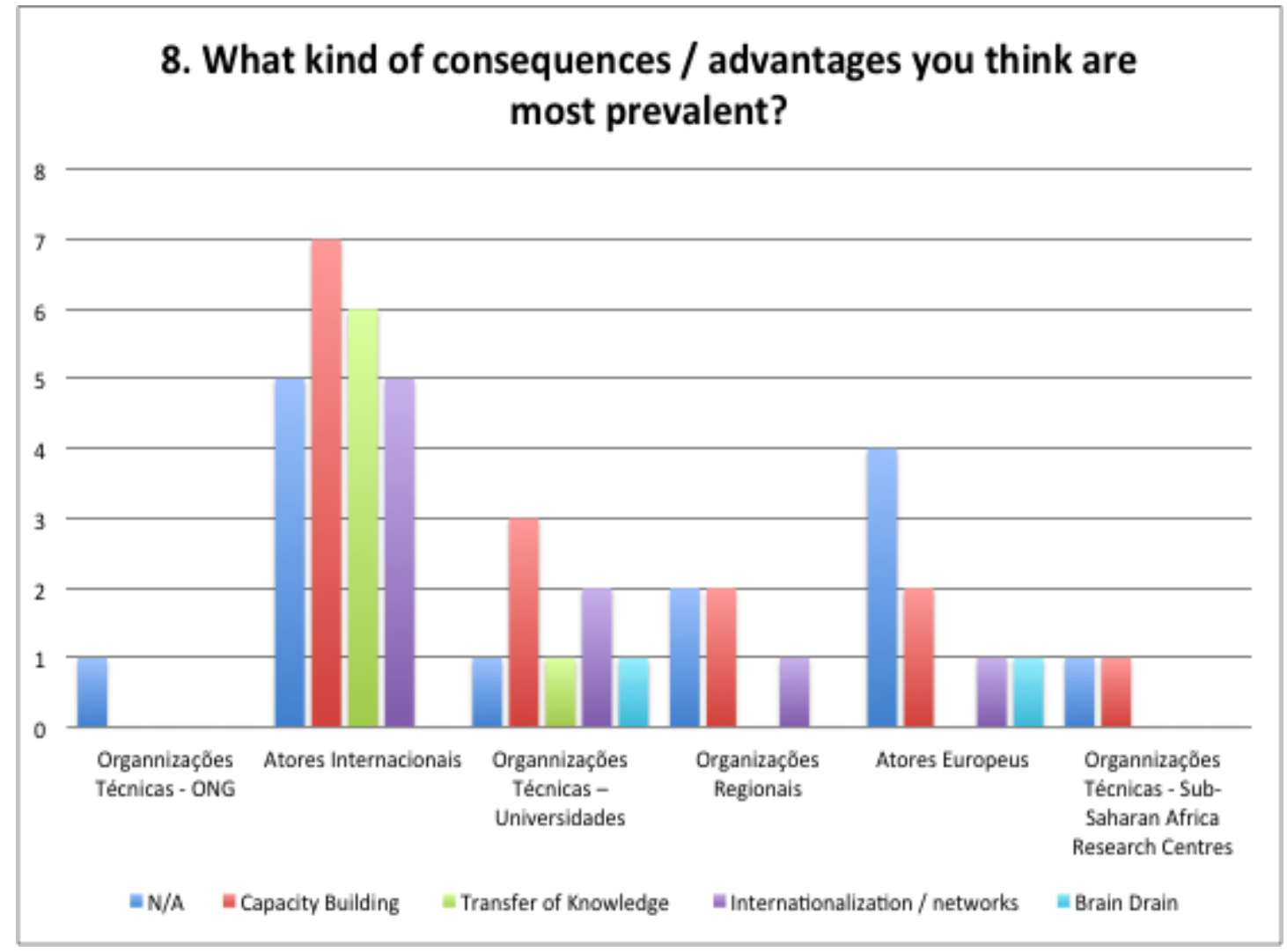


Uma vez que a Nova Agenda do Desenvolvimento procede os Objetivos do Milénio, e considerando todos os pontos positivos do ensino, pretende-se perceber se os Atores consideram que a mesma deva ter um foco especial no ensino superior. Efetivamente, a maioria (56\%) considera que sim (Gráfico 78), especialmente os Atores Internacionais, as Universidades e as Organizações Regionais, ainda que os primeiros estejam subdivididos (Gráfico 79). Um dos Atores Internacionais menciona que as discussões globais no âmbito da agenda de desenvolvimento pós-2015 enfatizam a necessidade de ir além do ensino primário e de promover um desenvolvimento equilibrado do sector do ensino, não só na escolaridade primária, mas também no ensino profissional e superior. Informa que a abordagem holística da UE garante que o apoio bilateral se centre na educação básica e no ensino profissional, enquanto o programa Erasmus + irá apoiar o ensino superior.

The on-going global discussions within the framework of post2015 development agenda emphasizes the need to move beyond primary education and promote a balanced development of the whole education sector from early childhood schooling to vocational and tertiary education. The EU holistic approach ensures that bilateral support focuses on basic education and vocational education, while the Erasmus+ programme will support higher education (Comentário de um Ator Internacional).

\section{Gráfico 78 - Opinião dos Atores no sentido de perceber se a Nova Agenda do Desenvolvimento deva ter um foco especial no ensino superior}

\section{In your opinion the new development agenda should have a special focus in higher education?}

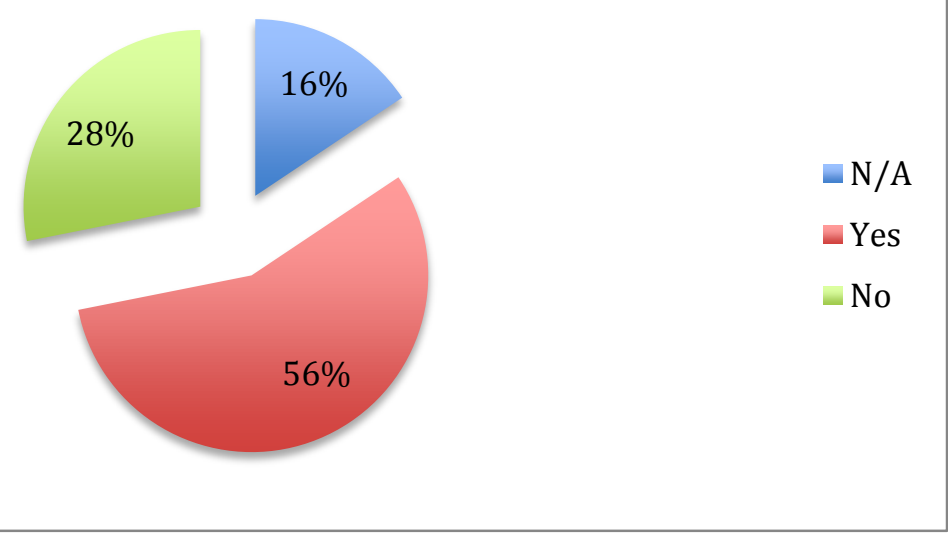


Gráfico 79 - Opinião dos Atores no sentido de perceber se a Nova Agenda do Desenvolvimento deva ter um foco especial no ensino superior

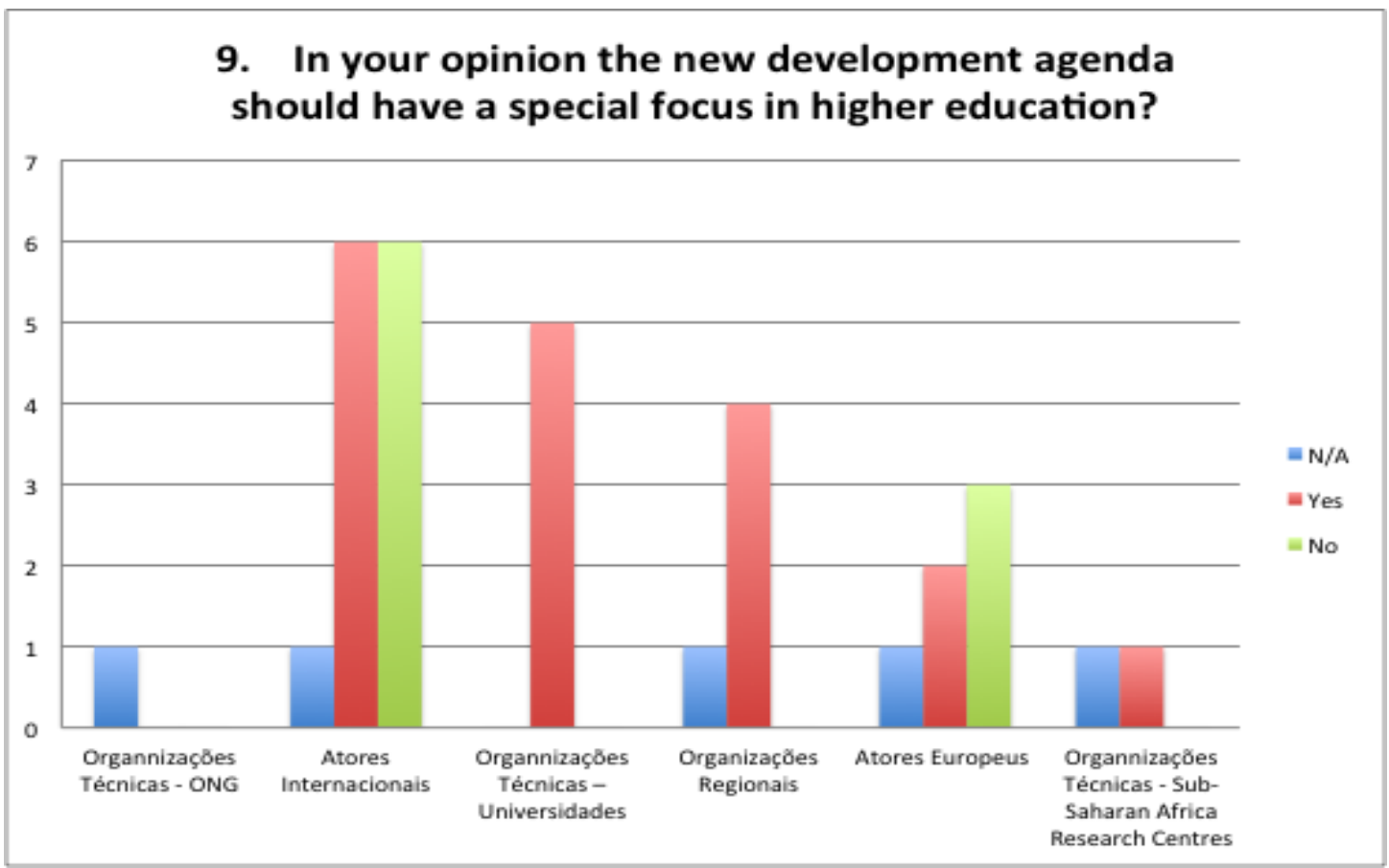

Por último, pretendeu-se apurar se os Atores consideram que existe um impacto positivo da educação na redução da pobreza, na melhoria da qualidade de vida e na promoção de sociedades mais justas, nos países em desenvolvimento. De uma forma geral todos consideram estes impactos positivos com especial enfoque para a redução da pobreza. Os atores Internacionais, seguidos dos Europeus e das Universidades são os que mais mencionam estes efeitos positivos da educação corroborando, de certa forma, os dados anteriormente analisados uma vez que consideram que a educação contribui para o progresso das sociedades através da produção de capital intelectual o qual contribui de diferentes formas para o bem-estar de todos (Gráfico 80 e Gráfico 81). Esta ideia está bem exposta nos comentários dos diferentes Atores como se pode constatar nos excertos transcritos.

1) Poverty reduction: Better prospects for pupils/students to get a job. Better quality of life: Cultural enrichment, combatting gender-based violence and stereotypes, social activities within 


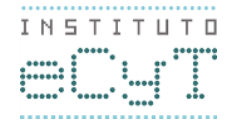

schools. Promotes fair societies: offers the opportunity to pupils/students to know and claim their rights, provides equal opportunities for employment, empowers women and other vulnerable population groups (Comentário de um Ator Europeu)

2) All of them. With better education you have access to better jobs; with better jobs you alleviate poverty and you have a better quality of life; with more education you have, in principle, more culture or you are more open to culture and therefore you can be more interventive or more attentive to political and societal questions; with more interventive citizens you have more control over the government and and more political intervention; this usually leads to fairer societies. (Comentário de um Ator Internacional)

3) If you are better educated you are better informed about opportunities for development (personal and professional) and you have the necessary skills for more jobs which increases significantly your chances to get out of poverty. Also, by being better informed you can more easily acknowledge the differences among people (social, cultural, etc.) and to understand the need of accepting these differences and learning to live all together. Being better informed decreases one's vulnerability (of being misled, manipulated, etc.) and empowers him/her to dictate his/her life which is important for building fair societies. (Comentário de um Ator Internacional ).

4) I choose better quality of life because it by achieving it you reduce poverty and promote fair societies. Education promotes quality human resources which has a role economic growth and societal development, educating future citizens, professionals and political leaders who can contribute to improving quality of life including good governance and ensuring effective, innovative, continuing curriculum development to provide the high level competences needed by all graduates to meet the future economic, social and political challenges. (Organizações Regionais). 
Gráfico 80 - Opinião dos Atores quanto ao impacto positivo da educação na redução da pobreza, na melhoria da qualidade de vida e na promoção de sociedades mais justas, nos países em desenvolvimento

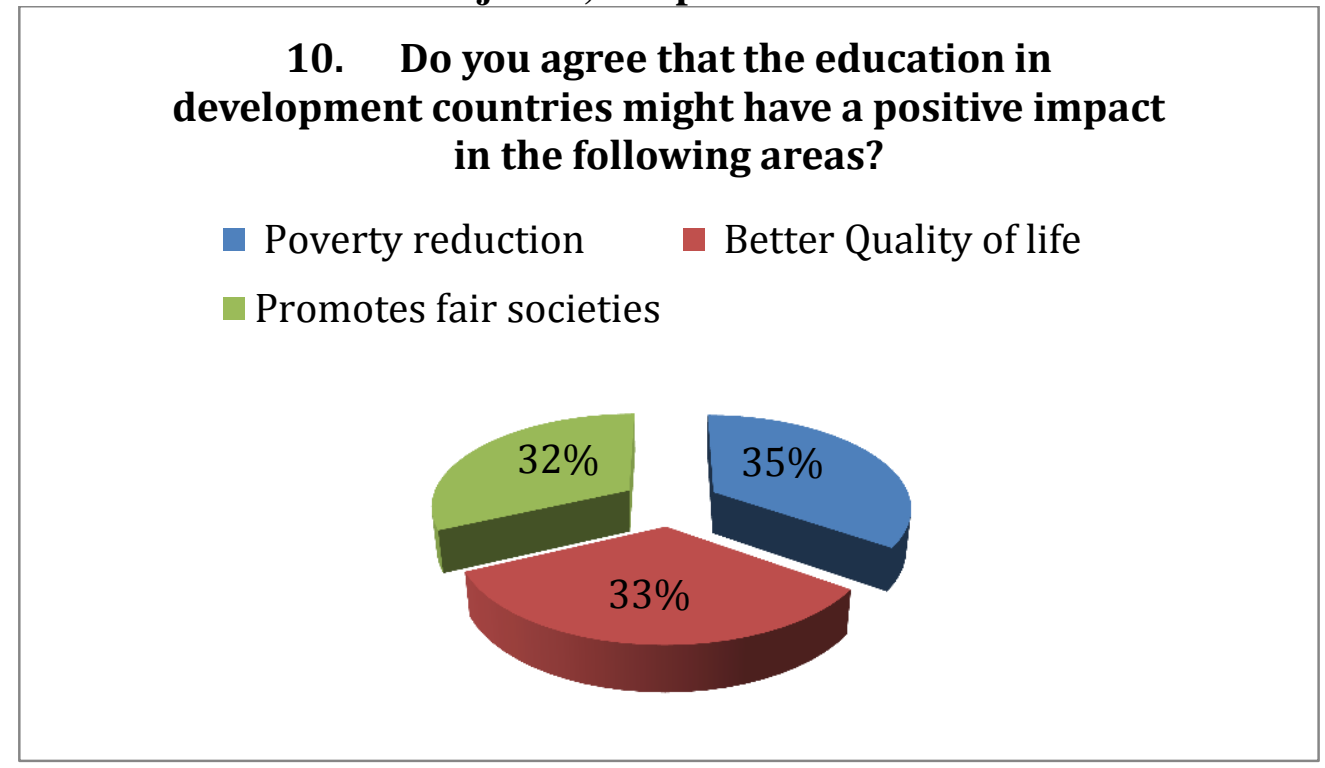

Gráfico 81 - Opinião por tipo de Ator quanto ao impacto positivo da educação na redução da pobreza, na melhoria da qualidade de vida e na promoção de sociedades mais justas, nos países em desenvolvimento

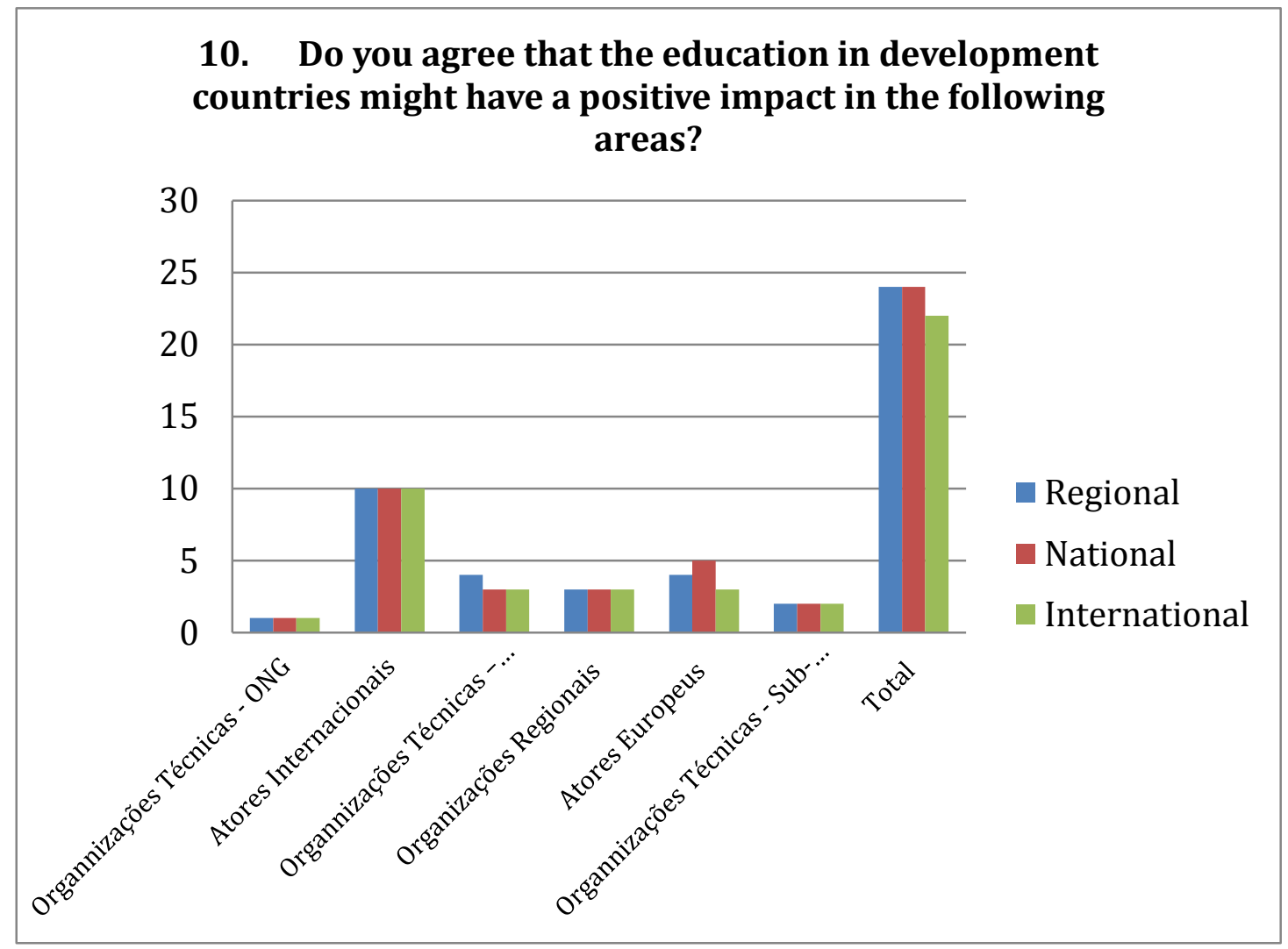


Uma vez analisadas todas as respostas dos Atores e confrontadas com o quadro teórico passamos às implicações que as mesmas possam ter ao nível da conceptualização modelo CATWOE, desenhado no âmbito do Ensino Superior.

7.2.Implicações na caracterização do modelo CATWOE no âmbito do Ensino Superior tendo em conta o impacto dos diferentes Atores (internos e externos), no contexto da ASS

Verificámos que a análise CATWOE segue uma rota bem definida onde as Instituições de Ensino Superior possuem um sistema que concede graus académicos aos estudantes $(\mathrm{X})$ que se qualificam com sucesso de acordo com uma determinada avaliação (Y) e de acordo com normas estabelecidas de forma a garantir uma certificação (Z). Através da sua graduação os estudantes oferecem aos potenciais empregadores a vantagem do seu conhecimento, competências e as qualificações requeridas pelos mesmos. Estamos perante um sistema que faz $\mathrm{X}$, através de Y para atingir Z. No entanto, tal como anteriormente demonstrado é conveniente analisar o efetivo contributo dos agentes externos, correlacionando o seu input com o output pretendido de acordo com uma abordagem sistémica do ensino superior. Neste sentido, caraterizou-se o modelo conceptual de análise e traçou-se a rota para perceção da problemática em causa em que se destaca a relevância das ações e intervenções dos Atores da Cooperação Internacional para o Desenvolvimento, em foco neste estudo, no processo de crescimento económico através da educação, e em especial do Ensino Superior. Uma vez inquiridos estes Atores analisaram-se os dados de forma a percecionar se as transformações modeladas são passíveis de serem efetivadas através das suas relações de poder ou se existem constrangimentos ambientais que impedem o funcionamento deste processo, e se se verificarem os resultados pretendidos ao nível do Output, na sua totalidade ou de forma parcial. Tendo em consideração estas premissas apresentam-se em seguida cada um dos elementos do modelo de acordo com a caraterização conceptual desenhada a qual ilustra a representação da relação das diferentes etapas do sistema e o papel dos 
Atores em cada uma delas seguindo uma prerrogativa de input - output do processo de transformação.

\subsubsection{O elemento Actors}

Os Atores foram definidos como os Atores Externos os quais produzem diretivas e desenham os programas de ajuda ao nível da Cooperação Internacional que permitem que as atividades educativas sejam levadas a cabo na África Subsariana, tendo em conta as especificidades de cada um dos países. Efetivamente, ao longo deste trabalho tem-se vindo a destacar a importância dos Atores Externos enquanto elemento chave da cooperação internacional para o desenvolvimento, proporcionando a criação de parcerias as quais são de extrema importância no desenvolvimento de capital humano. Desta forma, estes Atores são diretamente responsáveis pela operacionalização das políticas que fomentam a educação. Em relação às competências específicas necessárias para o bom funcionamento dos processos estabelecidos em $\mathrm{T}$ é necessário que estes Atores conheçam todos os elementos do sistema educacional, bem como todos os processos e indivíduos envolvidos, para contemplar os seus interesses de forma adequada. Devem, igualmente, ter conhecimento de todos os programas públicos, direta ou indiretamente relacionados ao tema em questão. Por outro lado, a comunicação e contato interpessoal (por lidar com educação e por estar num meio no qual se faz necessário lidar com diferentes grupos de interesse) com as entidades governamentais, os gestores públicos, a sociedade civil e os alunos são de extrema relevância. Porém, após efetuada a análise aos dados obtidos concluímos que nem sempre se verificam estes outputs na medida em que se verifica algum desconhecimento relacionado com a matéria em causa, assim como raramente se verificam contatos pessoais com todos os grupos de interesse no sentido de se averiguar quais as necessidades mais pertinentes ao nível do apoio. Estamos perante processos de ajuda, que não obstante o seu real e importante impacto ao nível da educação, carecem de avaliação, assim como de serem planeados de forma sistémica. 


\subsubsection{O elemento Owners}

Os detentores do poder local foram identificados como os Atores Internos (Organizações Nacionais, Órgãos de Governo, Decisores Políticos, Gestores IES), com influência no sistema educativo, não só através das diretivas impostas pelos Atores Externos na aplicação dos projetos ou programas destinados ao ensino superior, mas também pela forte relação de tomada de decisão que detém nestes centros de ensino como mencionado ao longo deste trabalho. A formulação das políticas públicas é realizada pelos agentes do poder, muito embora os gestores públicos envolvidos na implementação das mesmas não gozem da autonomia e poder de decisão, essencialmente ao nível das IES. Esta relação de interdependência tem consequências ao nível da transformação uma vez que na caraterização efetuada as IES transformam os estudantes em graduados, contudo para tal é necessário que se verifiquem as condições necessários para que este processo funcione, implicando que a aplicação das políticas públicas permita colmatar os constrangimentos que impedem a obtenção dos resultados previstos.

\subsubsection{O elemento Clients}

Os clientes foram caraterizados como os Estudantes e as Universidades em África, os quais são os beneficiários diretos do sistema de educação, visto que o mesmo é desenhado a pensar nestes. Atualmente, os indicadores educacionais demonstram que apesar das melhorias as taxas de inscrição no ensino superior as mesmas ainda são inferiores às verificados nos países desenvolvidos e cuja iliteracia ainda é um fator relevante a ser tido em conta na Agenda Pós-2015. Como beneficiários indiretos do sistema incluímos nesse elemento os professores e corpo administrativo das escolas, como agentes de transformação, embora não sejam o público - alvo final, mas cujo trabalho é fortemente afetado pelos outputs do sistema. Foram ainda identificados como beneficiários indiretos as famílias dos estudantes e as comunidades em geral, visto que a educação aumenta o potencial de desenvolvimento local, que pode resultar 
em aumento da qualidade de vida destas comunidades. No entanto, para que estes outputs se verifiquem é necessário uma maior ação da parte dos Atores Internos e Externos, nomeadamente no que respeita à promoção de políticas públicas que favoreçam o prosseguimento dos estudos, em específico ao nível do ensino superior. São vários os desafios enfrentados pelas Universidades os quais só poderão ser colmatados com o apoio destes Atores. De acordo com os dados obtidos podemos inferir o papel dos Atores neste nível de transformação tem, ainda, um grande percurso a decorrer, pois as preocupações focam-se nos níveis mais baixos de educação. A educação deve ser adequada à realidade da população a qual reflete a atuação dos próprios estudantes os quais passam a ser difusores do conhecimento, transferindo-o para as comunidades onde habitam. Desta forma é cada vez mais reconhecido, na arena política, que o processo de educação reflete indiretamente na sociedade como um todo, pois traz consequências relativas à produção, ao nível regional, e ao desenvolvimento económico do país, influência na distribuição geográfica populacional e o nível salarial dos graduados. A atuação dos Atores responsáveis pela implementação das políticas mencionadas pretende atingir os objetivos diretamente ligados à erradicação da pobreza, e as consequências mais amplas das suas ações dependem de inúmeros outros fatores que fogem ao seu controle.

\subsubsection{O Elemento Environment}

O sistema de implementação das políticas públicas para a educação, no contexto da ASS, está intrinsecamente relacionado com o sistema educacional como um todo, devendo obedecer às Diretrizes Nacionais de Educação. A oferta de educação dividese entre a esfera pública e a privada. No entanto, o governo ocupa um papel central como responsável pela definição dos princípios norteadores, estruturas curriculares e metas, além de regulamentação, fiscalização e o próprio fornecimento de educação pública e gratuita, enquanto bem público. De acordo com os dados apresentados a educação deveria ser maioritariamente pública, o que o que delimita a sua atuação, no âmbito da sua missão uma vez que depende do sistema político. Faz-se relevante, 
portanto, conhecer a formação histórica da evolução destas instituições e, por conseguinte, a dependência que tem vindo a ter das diferentes formas de governo e as influências que sofreu em cada um dos processos, essencialmente, na passagem para o período de modernização, onde se verifica uma maior preocupação com a internacionalização e globalização das IES. Nesta fase torna-se, cada vez mais, evidente o importante papel dos Atores Externos e Internos no processo de fortalecimento da educação e da inserção do tema na agenda governamental e internacional, desde o controle das ações à avaliação dos resultados, com uma participação ativa no desenho do formato geral e especificidades das políticas de educação ao nível do ensino superior de forma a colmatar os desafios que as mesmas enfrentam os quais constituem constrangimentos do sistema e imposições que impedem o sistema educativo superior de funcionar. Os mesmos foram identificados como: s qualidade só sistema educativo; o processo de avaliação e acreditação das normas; a instabilidade politica; as dificuldades ao nível do funcionamento; a tradição cultural; o acesso limitado e desigual; o processo de brain drain.

\subsubsection{O elemento Transformation}

O processo de transformação verifica-se na passagem dos estudantes a profissionais graduados o que permitirá melhorar as suas perspetivas de trabalho, a sua qualidade de vida, assim como podem contribuir para a alteração da sociedade que os rodeia. A cooperação tem-se mostrado essencial na promoção de políticas que lidam com situações complexas, podendo estabelecer-se de diversas formas na estrutura da administração pública, como já verificado. Seja pela parceria com organizações externas, pela inclusão da população, entre diversos níveis governamentais, entre sectores, ou mesmo entre agentes envolvidos no mesmo processo. $\mathrm{O}$ sistema de transformação permite não só aos estudantes tornarem-se graduados, mas também a transformação da própria sociedade uma vez que, tal como verificado, ao longo deste trabalho, estes graduados irão contribuir para o desenvolvimento e crescimento económico local, o que, por sua vez permite, a melhoria das condições de vida de toda uma população. Ao nível dos Atores, e de acordo com os dados obtidos, verifica-se 
uma mudança tendencial nas crenças desta correlação positiva entre o ensino superior e o desenvolvimento, no entanto, existe alguma incongruência quanto aos dados recolhidos que nos permita avaliar se as suas ações visam esta perspetiva de ensino como diretiva nos programas a desenvolver.

\subsubsection{O elemento Word View}

Em primeira instância destaca-se como visão do mundo a perceção da necessidade de elaboração de políticas educacionais específicas para o ensino superior, no contexto da ASS, as quais são efetivadas através dos diferentes Atores. Esta análise leva à definição de uma visão de mundo em transformação, percetível em relação a aspetos distintos, mas numa direção congruente. Verifica-se um esforço de coordenação entre os diferentes Atores, no que respeita aos programas educacionais e intersectoriais. As ações conjuntas levadas a cabo têm influência no processo de transformação visto que a obtenção de um grau académico por parte dos estudantes africanos potência melhores trabalhos e condições de vida, alterando a visão que o mundo e as empresas têm destes cidadãos. Cada vez mais diferentes Atores operam em conjunto, por meio de processos que valorizam a colaboração como mecanismo de formulação, implementação e avaliação de políticas públicas para a educação, em diferentes níveis de desenvolvimento, alguns ainda embrionários e outros já bem consolidados. Esta premissa da integração, somada à valorização do capital intelectual, constitui a visão que o mundo tem sobre o papel do ensino superior no crescimento das economias contribuindo para a promoção de sociedades autossustentáveis.

\subsection{O papel dos diferentes Atores no processo de transformação}

De acordo com a análise da opinião dos diferentes Atores referente às diferentes políticas e ações que têm vindo a ser aplicadas ao nível do Ensino Superior, apresentamos de seguida um quadro síntese que pretende aferir o verdadeiro papel 
que os mesmos assumem assim como possíveis ações que se identificam como necessárias ao nível dos input de forma a atingir os outputs que se evidenciam serem os otimizados de acordo com o estudo feito. Verificamos que de uma forma geral a opinião dos Atores vai ao encontro das necessidades vigentes e inerentes aos países em desenvolvimento aqui em causa. No entanto, é relevante mencionar que os esforços destes Atores estão ainda canalizados para o objetivo específico da erradicação da pobreza. Porém, de acordo com os depoimentos destes Atores estamos perante um processo de mudança. Existe a consciência de que o ensino superior constitui um importante fator no crescimento económico destes países através de um capital humano valorizado, muito embora esta crença não seja generalizada, visto que a maioria dos Atores considera os níveis mais baixos de ensino como prioridades, ainda que a evidência empírica demonstre, claramente, que níveis de ensino superior conduzem a sociedades mais desenvolvidas e garantem melhores condições de vida (Tabela 14). 


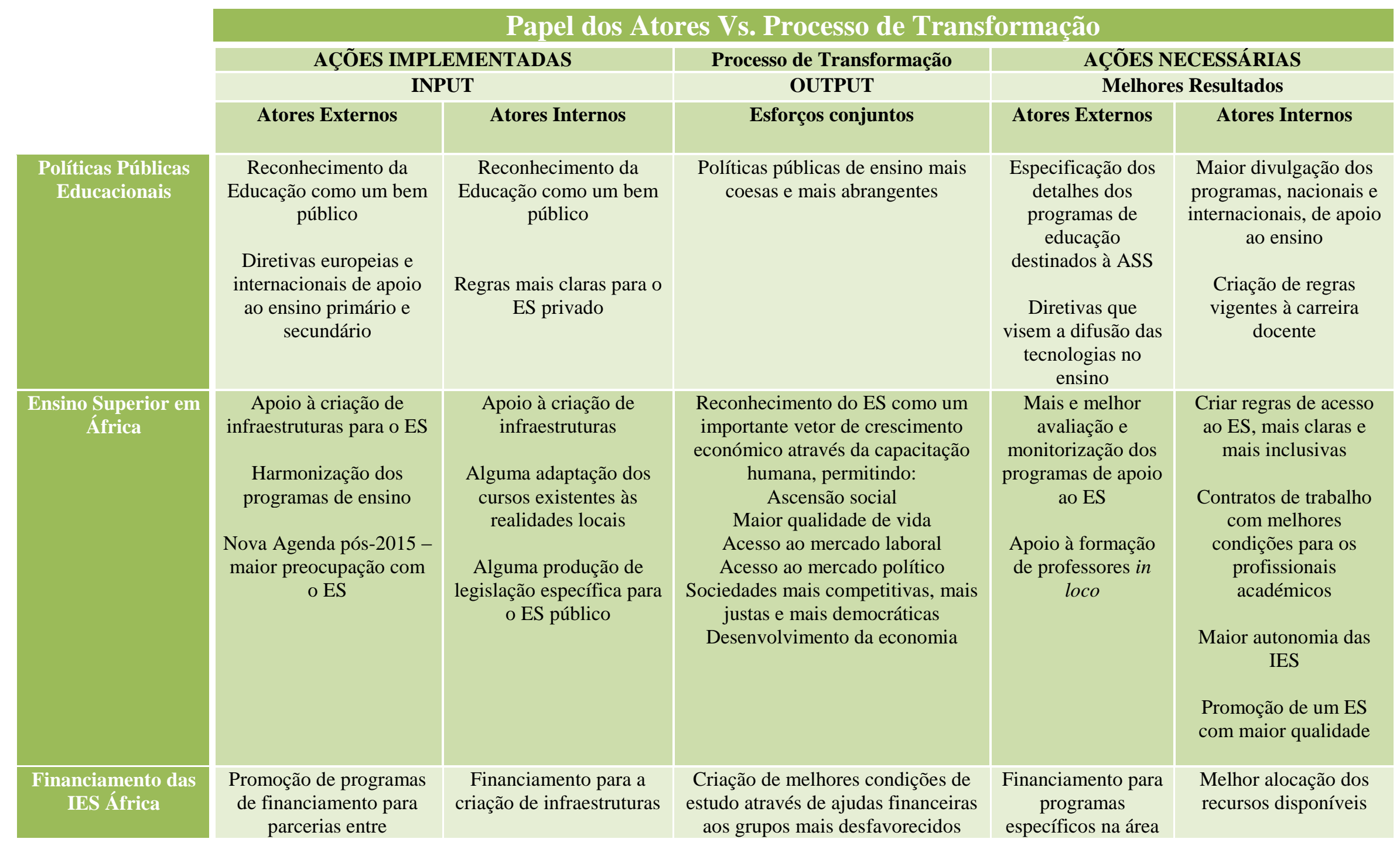




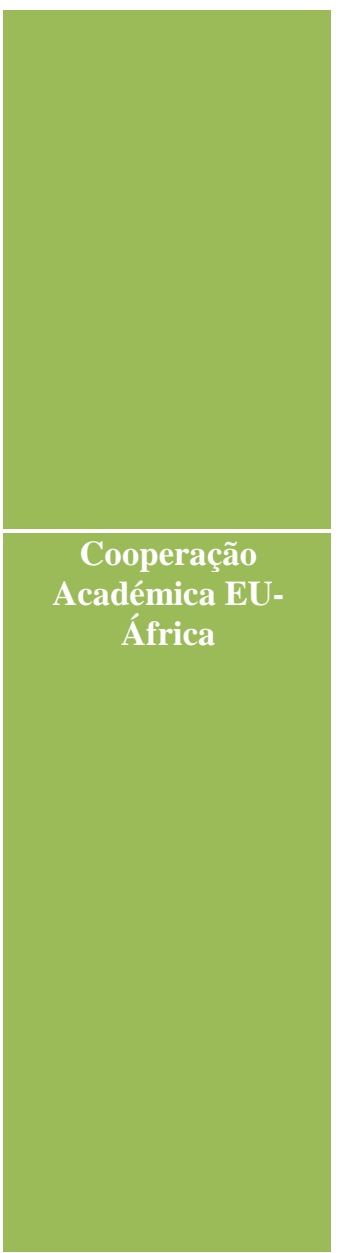

universidades, europeias e africanas

\section{Programas de}

Internacionalização

através de intercâmbios

de alunos e professores
Algum financiamento de apoio às IES

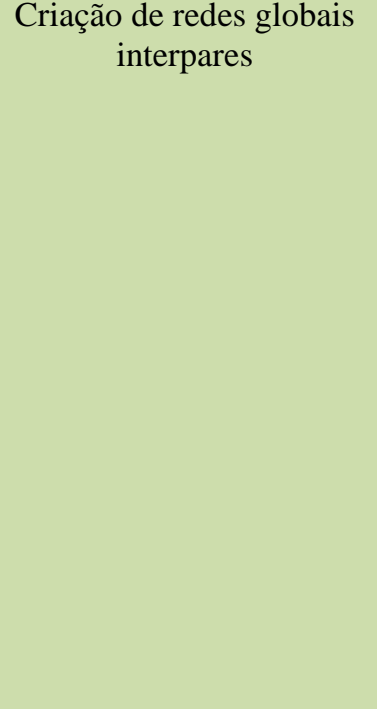

das tecnologias

Crescente apoio direcionado

especificamente para o ES

Desenvolvimento das sociedades

Crescimento económico

Melhores condições de vida

Reconhecimento dos Estudos

Benchmarketing de melhores práticas

Qualificação da mão-de-obra capital intelectual

Desenvolvimento tecnológico

Internacionalização e globalização

do conhecimento - mais inovação monitorização dos
Apoio a projetos de investigação efetuados em

parceria com as indústrias locais

\section{Avaliação} programas / projetos e dos seus resultados

Programas conjuntos mais coesos entre os diferentes stakeholders

Maior apoio para o desenvolvimento

$$
\text { das TIC }
$$

Promover parcerias com a indústria

Interface indústria / centros de investigação

Maior financiamento regional e nacional

Transformação do processo de brain drain em processo de brain gain

Maior apoio ao desenvolvimento de interfaces tecnológicas de apoio aos estudos online

Programas de inserção laboral dos graduados

Projetos tripartidos: universidades -

laboratórios de investigação - industria

Tabela 14 - Papel dos Atores Vs. Processo de Transformação 


\subsection{Síntese da análise}

Ao longo deste estudo temos vindo a evidenciar o papel dos Atores, internos e externos, na medida em que contribuem, através das suas ações conjuntas, para o crescimento económico de um conjunto de países em desenvolvimento como é o caso da África Subsariana. Porém, as opiniões divergem quanto ao tipo de ensino a ser fornecido e priorizado neste contexto. De uma forma geral, os apoios direcionam-se para o ensino primário e secundário, financiados pelos Governos de cada um dos países, na medida em que acreditam que estes níveis são os que necessitam de maior suporte assim como a educação a nestes níveis constitui o direito à educação enquanto um direito inalienável de qualquer cidadão, e consequentemente, como um direito público. Verificamos que o peso dos Atores não é, efetivamente, o mesmo pelo que podemos considerar que existem Atores com um papel chave, na medida em que influenciam o processo de transformação e são pouco dependentes dos outros elementos do sistema, existindo uma hierarquização dentro dos Atores nos seus vários níveis. É o exemplo dos Atores Externos, os quais através das medidas e ferramentas de cooperação internacional, anteriormente identificados, têm vindo a apoiar o sistema de educação e cujas ações dos Atores Internos dependem, em grande parte, dos apoios fornecidos por estes. Contudo, a visão dos Atores Externos, como já mencionado, tem como intuito a erradicação da pobreza como principal preocupação e cujas medidas impulsionadas até à data, no âmbito da educação, estejam relacionadas com este fator, apesar de se verificar uma atitude de mudança quanto ao ensino superior e o reconhecimento dos seus benefícios a vários níveis, incluindo a diminuição da pobreza e melhores condições de vida para toda a população. Os Atores Internos, por sua vez, tornam-se dependentes das medidas de apoio externas. Em especifico, os Atores locais, ao nível das Instituições de Ensino Superior, partilham da lógica que se encontra subjacente à ação inovadora, ou seja, a lógica que faz o apelo à diversificação da atividade económica local. Consideram que podem contribuir para o desenvolvimento do tecido empresarial. Neste sentido, apelam a um maior esforço do envolvimento das indústrias locais, no âmbito da criação de parcerias, para os desenvolvimentos de projetos de inovação face às necessidades 
locais. Desta forma preconiza-se a necessidade de promover sociedades mais sustentáveis e empreendedoras existindo concordância, por parte dos Atores envolvidos, quanto à necessidade de diversificar a atividade económica local, acreditando que os seus desafios estratégicos identificam-se mais com o desafio da abertura do território local ao investimento exterior, contribuindo para o seu processo de industrialização. Por último, apesar de se identificarem ações conjuntas entre os diferentes Atores verificamos, igualmente, que as alianças existentes carecem de maior coesão, uma vez que, embora trabalhem para um mesmo fim, as ações não são sistémicas, mas antes medidas isoladas com finalidades próprias de cada um dos departamentos e cujos outputs não visam os resultados de outras medidas promovidas por diferentes Atores, assim como se verificou o desconhecimento por parte de vários Atores das medidas existentes, da sua forma de aplicação, avaliação e monitorização. 
VNIVERSIDAD

DSALAMANCA 


\section{PARTE IV}

CONCLUSIÓN 
VNIVERSiDAD

SALAMANCA 


\section{Conclusión}

La cooperación internacional para el desarrollo constituye desde hace tiempo un importante factor de desarrollo en los países del África Subsahariana tanto a nivel económico como social. En este sentido, las acciones llevadas a cabo por cada uno de los actores, internos y externos que hemos analizado, constituyen relevantes herramientas de análisis y posterior apoyo si procede a este progreso.

A lo largo del tiempo se han ido creando diferentes medidas para dar uniformidad de las ayudas, ya que se ha constatado la persistente preocupación en reconocer la educación como uno de los principales factores promotores del desarrollo desde la perspectiva de entender a la educación como un bien público global. En realidad, la evidencia empírica demuestra que la educación básica siempre estuvo en el foco de las atenciones dejando de lado el papel de la enseñanza superior, no sólo por diversos condicionamientos propios de estos países en desarrollo, sino también por los requisitos trazados por los donantes internacionales en relación al cumplimiento de sus compromisos con los Gobiernos nacionales africanos, a pesar del hecho de que para la reducción de la pobreza y los objetivos del desarrollo del milenio eran, efectivamente, prioridades el desarrollo de todos los niveles educativos en lo que se refiere a la ayuda pública al desarrollo.

En este proceso habría sido importante dar mayor relieve a equipos profesionales cualificados que podrían implementar de forma más efectiva los objetivos definidos para la educaci\{on superior. Por otro lado, la emergencia de una economía global y competitiva pone de manifiesto la necesidad de un mayor alineamiento con el conocimiento que permitirá abrir los mercados nacionales contribuyendo a su internacionalización y al consecuente progreso social, económico y político. A medida que el conocimiento avanza las necesidades industriales aumenta en concordancia y la aplicación de las tecnologías se convierte en una realidad 
ineludible, lo que implica el desarrollo de una fuerza de trabajo que responda a las nuevas necesidades empresariales contribuyendo al desarrollo económico. Sin embargo, las matrículas en la enseñanza secundaria en el África subsahariana son todavía bajas y las de la enseñanza superior están muy por debajo de las necesidades para contribuir al proceso de aceleración económica y estabilización política en un mundo globalizado. Como se mencionó a lo largo de este estudio, África sigue muy por debajo del promedio mundial en lo que se refiere al nivel de las inscripciones de estudiantes en la enseñanza, lo que se debe, en parte, a la herencia cultural y política, pero también debido al hecho de que las alianzas Internacionales y europeas siempre se centran en la erradicación de la pobreza y la enseñanza primaria, dejando de lado la importancia que tiene la correlación entre los niveles de enseñanza primaria, secundaria y técnica con la superior para contribuir al crecimiento de la economía de forma sostenible. El cambio de actitud en las últimas décadas por parte de los actores en el sentido de invertir esta tendencia ha contribuido a la creación de asistencias y colaboraciones para el nivel de la enseñanza superior, especialmente entre Europa y África, y ha permitido crear varios apoyos y fondos que sostienen esta relación de una forma controlada con el objetivo de evitar los procesos de brain drain y, permitir que la mano de obra cualificada regrese a sus lugares de origen y contribuya al crecimiento económico sostenible. Para ello, la asistencia exterior es de extrema importancia en la creación de fondos que apoyen la cualificación de los recursos humanos de forma orientada. Ahora bien, para alcanzar estos objetivos la sociedad civil debe intervenir recursos adicionales y ofrecer una formación más especializada para que la transferencia de tecnología contribuya al tejido empresarial e industrial circundante. Sin embargo, la opinión de la comunidad internacional que se dedica a los planes de desarrollo difiere en cuanto a los niveles y condiciones que debe suministrar a los países en estudio. Si por un lado se reconoce que la educación es un importante factor de erradicación de la pobreza, por otro se comprueba que las intenciones de apoyo, por parte de los actores y a través de las diferentes herramientas de ayuda, se concentran en la enseñanza primaria y secundaria públicas. Sin embargo, estos Actores no dejan de considerar que, de hecho, niveles de educación superiores conducen a sociedades más equitativas y económicamente más sostenibles. La efectividad de este proceso requiere la alineación con las necesidades localmente 
comprobadas y, consecuentemente, la cooperación con el tejido empresarial para crear capital intelectual cuyas competencias se adapten a las necesidades de la industria y del comercio local para aprovechar al máximo los recursos naturales existentes.

La interacción compleja entre conocimientos, competencias y migración es ampliamente discutida en términos de los conceptos de 'brain drain', 'brain gain' $y$ 'brain waste'. El impacto de la migración internacional en el desarrollo se centró inicialmente en preocupaciones sobre la "fuga de cerebros". Esto es porque la educación se supone que es un factor determinante del crecimiento económico a largo plazo, pero también una de las causas de la salida de un gran número de trabajadores cualificados de los países en desarrollo hacia fuera. Por tanto, se considera una pérdida para el país en términos de reducción del potencial económico y disponibilidad de trabajadores calificados. La pérdida de personas cualificadas impone diferentes tipos de costos para los Estados, de los cuales el más obvio es el costo de la propia educación que, en muchos casos, ha sido subsidiada por el Estado. Además, la pérdida de profesionales cualificados puede, en algunos casos, poner en riesgo diferentes sectores de la economía. Por lo tanto, el impacto negativo sobre el desarrollo de los países pobres debe ser mitigado por el apoyo de los donantes a la educación y la formación en los países en desarrollo, especialmente en ámbitos en los que faltan las competencias necesarias. Sin embargo, es extremadamente difícil probar empíricamente el efecto de la fuga de cerebros de la emigración en un determinado país, existiendo pocos estudios basados en evidencias cuantitativas de ello. Comprender y medir todos los mecanismos en el trabajo requiere datos confiables y el análisis empírico. En cuanto al tamaño ya la estructura educativa de la migración internacional, hay una cantidad razonable de evidencias que sugieren que la fuga de cerebros es ahora mucho más extensa de lo que era hace dos o tres décadas. Por ejemplo, Haque y Jahangir (1999) indican que el número de emigrantes altamente calificados de África aumentó de 1.800 por año en promedio entre 1960-75 a 4.400 durante 1975-84 y 23.000 durante 1984-87. Estas tendencias fueron confirmadas en la década de 1990 frente a las políticas de inmigración cada vez más selectivas en todos los países de la Organización para la Cooperación y el Desarrollo Económico 
(OCDE). Hasta la fecha, a pesar de los estudios de caso y de las pocas evidencias, no existe una evaluación empírica sistemática de magnitud del drenaje cerebral. Muchas instituciones consideran la falta de datos internacionales armonizados, sobre la migración por país de origen y nivel educativo, como el principal problema para monitorear el alcance y el impacto de la fuga de cerebros en las áreas en desarrollo (Özden e Schiff, 2006). Lo que es cierto es que en la mayoría de los países hay una cierta relación entre bajos niveles de capital humano y bajas tasas de emigración de sus ciudadanos altamente cualificados, por lo que se ven poco afectados por la fuga de cerebros.

Desde 2007 la Fundación Europea de Formación (European Training Fundation), que es una agencia especializada de la UE encargada de apoyar el desarrollo del capital humano en los países en desarrollo, ha trabajado en el ámbito de las competencias de la migración y ha realizado investigaciones a gran escala. Las investigaciones están especialmente enfocadas en los perfiles de competencias de los migrantes y refugiados, en la experiencia de trabajo de migrantes, en la ganancia y la pérdida de aptitudes (skill gains y skill waste) antes, durante y después de la migración. Los resultados indican que la migración y el retorno de resultados presentan una notable variación de los patrones de migración en términos de duración, circularidad, regularidad, destino y las circunstancias individuales de cada país. La obtención de un grado de enseñanza superior en un país en desarrollo constituye, por paradójico que parezca, una reducción en la intención de migrar, aunque al mismo tiempo que aumenta la posibilidad potencial de hacerlo. Este factor de capacitación es más visible donde los niveles de educación general son mucho más bajos y la tasa de desempleo de graduados es alta. Las experiencias de migración pueden constituir, por otra parte, una tendencia de Brain Gain para mejorar las competencias de la mayoría de las personas. Tres elementos son necesarios para que la experiencia del migrante sea considerada como un beneficio positivo para su país de origen: deben desarrollar nuevas aptitudes durante su tiempo en el exterior, extendiendo sus conocimientos, experiencias, capacitación y aprendizaje en contextos formales o informales. Deben regresar después del período de ausencia, y el tipo de experiencia adquirida en el 
extranjero debe considerarse beneficioso en el país de origen para aumentar su empleabilidad cuando regresan.

En general, la propia experiencia de migración contribuye a un modesto proceso de brain gain de forma sutil, especialmente en países donde los niveles de educación son generalmente bajos. Sin embargo, la mayoría de estas nuevas habilidades nunca se certifican o se vuelven realmente visibles en el mercado laboral nacional para obtener el retorno esperado de los nuevos aprendizajes. Hay una necesidad de desarrollar mecanismos para la validación de tales habilidades, permitiendo que los retornados tengan capacidad para usar la experiencia ganada en la migración, como ventaja adicional al buscar un empleo en su país de origen. En la Unión Europea, los datos indican que una pequeña tasa de migrantes procedentes de los países en desarrollo tiene el propósito de desplazarse con el fin de obtener educación y formación. Estos flujos de estudiantes internacionales se caracterizan por una elevada proporción de retornados, reflejando así la circulación de cerebros y el alto retorno que permite que la educación adquirida en el exterior pase a formar parte del mercado de trabajo nacional. La circulación de cerebros puede desempeñar un papel positivo en el desarrollo, ya que la migración aumenta el capital humano y aumenta la adquisición y la explotación de conocimientos globales, la experiencia laboral y la creación de redes de trabajo e investigación. Los datos también sugieren que los países de la UE parecen ser menos atractivos que los de EE.UU. y Canadá en la circulación de los migrantes altamente cualificados, pues los mejores y los más brillantes estudiantes tienden a preferir a América del Norte como destino principal.

La experiencia de trabajo en el extranjero se basa en los limitados tipos de empleos y sectores abiertos a los inmigrantes, con problemas en la correspondencia entre el trabajo y el grado de formación, que normalmente será inadecuado y hará un uso limitado de las competencias del migrante. Construcción, servicios domésticos y personales, agricultura, servicios de hotelería, comercio, transporte e industria son los sectores más comunes que aceptan inmigrantes. Como la mayoría de los migrantes aceptan empleos cualificados por debajo de su nivel o no cualificados, esta situación 
lleva a la pérdida de competencias - Brain Waste -, ya que no se tenienen en cuenta sus niveles de educación aún siendo relativamente elevados.

Los actores europeos e internacionales se han comprometido a apoyar el desarrollo económico y la estabilidad de los países socios a través del diálogo político y el apoyo financiero, pero ¿qué papel juega en estos compromisos la educación? Por ejemplo, la revisión de la Política Europea de Vecindad reconoce la importancia de reforzar el vínculo entre el apoyo a la juventud, la educación y el empleo y un desarrollo económico más inclusivo. Además, la estrategia de ampliación de la UE hace un gran énfasis en la promoción del crecimiento inclusivo, a través de un nuevo enfoque sobre la gobernanza económica y la solicitud a los países para desarrollar programas globales de reforma económica en los que se incluyan los aspectos de formación del capital humano en sus diferentes escalas educativas. En este contexto, todas las reformas sociales y económicas apoyadas por la UE en los países socios tienen por objeto limitar el efecto "fuga de cerebros". Su estrategia tiene un importante componente de gobernanza. A este respecto, la Comisión Europea se ha comprometido a invertir en los jóvenes futuros líderes dentro de la sociedad civil local, en particular a través de la iniciativa Becas para la Sociedad Civil (Civil Society Fellowships), a través de los distintos componentes de los programas Erasmus $+\mathrm{y}$ también a través de los programas de cooperación de Apoyo a los sistemas de educación y formación profesional. Además, en muchos programas financiados por la UE de promoción de la movilidad para la UE, como Erasmus +, las tasas de retorno son elevadas, ya que el compromiso de regresar está claramente definido en los acuerdos contractuales con los alumnos. Estos programas demuestran la voluntad de la UE para promover la circulación de cerebros y la necesidad de animar a mujeres y hombres jóvenes a establecerse en su comunidad de origen y evitar la migración de los cualificados. Pero la responsabilidad mayor es de los países de origen, para poner en práctica las políticas y condiciones que permitirán que sus poblaciones puedan prosperar en sus propios países.

De acuerdo con los indicadores obtenidos en este estudio, la mayoría de los actores considera que la Nueva Agenda para el Desarrollo posterior a 2015 y los Objetivos de 
Desarrollo Sostenible debe enfocarse en la enseñanza superior como una preocupación y un objetivo a ser alcanzado. Por lo tanto, observamos que existe un impacto positivo en los actores de la Cooperación para el Desarrollo en las iniciativas de colaboración para la enseñanza superior de los países del África Subsahariana. Por otro lado, averiguamos que el nivel de influencia de estos actores es diferente, ya que los actores externos, a través de las medidas de apoyo al desarrollo, constituyen un importante factor de promoción de la educación, en tanto que público global, influyendo en el proceso de acuerdo con sus respectivas convicciones. Por otro lado, los actores locales comparten la lógica que se encuentra subyacente a la acción innovadora, es decir, la lógica que hace reclama la diversificación de la actividad económica local a través de una enseñanza superior de calidad y cuya cooperación con la sociedad civil debe ser promovida. En efecto, existe concordancia, por parte de los actores involucrados, en cuanto el apoyo que la educación superior supone para la diversidad de la actividad económica local, sin embargo sus desafíos estratégicos se identifican con la apertura del territorio local a la inversión exterior, contribuyendo a su proceso de industrialización, infiriendo una relación de dependencia entre las opciones de desarrollo y los actores externos. En la tesis se puede observar como estamos ante un juego de interdependencias donde cada uno de los actores interpreta un papel diferente. Sin embargo, podemos deducir que las acciones llevadas a cabo por los ellos son claves para que se transformen las percepciones sobre el papel de la enseñanza superior en los actuales modelos para el desarrollo..

Por lo que se refiere a la hipótesis central de la investigación, concluimos que el papel de los actores, internos y externos, es de extrema importancia en la creación de asociaciones y acciones de cooperación entre las universidades europeas y africanas en el desarrollo en el contexto del siglo XXI, en la medida en que crean las condiciones necesarias a través de herramientas e instrumentos propios en términos de ayuda al desarrollo. Sin embargo, el nivel de influencia de los actores varía bastante y su peso no es el mismo en cada tipo de de acción y las medidas implementadas, por lo que existen actores clave, que influyen mucho y son poco dependientes, estos son en particular los que hemos denominado como actores internacionales. Los actores locales de las instituciones de enseñanza superior comparten la la lógica que realizar 
los acuerdos y asociaciones defendiendo la diversificación de la actividad económica local, aunque sean actores dependientes de prácticamente todos los otros actores, pues están condicionados por la falta de autonomía y las limitaciones de los gobiernos locales, así como por las directivas establecidas por los actores europeos e internacionales que regulan los fondos y su aplicación, estando los mismos correlacionados con sus creencias en términos de prioridades educativas que se han de establecer en los países en desarrollo.

Por lo tanto, podemos sostener que existe una jerarquización de los actores en sus distintos niveles, existiendo igualmente una alianza y colaboración entre los actores, que resulta en los diversos acuerdos y asociaciones identificados a lo largo de este trabajo, y más precisamente en las asociación e iniciativas para el desarrollo basadas en los Objetivos de Desarrollo del Milenio y su sucesor los Objetivos del Desarrollo Sostenible. No obstante, verificamos de forma semejante, que a pesar de las acciones implementadas y del correspondiente proceso de transformación y de la forma de optimizar los outputs es necesario tener en cuenta otras medidas por parte de los actores internos y externos. Esto es debido a que se ha confirmado la hipótesis de que aunque hay una concordancia por parte de los actores involucrados en cuanto a la necesidad de fomentar la diversidad de la actividad económica local, lo cierto es que enfocan los desafíos estratégicos preconizando la apertura del territorio local a la inversión exterior para que contribuya a su proceso de industrialización.

Los actores internacionales constituyen un importante factor de apoyo a los países en desarrollo, pues permiten a través de sus acciones alentar el proceso de evolución y progreso de estas sociedades a través de la erradicación de la pobreza, pero también a través del desafío de la construcción de un capital intelectual capaz de transformar las mentalidades y las sociedades. Su acción constituye un hito en muchas de estas sociedades, en la medida en que han contribuido positivamente al desarrollo de países con carencias significativas y cuyas poblaciones han mejorado su calidad de vida a través de los esfuerzos conjuntos efectuados por la comunidad internacional. Esto ha sido así cuando e foco estuvo en la educación primaria y secundaria. Sin embargo, ahora estamos ante un escenario desafiante, no sólo por la coyuntura económica 
mundial debilitada, sino también por las exigencias de un mundo globalizado e internacionalizado donde la educación superior juega un papel más relevante en las relaciones de los países menos desarrollados con los más desarrollados y viceversa. 
VNIVERSIDAD

DSALAMANCA 


\section{Bibliografia}

Adeboye, T. (2000). "Science and Technology and Economic Policy Making in Africa: Individual and Institutional Linkages" em Jeggan C. Sengor (Ed.) Science and Technology Policy in Africa by Asmara, Eritrea Africa World Press, Inc.

Adegbola, A. (2003). "Science, Technology and Culture in Africa: Challenges and Prospects" em Ayo Fadahunsi (ed.) Philosophy, Science and Technology, Ibadan: Hope Publications.

AfDB, OECD, UNDP, ECA (2013). African Economic Outlook: Structural Transformation and Natural Resources. Paris, OECD.

AfDB, OECD, UNDP, ECA (2014). African Economic Outlook: Global Value Chains and Africa's Industrialization. Paris, OECD.

Afonso, M. e Fernandes, A. (2005). abCD Introdução à Cooperação para o Desenvolvimento. CIUDAD Instituto Marquês de Valle Flôr \& Oikos - Cooperação e Desenvolvimento.

African Civil Society Groups (2007). Statement from participants. Civil Society Workshop on Open Access to ICT infrastructure in Africa. Kigalli, Rwanda, [Em linha]. Disponível em: http://www.apc.org/english/news/index.shtml?x=5262405. Acedido em Maio 2014.

African Development Forum (1999). A strategy to accelerate African development through the in-creased use of Information and Communication Technologies. [Em linha]. Disponível em: http://www.uneca.org/ADF99/adf99strategy.htm. Acedido em Setembro 2013.

Ajayi, J.F.A.; Goma, L.K.H. e Johnson, G.A. (1996). The African Experience with 
Higher Education. Association of African Universities, James Currey, Ltd.

Akoojee, S. e McGrath, S. (2004). Assessing the Impact of Globalization on South African Education and Training: A Review of the Evidence so Far. Globalization, Societies and Education. 2(1): 25-46.

Alderman, G. (2001). The Globalization of Higher Education: Some Observations Regarding the Free Market and the National Interest. Higher Education in Europe. 26 (1):47-52.

Ali, A. S. (2003). "Culture, Technology and Society" em Ayo Fadahunsi (ed.) Philosophy, Science and Technology. Ibadan: Hope Publications.

Allen, M. e Ogilvie, L. (2004). Internationalization of higher education: potentials and pitfalls for nursing education. Faculty of Nursing, University of Alberta, Edmonton, Alberta, Canada.

Allen, M. e Ogilvie, L. (2004). International Council of Nurses. International Nursing Review, 51:73-80.

Alozie, P. (2008). "African Philosophy for Survival in the 21st Century" em M.F. Asiegbu et. al. (ed.) Four Decades of African Philosophy: Issues and Perspectives. Ibadan: Hope Publications.

Altbach, P. G. (2004). Globalization and the University: Myths and Realities in an Unequal World. Tertiary Education and Management, 10:3-25. Disponível em https://doi.org/10.1023/B:TEAM.0000012239.55136.4b .

Altinok, N. (2007). Human capital quality and economic growth. Institute for Researchin the Sociology and Economics of Education. Working paper DT 2007/1.

Antunes, R. (2000). Os sentidos do trabalho: Ensaio sobre a afirmação e a negação do trabalho. 2 Ed. São Paulo: Boitempo .

Arnove, R. e Torres, C. (1999). Comparative Education: The Dialectic of the Global and the Local. New York: Rowman and Littlefield Publishers, Inc., 434 pp. 
AU/NEPAD (2005). Consolidated science and technology plan of action (CPA), 2006-2010. African Union Commission, Addis Ababa, Ethiopia.

AUC, UNECA, AfDB e UNDP (2012). Assessing Progress in Africa toward the Millennium Development Goals. Merging perspectives from Africa on the post-2015 development agenda. Addis Ababa, Ethiopia

Banco Mundial (2010). Acelerando o passo. Educação terciária para o crescimento económico na África subsariana. Washington DC: Banco Mundial.

Bardin, L. (1994). Análise de Conteúdo. Lisboa: Edições Setenta.

Barro, R. e Sala-i-Martin, X. (1995). Economic Growth. New York, McGraw-Hill.

BBC World Service Trust (2006). African Media Development Initiative. [Em linha]. Disponível em: http://www.bbc.co.uk/worldservice/trust/specials/1552_trust_amdi/index.shtml .

Becker, G. (1993). Human capital: a theorical and pratical analysis with special reference to education. 3.ed. New York, The University of Chicago, Press. ISBN 0226-04120-4.

Beebe, M. (2004). Impact of ICT Revolution on the African Academic Landscape. CODESRIA. Senegal: Proceedings of Conference on Electronic Publishing and Dissemination, Dakar 1-2 September 2004.

Bell, B. e Cowie, B. (2001). Formative assessment and science education. Dordrecht: Kluwer Academic Publishers.

Bell, B., e Cowie, B. (1999). "Researching formative assessment" em J. Loughran (Ed.). Researching teaching. London: Falmer Press.

Bergvall-Kareborn, B. (2002a). Enriching the model-building phase of soft systems methodology. Syst. Res. Behav. Sci. 19, 27-48.

Bergvall-Kareborn, B.; Mirijamdotter, A.; Basden, A. (2004). Basic principles of SSM 
modeling: an examination of CATWOE from a soft perspective. Systemic Practice and Action Research, 17(2): 55-73.

Bloom, D.; Canning, D. e Chan, K. (2006). Higher Education and Economic Development in Africa. Harvard University. Human Development Sector, Africa Region.

Bunting, I. (2006). "Funding". em N. Cloete, P. Maasen, R. Fehnel, T. Moja, H. Perold \& T. Gibbon (Eds) Transformations in higher education: global pressures and local realities. Dordrecht, Springer, 73-94.

Bunting, I. e Cloete, N. (2009). "Governing access to higher education in South Africa" em Featherman, D.L., Krislov, M., Hall, M. (2009). The Next Twenty-five Years: Affirmative Action in Higher Education in the United States and South Africa. (Livro electrónico). University of Michigan Press. Disponivel em https://books.google.be/books?id=bOuWQuW6DfUC .

Cloete, N. e Bunting, I. (2000). Higher Education Transformation: Assessing Performance in South Africa. Pretoria, South Africa. Center for Higher Education Transition.

Cardoso, C. (2008). "A experiência do CODESRIA em material de cooperação académica" em Mansson et al (2008). África - Europa: Cooperação Académica. Fundação Friedrich Ebert.

Carvalho, M. e Albernaz, G. (2008). "Cooperação Académica entre Africa e Europa" em Tolentino et al (2008). "África-Europa: Cooperação Académica". Lisboa, Fundação Friedrich Ebert.

Castles, S. (2001). Studying Social Transformation. International. Refugee Studies Centre, University of Oxford. Political Science Review. Volume: 22 issue: 1, page(s): 13-32. 
CEC - Commission of the European Communities (2006). Efficiency and equity in European education and training systems. Bruxelas, CEC. [Em linha]. Disponível em http://ec.europa.eu/education/policies/2010/doc/comm481_en.pdf .

Cervo, L. e Bervian, A. (1983). Metodologia Científica. 3 ed. São Paulo: McGrawHill do Brasil.

Chase Dunn, C. (2001). Globalization: A World-Systems Perspective. Proto Sociology, 15, pp. 26-50.

Chiavenato, I. (1999). Introdução à Teoria Geral da Administração. $4^{\mathrm{a}}$ Edição, Ed. Makron Books.

Checkland, P. e Scholes, J. (1999). Soft systems methodology in action. Chichester, GB: John Wiley \& Sons.

Clark, B. R. (1998). Creating entrepreneurial universities: organizational pathways of transformations. Oxford, Pergamon.

Clyne, F. et al. (2000). International Education in Australian Universities: Concepts and Definitions. Paper Presented at the Annual Conference of the Comparative and International Education Society.

Cohen, N. (2006). African Languages Grow as a Presence on Wikipedia. New York Times.

Coker-Kolo, D. e William, K. (2013). The Role for African Universities in a Changing World. Journal of Third World Studies. Vol. 30, No. 1.

Coleman, D.C. e Macleod, C. (1986). Attitudes to New techniques: British Businessmen, 1800-1950. Economic Histoty Review, 26.

Crosier, D. e Parveva, T. (2013). The Bologna Process: Its impact in Europe and beyond. UNESCO:International Institute for Educational Planning. Paris. [Em linha]. Disponível em: $\quad$ http://unesdoc.unesco.org/images/0022/002206/220649e.pdf. Acedido em Janeiro de 2014. 
Dahlman, C. (2007). "The Challenge of the Knowledge Economy for Latin America". Globalisation, Competitiveness and Governability Journal, vol (1).

Danofsky, S. (2005). Open Access for Africa. Challenges, Recommendations and Examples. New York: United Nations ICT Task Force.

David Paul, A. e Foray, D. (2002). "An Introduction to the Economy and the Knowledge Society”. International Social Science Journal, Vol. 171, pp. 1-23.

De Bloom, H. e Rosovsky, H. (2006). "Beyond Private Gain: The Public Benefits of Higher Education" em Bloom D., Canning D. e Chan K. (2006). Higher Education and Economic Development in Africa. Harvard University. Human Development Sector, Africa Region.

De Wit, H. e Wit, M. (2011). "Trends, Issues and Challenges in Internationalisation of Higher Education." Centre for Applied Research on Economics \& Management, School of Economics and Management of the Hogeschool van Amsterdam. ISBN 9081712217.

Deketele, J. M. (1997). "Higher Education in the Twenty-First Century: African Regional Consultation Preparatory to the World Conference on Higher Education". Dakar: BREDA.

Department of Education. (2005). Student Enrolment Planning in Higher Education. Pretoria: Government of South Africa.

Desjardins, R. (2003). "Determinants of economic and social outcomes from a lifewide learning perspective in Canada". Education Economics, Vol. 11, N. 1, pp.11-38.

Digital Opportunity Task Force (2002). Report Card. Digital Opportunities for All. [Em linha]. Disponível em: http://www.g8.gc.ca/2002Kananaskis/pdf/GeneralReport_e.pdf . Acedido em Março 2015. 
Dunn, M. e Nilan, P. (2007). Balancing economic and other discourses in the internationalization of higher education in South Africa. Review of Education $53: 265-281$.

Edwards, R. e Usher, R. (2000). Globalization and Pedagogy: Space, Place and Identity. London: Routledge. International Education Association of South Africa.

Etta, F. e Parvyn-Wamahiu, S. (Ed.) (2003). Information and communication technologies for development in Africa. Ottawa and Dakar: IDRC.

EU (undated). Financing ICT for development: the EU approach. [Em linha]. Disponível em: http://www.dfid.gov.uk/pubs/files/eu-financ-wsis-english.pdf. Acedido em Outubro 2014.

EU (sem data). The Africa-EU Strategic Partnership. A Joint Africa-EU Strategy. [Em linha]. Disponível em: http://www.eu2007.pt/NR/rdonlyres/D449546C-BF424CB3-B566-407591845C43/0/071206jsapenlogos_formatado.pdf. Acedido em Outubro 2014 .

EUA (2010). Africa-Europe Higher Education Cooperation for Development: Meeting Regional and Global Challenges. White paper - Access to Success Project (2008 - 2010). [Em linha]. Disponível em: http://www.eua.be/Libraries/publicationshomepage-list/Africa-

Europe_Higher_Education_Cooperation_White_Paper_EN_FR.pdf?sfvrsn=0.

Acedido em Novembro 2014.

European Commission (2014). Fourth EU-Africa Summit: Roadmap 2014-2017. Publications Office of the European Union, Brussels.

European Union (2013). Annual Report, 2013 on the European Union's Development and external assistance policies and their implementation in 2012. Publications Office of the European Union, Luxembourg.

Eze, O. (1986). Transfer of Technology to Developing Countries. Lagos, Nigerian Institute of International Affairs. 
Faria, R. (2014). A Cooperação Portuguesa no contexto da Cooperação Internacional para o Desenvolvimento (1998-2012): um ensaio de modelização. Tese de Doutoramanto. Universidade de Coimbra, Faculdade de Letras.

Farrell, G.; Isaacs, S. e Trucano, M. (2007). The NEPAD e-Schools Demonstration Project: A Work in Progress. A Public Report. Vancouver, Washington: Commonwealth of Learning, infoDev.

Fasal, R. e Lingard, B. (2000). Globalization and Education: Complexities and Contingencies. Educational Theory 50(4): 419-426.

Ferreira, Francisco H. G., Julian Messina, Jamele Rigolini, Luis-Felipe López-Calva, Maria Ana Lugo, y Renos Vakis (2013). La movilidad económica y el crecimiento de la clase media en América Latina. Washington, DC: Banco Mundial. Licencia: Creative Commons de Reconocimiento CC BY 3.0. [Em linha]. Disponível em https://openknowledge.worldbank.org/bitstream/handle/10986/11858/9780821397527 .pdf [. Acedido em Maio 2016.

Ferri, G. (2003) e Stiglitz, J. (2002). Globalization and Its Discontents. Economic Notes, 32: 123-142. doi: 10.1046/j.0391-5026.2003.00107.

Fonseca, S. (2002). "Metodologia da pesquisa científica." Fortaleza: UEC, Apostila.

Frieden, Jeffry A. (2007). "Global Capitalism: Its Fall and Rise in the Twentieth Century". W. W. Norton \& Company.

Gebremeskel, H. H. (2014). Influence of the Bologna Process on African higher education: Ethiopian higher education in focus. International Journal of Research Studies in Education. Volume 3, Number 4, 85-98.

Gerhardt, T. e Silveira, D. (2009). "Métodos de Pesquisa". Universidade Federal do Rio Grande do Sul. Universidade Aberta do Brasil - UAB/UFRGS. Porto Alegre: Editora da UFRGS. 
Gerster, R. e Zimmermann, S. (2003). Building Digital Opportunities (BDO) Programme: ICTs and Poverty Reduction in Sub-Saharan Africa. A Learning Study. [Em linha]. Disponível em: http://www.gersterconsulting.ch/docs/Synthesis_report.pdf. Acedido em Julho 2015.

Gerster, R. e Zimmermann, S. (2005). Up-scaling Pro-Poor ICT-Policies and Practices. A review of experience with emphasis on low-income countries in Asia and Africa. [Em linha]. Disponível em: http://www.gersterconsulting.ch/docs/Upscaling_ProPoor_ICTPolicies_Practices.pdf . Acedido em Julho 2015.

GeSCI - African Leadership in ICT Program (2010). Science and Technology and the Knowledge Society in Africa. ICT, Science and Technology Division (ISTD), United Nations Economic Commission for Africa (UNECA), Addis Ababa, Ethiopia.

Giddens, A. (2000). Runway World: How Globalization is Reshaping Our Lives. New Work Routledge.

Gillwald, A. e Lisham, A. (2007). The Political Economy of ICT Policy Making in Africa: Historical Contexts of Regulatory Frameworks, Policy Performance, Research Questions and Methodological Issues. [Em linha]. Disponível em: http://www.aercafrica.org/documents/ICT_project_working_papers/Adam_Gillwald_ The_Political_EconomyofICTPolicyMaking.pdf . Acedido em Junho 2015.

Girard, B. (2003). The One to Watch. Radio, New ICTs and Interactivity. Rome, FAO. Goddard, E.J. (2009). Reinventing the Civic University. NESTA, London, UK . [Em linha]. Disponível em http://www.nesta.org.uk/sites/default/files/reinventing the_civic_university.pdf. Acedido em Fevereiro 2016.

Hafkin, N. (2008). Enabled Women in Knowledge Societies. Case study: The Philippines and Thailand, i4D, Massachusetts, USA. 
Halsey, A.H.; Lauder, H.; Brown, P. e Wells, A.S. (1997). "Education: Culture, Economy, and Society." Oxford, Oxford University Press. ISBN-13: 9780198781875 .

Haque, N.U. e Jahangir A. (1999). "The Quality of Governance: Second-Generation Civil Reform in Africa." Journal of African Economies, 8: 65-106.

Harvey, D. (2007). "A Brief History of Neoliberalism". Oxford University Press. ISBN 9780199283279.

Held, D. et al. (1999). Global Transformations. Politics, Economics and Culture. Stanford University Press, Stanford.

Hess, C. \& Ostrom, E. (2007). Understanding Knowledge as a Commons: From Theory to Practice. Cambridge, MA: MIT Press.

Hewitt, A. e Gillson, I. (2003). "A Review of the Trade and Poverty Content in PRSPS and Loan-Related Documents". Overseas Development Institute (ODI), London.

Hood, C. (1989). Public administration and public policy: In-tellectual challenges for the 1990s. Australian Journal of Public Administration 48:346-58.

Hugon, P. (1999). L'Economie de l'Afrique. Editora La Découverte, Paris, , $2^{\mathrm{a}}$ ed.

Indjikian, R. e Siegel, D.S. (2005). The Impact of Investment in IT on Economic Performance: Implications for Developing Countries. World Development, 33, 5, 681-700.

infoDev, A. (2005). Promoting Private Sector Investment and Innovation To Address the Information and Communication Needs Of the Poor in Sub-Saharan Africa. Washington DC: World Bank.

International Organization for Migration - IOM (2005). "The Millennium Development Goals and Migration”. Migration Research Series, Geneva. 
ITU (2007a). Connect Africa Summit - Background Paper - Session Three. Extending Rural ICT Access in Africa. [Em linha]. Disponível em: http://www.itu.int/ITUD/connect/africa/2007/summit/pdf/s3-backgrounder.pdf . Acedido em Julho 2013.

ITU (2007b). Connect Africa Summit - Outcomes Report. [Em linha]. Disponível em: http://www.itu.int/ITU-D/connect/africa/2007/finalreport.pdf . Acedido em Julho 2013.

Iweriebor, E.G. (2004). Nigerian Technology Development since Independence. Ibadan: Book Builders.

Jarvis, P. (2001). Universities and Corporate Universities. The Higher Learning Industry in Global Society. Stylus Publishing, Sterling, VA.

Jenkins, H. (1995). “Education and Production in the United Kingdom." Economics Discussion Paper No 101, Nuffield College, Oxford University.

Jensen, M. (2003). ICTs in Africa: A status report. Chapter 6 of the 2002-2003 global competitive-ness report. [Em linha]. Disponível em: http://www.weforum.org/pdf/Global_Competitiveness_Reports/Reports/GITR_2002_ 2003/ICT_Africa.pdf . Acedido em Agosto 2015.

Jensen, M. (2006). Open access - Lowering the costs of international bandwidth in Africa. APC Issue Papers. [Em linha]. Disponível em: http://rights.apc.org/documents/open_access_EN.pdf> .

Johnstone, D. B. (2006a). In responses to austerity: the imperatives and limitations of revenue diversification in higher education. em D. B. Johnstone (Ed.) Financing higher education: cost sharing in international perspective. New York, Sense Publishers, 33-51.

Johnstone, D. B. (2006b). "Cost-sharing and the cost-effectiveness of grants and loan subsidies to higher education" em Teixeira, P. N. ; Johnstone, B. D. ; Rosa, M. J. ; Vossensteyn, H. (Eds) Cost-sharing and accessibility in higher education: a fairer deal? (Dordrecht, Springer), 51-78. 
Jongbloed, B. (2006). Strengthening consumer choice in higher education. Em P.N. Teixeira, B.D. Johnstone, M. J. Rosa \& H. Vossensteyn (Eds) Cost-sharing and accessibility in higher education: a fairer deal? (Dordrecht, Springer), 19-50.

Juma, C. (2006). "Reinventing growth: Science, Technology and Innovation in Africa", International Journal of Technology and Globalisation, vol. 2, Nos. 3/4.

Kasekende, L. e Shetty, S. (2008). Africa's Economic Prospect and Challenges. [Em linha].

Disponível

em:

http://www.sarpn.org.za/documents/d0003008/Africa_ecn_prospect_challenges_Feb2 008.pdf . Acedido em Julho 2014.

Kaul, I. e Conceição et al (2003). Providing Global Public Goods; Managing Globalization. New York, Oxford University Press.

Kaul, I. e Katell le Goulven et al (1999). Global Public Goods; International Cooperation in the 21 st Century. New York, Oxford University Press.

Khisty, C. (1995). Soft-Systems Methodology as Learning and Management Tool. Journal of Urban Planning and Development. 91-107.

King, D. (1997). The Challenges of Globalizing Higher Education in a Parochial Policy-making Environment. Presented at the International Congress on Challenges to Education, Kihei, Hawaii, 18 July 1997.

King, K. (2007). "Higher Education and International Cooperation - The role of academic collaboration in the developing world". Edinburgh University.

Kitson, M. et al (2009). The Connected University: Driving Recovery and Growth in the UK Economy. NESTA Research report. [Em linha]. Disponível em: http://www.nesta.org.uk/sites/default/files/the connected_university.pdf. Consultado em Maio 2016.

Klein, R. G. (2008). Out of Africa and the evolution of human behavior. Evol. 
Anthropol., 17: 267-281. doi: 10.1002/evan.20181.

Knight, J. (2002). Trade in Higher Education Services: The Implications of GATS. London: The Observatory on Borderless Higher Education.

Knight, J. (2003a). Updating the Definition of Internationalization. International Higher Education 33 (Fall): 2-3.

Knight, J. (2003b). "Internationalization: Meanings and Models". em Internationalization and Quality in South African Universities. Ed. by Smout. Michael Vol . New York: Carnegie Corporation.

Knight, J. e De Wit, H. (1997). Internationalization of Higher Education in Asia Pacific Countries. Amsterdam: European Association for International Education/OECD.

Knight, J. e Teffera, D. (2008). "African Higher Education - The international dimension". Boston College - Centre for International Higher Education.

Le Roux, P. e Breier, B. (2007). Steering from a distance: funding mechanisms and student access and success in higher education in South Africa. Paper prepared for the First Annual SANORD Centre Conference. University of the Western Cape, 5-7 September.

Lederman, D. e Maloney, W.F. (2003). “ $R \& D$ and Development." Policy Research Working Paper No. 3024.

Lin, T.C. (2004). "The Role of higher education in economic development: an empirical study of Taiwan case.” Journal of Asian Economics 15 (2): 355-371.

Livraghi, G. (2007). Data on internet activity worldwide (hostcount). [Em linha]. Disponivel em: http://www.gandalf.it/data/data1.htm [17 Março 2008].

Lopes, C. (2008). Os quatro desafios para a cooperação académica. Em Tolentino et al (2008). "África-Europa: Cooperação Académica". Fundação Friedrich Ebert. ISBN: 978-989-8005-04-5. 
Lulat, Y.G-M. (2003). 'The development of higher education in Africa: A historical survey'. Em Teferra, D. e Altbach, P.G. (eds.), African Higher Education: An International Reference Handbook. Bloomington: Indiana University Press, pp. 1531.

Macgregor, K. (2005). Foreign Student Flock to Study in SA. The Times Higher Education Supplement.

Mahbubani, K. (2001). Can Asians Think? Toronto: Key Porter Books.

Mansson et al (2008). África - Europa: Cooperação Académica. Fundação Friedrich Ebert.

Marah, J.K. (2006). "Famine, Hunger and Starvation in Africa: Challenge to African and World Leaders". AuthorHouse. ISBN 9781467803908.

Marangos, J. (2009). What happened to the Washington Consensus? The evolution of international development policy. The Journal of Socio-Economics, vol. 38, issue 1, january, pp. 197-208.

Marginson, S. (1999). After Globalization: The Emerging Politics of Education. Journal of Education Policy.

Martin Arnaiz, J.L. (2011). Los vínculos entre el nivel educativo y la cuota de mercado en África. Regional and Sectoral Economic Studies. EAAEDS, Vol. 11-2 . [Em linha]. Disponível em: http://www.usc.es/economet/journals2/eers/eers1129.pdf. Acedido em Maio 2016.

Mayoral, J. (2006). Desarrollo económico u educación. Indicios históricos en las primeras "revoluciones industriales". Faculdad de Educación. UNED. Educación XX1, 9, pp. 35-55.

McBurnie, G. (2001). Leveraging Globalization as a Policy Paradigm for Higher Education. Higher Education in Europe.

Merisotis, J. P. e Gilleland, D. S. (2000). Funding South African higher education: 
steering mechanisms to meet national goals. Washington DC, Institute for Higher Education Policy.

Meulemeester, J. e Rochat, D. (1995). "A causality analysis of the link between higher education and economic development." Economics of Education Review (14) 4: $251-361$.

Mingers, J. (1992). Recent developments in critical management science. Journal of the Operational Research Society, vol. 43, no. 1, pp. 1-10.

Monks, J. (2000). "The returns to individual and college characteristics - evidence from the national longitudinal survey of youth". Economic of Education Review, Vol.19, Issue 3, June 2000, pp. 279-289.

Moodley, S. (2002). Competing in the Digital Economy? The Dynamics and Impacts of B2B E-commerce on the South African Manufacturing Sector. WIDER Discussion Paper. Helsinki: UNU/WIDER.

Mukhebi, A. (2004). Kenya Agricultural Commodity Exchange Limited (KACE). Reaching the Poor in Rural Kenya with Market Information: A Case Study of a Market Information System. CTA Seminar 2004 on the Role of Information Tools in Food Security. [Em linha]. Disponível em: http://www.cta.int/ctaseminar2004/MukhebiKACE.pdf . Acedido em Outubro 2013.

Munene, I.I. (2009). Transforming the Academia: Exploring African Universities in a Comparative Context. Nova Science Publishers. ISBN 9781607419723.

Nakabashi, L. e Figueiredo, L. (2008). Mensurando os impactos directos e indirectos do capital humano sobre o crescimento. Economia Aplicada, Vol. 12, N. 1, pp.151171.

Nampota, D.; Thompson, J. e Wikeley, F. (2002). The Development of Human Capacity in Malawi: The Role of Science and Technology. International Review of Education (2009) 55, pp. 59-74. 
Navarro, V. (1998). Neoliberalism, Globalization, Unemployment, Inequalities, and the Welfare State. International Journal of Health Services.

NEPAD (2002). Human Development Program: Bridging the Education Gap. Midrand, South Africa: NEPAD.

NEPAD (2007). Learning from capacity and consensus-building activities to establish the NEPAD ICT Broadband Infrastructure Network. [Em linha]. Disponível em: http://www.eafricacommission.org/docs/Lessons_Learnt_Report_NEPAD_1.pdf . Acedido Janeiro 2014.

NESTA (2007). "UDI/12”, Policy Briefing. [Em linha]. Disponível em: http://www.nesta.org.uk/sites/default/files/five_ways_universities_drive_innovation.p df . Acedido Maio 2016.

Neubert, D. (2008). Cooperação Universitária entre Alemanha e África: desafios e alguns ensinamentos. em Mansson et al (2008). África - Europa: Cooperação Académica. Fundação Friedrich Ebert.

Ntshoe, I. (2004). The Politics and Economics of Postapartheid Higher Education Transformation. Comparative Education Review 48(2): 202-222.

NÚÑEZ, C. E. e TORTELLA, G. (1993.). La maldición divina. Ignorancia y atraso económico en perspectiva histórica. Madrid, Alianza Universidad.

Nyangau, J. Z. (2014). Higher Education as an Instrument of Economic Growth in Kenya. FIRE: Forum for International Research Education, 1(1). [Em linha]. Disponível em http://preserve.lehigh.edu/fire/vol1/iss1/3. Acedido em Maio 2016.

Ó Siochrú, S. e Girard, B. (2005). Community-based Networks and Innovative Technologies: New models to serve and empower the poor. A Report for UNDP. Making ICT Work for the Poor. New York: UNDP.

Obuah, E. (2010). Moving Africa Toward Sustainable Growth \& Technological Development. International Academy of African Business Development, Proceedings of the $11^{\text {th }}$ Annual International Conference. 
OCDE/CAD (1992). Principios do CAD para uma ajuda eficaz. Paris, OCDE.

OECD (2003). Integrating Information and Communication Technologies in Development Programs. Policy Brief, November 2003. [Em linha]. Disponível em: http://www.oecd.org/dataoecd/2/57/20611917.pdf . Acedido em Dezembro 2014.

OECD (2007). No more failures: ten steps to equity in education. ISBN 978-92-6403259-0. [Em linha]. Disponível em: http://www.oecd.org/education/school/39676364.pdf. Acedido em Novembro 2014.

OECD (2007). Promoting pro-poor growth. Policy guidance for donors. DAC guidelines and reference series. Paris: OECD.

OECD (2012). Indicadores Educacionais em foco. Paris: OECD.

OECD (2013). Education at a Glance 2013: OECD Indicators. OECD Publishing. [Em linha]. Disponível em: http://dx.doi.org/10.1787/eag-2013-en Acedido em Julho 2014.

OECD/DAC (2005). Good Practice Paper on ICTs for Economic Growth and Poverty Reduction. Paris: OECD.

OCDE (2016). États de fragilité 2015: Réaliser les ambitions de l'après-2015. Éditions OCDE, Paris. [Em linha]. Disponível em: http://dx.doi.org/10.1787/9789264248878-fr . Acedido Junho 2016.

Ogungbure, A. (2011). The Possibilities of Technological Development in Africa: An Evaluation of the Role of Culture Department of Philosophy,. University of Ibadan, Nigeria. The Journal of Pan African Studies, vol.4, no.3.

OIT (2002). Relatório sobre trabalho decente e a Economia Informal. Conferência Geral da OIT $\left(90^{\mathrm{a}}\right.$ sessão).

OIT (2006). A OIT e a Economia Informal. Escritório da OIT em Lisboa. 
Okpaku, J. O. (Ed.) (2003). Information and Communications Technologies for African Development. An Assessment of Progress and the Challenges Ahead. New York: United Nations ICT Task Force.

OLUKOSHI, A. e ZELEZA. T. (2004). The African university in the twenty-first century: Future challenges and a Research Agenda. Em OLUKOSHI, Adebayo and ZELEZA, Paul. T (Orgs.). African Universities in the twenty-first century: p. 595617. Dakar: Council of the Development of Social Research in Africa (CODESRIA).

Oladipo, O. (2009). Philosophy and Social Reconstruction in Africa. Ibadan: Hope Publications.

Ostrom, E. (1990). Governing the commons: The evolution of institutions for collective action. Cambridge, UK and New York, NY: Cambridge, University Press.

Ouma, G. (2007). Reducing resource dependence on government funding: the case of public universities in Kenya and South Africa. Tese de Doutoramento. Universidade de Cabo Verde.

Özden, C. e Schiff, M. (2006). International migration, remittances and the brain drain. Copublicação de World Bank e Palgrave Macmillan. Washington DC e Nova York.

Paltridge, S. (2008). Global Opportunities for Internet Access Developments. [Online]. Paris: OECD/Directorate for Science, Technology and Industry/Development Cooperation Directorate.

Panos (2007). Mapping declarations and statements on communication for development. London: Panos.

Panos (2007). Technology in emerging economies: Of Internet cafés and power cuts. Emerging economies are better at adopting new technologies than at putting them into widespread use. The Economist.

Pedrosa et al (2005). "Governar a universidade portuguesa: missão, organização, 
funcionamento e autonomia". Fundação Calouste Gulbenkian, Serviço de Educação e Bolsas. ISBN 9723111209, 9789723111200.

Perna, L. (2003). The Private Benefits of Higher Education: An Examination of the Earnings Premium. Research in Higher Education, Vol. 44, N. 4.

Petrella, R. (2005). El derecho a soñar. Propuestas para una sociedad más humana. Barcelona: Intermón Oxfam.

Peyer, C. (2005). WSIS and the struggle to bridge the digital divide: A lack of commitments. $\quad[$ linha]. Disponível em: http://www.twnside.org.sg/title2/resurgence/184/cover2.doc .

Pfeffer, G. e Salancik, G. R. (1978). The external control of organizations: a resource dependence perspective. New York. Harper Row.

Pietrobelli, C. (2006). Science and Innovation Policy: Fostering Technological Capabilities in Sub-Saharan Africa. [Em linha]. Disponível em: www.scidev.net/en/scienec-and-innovation-policy/r-din-africa/policy-briefs/fosteringtechnologiccal-capabilities-in-sub-sahara.html . Acedido em Fevereiro 2016.

Pollitt, C. (1993). Managerialism and the Public Services. 2nd edn. Blackwell, Oxford, UK.

Pratt, G. e Poole, D. (1999). Globalisation and Australian universities, policies and impacts. International Journal of Public Sector Management, 12(6), 533-544.

Pratt, G. e Poole, D. (2000). Global comparations " $R$ " us? The impact of globalization on Australian universities. Australian Universities Review, vol 2/ 19991/2000, p. 16-23.

Psacharopoulos, George (2007). The Costs of School Failure. A Feasibility Study. Analytical Report for the European Comission. European Expert Network on Economics of Education, European Commision. Disponível em: 
http://www.eenee.de/portal/page/portal/EENEEContent/_IMPORT_TELECENTRU M/DOCS/EENEE_AR2.pdf .

Reich, R. (1992). The Work of Nations: Preparing Ourselves for 2lst-Century Capitalism. Vintage Books. New York: Knopf, 1992. 331p. ISBN-10: 0679736158.

René, G. e Maurice, L. (1993). Le Plan Marshall et le relèvement de L'Europe. Paris, CHEFF.

Research ICT Africa Network (2006). Towards an African e-Index. SME e-access and usage across 14 African countries. [Em linha]. Disponível em: http://www.researchictafrica.net/images/upload/SME_book-Web.pdf . Acedido em Julho 2014.

Rodrik, D. (2002). After neoliberalism, what? [Em linha]: Disponível em: http://www.sss.ias.edu/files/pdfs/Rodrik/Commentary/after-neoliberalism-what.pdf Acedido em Setembro 2013.

Rodrik, D. (2003). Growth strategies. Nber working paper series. [Em linha]. Disponível em: http://www.nber.org/papers/w10050.pdf?new_window=1 . Acedido em Julho 2013.

Romo, A.P. e Nubiola, J. (2005). Virtudes democráticas en la educación de hoy: la propuesta pedagógica de John Dewey. Departamento de Filosofía. Universidad de Navarra.

Rosan, R. (2002). The key role of universities in our nation's economic growth and urban revitalization. Urban Land Institute.

Sall, H. N. e Ndiaye, B. D. (2007). Higher Education in Africa:Between Perspectives Opened by the Bologna Process and the Commodification of Education. European Education, vol. 39, n 4 , pp 43-57.

Sanderson, M. (1983). Education, Economic Change and Society in England 17801870. Londres:McMillan. 
Sangreman, C. (2009c). A teoria da Cooperação Internacional para o Desenvolvimento e o estado de arte da Cooperação Portuguesa. Em Sangreman, C., coord., A Cooperação descentralizada e as dinâmicas de mudança em países africanos - os casos de Cabo Verde e da Guiné-Bissau. Lisboa: CEsA e ACEP, pp. 25-97.

Sarrocco, C. (2002). Elements and Principles of the Information Society. [Em linha]. Disponível em: http://www.itu.int/osg/spu/wsisthemes/Access/BackgroundPaper/IS\%20Principles.doc . Acedido em Julho 2013.

Scott, P. (2000). Globalisation and Higher Education: Challenge for the 21st Century. Journal of Studies in International Education.

Sebastán, J. (2004). Cooperación y internacionalización de las universidades. 1. ${ }^{\text {a Ed., }}$ Buenos Aires:Biblos.

Seddoh, K.F. (2003). The Development of Higher Education in Africa. Higher Education in Europe. Vol. XXVIII, No. 1, Carfax Publishing, Taylor \& Francis Group.

Seyon, P. (2003). 'Liberia', em Teferra, D. and Altbach, P.G. (eds.), African Higher Education: An International Reference Handbook. Bloomington: Indiana University Press, pp. 381-390.

Silva, D. (2003). Tópicos avançados de estatística na pesquisa em Administração de Empresas. Notas de aula.

Silveira, L. et al (2005). Instituições de Ensino Superior: os desafios do desenvolvimento da administração contemporânea - perspectias e realidades. V Coloquio Internacional sobre Gestion Universitária en America del Sur. Mar del Plata, 8-10 Deciembre de 2005.

Schofield, R. S. (1973). Dimensions of Illiteracy, 1750-1850. Explorations in Economic History, vol. 10: 437-454. 
Smout, M. (2003). Quality Assurance and Internationalization. Em Internationalization and Quality in South African Universities, ed. by Michael Smout Vol. New York: Carnegie Corporation.

Smyth D.S, Checkland, P.B (1976). Using systems approach: The structure of root definitions. Journal of Applied Systems Analysis, 5(1).

Sobrinho, J.D. (2013). Higher Education: public good, equity, and democratization. Avaliação, Campinas; Sorocaba, SP, v. 18, n. 1, p. 107-126. [Em linha]. Disponível em:http://periodicos.uniso.br/ojs/index.php?journal=avaliacao\&page=article\&op=vie w\&path\%5B\%5D=1573\&path\%5B\%5D=1496. Acedido Maio 2016.

Song, S. (2007). The Future of Access. [Em linha]. Disponível em: http://www.gkpcms.com/beyondtunis/index.cfm/elementid/146/The-Future-ofAccess. Acedido em Julho 2013.

Souter, D. (2004). ICT and Economic Growth in Developing Countries. [Em linha]. Disponível em: http://unpan1.un.org/intradoc/groups/public/documents/APCITY/UNPAN022641.pdf. Acedido em Julho 2014.

Southwood (2007). Russel Kenya's economy held back by lack of online payment authorisation systems. Balancing Act News Update.

Southwood (2008). Russel African countries' ICT policy-going from the blah, blah, blah cycle to getting something done. Balancing Act News Update.

Southwood, (2008). Russel West African license tendering processes - a case to answer. Balancing Act News Update.

Stecklow, S. e Bandler, J. (2007). A Little Laptop With Big Ambitions. Wall Street Journal.

Steyn, G. e de Villiers, P. (2006). The impact of changing funding sources on higher education institutions in South Africa. Pretoria, Council on Higher Education. 
Stiglitz, J. (1998). More instruments and broader goals: moving toward the PostWashington Consensus. Wider Annual Lectures 2.The United Nations University.

Stiglitz, J. (2007). Rich Countries, Poor People? New Perspectives Quarterly, 24: 7 9. doi: 10.1111/j.1540-5842.2007.00856.

Streeck, W. (1998). The Internationalization of Industrial Relations in Europe: Prospects and Problems. Politics and Society.

Sudmant, W. (2002). The economic impact of the University of British Columbia on the Great Vancouver Regional District. Planning and Institutional Research. University of British Columbia.

Sundfeld, C.A. (2001). Fundamentos de direito público. 4. Ed. São Paulo: Malheiros.

Teferra, D. e Altbach, G. (2004). African higher education: Challenges for the 21st century. Kluwer Academic Publishers. Higher Education 47: 21-50.

Teixeira, P. N. ; Johnstone, B. D. ; Rosa, M. J. ; Vossensteyn, H. (2006). Cost-sharing and accessibility in higher education: a fairer deal? Dordrecht, Springer, 51-78.

Teixeiria, P. N.; Johnstone, D. B.; Rosa, M. J. e Vossensteyn, H. (Eds) (2006). Cost sharing and accessibility in higher education: a fairer deal?. Springer, Dordrecht).

Tejada, G. (2008). Uma cooperação académica e científica internacional em prol do avanço do desenvolvimento em África. Em Mansson et al (2008). África - Europa: Cooperação Académica. Fundação Friedrich Ebert.

The African News Source (2008). The Kigali Protocol for the NEPAD ICT Network Comes into Force. [Em linha]. Disponível em: http://appablog.wordpress.com/2008/02/19/the-kigali-protocol-for-the-nepad-ictnetwork-comes-into-force/ . Acedido em Maio 2015.

The Prince's Trust (2007). The Cost of Exclusion. Counting the Cost of Youth Disadvantage in the UK. Londres, The Prince's Trust With the Centre for Economic Performance and London School of Economics. 
Tikly, L. (2001). Globalization and Education in the Postcolonial World: Towards a Conceptual Framework. Comparative Education.

Tilak, JBG (2003). Higher Education and Development. Conference Paper: International Seminar, University XXI. [Em linha]. Disponível em: www.mec.gov.br/univxxi/pdf/Jandhyala.pdf. Acedido em Fevereiro 2015.

Tilak, JBG. (2003). Higher Education and Development, in the Handbook on Educational Research in the Asia Pacific Region. Eds. J.P. Kleeves \& Ryo Watanabe. Dordrecht: Kluwer Academic Publishers, pp. 809-26.

Tolentino et al (2008). África-Europa: Cooperação Académica. Lisboa, Fundação Friedrich Ebert. ISBN: 978-989-8005-04-5.

Tolentino, A. (2006). Universidade e transformação social nos pequenos Estados em desenvolvimento: o caso de Cabo Verde. Tese de Doutoramento. Universidade de Lisboa, Faculdade de Psicologia e de Ciências da Educação.

Turpin, T. (2004). Higher Education and Regional Development: Tensions, Challenges and Options in East and South East Asia. 18th Australian International Education Conference - IDP.

UN (2013). Report of the Secretary-General on the work of the Organization: Millennium Development Goals, targets and indicators: statistical tables. [Em linha]. Disponível em: http://mdgs.un.org/unsd/mdg/Resources/Static/Products/SGReports/68_1/A_68_1_E. pdf . Acedido em Maio 2015.

UNCTAD (2006). Information economy reports 2006. The development perspective. New York and Geneva: United Nations.

UNCTAD (2007). Information Economy Report 2007-2008. Science and technology for development: the new paradigm of ICT. New York and Geneva: United Nations. 
UNCTAD (2007). The Least Developed Countries Report 2007. Knowledge, Technical Learning and Innovation for Development. The least developed countries report. New York and Geneva, United Nations.

UNCTAD (2014). World Investment Report 2014: Investing in the SDGs: An Action Plan. New York and Geneva, United Nations.

UNECA (2003). SCAN-ICT: Indicators of Information and Communications Technologies. The Impact of Information and Communications Technology at the country level. $\quad[$ Em linha]. Disponível em: http://www.uneca.org/aisi/docs/ScanICT.pdf. Acedido em Maio 2015.

UNECA (2005). African Regional Action Plan of the Knowledge Economy. ARAPKE. A Framework for Action. [Em linha]. Disponível em: http://www.uneca.org/aisi/arapke/content/ARAPKE\%20\%20A\%20Framework\%20fo r\%20Action\%20-\%20EN.pdf . Acedido em Maio 2015.

UNECA (2006). Report of the Forum on ICTs, Trade and Economic Growth. Addis Abeba, 14-16 March 2006. [Em linha]. Disponível em: http://www.uneca.org/e-trade/. Acedido em Maio 2015.

UNECA (2013). Making the Most of Africa's Commodities: Industrializing for Growth, Jobs and Economic Transformation by the Economic Commission for Africa. Addis Ababa, Ethiopia. ISBN-13: 978-92-1-125119-7.

UNECA/IST (2010). A technology resurgence? Africa in the global flows of technology, UNECA series of technology transfer for Africa's development. UNECA, Addis Ababa, Ethiopia.

UNESCO (1999). O Ensino Superior no Século XXI - Visão e Ações. Documento de Trabalho. Paris, Outubro de 1998. Em Tendências da Educação Superior para o Século XXI. Brasília: UNESCO / CRUB.

UNESCO (2006). Global Education Digest 2006. Paris, France.

UNESCO (2010). História geral da África, VII: África sob dominação colonial, 1880 
-1935. Editado por Albert Adu Boahen. - 2.ed. rev. - Brasília, 1040 p.

UNESCO (2013/4). Relatório de monitoramento global de EPT. [Em linha]. Disponível em: http://unesdoc.unesco.org/images/0022/002256/225654por.pdf. Acedido em Maio 2016.

UNESCO (2014a). "Wanted: Trained teachers to ensure every child's right to primary education". POLICY PAPER, 15. [Em linha]. Disponível em: http://www.uis.unesco.org/Education/Documents/fs30-teachers-en.pdf Acedido em Maio 2016.

UNESCO (2014b). EFA global Monitoring Report: Teaching and learning achieving quality for all. Paris, France.

UNESCO Institute for Statistics. (Ed.) (2005). Measuring Linguistic Diversity on the Internet. Paris: UNESCO.

United Nations (2013). A renewed global partnership for development. UN System Task Team on the Post-2015 Development Agenda. New Work.

United Nations (2014). The road to dignity by 2030: ending poverty, transforming all lives and protecting the planet. Synthesis report of the Secretary-General on the post 2015 sustainable development agenda.

United Nations Economic Commission for Africa (2008). Medium-Term Strategy for 2008 -2013. United Nations Educational, Scientific and Cultural Organization, Paris, France.

Van Damme, D. (2001). Quality Issues in the Internationalization of Higher Education. Kluwer Academic Publishers. 41: 415-441.

Varela, B. (2015). O Ensino Superior em África: potencialidades, desafios e perspetivas. Edições Uni-CV.

Ventura, J.P. (2013). El Potencial Económico de África: las claves de su crecimiento. United Explanations, Barcelona. [Em linha]. Disponível em: 
http://www.unitedexplanations.org/2013/07/09/el-potencial-economico-de-africa-lasclaves-de-su-crecimiento/ Acedido em Abril 2016.

Wagner De Cerqueria, Francisco (2016). As duas Áfricas. Brasil Escola. S. Paulo. [Em linha]. Disponível em: http://brasilescola.uol.com.br/geografia/as-duasafricas.htm Acedido em Maio 2016.

Wangenge-Ouma, G. (2010). Funding and the attainment of transformation goals in South Africa's higher education. University of the Western Cape, South Africa. Oxford Review of Education, Vol. 36, No. 4, pp. 481-497.

Wangenge-Ouma, G. e Cloete, N. (2008). Financing higher education in South Africa: public funding, non-government revenue and tuition fees. South African Journal of Higher Education, 22(4), 906-919.

Warner, G. (1992). International Models and the Role of the University. International Education Magazine.

Warren-Rodriguez, A. (2007). Science and Technology and the PRSP Process: A Survey of Recent Country Experiences. School of Oriental and African Studies, Background Paper No.8.

Wild, K. (1999). From ISAD to ADF: the expansion of interest in ICTs in Africa from 1996 to 1999. The African Computing \& Telecommunications Summit, Cambridge, 25 - 27 August 1999. [Em linha]. Disponível em: http://www.uneca.org/adf99/kate.htm. Acedido em Março 2014.

Wilson, E. e Wong, K. (2003). African information revolution: a balance sheet. Telecommunications Policy, 27, 155-177.

Wilson, L. (2010). Africa-Europe Higher Education Cooperation for Development: Meeting Regional and Global Challenges. White Paper. European University Association.

WINKLER, D. R. (1993). Rol pertinente del gobierno en el financiamiento de la educación superior. Seminário internacional sobre educación superior. La Paz: 


\section{UDAPSO.}

Woessmann, Ludger (2006). Efficiency and equity of European education and training policies. CESifo, Working Paper, 1779.

Wolff, E.N. e Gittleman, M. (1993). The role of education in productivity convergence: does higher education matter? em Bloom D., Canning D., e Chan K. (2006). "Higher Education and Economic Development in Africa." Harvard University. Human Development Sector, Africa Region.

Wondimu, H. (2003). Ethiopia, em Teferra, D. e Altbach, P.G. (eds.). African Higher Education: An International Reference Handbook. Bloomington: Indiana University Press, pp. 316-325.

World Bank (2006). International Migration, Remittances e Brain Drain. Washington DC: World Bank.

World Bank (2001). Attacking poverty. Published for the World Bank. World development report. Ox-ford: Oxford University Press.

World Bank (2002). Constructing Knowledge Societies: New Challenges for Tertiary Education. World Bank, Washington DC.

World Bank (2004). Improving Tertiary Education in Sub-Saharan Africa: Things That Work. Report of a regional training conference held in Accra, Ghana, September 22-25, 2004. Papers and final report. [Em linha]. Disponível em: www.worldbank.org/afr/teia. Acedido em Maio 2015.

World Bank (2008). Africa Development Indicators 2007. Washington DC: World Bank.

World Bank (2008). Global Economic Prospects. Technology diffusion in the developing world. Global economic prospects. Washington DC: World Bank.

World Bank Group (2006). Information and communications for development. Global trends and policies. Washington DC: World Bank. 
Yang, R. (2004). Internationalizing Chinese Higher Education: a Case Study of a Major Comprehensive University. Em "Internationalizing Higher Education: Critical Explorations of Pedagogy and Policy", ed. by Peter Ninnes and Meeri Hellsten, 97118. Hong Kong: CERC/Springer.

Yusuf, S. e Evenett, S. T. (2002). Can East Asia Compete: Innovation for Global Markets. World Bank, Washington D.C.

Zalanga, S. (2009). Interdisciplinary Studies and Scholarship: Issues, Challenges, and Implications for "Third World" Development and Social Change. Human Architecture: Journal of the Sociology of Self-Knowledge: Vol. 7: Iss. 3, Article 6.

[Em linha]. . Disponível em: http://scholarworks.umb.edu/humanarchitecture/vol7/iss3/6 . Acedido em Maio 2015.

Zeleza, P. (2005). Transnational Education and African Universities. Journal of Higher Education in Africa 3 (1): 1-28.

Zhen-Wei Qiang, C.; Pitt, A. Ayers, S. (2004). Contribution of Information and Communication Technologies to Growth. World Bank working paper. Washington DC, World Bank.

Ziderman, A. e Albrecht, D. (1995). Financing universities in developing countries. Washington DC, The Falmer Press. 
VNIVERSIDAD

ĐSALAMANCA 


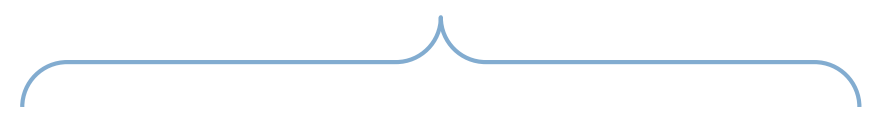

Anexos 
VNIVERSIDAD

ĐSALAMANCA 
Anexo 1 - África: Lista de países por data de independência ou criação

\begin{tabular}{|c|c|c|}
\hline País & Criação / Independência & Independência de qual país \\
\hline Angola & 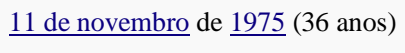 & Portugal \\
\hline Argélia & 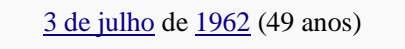 & França \\
\hline Benim & 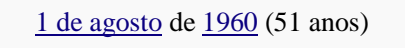 & rança \\
\hline Botswana & 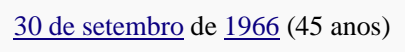 & Reino Unido \\
\hline Burkina Faso & 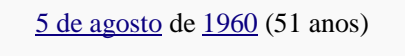 & rrança \\
\hline Burundi & 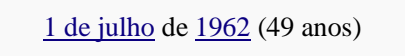 & élgica \\
\hline Cabo Verde & 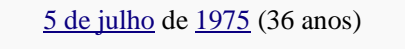 & Portugal \\
\hline - Camarões & 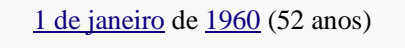 & França \\
\hline hade & 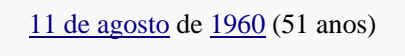 & França \\
\hline Comores & 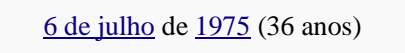 & França \\
\hline Costa do Marfim & 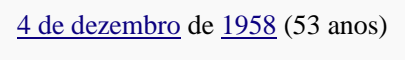 & França \\
\hline Djibouti & 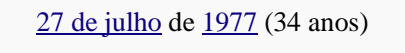 & França \\
\hline
\end{tabular}


VNIVERSiDAD

DSALAMANCA

\begin{tabular}{|c|c|c|}
\hline País & Criação / Independência & Independência de qual país \\
\hline Egito & 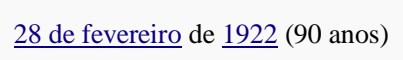 & Reino Unido \\
\hline (1) Eritreia & 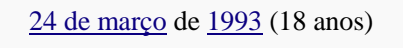 & Etiópia \\
\hline Etiópia & 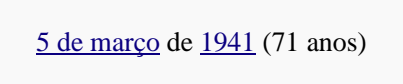 & $\begin{array}{c}\text { Haile Selassie restaurou-o, } \\
\text { terminando com a ocupação italiana. }\end{array}$ \\
\hline Gabão & 17 de agosto de 1960 (51 anos) & França \\
\hline Gana & 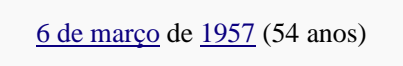 & Reino Unido \\
\hline Guiné & 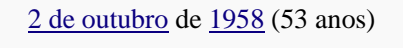 & França \\
\hline Guiné Equatorial & 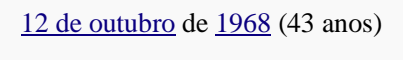 & Espanha \\
\hline - Guiné-Bissau & 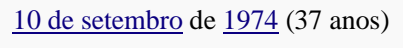 & 9 Portugal \\
\hline Gâmbia & 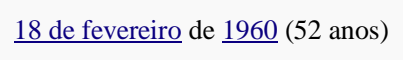 & Reino Unido \\
\hline Lesoto & 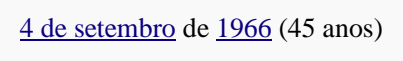 & $\underline{\text { Reino Unido }}$ \\
\hline 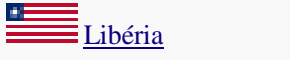 & 26 de julho de 1847 (164 anos) & Estados Unidos \\
\hline Líbia & 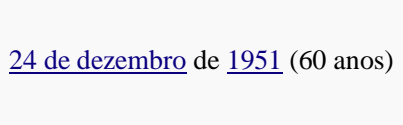 & (Abandonada pela \\
\hline
\end{tabular}


IN 5 T I T U T D

$\mathrm{EPT}$

\begin{tabular}{|c|c|c|}
\hline País & Criação / Independência & Independência de qual país \\
\hline Madagáscar & 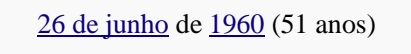 & França \\
\hline Malawi & 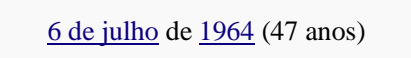 & Reino Unido \\
\hline Mali & 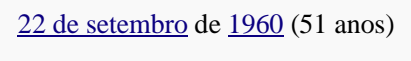 & França \\
\hline$\underline{\text { Marrocos }}$ & 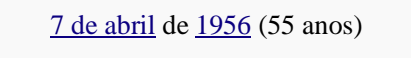 & $\underline{\text { França }}$ \\
\hline Mauritânia & 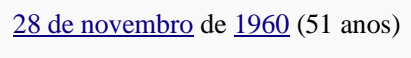 & França \\
\hline Maurícia & 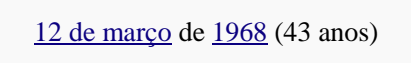 & $\underline{\text { Reino Unido }}$ \\
\hline Moçambique & 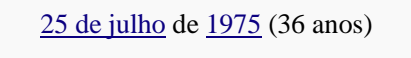 & Portugal \\
\hline Namíbia & 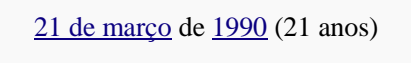 & rica do Sul \\
\hline Nigéria & 1 de janeiro de $\underline{1960}$ (52 anos) & $\underline{\text { Reino Unido }}$ \\
\hline Níger & 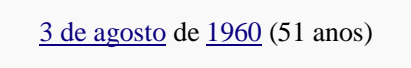 & França \\
\hline Q Quênia & 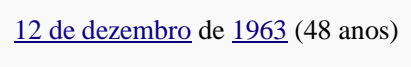 & Reino Unido \\
\hline República Centro-Africana & 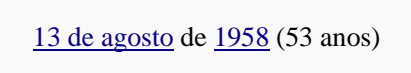 & França \\
\hline * República Democrática do Congo & 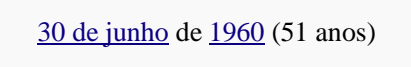 & lgica \\
\hline
\end{tabular}




\begin{tabular}{|c|c|c|}
\hline País & Criação / Independência & Independência de qual país \\
\hline República do Congo & 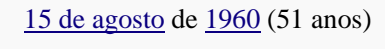 & França \\
\hline Ruanda & 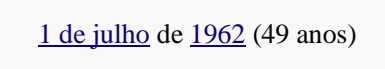 & Bélgica \\
\hline - Senegal & 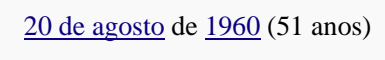 & França \\
\hline Serra Leoa & 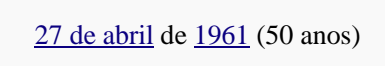 & Reino Unido \\
\hline 2 Seychelles & 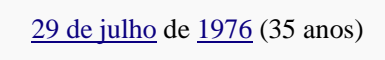 & $\underline{\text { Reino Unido }}$ \\
\hline * Somália & 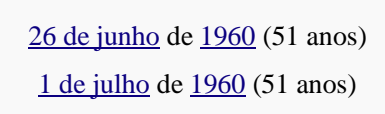 & $\frac{\text { Reino Unido }}{\text { Itália }}$ \\
\hline Suazilândia & 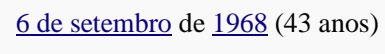 & Reino Unido \\
\hline Sudão & 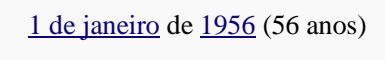 & Reino Unido \\
\hline Sudão do Sul & 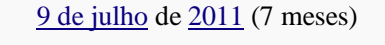 & Sudão \\
\hline .. São Tomé e Príncipe & 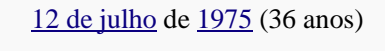 & 9 Portugal \\
\hline Tanzânia & 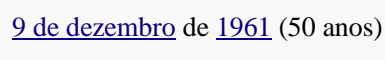 & Reino Unido \\
\hline+ Togo & 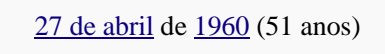 & França \\
\hline
\end{tabular}


I N 5 T I T U T U

:

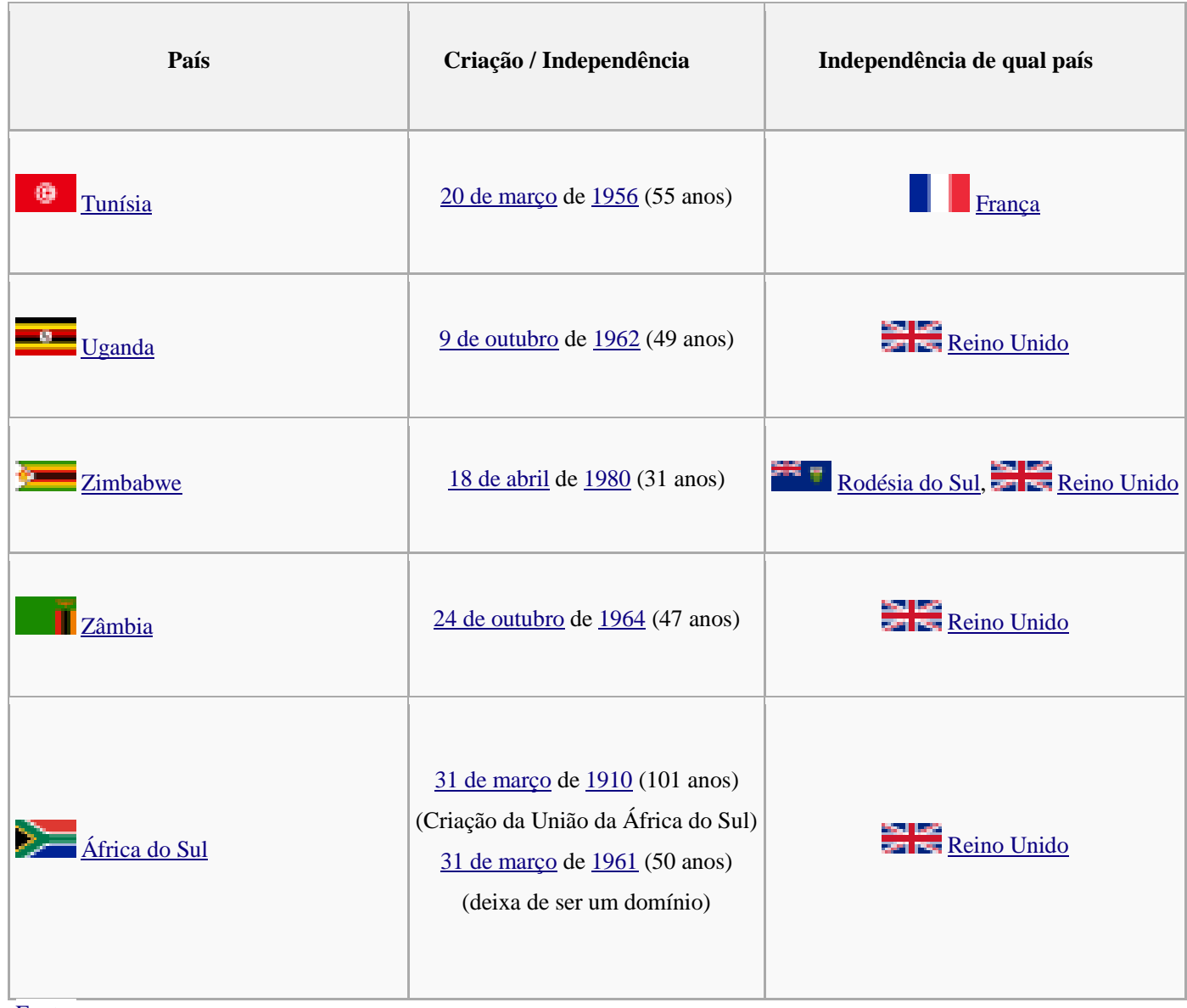

Fonte:

http://pt.wikipedia.org/wiki/Anexo:Lista de pa\%C3\%ADses_por data de independ\%C3\%AAncia ou cria\% $3 \%$ A $3 \%$ C3\% 33 o 
VNIVERSIDAD

DSALAMANCA 
Anexo 2 - Documentos políticos europeus relacionados com os ODM - 2002 2011

Documento
EU Donor Atlas 2011
COM(2011) 541 final. COMMUNICATION FROM THE
COMMISSION TO THE EUROPEAN PARLIAMENT, THE
COUNCIL, THE EUROPEAN ECONOMIC AND SOCIAL
COMMITTEE AND THE COMMITTE OF THE REGIONS.
PROPOSAL FOR THE EU COMMON POSITION FOR THE 4TH
HIGH LEVEL FORUM
ON AID EFFECTIVENESS, BUSAN

SEC(2011) 215 final. COMMISSION STAFF WORKING DOCUMENT. Implementation Plan of the EU Strategy for supporting disaster risk reduction in developing countries 2011-2014

Enhancing EU Accountability on Financing for Development: towards the EU Official Development Assistance Peer Review - Annual Report 2011

The report consists of:

- A communication, "Enhancing EU Accountability on Financing for Development. Towards the EU Official Development Assistance Peer Review" (COM(2011) 218 final)

- A report, "EU Accountability Report 2011 on Financing for Development. Review of progress of the EU and its Member States (SEC(2011)500 final)

COUNCIL OF THE EUROPEAN UNION. EU Common Position for the Fourth High Level Forum on Aid Effectiveness (Busan, 29 November - 1 December 2011)

$\operatorname{COM}(2011) 218$ final. COMMUNICATION FROM THE COMMISSION TO THE EUROPEAN PARLIAMENT, THE COUNCIL, THE ECONOMIC AND SOCIAL COMMITTEE AND THE COMMITTEE OF THE REGIONS. Enhancing EU Accountability on Financing for Development towards the EU Official Development Assistance Peer Review. \{SEC(2011) 500 final\} $\{\operatorname{SEC}(2011) 501$ final $\}\{\operatorname{SEC}(2011) 502$ final $\}$ \{SEC(2011) 503 final $\}$ SSEC(2011) 504 final $\}$ \{SEC(2011) 505 final $\}$

$\operatorname{COM}(2011) 637$ final. COMMUNICATION FROM THE COMMISSION TO THE EUROPEAN PARLIAMENT, THE COUNCIL, THE EUROPEAN ECONOMIC AND SOCIAL COMMITTEE AND THE COMMITTEE OF THE REGIONS. Increasing the impact of EU Development Policy: an Agenda for Change $\{$ SEC(2011) 1172 final $\}$

$\{\operatorname{SEC}(2011) 1173$ final $\}$

EU-US Development Dialogue: Roadmap on the Millennium Development Goals in 2010-2011,

EU-US Transatlantic Development Dialogue: Road Map for Cooperation in Food Security - 2010-2011

SEC(2010)418, Progress made on the Millennium Development Goals and key challenges for the road ahead

COM/2010/0159 final. Communication from the Commission to the European Parliament, the Council, the European Economic and Social Committee, and the Committee of the Regions - A twelve-point EU action plan in support of the Millennium Development Goals $\{\operatorname{SEC}(2010) 418\}\{\operatorname{SEC}(2010) 419\} \quad\{\operatorname{SEC}(2010) 420\} \quad\{\operatorname{SEC}(2010)$ $421\}\{\operatorname{SEC}(2010) 422\}$

SEC(2010) 422 final. Commission staff working document - Aid

Ano Acessivel em:

2011 http://development.donoratlas.eu/home.html

2011 http://eur-

lex.europa.eu/LexUriServ/LexUriServ.do?uri=COM:2 011:0541:FIN:EN:PDF

2011 http://ec.europa.eu/europeaid/what/environment/docum ents/implementation-plan-disaster-risk-reduction-20112014 en.pdf

2011 http://ec.europa.eu/europeaid/how/accountability/euannual-accountability-reports/index_en.htm

http://ec.europa.eu/europeaid/how/accountability/euannual-accountability-reports/documents/euaccountability-review-2011 en.pdf

http://ec.europa.eu/europeaid/how/accountability/euannual-accountability-reports/documents/workingdocument-vol1 en.pdf

2011 http://consilium.europa.eu/uedocs/cms data/docs/press data/EN/foraff/126060.pdf

2011 http://ec.europa.eu/europeaid/how/accountability/euannual-accountability-reports/documents/euaccountability-review-2011_en.pdf

2011 http://ec.europa.eu/europeaid/what/developmentpolicies/documents/agenda for change en.pdf

http://ec.europa.eu/development/icenter/repository/eu us roadmap mdg en.pdf

http://ec.europa.eu/development/icenter/repository/eu us roadmap food security en.pdf

2010 http://eur-

lex.europa.eu/LexUriServ/LexUriServ.do?uri=SEC:20 10:0418:FIN:EN:PDF

2010 http://ec.europa.eu/development/icenter/repository/CO MM_COM_2010_0159_MDG_EN.PDF

http://eur- 


\begin{tabular}{|c|c|c|}
\hline Documento & Ano & Acessivel em: \\
\hline $\begin{array}{l}\text { Effectiveness - Annual Progress Report } 2010 \text { accompanying the } \\
\text { Communication from the Commission to the European Parliament, the } \\
\text { Council, the European Economic and Social Committee and the } \\
\text { Committee of the Regions - A twelve-point EU action plan in support } \\
\text { of the Millennium Development Goals \{COM(2010) 159\} } \\
\{\text { SEC(2010) 418\} \{SEC(2010) } 419\}\{\text { SEC(2010) } 420\}\{\text { SEC(2010) } \\
421\}\end{array}$ & & $\begin{array}{l}\text { lex.europa.eu/LexUriServ/LexUriServ.do?uri=SEC:20 } \\
\text { 10:0422:FIN:EN:PDF }\end{array}$ \\
\hline $\begin{array}{l}\text { SEC/2010/0421 final. Commission staff working document - Policy } \\
\text { Coherence for Development Work Programme 2010- } 2013 \\
\text { accompanying the Communication from the Commission to the } \\
\text { European Parliament, the Council, the European Economic and Social } \\
\text { Committee and the Committee of the Regions - A twelve-point EU } \\
\text { action plan in support of the Millennium Development Goals } \\
\{\text { COM(2010) } 159\}\{\text { SEC(2010) } 418\}\{\text { SEC(2010) } 419\}\{\text { SEC(2010) } \\
420\}\{\text { SEC(2010) } 422\}\end{array}$ & 2010 & $\begin{array}{l}\frac{\text { http://eur- }}{\text { lex.europa.eu/LexUriServ/LexUriServ.do?uri=SEC:20 }} \\
\underline{\text { 10:0421:FIN:EN:PDF }}\end{array}$ \\
\hline $\begin{array}{l}\text { SEC/2010/0420 final. Commission staff working document - } \\
\text { Financing for Development - Annual progress Report } 2010 \text { - Getting } \\
\text { back on track to reach the EU } 2015 \text { target on ODA spending? } \\
\text { accompanying the Communication from the Commission to the } \\
\text { European Parliament, the Council, the European Economic and Social } \\
\text { Committee and the Committee of the Regions - A twelve-point EU } \\
\text { action plan in support of the Millennium Development Goals } \\
\{\text { COM(2010) } 159\} \text { SEC (2010) } 418\} \text { \{SEC(2010) } 419\} \text { SSEC(2010) } \\
421\}\{\text { SEC(2010) } 422\}\end{array}$ & 2010 & $\begin{array}{l}\text { http://eur- } \\
\text { lex.europa.eu/LexUriServ/LexUriServ.do?uri=SEC:20 } \\
\text { 10:0420:FIN:EN:PDF }\end{array}$ \\
\hline $\begin{array}{l}\text { SEC/2010/0419 final. Commission staff working document - Aid for } \\
\text { Trade Monitoring Report } 2010 \text { accompanying the Communication } \\
\text { from the Commission to the European Parliament, the Council, the } \\
\text { European Economic and Social Committee and the Committee of the } \\
\text { Regions - A twelve-point EU action plan in support of the Millennium } \\
\text { Development Goals }\{\text { COM(2010) } 159\}\{\text { SEC(2010) } 418\}\{\text { SEC }(2010) \\
420\}\{\text { SEC(2010) } 421\}\{\text { SEC(2010) } 422\}\end{array}$ & 2010 & $\begin{array}{l}\text { http://eur- } \\
\text { lex.europa.eu/LexUriServ/LexUriServ.do?uri=SEC:20 } \\
\text { 10:0419:FIN:EN:PDF }\end{array}$ \\
\hline $\begin{array}{l}\text { SEC/2010/0418 final. Commission staff working document - Progress } \\
\text { made on the Millennium Development Goals and key challenges for } \\
\text { the road ahead accompanying the Communication from the } \\
\text { Commission to the European Parliament, the Council, the European } \\
\text { Economic and Social Committee and the Committee of the Regions - } \\
\text { A twelve-point EU action plan in support of the Millennium } \\
\text { Development Goals }\{C O M(2010) 159\}\{\text { SEC(2010) } 419\}\{\text { SEC }(2010) \\
420\}\{\text { SEC }(2010) 421\}\{\operatorname{SEC}(2010) 422\}\end{array}$ & 2010 & $\begin{array}{l}\text { http://eur- } \\
\text { lex.europa.eu/LexUriServ/LexUriServ.do?uri=SEC:20 } \\
\text { 10:0418:FIN:EN:PDF }\end{array}$ \\
\hline $\begin{array}{l}\text { COM(2010) } 126 \text { final. COMMUNICATION FROM THE } \\
\text { COMMISSION TO THE COUNCIL AND THE EUROPEAN } \\
\text { PARLIAMENT. Humanitarian Food Assistance }\{\text { SEC }(2010) 374\end{array}$ & 2010 & $\begin{array}{l}\text { http://ec.europa.eu/development/icenter/repository/CO } \\
\text { MM_PDF_COM_2010_0126_EN.PDF }\end{array}$ \\
\hline $\begin{array}{l}\text { COM(2010)127 final. COMMUNICATION FROM THE } \\
\text { COMMISSION TO THE COUNCIL AND THE EUROPEAN } \\
\text { PARLIAMENT An EU policy framework to assist developing } \\
\text { countries in addressing food security challenges SEC(2010)379, } \\
\text { Brussels, } 31.3 .2010 \text {, }\end{array}$ & 2010 & $\begin{array}{l}\text { http://ec.europa.eu/development/icenter/repository/CO } \\
\underline{\text { MM PDF COM } 2010 \text { 0127 EN.PDF }}\end{array}$ \\
\hline $\begin{array}{l}\text { COM(2010)128 final. COMMUNICATION FROM THE } \\
\text { COMMISSION TO THE COUNCIL, THE EUROPEAN } \\
\text { PARLIAMENT, THE EUROPEAN ECONOMIC AND SOCIAL } \\
\text { COMMITTEE AND THE COMMITTEE OF THE REGIONS The EU } \\
\text { Role in Global Health SEC(2010)380 SEC(2010)381 }\end{array}$ & 2010 & $\begin{array}{l}\underline{\text { http://ec.europa.eu/development/icenter/repository/CO }} \\
\underline{\text { MM PDF COM } 2010 \text { 0128 EN.PDF }}\end{array}$ \\
\hline $\begin{array}{l}\text { COM(2010)163 final. COMMUNICATION FROM } \\
\text { COMMISSION THE THE EUROPEAN PARLIAMENT, THE } \\
\text { COUNCIL AND THE EUROPEAN ECONOMIC AND SOCIAL } \\
\text { COMMITTEE. Tax and Development Cooperating with Developing } \\
\text { Countries on Promoting Good Governance in Tax Matters } \\
\text { SEC(2010)426 }\end{array}$ & 2010 & $\begin{array}{l}\text { http://ec.europa.eu/development/icenter/repository/CO } \\
\text { MM_COM_2010_0163_TAX_DEVELOPMENT_EN } \\
\underline{\text { PDF }}\end{array}$ \\
\hline $\begin{array}{l}\text { SEC(2010) } 265 \text { final. COMMISSION STAFF WORKING } \\
\text { DOCUMENT. EU Plan of Action on Gender Equality and Women's } \\
\text { Empowerment in Development } 2010-2015\end{array}$ & 2010 & $\begin{array}{l}\text { http://ec.europa.eu/development/icenter/repository/SE } \\
\underline{\text { C_2010_265_gender_action_plan_EN.pdf }}\end{array}$ \\
\hline $\begin{array}{l}\text { SEC(2010)121 final. COMMISSION STAFF WORKING } \\
\text { DOCUMENT. More and Better Education in Developing Countries }\end{array}$ & 2010 & $\begin{array}{l}\text { http://ec.europa.eu/development/icenter/repository/SE } \\
\text { C2010_0121_EN.pdf }\end{array}$ \\
\hline
\end{tabular}


Documento $\quad$ Ano

C/2010/9263. FOOD SECURITY THEMATIC PROGRAMME. THEMATIC STRATEGY PAPER (UPDATE) and MULTIANNUAL INDICATIVE PROGRAMME 2011-2013. 21 December 2010,

ENVIRONMENT AND NATURAL RESOURCES THEMATIC PROGRAMME, 2011-2013 STRATEGY PAPER\&MULTIANNUAL INDICATIVE PROGRAMME, Final draft (reflecting DCI Committee comments 29/10/2010).

EU CONTRIBUTION TO THE MILLENNIUM DEVELOPMENT GOALS. Some key results from European Commission programmes 2010

SEC/2009/0445 final. Communication from the Commission to the European Parliament, the Council, the European Economic and Social Committee and the Committee of the Regions : supporting developing countries in coping with the crisis - Millennium Development Goals : impact of the Financial Crisis on Developing countries $\{\mathrm{COM}(2009)$ 160 final $\}\{\operatorname{SEC}(2009) 442\} \quad\{\operatorname{SEC}(2009) 443\} \quad\{\operatorname{SEC}(2009) 444\}$. 8.4.2009,

SEC(2008) 433. COMMISSION STAFF WORKING PAPER accompanying the COMMUNICATION FROM THE COMMISSION TO THE EUROPEAN PARLIAMENT, THE COUNCIL, THE EUROPEAN ECONOMIC AND SOCIAL COMMITTEE AND THE COMMITTEE OF THE REGIONS. The EU -- a global partner for development Speeding up progress towards the Millennium Development Goals. The Millennium Development Goals - State of Play $\{\operatorname{COM}(2008) \quad 177\} \quad\{\operatorname{SEC}(2008) \quad 431\} \quad\{\operatorname{SEC}(2008) \quad 432\}$ $\{\operatorname{SEC}(2008) 434\}\{\operatorname{SEC}(2008) 435\}$,

SEC(2008) 432/2. COMMISSION STAFF WORKING PAPER accompanying the COMMUNICATION FROM THE COMMISSION TO THE EUROPEAN PARLIAMENT, THE COUNCIL, THE EUROPEAN ECONOMIC AND SOCIAL COMMITTEE AND THE COMMITTEE OF THE REGIONS. The EU -- a global partner for development. Speeding up progress towards the Millennium Development Goals. The Monterrey process on Financing for Development - the European Union's contribution to Doha and beyond. Annual progress report $2008\{\mathrm{COM}(2008) 177\} \quad$ SEC(2008) 431\} $\{\operatorname{SEC}(2008) 433\}\{\operatorname{SEC}(2008) 434\}\{\operatorname{SEC}(2008) 435\}$,

Social health protection and health-care financing in developing countries: towards a framework for concerted intervention by the European Union Joint Presidency/Commission Non-paper for presentation and discussion during the informal meeting of Development Ministers (28-30 September 2008, Bordeaux),

COM/2008/0177 final. Communication from the Commission to the European Parliament, the Council, the European Economic and Social Committee and the Committee of the Regions - The EU - a global partner for development - Speeding up progress towards the millennium development goals \{SEC(2008) 431\} \{SEC(2008) 432\} $\{$ SEC(2008) 433\} \{SEC(2008) 434\} \{SEC(2008) 435\},

AFRICA-EU PARTNERSHIP ON THE MILLENNIUM DEVELOPMENT GOALS

Investing in People Thematic Strategy Paper and Multi-Annual Indicative Programme 2007-2010,

(2006/C 46/01) The European Consensus on Development 2005

2006/C 46/01. THE EUROPEAN CONSENSUS ON DEVELOPMENT. EUROPEAN PARLIAMENT COUNCIL COMMISSION Joint statement by the Council and the representatives of the governments of the Member States meeting within the Council, the European Parliament and the Commission on European Union Development Policy: 'The European Consensus.

$\operatorname{COM}(2005) 179$ final. COMMUNICATION FROM THE COMMISSION TO THE COUNCIL AND THE EUROPEAN PARLIAMENT A European Programme for Action to Confront HIV/AIDS, Malaria and Tuberculosis through External Action (2007-
2010 http://ec.europa.eu/development/icenter/repository/FST P\%202011-2013_Commission\%20adoption.pdf

2010 http://ec.europa.eu/europeaid/how/finance/dci/docume nts/enrtp strategy paper 2011-2013.pdf

2010 http://ec.europa.eu/europeaid/infopoint/publications/eu ropeaid/documents/188a_mdg_en.pdf

2009 http://eur-

lex.europa.eu/LexUriServ/LexUriServ.do?uri=SEC:20 09:0445:FIN:EN:PDF

2008 http://ec.europa.eu/development/icenter/repository/SE C(2008)433\%20MDG.pdf

2008 http://ec.europa.eu/development/icenter/repository/SE C(2008)\%20432\%20FfD-3.pdf

2008 http://ec.europa.eu/development/icenter/repository/soci al health_protection codev 2008 en.pdf

2008 http://eur-

lex.europa.eu/LexUriServ/LexUriServ.do?uri=COM:2 008:0177:FIN:EN:PDF

2007 http://ec.europa.eu/development/icenter/repository/EA $\underline{\text { S2007 action plan millennium en.pdf }}$

2006 http://ec.europa.eu/development/icenter/repository/how _we_do_strategy_paper_en.pdf

2006 http://ec.europa.eu/development/icenter/repository/euro pean_consensus 2005 en.pdf

2006 http://ec.europa.eu/development/icenter/repository/euro pean consensus 2005 en.pdf

2005 http://eur-

lex.europa.eu/LexUriServ/LexUriServ.do?uri=COM:2 005:0179:FIN:EN:PDF 


\begin{tabular}{|c|c|c|}
\hline Documento & Ano & Acessivel em: \\
\hline \multicolumn{3}{|l|}{ 2011). 27.04.2005, } \\
\hline $\begin{array}{l}\text { COM/2005/0133 final. Communication from the Commission to the } \\
\text { Council and the European Parliament - Accelerating progress towards } \\
\text { attaining the Millennium Development Goals - Financing for } \\
\text { Development and Aid Effectiveness \{SEC(2005) 453\} \{SEC }(2005) \\
454\} \text {. Brussels, 12.4.2005, }\end{array}$ & 2005 & $\begin{array}{l}\text { http://eur- } \\
\text { lex.europa.eu/LexUriServ/LexUriServ.do?uri=CELEX: } \\
\text { 52005DC0133:EN:HTML }\end{array}$ \\
\hline $\begin{array}{l}\text { COM/2005/0132 final. Communication from the Commission to the } \\
\text { Council, the European Parliament and the Economic and Social } \\
\text { Committee - Speeding up progress towards the Millennium } \\
\text { Development Goals - The European Union's contribution }\{\text { SEC }(2005) \\
452\} \text { SSEC(2005) } 456\} \text {. }\end{array}$ & 2005 & $\begin{array}{l}\text { http://eur- } \\
\text { lex.europa.eu/LexUriServ/LexUriServ.do?uri=COM:2 } \\
\underline{\text { 005:0132:FIN:EN:PDF }}\end{array}$ \\
\hline \begin{tabular}{llllll} 
COM(2002) & 116 & final. & \multicolumn{1}{c}{ COMMUNICATION } & FROM & THE \\
COMMISSION & TO THE COUNCIL AND THE EUROPEAN \\
PARLIAMENT & ON EDUCATION AND TRAINING IN THE \\
CONTEXT OF & POVERTY REDUCTION IN DEVELOPING \\
COUNTRIES & & & &
\end{tabular} & 2002 & $\begin{array}{l}\underline{\text { http://eur- }} \\
\text { lex.europa.eu/LexUriServ/LexUriServ.do?uri=COM:2 } \\
\underline{\text { 002:0116:FIN:EN:PDF }}\end{array}$ \\
\hline $\begin{array}{l}\text { Introduction to the instruments and thematic programmes for } 2007 \text { - } \\
2010\end{array}$ & 2008 & $\begin{array}{l}\text { http://ec.europa.eu/europeaid/infopoint/publications/eu } \\
\text { ropeaid/documents/euaidthematiclines en.pdf }\end{array}$ \\
\hline $\begin{array}{l}\text { EU CONTRIBUTION TO THE MILLENNIUM DEVELOPMENT } \\
\text { GOALS. Some key results from European Commission programmes, } \\
2010\end{array}$ & 2010 & $\begin{array}{l}\text { http://ec.europa.eu/europeaid/infopoint/publications/eu } \\
\underline{\text { ropeaid/documents/188a_mdg_en.pdf }}\end{array}$ \\
\hline \multicolumn{3}{|l|}{ Useful web resources } \\
\hline Evaluation reports & Var. & $\begin{array}{l}\underline{\mathrm{http}: / / \mathrm{ec} . \text { europa.eu/europeaid/how/evaluation/evaluatio }} \\
\underline{\mathrm{n} \text { reports/index en.htm }}\end{array}$ \\
\hline Development and Cooperation-Europeaid & & http://ec.europa.eu/europeaid/what/index_en.htm \\
\hline CSPs & & http://eeas.europa.eu/countries/index en.htm \\
\hline The EU and the Millennium Development Goals & & $\begin{array}{l}\text { http://ec.europa.eu/europeaid/what/millenium- } \\
\text { development-goals/index_en.htm }\end{array}$ \\
\hline
\end{tabular}


Anexo 3 - Despesa Publica em Educação, por região e nível de rendimentos, 1999 e 2011

\begin{tabular}{|c|c|c|c|c|c|c|}
\hline \multicolumn{7}{|c|}{ Despesa Publica em Educação, por região e nível de rendimentos, 1999 e 2011} \\
\hline & \multicolumn{6}{|c|}{ Despesa Publica em Educação } \\
\hline & \multicolumn{2}{|c|}{$\% \mathrm{PIB}$} & \multicolumn{2}{|c|}{$\begin{array}{c}\text { \% de despesa } \\
\text { publica em educação }\end{array}$} & \multicolumn{2}{|c|}{$\begin{array}{c}\text { Per Capita (ensino } \\
\text { primário) (PPP }\end{array}$} \\
\hline & 1999 & 2011 & 1999 & 2011 & 1999 & 2011 \\
\hline Mundo & 4.6 & 5.1 & 15 & 15.5 & 2149 & 3.089 \\
\hline Baixo rendimento & 3.1 & 4.1 & 16.4 & 18.3 & 102 & 115 \\
\hline Rendimentos médios & 4.6 & 5.1 & 15.9 & 16.9 & 356 & 545 \\
\hline Rendimentos médios altos & 4.8 & 5.1 & 15.8 & 15.5 & 1117 & 1745 \\
\hline Rendimentos altos & 5.3 & 5.6 & 13.3 & 13.2 & 4752 & 6721 \\
\hline Africa Subsariana & 4 & 5 & 17.1 & 18.7 & 345 & 468 \\
\hline Estados Arabes & 5.3 & 4.8 & 21 & 18.1 & 822 & 1338 \\
\hline Asia Central & 3.4 & 4.1 & 15.4 & 12.3 & & \\
\hline Asia do Leste e Pacifico & 3.9 & 4.4 & 15 & 16.6 & 2216 & 3245 \\
\hline Asia so Leste e sul & 3.9 & 3.7 & 14.6 & 15 & 297 & 573 \\
\hline America Latina e Caraibas & 5 & 5.5 & 14.4 & 16.2 & 1142 & 1753 \\
\hline Europa Central e do Leste & 4.8 & 5.2 & 12.4 & 12.2 & 1813 & 3846 \\
\hline America do Norte e Europa Oeste & 5.6 & 6.2 & 13.3 & 13.1 & 5990 & 8039 \\
\hline
\end{tabular}

Fonte: UNESCO, 2013 


\section{Anexo 4 - Rendimento, várias Regiões do Mundo, 1999 e 2011}

\begin{tabular}{|c|c|c|}
\hline & 1999 & 2011 \\
\hline Mundo & 2149 & 3.089 \\
\hline Baixo rendimento & 102 & 115 \\
\hline Rendimentos médios & 356 & 545 \\
\hline Rendimentos médios altos & 1117 & 1745 \\
\hline Rendimentos altos & 4752 & 6721 \\
\hline Africa Subsariana & 345 & 468 \\
\hline Estados Arabes & 822 & 1338 \\
\hline \multicolumn{3}{|l|}{ Asia Central } \\
\hline Asia do Leste e Pacifico & 2216 & 3245 \\
\hline Asia so Leste e sul & 297 & 573 \\
\hline America Latina e Caraibas & 1142 & 1753 \\
\hline Europa Central e do Leste & 1813 & 3846 \\
\hline America do Norte e Europa Oeste & 5990 & 8039 \\
\hline
\end{tabular}

Fonte: Dados obtidos e adaptados em EFA Global Monitoring Report team calculations (2013), based on UIS database 
Anexo 5 - Total da ajuda financeira para a educação e para o ensino básico, por região e de acordo com o rendimento, $2002-2011$

\begin{tabular}{|l|r|r|r|r|r|r|r|r|}
\hline \multirow{2}{*}{ Total da ajuda financeira para a educação e para o ensino básico, por região e de acordo com o rendimento, 2002-2011 } \\
\cline { 2 - 8 } & \multicolumn{2}{|c|}{ Total da ajuda para a educação } & \multicolumn{2}{|c|}{ Total da ajuda para a educação básica } \\
\cline { 2 - 8 } & \multicolumn{2}{|c|}{ Constante 2011 US\$ Milhões } & Constante 2011 US\$ Milhões & Per Capita \\
\cline { 2 - 8 } & 2002 & 2010 & 2011 & 2002 & 2010 & 2011 & 2011 \\
\hline Mundo & 7799 & 14419 & 13413 & 3133 & 6174 & 5819 & 9 \\
\hline Baixo rendimento & 2145 & 3796 & 3461 & 1240 & 2047 & 1858 & 16 \\
\hline Rendimentos médios & 3012 & 5407 & 5371 & 1290 & 2451 & 2607 & 9 \\
\hline Rendimentos médios altos & 1652 & 2800 & 2641 & 302 & 595 & 579 & 3 \\
\hline Rendimentos altos & 25 & 36 & 13 & 6 & 9 & 6 & 1 \\
\hline Não alocados de acordo com o rendimento & 964 & 2379 & 1926 & 296 & 1072 & 769 & 0 \\
\hline Estados Arabes & 1053 & 1939 & 1922 & 221 & 825 & 845 & 20 \\
\hline Europa Central e do Leste & 305 & 574 & 517 & 90 & 80 & 64 & 6 \\
\hline Asia Central & 130 & 331 & 346 & 43 & 99 & 101 & 18 \\
\hline Asia do Leste e Pacifico & 1155 & 2309 & 2060 & 253 & 687 & 552 & 4 \\
\hline America Latina e Caraibas & 560 & 1110 & 948 & 226 & 438 & 381 & 6 \\
\hline Asia so Leste e sul & 967 & 2267 & 2417 & 597 & 1309 & 1445 & 8 \\
\hline Africa Subsariana & 2816 & 3959 & 3647 & 1490 & 1891 & 1757 & 13 \\
\hline Territórios ultramarinos & 254 & 523 & 74 & 127 & 243 & 26 & 0 \\
\hline Não alocados de acordo com a região ou o país & 559 & 1406 & 1481 & 86 & 602 & 648 & 0 \\
\hline
\end{tabular}

Fonte: OECD-DAC (2013) 


\section{Anexo 6 - Instituições de Ensino Superior, públicas e privadas, atualmente em funcionamento}

\begin{tabular}{|c|c|c|}
\hline País / Independência & Universidades Públicas & Universidades Privadas \\
\hline $\begin{array}{l}\text { Angola }-11 \text { de novembro de } 1975 \\
\text { (36 anos) - Independência de } \\
\text { Portugal }\end{array}$ & $\begin{array}{l}\text { Agostinho Neto Universidade - } \\
\text { Luanda; Universidade José Eduardo } \\
\text { dos Santos - Huambo; Universidade } \\
\text { Katyavala Bwila - Benguela; } \\
\text { Universidade Mandume ya Ntemufayo } \\
\text { - Lubango; Universidade } 11 \text { de } \\
\text { Novembro - Cabinda; Universidade } \\
\text { Kimpa Vita - Uíge; Universidade Lueij } \\
\text { A'Nkonda - Malanje; Instituto Superior } \\
\text { de Relações Internacionais - instituto } \\
\text { apoiado por MIREX }\end{array}$ & $\begin{array}{l}\text { Universidade Independente de Angola, } \\
\text { Luanda; Universidade Católica de Angola - } \\
\text { Luanda; Universidade Lusíada - suportada pela } \\
\text { universidade Portuguese com campus em } \\
\text { Luanda, Benguela e Cabinda; Universidade } \\
\text { Jean Piaget de Angola - Universidade } \\
\text { Portuguesa em Luanda e Benguela; } \\
\text { Universidade Lusófona, Universidade Privada } \\
\text { Portuguese - Luanda; Universidade Metodista } \\
\text { de Angola - Luanda; Universidade } \\
\text { Metropolitana - Luanda; Universidade Privada } \\
\text { de Angola - Luanda e Lubango; Universidade } \\
\text { Óscar Luas- } \\
\text { Universidade de Belas - Luanda; Universidade } \\
\text { Gregório Semedo - Luanda; Universidade } \\
\text { Técnica de Angola - Luanda; Instituto } \\
\text { Superior Politécnico do Huambo - Huambo; } \\
\text { Instituto Superior Politécnico do Cazenga - } \\
\text { Politécnico - Luanda; Instituto Superior de } \\
\text { Ciências Sociais e Relações Internacionais - } \\
\text { Luanda; Instituto Superior Politécnico do Sol } \\
\text { Nascente - Politécnico - Huambo [1]; Instituto } \\
\text { Superior Politécnico de Tenologias e } \\
\text { Ciências, instituto suportado por SONANGOL } \\
\text { - Luanda }\end{array}$ \\
\hline $\begin{array}{l}\frac{\text { Benim - } 1 \text { de }}{\text { agosto de } 1960 \text { (51 anos) - }} \\
\underline{\text { Independência de França }}\end{array}$ & $\begin{array}{l}\text { Universidade Nacional de Benim com } \\
\text { 10 departamentos: o Campus de } \\
\text { Abomey Calavi ; a Faculdade de } \\
\text { Economia e Gestão (FASEG); A } \\
\text { Faculdade de Direito Ciência Politica } \\
\text { FADESP); A Faculdade de Arte e } \\
\text { Ciências Sociais (FLASH); A } \\
\text { Faculdade de Ciências e Tecnologia } \\
\text { (FAST); A Faculdade de Ciências da } \\
\text { Saúde (FSS); A Universidade de } \\
\text { Parakou (UNIPAR); A Escola } \\
\text { Economia Aplicada e Gestão } \\
\text { (ENEAM); A Escola Nacional de } \\
\text { Administração e Prossecução (ENAM); } \\
\text { A Escola Politécnica de Abomey } \\
\text { Calavi (EPAC); A Escola de Formação } \\
\text { de Professores de Porto-Novo (ENS); } \\
\text { O Instituto de Matemática e Física } \\
\text { (IMSP); A Faculdade de Ciências da } \\
\text { Agricultura (FSA). }\end{array}$ & $\begin{array}{l}\text { Universidade de Benin, Cotonu; Universidade, } \\
\text { Port Novo ; Universidade de Administração ; } \\
\text { Centre Africain des Hautes Etudes DSE ; } \\
\text { Universidade de Ciência e Tecnologia, } \\
\text { Parakou.; Ecole des Techniciens Supérieurs du } \\
\text { Bénin (ECO.TU.S-BENIN) ; École du } \\
\text { Patrimoine Africain Institut Supérieur Mount } \\
\text { Royal (MRUB); École Professionnelle } \\
\text { Spécialisée - La Cite; University Learning } \\
\text { Center for Programming; Faculté des Sciences } \\
\text { Agronomiques; Institut de Mathématiques et } \\
\text { de Sciences Physiques de Porto Novo ; Institut } \\
\text { Régional du Génie Industriel, des } \\
\text { Biotechnologies et Sciences Appliquées } \\
\text { (IRGIB-Afrique); Institut Supérieur Fopase de } \\
\text { Cotonou ; Institut Universitaire Bilingue } \\
\text { Rehoboth, Porto-Novo; Institut Universitaire } \\
\text { du Bénin (IUB); Intercontinental Universidade } \\
\text { (ICU), Porto-Novo, West Africa ISM Adonai } \\
\text { Universidade, Porto-Novo Les Cours Sonou } \\
\text { Universidade (LCS Universidade); Université } \\
\text { Africaine de Technologie et de Management } \\
\text { Université de Parakou; Faculté d'Agronomie } \\
\text { Université des Sciences Appliquée et } \\
\text { Management; Université des Sciences et } \\
\text { Technologies du Bénin; Pinnacle African } \\
\text { Universidade, Porto-Novo ; Ecole Supérieure } \\
\text { de Commerce et d'Administration des } \\
\text { Entreprises du Ben (ESCAE-Benin) St. } \\
\text { Louis; African Universidade - Republic of } \\
\text { Benin. (SLAUB) }\end{array}$ \\
\hline$\frac{\text { Botswana }-30 \text { de setembro de } 1966}{\underline{\text { (45 anos) - Reino Unido }}}$ & & $\begin{array}{l}\text { Universidade de Botswana; Universidade } \\
\text { Internacional de Botswana - Ciência \& } \\
\text { Tecnologia; Colégio de Agricultura de } \\
\text { Botswana; Colégio de Contabilidade de } \\
\text { Botswana; Universidade de Botho; Colégio } \\
\text { Universitário ABM; Universidade de }\end{array}$ \\
\hline
\end{tabular}




\begin{tabular}{|c|c|c|}
\hline & & $\begin{array}{l}\text { Botswana - Escola de Comunicação e Arte; } \\
\text { Colégio Universal de Direito de Gaborone; } \\
\text { Colégio Nova Era; Instituto de Estudos } \\
\text { Profissionais de Gaborone; Instituto de } \\
\text { Excelência Profissional; Universidade De } \\
\text { Tecnologia Criativa de Limkokwing }\end{array}$ \\
\hline$\frac{\text { Burkina Faso - } 5 \text { de }}{\text { agosto de } 1960 \text { (51 anos) - França }}$ & & $\begin{array}{l}\text { Institut Supérieur d'Informatique et de Gestion } \\
\text { Université de Ouagadougou; University of } \\
\text { United Popular Nations (UUPN) }\end{array}$ \\
\hline$\frac{\text { Burundi - } 1 \text { de }}{\text { julho de } 1962 \text { (49 anos) - Bélgica }}$ & & $\begin{array}{l}\text { École Normale Supérieure Burundi; Hope } \\
\text { Africa University; Université de Ngozi; } \\
\text { Université du Burundi; Université Lumière de } \\
\text { Bujumbura; } \quad \text { Université du lac } \\
\text { TANGANYIKA; Université de Mwaro }\end{array}$ \\
\hline $\begin{array}{l}\text { Cabo Verde }-5 \text { de } \\
\text { julho de } 1975 \text { (36 anos) - Portugal }\end{array}$ & $\begin{array}{l}\text { Escola de Hotelaria e Turismo de Cabo } \\
\text { Verde; Escola de Negócios e } \\
\text { Tecnologias de Cabo Verde; Instituto } \\
\text { Superior de Ciências Jurídicas e } \\
\text { Sociais; Universidade de Cabe Verde; } \\
\text { Instituto Superior de Ciências } \\
\text { Económicas e Empresariais;; Mindelo } \\
\text { Escola Internacional de Arte; } \\
\text { Universidade Intercontinental de Cabo } \\
\text { Verde }\end{array}$ & $\begin{array}{l}\text { Universidade de Santiago; Universidade Jean } \\
\text { Piaget ; Universidade de Mindelo ; } \\
\text { Universidade Lusófona De Cabo Verde }\end{array}$ \\
\hline$\frac{\text { Camarões - } 1 \text { de }}{\text { janeiro de } 1960 \text { (52 anos) - França }}$ & $\begin{array}{l}\text { Universidade de Buea; Universidade de } \\
\text { Bamenda; Universidade de Douala; } \\
\text { Universidade de Dschang; } \\
\text { Universidade de Ngaoundéré; } \\
\text { Universidade de Yaoundé I; } \\
\text { Universidade de Yaoundé II at Soa; } \\
\text { Universidade de Maroua }\end{array}$ & $\begin{array}{l}\text { Santa Mônica Universidade (SMU): A } \\
\text { Universidade Internacional Americana, Buea, } \\
\text { Camarões; Instituto Americano de Camarões, } \\
\text { AIC Ngoketunjia; Universidade Adventista } \\
\text { Cosendai; Nanga Eboko International } \\
\text { University, Bamenda; Redenção Instituto } \\
\text { Superior de Ciências Biomédicas e da } \\
\text { Administração (RHIBMS), Muyuka sudoeste } \\
\text { dos Camarões. Universidade Católica da } \\
\text { África Central, Yaoundé; Université } \\
\text { Catholique Saint-Jérôme de Douala; Université } \\
\text { des Montagnes (UDM), Bangangté; Université } \\
\text { de Yaoundé Sud Ndi Samba Católica } \\
\text { Universidade Instituto de Buea (CUIB); } \\
\text { Bamenda Universidade de Ciência e } \\
\text { Tecnologia (busto); Universidade Católica de } \\
\text { Camarões, Bamenda (CATUC); Université } \\
\text { Protestante Edwin Cozzens d'Elat (UPEC); } \\
\text { Ebolowa PK Fokam Instituto de Excelência, } \\
\text { Yaoundé; Université d'Afrique Centrale } \\
\text { Protestante (UPAC), Yaoundé; Camarões } \\
\text { Christian University, Bali; Universidade } \\
\text { College de Tecnologia Buea, Buea; Fomic } \\
\text { Politécnica, Buea; Nacional Bambuí Instituto } \\
\text { Politécnico de Ciência Tecnologia Camarões, } \\
\text { Bamenda; Petroleum Business Academy, } \\
\text { Buea; JSF Politécnica Bomaka-Buea; Instituto } \\
\text { Superior Trustech de Tecnologia e Gestão } \\
\text { Profissional; Alpha Instituto Superior de } \\
\text { Ciências Biomédicas d Tecnológica, Douala }\end{array}$ \\
\hline $\begin{array}{l}\text { Chade }-11 \text { de agosto de } 1960 \\
\text { (51 anos) - França }\end{array}$ & & $\begin{array}{l}\text { Université de N'Djamena; Université Roi } \\
\text { Fayçal au Tchad }\end{array}$ \\
\hline $\begin{array}{l}\text { Comoros }-6 \text { de } \\
\text { julho de } 1975 \text { (36 anos) }\end{array}$ & & Universidade de Cômoros \\
\hline $\begin{array}{l}\text { Côte d'Ivoire (Costa do Marfim) - } 4 \\
\text { de dezembro de } 1958 \text { (53 anos) - } \\
\text { França }\end{array}$ & & $\begin{array}{l}\text { Animação e centro de formação de professores } \\
\text { em Yamoussoukro; Pedagógica Nacional } \\
\text { Intitute de Educação Técnica e Prdeessionnel } \\
\text { (IPNETP); Profissionalizada centro acadêmico } \\
\text { de Abidjan; Material especial Escola Abidjan; } \\
\text { Grupo Pigier; HEC Abidjan; Centro } \\
\text { Internacional de Educação a Distância } \\
\text { (CIFAD); Institut National Polytechnique Felix } \\
\text { Houphouet-Boigny (Yamoussoukro) (INPHB); } \\
\text { Instituto Superior de Comércio e } \\
\text { Administração de Empresas de Yamoussoukro }\end{array}$ \\
\hline
\end{tabular}




\begin{tabular}{|c|c|}
\hline & $\begin{array}{l}\text { (ISCAE); Instituto Superior de Carreira } \\
\text { Commerciales (ISCC) Instituto Superior de } \\
\text { Tecnologia em Côte d'Ivoire (ISTCI); Centro } \\
\text { Universitário canadense da África Ocidental; } \\
\text { Universidade de Abobo-Adjame; Alassane } \\
\text { Ouattara (Bouaké) University; Universidade } \\
\text { Nangui Abrogoua (Abidjan) Universidade de } \\
\text { Cocody (Abidjan) Universidade de Ciência e } \\
\text { Tecnologia da Costa do Marfim (USTCI); } \\
\text { Universidade Peleforo Gon Coulibaly } \\
\text { (Korhogo); Universite Jean Lorougnon Guede } \\
\text { (Daloa); Internacional Universidade de Grand- } \\
\text { Bassam / Universidade Internacional de Grand- } \\
\text { Bassam; Ecole Normale Superieure (ENS); } \\
\text { Escola Nacional de Estatística e Economia } \\
\text { Aplicada (ENSEA); Escola Superior de } \\
\text { Comunicação africano Técnico (ESATIC); } \\
\text { Instituto Nacional de Artes e Açãa Cultural } \\
\text { (INSAAC); Instituto Nacional da Juventude e } \\
\text { Desportos (INJS); Graduate School of } \\
\text { Management (GSM), Abidjan }\end{array}$ \\
\hline $\begin{array}{l}\text { Djibouti - } 27 \text { de } \\
\text { julho de } 1977 \text { (34 anos) - França }\end{array}$ & Université de Djibouti \\
\hline $\begin{array}{l}\text { Eritreia - } 24 \text { de } \\
\text { março de } 1993 \text { (18 anos) - Etiópia }\end{array}$ & $\begin{array}{l}\text { Hamelmalo Faculdade de Agricultura - } \\
\text { Hamelmalo sub-região; Colégio de Artes e } \\
\text { Ciências Sociais - Adi Keyh; Faculdade de } \\
\text { Administração e Economia - Halhale; Colégio } \\
\text { de Ciências do Mar e Tecnologia - Massawa; } \\
\text { Asmara Faculdade Ciências da Saúde - } \\
\text { Asmara; Orota Escola de Medicina - Asmara; } \\
\text { Instituto Eritreia de Tecnologia - Mai Nefhi } \\
\text { (Faculdade de Ciências e Faculdade de } \\
\text { Engenharia) }\end{array}$ \\
\hline $\begin{array}{l}\text { Etiópia }-5 \text { de } \\
\text { março de } 1941 \text { ( } 71 \text { anos }) \text { - Haile } \\
\text { Selassie restaurou-o, terminando } \\
\text { com a ocupação italiana. }\end{array}$ & Anexo \\
\hline$\frac{\text { Gabão - } 17 \text { de agosto de } 1960}{(51 \text { anos) - França }}$ & $\begin{array}{l}\text { Omar Bongo Universidade; Universidade de } \\
\text { Ciências e Tecnologias de Masuku; De } \\
\text { Ciências da Saúde da Faculdade de Medicina; } \\
\text { Centro Internacional de Pesquisa Médica de } \\
\text { Franceville; Escola Nacional Florestal, } \\
\text { Libreville; Escola Nacional de Direito; Escola } \\
\text { Superior de Educação; Secretário de } \\
\text { Aprendizagem Escola Nacional; Engenharia } \\
\text { Escola Politécnica de Masuku; Instituto } \\
\text { Africano de Ciência da Computação; Instituto } \\
\text { Nacional de Negócios; Instituto de Economia e } \\
\text { Finanças; Escola Nacional de Administração }\end{array}$ \\
\hline $\begin{array}{l}\text { Gana - } 6 \text { de } \\
\text { março de } 1957 \text { (54 anos) - Reino } \\
\text { Unido }\end{array}$ & Anexo \\
\hline $\begin{array}{l}\text { Guiné - } 2 \text { de } \\
\text { outubro de } 1958 \text { (53 anos) - França }\end{array}$ & $\begin{array}{l}\text { Université Kdei Annan de Guinee Université } \\
\text { Utad-Guinée }\end{array}$ \\
\hline $\begin{array}{l}\text { Guiné Equatorial - } 12 \mathrm{de} \\
\text { outubro de } 1968(43 \text { anos }) \text { - Espanha }\end{array}$ & $\begin{array}{l}\text { Universidade da Guiné Equatorial; Colégio } \\
\text { Nacional Enrique Nvó Okenve, Malabo e Bata }\end{array}$ \\
\hline $\begin{array}{l}\text { Guiné-Bissau }-10 \text { de } \\
\text { setembro de } 1974(37 \text { anos) - } \\
\text { Portugal }\end{array}$ & $\begin{array}{l}\text { Universidade Amílcar Cabral (a partir de } 2008 \\
\text { suspensa por três anos); Universidade Colinas } \\
\text { de Boé; Universidade Lusófona (extensão da } \\
\text { Universidade Portuguesa) } \\
\text { Universidade Jean Piaget (extensão do Instituto } \\
\text { Português Jean Piaget) }\end{array}$ \\
\hline$\frac{\text { Gâmbia - } 18 \text { de fevereiro de } 1960}{\text { (52 anos) - Reino Unido }}$ & $\begin{array}{l}\text { Universidade da Gambia; American } \\
\text { International University, West Africa }\end{array}$ \\
\hline
\end{tabular}




\begin{tabular}{|c|c|c|}
\hline $\begin{array}{l}\text { Lesoto - } 4 \text { de setembro de } 1966 \\
\text { (45 anos) - Reino Unido }\end{array}$ & & $\begin{array}{l}\text { National University of Lesotho; Limkokwing } \\
\text { University of Creative Technology }\end{array}$ \\
\hline $\begin{array}{l}\text { Libéria - } 26 \text { de } \\
\text { julho de } 1847 \text { (164 anos) - Estados } \\
\underline{\text { Unidos }}\end{array}$ & $\begin{array}{l}\text { Universidade da Libéria, Monróvia, } \\
\text { Montserrado County, o mais antigo } \\
\text { instituto não europeu Áfricano de } \\
\text { ensino superior (17.620 alunos a partir } \\
\text { de 2009); William VS Tubman } \\
\text { University, Cabo Palmas, Maryland } \\
\text { County, anteriormente William VS } \\
\text { Tubman College of Technology ( } 288 \\
\text { alunos a partir de 2009) }\end{array}$ & $\begin{array}{l}\text { Africano Bible College University, Yekepa, } \\
\text { Nimba County (65 alunos a partir de 2009); } \\
\text { Africano Metodista Episcopal University, } \\
\text { Montserrado County ( } 3432 \text { estudantes a partir } \\
\text { de 2009) } \\
\text { Africano Metodista Episcopal Sião University, } \\
\text { Montserrado County (2325 estudantes a partir } \\
\text { de 2009); Universidade Cuttington, Suacoco, } \\
\text { Bong County mais antiga universidade privada } \\
\text { e co-educação na África (2287 alunos como de } \\
\text { 2009); Stella Maris Politécnica, Monrovia, } \\
\text { Montserrado County (2090 estudantes a partir } \\
\text { de 2009); United Methodist University, } \\
\text { Monrovia, Montserrado County (3118 } \\
\text { estudantes a partir de 2009); Universidade } \\
\text { Adventista da África Ocidental, Monrovia, } \\
\text { Montserrado County }\end{array}$ \\
\hline $\begin{array}{l}\frac{\text { Líbia - } 24 \text { de dezembro de } 1951}{\text { (60 anos) - Reino Unido, França }} \\
\underline{\text { (Abandonada pela Itália) }}\end{array}$ & & $\begin{array}{l}\text { Academia de Pós-Graduação - Universidade de } \\
\text { Tripoli; A Escola Superior de Tecnologia da } \\
\text { Computação; Líbia Universidade Médica } \\
\text { Internacional; Misrata Universidade } \\
\text { Omar Al-Mukhtar University; Universidade } \\
\text { Aberta da Líbia; Universidade Sabha; Al } \\
\text { Zawiya University; Universidade Benghazi }\end{array}$ \\
\hline$\frac{\text { Madagáscar - } 26 \text { de }}{\text { junho de } 1960 \text { (51 anos) - França }}$ & & 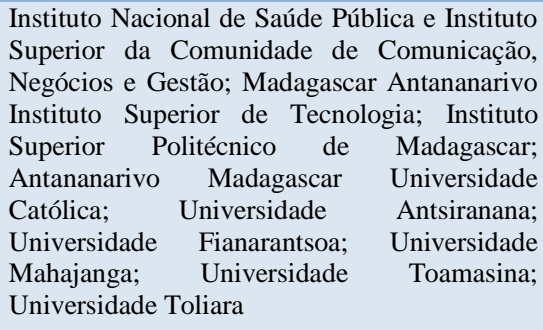 \\
\hline $\begin{array}{l}\text { Malawi - } 6 \text { de } \\
\text { julho de } 1964 \text { (47 anos) - Reino } \\
\underline{\text { Unido }}\end{array}$ & $\begin{array}{l}\text { Faculdade de Medicina, Universidade } \\
\text { de Malawi; Chancellor College, } \\
\text { Universidade de Malawi; Kamuzu } \\
\text { College of Nursing; Malawi } \\
\text { Polytechnic; Mzuzu Universidade - } \\
\text { Malawi College of Health Sciences; } \\
\text { Malawi University of Science and } \\
\text { Technology; Lilongwe University of } \\
\text { Agriculture and Natural Resources }\end{array}$ & $\begin{array}{l}\text { Skyway Universidade; Colégio Nacional de } \\
\text { Tecnologia da Informação (NACIT); } \\
\text { Universidade de Livingstonia; Bíblia africano } \\
\text { Colégio Universidade; Explora Universidade; } \\
\text { Católica Universidade de Malawi; Blantyre } \\
\text { Internacional Universidade; Assembléias de } \\
\text { Deus Malawi Universidade; São João de Deus } \\
\text { Collège de Ciências da Saúde; Malawi } \\
\text { Adventista Universidade; ShareWORLD Abrir } \\
\text { Universidade }\end{array}$ \\
\hline $\begin{array}{l}\text { Mali }-22 \text { de setembro de } 1960 \\
\underline{\text { (51 anos) - França }}\end{array}$ & & $\begin{array}{l}\text { Universidade de Bamako; Universidade de } \\
\text { Mali; Universidade de Sankoré; Universidade } \\
\text { de Timbuktu }\end{array}$ \\
\hline $\begin{array}{l}\frac{\text { Mauritânia }-28 \text { de }}{\text { novembro de } 1960 \text { (51 anos) - }} \\
\text { França }\end{array}$ & & $\begin{array}{l}\text { Escola Nacional de Administração - (Ecole } \\
\text { Nationale d'Administration, ENA) desde 1966, } \\
\text { que se tornou uma Escola de Ciências Técnicas } \\
\text { - (Técnicas Faculté des Sciences, FST), em } \\
\text { 1995; Instituto Mauritano de Investigação } \\
\text { Científica - (Institut de Recherche Scientifique } \\
\text { Mauritanien, TMI) em 1974; Instituto } \\
\text { Avançado de Estudos Islâmicos e Pesquisa - } \\
\text { (Institut Supérieur d'Etudes et de Recherche } \\
\text { Islâmicas, Iseri), em 1979; Instituto de } \\
\text { Ciências árabes e islâmicos em 1979; Centro } \\
\text { Avançado de Educação Técnica - (Centre } \\
\text { Technique d'Enseignement Supérieur, CSET) } \\
\text { em 1980; Nouakchott Universidade (NU) - } \\
\text { (Université de Nouakchott), em 1981; Escola } \\
\text { de Direito e Economia Escola de Letras e } \\
\text { Ciências Humanas Instituto Científico } \\
\text { Avançado - (Institut Supérieur Scientifique, }\end{array}$ \\
\hline
\end{tabular}




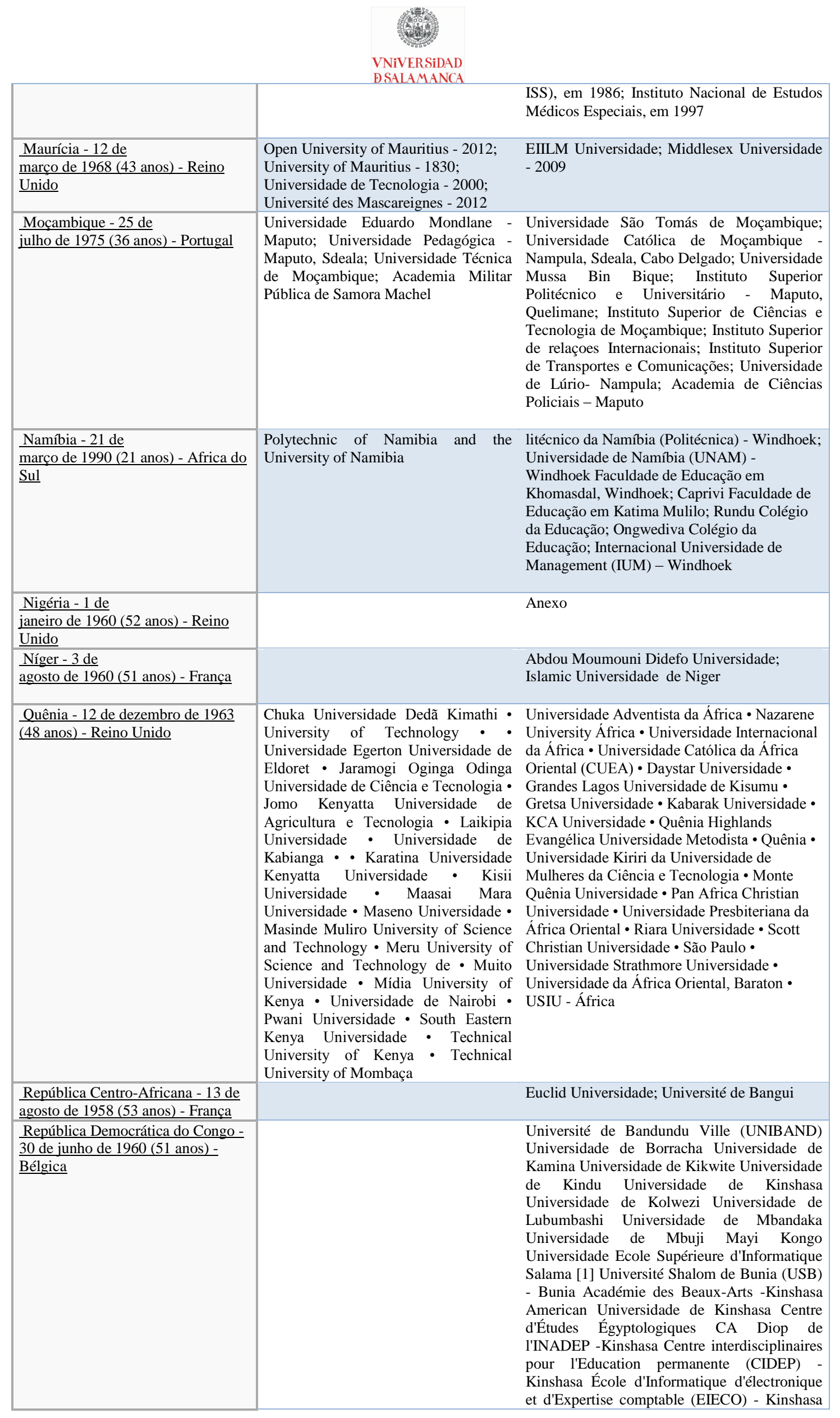




\begin{tabular}{|c|c|c|}
\hline & & 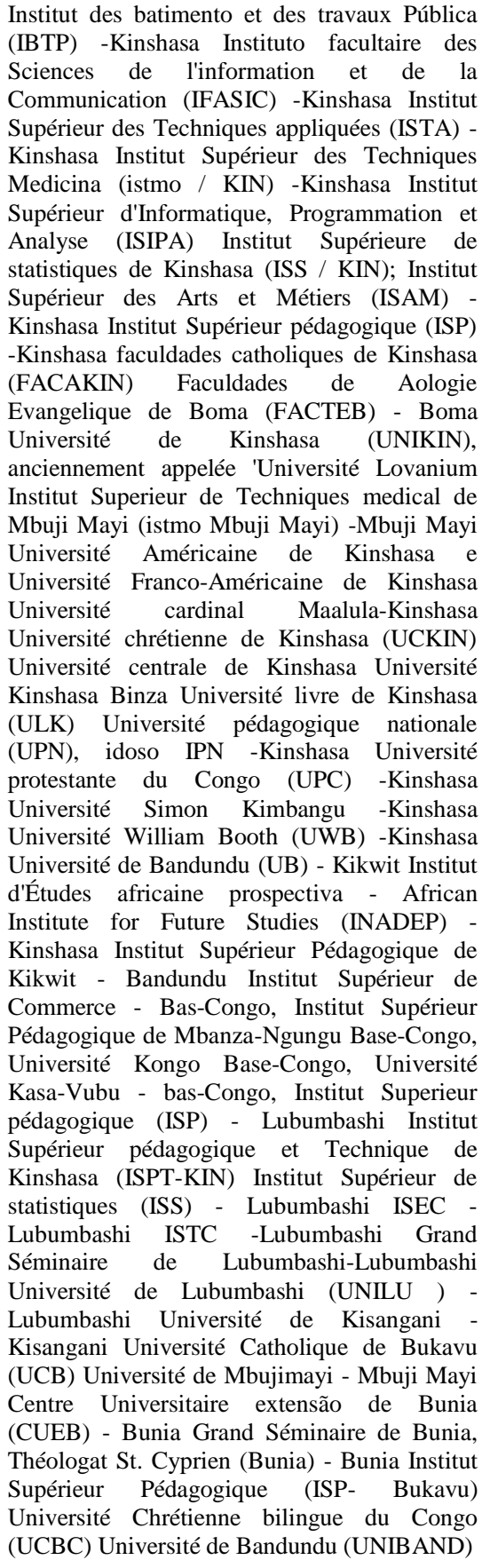 \\
\hline$\frac{\text { República do Congo - } 15 \text { de }}{\text { agosto de } 1960 \text { (51 anos) - França }}$ & & $\begin{array}{l}\text { Higher Institute de Technology de Central } \\
\text { Africa Marien Ngouabi Universidade } \\
\text { Christian Polytechnic and Prdeessional } \\
\text { Institute de Arts Institute de Business and } \\
\text { Economical Development Mondongo Higher } \\
\text { Institute de Agricultural Sciences }\end{array}$ \\
\hline $\begin{array}{l}\text { Ruanda - } 1 \text { de } \\
\text { julho de } 1962 \text { (49 anos) - Bélgica }\end{array}$ & $\begin{array}{l}\text { Universidade de Ruanda (UR); } \\
\text { Faculdade de Letras e Ciências Sociais } \\
\text { (CASS); Escola Superior de } \\
\text { Agricultura e Medicina Veterinária } \\
\text { (CAVM); Faculdade de Negócios e } \\
\text { Economia (CBE); Faculdade de } \\
\text { Educação (CE); Faculdade de } \\
\text { Medicina e Ciências da Saúde } \\
\text { (CMHS); Faculdade de Ciências e } \\
\text { Tecnologia (CST); Ruanda Teachers } \\
\text { College (RTC); Tumba College of }\end{array}$ & $\begin{array}{l}\text { Instituto Católico de Kabgayi (ICK) / } \\
\text { Universidade Independente Kigali (ULK) } \\
\text { Instituto de Agricultura, Tecnologia e } \\
\text { Educação de Kibungo (INATEK) Instituto } \\
\text { Akilah para as Mulheres } \\
\text { (www.akilahinstitute.org) Instituto Adventista } \\
\text { Kigali laïque (INILAK) / África Oriental } \\
\text { (AUCA) Instituto de Educação Superior de } \\
\text { Ruhengeri (INES) / Católica Universidade de } \\
\text { Ruanda (CUR) / Kigali Institute of } \\
\text { Management (KIM) Byumba Politécnico (IPB) }\end{array}$ \\
\hline
\end{tabular}




\begin{tabular}{|c|c|c|}
\hline & $\begin{array}{l}\text { Technology (TCT): politécnico } \\
\text { Integrado Regional Centro Kicukiro } \\
\text { Campus (IPRC); Instituto de Práticas e } \\
\text { Desenvolvimento Legal (ILPD) }\end{array}$ & $\begin{array}{l}\text { Instituto protestante de Artes e Ciências } \\
\text { Sociais (PIASS Adventista Universidade } \\
\text { Central e ) Universidade Ruanda Turismo } \\
\text { College (RTUC) Mount Kenya Universidade } \\
\text { Kigali Campus (MKU Kigali) Católica } \\
\text { Instituto Kabgayi (ICK) Kigali Independent } \\
\text { University (ULK) Instituto de Agricultura, } \\
\text { Tecnologia e Educação de Kibungo (INATEK) } \\
\text { Instituto Adventista laïque Kigali (INILAK) } \\
\text { Adventist University of Central e Leste da } \\
\text { África (AUCA) de Ruhengeri Instituto de } \\
\text { Ensino Superior (INES) Católica Universidade } \\
\text { de Ruanda (CUR) Kigali Institute of } \\
\text { Management (KIM) Byumba Politécnico (IPB) } \\
\text { Instituto protestante de Artes e Ciências } \\
\text { Sociais (PIASS) Universidade Ruanda } \\
\text { Turismo College (RTUC) Mount Kenya } \\
\text { Universidade Kigali Campus (MKU Kigali) } \\
\text { Kibogora Politécnica (KP) [4] }\end{array}$ \\
\hline$\frac{\text { Senegal }-20 \text { de agosto de } 1960}{\underline{(51 \text { anos })+\text { França }}}$ & $\begin{array}{l}\text { Universidade Cheikh Anta Diop, } \\
\text { Dakar, 24 de fevereiro, 1957; } \\
\text { Universidade Gaston Berger, Saint- } \\
\text { Louis, } 17 \text { de dezembro de 1990; } \\
\text { Universidade Ziguinchor, Ziguinchor, } \\
\text { F51 Fevereiro de 2007; Universidade } \\
\text { Thies em Thies, 2007; Alioune Diop } \\
\text { University, Bambey 2004 (inaugurado } \\
\text { em 2007) }\end{array}$ & $\begin{array}{l}\text { Université Euro-Afrique, Dakar Campus } \\
\text { Suffolk Universidade Dakar, Dakar Bourguiba } \\
\text { Universidade Dakar, Dakar Université du } \\
\text { Sahel, Dakar Amadou Ba Universidade } \\
\text { Hampaté, Dakar L'Université de l'Enterprise } \\
\text { Dakar }\end{array}$ \\
\hline $\begin{array}{l}\text { Serra Leoa - } 27 \text { de } \\
\text { abril de } 1961 \text { (50 anos) - Reino } \\
\underline{\text { Unido }}\end{array}$ & & $\begin{array}{l}\text { Universidade de Serra Leone } \\
\text { Eastern Polytechnic, Fourah Bay College; } \\
\text { Njala Universidade; (College de Medicine and } \\
\text { Allied Health Sciences); niversidade de } \\
\text { Makeni }\end{array}$ \\
\hline $\begin{array}{l}\text { Seychelles }-29 \text { de } \\
\text { julho de } 1976 \text { (35 anos) - Reino } \\
\underline{\text { Unido }}\end{array}$ & & $\begin{array}{l}\text { Seychelles Polytechnic; Universidade de } \\
\text { Seychelles }\end{array}$ \\
\hline $\begin{array}{l}\text { Somália - } 26 \text { de } \\
\text { junho de } 1960 \text { (51 anos) } 1 \text { de } \\
\text { julho de } 1960 \text { (51 anos) - Reino } \\
\underline{\text { Unido / Itália }}\end{array}$ & & 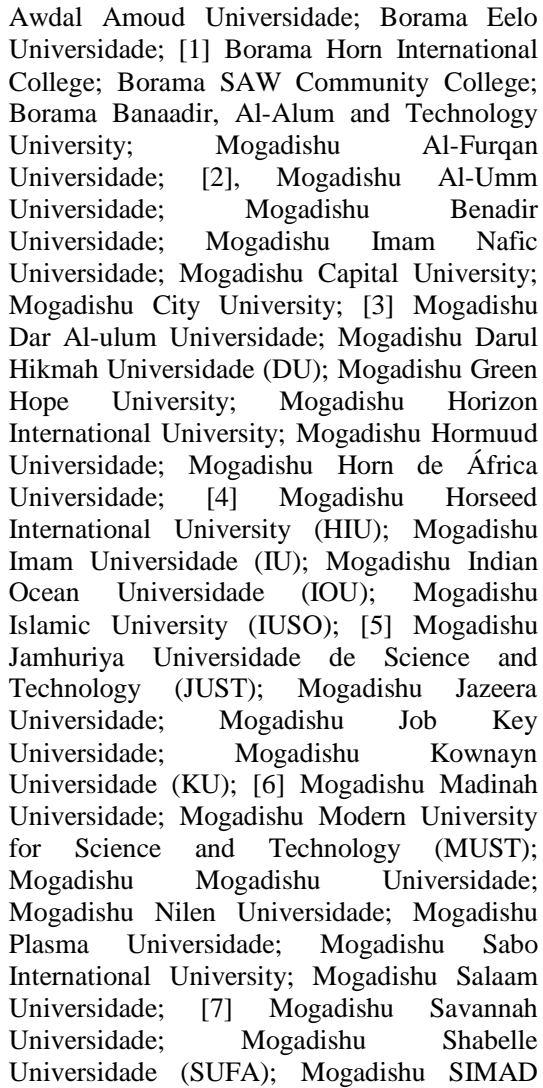 \\
\hline
\end{tabular}




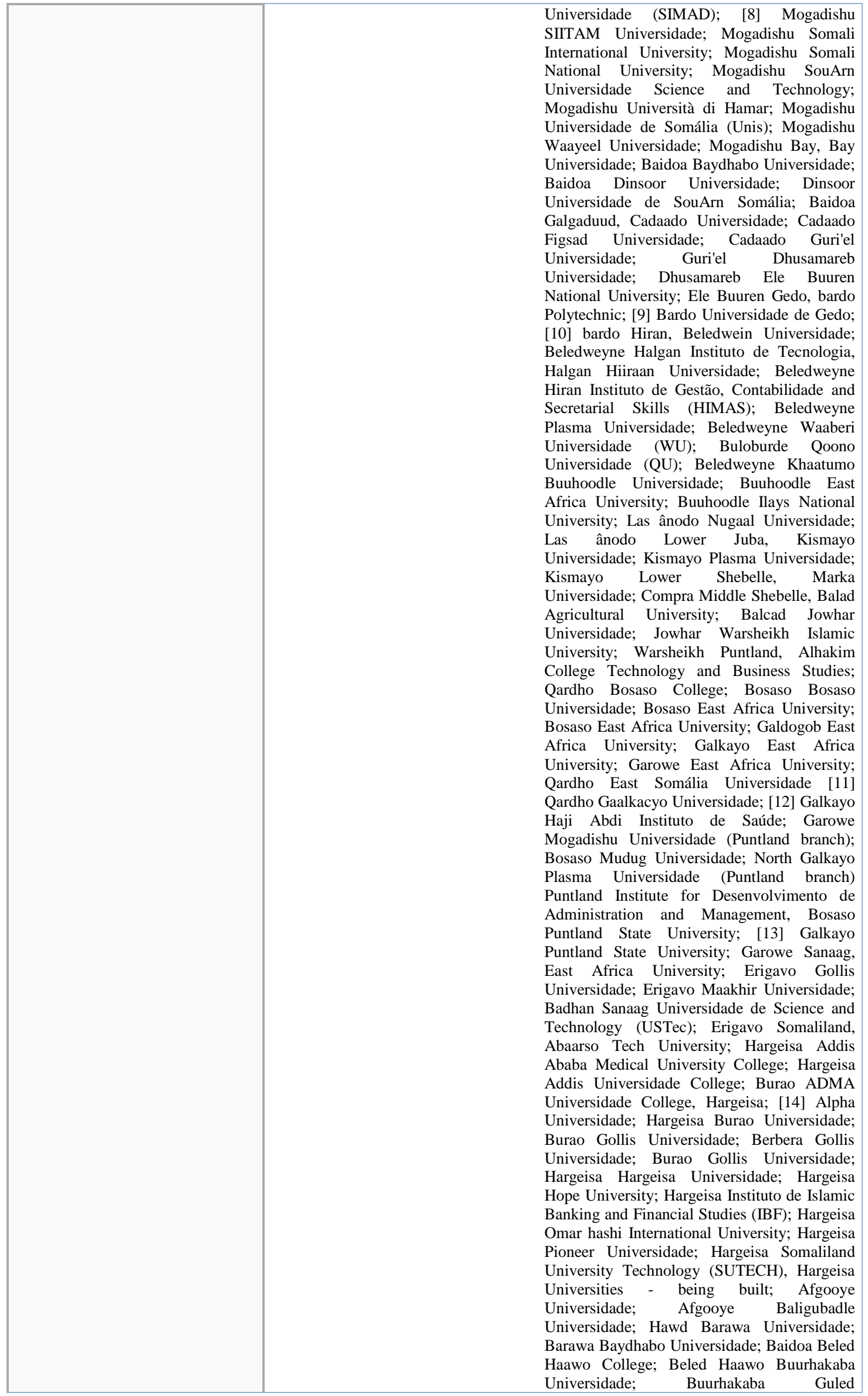




\begin{tabular}{|c|c|c|}
\hline & & $\begin{array}{l}\text { Universidade; Las ânodo Hamar Jadid } \\
\text { Universidade; Mogadishu Hudur Universidade, } \\
\text { Huddur Lowisheri Instituto de Tecnologia; } \\
\text { Diinsoor Omar hashi International University; } \\
\text { Hargeisa Qoryoley Universidade; Qoryoley } \\
\text { Sarmaan Universidade; Huddur Waajid } \\
\text { Universidade, Waajid }\end{array}$ \\
\hline $\begin{array}{l}\text { Suazilândia }-6 \text { de setembro de } 1968 \\
\text { (43 anos) - Reino Unido }\end{array}$ & & $\begin{array}{l}\text { Universidade de Swazilandia, Southern } \\
\text { Nazarene Africano; Christian Universidade; } \\
\text { Limkokwing Universidade de Tecnologia } \\
\text { Criativa }\end{array}$ \\
\hline $\begin{array}{l}\text { Sudão - } 1 \text { de } \\
\text { janeiro de } 1956 \text { (56 anos) - Egito / } \\
\text { Reino Unido }\end{array}$ & $\begin{array}{l}\text { Al Fashir University, El Fasher; } \\
\text { Universidade Al-Neelain, Cartum e } \\
\text { outros locais; Al Zaiem Alazhari } \\
\text { University, Cartum; Blue Nile } \\
\text { University, Ad-Damazeen; } \\
\text { Universidade Dalanj, Dalang; El Imam } \\
\text { Mahdi El University, Kosti, } \\
\text { Universidade Internacional de África, } \\
\text { Cartum; Universidade Karary, } \\
\text { Omdurman; Nile Valley University, } \\
\text { Cartum; Universidade Islâmica } \\
\text { Omdurman, Omdurman; Universidade } \\
\text { Aberta do Sudão; Cartum; Instituto de } \\
\text { Saúde Pública, Cartum; Universidade } \\
\text { do Mar Vermelho, Port Sudan; } \\
\text { Universidade Sudão da Ciência e } \\
\text { Tecnologia, Cartum e outros locais; } \\
\text { Universidade de Bakht Al-Ruda, Al- } \\
\text { Dewaym; Universidade de Dongola, } \\
\text { Dongola; Universidade de Al Qadarif, } \\
\text { Al Qadarif; Universidade de Gezira, } \\
\text { Wad Medani; Universidade de Kassala, } \\
\text { Kassala; Universidade de Cartum, } \\
\text { Cartum; Universidade de Kordofan, } \\
\text { Al-Ubayid; Universidade de Nyala, } \\
\text { Nyala; Universidade do Senar, Senar; } \\
\text { Universidade de Shendi, Shendi; } \\
\text { Universidade do Sagrado Alcorão e } \\
\text { ciências islâmicas, Omdurman; } \\
\text { University of West Kordofan, Al- } \\
\text { Foula; Universidade de Zalingei, } \\
\text { Zalingei. }\end{array}$ & $\begin{array}{l}\text { Wad Medani Ahlia College, Wad Medani; } \\
\text { Universidade Ahfad para Mulheres, } \\
\text { Omdurman; Nilo College, Bahri; Universidade } \\
\text { AlMughtaribeen, Cartum; Bayan Faculdade de } \\
\text { Ciência e Tecnologia, Cartum; Canadian } \\
\text { College sudanesa, Cartum; Elrazi Faculdade de } \\
\text { Medicina Ciências Tecnológicas, Cartum; } \\
\text { Universidade futuro do Sudão, Cartum; Garden } \\
\text { City College de Ciência e Tecnologia, Cartum; } \\
\text { Nahda College, Cartum; Colégio Nacional de } \\
\text { Médicos e Técnicos Estudos, Cartum; National } \\
\text { University Ribat, Cartum; Omdurman Ahlia } \\
\text { University, Omdurman; Universidade de } \\
\text { Ciências Médicas e Tecnologia, Cartum; } \\
\text { Universidade de Ciência e Tecnologia - } \\
\text { Omdurman; Alto Nilo University, Malakal; } \\
\text { Cartum Faculdade de Ciências Médicas, } \\
\text { Khartoum }\end{array}$ \\
\hline $\begin{array}{l}\text { Sudão do Sul - } 9 \text { de } \\
\text { julho de } 2011 \text { ( } 7 \text { meses }) \text { - Sudão }\end{array}$ & $\begin{array}{l}\text { Colégio Nacional do Sudão do Sul, } \\
\text { Juba; Juba Universidade Nacional, } \\
\text { Juba, 1977; Rumbek Universidade, } \\
\text { Rumbek; 2010 [1]; Universidade de } \\
\text { Bahr El Ghazal, Wau [2]; Universidade } \\
\text { de NorArn Bahr El Ghazal, Aweil; } \\
\text { 2011 [3]; Alto Nilo Universidade, } \\
\text { Malakal; 1991; John Garang Memorial } \\
\text { Universidade, Bor; 2006 }\end{array}$ & $\begin{array}{l}\text { Akobo Património e Memorial University, } \\
\text { Akobo; Católica Universidade do Sudão do } \\
\text { Sul, Juba \& Wau; 2008; Universidade de St. } \\
\text { Mary, em Juba, Juba; 2009; Yei Agrícola e } \\
\text { Mecânica Universidade, Yei; Sudão do Sul } \\
\text { cristão Universidade Juba, fundado em 201; } \\
\text { Bentiu Heritage \& Memorial Universidade, } \\
\text { previsto para ser baseado em Bentiu; Ebony } \\
\text { Universidade, com base na Grande Bahr-el- } \\
\text { Ghazal, Wau. }\end{array}$ \\
\hline$\frac{\text { São Tomé e Príncipe - } 12 \text { de }}{\text { julho de } 1975 \text { (36 anos) - Portugal }}$ & & $\begin{array}{l}\text { Instituto Superior Politécnico; Instituto } \\
\text { Universitário de Contabilidade, Administração } \\
\text { e Informática; National Lyceum (São Tomé e } \\
\text { Príncipe); Universidade Lusíada de São Tomé } \\
\text { e Príncipe }\end{array}$ \\
\hline $\begin{array}{l}\text { Tanzânia - } 9 \text { de dezembro de } 1961 \\
\text { (50 anos) - Reino Unido }\end{array}$ & & Anexo \\
\hline $\begin{array}{l}\text { Togo - } 27 \text { de } \\
\text { abril de } 1960 \text { (51 anos) - frança }\end{array}$ & & $\begin{array}{l}\text { African Crafts School of Architecture and } \\
\text { Urbanism; Catholic University ofe West } \\
\text { Africa; Universidade de Kara; Universidade } \\
\text { de Lomé; University of Science and } \\
\text { Technology de Togo }\end{array}$ \\
\hline $\begin{array}{l}\text { Uganda - } 9 \text { de } \\
\text { outubro de } 1962 \text { (49 anos) - Reino }\end{array}$ & $\begin{array}{l}\text { Busitema Universidade (BU); } \\
\text { Busitema, Busia District; } 2007 \text { Gulu }\end{array}$ & $\begin{array}{l}\text { Africa Renewal Universidade (Uganda) (ARU) } \\
\text { Wakiso District; } 2013 \text { Colégio Africano Bíblia }\end{array}$ \\
\hline
\end{tabular}




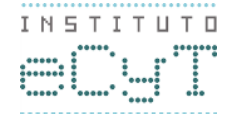

\begin{tabular}{|c|c|c|}
\hline$\underline{\text { Unido }}$ & $\begin{array}{l}\text { Universidade (GU), Gulu; 2002; Lira } \\
\text { Universidade College, A Constituent } \\
\text { College de Gulu Universidade (LUC), } \\
\text { Lira; 2009 Kyambogo Universidade } \\
\text { (Kyu), Kyambogo, Kampala; 2003; } \\
\text { Makerere University (MAK), } \\
\text { Makerere, Kampala; 1922; } \\
\text { Metropolitan University Business } \\
\text { School (MUBS), Nakawa, Kampala; } \\
\text { 1997 } \\
\text { Mbarara University Science \& } \\
\text { Technology (MUST), Mbarara; 1989; } \\
\text { Muni Universidade (UM), Aruã; 2013; } \\
\text { Soroti Universidade (SUN), Soroti; } \\
2015\end{array}$ & $\begin{array}{l}\text { (Uganda) (ABC), Lubowa, Wakiso District; } \\
2005 \text { Africano Universidade Rural (ARUW), } \\
\text { Kagadi de } 2007 \text { [5] Aga Khan Universidade, } \\
\text { Kampala; 2001 All Saints Universidade } \\
\text { (ASU), Lira; 2008 Ankole Ocidental } \\
\text { Universidade (UTA), Kabwohe; 2005 Bishop } \\
\text { Stuart Universidade (BSU), Mbarara; 2003 } \\
\text { Bugema Universidade (BUU), Luweero } \\
\text { Distrito; 1997 Busoga Universidade (BGU), } \\
\text { Iganga; 1999 Cavendish Universidade Uganda } \\
\text { (CUU), Kampala; 2008 International School de } \\
\text { Negócios e Tecnologia (ISBAT), Kampala, } \\
\text { Uganda [6] Internacional em Ciências da } \\
\text { Saúde da Universidade (IHSU), Kampala.; } \\
\text { Internacional 2008 Universidade de East } \\
\text { Africa (IUEA), Kansanga, Kampala (2011) [7] } \\
\text { Universidade Islâmica de Uganda (IUIU), } \\
\text { Mbale; 1988 Kabale Universidade (Kabu), } \\
\text { Kabale; 2001 Kampala Internacional } \\
\text { Universidade (KIU), Kampala; 2001 Kampala } \\
\text { Universidade (KU), Kampala; 2005 Kumi } \\
\text { Universidade (KUMU), Kumi; 1999 } \\
\text { Livingstone Internacional Universidade } \\
\text { (Mbale), Mbale; 2011 Muteesa I Real } \\
\text { Universidade (MRU), Masaka; 2007 } \\
\text { Montanhas de A Universidade Moon (MMU), } \\
\text { Fort Portal; 2005 Ndejje Universidade (NDU), } \\
\text { Luweero; 1992 Nkumba Universidade (NU), } \\
\text { Entebbe; 1999 Nsaka Universidade (NSU), } \\
\text { Jinja; 2013 St. Augustine Internacional } \\
\text { Universidade (Uganda) (SIAU), Kampala, } \\
\text { Bunga, Kisoro, Mulago, Namugongo; 2012 St. } \\
\text { Lawrence Universidade (Uganda) (slau), } \\
\text { Kampala; 2006 Uganda Christian Universidade } \\
\text { (UCU), Mukono; 1997 Uganda Mártires } \\
\text { Universidade (UMU), Nkozi, Mpigi Distrito; } \\
\text { 1993 Uganda Pentecostal Universidade (UPU), } \\
\text { Fort Portal; 2005 Uganda Tecnologia e Gestão } \\
\text { Universidade (UTAMU), Kampala; 2012 [8] } \\
\text { Victoria Universidade Uganda (VUU), Jinja } \\
\text { Road, Kampala; 2011 [9] }\end{array}$ \\
\hline $\begin{array}{l}\frac{\text { Zimbabwe }-18 \text { de }}{\text { abril de } 1980 \text { (31 anos) - Rodésia }} \\
\underline{\text { do Sul, Reino Unido }}\end{array}$ & & $\begin{array}{l}\text { Universidade de Zimbabwe; Universidade } \\
\text { Nacional de Ciência e Tecnologia; Zimbabwe } \\
\text { Universidade Católica do Zimbabwe Midlands } \\
\text { Estado; Universidade Zimbabwe; Abra } \\
\text { Universidade Lupane Estado; Universidade } \\
\text { Harare Instituto de Tecnologia; Grande } \\
\text { Zimbabwe Universidade antigamente Estado } \\
\text { Masvingo; Universidade Solusi; Universidade } \\
\text { da Africa; Universidade Chinhoyi } \\
\text { Universidade de Tecnologia de Bindura; } \\
\text { Universidade de Ciências da Educação da } \\
\text { Mulher; Universidade na África Gwanda } \\
\text { Estado; Universidade Zimbabwe Ezekiel Guti; } \\
\text { Universidade Igreja Reformada Universisty }\end{array}$ \\
\hline $\begin{array}{l}\text { Zâmbia - } 24 \text { de outubro de } 1964 \\
\text { (47 anos) - Reino Unido }\end{array}$ & $\begin{array}{l}\text { Universidade da Zâmbia; Copperbelt } \\
\text { Universidade Mulungushi; Uiversidade } \\
\text { Nkrumah; Universidade Evelyn Hone } \\
\text { College }\end{array}$ & $\begin{array}{l}\text { Universidade Internacional da Aliança; Levy } \\
\text { Mwanawasa (COSETCO) University; Zâmbia } \\
\text { Universidade Aberta; Cavendish Universidade } \\
\text { da Zâmbia; Universidade Adventista Zâmbia; } \\
\text { Universidade Northrise; Universidade de } \\
\text { Lusaka; Copperstone Universidade; Chreso } \\
\text { Universidade; Zâmbia Católica Universidade; } \\
\text { East West Universidade Collegel; DMI St. } \\
\text { Eugene Universidade (Z); Livingstone } \\
\text { Internacional Universidade de Turismo de } \\
\text { Excelência e Gestão de Empresas } \\
\text { (LIUTEBM); Universidade de África; Centro } \\
\text { de Estudos Zâmbia Accountacy (ZCAS); A } \\
\text { Universidade de Lusaka; Instituto Nacional de } \\
\text { Administração Pública (INAP); Informação e } \\
\text { Comunicação da Universidade (UTI Zâmbia) }\end{array}$ \\
\hline
\end{tabular}


VNIVERSIDAD

DSALAMANCA

África do Sul - 31 de

Anexo

março de 1910 (101 anos) (Criação

da União da África do Sul) 31 de

março de 1961 (50 anos)(deixa de

ser um domínio) - Reino Unido 
GANA

\begin{tabular}{|c|c|c|c|c|c|c|c|}
\hline Nome & Acrónimo & $\begin{array}{c}\text { Foundad } \\
\text { a } \\
\end{array}$ & $\begin{array}{c}\text { Graduaçõe } \\
\text { s }\end{array}$ & $\begin{array}{c}\text { Pósgradu } \\
\text { ações }\end{array}$ & $\begin{array}{l}\text { Total } \\
(2011) \\
\end{array}$ & Localização & Website \\
\hline \multicolumn{8}{|c|}{ Universidades Públicas } \\
\hline$\frac{\text { University of }}{\text { Ghana }}$ & Legon & 1948 & & & 38,000 & $\begin{array}{c}\text { Legon, } \\
\text { Accra, Korle } \\
\text { Bu and } \\
\text { Atomic, } \\
\text { Greater } \\
\text { Accra, } \\
\text { Ghana. } \\
\text { Including } \\
\text { over 10 } \\
\text { Workers } \\
\text { Colleges all } \\
\text { over the ten } \\
\text { regions of } \\
\text { Ghana. }\end{array}$ & $\underline{\text { Legon }}$ \\
\hline 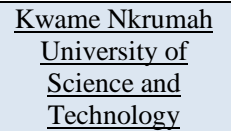 & KNUST & 1952 & 21,285 & 2,306 & 23,591 & $\begin{array}{l}\text { Kumasi, } \\
\text { Ashanti, } \\
\text { Ghana }\end{array}$ & $\underline{\text { KNUST }}$ \\
\hline $\begin{array}{l}\text { University of } \\
\underline{\text { Cape Coast }}\end{array}$ & Cape Vars & 1961 & & & & $\begin{array}{l}\text { Cape Coast, } \\
\text { Central, } \\
\text { Ghana }\end{array}$ & $\underline{\text { Cape Vars }}$ \\
\hline$\frac{\frac{\text { University of }}{\text { Education, }}}{\text { Winneba }}$ & UEW & 1992 & & & 16,879 & $\begin{array}{c}\text { Winneba, } \\
\text { Central, } \\
\text { Ghana }\end{array}$ & $\underline{\text { UEW }}$ \\
\hline$\frac{\frac{\text { University for }}{\text { Development }}}{\text { Studies }}$ & UDS & 1992 & & & & $\begin{array}{c}\text { Tamale, } \\
\text { Northern, } \\
\text { Ghana }\end{array}$ & $\underline{\text { UDS }}$ \\
\hline$\frac{\frac{\text { University of }}{\text { Professional }}}{\underline{\text { Studies }}}$ & UPS & 1965 & & & 10,000 & $\begin{array}{l}\text { Accra, } \\
\text { Greater } \\
\text { Accra, } \\
\text { Ghana } \\
\end{array}$ & $\underline{\text { UPS }}$ \\
\hline $\begin{array}{l}\frac{\text { University of }}{\text { Mines and }} \\
\text { Technology }\end{array}$ & UMAT & 2001 & & & & $\begin{array}{c}\text { Tarkwa, } \\
\text { Western, } \\
\text { Ghana }\end{array}$ & $\underline{\mathrm{UMaT}}$ \\
\hline $\begin{array}{c}\begin{array}{c}\text { University of } \\
\text { Health and Allied }\end{array} \\
\underline{\text { Sciences }}\end{array}$ & UHAS & 2011 & & & & $\begin{array}{c}\text { Ho, Volta, } \\
\text { Ghana }\end{array}$ & $\underline{\text { UHAS }}$ \\
\hline $\begin{array}{c}\begin{array}{c}\text { University Of } \\
\text { Energy And } \\
\text { Natural Resources }\end{array} \\
\end{array}$ & UENR & 2012 & & & & $\begin{array}{c}\text { Sunyani, } \\
\text { Brong } \\
\text { Ahafo, } \\
\text { Ghana }\end{array}$ & $\underline{\text { UENR }}$ \\
\hline$\frac{\begin{array}{c}\text { Professional } \\
\text { Public institutes / }\end{array}}{\text { Public }}$ & - & - & - & - & - & - & - \\
\hline $\begin{array}{c}\text { Ghana Armed } \\
\text { Forces Command } \\
\text { and Staff College }\end{array}$ & GAFCSC & & & & & $\begin{array}{l}\text { Accra, } \\
\text { Greater } \\
\text { Accra, } \\
\text { Ghana }\end{array}$ & $\underline{\text { GAFCSC }}$ \\
\hline \multirow[t]{2}{*}{$\begin{array}{c}\text { Ghana Institute of } \\
\text { Journalism }\end{array}$} & GIJ & & & & & $\begin{array}{l}\text { Accra, } \\
\text { Greater } \\
\text { Accra, } \\
\text { Ghana }\end{array}$ & $\underline{\mathrm{GIJ}}$ \\
\hline & & & & & & $\begin{array}{l}\frac{\text { (Formerly }}{\text { affiliated to }} \\
\text { the } \\
\frac{\text { University of }}{\text { Ghana) }} \\
\end{array}$ & \\
\hline$\frac{\text { Ghana Institute of }}{\underline{\text { Languages }}}$ & GIL & 1961 & & & & $\begin{array}{l}\text { Accra, } \\
\text { Greater } \\
\text { Accra, } \\
\text { Ghana }\end{array}$ & $\underline{\text { GIL }}$ \\
\hline & & & & & & (Affiliated to & \\
\hline
\end{tabular}


VNIVERSIDAD

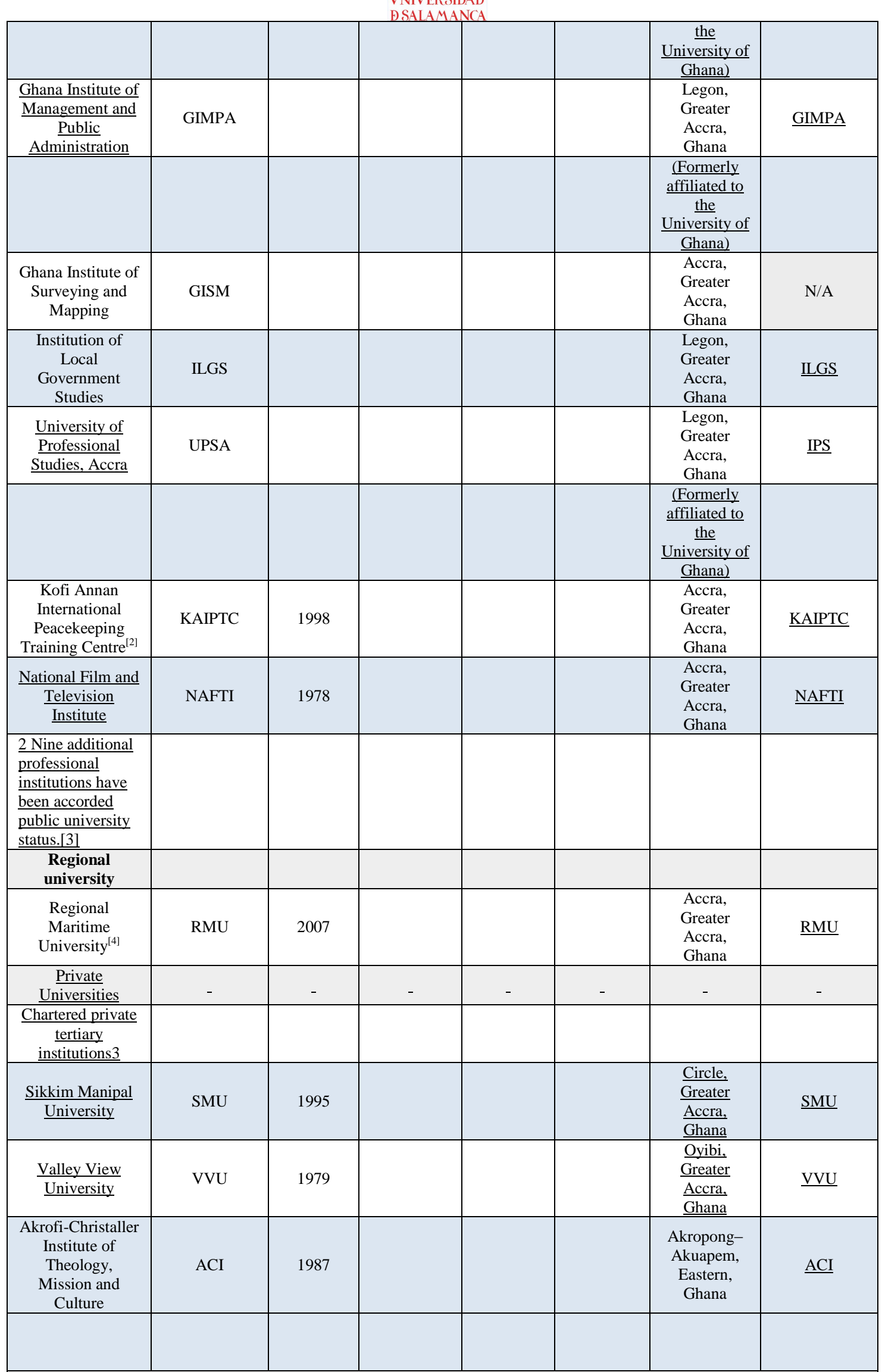

Outras Universidades e Colégios e Universidades Privadas 


\begin{tabular}{|c|c|c|c|c|c|c|c|}
\hline$\frac{\frac{\text { (University of }}{\text { Ghana Affiliatied }}}{\text { Institutions) }}$ & & & & & & & \\
\hline$\frac{\text { Accra Institute of }}{\underline{\text { Technology }}}$ & AIT & 2005 & 2,100 & 350 & 2,450 & $\begin{array}{c}\text { Cantonments } \\
\text {, Greater } \\
\text { Accra, } \\
\text { Ghana }\end{array}$ & AIT \\
\hline $\begin{array}{l}\frac{\text { African }}{\text { University }} \\
\text { College of } \\
\text { Communications } \\
\end{array}$ & AUCC & & & & & $\begin{array}{c}\text { Adabraka, } \\
\text { Greater } \\
\text { Accra, } \\
\text { Ghana }\end{array}$ & $\underline{\mathrm{AUCC}}$ \\
\hline $\begin{array}{l}\text { Anglican } \\
\text { University } \\
\text { College of } \\
\text { Technology }\end{array}$ & $\begin{array}{c}\text { ANG.U.TEC } \\
\text { H }\end{array}$ & 2008 & & & & $\begin{array}{c}\text { Nkoranza } \\
\text { Campus, } \\
\text { Nkoranza, } \\
\text { Brong } \\
\text { Ahafo, } \\
\text { Ghana }\end{array}$ & $\frac{\text { ANG.U.TEC }}{\underline{H}}$ \\
\hline $\begin{array}{c}\frac{\text { Catholic }}{\text { University }} \\
\text { College of Ghana } \\
\end{array}$ & CUG & 2003 & & & & $\begin{array}{c}\text { Fiapre, } \\
\text { Sunyani, } \\
\text { Brong } \\
\text { Ahafo, } \\
\text { Ghana }\end{array}$ & $\underline{\mathrm{CUG}}$ \\
\hline $\begin{array}{c}\text { Christian Service } \\
\text { University } \\
\text { College }^{[5]}\end{array}$ & CSUC & 1974 & & & & $\begin{array}{c}\text { Kumasi, } \\
\text { Ashanti, } \\
\text { Ghana }\end{array}$ & $\underline{\text { CSUC }}$ \\
\hline $\begin{array}{c}\text { Good News } \\
\text { Theological } \\
\text { Seminary }\end{array}$ & GNTCS & & & & & $\begin{array}{l}\frac{\text { Oyibi, }}{\text { Greater }} \\
\text { Accra, } \\
\text { Ghana }\end{array}$ & $\underline{\text { GNTCS }}$ \\
\hline $\begin{array}{c}\text { Islamic } \\
\text { University } \\
\text { College, Ghana }^{[6]}\end{array}$ & ICUG & 1988 & & & & $\begin{array}{c}\text { East Legon, } \\
\text { Greater } \\
\text { Accra, } \\
\text { Ghana } \\
\end{array}$ & $\underline{\text { ICUG }}$ \\
\hline $\begin{array}{l}\text { Knutsford } \\
\text { University } \\
\text { College }\end{array}$ & Knutsford & & & & & $\begin{array}{c}\text { East Legon, } \\
\text { Greater } \\
\text { Accra, } \\
\text { Ghana }\end{array}$ & $\underline{\text { Knutsford }}$ \\
\hline $\begin{array}{c}\text { Lancaster } \\
\text { University, Ghana }\end{array}$ & LUG & 2013 & & & & $\begin{array}{l}\text { Accra, } \\
\text { Greater } \\
\text { Accra, } \\
\text { Ghana }\end{array}$ & $\underline{\mathrm{LUG}}$ \\
\hline $\begin{array}{c}\text { Methodist } \\
\text { University } \\
\text { College Ghana }^{[6]}\end{array}$ & MUCG & 2000 & & & 1,887 & $\begin{array}{c}\text { Dansoman, } \\
\text { Accra, } \\
\text { Greater } \\
\text { Accra, } \\
\text { Ghana }\end{array}$ & $\underline{\mathrm{MUCG}}$ \\
\hline $\begin{array}{l}\text { Pentecost } \\
\text { University } \\
\text { College }^{[6]}\end{array}$ & Pent Vars & 2003 & & & & $\begin{array}{c}\frac{\text { Sowutuom, }}{\text { Greater }} \\
\underline{\text { Accra, }} \\
\text { Ghana } \\
\end{array}$ & $\underline{\text { Pent Vars }}$ \\
\hline $\begin{array}{l}\text { Presbyterian } \\
\text { University } \\
\text { College }^{[5]}\end{array}$ & PUC & 2003 & & & & $\begin{array}{l}\text { Abetifi- } \\
\text { Kwahu, } \\
\text { Akropong- } \\
\text { Akuapem, } \\
\text { Agogo } \\
\text { Asante- } \\
\text { Akyem and } \\
\text { Tema, } \\
\text { Ghana } \\
\end{array}$ & N/A \\
\hline \multirow[t]{2}{*}{$\begin{array}{l}\text { Wisconsin } \\
\text { International } \\
\text { University } \\
\text { College }^{[6]}\end{array}$} & WIUC & 2000 & & & & $\frac{\frac{\text { Agbogba }}{\text { Junction, }}}{\frac{\text { Greater }}{\text { Accra, }}}$ & $\underline{\text { WIUC }}$ \\
\hline & & & & & & $\begin{array}{l}\frac{\text { (Affiliated to }}{\text { the }} \\
\text { University of } \\
\text { Cape Coast) } \\
\end{array}$ & \\
\hline$\frac{\frac{\text { Central }}{\text { University }}}{\underline{\text { College }}}$ & Central & 1998 & 8,400 & & & $\begin{array}{l}\text { Accra, } \\
\text { Greater } \\
\text { Accra, } \\
\text { Ghana }\end{array}$ & $\underline{\text { Central }}$ \\
\hline
\end{tabular}


VNIVERSIDAD

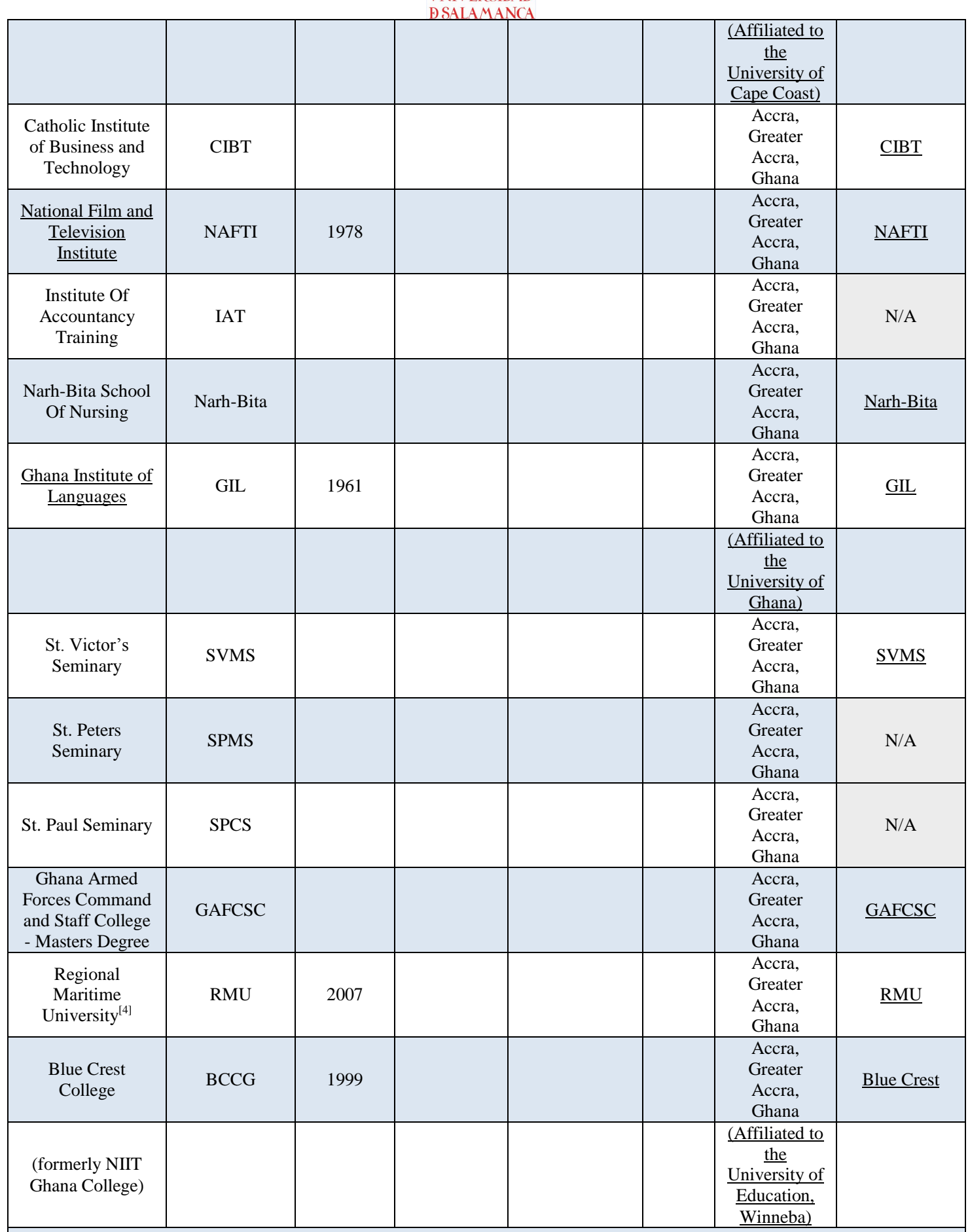

Kwame Nkrumah University of Science \& Technology Affiliated Institutions

\begin{tabular}{|c|c|c|c|c|c|c|c|}
\hline$\frac{\text { Accra Institute of }}{\underline{\text { Technology }}}$ & AIT & 2005 & 2,100 & 350 & 2,450 & $\begin{array}{l}\text { Cantonments } \\
\text {, Greater } \\
\text { Accra, } \\
\text { Ghana }\end{array}$ & $\underline{\mathrm{AIT}}$ \\
\hline $\begin{array}{c}\text { Osei Tutu II } \\
\text { Institute for } \\
\text { Advanced ICT } \\
\text { Studies }\end{array}$ & & & & & & $\begin{array}{c}\text { Kumasi, } \\
\text { Ashanti, } \\
\text { Ghana }\end{array}$ & N/A \\
\hline$\frac{\text { KAAF University }}{\underline{\text { College }}}$ & KUC & & & & & $\begin{array}{c}\text { Gomoa } \\
\text { Buduburam, } \\
\text { Central } \\
\text { Region, } \\
\text { Ghana }\end{array}$ & $\underline{\text { KUC }}$ \\
\hline
\end{tabular}




\begin{tabular}{|c|c|c|c|c|c|}
\hline $\begin{array}{l}\text { All Nations } \\
\text { University }^{[5]}\end{array}$ & ANU & 2002 & & $\begin{array}{c}\text { Koforidua, } \\
\text { Eastern, } \\
\text { Ghana }\end{array}$ & $\underline{\mathrm{ANU}}$ \\
\hline & & & & $\begin{array}{l}\frac{\text { Affiliated to }}{\text { the Kwame }} \\
\frac{\text { Nkrumah }}{\text { University of }} \\
\frac{\text { Science \& }}{\text { Technology) }}\end{array}$ & \\
\hline $\begin{array}{l}\text { Radford } \\
\text { University } \\
\text { College } \\
\end{array}$ & Radford & & & $\begin{array}{c}\text { Kumasi, } \\
\text { Ashanti, } \\
\text { Ghana }\end{array}$ & $\underline{\text { Radford }}$ \\
\hline $\begin{array}{c}\text { Garden City } \\
\text { University } \\
\text { College }^{[5]} \\
\end{array}$ & GCUC & 2001 & & $\begin{array}{c}\text { Kumasi, } \\
\text { Ashanti, } \\
\text { Ghana }\end{array}$ & $\underline{\text { GCUC }}$ \\
\hline $\begin{array}{c}\text { Regent University } \\
\text { College of } \\
\text { Science and } \\
\text { Technology } \\
5]\end{array}$ & Regent & 2003 & & $\begin{array}{l}\text { Accra, } \\
\text { Greater } \\
\text { Accra, } \\
\text { Ghana }\end{array}$ & $\underline{\text { Regent }}$ \\
\hline & & & & $\begin{array}{c}\text { (Affiliated to } \\
\text { the } \\
\text { Maastricht } \\
\text { School of } \\
\text { Management } \\
\text {, } \\
\text { Netherlands) }\end{array}$ & \\
\hline \multirow[t]{2}{*}{$\begin{array}{l}\frac{\text { Technical }}{\text { University }} \\
\text { College[7] }\end{array}$} & TUC & & & $\begin{array}{l}\text { Tamale, } \\
\text { Northern } \\
\text { Region, } \\
\text { Ghana }\end{array}$ & N/A \\
\hline & & & & $\begin{array}{l}\frac{\text { (Affiliated to }}{\text { the }} \\
\frac{\text { University of }}{\text { Ghana) }}\end{array}$ & \\
\hline $\begin{array}{c}\text { Spiritan } \\
\text { University } \\
\text { College } \\
\end{array}$ & Spiritan & & & $\begin{array}{c}\text { Ejisu, } \\
\text { Ashanti, } \\
\text { Ghana }\end{array}$ & $\underline{\text { Spiritan }}$ \\
\hline $\begin{array}{l}\text { Data Link } \\
\text { University } \\
\text { College }\end{array}$ & DLUC & 2006 & & $\begin{array}{l}\text { Tema, } \\
\text { Greater } \\
\text { Accra, } \\
\text { Ghana }\end{array}$ & $\underline{\text { DLUC }}$ \\
\hline $\begin{array}{c}\text { Mountcrest } \\
\text { University } \\
\text { College }\end{array}$ & MCUC & & & $\begin{array}{l}\text { Kanda, } \\
\text { Accra, } \\
\text { Greater } \\
\text { Accra, } \\
\text { Ghana }\end{array}$ & $\underline{\text { MCUC }}$ \\
\hline $\begin{array}{c}\frac{\text { University }}{\text { College of }} \\
\frac{\begin{array}{c}\text { Agriculture and } \\
\text { Environmental }\end{array}}{\text { Studies }}\end{array}$ & UCAES & 1963 & & $\frac{\underline{\text { Bunso, }}}{\underline{\text { Eastern }}} \frac{\text { Region, }}{\text { Ghana }}$ & $\underline{\text { UCAES }}$ \\
\hline \multicolumn{6}{|l|}{$\begin{array}{c}\frac{\text { University of }}{\text { Cape Coast }} \\
\text { Affiliatied } \\
\text { Institutions } \\
\end{array}$} \\
\hline \multirow[t]{2}{*}{$\frac{\frac{\text { Central }}{\text { University }}}{\underline{\text { College }}}$} & Central & 1998 & 8,400 & $\begin{array}{l}\text { Accra, } \\
\text { Greater } \\
\text { Accra, } \\
\text { Ghana }\end{array}$ & Central \\
\hline & & & & $\begin{array}{l}\frac{\text { (Affiliated to }}{\text { the }} \\
\text { University of } \\
\text { Cape Coast) }\end{array}$ & \\
\hline $\begin{array}{c}\text { Ashesi } \\
\text { University }^{[5]}\end{array}$ & Ashesi & 2002 & $550+$ & $\begin{array}{l}\text { Accra, } \\
\text { Greater } \\
\text { Accra, } \\
\text { Ghana }\end{array}$ & $\underline{\text { Ashesi }}$ \\
\hline $\begin{array}{l}\text { Entrepreneurship } \\
\text { Training Institute }\end{array}$ & ETI & & & $\begin{array}{l}\text { Accra, } \\
\text { Greater } \\
\text { Accra, } \\
\text { Ghana }\end{array}$ & N/A \\
\hline $\begin{array}{c}\text { Deltas University } \\
\text { College }\end{array}$ & DUC & & & $\begin{array}{l}\text { Accra, } \\
\text { Greater }\end{array}$ & N/A \\
\hline
\end{tabular}


VNIVERSIDAD

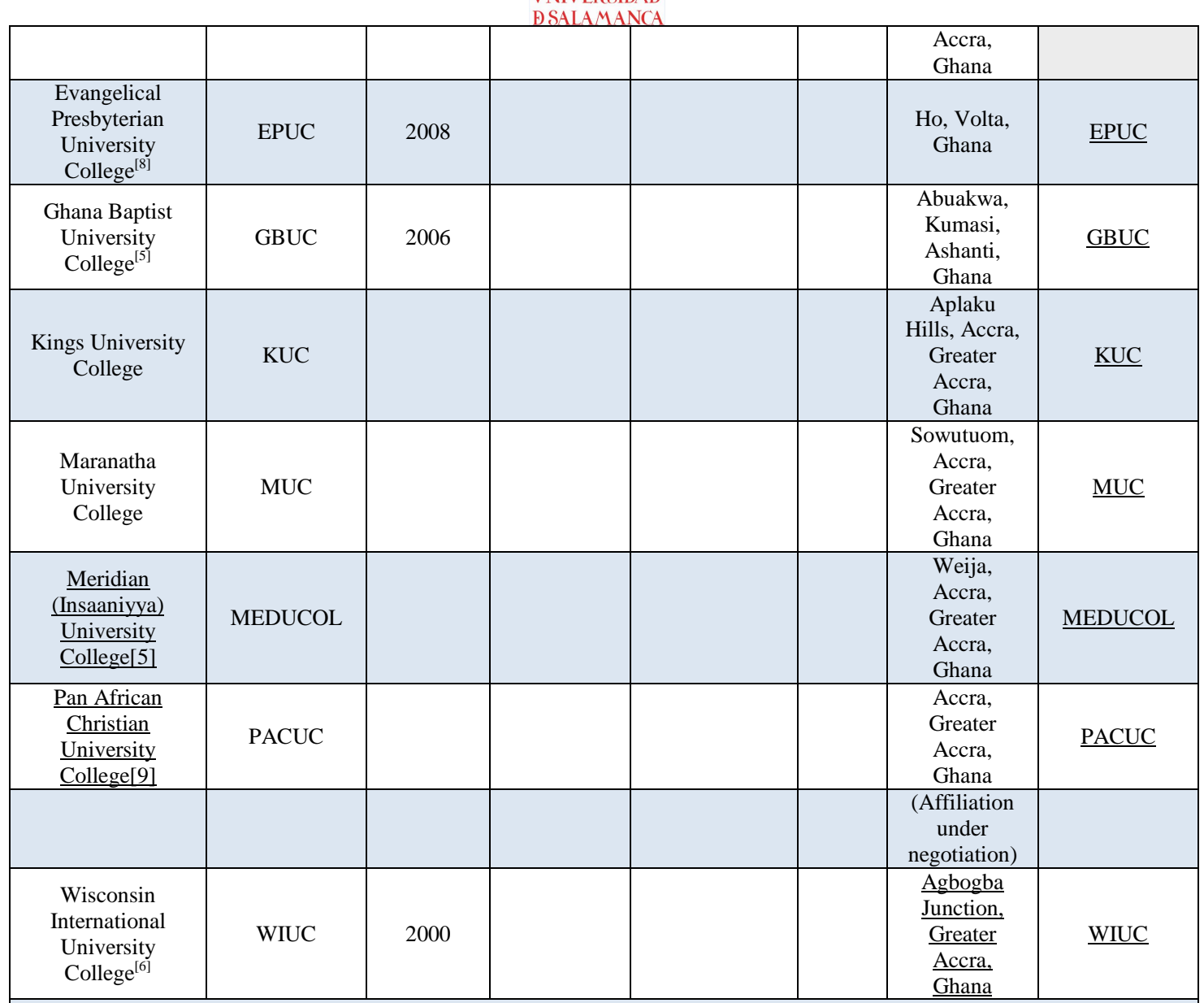

(Also affiliated to the University of Ghana)

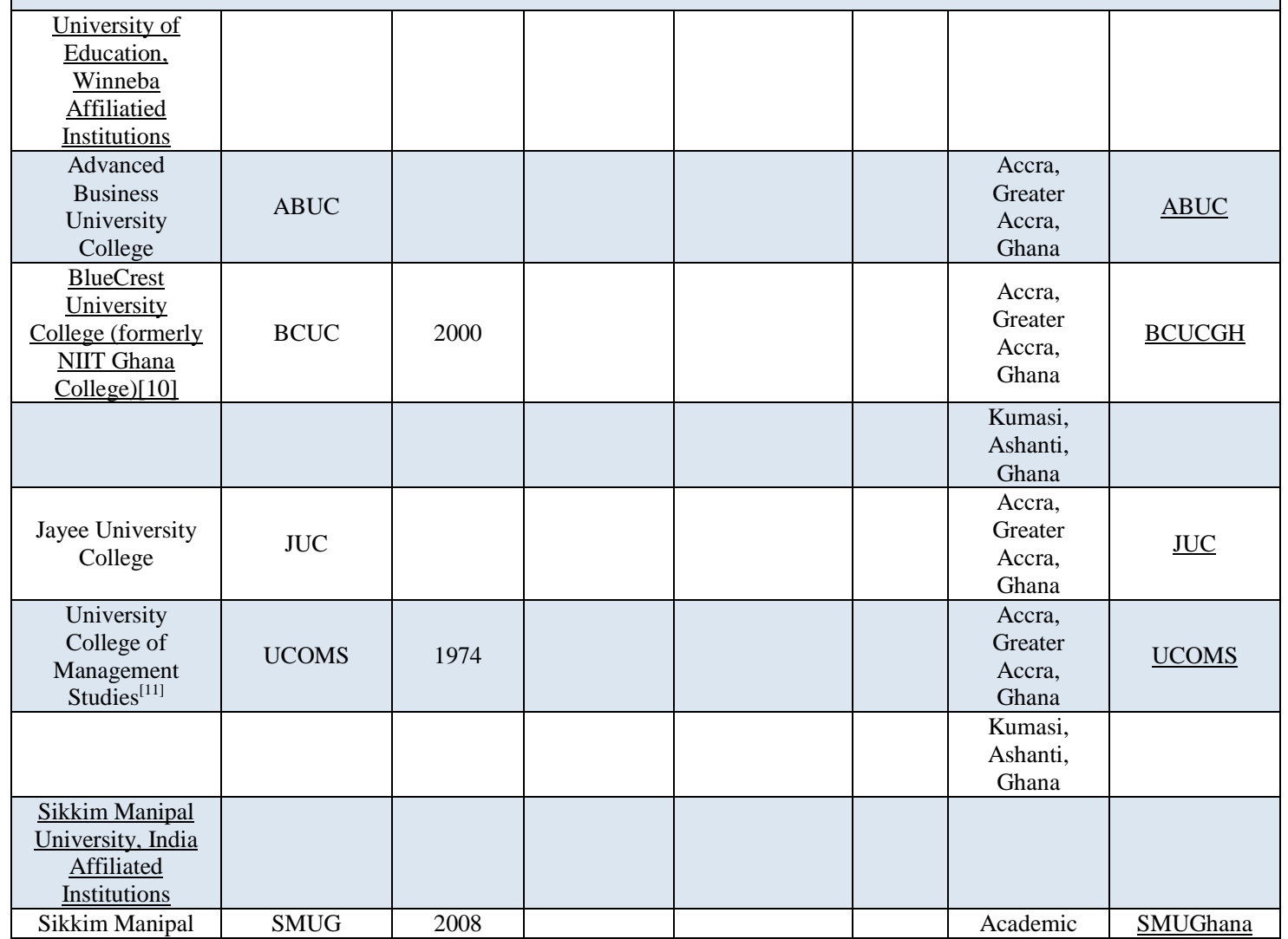




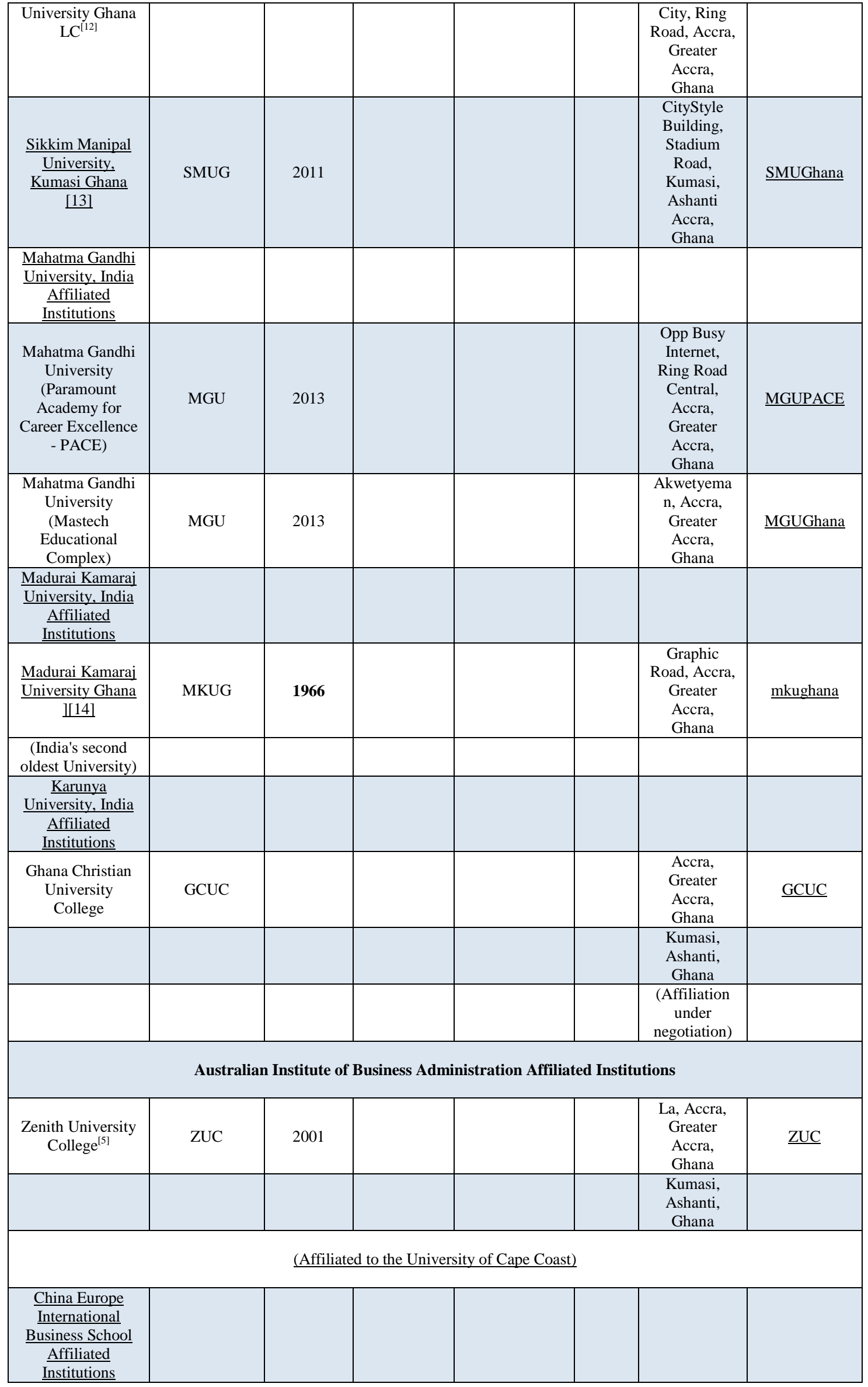


VNiVERSiDAD

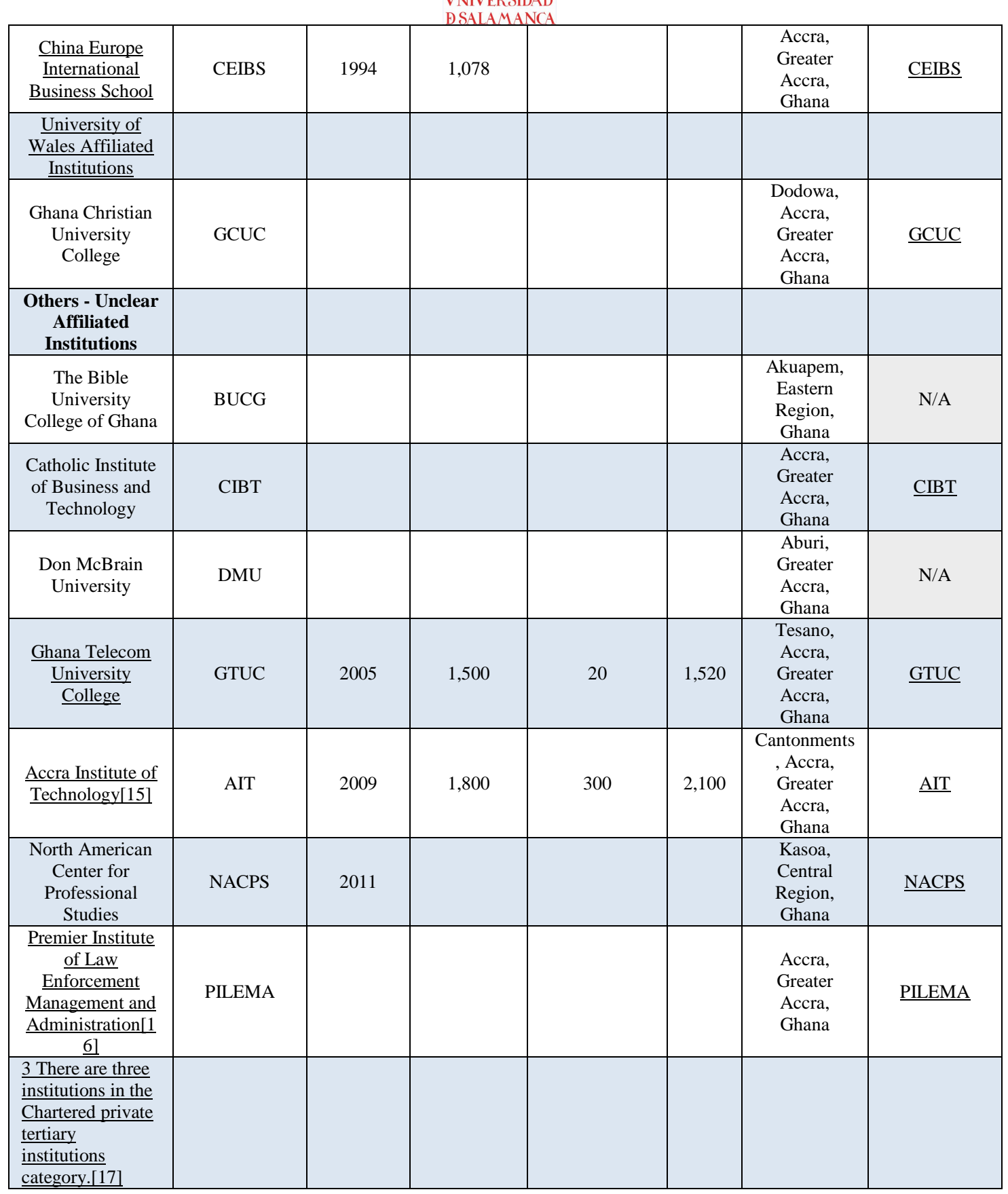


Nigéria

\begin{tabular}{|c|c|c|c|c|c|c|}
\hline Nome & Estado & Acrónimo & Tipo & Localização & Financiamento & Fundada \\
\hline fopase University & PortNovo & PortNovo & Universidade & Benin & Privada & \\
\hline Abia State University & Abia & $\mathrm{ABSU}$ & Universidade & Uturu & Publica & 1981 \\
\hline Afe Babalola University & Ekiti & ABUAD & Universidade & Ado-Ekiti & Privada & 2009 \\
\hline $\begin{array}{l}\text { Akwa Ibom State University } \\
\text { of Science and Technology }\end{array}$ & $\begin{array}{l}\overline{\text { Akwa }} \\
\text { Ibom }\end{array}$ & AKUTECH & $\begin{array}{c}\text { Ciência e } \\
\text { Tecnologia }\end{array}$ & $\underline{\text { Uyo }}$ & Publica & 2010 \\
\hline $\begin{array}{l}\text { American University of } \\
\text { Nigeria }\end{array}$ & Adamawa & AUN & Universidade & $\underline{\text { Yola }}$ & Privada & 2005 \\
\hline $\begin{array}{l}\text { Abubakar Tafawa Balewa } \\
\text { University }\end{array}$ & $\underline{\text { Bauchi }}$ & ATBU & Universidade & $\underline{\text { Bauchi }}$ & Federal & 1980 \\
\hline Adamawa State University & Adamawa & ADSU & Universidade & Mubi & Publica & 2002 \\
\hline Achievers University & Ondo & $\mathrm{AC}$ & Universidade & Owo & Privada & 2007 \\
\hline Ahmadu Bello University & Kaduna & $\mathrm{ABU}$ & Universidade & $\overline{\text { Zaria }}$ & Federal & 1962 \\
\hline Al-Hikmah University & Kwara & AHU & Islamica & Ilorin & Privada & 2005 \\
\hline Ambrose Alli University & $\underline{\underline{E d o}}$ & AAU & Universidade & Ekpoma & Publica & 1981 \\
\hline $\begin{array}{l}\text { Anambra State University } \\
\text { formerly Anambra State } \\
\text { University Of Science And } \\
\text { Technology }\end{array}$ & Anambra & ANSU & Universidade & $\underline{\text { Uli }}$ & Publica & 2000 \\
\hline Ajayi Crowther University & Oyo & $\mathrm{ACU}$ & Universidade & Oyo & Privada & $1853(1)$ \\
\hline Bayero University & Kano & BUK & Universidade & Kano & Federal & 1977 \\
\hline Babcock University & Ogun & $\mathrm{BU}$ & Universidade & Ilishan-Remo & Privada & 1959 \\
\hline $\begin{array}{l}\text { Bells University of } \\
\text { Technology }\end{array}$ & $\underline{\text { Ogun }}$ & BUT & Universidade & $\underline{\text { Ota }}$ & Privada & 2004 \\
\hline Benson Idahosa University & Edo & $\mathrm{BIU}$ & Universidade & Benin City & Privada & 2002 \\
\hline Benue State University & Benue & BSU & Universidade & Makurdi & Publica & 1992 \\
\hline ECWA Bingham University & Nassarawa & $\mathrm{BU}$ & Universidade & New Karu & Privada & 2005 \\
\hline Bowen University & Osun & $\mathrm{BU}$ & Universidade & $\underline{\text { Iwo }}$ & Privada & 2002 \\
\hline $\begin{array}{l}\text { Bukar Abba Ibrahim } \\
\text { University }\end{array}$ & Yobe & YSU & Universidade & Damaturu & Publica & 2006 \\
\hline Cetep University & Lagos & $\mathrm{CU}$ & Universidade & $\underline{\text { Lagos }}$ & Privada & \\
\hline Caleb University & Lagos & CUl & Universidade & Ikorodu, Lagos & Private & 2008 \\
\hline Caritas University & Enugu & $\mathrm{CU}$ & Universidade & Enugu & Privada & 2004 \\
\hline City University & Lagos & $\mathrm{CU}$ & Universidade & Yaba & Privada & \\
\hline $\begin{array}{l}\text { National Open University of } \\
\text { Nigeria }\end{array}$ & $\underline{\underline{\text { Lagos }}}$ & NOUN & Universidade & $\frac{\text { Victoria Island, }}{\underline{\text { Lagos }}}$ & Federal & 1983 \\
\hline$\frac{\text { City University of }}{\text { Technology }}$ & $\underline{\text { Kaduna }}$ & CUT & Universidade & $\underline{\text { Kaduna }}$ & Privada & \\
\hline Covenant University & Ogun & $\mathrm{CU}$ & Universidade & Ota & Privada & 2002 \\
\hline Crawford University & Ogun & $\mathrm{CU}$ & Universidade & $\frac{\text { Faith City, }}{\text { Igbesa }}$ & Privada & 2005 \\
\hline Crawford University & $\underline{\text { Ekiti }}$ & $\mathrm{CU}$ & Universidade & $\frac{\text { Oye-Ekiti }}{\text { Campus }}$ & Privada & 2005 \\
\hline Crescent University & Ogun & $\mathrm{CU}$ & Universidade & Abeokuta & Privada & 2005 \\
\hline $\begin{array}{l}\text { Cross River State University } \\
\text { of Technology }\end{array}$ & $\begin{array}{l}\overline{\text { Cross }} \\
\text { River } \\
\end{array}$ & CRSUT & Tecnologica & $\begin{array}{c}\text { Ekpo-Abasi, } \\
\text { Calabar }\end{array}$ & Publica & \\
\hline $\begin{array}{l}\text { Delta State University, } \\
\text { Abraka }\end{array}$ & $\underline{\text { Delta }}$ & DELSU & Tecnologica & $\underline{\text { Abraka }}$ & Publica & 1992 \\
\hline Ebonyi State University & Ebonyi & EBSU & Universidade & Abakaliki & Publica & 1996 \\
\hline Elizade University & Ondo & & Universidade & Ilara-Mokin & Privada & 2012 \\
\hline $\begin{array}{l}\text { Fountain University, } \\
\text { Osogbo }\end{array}$ & Osun & FUO & Universidade & $\underline{\text { Osun }}$ & Privada & 2007 \\
\hline $\begin{array}{l}\text { Federal University, Dutsin- } \\
\text { Ma }\end{array}$ & $\underline{\text { Katsina }}$ & FUDM & Universidade & $\underline{\text { Katsina }}$ & Federal & \\
\hline $\begin{array}{l}\text { Federal University of } \\
\text { Technology Akure }\end{array}$ & $\underline{\text { Ondo }}$ & FUTA & Tecnologica & $\underline{\text { Akura }}$ & Federal & 1981 \\
\hline Gregory University & Abia & & Universidade & Uturu & Privada & 2012 \\
\hline Godfrey Okoye University & Enugu & $\mathrm{GOU}$ & Universidade & Enugu & Privada & 2009 \\
\hline Landmark University & Kwara & $\mathrm{LU}$ & Universidade & Omu-Aran & Privada & 2011 \\
\hline Lagos State University & $\underline{\text { Lagos }}$ & LASU & Universidade & $\begin{array}{l}\text { Ojo, Lagos } \\
\text { State } \\
\end{array}$ & Publica & 1983 \\
\hline $\begin{array}{l}\text { Nigerian Turkish Nile } \\
\text { University }\end{array}$ & $\underline{\mathrm{FCT}}$ & NTNU & Universidade & Abuja & Privada & 1998 \\
\hline Taraba State University & Taraba & & Universidade & Jalingo & Publica & \\
\hline$\underline{\text { University of Benin }}$ & $\underline{\text { Benin City }}$ & UNIBEN & Universidade & $\begin{array}{c}\text { Benin City, } \\
\text { Edo State }\end{array}$ & Federal & 1970 \\
\hline$\underline{\text { University of Calabar }}$ & $\underline{\text { Calabar }}$ & UNICAL & Universidade & $\begin{array}{l}\text { Calabar, Cross } \\
\text { River State }\end{array}$ & Federal & 1975 \\
\hline
\end{tabular}


VNiVERSIDAD

\begin{tabular}{|l|c|c|c|c|c|c|}
\hline University of Lagos & $\underline{\text { Lagos }}$ & UNILAG & Universidade & $\begin{array}{c}\text { Lagos, Lagos } \\
\text { State }\end{array}$ & Federal & 1962 \\
\hline$\underline{\text { University of Port Harcourt }}$ & $\underline{\text { Rivers }}$ & UPH & Universidade & $\begin{array}{c}\text { Port Harcourt, } \\
\text { Rivers State }\end{array}$ & Federal & 1975 \\
\hline $\begin{array}{l}\text { University of Nigeria, } \\
\text { Nsukka }\end{array}$ & $\underline{\text { Enugu }}$ & UNN & Universidade & $\underline{\text { Enugu }}$ & Federal & 1955 \\
\hline $\begin{array}{l}\text { Veritas University (Catholic } \\
\text { University of Nigeria) } \\
\text { Abuja }\end{array}$ & $\underline{\text { Abuja }}$ & VUNA & Universidade & $\underline{\text { Bwari }}$ & Privada & 2007 \\
\hline
\end{tabular}

Esta é uma lista de universidades na Nigéria. A Nigéria está organizada em 36 Estados e um Território da Capital Federal (FCT), em Abuja. Como resultado de anos de boom do petróleo na década de 1970, o ensino superior foi ampliado para chegar a cada sub-região da Nigéria. O governo federal e os governos estaduais foram previamente as únicas entidades licenciadas para operar como universidades. Recentemente, licenças foram concedidas a indivíduos, sociedades e entidades religiosas para estabelecer universidades privadas no país. A Comissão Nacional de Universidades (NUC) é o principal organismo de acreditação que impõe um padrão uniforme e define a capacidade de admissão de cada universidade na Nigéria. 
Tanzânia

\begin{tabular}{|c|c|c|c|c|c|c|}
\hline Nome & Tipo & Acrónimo & Fundada & $\begin{array}{c}\text { Estatuto de } \\
\text { Universidade }\end{array}$ & Nome Original & Local \\
\hline $\begin{array}{l}\text { University of Dar es } \\
\text { Salaam }\end{array}$ & Publica & UDSM & 1961 & 1970 & $\begin{array}{c}\text { University College, Dar } \\
\text { es Salaam }\end{array}$ & 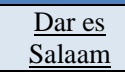 \\
\hline $\begin{array}{l}\text { Sokoine University of } \\
\text { Agriculture }\end{array}$ & Publica & SUA & 1965 & 1984 & $\begin{array}{c}\text { Faculty of Agriculture, } \\
\text { UDSM }\end{array}$ & Morogoro \\
\hline $\begin{array}{l}\text { The Open University of } \\
\text { Tanzania }\end{array}$ & Publica & OUT & 1992 & 1992 & - & $\underline{\text { Dar es }}$ \\
\hline Ardhi University & Publica & $\mathrm{AU}$ & 1956 & 2007 & $\frac{\text { Ardhi Institute and }}{\text { UCLAS }}$ & $\overline{\underline{\text { Dar es }}}$ \\
\hline$\frac{\text { State University of }}{\text { Zanzibar }}$ & Publica & SUZA & 1999 & 1999 & - & $\frac{\overline{\text { Zanzibar }}}{\text { Urban }}$ \\
\hline$\underline{\text { Mzumbe University }}$ & Publica & MU & 1975 & 2001 & $\begin{array}{c}\text { Institute of Development } \\
\text { Management }\end{array}$ & Morogoro \\
\hline $\begin{array}{l}\text { Muhimbili University of } \\
\text { Health and Allied } \\
\text { Sciences }\end{array}$ & Publica & MUHAS & 1963 & 2007 & $\begin{array}{l}\text { Dar es Salaam School of } \\
\underline{\text { Medicine and MUCHS }}\end{array}$ & $\underline{\text { Dar es }}$ \\
\hline $\begin{array}{l}\text { Nelson Mandela African } \\
\text { Institute of Science and } \\
\text { Technology }\end{array}$ & Publica & $\begin{array}{l}\text { NM- } \\
\text { AIST }\end{array}$ & 2009 & 2010 & - & Arusha \\
\hline University of Dodoma & Publica & UDOM & 2007 & 2007 & - & Dodoma \\
\hline $\begin{array}{l}\text { Katavi University of } \\
\text { Agriculture }\end{array}$ & Publica & KUA & & & - & $\underline{\text { Katavi }}$ \\
\hline $\begin{array}{l}\text { Mbeya University of } \\
\text { Science and Technology }\end{array}$ & Publica & MUST & 1986 & $2012 / 13$ & $\begin{array}{l}\text { Mbeya Technical } \\
\text { College and MIST }\end{array}$ & Mbeya \\
\hline $\begin{array}{l}\text { Hubert Kairuki Memorial } \\
\text { University }\end{array}$ & Privada & HKMU & 1997 & MMHEN & $\begin{array}{c}\text { Mikocheni International } \\
\text { University }\end{array}$ & $\begin{array}{l}\underline{\text { Dar es }} \\
\underline{\text { Salaam }} \\
\end{array}$ \\
\hline $\begin{array}{l}\text { International Medical and } \\
\text { Technological University }\end{array}$ & Privada & IMTU & 1997 & $\underline{\mathrm{VEF}}$ & - & $\begin{array}{c}\text { Dar es } \\
\text { Salaam }\end{array}$ \\
\hline $\begin{array}{l}\text { Tumaini University } \\
\text { Makumira }\end{array}$ & Privada & TUMA & 1997 & $\underline{\text { Lutheran }}$ & $\begin{array}{c}\text { Lutheran Theological } \\
\text { College Makumira }\end{array}$ & $\underline{\text { Arusha }}$ \\
\hline $\begin{array}{l}\text { St. Augustine University } \\
\text { of Tanzania }\end{array}$ & Privada & SAUT & 2002 & $\underline{\text { Catholic }}$ & $\begin{array}{l}\text { Nyegezi Social Training } \\
\text { Institute }\end{array}$ & Mwanza \\
\hline Zanzibar University & Privada & $\mathrm{ZU}$ & 2002 & $\underline{\text { Islamic }}$ & - & $\frac{\text { Zanzibar }}{\text { Urban }}$ \\
\hline Mount Meru University & Privada & MMU & 2005 & $\underline{\text { Baptist }}$ & $\begin{array}{c}\text { International Baptist } \\
\text { Theological Seminary of } \\
\text { Eastern Africa }\end{array}$ & Arusha \\
\hline$\underline{\text { University of Arusha }}$ & Privada & UoA & 2006 & $\frac{\text { Seventh-day }}{\underline{\text { Adventist }}}$ & $\begin{array}{c}\text { Tanzania Adventist } \\
\text { College }\end{array}$ & Arusha \\
\hline $\begin{array}{l}\text { Teofilo Kisanji } \\
\text { University }\end{array}$ & Privada & TEKU & 2007 & Moravian & - & Mbeya \\
\hline $\begin{array}{l}\text { Muslim University of } \\
\text { Morogoro }\end{array}$ & Privada & MUM & 2004 & $\underline{\text { Islamic }}$ & - & Morogoro \\
\hline $\begin{array}{l}\text { St. John's University of } \\
\text { Tanzania }\end{array}$ & Privada & SJUT & 2007 & $\underline{\text { Anglican }}$ & - & $\underline{\text { Dodoma }}$ \\
\hline University of Bagamoyo & Privada & UB & 2010 & $\begin{array}{l}\text { TANLET and } \\
\text { LHRC }\end{array}$ & - & $\underline{\text { Dar es }}$ \\
\hline $\begin{array}{l}\text { Eckernforde Tanga } \\
\text { University }\end{array}$ & Privada & ETU & 2010 & & - & Tanga \\
\hline $\begin{array}{l}\text { Catholic University of } \\
\text { Health and Allied } \\
\underline{\text { Sciences }}\end{array}$ & Privada & CUHAS & 1994 & $\underline{\text { Catholic }}$ & - & $\underline{\text { Mwanza }}$ \\
\hline $\begin{array}{l}\text { St. Joseph University In } \\
\text { Tanzania }\end{array}$ & Privada & SJUIT & 2011 & $\underline{\text { Catholic }}$ & - & $\underline{\text { Dar es }}$ \\
\hline $\begin{array}{l}\text { United African } \\
\text { University of Tanzania }\end{array}$ & Privada & UAUT & 2012 & $\begin{array}{l}\text { Korea Church } \\
\text { Mission }\end{array}$ & - & $\frac{\text { Dar es }}{\text { Salaam }}$ \\
\hline $\begin{array}{l}\text { Sebastian Kolowa } \\
\text { Memorial University }\end{array}$ & Privada & SEKOMU & 2012 & $\underline{\text { Lutheran }}$ & $\begin{array}{c}\text { Sebastian Kolowa } \\
\text { University College }\end{array}$ & $\underline{\text { Tanga }}$ \\
\hline $\begin{array}{l}\text { Tanzania International } \\
\text { University }\end{array}$ & Privada & TIU & & & - & $\underline{\text { Dar es }}$ \\
\hline
\end{tabular}




\section{Africa do Sul}

\section{Universidades Tradicionais}

\begin{tabular}{|c|c|c|c|c|c|c|c|}
\hline Nome & Acrónimo & Fundada & $\begin{array}{l}\text { Estatuto de } \\
\text { Universidade }\end{array}$ & Graduados & Posgraduados & $\begin{array}{l}\text { Total } \\
(2011)\end{array}$ & Local \\
\hline $\begin{array}{l}\text { University of } \\
\text { Cape Town }\end{array}$ & $\begin{array}{l}\text { Ikeys / } \\
\text { UCT }\end{array}$ & $\frac{1 \text { October }}{1829[3]}$ & $\frac{2 \text { April }}{1918[3]}$ & 15,800 & 6,700 & 23,500 & Cape Town \\
\hline $\begin{array}{l}\text { University of } \\
\text { Fort Hare }\end{array}$ & UFH & $\underline{1916[4]}$ & & 9,074 & 2,000 & 11,074 & $\begin{array}{c}\text { Alice, East } \\
\text { London, Bhisho }\end{array}$ \\
\hline $\begin{array}{l}\text { University of } \\
\underline{\text { the Free State }}\end{array}$ & $\begin{array}{l}\text { Kovsies / } \\
\text { UFS }\end{array}$ & $\begin{array}{c}\underline{28} \\
\underline{\text { January }} \\
\underline{1904[5]}\end{array}$ & $\underline{1950[6]}$ & 21,193 & 5,082 & $\underline{26,275[7]}$ & $\begin{array}{l}\text { Bloemfontein, } \\
\text { QwaQwa }\end{array}$ \\
\hline $\begin{array}{l}\frac{\text { University of }}{\text { KwaZulu- }} \\
\text { Natal }\end{array}$ & $\begin{array}{l}\text { UKZN / } \\
\text { Natal }\end{array}$ & $\frac{1 \text { January }}{\underline{20041[8]}}$ & $\frac{1 \text { January }}{\underline{2004[8]}}$ & 24,897 & 3,807 & 37,850 & $\begin{array}{c}\text { Durban, } \\
\text { Pietermaritzburg, } \\
\text { Pinetown, } \\
\text { Westville }\end{array}$ \\
\hline $\begin{array}{l}\text { University of } \\
\text { Limpopo }\end{array}$ & Turfloop & $\frac{1 \text { January }}{20051[9]}$ & $\frac{\text { 1 January }}{2005[9]}$ & 17,273 & 3,327 & 20,600 & $\begin{array}{l}\text { Polokwane, Ga- } \\
\text { Rankuwa }\end{array}$ \\
\hline$\frac{\text { North-West }}{\text { University }}$ & $\begin{array}{l}\text { NWU / } \\
\text { Pukke / } \\
\text { Potch }\end{array}$ & $\frac{1 \text { January }}{\underline{20041[10]}}$ & $\frac{1 \text { January }}{\underline{2004[10]}}$ & 43,596 & 3,235 & 44,008 & $\begin{array}{c}\text { Mafikeng, } \\
\text { Mankwe, } \\
\text { Potchefstroom, } \\
\text { Vanderbijlpark }\end{array}$ \\
\hline $\begin{array}{l}\text { University of } \\
\text { Pretoria }\end{array}$ & $\begin{array}{c}\text { Tuks / } \\
\text { Tukkies / } \\
\text { UP[11] }\end{array}$ & $\underline{4 \mathrm{March}}$ & $\frac{10 \text { October }}{\underline{1930[13]}}$ & $\underline{28,450[14]}$ & $\underline{10,484[14]}$ & 38,934 & $\begin{array}{c}\text { Pretoria, } \\
\text { Johannesburg }^{2[15]}\end{array}$ \\
\hline $\begin{array}{l}\text { Rhodes } \\
\text { University } \\
\end{array}$ & $\begin{array}{c}\text { Rhodes / } \\
\text { RU }\end{array}$ & $\underline{31 \mathrm{May}}$ & 10-Mar-51 & 5,456 & 1,127 & 6,700 & Grahamstown \\
\hline $\begin{array}{l}\text { University of } \\
\text { Stellenbosch }\end{array}$ & $\begin{array}{l}\text { Maties, } \\
\text { Stellies }\end{array}$ & $\underline{1866[17]}$ & $\begin{array}{l}2 \text { April } \\
\underline{1918[17]}\end{array}$ & $\underline{17,970[18]}$ & 9,853 & 27,823 & $\begin{array}{c}\text { Stellenbosch, } \\
\text { Saldanha Bay, } \\
\text { Bellville, } \\
\text { Tygerberg }\end{array}$ \\
\hline $\begin{array}{l}\frac{\text { University of }}{\text { the Western }} \\
\text { Cape }\end{array}$ & $\begin{array}{c}\text { UWC / } \\
\text { Bush / U } \\
\text { Dubs }\end{array}$ & $\underline{1959[19]}$ & $\underline{1970[19]}$ & 11,836 & 3,390 & 15,226 & $\frac{\text { Bellville (Cape }}{\text { Town) }}$ \\
\hline $\begin{array}{l}\text { University of } \\
\text { the } \\
\text { Witwatersrand }\end{array}$ & Wits & $\underline{1896[20]}$ & $\underline{1922[20]}$ & 18,911 & 9,023 & 27,934 & $\underline{\text { Johannesburg }}$ \\
\hline
\end{tabular}

\section{Universidades Abrangentes}

\begin{tabular}{|c|c|c|c|c|c|c|}
\hline Nome & $\overline{\text { Acrónimo }}$ & Fundada & Graduados & Posgraduados & Total & Local \\
\hline$\frac{\text { University of }}{\text { Johannesburg }}$ & UJ & $\begin{array}{l}1 \text { January } 2005^{1}(1967 \\
\text { as RAU, Technikon } \\
\text { Witwatersrand and the } \\
\text { East Rand campus of } \\
\text { Vista University) }\end{array}$ & & & 48,000 & $\begin{array}{l}\text { Johannesburg, } \\
\text { Soweto }\end{array}$ \\
\hline $\begin{array}{l}\text { Nelson } \\
\text { Mandela } \\
\text { Metropolitan } \\
\text { University }\end{array}$ & $\begin{array}{l}\text { Madibaz / } \\
\text { NMMU }\end{array}$ & $\frac{1 \text { January } 20052(1964}{\underline{\text { as UPE) }}}$ & 19,768 & 2,884 & 22,652 & $\begin{array}{l}\text { Port Elizabeth, } \\
\text { George }\end{array}$ \\
\hline $\begin{array}{l}\text { University of } \\
\text { South Africa } \\
\end{array}$ & Unisa & $1873(\mathrm{UCGH})$ & & & 300,000 & $\begin{array}{l}\frac{\text { Distance education, }}{\text { headquartered in }} \\
\frac{\text { Pretoria, campuses }}{\text { and regional offices }} \\
\frac{\text { nationwide }}{\text { nationise }}\end{array}$ \\
\hline $\begin{array}{l}\text { University of } \\
\underline{\text { Venda }}\end{array}$ & Univen & 1982 & & & 10,968 & Thohoyandou \\
\hline$\frac{\text { Walter Sisulu }}{\text { University }}$ & WSU & 1977 (Unitra) & & & & $\begin{array}{l}\text { East London, } \\
\text { Butterworth, } \\
\text { Mthatha, } \\
\text { Queenstown }\end{array}$ \\
\hline$\frac{\text { University of }}{\text { Zululand }}$ & UniZulu & 1960 & 6,456 & 369 & 6,825 & Empangeni \\
\hline
\end{tabular}




\begin{tabular}{|c|c|c|c|c|c|c|c|}
\hline Nome & Acrónimo & Fundada & $\begin{array}{c}\text { Estatuto de } \\
\text { Universidade } \\
\end{array}$ & Graduados & Posgraduados & Total(2011) & Local \\
\hline $\begin{array}{l}\text { Cape } \\
\text { Peninsula } \\
\text { University } \\
\frac{\text { of }}{\text { Technology }}\end{array}$ & CPUT & 20051 & 2005 & & & 32,000 & $\begin{array}{c}\text { Bellville, Cape } \\
\text { Town }\end{array}$ \\
\hline $\begin{array}{l}\text { Central } \\
\text { University } \\
\text { of } \\
\text { Technology }\end{array}$ & CUT & 1981 & & & & 9,933 & $\begin{array}{l}\text { Bloemfontein, } \\
\text { Welkom }\end{array}$ \\
\hline $\begin{array}{l}\text { Durban } \\
\text { University } \\
\text { of } \\
\text { Technology }\end{array}$ & DUT & 20021 & 2002 & & & 23,000 & $\begin{array}{c}\text { Durban, } \\
\text { Pietermaritzburg }\end{array}$ \\
\hline $\begin{array}{l}\text { Mangosuthu } \\
\text { University } \\
\text { of } \\
\text { Technology }\end{array}$ & MUT & 1979 & & & & & $\underline{\text { Umlazi }}$ \\
\hline $\begin{array}{l}\text { Tshwane } \\
\text { University } \\
\text { of } \\
\text { Technology }\end{array}$ & TUT & 20031 & 2003 & & & 60,000 & $\begin{array}{c}\text { Pretoria, } \\
\text { Nelspruit, } \\
\text { Polokwane, Ga- } \\
\text { Rankuwa, } \\
\text { Soshanguve, } \\
\text { Witbank }\end{array}$ \\
\hline $\begin{array}{l}\frac{\text { Vaal }}{\text { University }} \\
\frac{\text { of }}{\text { Technology }}\end{array}$ & VUT & 1966 & 2003 & & & 17,000 & $\begin{array}{l}\text { Vanderbijlpark, } \\
\text { Secunda, } \\
\text { Kempton Park, } \\
\text { Klerksdorp, } \\
\text { Upington }\end{array}$ \\
\hline
\end{tabular}

\section{Universidades e Colégios Privados}

\begin{tabular}{|c|c|c|c|c|c|}
\hline Nome & Acrónimo & Fundada & Matriculados & Tipo & Local \\
\hline $\begin{array}{l}\text { AFDA, The South } \\
\text { African School of } \\
\text { Motion Picture Medium } \\
\text { and Live Performance }\end{array}$ & AFDA & 1994 & & Film school & Johannesburg \\
\hline $\begin{array}{l}\text { Auckland Park } \\
\text { Theological Seminary }\end{array}$ & ATS & & & $\begin{array}{c}\text { Theological } \\
\text { Seminary }\end{array}$ & Johannesburg \\
\hline $\begin{array}{l}\text { Baptist Theological } \\
\text { College of Southern } \\
\text { Africa }\end{array}$ & & 1951 & & $\begin{array}{l}\text { Theological } \\
\text { Seminary }\end{array}$ & Johannesburg \\
\hline $\begin{array}{l}\text { Boston City Campus and } \\
\text { Business College }\end{array}$ & & 1992 & & & \\
\hline Cornerstone Institute & & 1970 & & $\underline{\text { University }}$ & $\begin{array}{c}\text { Cape Town (Learning } \\
\text { Communities: Johannesburg, } \\
\text { Hatfield, Nelspruit, Witbank, } \\
\text { Eastern Cape, Hermanus, } \\
\text { Helderberg, Plettenberg Bay, } \\
\text { George) }\end{array}$ \\
\hline CTI Education Group & & 1979 & & College & South Africa \\
\hline Damelin & & 1943 & 100000 & Private College & $\begin{array}{c}\text { Durban, Johannesburg, Cape } \\
\text { town, Pretoria, Pietermaritzburg, } \\
\text { East London, Bloemfontein, Port } \\
\text { Elizabeth }\end{array}$ \\
\hline $\begin{array}{l}\text { Doxa Deo School of } \\
\text { Divinity }\end{array}$ & & & & $\begin{array}{c}\text { Theological } \\
\text { Seminary }\end{array}$ & \\
\hline $\begin{array}{l}\text { George Whitefield } \\
\text { College }\end{array}$ & & 1989 & & $\begin{array}{l}\text { Theological } \\
\text { Seminary }\end{array}$ & Cape Town \\
\hline $\begin{array}{l}\text { IMM Graduate School of } \\
\text { Marketing }\end{array}$ & & & & $\begin{array}{l}\text { Marketing } \\
\text { school }\end{array}$ & Johannesburg \\
\hline Inscape Design College & & & & Design college & Johannesburg \\
\hline $\begin{array}{l}\text { Management College of } \\
\text { Southern Africa }\end{array}$ & & 1995 & & College & Durban \\
\hline $\begin{array}{l}\text { Midrand Graduate } \\
\text { Institute }\end{array}$ & MGI & 1989 & & University & $\underline{\text { Midrand }}$ \\
\hline Milpark Business School & & 1997 & & University & $\begin{array}{l}\text { Primarily distance education } \\
\text { (campuses: Johannesburg, }\end{array}$ \\
\hline
\end{tabular}


VNiVERSIDAD

\begin{tabular}{|c|c|c|c|c|c|}
\hline & & & & & Durban, Cape Town) \\
\hline $\begin{array}{l}\text { Oval Education } \\
\text { International }\end{array}$ & $\begin{array}{c}\text { Oval } \\
\text { Campus }\end{array}$ & 1989 & & $\begin{array}{l}\text { Private Higher } \\
\text { Education }\end{array}$ & $\begin{array}{c}\text { Cape Town, Durban, } \\
\text { Johannesburg, Pietermaritzburg, } \\
\text { Limpopo }\end{array}$ \\
\hline $\begin{array}{l}\text { Qualitas Career } \\
\text { Academy }\end{array}$ & & 2008 & & $\begin{array}{l}\text { Private college. } \\
\text { Full-time, part- } \\
\text { time \& } \\
\text { corporate. }\end{array}$ & $\begin{array}{c}\text { Bloemfontein, George, } \\
\text { Kimberley, Newcastle, Table } \\
\text { View, Vanderbijlpark }\end{array}$ \\
\hline Monash South Africa & Monash & 2001 & & University & Johannesburg \\
\hline $\begin{array}{l}\text { [The Open Window } \\
\text { School of Visual } \\
\text { Communication] }\end{array}$ & TOW & 1989 & 486 & $\begin{array}{l}\text { Graphic Design, } \\
\text { Film and } \\
\text { Animation } \\
\text { school. }\end{array}$ & $\underline{\text { Pretoria }}$ \\
\hline $\begin{array}{l}\text { South African } \\
\text { Theological Seminary }\end{array}$ & & 1996 & & $\begin{array}{l}\text { Theological } \\
\text { Seminary }\end{array}$ & $\underline{\text { Johannesburg }}$ \\
\hline $\begin{array}{l}\text { St Augustine College of } \\
\text { South Africa }\end{array}$ & & Jul-99 & & College & $\underline{\text { Johannesburg }}$ \\
\hline $\begin{array}{l}\text { Stenden University } \\
\text { South Africa2 } \\
\end{array}$ & Stenden & $\begin{array}{c}\text { 10-Apr- } \\
02\end{array}$ & & $\begin{array}{c}\text { Hospitality } \\
\text { School }\end{array}$ & $\underline{\text { Port Alfred }}$ \\
\hline Varsity College & & 1993 & & University & $\begin{array}{c}\text { Cape Town, Port Elizabeth, } \\
\text { Pretoria, Durban, Johannesburg, } \\
\text { Pietermaritzburg }\end{array}$ \\
\hline
\end{tabular}

\section{Instituiç̃̃es Fechadas}

\begin{tabular}{|c|c|c|c|c|}
\hline Nome & Local & Fundada & Fechada & Nota \\
\hline Bond South Africa & Sandton & & $2004[21]$ & \\
\hline Border Technikon & & & 2005 & $\begin{array}{c}\text { Now part of Walter Sisulu University for } \\
\text { Technology and Science }\end{array}$ \\
\hline $\begin{array}{l}\text { University of } \\
\text { Bophuthatswana } \\
\end{array}$ & & & & Now part of North-West University \\
\hline $\begin{array}{l}\text { University of the } \\
\text { Cape of Good Hope }\end{array}$ & Cape Town & 1873 & 1916 & $\underline{\text { Renamed University of South Africa }}$ \\
\hline Cape Technikon & & & & $\begin{array}{c}\text { Now part of Cape Peninsula University of } \\
\text { Technology }\end{array}$ \\
\hline $\begin{array}{l}\text { University of Durban- } \\
\text { Westville }\end{array}$ & Durban & 1972 & $\frac{1 \text { January }}{2004[8]}$ & Now part of University of KwaZulu-Natal \\
\hline $\begin{array}{l}\text { Eastern Cape } \\
\text { Technikon }\end{array}$ & & 1994 & 2005 & $\begin{array}{c}\text { Now part of Walter Sisulu University for } \\
\text { Technology and Science }\end{array}$ \\
\hline $\begin{array}{l}\text { Medical University of } \\
\text { South Africa }\end{array}$ & Ga-Rankuwa & 1976 & $\begin{array}{l}\text { 1 January } \\
2005[9] \\
\end{array}$ & Now part of University of Limpopo \\
\hline Technikon Natal & & & & Now part of Durban University of Technology \\
\hline $\begin{array}{l}\text { University of the } \\
\text { North }\end{array}$ & Polokwane & 1959 & $\frac{1 \text { January }}{2005[9]}$ & Now part of University of Limpopo \\
\hline$\underline{\text { University of Natal }}$ & $\begin{array}{c}\text { Pietermaritzburg, } \\
\text { Durban }\end{array}$ & 1910 & $\begin{array}{l}\text { 1 January } \\
\text { 2004[8] } \\
\end{array}$ & Now part of University of KwaZulu-Natal \\
\hline $\begin{array}{l}\text { University of North- } \\
\text { West, formerly the } \\
\text { University of } \\
\text { Bophuthatswana }\end{array}$ & Mafikeng & & $\frac{1 \text { January }}{2004[10]}$ & Now part of North-West University \\
\hline $\begin{array}{l}\text { Port Elizabeth } \\
\text { Technikon }\end{array}$ & $\begin{array}{l}\text { Port Elizabeth, } \\
\text { George }\end{array}$ & $\underline{1882[22]}$ & 2005 & $\begin{array}{c}\text { Now part of Nelson Mandela Metropolitan } \\
\text { University }\end{array}$ \\
\hline $\begin{array}{l}\text { University of Port } \\
\text { Elizabeth }\end{array}$ & Port Elizabeth & 31-Jan-64 & 2005 & $\frac{\text { Now part of Nelson Mandela Metropolitan }}{\text { University }}$ \\
\hline $\begin{array}{l}\text { Potchefstroom } \\
\text { University for } \\
\text { Christian Higher } \\
\text { Education }\end{array}$ & Potchefstroom & $\begin{array}{c}29 \\
\text { November } \\
1869\end{array}$ & $\frac{1 \text { January }}{2004[10]}$ & Now part of North-West University \\
\hline $\begin{array}{l}\text { Rand Afrikaans } \\
\text { University }\end{array}$ & Johannesburg & 1967 & 2005 & Now part of University of Johannesburg \\
\hline Technikon SA & & & 1 January & Now part of University of South Africa \\
\hline $\begin{array}{l}\text { Transvaal University } \\
\text { College }\end{array}$ & $\begin{array}{l}\text { Johannesburg, } \\
\text { Pretoria }\end{array}$ & 1906 & $1910 / 1930$ & $\begin{array}{c}\text { Predecessor of the University of Pretoria and the } \\
\text { University of the Witwatersrand. The University } \\
\text { of the Witwatersrand was named the Transvaal } \\
\text { University College from } 1906 \text { to } 1910 \text {. The } \\
\text { University of Pretoria was established as the } \\
\text { Pretoria branch of the Transvaal University } \\
\text { College in } 1908 \text { and retained that name until } \\
1930 .\end{array}$ \\
\hline
\end{tabular}




\begin{tabular}{|l|c|c|c|c|}
\hline University of Transkei & Transkei & 1977 & 2005 & $\frac{\text { Now part of Walter Sisulu University for }}{\text { Technology and Science }}$ \\
\hline Vista University & $\begin{array}{c}\text { Multi-city campus } \\
\text { university }\end{array}$ & 1981 & $2004 / 2005$ & $\begin{array}{c}\text { Now merged with the Nelson Mandela } \\
\text { Metropolitan University, the University of the } \\
\text { Free State, the University of Johannesburg, the } \\
\text { University of Pretoria, the University of South } \\
\text { Africa and the Vaal University of Technology. }\end{array}$ \\
\hline$\underline{\text { Technikon }}$ & Johannesburg & 1925 & 2005 & $\underline{\text { University of Johannesburg }}$ \\
\hline
\end{tabular}

$\underline{\text { Referencias }}$

1. SA Higher Education, South African Universities Vice-Chancellors Association. Retrieved 30 January 2012.

2. HESA Structures (2005). Higher Education South Africa. Retrieved 24 February 2012.

3. http://www.uct.ac.za/about/intro/history/ Our history Retrieved 13 May 2011

4. http://www.thepresidency.gov.za/pebble.asp?relid=1042 University of Fort Hare (1916-) Retrieved 14 May 2011

5. http://www.ufs.ac.za/content.aspx?id=11 Brief History Retrieved 28 April 2011

6. http://www.sarua.org/?q=uni_University\%20of\%20the\%20Free\%20State University of the Free State Retrieved 13 May 2011

7. http://www.ufs.ac.za/content.aspx?cid=19 About the UFS Retrieved 17 January 2010

8. http://www.ukzn.ac.za/About-UKZN/UKZN-History.aspx History - University of KwaZulu-Natal Retrieved 13 May 2011

9. http://www.ul.ac.za/index.php?Entity=UL\%20Historical\%20Background UL Historical Background Retrieved 13 May 2011

10. http://www.nwu.ac.za/nwu/history.html THE NWU Retrieved 14 May 2011

11. Welcome to the University of Pretoria Retrieved 1 October 2011

12. http://web.up.ac.za/default.asp?ipkCategoryID $=2 \&$ subid=2\&ipklookid=2 History of the University of Pretoria. Retrieved 31 August 2011.

13. http://www.artefacts.co.za/main/Buildings/style_det.php?styleid=368 Retrieved 21 May 2011

14. http://web.up.ac.za/sitefiles/file/web-team/UP\%20in\%20a\%20Nutshell\%202009.pdf UP in a Nutshell 2009. Retrieved 31 August 2011.

15. Campuses Retrieved 1 October 2011

16. http://www.ru.ac.za/rhodes/introducingrhodes/historyofrhodes Rhodes History of Rhodes Retrieved 28 April 2011

17. http://www.sun.ac.za/university/history/history.htm Retrieved 13 May 2011

18. "Stellenbosch University Statistical Profile 2012", Official Stellenbosch University Website, SU Consensus, June 2012 19.

http://www.uwc.ac.za/index.php?module=cms\&action=showfulltext\&id=gen11Srv7Nme54_8987_1210050562\&menustate=abo ut Retrieved 13 May 2011

20. http://www.wits.ac.za/aboutwits/introducingwits/short-history-of-theuniversity/3162/short_history_of_the_university.html Retrieved 13 May 2011

21. The Observatory on Borderless Higher Education (2004). Breaking News Archive - June 2004. Retrieved 2 February 2008.

22. "Port Elizabeth (PE) Technikon". Study South Africa. Retrieved 25 November 2013.

23. http://www.unisa.ac.za/Default.asp?Cmd=ViewContent\&ContentID=7 Our history Retrieved 28 April 2011 
VNIVERSIDAD

ĐSALAMANCA 
Anexo 7 - Total de Matriculas no ensino superior. Público e privado. Full e part time. Total - 2000 - 2011

Rácio bruto de graduação, ISCED 5A $10^{\circ}$ Curso (\%)

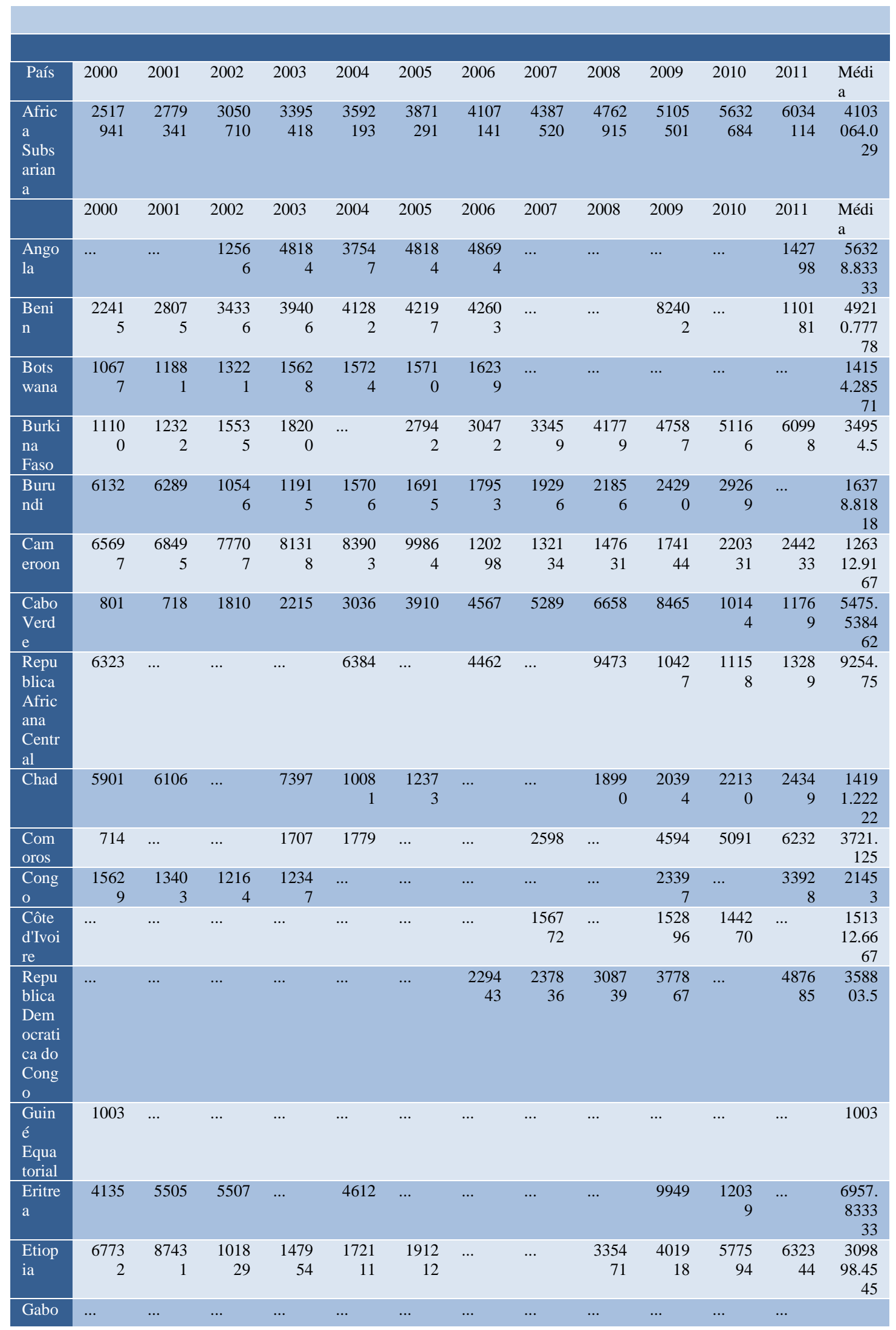


VNIVERSIDAD

DSALAMANCA

\begin{tabular}{|c|c|c|c|c|c|c|c|c|c|c|c|c|c|}
\hline $\mathrm{n}$ & & & & & & & & & & & & & \\
\hline $\begin{array}{l}\text { Gam } \\
\text { bia }\end{array}$ & 1212 & $\ldots$ & $\ldots$ & $\ldots$ & 1530 & $\ldots$ & $\ldots$ & $\ldots$ & 6489 & $\ldots$ & $\ldots$ & $\ldots$ & 3077 \\
\hline Gana & $\ldots$ & $\ldots$ & $\ldots$ & $\ldots$ & $\ldots$ & $\begin{array}{r}1195 \\
59\end{array}$ & $\begin{array}{r}1101 \\
84\end{array}$ & $\begin{array}{r}1400 \\
17\end{array}$ & $\begin{array}{r}1902 \\
73\end{array}$ & $\begin{array}{r}2033 \\
76\end{array}$ & $\ldots$ & $\begin{array}{r}2858 \\
62\end{array}$ & $\begin{array}{r}1920 \\
87.85 \\
71\end{array}$ \\
\hline $\begin{array}{l}\text { Guin } \\
\text { é }\end{array}$ & $\ldots$ & $\ldots$ & $\ldots$ & $\begin{array}{r}1685 \\
8\end{array}$ & $\begin{array}{r}1721 \\
8\end{array}$ & $\begin{array}{r}2378 \\
8\end{array}$ & $\begin{array}{r}4271 \\
1\end{array}$ & $\begin{array}{r}6826 \\
1\end{array}$ & $\begin{array}{r}8022 \\
2\end{array}$ & $\begin{array}{r}8388 \\
7\end{array}$ & $\begin{array}{r}9852 \\
8\end{array}$ & $\begin{array}{r}1031 \\
92\end{array}$ & $\begin{array}{r}6358 \\
3.8\end{array}$ \\
\hline $\begin{array}{l}\text { Guin } \\
\text { é- } \\
\text { Bissa } \\
\text { u }\end{array}$ & $\ldots$ & $\ldots$ & $\ldots$ & $\ldots$ & $\ldots$ & 3122 & 3689 & $\ldots$ & $\ldots$ & $\ldots$ & $\ldots$ & $\ldots$ & $\begin{array}{r}3405 \\
5\end{array}$ \\
\hline $\begin{array}{l}\text { Keni } \\
\text { a }\end{array}$ & $\begin{array}{r}8901 \\
6\end{array}$ & $\begin{array}{r}9462 \\
9\end{array}$ & $\begin{array}{r}9811 \\
5\end{array}$ & $\ldots$ & $\begin{array}{r}1084 \\
07\end{array}$ & $\begin{array}{r}1135 \\
32\end{array}$ & $\ldots$ & $\ldots$ & $\ldots$ & $\begin{array}{r}1679 \\
83\end{array}$ & $\ldots$ & $\ldots$ & $\begin{array}{r}1119 \\
47\end{array}$ \\
\hline $\begin{array}{l}\text { Lesot } \\
\text { o }\end{array}$ & 4470 & 4976 & 5005 & 6108 & $\ldots$ & 7918 & 8500 & $\ldots$ & $\ldots$ & $\ldots$ & $\ldots$ & $\ldots$ & $\begin{array}{r}8926 . \\
2857 \\
14\end{array}$ \\
\hline $\begin{array}{l}\text { Liber } \\
\text { ia }\end{array}$ & $\begin{array}{r}5225 \\
1\end{array}$ & $\ldots$ & $\ldots$ & $\ldots$ & $\ldots$ & $\ldots$ & $\ldots$ & $\ldots$ & $\ldots$ & $\ldots$ & $\begin{array}{r}3347 \\
0\end{array}$ & $\ldots$ & $\begin{array}{r}4320 \\
1.333 \\
33\end{array}$ \\
\hline Mada & 3204 & 3071 & 3192 & 3548 & 4214 & 4494 & 4968 & 5831 & 6206 & 6846 & 7444 & 8554 & 5430 \\
\hline $\begin{array}{l}\text { gasca } \\
\mathrm{r}\end{array}$ & 6 & 2 & 5 & 0 & 3 & 8 & 0 & 3 & 9 & 0 & 4 & 8 & $\begin{array}{r}7.923 \\
08\end{array}$ \\
\hline $\begin{array}{l}\text { Mala } \\
\text { wi }\end{array}$ & 3584 & 4129 & 4531 & 4757 & 5782 & 5810 & 6298 & 6458 & $\ldots$ & $\ldots$ & $\begin{array}{r}1029 \\
6\end{array}$ & $\begin{array}{r}1220 \\
3\end{array}$ & $\begin{array}{r}6384 . \\
8\end{array}$ \\
\hline Mali & $\begin{array}{r}1975 \\
1\end{array}$ & $\begin{array}{r}2186 \\
1\end{array}$ & $\begin{array}{r}2263 \\
2\end{array}$ & $\ldots$ & $\ldots$ & $\ldots$ & $\ldots$ & $\begin{array}{r}5942 \\
8\end{array}$ & $\begin{array}{r}6783 \\
9\end{array}$ & $\begin{array}{r}7666 \\
7\end{array}$ & $\begin{array}{r}8118 \\
8\end{array}$ & $\begin{array}{r}8765 \\
3\end{array}$ & $\begin{array}{r}5936 \\
6.333 \\
33\end{array}$ \\
\hline $\begin{array}{l}\text { Maur } \\
\text { itius }\end{array}$ & $\begin{array}{r}1213 \\
0\end{array}$ & $\begin{array}{r}1877 \\
9\end{array}$ & $\begin{array}{r}1685 \\
9\end{array}$ & $\begin{array}{r}1695 \\
5\end{array}$ & $\begin{array}{r}1762 \\
7\end{array}$ & $\begin{array}{r}2051 \\
4\end{array}$ & $\begin{array}{r}2222 \\
1\end{array}$ & $\begin{array}{r}2297 \\
1\end{array}$ & $\begin{array}{r}2557 \\
8\end{array}$ & $\begin{array}{r}3054 \\
5\end{array}$ & $\begin{array}{r}3342 \\
7\end{array}$ & $\begin{array}{r}3590 \\
6\end{array}$ & $\begin{array}{r}2412 \\
9\end{array}$ \\
\hline $\begin{array}{l}\text { Moça } \\
\text { mbiq } \\
\text { ue }\end{array}$ & $\begin{array}{r}1161 \\
9\end{array}$ & $\ldots$ & $\ldots$ & $\begin{array}{r}1722 \\
5\end{array}$ & $\begin{array}{r}2225 \\
6\end{array}$ & $\begin{array}{r}2829 \\
8\end{array}$ & $\ldots$ & $\ldots$ & $\begin{array}{r}7545 \\
7\end{array}$ & $\begin{array}{r}8407 \\
4\end{array}$ & $\ldots$ & $\begin{array}{r}1134 \\
64\end{array}$ & $\begin{array}{r}5034 \\
1.857 \\
14\end{array}$ \\
\hline $\begin{array}{l}\text { Nami } \\
\text { bia }\end{array}$ & $\ldots$ & $\begin{array}{r}1333 \\
9\end{array}$ & $\begin{array}{r}1103 \\
0\end{array}$ & $\begin{array}{r}1178 \\
8\end{array}$ & $\ldots$ & $\begin{array}{r}1356 \\
6\end{array}$ & $\begin{array}{r}1318 \\
5\end{array}$ & $\ldots$ & $\begin{array}{r}1970 \\
7\end{array}$ & $\ldots$ & $\ldots$ & $\ldots$ & $\begin{array}{r}1376 \\
9.166 \\
67\end{array}$ \\
\hline Niger & $\ldots$ & $\ldots$ & $\ldots$ & 8850 & 8774 & $\begin{array}{r}1079 \\
9\end{array}$ & $\begin{array}{r}1120 \\
8\end{array}$ & $\begin{array}{r}1086 \\
9\end{array}$ & $\begin{array}{r}1282 \\
3\end{array}$ & $\begin{array}{r}1599 \\
2\end{array}$ & $\begin{array}{r}1709 \\
6\end{array}$ & $\begin{array}{r}1832 \\
8\end{array}$ & $\begin{array}{r}1365 \\
0.3\end{array}$ \\
\hline $\begin{array}{l}\text { Niger } \\
\text { ia }\end{array}$ & $\ldots$ & $\ldots$ & $\ldots$ & $\begin{array}{r}1234 \\
219\end{array}$ & $\begin{array}{r}1289 \\
656\end{array}$ & $\begin{array}{r}1391 \\
527\end{array}$ & $\ldots$ & $\ldots$ & $\ldots$ & $\ldots$ & $\ldots$ & $\ldots$ & $\begin{array}{r}1305 \\
134\end{array}$ \\
\hline $\begin{array}{l}\text { Ruan } \\
\text { da }\end{array}$ & 9357 & $\begin{array}{r}1280 \\
2\end{array}$ & $\begin{array}{r}1594 \\
0\end{array}$ & $\begin{array}{r}2039 \\
3\end{array}$ & $\begin{array}{r}2523 \\
3\end{array}$ & $\begin{array}{r}2778 \\
7\end{array}$ & $\begin{array}{r}3714 \\
9\end{array}$ & $\begin{array}{r}4101 \\
3\end{array}$ & $\begin{array}{r}4512 \\
8\end{array}$ & $\begin{array}{r}5521 \\
3\end{array}$ & $\begin{array}{r}6273 \\
4\end{array}$ & $\begin{array}{r}7367 \\
4\end{array}$ & $\begin{array}{r}3831 \\
2.384 \\
62\end{array}$ \\
\hline $\begin{array}{l}\text { Sao } \\
\text { Tom } \\
\text { e e } \\
\text { Princ } \\
\text { ipe } \\
\end{array}$ & & . & . & . & . & $\cdot$ & . & . & . & 704 & 766 & $\ldots$ & $\begin{array}{r}963.6 \\
6666 \\
67\end{array}$ \\
\hline $\begin{array}{l}\text { Sene } \\
\text { gal }\end{array}$ & $\ldots$ & $\ldots$ & $\ldots$ & $\ldots$ & $\begin{array}{r}5228 \\
2\end{array}$ & $\begin{array}{r}5912 \\
7\end{array}$ & $\begin{array}{r}6253 \\
9\end{array}$ & $\begin{array}{r}7121 \\
1\end{array}$ & $\begin{array}{r}9135 \\
9\end{array}$ & $\begin{array}{r}9437 \\
1\end{array}$ & $\begin{array}{r}9210 \\
6\end{array}$ & $\ldots$ & $\begin{array}{r}7471 \\
3.571 \\
43\end{array}$ \\
\hline $\begin{array}{l}\text { Seich } \\
\text { elles }\end{array}$ & $\cdot$ & . & . & . & . & . & . & . & . & $\ldots$ & $\ldots$ & 189 & 146 \\
\hline $\begin{array}{l}\text { Sierr } \\
\text { a } \\
\text { Leon } \\
\mathrm{e}\end{array}$ & 6744 & 8913 & 9041 & $\ldots$ & $\ldots$ & $\ldots$ & $\ldots$ & $\ldots$ & $\ldots$ & $\ldots$ & $\ldots$ & $\ldots$ & $\begin{array}{r}8232 . \\
6666 \\
67\end{array}$ \\
\hline $\begin{array}{l}\text { Soma } \\
\text { lia }\end{array}$ & $\ldots$ & $\ldots$ & $\ldots$ & $\ldots$ & $\ldots$ & $\cdots$ & $\cdots$ & $\cdots$ & $\cdots$ & $\ldots$ & $\ldots$ & $\cdots$ & \\
\hline $\begin{array}{l}\text { Afric } \\
\text { a do } \\
\text { Sul } \\
\end{array}$ & $\ldots$ & $\ldots$ & $\ldots$ & $\ldots$ & $\ldots$ & $\ldots$ & $\ldots$ & $\ldots$ & $\ldots$ & $\ldots$ & $\ldots$ & $\ldots$ & \\
\hline $\begin{array}{l}\text { Swaz } \\
\text { iland }\end{array}$ & 4738 & 4761 & 5193 & 5369 & 6594 & 5897 & 5692 & $\ldots$ & $\ldots$ & $\ldots$ & $\ldots$ & 8904 & $\begin{array}{r}5893 . \\
5\end{array}$ \\
\hline Togo & $\ldots$ & $\ldots$ & $\ldots$ & $\ldots$ & $\ldots$ & $\ldots$ & $\begin{array}{r}2807 \\
6\end{array}$ & $\begin{array}{r}3250 \\
2\end{array}$ & $\ldots$ & $\ldots$ & $\begin{array}{r}5595 \\
9\end{array}$ & $\begin{array}{r}6349 \\
6\end{array}$ & $\begin{array}{r}4913 \\
0\end{array}$ \\
\hline $\begin{array}{l}\text { Ugan } \\
\text { da }\end{array}$ & $\begin{array}{r}5576 \\
7\end{array}$ & $\begin{array}{r}6258 \\
6\end{array}$ & $\begin{array}{r}7995 \\
8\end{array}$ & $\begin{array}{r}8833 \\
0\end{array}$ & $\begin{array}{r}8836 \\
0\end{array}$ & $\ldots$ & $\begin{array}{r}9260 \\
5\end{array}$ & $\ldots$ & $\begin{array}{r}1077 \\
28\end{array}$ & $\begin{array}{r}1238 \\
87\end{array}$ & $\ldots$ & $\begin{array}{r}2895 \\
45\end{array}$ & $\begin{array}{r}1098 \\
62.88 \\
89\end{array}$ \\
\hline $\begin{array}{l}\text { Repu } \\
\text { blica } \\
\text { Unid }\end{array}$ & $\begin{array}{r}2074 \\
0\end{array}$ & $\begin{array}{r}2196 \\
0\end{array}$ & $\begin{array}{r}2360 \\
3\end{array}$ & $\begin{array}{r}3104 \\
9\end{array}$ & $\begin{array}{r}4294 \\
8\end{array}$ & $\begin{array}{r}5155 \\
4\end{array}$ & $\ldots$ & $\ldots$ & $\ldots$ & $\ldots$ & $\begin{array}{r}8511 \\
3\end{array}$ & $\ldots$ & $\begin{array}{r}5537 \\
2.625\end{array}$ \\
\hline
\end{tabular}


IN 5 T I T UT

:

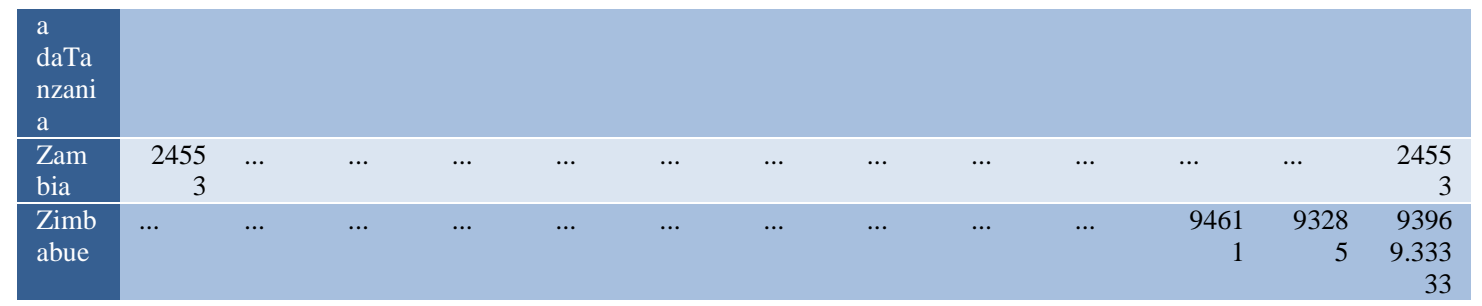

Fonte: Dados obtidos e adaptados em Unesco Institute for Statistics, Higher Education Data 


\section{Anexo 8 - Rácio de graduação no ensino superior de acordo com a area de curso, ISCED 5A 1. Curso (\%), Média 2000-2012}

\begin{tabular}{|c|c|c|c|c|c|c|c|c|}
\hline & $\begin{array}{l}\text { Humani } \\
\text { dades e } \\
\text { Artes }\end{array}$ & $\begin{array}{l}\text { Ciências } \\
\text { Sociais, } \\
\text { Gestão e } \\
\text { Direito }\end{array}$ & $\begin{array}{l}\text { Ciên } \\
\text { cias }\end{array}$ & $\begin{array}{c}\text { Engenharia } \\
\text { s, materiais } \\
\text { e } \\
\text { Construção }\end{array}$ & $\begin{array}{l}\text { Agri } \\
\text { cultu } \\
\text { ra }\end{array}$ & Saúde & Serviços & $\begin{array}{c}\text { Progra } \\
\text { mas } \\
\text { Gerais }\end{array}$ \\
\hline Angola & & $4,648.000$ & $\begin{array}{r}1,220 \\
.000\end{array}$ & $1,079.000$ & & $\begin{array}{r}934.0 \\
00\end{array}$ & & $\begin{array}{r}335.00 \\
0\end{array}$ \\
\hline Benin & $\begin{array}{r}23,494.0 \\
00\end{array}$ & $44,311.000$ & $\begin{array}{r}9,459 \\
.000\end{array}$ & $3,510.000$ & $\begin{array}{r}1,532 \\
.000\end{array}$ & $\begin{array}{r}2,313 \\
500\end{array}$ & $\begin{array}{r}1,894.50 \\
0\end{array}$ & $\begin{array}{r}7,658.0 \\
00\end{array}$ \\
\hline \multicolumn{9}{|l|}{ Botswana } \\
\hline Burkina Faso & $\begin{array}{r}8,078.57 \\
1\end{array}$ & $25,526.286$ & $\begin{array}{r}6,626 \\
.000\end{array}$ & $1,292.714$ & $\begin{array}{r}447.5 \\
00\end{array}$ & $\begin{array}{r}2,908 \\
714\end{array}$ & 694.143 & 69.000 \\
\hline Burundi & $\begin{array}{r}1,482.00 \\
0\end{array}$ & $2,978.000$ & $\begin{array}{r}512.0 \\
00\end{array}$ & 500.000 & $\begin{array}{r}392.0 \\
00\end{array}$ & $\begin{array}{r}672.0 \\
00\end{array}$ & & $\begin{array}{r}1,349.0 \\
00\end{array}$ \\
\hline Cameroon & $\begin{array}{r}16,383.5 \\
71\end{array}$ & $86,251.857$ & $\begin{array}{l}28,05 \\
7.000\end{array}$ & $6,388.714$ & $\begin{array}{r}786.2 \\
86\end{array}$ & $\begin{array}{r}3,010 \\
143\end{array}$ & 711.200 & $\begin{array}{r}10,403 . \\
000\end{array}$ \\
\hline Cabo Verde & 338.400 & $4,897.800$ & $\begin{array}{r}969.4 \\
00\end{array}$ & $1,004.000$ & $\begin{array}{r}51.00 \\
0\end{array}$ & $\begin{array}{r}688.4 \\
00\end{array}$ & 241.800 & $\begin{array}{r}166.80 \\
0\end{array}$ \\
\hline $\begin{array}{l}\text { Republica da Africa } \\
\text { Central }\end{array}$ & $\begin{array}{r}4,128.50 \\
0\end{array}$ & $4,327.000$ & $\begin{array}{r}1,405 \\
.000\end{array}$ & 377.500 & $\begin{array}{r}263.5 \\
00\end{array}$ & $\begin{array}{r}1,073 \\
000\end{array}$ & 37.000 & \\
\hline \multicolumn{9}{|l|}{ Chad } \\
\hline Comoros & 914.500 & $2,062.500$ & $\begin{array}{r}562.5 \\
00\end{array}$ & 75.000 & & $\begin{array}{r}176.0 \\
00\end{array}$ & 286.000 & \\
\hline Congo & $\begin{array}{r}2,101.00 \\
0\end{array}$ & $6,598.500$ & $\begin{array}{r}1,422 \\
.000\end{array}$ & 116.000 & $\begin{array}{r}397.0 \\
00\end{array}$ & $\begin{array}{r}411.0 \\
00\end{array}$ & 27.000 & $\begin{array}{r}1,579.0 \\
00\end{array}$ \\
\hline Côte d'Ivoire & $\begin{array}{r}19,266.6 \\
67\end{array}$ & $73,188.000$ & $\begin{array}{l}18,29 \\
6.000\end{array}$ & $12,025.000$ & $\begin{array}{r}620.6 \\
67\end{array}$ & $\begin{array}{r}9,392 \\
333\end{array}$ & $\begin{array}{r}6,483.66 \\
7\end{array}$ & $\begin{array}{r}6,306.0 \\
00\end{array}$ \\
\hline $\begin{array}{l}\text { Republica Democrática } \\
\text { do Congo }\end{array}$ & $\begin{array}{r}17,086.5 \\
00\end{array}$ & $\begin{array}{r}183,263.50 \\
0\end{array}$ & $\begin{array}{l}14,23 \\
9.000\end{array}$ & $31,163.000$ & $\begin{array}{l}33,87 \\
9.000\end{array}$ & $\begin{array}{r}116,4 \\
33.00 \\
0\end{array}$ & $\begin{array}{r}4,328.50 \\
0\end{array}$ & $\begin{array}{r}27,736 \\
500\end{array}$ \\
\hline \multicolumn{9}{|l|}{ Guiné Equatorial } \\
\hline Eritrea & 408.000 & $1,389.500$ & $\begin{array}{r}832.5 \\
00\end{array}$ & $1,865.000$ & $\begin{array}{r}801.0 \\
00\end{array}$ & $\begin{array}{r}722.5 \\
00\end{array}$ & & \\
\hline Etiopia & $\begin{array}{r}8,908.12 \\
5\end{array}$ & $70,722.875$ & $\begin{array}{l}16,82 \\
1.500\end{array}$ & $16,675.625$ & $\begin{array}{l}12,81 \\
4.750\end{array}$ & $\begin{array}{l}12,54 \\
4.625\end{array}$ & 360.000 & $\begin{array}{r}504.42 \\
9\end{array}$ \\
\hline \multicolumn{9}{|l|}{ Gabon } \\
\hline Gambia & 529.000 & 288.000 & $\begin{array}{r}314.0 \\
00\end{array}$ & & & $\begin{array}{r}231.0 \\
00\end{array}$ & & $\begin{array}{r}113.00 \\
0\end{array}$ \\
\hline Gana & & $\begin{array}{r}122,195.00 \\
0\end{array}$ & $\begin{array}{l}25,32 \\
7.750\end{array}$ & $18,965.250$ & $\begin{array}{r}8,258 \\
.750\end{array}$ & $\begin{array}{r}9,523 \\
250\end{array}$ & $\begin{array}{r}2,426.50 \\
0\end{array}$ & $\begin{array}{r}2,241.0 \\
00\end{array}$ \\
\hline Guiné & $\begin{array}{r}7,895.50 \\
0\end{array}$ & $18,539.250$ & $\begin{array}{l}10,95 \\
8.000\end{array}$ & $4,730.667$ & $\begin{array}{r}4,656 \\
.000\end{array}$ & $\begin{array}{r}5,139 \\
250\end{array}$ & $\begin{array}{r}1,240.25 \\
0\end{array}$ & $\begin{array}{r}659.00 \\
0\end{array}$ \\
\hline \multicolumn{9}{|l|}{ Guiné-Bissau } \\
\hline Kenia & $\begin{array}{r}7,008.50 \\
0\end{array}$ & $19,560.500$ & $\begin{array}{r}9,666 \\
.000\end{array}$ & $17,043.500$ & $\begin{array}{r}6,795 \\
.000\end{array}$ & $\begin{array}{r}8,685 \\
000\end{array}$ & 766.500 & $\begin{array}{r}1,138.5 \\
00\end{array}$ \\
\hline Lesoto & 649.000 & $2,636.000$ & $\begin{array}{r}1,838 \\
.000\end{array}$ & 52.000 & $\begin{array}{r}89.00 \\
0\end{array}$ & $\begin{array}{r}86.00 \\
0\end{array}$ & & \\
\hline Liberia & $\begin{array}{r}9,336.33 \\
3\end{array}$ & $17,256.333$ & $\begin{array}{r}3,365 \\
.333\end{array}$ & $1,965.333$ & $\begin{array}{r}1,829 \\
.667\end{array}$ & $\begin{array}{r}5,767 \\
667\end{array}$ & $\begin{array}{r}3,525.00 \\
0\end{array}$ & $\begin{array}{r}1,149.5 \\
00\end{array}$ \\
\hline Madagascar & $\begin{array}{r}7,035.12 \\
5\end{array}$ & $37,580.000$ & $\begin{array}{r}8,107 \\
.375\end{array}$ & $4,623.750$ & $\begin{array}{r}1,589 \\
.750\end{array}$ & $\begin{array}{r}5,295 \\
375\end{array}$ & 605.875 & $\begin{array}{r}364.71 \\
4\end{array}$ \\
\hline \multicolumn{9}{|l|}{ Malawi } \\
\hline Mali & $\begin{array}{r}21,122.6 \\
00\end{array}$ & $39,764.200$ & $\begin{array}{r}5,253 \\
.000\end{array}$ & $1,189.800$ & $\begin{array}{r}957.2 \\
00\end{array}$ & $\begin{array}{r}5,808 \\
200\end{array}$ & 678.600 & $\begin{array}{r}1,840.6 \\
00\end{array}$ \\
\hline Mauritius & $\begin{array}{r}2,314.50 \\
0\end{array}$ & $21,026.000$ & $\begin{array}{r}4,472 \\
.000\end{array}$ & $2,807.000$ & $\begin{array}{r}359.5 \\
00\end{array}$ & $\begin{array}{r}1,858 \\
500\end{array}$ & 915.000 & $\begin{array}{r}143.00 \\
0\end{array}$ \\
\hline Moçambique & $\begin{array}{r}3,809.80 \\
0\end{array}$ & $26,873.000$ & $\begin{array}{r}4,613 \\
.000\end{array}$ & $4,855.400$ & $\begin{array}{r}2,779 \\
.200\end{array}$ & $\begin{array}{r}2,651 \\
600\end{array}$ & $\begin{array}{r}1,405.80 \\
0\end{array}$ & $\begin{array}{r}138.00 \\
0\end{array}$ \\
\hline Namibia & $\begin{array}{r}1,537.00 \\
0\end{array}$ & $6,500.500$ & $\begin{array}{r}1,439 \\
.500\end{array}$ & 533.000 & $\begin{array}{r}472.5 \\
00\end{array}$ & $\begin{array}{r}779.5 \\
00\end{array}$ & 299.000 & $\begin{array}{r}179.50 \\
0\end{array}$ \\
\hline Niger & $\begin{array}{r}2,198.00 \\
0\end{array}$ & $7,346.000$ & $\begin{array}{r}1,558 \\
.000\end{array}$ & 367.667 & $\begin{array}{r}403.4 \\
29\end{array}$ & $\begin{array}{r}2,819 \\
143\end{array}$ & 632.000 & $\begin{array}{r}682.60 \\
0\end{array}$ \\
\hline
\end{tabular}




\section{N 5 T I T U T Q \\ :}

\begin{tabular}{|c|c|c|c|c|c|c|c|c|c|}
\hline Nigeria & & & & & & & & & \\
\hline Ruanda & $\begin{array}{r}3,768.00 \\
0\end{array}$ & $40,047.000$ & $\begin{array}{r}9,652 \\
.000\end{array}$ & $3,900.000$ & $\begin{array}{r}5,102 \\
.000\end{array}$ & $\begin{array}{r}4,886 \\
000\end{array}$ & \multicolumn{2}{|l|}{$\begin{array}{r}1,433.00 \\
0\end{array}$} & \\
\hline \multicolumn{10}{|l|}{ Sao Tome e Principe } \\
\hline \multicolumn{10}{|l|}{ Senegal } \\
\hline Seichelles & 7.000 & 39.500 & $\begin{array}{r}13.00 \\
0\end{array}$ & & & & \multicolumn{3}{|c|}{6.000} \\
\hline Sierra Leone & $\begin{array}{r}1,366.50 \\
0\end{array}$ & 686.500 & $\begin{array}{r}372.0 \\
00\end{array}$ & 64.500 & $\begin{array}{r}844.0 \\
00\end{array}$ & $\begin{array}{r}268.0 \\
00\end{array}$ & \multicolumn{2}{|l|}{47.500} & \\
\hline \multicolumn{10}{|l|}{ Somalia } \\
\hline \multicolumn{10}{|l|}{ Africa do sul } \\
\hline Suaziland & 928.600 & $2,009.800$ & $\begin{array}{r}274.4 \\
00\end{array}$ & 259.800 & $\begin{array}{r}272.2 \\
00\end{array}$ & $\begin{array}{r}429.0 \\
00\end{array}$ & 65.750 & 22.000 & \\
\hline \multicolumn{10}{|l|}{ Togo } \\
\hline Uganda & $\begin{array}{r}3,421.00 \\
0\end{array}$ & $24,325.000$ & $\begin{array}{r}1,888 \\
.000\end{array}$ & $4,725.000$ & $\begin{array}{r}1,615 \\
.000\end{array}$ & $\begin{array}{r}3,037 \\
000\end{array}$ & $\begin{array}{r}2,354.33 \\
3\end{array}$ & $\begin{array}{rr}3 & 1,107.0 \\
3 & 00\end{array}$ & \\
\hline $\begin{array}{l}\text { Republica Unida da } \\
\text { Tanzania }\end{array}$ & $\begin{array}{r}6,614.00 \\
0\end{array}$ & $68,391.000$ & $\begin{array}{r}8,318 \\
.000\end{array}$ & $5,846.000$ & $\begin{array}{r}1,636 \\
.000\end{array}$ & $\begin{array}{r}7,424 \\
000\end{array}$ & $\begin{array}{r}1,514.00 \\
0\end{array}$ & $\begin{array}{r}6,499.0 \\
00\end{array}$ & \\
\hline \multicolumn{10}{|l|}{ Zambia } \\
\hline \multirow[t]{3}{*}{ Zimbabue } & $\begin{array}{r}10,041.0 \\
00\end{array}$ & $36,081.667$ & $\begin{array}{r}7,101 \\
.667\end{array}$ & $11,867.000$ & $\begin{array}{r}2,296 \\
.333\end{array}$ & $\begin{array}{r}5,961 \\
000\end{array}$ & \multicolumn{2}{|c|}{$\begin{array}{rr}1,744.66 & 5,440.0 \\
7 & 00\end{array}$} & \\
\hline & \multicolumn{8}{|c|}{$\begin{array}{l}\text { Rácio de graduação no ensino superior de acordo com a área de curso, ISCED 5A 1. Curso } \\
(\%) \text {, Média 2000-2012 }\end{array}$} & \\
\hline & $\begin{array}{c}\text { Humanid } \\
\text { ades e } \\
\text { Artes }\end{array}$ & $\begin{array}{l}\text { Ciências } \\
\text { Sociais, } \\
\text { Gestão e } \\
\text { Direito }\end{array}$ & $\begin{array}{l}\text { Ciên } \\
\text { cias }\end{array}$ & $\begin{array}{c}\text { Engenharias, } \\
\text { materiais e } \\
\text { Construção }\end{array}$ & $\begin{array}{l}\text { Agric } \\
\text { ultura }\end{array}$ & Saúde & $\begin{array}{l}\text { Serv } \\
\text { iços }\end{array}$ & $\begin{array}{l}\text { Programas } \\
\text { Gerais }\end{array}$ & Total \\
\hline Africa Subsariana & $\begin{array}{r}192171.2 \\
9\end{array}$ & 1001310.07 & $\begin{array}{r}2049 \\
52.93\end{array}$ & 159867.22 & $\begin{array}{r}9194 \\
0.23\end{array}$ & $\begin{array}{r}22192 \\
8.70\end{array}$ & $\begin{array}{r}347 \\
17.5 \\
8\end{array}$ & 77830.14 & $\begin{array}{r}8462418.1 \\
6\end{array}$ \\
\hline
\end{tabular}

Fonte: Dados obtidos e adaptados em UNESCO Institute for Statistics, Higher Education Data 


\begin{tabular}{|c|c|c|c|c|c|c|c|c|c|c|c|c|c|}
\hline Ano & 2000 & $\begin{array}{l}20 \\
01\end{array}$ & $\begin{array}{l}200 \\
2\end{array}$ & 2003 & 2004 & 2005 & $\begin{array}{l}200 \\
6\end{array}$ & $\begin{array}{l}200 \\
7\end{array}$ & $\begin{array}{l}200 \\
8\end{array}$ & $\begin{array}{l}200 \\
9\end{array}$ & $\begin{array}{l}201 \\
0\end{array}$ & $\begin{array}{l}201 \\
1\end{array}$ & $\begin{array}{l}201 \\
2\end{array}$ \\
\hline \multicolumn{14}{|l|}{ País } \\
\hline $\begin{array}{l}\text { Sub-Saharan } \\
\text { Africa }\end{array}$ & $\cdots$ & $\cdots$ & $\cdots$ & $\cdots$ & $\cdots$ & $\ldots$ & $\cdots$ & $\cdots$ & $\cdots$ & $\cdots$ & $\cdots$ & $\cdots$ & $\cdots$ \\
\hline Angola & $\ldots$ & $\ldots$ & $\begin{array}{r}125 \\
66\end{array}$ & $\begin{array}{r}4818 \\
4\end{array}$ & $\begin{array}{r}3754 \\
7\end{array}$ & $\begin{array}{r}4818 \\
4\end{array}$ & $\begin{array}{r}486 \\
94\end{array}$ & $\ldots$ & $\ldots$ & $\ldots$ & $\ldots$ & $\begin{array}{l}142 \\
798\end{array}$ & $\ldots$ \\
\hline Benin & 22415 & $\begin{array}{r}28 \\
07 \\
5\end{array}$ & $\begin{array}{r}343 \\
36\end{array}$ & $\begin{array}{r}3940 \\
6\end{array}$ & $\begin{array}{r}4128 \\
2\end{array}$ & $\begin{array}{r}4219 \\
7\end{array}$ & $\begin{array}{r}426 \\
03\end{array}$ & $\ldots$ & $\cdots$ & $\begin{array}{r}824 \\
02\end{array}$ & $\ldots$ & $\begin{array}{l}110 \\
181\end{array}$ & $\ldots$ \\
\hline Botswana & 10677 & $\begin{array}{r}11 \\
88 \\
1\end{array}$ & $\begin{array}{r}132 \\
21\end{array}$ & $\begin{array}{r}1562 \\
8\end{array}$ & $\begin{array}{r}1572 \\
4\end{array}$ & $\begin{array}{r}1571 \\
0\end{array}$ & $\begin{array}{r}162 \\
39\end{array}$ & $\cdots$ & $\cdots$ & $\cdots$ & $\cdots$ & $\ldots$ & $\ldots$ \\
\hline Burkina Faso & 11100 & $\begin{array}{r}12 \\
32 \\
2\end{array}$ & $\begin{array}{r}155 \\
35\end{array}$ & $\begin{array}{r}1820 \\
0\end{array}$ & $\cdots$ & $\begin{array}{r}2794 \\
2\end{array}$ & $\begin{array}{r}304 \\
72\end{array}$ & $\begin{array}{r}334 \\
59\end{array}$ & $\begin{array}{r}417 \\
79\end{array}$ & $\begin{array}{r}475 \\
87\end{array}$ & $\begin{array}{r}511 \\
66\end{array}$ & $\begin{array}{r}609 \\
98\end{array}$ & $\begin{array}{r}688 \\
94\end{array}$ \\
\hline Burundi & 6132 & $\begin{array}{l}62 \\
89\end{array}$ & $\begin{array}{r}105 \\
46\end{array}$ & $\begin{array}{r}1191 \\
5\end{array}$ & $\begin{array}{r}1570 \\
6\end{array}$ & $\begin{array}{r}1691 \\
5\end{array}$ & $\begin{array}{r}179 \\
53\end{array}$ & $\begin{array}{r}192 \\
96\end{array}$ & $\begin{array}{r}218 \\
56\end{array}$ & $\begin{array}{r}242 \\
90\end{array}$ & $\begin{array}{r}292 \\
69\end{array}$ & $\ldots$ & $\ldots$ \\
\hline Cameroon & 65697 & $\begin{array}{r}68 \\
49 \\
5\end{array}$ & $\begin{array}{r}777 \\
07\end{array}$ & $\begin{array}{r}8131 \\
8\end{array}$ & $\begin{array}{r}8390 \\
3\end{array}$ & $\begin{array}{r}9986 \\
4\end{array}$ & $\begin{array}{l}120 \\
298\end{array}$ & $\begin{array}{l}132 \\
134\end{array}$ & $\begin{array}{l}147 \\
631\end{array}$ & $\begin{array}{l}174 \\
144\end{array}$ & $\begin{array}{l}220 \\
331\end{array}$ & $\begin{array}{l}244 \\
233\end{array}$ & $\ldots$ \\
\hline Cabo Verde & 801 & $\begin{array}{r}71 \\
8\end{array}$ & $\begin{array}{r}181 \\
0\end{array}$ & 2215 & 3036 & 3910 & $\begin{array}{r}456 \\
7\end{array}$ & $\begin{array}{r}528 \\
9\end{array}$ & $\begin{array}{r}665 \\
8\end{array}$ & $\begin{array}{r}846 \\
5\end{array}$ & $\begin{array}{r}101 \\
44\end{array}$ & $\begin{array}{r}117 \\
69\end{array}$ & $\begin{array}{r}118 \\
00\end{array}$ \\
\hline $\begin{array}{l}\text { Central African } \\
\text { Republic }\end{array}$ & 6323 & $\ldots$ & $\ldots$ & $\ldots$ & 6384 & $\cdots$ & $\begin{array}{r}446 \\
2\end{array}$ & $\cdots$ & $\begin{array}{r}947 \\
3\end{array}$ & $\begin{array}{r}104 \\
27\end{array}$ & $\begin{array}{r}111 \\
58\end{array}$ & $\begin{array}{r}132 \\
89\end{array}$ & $\begin{array}{r}125 \\
22\end{array}$ \\
\hline Chad & 5901 & $\begin{array}{l}61 \\
06\end{array}$ & $\ldots$ & 7397 & $\begin{array}{r}1008 \\
1\end{array}$ & $\begin{array}{r}1237 \\
3\end{array}$ & $\ldots$ & $\cdots$ & $\begin{array}{r}189 \\
90\end{array}$ & $\begin{array}{r}203 \\
94\end{array}$ & $\begin{array}{r}221 \\
30\end{array}$ & $\begin{array}{r}243 \\
49\end{array}$ & $\cdots$ \\
\hline Comoros & 714 & $\ldots$ & $\ldots$ & 1707 & 1779 & $\ldots$ & $\ldots$ & $\begin{array}{r}259 \\
8\end{array}$ & $\cdots$ & $\begin{array}{r}459 \\
4\end{array}$ & $\begin{array}{r}509 \\
1\end{array}$ & $\begin{array}{r}623 \\
2\end{array}$ & $\begin{array}{r}705 \\
4\end{array}$ \\
\hline Congo & 15629 & $\begin{array}{r}13 \\
40 \\
3\end{array}$ & $\begin{array}{r}121 \\
64\end{array}$ & $\begin{array}{r}1234 \\
7\end{array}$ & $\cdots$ & $\ldots$ & $\cdots$ & $\cdots$ & $\cdots$ & $\begin{array}{r}233 \\
97\end{array}$ & $\ldots$ & $\begin{array}{r}339 \\
28\end{array}$ & $\begin{array}{r}393 \\
03\end{array}$ \\
\hline Côte d'Ivoire & $\ldots$ & $\ldots$ & $\ldots$ & $\ldots$ & $\ldots$ & $\ldots$ & $\ldots$ & $\begin{array}{l}156 \\
772\end{array}$ & $\ldots$ & $\begin{array}{l}152 \\
896\end{array}$ & $\begin{array}{l}144 \\
270\end{array}$ & $\ldots$ & $\ldots$ \\
\hline $\begin{array}{l}\text { Democratic } \\
\text { Republic of the } \\
\text { Congo }\end{array}$ & $\cdots$ & $\ldots$ & $\cdots$ & $\ldots$ & $\cdots$ & $\cdots$ & $\cdots$ & $\begin{array}{l}237 \\
836\end{array}$ & $\begin{array}{l}308 \\
739\end{array}$ & $\begin{array}{l}377 \\
867\end{array}$ & $\cdots$ & $\begin{array}{l}487 \\
685\end{array}$ & $\begin{array}{l}511 \\
251\end{array}$ \\
\hline Equatorial Guinea & 1003 & $\cdots$ & $\cdots$ & $\cdots$ & $\ldots$ & $\cdots$ & $\ldots$ & $\cdots$ & $\cdots$ & $\cdots$ & $\cdots$ & $\cdots$ & $\ldots$ \\
\hline Eritrea & 4135 & $\begin{array}{l}55 \\
05\end{array}$ & $\begin{array}{r}550 \\
7\end{array}$ & $\ldots$ & 4612 & $\ldots$ & $\ldots$ & $\cdots$ & $\cdots$ & $\begin{array}{r}994 \\
9\end{array}$ & $\begin{array}{r}120 \\
39\end{array}$ & $\ldots$ & $\ldots$ \\
\hline Ethiopia & 67732 & $\begin{array}{r}87 \\
43 \\
1\end{array}$ & $\begin{array}{l}101 \\
829\end{array}$ & $\begin{array}{r}1479 \\
54\end{array}$ & $\begin{array}{r}1721 \\
11\end{array}$ & $\begin{array}{r}1912 \\
12\end{array}$ & $\ldots$ & $\ldots$ & $\begin{array}{l}335 \\
471\end{array}$ & $\begin{array}{l}401 \\
918\end{array}$ & $\begin{array}{l}577 \\
594\end{array}$ & $\begin{array}{l}632 \\
344\end{array}$ & $\begin{array}{l}693 \\
287\end{array}$ \\
\hline Gabon & $\cdots$ & $\ldots$ & $\cdots$ & $\cdots$ & $\cdots$ & $\cdots$ & $\ldots$ & $\cdots$ & $\cdots$ & $\cdots$ & $\cdots$ & $\cdots$ & $\ldots$ \\
\hline Gambia & 1212 & $\ldots$ & $\ldots$ & $\ldots$ & 1530 & $\ldots$ & $\ldots$ & $\ldots$ & $\begin{array}{r}648 \\
9\end{array}$ & $\ldots$ & $\ldots$ & $\ldots$ & $\ldots$ \\
\hline Ghana & $\cdots$ & $\cdots$ & $\ldots$ & $\ldots$ & $\ldots$ & $\begin{array}{r}1195 \\
59\end{array}$ & $\begin{array}{l}110 \\
184\end{array}$ & $\begin{array}{l}140 \\
017\end{array}$ & $\begin{array}{l}190 \\
273\end{array}$ & $\begin{array}{l}203 \\
376\end{array}$ & $\ldots$ & $\begin{array}{l}285 \\
862\end{array}$ & $\begin{array}{l}295 \\
344\end{array}$ \\
\hline Guinea & $\cdots$ & $\ldots$ & $\ldots$ & $\begin{array}{r}1685 \\
8\end{array}$ & $\begin{array}{r}1721 \\
8\end{array}$ & $\begin{array}{r}2378 \\
8\end{array}$ & $\begin{array}{r}427 \\
11\end{array}$ & $\begin{array}{r}682 \\
61\end{array}$ & $\begin{array}{r}802 \\
22\end{array}$ & $\begin{array}{r}838 \\
87\end{array}$ & $\begin{array}{r}985 \\
28\end{array}$ & $\begin{array}{l}103 \\
192\end{array}$ & $\begin{array}{l}101 \\
173\end{array}$ \\
\hline Guinea-Bissau & $\ldots$ & $\cdots$ & $\ldots$ & $\cdots$ & $\cdots$ & 3122 & $\begin{array}{r}368 \\
9\end{array}$ & $\cdots$ & $\cdots$ & $\cdots$ & $\cdots$ & $\cdots$ & $\ldots$ \\
\hline Kenya & 89016 & $\begin{array}{r}94 \\
62 \\
9\end{array}$ & $\begin{array}{r}981 \\
15\end{array}$ & $\ldots$ & $\begin{array}{r}1084 \\
07\end{array}$ & $\begin{array}{r}1135 \\
32\end{array}$ & $\ldots$ & $\ldots$ & $\ldots$ & $\begin{array}{l}167 \\
983\end{array}$ & $\ldots$ & $\ldots$ & $\ldots$ \\
\hline Lesotho & 4470 & $\begin{array}{l}49 \\
76\end{array}$ & $\begin{array}{r}500 \\
5\end{array}$ & 6108 & $\ldots$ & 7918 & $\begin{array}{r}850 \\
0\end{array}$ & $\ldots$ & $\ldots$ & $\ldots$ & $\ldots$ & $\ldots$ & $\begin{array}{r}255 \\
07\end{array}$ \\
\hline Liberia & 52251 & $\ldots$ & $\ldots$ & $\ldots$ & $\ldots$ & $\ldots$ & $\ldots$ & $\ldots$ & $\ldots$ & $\ldots$ & $\begin{array}{r}334 \\
70\end{array}$ & $\ldots$ & $\begin{array}{r}438 \\
83\end{array}$ \\
\hline Madagascar & 32046 & $\begin{array}{r}30 \\
71 \\
2\end{array}$ & $\begin{array}{r}319 \\
25\end{array}$ & $\begin{array}{r}3548 \\
0\end{array}$ & $\begin{array}{r}4214 \\
3\end{array}$ & $\begin{array}{r}4494 \\
8\end{array}$ & $\begin{array}{r}496 \\
80\end{array}$ & $\begin{array}{r}583 \\
13\end{array}$ & $\begin{array}{r}620 \\
69\end{array}$ & $\begin{array}{r}684 \\
60\end{array}$ & $\begin{array}{r}744 \\
44\end{array}$ & $\begin{array}{r}855 \\
48\end{array}$ & $\begin{array}{r}902 \\
35\end{array}$ \\
\hline Malawi & 3584 & $\begin{array}{l}41 \\
29\end{array}$ & $\begin{array}{r}453 \\
1\end{array}$ & 4757 & 5782 & 5810 & $\begin{array}{r}629 \\
8\end{array}$ & $\begin{array}{r}645 \\
8\end{array}$ & $\ldots$ & $\ldots$ & $\begin{array}{r}102 \\
96\end{array}$ & $\begin{array}{r}122 \\
03\end{array}$ & $\ldots$ \\
\hline Mali & 19751 & 21 & 226 & $\ldots$ & $\ldots$ & $\ldots$ & $\ldots$ & $\ldots$ & 678 & 766 & 811 & 876 & 972 \\
\hline
\end{tabular}




\begin{tabular}{|c|c|c|c|c|c|c|c|c|c|c|c|c|c|}
\hline & & $\begin{array}{r}86 \\
1\end{array}$ & 32 & & & & & & 39 & 67 & 88 & 53 & 79 \\
\hline Mauritius & 12130 & $\begin{array}{r}18 \\
77 \\
9\end{array}$ & $\begin{array}{r}168 \\
59\end{array}$ & $\begin{array}{r}1695 \\
5\end{array}$ & $\begin{array}{r}1762 \\
7\end{array}$ & $\begin{array}{r}2051 \\
4\end{array}$ & $\begin{array}{r}222 \\
21\end{array}$ & $\begin{array}{r}229 \\
71\end{array}$ & $\begin{array}{r}255 \\
78\end{array}$ & $\begin{array}{r}305 \\
45\end{array}$ & $\begin{array}{r}334 \\
27\end{array}$ & $\begin{array}{r}359 \\
06\end{array}$ & $\begin{array}{r}401 \\
65\end{array}$ \\
\hline Mozambique & 11619 & $\ldots$ & $\ldots$ & $\begin{array}{r}1722 \\
5\end{array}$ & $\begin{array}{r}2225 \\
6\end{array}$ & $\begin{array}{r}2829 \\
8\end{array}$ & $\ldots$ & $\ldots$ & $\begin{array}{r}754 \\
57\end{array}$ & $\begin{array}{r}840 \\
74\end{array}$ & $\ldots$ & $\begin{array}{l}113 \\
464\end{array}$ & $\ldots$ \\
\hline Namibia & $\ldots$ & $\begin{array}{r}13 \\
33 \\
9\end{array}$ & $\begin{array}{r}110 \\
30\end{array}$ & $\begin{array}{r}1178 \\
8\end{array}$ & $\ldots$ & $\begin{array}{r}1356 \\
6\end{array}$ & $\begin{array}{r}131 \\
85\end{array}$ & $\ldots$ & $\begin{array}{r}197 \\
07\end{array}$ & $\ldots$ & $\ldots$ & $\ldots$ & $\ldots$ \\
\hline Niger & $\ldots$ & $\ldots$ & $\ldots$ & 8850 & 8774 & $\begin{array}{r}1079 \\
9\end{array}$ & $\begin{array}{r}112 \\
08\end{array}$ & $\begin{array}{r}108 \\
69\end{array}$ & $\begin{array}{r}128 \\
23\end{array}$ & $\begin{array}{r}159 \\
92\end{array}$ & $\begin{array}{r}170 \\
96\end{array}$ & $\begin{array}{r}183 \\
28\end{array}$ & $\begin{array}{r}217 \\
64\end{array}$ \\
\hline Nigeria & $\ldots$ & $\ldots$ & $\ldots$ & $\begin{array}{r}1234 \\
219\end{array}$ & $\begin{array}{r}1289 \\
656\end{array}$ & $\begin{array}{r}1391 \\
527\end{array}$ & $\ldots$ & $\ldots$ & $\ldots$ & $\ldots$ & $\ldots$ & $\ldots$ & $\ldots$ \\
\hline Rwanda & 9357 & $\begin{array}{r}12 \\
80 \\
2\end{array}$ & $\begin{array}{r}159 \\
40\end{array}$ & $\begin{array}{r}2039 \\
3\end{array}$ & $\begin{array}{r}2523 \\
3\end{array}$ & $\begin{array}{r}2778 \\
7\end{array}$ & $\begin{array}{r}371 \\
49\end{array}$ & $\begin{array}{r}410 \\
13\end{array}$ & $\begin{array}{r}451 \\
28\end{array}$ & $\begin{array}{r}552 \\
13\end{array}$ & $\begin{array}{r}627 \\
34\end{array}$ & $\ldots$ & $\begin{array}{r}716 \\
38\end{array}$ \\
\hline $\begin{array}{l}\text { Sao Tome and } \\
\text { Principe }\end{array}$ & . & . & . & . & . & . & & . & & 704 & 766 & $\ldots$ & $\begin{array}{r}142 \\
1\end{array}$ \\
\hline Senegal & $\ldots$ & $\ldots$ & $\ldots$ & $\ldots$ & $\begin{array}{r}5228 \\
2\end{array}$ & $\begin{array}{r}5912 \\
7\end{array}$ & $\begin{array}{r}625 \\
39\end{array}$ & $\begin{array}{r}712 \\
11\end{array}$ & $\begin{array}{r}913 \\
59\end{array}$ & $\begin{array}{r}943 \\
71\end{array}$ & $\begin{array}{r}921 \\
06\end{array}$ & $\ldots$ & $\ldots$ \\
\hline Seychelles & . & . & . & . & . & . & . & . & . & $\cdots$ & $\ldots$ & 189 & 103 \\
\hline Sierra Leone & 6744 & $\begin{array}{l}89 \\
13\end{array}$ & $\begin{array}{r}904 \\
1\end{array}$ & $\ldots$ & $\ldots$ & $\ldots$ & $\ldots$ & $\ldots$ & $\ldots$ & $\ldots$ & $\cdots$ & $\ldots$ & $\cdots$ \\
\hline Somalia & $\cdots$ & $\cdots$ & $\ldots$ & $\cdots$ & $\cdots$ & $\cdots$ & $\cdots$ & $\cdots$ & $\cdots$ & $\cdots$ & $\cdots$ & $\cdots$ & $\cdots$ \\
\hline South Africa & $\cdots$ & $\cdots$ & $\cdots$ & $\cdots$ & $\cdots$ & $\cdots$ & $\cdots$ & $\cdots$ & $\cdots$ & $\cdots$ & $\cdots$ & $\cdots$ & $\cdots$ \\
\hline Swaziland & 4738 & $\begin{array}{l}47 \\
61\end{array}$ & $\begin{array}{r}519 \\
3\end{array}$ & 5369 & 6594 & 5897 & $\begin{array}{r}569 \\
2\end{array}$ & $\ldots$ & $\ldots$ & $\ldots$ & $\ldots$ & $\begin{array}{r}890 \\
4\end{array}$ & $\ldots$ \\
\hline Togo & $\ldots$ & $\ldots$ & $\ldots$ & $\ldots$ & $\ldots$ & $\ldots$ & $\begin{array}{r}280 \\
76\end{array}$ & $\begin{array}{r}325 \\
02\end{array}$ & $\ldots$ & $\ldots$ & $\begin{array}{r}559 \\
59\end{array}$ & $\begin{array}{r}634 \\
96\end{array}$ & $\begin{array}{r}656 \\
17\end{array}$ \\
\hline Uganda & 55767 & $\begin{array}{r}62 \\
58 \\
6\end{array}$ & $\begin{array}{r}799 \\
58\end{array}$ & $\begin{array}{r}8833 \\
0\end{array}$ & $\begin{array}{r}8836 \\
0\end{array}$ & $\ldots$ & $\begin{array}{r}926 \\
05\end{array}$ & $\ldots$ & $\begin{array}{l}107 \\
728\end{array}$ & $\begin{array}{l}123 \\
887\end{array}$ & $\ldots$ & $\begin{array}{l}289 \\
545\end{array}$ & $\ldots$ \\
\hline $\begin{array}{l}\text { United Republic } \\
\text { of Tanzania }\end{array}$ & $\ldots$ & $\begin{array}{r}21 \\
96 \\
0\end{array}$ & $\ldots$ & $\begin{array}{r}3104 \\
9\end{array}$ & $\begin{array}{r}4294 \\
8\end{array}$ & $\begin{array}{r}5155 \\
4\end{array}$ & $\ldots$ & $\ldots$ & $\ldots$ & $\ldots$ & $\ldots$ & $\ldots$ & $\begin{array}{l}166 \\
014\end{array}$ \\
\hline Zambia & 24553 & $\cdots$ & $\ldots$ & $\ldots$ & $\cdots$ & $\cdots$ & $\ldots$ & $\ldots$ & $\ldots$ & $\cdots$ & $\cdots$ & $\cdots$ & $\cdots$ \\
\hline Zimbabwe & $\ldots$ & $\ldots$ & $\ldots$ & $\ldots$ & $\ldots$ & $\ldots$ & $\ldots$ & $\ldots$ & $\ldots$ & $\ldots$ & $\begin{array}{r}946 \\
11\end{array}$ & $\begin{array}{r}932 \\
85\end{array}$ & $\begin{array}{r}940 \\
12\end{array}$ \\
\hline
\end{tabular}

Fonte: Dados obtidos e adaptados em UNESCO Institute for Statistics, Higher

Education Data 


\section{Anexo 10 - Centros de Investigação na Africa Subsariana classificados no ranking mundial}

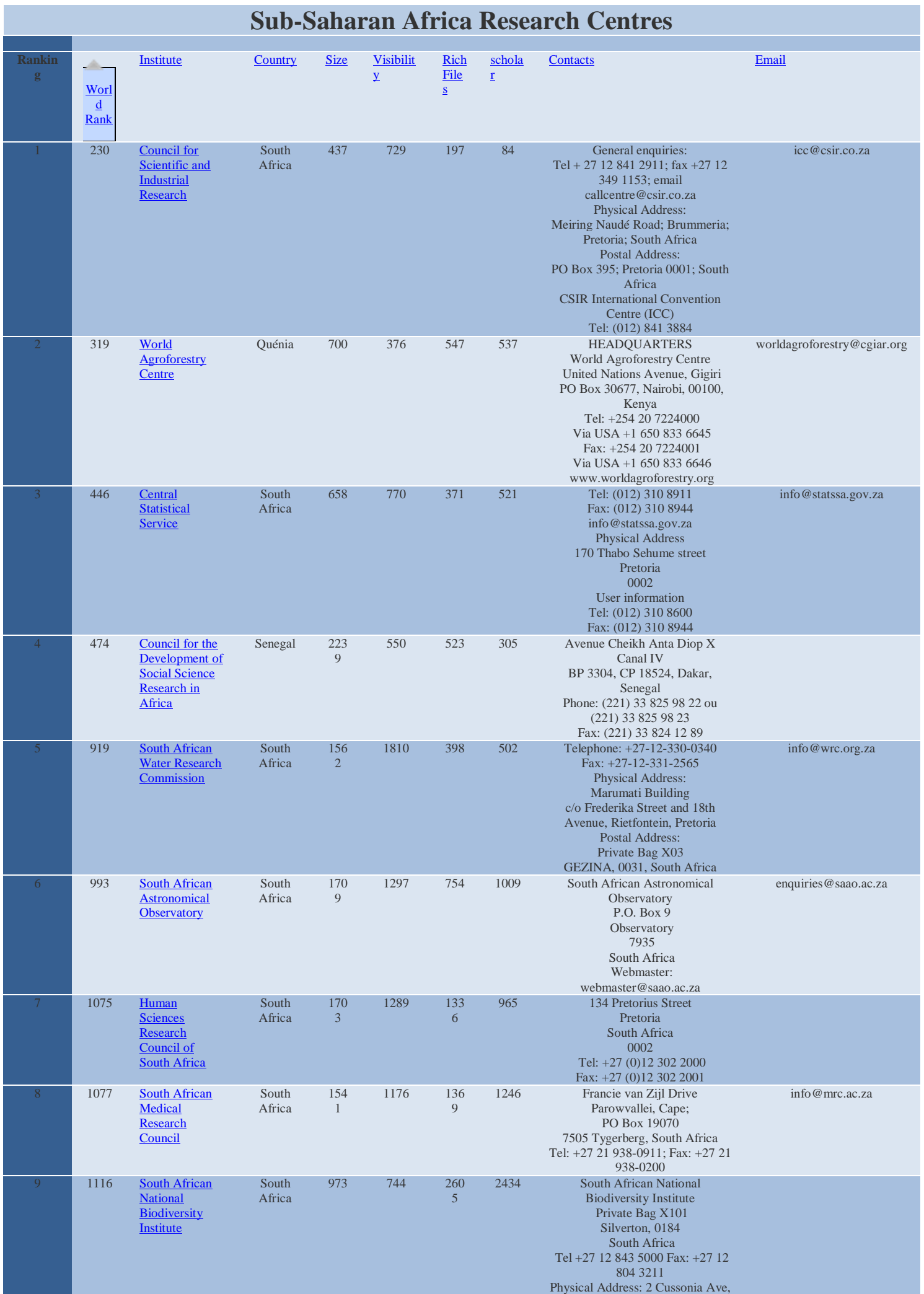




\begin{tabular}{|c|c|c|c|c|c|c|c|c|c|}
\hline & & & & & & & & Brummeria, Pretoria. & \\
\hline 10 & 1272 & $\begin{array}{l}\frac{\text { National }}{\text { Research }} \\
\text { Foundation }\end{array}$ & $\begin{array}{l}\text { South } \\
\text { Africa }\end{array}$ & $\begin{array}{c}146 \\
1\end{array}$ & 1246 & $\begin{array}{c}125 \\
8\end{array}$ & 1917 & $\begin{array}{c}\text { Meiring Naudé Road } \\
\text { Brummeria } \\
\text { Pretoria } \\
\text { South Africa } \\
\text { Postal Address } \\
\text { Box } 2600 \\
\text { Pretoria 0001 } \\
\text { South Africa } \\
\text { Phone Numbers - +27 (0)12481 } \\
4000 \\
\text { Fax Number - +27 (0)12349 } 1179\end{array}$ & info@nrf.ac.za \\
\hline 11 & 1278 & $\begin{array}{l}\text { African Institute } \\
\text { for } \\
\text { Mathematical } \\
\underline{\text { Sciences }}\end{array}$ & $\begin{array}{l}\text { South } \\
\text { Africa }\end{array}$ & $\begin{array}{c}139 \\
0\end{array}$ & 1850 & $\begin{array}{c}122 \\
9\end{array}$ & 976 & $\begin{array}{l}\text { AIMS may also be contacted at } \\
\text { the following address: } \\
\text { Administrative Officer, } \\
\text { African Institute for Mathematical } \\
\text { Sciences, } \\
\text { 6-8 Melrose Road, } \\
\text { Muizenberg 7945, } \\
\text { South Africa } \\
\text { Tel: }+27 \text { (21) } 7879320 \\
\text { Fax: }+27 \text { (21) } 7879321\end{array}$ & \\
\hline 12 & 1284 & $\begin{array}{l}\text { African Wildlife } \\
\text { Foundation }\end{array}$ & Quénia & $\begin{array}{c}197 \\
6\end{array}$ & 472 & $\begin{array}{c}300 \\
2\end{array}$ & 3219 & $\begin{array}{l}\text { African Wildlife Foundation } \\
\text { Ngong Road, Karen } \\
\text { P.O. Box 310, 00502 } \\
\text { NAIROBI, KENYA map } \\
\text { Tel: +254 } 202765000 \\
\text { Fax: +254 20 2765030 }\end{array}$ & africanwildlife@awf.org \\
\hline 13 & 1632 & $\begin{array}{l}\text { Kenya } \\
\text { Agricultural } \\
\text { Research } \\
\underline{\text { Institute }}\end{array}$ & Quénia & $\begin{array}{c}282 \\
5\end{array}$ & 1900 & $\begin{array}{c}218 \\
0\end{array}$ & 855 & $\begin{array}{c}\text { The Director, KARI } \\
\text { Location: Kaptagat Rd, Loresho } \\
\text { Nairobi Kenya } \\
\text { Post Office: P.O.Box 57811, City } \\
\text { Square, NAIROBI, 00200, Kenya } \\
\text { Fax: +254-020-4183344 } \\
\text { Tel No(s): +254-020-4183720, } \\
\text { 4183301-20, } 4183307\end{array}$ & Resource.center@kari.org \\
\hline 14 & 1706 & $\begin{array}{l}\frac{\text { University }}{\text { Computing }} \\
\text { Centre Ltd }\end{array}$ & Tanzânia & $\begin{array}{c}160 \\
1\end{array}$ & 530 & $\begin{array}{c}426 \\
0\end{array}$ & 4960 & $\begin{array}{l}\text { Dar es Salaam - Head Office } \\
\text { University Computing Centre } \\
\text { University Road } \\
\text { Mlimani Campus } \\
\text { P.O.Box 35062 } \\
\text { Dar es Salaam } \\
\text { Tanzania } \\
\text { E-mail: training @udsm.ac.tz } \\
\text { Tel: } 255-22-2410641 / 45 \\
\text { Fax: } 255-22-2410690\end{array}$ & helpdesk@ucc.co.tz \\
\hline 15 & 1855 & 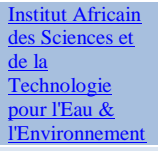 & $\begin{array}{l}\text { Burkina } \\
\text { Faso }\end{array}$ & 716 & 2637 & $\begin{array}{c}289 \\
8\end{array}$ & 1816 & $\begin{array}{c}\text { Burkina Faso } \\
\text { Adresse : Rue de la Science - } 01 \\
\text { BP 594 Ouagadougou } 01- \\
\text { Burkina Faso } \\
\text { Téléphone : }+22650492800 \\
\text { Fax : }+22650492801\end{array}$ & 2ie@2ie-edu.org \\
\hline 16 & 2128 & $\begin{array}{l}\text { South African } \\
\text { Weather Service }\end{array}$ & $\begin{array}{l}\text { South } \\
\text { Africa }\end{array}$ & $\begin{array}{c}396 \\
0\end{array}$ & 635 & $\begin{array}{c}410 \\
8\end{array}$ & 4173 & $\begin{array}{c}\text { South African Weather Service } \\
\text { 442 Rigel Avenue South, } \\
\text { Erasmusrand, 0181 } \\
\text { Private Bag X097 } \\
\text { Pretoria 0001 } \\
\text { Tel: }+27123676000 \\
\text { Fax: }+27123676200\end{array}$ & \\
\hline 17 & 2139 & $\begin{array}{l}\text { African Medical } \\
\text { Research } \\
\text { Foundation }\end{array}$ & Quénia & $\begin{array}{c}261 \\
9\end{array}$ & 898 & $\begin{array}{c}407 \\
2\end{array}$ & 4173 & $\begin{array}{c}\text { Amref Health Africa Headquarters, } \\
\text { Langata Road, P.O Box 27691 - } \\
\text { 00506, Nairobi, Kenya. Tel: }+254 \\
20 \text { 6993000 Fax: }+25420609518 \text { - } \\
\text { See more at: } \\
\text { http://amref.org/about-us/contact- } \\
\text { amref- } \\
\text { headquarters/\#sthash.6XqS62hb.dp } \\
\text { uf }\end{array}$ & \\
\hline 18 & 2149 & $\begin{array}{l}\text { Agricultural } \\
\text { Research } \\
\text { Council Pretoria }\end{array}$ & $\begin{array}{l}\text { South } \\
\text { Africa }\end{array}$ & $\begin{array}{c}339 \\
3\end{array}$ & 1799 & $\begin{array}{c}281 \\
0\end{array}$ & 1927 & $\begin{array}{c}\text { AGRICULTURAL RESEARCH } \\
\text { COUNCIL } \\
\text { Physical Address: } \\
\text { 1134 Park street, Hatfield, Pretoria } \\
\text { Postal address: } \\
\text { P.O. Box 8783, Pretoria, 0001, } \\
\text { SOUTH AFRICA ARC-Grain } \\
\text { Crops Institute (ARC-GCI) } \\
\text { Tel: +27 (0)18 299 6100 } \\
\text { Fax: }+27 \text { (0)18 294 7146 }\end{array}$ & jamesm@arc.agric.za \\
\hline 19 & 2233 & $\begin{array}{l}\text { African } \\
\text { Academy of } \\
\text { Sciences }\end{array}$ & Quénia & $\begin{array}{c}523 \\
0\end{array}$ & 392 & $\begin{array}{c}550 \\
9\end{array}$ & 4173 & & \\
\hline 20 & 2693 & $\begin{array}{l}\text { Africa Rice } \\
\text { Center }\end{array}$ & Benim & $\begin{array}{c}384 \\
8\end{array}$ & 3015 & $\begin{array}{c}243 \\
7\end{array}$ & 1945 & $\begin{array}{c}\text { Africa Rice Center (AfricaRice) } \\
\text { 01 B.P. } 2031 \\
\text { Cotonou } \\
\text { Benin } \\
\text { Tel }+22964181313 / 6418 \\
1414 / 64181515 / 64181616 \\
\text { Fax }+22964227809\end{array}$ & AfricaRice@cgiar.org \\
\hline 21 & 2775 & $\begin{array}{l}\text { African } \\
\text { Agricultural } \\
\text { Technology } \\
\text { Foundation }\end{array}$ & Quénia & $\begin{array}{c}368 \\
7\end{array}$ & 2909 & $\begin{array}{c}299 \\
0\end{array}$ & 2102 & $\begin{array}{c}\text { The African Agricultural } \\
\text { Technology Foundation (AATF) } \\
\text { P.O. Box } 30709 \\
\text { Nairobi } 00100 \\
\text { Kenya } \\
\text { Tel: } 254-204223700 \\
\text { Fax: } 254-204223701 \\
\text { Via USA: Tel: } 1650833666 \\
\text { Fax: } 16508336661\end{array}$ & aatf@aatf-africa.org \\
\hline 22 & 2946 & Ithemba & South & 270 & 2905 & 219 & 4075 & The Director & Director@tlabs.ac.za \\
\hline
\end{tabular}


VNIVERSIDAD

DSALAMANCA

\begin{tabular}{|c|c|c|c|c|c|c|c|c|c|}
\hline & & $\begin{array}{l}\frac{\text { Laboratory for }}{\text { Accelerator- }} \\
\text { Based Science }\end{array}$ & Africa & 5 & & 0 & & $\begin{array}{c}\text { iThemba LABS } \\
\text { PO Box } 722 \\
\text { Somerset West } 7129 \\
\text { South Africa } \\
\text { Tel: }+27 \text { (21) } 8431000 \\
\text { Fax: +27 (21) } 8433525 \\
\text { Physical Address: } \\
\text { Old Faure Road } \\
\text { Faure }\end{array}$ & \\
\hline 23 & 2995 & $\begin{array}{l}\text { Wellcome Trust } \\
\text { Research } \\
\text { Laboratories } \\
\underline{\text { Nairobi }}\end{array}$ & Kenya & $\begin{array}{c}342 \\
1\end{array}$ & 1468 & $\begin{array}{c}655 \\
6\end{array}$ & 2290 & & \\
\hline 24 & 3032 & $\begin{array}{l}\text { International } \\
\text { Centre of Insect } \\
\text { Physiology and } \\
\text { Ecology }\end{array}$ & Quénia & $\begin{array}{c}273 \\
3\end{array}$ & 2522 & $\begin{array}{c}228 \\
9\end{array}$ & 4960 & $\begin{array}{c}\text { icipe-African Insect Science for } \\
\text { Food and Health } \\
\text { P.O. Box 30772-00100 } \\
\text { Nairobi, Kenya } \\
\text { Tel: }+254(20) 8632000 \\
\text { Fax: +254 (20) } 8632001 / 8632002\end{array}$ & icipe@icipe.org \\
\hline 25 & 3074 & $\begin{array}{l}\text { Council for } \\
\text { Mineral } \\
\underline{\text { Technology }}\end{array}$ & $\begin{array}{l}\text { South } \\
\text { Africa }\end{array}$ & $\begin{array}{c}401 \\
1\end{array}$ & 3671 & $\begin{array}{c}228 \\
3\end{array}$ & 2340 & $\begin{array}{c}\text { Contact Number: } \\
\text { +27 } 117094111 \\
\text { Fax Number: } \\
\text { +27 } 117932413 \\
\text { Postal Address: } \\
\text { Private Bag X3015, Randburg, } \\
\text { South Africa, 2125 } \\
\text { Physical Address: } \\
\text { 200 Malibongwe Drive, Strijdom } \\
\text { Park, Randburg }\end{array}$ & \\
\hline 26 & 3103 & $\begin{array}{l}\frac{\text { National }}{\text { Institute for }} \\
\underline{\text { Communicable }} \\
\underline{\text { Diseases }}\end{array}$ & $\begin{array}{l}\text { South } \\
\text { Africa }\end{array}$ & $\begin{array}{c}447 \\
9\end{array}$ & 3778 & $\begin{array}{c}313 \\
7\end{array}$ & 1586 & $\begin{array}{c}\text { Postal Address } \\
\text { Private Bag X4 } \\
\text { Sandringham } \\
\text { Johannesburg } \\
2131 \\
\text { SOUTH AFRICA } \\
\text { Tel: } 27-113866000 \\
\text { Fax: } 27-118820596\end{array}$ & nicdmail@nicd.ac.za \\
\hline 27 & 3358 & $\begin{array}{l}\text { Hartebeesthoek } \\
\underline{\text { Radio }} \\
\text { Astronomy } \\
\underline{\text { Observatory }}\end{array}$ & $\begin{array}{l}\text { South } \\
\text { Africa }\end{array}$ & $\begin{array}{c}399 \\
4\end{array}$ & 2530 & $\begin{array}{c}436 \\
9\end{array}$ & 3535 & $\begin{array}{l}\text { Hartebeesthoek Radio Astronomy } \\
\text { Observatory } \\
\text { P.O.Box 443, Krugersdorp 1740, } \\
\text { South Africa } \\
\text { http://www.hartrao.ac.za } \\
\text { Phone: }+27 \text { (12) 301-3100 } \\
\text { Fax: +27 (12) 301-3300 } \\
\text { general inquiries - e-mail: } \\
\text { info @ hartrao.ac.za } \\
\text { inquiries about visiting hartrao }\end{array}$ & aware@hartrao.ac.za \\
\hline 28 & 3367 & $\begin{array}{l}\text { Anglo Platinum } \\
\text { Research Centre }\end{array}$ & $\begin{array}{l}\text { South } \\
\text { Africa }\end{array}$ & $\begin{array}{c}377 \\
6\end{array}$ & 2727 & $\begin{array}{c}228 \\
9\end{array}$ & 4960 & & \\
\hline 29 & 3546 & $\begin{array}{l}\text { South African } \\
\text { National Space } \\
\text { Agency SANSA }\end{array}$ & $\begin{array}{l}\text { South } \\
\text { Africa }\end{array}$ & $\begin{array}{c}317 \\
9\end{array}$ & 2436 & $\begin{array}{c}437 \\
9\end{array}$ & 4960 & $\begin{array}{l}\text { SANSA Corporate Office } \\
\text { (T) 012 844-0500 } \\
\text { (F) 012 844-0396 } \\
\text { (E) information@sansa.org.za } \\
\text { Physical Address: } \\
\text { South African National Space } \\
\text { Agency (SANSA) } \\
\text { Enterprise Building } \\
\text { Mark Shuttleworth Street } \\
\text { Innovation Hub } \\
\text { Pretoria 0087, Gauteng, South } \\
\text { Africa }\end{array}$ & \\
\hline 30 & 3597 & $\begin{array}{l}\text { Namulonge } \\
\text { Agricultural and } \\
\text { Animal } \\
\text { Production } \\
\text { Research } \\
\text { Institute Uganda } \\
\end{array}$ & Uganda & $\begin{array}{c}541 \\
8\end{array}$ & 3595 & $\begin{array}{c}460 \\
6\end{array}$ & 1765 & $\begin{array}{c}\text { NARO Secretariat } \\
\text { Plot 3, Lugard Avenue, Entebbe } \\
\text { P.O.Box 295, } \\
\text { Entebbe, } \\
\text { Uganda } \\
\text { Tel: } 256-41-320512 \\
\text { Tel: } 256-41-320341 / 2 \\
\text { Tel: } 256-41-320178 \\
\text { Fax: } 256-41-321070 \\
\text { Email: dgnaro@infocom.co.ug }\end{array}$ & dgnaro@naro.go.ug \\
\hline 31 & 3709 & $\begin{array}{l}\text { Kenya Medical } \\
\text { Research } \\
\text { Institute }\end{array}$ & Kenya & $\begin{array}{c}191 \\
9\end{array}$ & 3179 & $\begin{array}{c}575 \\
7\end{array}$ & 4173 & $\begin{array}{c}\text { Kenya Medical Research Institute } \\
\text { Mbagathi Rd. Nairobi, Kenya } \\
\text { P.O. BOX 54840 - 00200 } \\
\text { Tel:+254 (0)20 2713349 } \\
\text { +254 (0)202722541 } \\
0722-205901\end{array}$ & \\
\hline 32 & 3901 & $\begin{array}{l}\text { African } \\
\text { Population and } \\
\underline{\text { Health Research }} \\
\underline{\text { Center }}\end{array}$ & Kenya & $\begin{array}{c}453 \\
6\end{array}$ & 3320 & $\begin{array}{c}584 \\
0\end{array}$ & 2537 & $\begin{array}{c}\text { African Population \& Health } \\
\text { Research Center } \\
\text { APHRC Campus, 2nd Floor } \\
\text { Manga Close, Off Kirawa Road } \\
\text { P.O. Box 10787-00100, } \\
\text { Nairobi, Kenya } \\
\\
\text { Telephone: }+254 \text { (20) } 4001000, \\
266 \text { 2244, or } 2662255 \\
\text { Mobile: }+254722205933,733 \\
410102 \\
\text { Fax: }+254 \text { (20) } 4001101\end{array}$ & info@aphrc.org \\
\hline$\overline{33}$ & 3965 & $\begin{array}{l}\text { International } \\
\text { Ocean Institute }\end{array}$ & $\begin{array}{l}\text { South } \\
\text { Africa }\end{array}$ & $\begin{array}{c}306 \\
6\end{array}$ & 5830 & $\begin{array}{c}199 \\
5\end{array}$ & 2823 & $\begin{array}{c}\text { Mr Adnan Awad } \\
\text { Director } \\
\text { Department of Biodiversity and } \\
\text { Conservation Biology } \\
\text { University of the Western Cape } \\
\text { P. Bag X17, } \\
\text { Bellville } 7535 \\
\text { South Africa }\end{array}$ & awad.adnan@gmail.com \\
\hline
\end{tabular}


IN 5 T I T U T Q

:

\begin{tabular}{|c|c|c|c|c|c|c|c|c|c|}
\hline & & & & & & & & $\begin{array}{c}\text { aawad@uwc.ac.za } \\
\text { Tel: +27 } 219593088 \\
\text { Fax: +27 } 219591213\end{array}$ & \\
\hline 34 & 4088 & $\begin{array}{l}\frac{\text { Africa Centre }}{\text { for Health and }} \\
\underline{\text { Population }} \\
\underline{\text { Studies }}\end{array}$ & $\begin{array}{l}\text { South } \\
\text { Africa }\end{array}$ & $\begin{array}{c}353 \\
4\end{array}$ & 5629 & $\begin{array}{c}300 \\
2\end{array}$ & 2523 & $\begin{array}{c}\text { R618 en Route to Hlabisa } \\
\text { Somkhele } \\
\text { Mtubatuba } \\
\text { Kwa-Zulu Natal } \\
\text { South Africa } \\
\text { Tel } \\
+27(0) 355507509 \\
\text { Fax } \\
+27(0) 355507565\end{array}$ & rnaicker@africacentre.ac.za \\
\hline 35 & 4313 & $\begin{array}{l}\text { Kenya Institute } \\
\text { for Public } \\
\text { Policy Research } \\
\underline{\text { and Analysis }}\end{array}$ & Quénia & $\begin{array}{c}223 \\
9\end{array}$ & 3412 & $\begin{array}{c}621 \\
2\end{array}$ & 4960 & & \\
\hline 36 & 4484 & $\begin{array}{l}\text { National Health } \\
\text { Laboratory } \\
\text { Services }\end{array}$ & $\begin{array}{l}\text { South } \\
\text { Africa }\end{array}$ & $\begin{array}{c}453 \\
6\end{array}$ & 4714 & $\begin{array}{c}363 \\
6\end{array}$ & 4173 & $\begin{array}{c}\text { Modderfontein Road } \\
\text { Sandringham } \\
\text { Johannesburg } \\
\text { South Africa } \\
\text { (GPS co-ordinates: } \\
\text { S26 } 26^{\circ} 07.892 \\
\text { E028 } \\
\text { Private Bag X8, Sandringham } \\
2131 \\
\text { Johannesburg, South Africa } \\
\text { Tel: (011) 386-6000 } \\
\text { Fax: (011) 386-6620 } \\
\text { For Finance enquiries, write to: }\end{array}$ & financesupport@nhls.ac.za \\
\hline 37 & 4597 & $\begin{array}{l}\text { National } \\
\text { Astrophysics } \\
\text { and Space } \\
\text { Science } \\
\text { Programme }\end{array}$ & $\begin{array}{l}\text { South } \\
\text { Africa }\end{array}$ & $\begin{array}{c}284 \\
6\end{array}$ & 5387 & $\begin{array}{c}443 \\
0\end{array}$ & 4173 & $\begin{array}{c}\text { Department of Astronomy } \\
\text { University of Cape Town } \\
\text { Private Bag } \\
\text { Rondebosch } \\
7701 \\
\text { Dr. Kurt Van der Heyden } \\
\text { Tel: } \\
+2721650-4042 \\
\text { Fax: } \\
+27216504547\end{array}$ & $\begin{array}{c}\text { kurt.vanderheyden@uct.ac.z } \\
\text { a }\end{array}$ \\
\hline 38 & 4664 & MRC Keneba & Gambia & $\begin{array}{c}330 \\
1\end{array}$ & 4787 & $\begin{array}{c}456 \\
9\end{array}$ & 4960 & $\begin{array}{c}\text { Medical Research Council Unit, } \\
\text { The Gambia } \\
\text { Atlantic Boulevard, Fajara } \\
\text { P. O. Box 273, Banjul } \\
\text { The Gambia }\end{array}$ & information@mrc.gm \\
\hline 39 & 4844 & $\begin{array}{l}\text { Geological } \\
\text { Survey of South } \\
\underline{\text { Africa }}\end{array}$ & $\begin{array}{l}\text { South } \\
\text { Africa }\end{array}$ & $\begin{array}{c}408 \\
9\end{array}$ & 2856 & $\begin{array}{c}667 \\
9\end{array}$ & 4960 & $\begin{array}{c}\text { COUNCIL FOR GEOSCIENCE } \\
280 \text { Pretoria Street, SILVERTON } \\
\text { Private Bag x112 } \\
\text { Pretoria } \\
\text { Republic of South Africa } \\
\text { Phone: }+27128411911 \\
\text { Facsimile: }+27128411221\end{array}$ & info@geoscience.org.za \\
\hline 40 & 4886 & $\begin{array}{l}\text { Climate } \\
\underline{\text { Prediction and }} \\
\underline{\text { Applications }} \\
\underline{\text { Centre Kenya }}\end{array}$ & Quénia & $\begin{array}{c}391 \\
4\end{array}$ & 5461 & $\begin{array}{c}348 \\
6\end{array}$ & 4960 & $\begin{array}{c}\text { The Director } \\
\text { IGAD Climate Prediction and } \\
\text { Applications Center } \\
\text { P.O. Box 10304 -00100 Nairobi, } \\
\text { KENYA } \\
\text { TEL: } 2543514426 \text { or } 25420387 \\
8340 \\
\text { FAX: } 254203878343\end{array}$ & info@icpac.net \\
\hline 41 & 4915 & $\begin{array}{l}\text { Sports Science } \\
\text { Institute of } \\
\text { South Africa }\end{array}$ & $\begin{array}{l}\text { South } \\
\text { Africa }\end{array}$ & $\begin{array}{c}520 \\
9\end{array}$ & 3978 & $\begin{array}{c}540 \\
1\end{array}$ & 4960 & $\begin{array}{c}\text { Telephone } \\
\text { [27] } 216595600 \\
\text { Fax } \\
{[27] 216595601} \\
\text { Physical Address } \\
\text { Boundary Rd } \\
\text { Newlands } \\
7700 \\
\text { Postal Address } \\
\text { Private Bag X5 } \\
\text { Newlands } \\
7725\end{array}$ & info@ssisa.com \\
\hline 42 & 4950 & $\begin{array}{l}\frac{\text { Grootfontein }}{\text { Agricultural }} \\
\text { Development } \\
\text { Institute }\end{array}$ & $\begin{array}{l}\text { South } \\
\text { Africa }\end{array}$ & $\begin{array}{c}402 \\
7\end{array}$ & 5311 & $\begin{array}{c}589 \\
0\end{array}$ & 3224 & $\begin{array}{c}\text { Postal address: } \\
\text { Director } \\
\text { G A D I } \\
\text { Private Bag X529 } \\
\text { Middelburg } \\
\text { Eastern Cape } \\
5900 \\
\text { Phone: }+27(0) 498026600 \text { or } \\
\quad+27(0) 498421113 \\
\text { Fax: } \quad+27(0) 498424352\end{array}$ & \\
\hline 43 & 4962 & $\begin{array}{l}\text { Infectious } \\
\text { Diseases } \\
\text { Institute } \\
\text { Makerere } \\
\text { University }\end{array}$ & Uganda & $\begin{array}{c}438 \\
1\end{array}$ & 5392 & $\begin{array}{c}471 \\
5\end{array}$ & 4114 & $\begin{array}{c}\text { Infectious Diseases Institute } \\
\text { P.O. Box } 22418 \\
\text { Kampala, Uganda } \\
\text { Telephone: } \\
+256-41-4307000 \\
\text { +256-31-2307000 } \\
\text { Fax: } \\
\text { +256-41-4307290 } \\
\text { +256-31-2307290 } \\
\text { Email: } \\
\text { General: office @idi.co.ug } \\
\text { Training and Capacity } \\
\text { Development: }\end{array}$ & research@idi.co.ug \\
\hline 44 & 5004 & $\begin{array}{l}\text { South African } \\
\frac{\text { Institute for }}{\text { Aquatic }}\end{array}$ & $\begin{array}{l}\text { South } \\
\text { Africa }\end{array}$ & $\begin{array}{c}556 \\
7\end{array}$ & 4562 & $\begin{array}{c}458 \\
4\end{array}$ & 4960 & $\begin{array}{l}\text { South African Institute for Aquatic } \\
\text { Biodiversity } \\
\text { Somerset Street }\end{array}$ & \\
\hline
\end{tabular}


VNIVERSIDAD

DSALAMANCA

\begin{tabular}{|c|c|c|c|c|c|c|c|c|c|}
\hline & & $\underline{\text { Biodiversity }}$ & & & & & & $\begin{array}{c}\text { Grahamstown, } 6139 \\
\text { Private Bag } 1015 \\
\text { Grahamstown, } 6140 \\
\text { South Africa } \\
\text { Tel: +27 (0)46 603 } 5800 \\
\text { Fax: }+27 \text { (0)46 } 6222403\end{array}$ & \\
\hline \multirow[t]{2}{*}{45} & \multirow[t]{2}{*}{5311} & \multirow[t]{2}{*}{$\begin{array}{l}\frac{\text { Botswana }}{\text { Institute for }} \\
\text { Development } \\
\text { Policy Analysis }\end{array}$} & \multirow[t]{2}{*}{ Botswana } & \multirow[t]{2}{*}{$\begin{array}{c}642 \\
7\end{array}$} & \multirow[t]{2}{*}{4948} & \multirow[t]{2}{*}{$\begin{array}{c}608 \\
0\end{array}$} & \multirow[t]{2}{*}{2956} & $\begin{array}{l}\text { BIDPA House } \\
\text { Plot } 134 \text { Tshwene Drive } \\
\text { Millennium Office Park } \\
\text { Gaborone }\end{array}$ & \multirow[t]{2}{*}{ webmaster@bidpa.bw } \\
\hline & & & & & & & & \begin{tabular}{ccc}
\multicolumn{2}{c}{ Telephone: } & +267 \\
& 3971750 & \\
Fax: & & +267 \\
\multicolumn{3}{c}{3971748} \\
Website: http://www.bidpa.bw
\end{tabular} & \\
\hline 46 & 5428 & $\begin{array}{l}\text { Institut de } \\
\text { Recherche } \\
\text { Scientifique et } \\
\text { Technologique / } \\
\text { Ouagadougou }\end{array}$ & Ruanda & $\begin{array}{c}614 \\
6\end{array}$ & 5015 & $\begin{array}{c}559 \\
2\end{array}$ & 4433 & & \\
\hline 47 & 5515 & $\begin{array}{l}\text { Cape Shoulder } \\
\underline{\text { Institute }}\end{array}$ & $\begin{array}{l}\text { South } \\
\text { Africa }\end{array}$ & $\begin{array}{c}591 \\
5\end{array}$ & 5084 & $\begin{array}{c}577 \\
4\end{array}$ & 4511 & $\begin{array}{l}\text { Southern Suburbs - Newlands } \\
\text { Sport Science Institute } \\
\text { Boundary Road, Newlands, Cape } \\
\text { Town } \\
\text { Tel: (021) } 9111017 \text {, } \\
\text { Fax: (021) } 9111019\end{array}$ & shoulder@iafrica.com \\
\hline 48 & 5544 & $\begin{array}{l}\text { Oceanographic } \\
\text { Research } \\
\text { Institute }\end{array}$ & $\begin{array}{l}\text { South } \\
\text { Africa }\end{array}$ & $\begin{array}{c}578 \\
5\end{array}$ & 5643 & $\begin{array}{c}487 \\
3\end{array}$ & 4651 & $\begin{array}{c}\text { Oceanographic Research Institute } \\
\text { PO Box 10712 } \\
\text { Marine Parade } \\
\text { Durban } \\
4056 \\
\text { SOUTH AFRICA } \\
\text { Phone: }+27 \text { (0) } 313288222 \\
\text { Fax: }+27 \text { (0) } 313288188\end{array}$ & ori@saambr.org.za \\
\hline 49 & 5647 & $\begin{array}{l}\text { Kenya Marine } \\
\text { and Fisheries } \\
\text { Research } \\
\underline{\text { Institute }}\end{array}$ & Quénia & $\begin{array}{c}694 \\
1\end{array}$ & 4332 & $\begin{array}{c}573 \\
8\end{array}$ & 4960 & $\begin{array}{c}\text { The Director } \\
\text { Kenya Marine and Fisheries } \\
\text { Research Institute } \\
\text { Headquater \& Mombasa Station } \\
\text { P.O. Box } 81651080100 \\
\text { Mombasa, KENYA } \\
\text { Tel: }+254(041) 475151 / 4 \\
\text { Wireless: +254 (020) 8021560/1 } \\
\text { Fax: }+254 \text { (041) } 475157\end{array}$ & director@kmfri.co.ke \\
\hline 50 & 5663 & $\begin{array}{l}\text { International } \\
\text { Trypanotoleranc } \\
\text { e Centre }\end{array}$ & Gambia & $\begin{array}{c}663 \\
8\end{array}$ & 6014 & $\begin{array}{c}478 \\
7\end{array}$ & 3498 & $\begin{array}{c}\text { International Trypanotolerance } \\
\text { Centre } \\
\text { PMB 14 } \\
\text { Banjul } \\
\text { The Gambia } \\
\\
\text { Tel: }+2204462928 \\
\text { Fax: }+2204462924\end{array}$ & itc@itc.gm \\
\hline 51 & 5683 & $\begin{array}{l}\text { Mauritius Sugar } \\
\text { Industry } \\
\underline{\text { Research }} \\
\underline{\text { Institute }}\end{array}$ & Maurícias & $\begin{array}{c}399 \\
7\end{array}$ & 6835 & $\begin{array}{c}322 \\
6\end{array}$ & 4651 & $\begin{array}{c}\text { Mauritius Sugarcane Industry } \\
\text { Research Institute } \\
\text { Address : } \\
\text { Mauritius Cane Industry Authority } \\
\text { Moka Road, Reduit, Mauritius } \\
\text { Telephone : } \\
\text { + (230) 454-1061 } \\
\text { Telefax : } \\
\text { + (230) } 454-1971\end{array}$ & contact@msiri.mu \\
\hline 52 & 5739 & $\begin{array}{l}\text { Institut } \\
\text { Senegalais de } \\
\text { Recherches } \\
\text { Agricoles }\end{array}$ & Senegal & $\begin{array}{c}521 \\
5\end{array}$ & 4871 & $\begin{array}{c}640 \\
9\end{array}$ & 4960 & $\begin{array}{c}\text { Nos coordonnéesInstitut } \\
\text { Sénégalais de Recherches } \\
\text { Agricoles } \\
\text { Route des hydrocarbures } \\
\text { Bel-air } \\
\text { BP 3120 Dakar } \\
\text { Sénégal } \\
\text { Tél: +221 } 338591720 \\
\text { Fax: +221 } 338322427\end{array}$ & info@isra.sn \\
\hline 53 & 5786 & $\begin{array}{l}\text { National } \\
\text { Metrology } \\
\text { Institute of } \\
\text { South Africa } \\
\end{array}$ & $\begin{array}{l}\text { South } \\
\text { Africa }\end{array}$ & $\begin{array}{c}435 \\
4\end{array}$ & 6390 & $\begin{array}{c}484 \\
2\end{array}$ & 4960 & $\begin{array}{c}\text { Private Bag X34 } \\
\text { Lynnwood Ridge } \\
\text { Pretoria } \\
0040 \\
\text { South Africa } \\
\text { Calibration office: } \\
\text { Reception: } \\
\text { Fax: +27 12841 } 2102 \\
\text { +27 } 128414152 \\
\text { +27 12841 } 2131\end{array}$ & enquiries.info@nmisa.org \\
\hline 54 & 5906 & $\begin{array}{l}\text { Mpala Research } \\
\underline{\text { Centre }}\end{array}$ & Quénia & $\begin{array}{c}683 \\
8\end{array}$ & 5361 & $\begin{array}{c}540 \\
1\end{array}$ & 4960 & $\begin{array}{c}\text { Mpala Research Centre } \\
\text { PO Box 555 } \\
\text { Nanyuki, } \\
\text { Kenya } \\
\text { Office Contacts } \\
+254 \text { (0) 202-597401 } \\
\text { +254 (0) 202-597402 } \\
\text { Dr. Margaret Kinnaird, Director } \\
\text { tel: +020-352-3480 }\end{array}$ & mkinnaird@mpala.org \\
\hline 55 & 5915 & $\begin{array}{l}\text { Institut de } \\
\text { Recherche pour } \\
\text { le } \\
\text { Développement } \\
\text { Dakar }\end{array}$ & Senegal & $\begin{array}{c}303 \\
0\end{array}$ & 6858 & $\begin{array}{c}498 \\
7\end{array}$ & 4960 & $\begin{array}{l}\text { Sénégal Cap-Vert, Gambie, } \\
\text { Guinée-Bissau et Mauritanie }\end{array}$ & \\
\hline 56 & 5943 & Aurum Institute & South & 619 & 5916 & 569 & 4511 & Postnet Suite \#300, Private Bag & info@auruminstitute.org \\
\hline
\end{tabular}




\begin{tabular}{|c|c|c|c|c|c|c|c|c|c|}
\hline & & $\begin{array}{l}\text { for Health } \\
\underline{\text { Research }}\end{array}$ & Africa & 0 & & 9 & & $\begin{array}{c}\text { X30500, Houghton, } 2041 \\
\text { Telephone: +27 (0) } 105901300 \\
\text { Fax: +27 (0) } 114844682\end{array}$ & \\
\hline 57 & 5958 & $\begin{array}{l}\frac{\text { Centre National }}{\text { de la Recherche }} \\
\text { Scientifique et } \\
\text { Technologique } \\
\text { CENAREST } \\
\text { Gabon }\end{array}$ & Gabon & $\begin{array}{c}622 \\
8\end{array}$ & 6659 & $\begin{array}{c}507 \\
7\end{array}$ & 3271 & & \\
\hline 58 & 5961 & $\begin{array}{l}\frac{\text { Desert Research }}{\text { Foundation of }} \\
\underline{\text { Namibia }}\end{array}$ & Namíbia & $\begin{array}{c}638 \\
8\end{array}$ & 4679 & $\begin{array}{c}651 \\
2\end{array}$ & 4960 & $\begin{array}{c}\text { Desert Research Foundation of } \\
\text { Namibia } \\
7 \text { Rossini Str. Windhoek West } \\
\text { PO BOX } 20232 \text { Windhoek, } \\
\text { Namibia } \\
\text { Tel: }+264-61-377500 \\
\text { Fax: +264-61-230172 }\end{array}$ & drfn@drfn.org.na \\
\hline 59 & 5966 & $\begin{array}{l}\text { Institut Pasteur } \\
\underline{\text { de Dakar }}\end{array}$ & Senegal & $\begin{array}{c}554 \\
5\end{array}$ & 6049 & $\begin{array}{c}559 \\
2\end{array}$ & 4960 & $\begin{array}{c}\text { Adresses de l' Institut Pasteur de } \\
\text { Dakar } \\
\text { 36, Avenue Pasteur } \\
\text { B.P. } 220 \text { - DAKAR } \\
\text { Tél. : + } 221338399200 \\
\text { Fax : + } 221338399210\end{array}$ & pasteurdakar@pasteur.sn \\
\hline 60 & 5973 & $\begin{array}{l}\frac{\text { Ifakara Health }}{\text { Research and }} \\
\text { Development } \\
\text { Center }\end{array}$ & Tanzânia & $\begin{array}{c}566 \\
3\end{array}$ & 4402 & $\begin{array}{c}694 \\
5\end{array}$ & 4960 & $\begin{array}{c}\text { Telephone Us: } \\
+255232440065 \\
\text { Fax Us: } \\
+255232333487 \\
\text { Visit Us: } \\
\text { Centre } \\
\text { Bagamoyo Research and Training } \\
\text { Bagamoyo District Hospital } \\
\text { Bagamoyo } \\
\text { P.O. Box } 74\end{array}$ & bagamoyo @ ihi.or.tz \\
\hline 61 & 5975 & $\begin{array}{l}\text { African } \\
\text { Conservation } \\
\text { Centre }\end{array}$ & Quénia & $\begin{array}{c}485 \\
2\end{array}$ & 4798 & $\begin{array}{c}694 \\
5\end{array}$ & 4960 & $\begin{array}{c}\text { Karen area of Nairobi, opposite } \\
\text { Hillcrest Preparatory } \\
\text { School,Hekima Road,off Fairacres } \\
\text { Rd, Off Langata Road } \\
\text { PO Box 15289-00509 } \\
\text { Nairobi, KENYA }\end{array}$ & \\
\hline 62 & 6055 & $\begin{array}{l}\frac{\text { Centre for }}{\text { Infectious }} \\
\text { Disease } \\
\text { Research in } \\
\text { Zambia }\end{array}$ & Zâmbia & $\begin{array}{c}627 \\
5\end{array}$ & 5309 & $\begin{array}{c}629 \\
0\end{array}$ & 4960 & $\begin{array}{c}\text { CIDRZ Head Office } \\
\text { Plot } 5032 \text { Great North Rd. } \\
\text { Lusaka, Zambia } \\
\text { Mailing Address } \\
\text { CIDRZ } \\
\text { P.O. Box } 34681 \\
\text { Lusaka, Zambia } 10101 \\
\text { Enquiries: +260211 } 242257 / 8 / 9\end{array}$ & info@cidrz.org \\
\hline 63 & 6158 & $\begin{array}{l}\frac{\text { Stellenbosch }}{\text { Institute for }} \\
\text { Advanced Study }\end{array}$ & $\begin{array}{l}\text { South } \\
\text { Africa }\end{array}$ & $\begin{array}{c}570 \\
0\end{array}$ & 6235 & $\begin{array}{c}575 \\
7\end{array}$ & 4960 & $\begin{array}{c}\text { Prof Hendrik B Geyer } \\
\text { Director: STIAS } \\
\text {-Tel: +27 (0) 21 } 8082185 \\
\text { Ms Maria Mouton } \\
\text { PA to the STIAS Director } \\
\text {-E-mail: mmouton@sun.ac.za } \\
\text {-Tel: +27 (0) } 218082963 \\
\text {-Fax: }+27(0) 218082184 \\
\text { Mailing address } \\
\text { Mostertsdrift } \\
\text { Private Bag X1 } \\
\text { Matieland 7602 } \\
\text { South Africa }\end{array}$ & hbg@sun.ac.za \\
\hline 64 & 6176 & $\begin{array}{l}\text { Centre Pasteur } \\
\underline{\text { du Cameroun }}\end{array}$ & Cameron & $\begin{array}{c}640 \\
7\end{array}$ & 6511 & $\begin{array}{c}546 \\
8\end{array}$ & 4075 & & \\
\hline 65 & 6214 & $\begin{array}{l}\text { National } \\
\text { Agricultural } \\
\text { Extension and } \\
\text { Research } \\
\text { Liaison Services } \\
\text { iaison }\end{array}$ & Nigéria & $\begin{array}{c}540 \\
4\end{array}$ & 6886 & $\begin{array}{c}424 \\
3\end{array}$ & 4960 & $\begin{array}{c}\text { Executive Director, } \\
\text { NAERLS Complex, } \\
\text { Ahmadu Bello University, } \\
\text { Samaru } \\
\text { P.M.B } 1067 \\
\text { Zaria } \\
\text { Kaduna State } \\
\text { Nigeria } \\
+234-069-879449\end{array}$ & \\
\hline 66 & 6219 & $\begin{array}{l}\text { Lung Institute } \\
\text { University of } \\
\text { Cape Town }\end{array}$ & $\begin{array}{l}\text { South } \\
\text { Africa }\end{array}$ & $\begin{array}{c}618 \\
4\end{array}$ & 6822 & $\begin{array}{c}463 \\
8\end{array}$ & 4173 & $\begin{array}{c}\text { Administration } \\
\text { Contact: Cheryl Nel } \\
\text { Tel: +27 (0) } 214066862 \\
\text { Fax: +27(0) } 214066851\end{array}$ & cheryl.nel@uct.ac.za \\
\hline 67 & 6347 & $\frac{\text { Geological }}{\frac{\text { Survey of }}{\text { Namibia }}}$ & Namibia & $\begin{array}{c}723 \\
3\end{array}$ & 4993 & $\begin{array}{c}640 \\
9\end{array}$ & 4960 & Director Dr. G. Schneider & gschneider@mme.gov.na \\
\hline 68 & 6442 & $\begin{array}{l}\text { Forestry \& } \\
\text { Forest Products } \\
\text { Research Centre } \\
\text { South Africa } \\
\end{array}$ & $\begin{array}{l}\text { South } \\
\text { Africa }\end{array}$ & $\begin{array}{c}706 \\
6\end{array}$ & 6143 & $\begin{array}{c}621 \\
2\end{array}$ & 4114 & $\begin{array}{c}\text { Telephone } \\
\text { Tel: +27 (031) 242 2300 (CSIR } \\
\text { Switchboard) } \\
\text { Fax: +27 (031) 261-1216 } \\
\text { (Alternate: 2509) } \\
\text { Forestry \& Forest Products } \\
\text { Research Centre } \\
\text { P O Box 17001 } \\
\text { Congella } \\
4013 \\
\text { South Africa }\end{array}$ & forestopt@csir.co.za \\
\hline 69 & 6462 & $\begin{array}{l}\frac{\text { Institut }}{\text { d'Economie }} \\
\text { Rurale du Mali } \\
\end{array}$ & Mali & $\begin{array}{c}608 \\
4\end{array}$ & 6528 & $\begin{array}{c}599 \\
3\end{array}$ & 4960 & & \\
\hline 70 & 6476 & $\begin{array}{l}\text { Gobabeb } \\
\text { Training and } \\
\text { Research Centre } \\
\text { Walvis Bay }\end{array}$ & Namibia & $\begin{array}{c}527 \\
3\end{array}$ & 6417 & $\begin{array}{c}646 \\
4\end{array}$ & 4960 & $\begin{array}{c}\text { Gobabeb Research and Training } \\
\text { Centre } \\
\text { P.O. Box 953, Walvis Bay } \\
\text { Tel: +264 64694 } 199 \\
\text { Fax: +26464694197 }\end{array}$ & gobabeb@gobabeb.org \\
\hline
\end{tabular}


VNIVERSIDAD

\begin{tabular}{|c|c|c|c|c|c|c|c|c|c|}
\hline & 6483 & $\begin{array}{l}\text { Centre de } \\
\text { Recherche } \\
\text { Medicale et } \\
\text { Sanitaire } \\
\text { Niamey }\end{array}$ & Niger & $\begin{array}{c}639 \\
6\end{array}$ & 7002 & $\begin{array}{l}460 \\
6\end{array}$ & 4651 & $\begin{array}{c}\text { CERMES - BP } 10887 \text { Niamey, } \\
\text { Niger - Tél : } 0022720752040 \text { - } \\
0022720752045 \text { - Fax : } 00227 \\
753180 \text { - }\end{array}$ & cermes@cermes.org \\
\hline 72 & 6490 & $\begin{array}{l}\frac{\text { Tanzania }}{\text { Wildlife }} \\
\underline{\text { Research }} \\
\underline{\text { Institute }}\end{array}$ & Tanzania & $\begin{array}{c}342 \\
5\end{array}$ & 6607 & $\begin{array}{c}678 \\
8\end{array}$ & 4960 & $\begin{array}{c}\text { Tanzania Wildlife Research } \\
\text { Institute, } \\
\text { P.O.Box } 661 \text { Arusha Tanzania, } \\
\text { Tel: }+255272549571, \\
\text { Fax: }+255272548240 \\
\text { Research Clearance Email : } \\
\text { researchclearance @ tawiri.or.tz }\end{array}$ & info@tawiri.or.tz \\
\hline 73 & 6530 & $\begin{array}{l}\frac{\text { US Army }}{\text { Medical }} \\
\text { Research Unit } \\
\text { Kenya }\end{array}$ & Kenya & $\begin{array}{c}482 \\
6\end{array}$ & 5892 & $\begin{array}{c}718 \\
3\end{array}$ & 4960 & $\begin{array}{c}\text { HEAD OFFICE } \\
\text { American Embassy } \\
\text { USAMRU-K } \\
\text { P.O Box 606-00621, Village } \\
\text { Market } \\
\text { Nairobi, Kenya } \\
\text { MOBILE : }+254202729303,20 \\
2713689 \\
\text { LANDLINE }:+254722 \text { 204527 / } \\
733623637\end{array}$ & info@wrp-nbo.org \\
\hline 74 & 6551 & $\begin{array}{l}\text { Botswana } \\
\text { Technology } \\
\underline{\text { Centre }}\end{array}$ & Kenya & $\begin{array}{c}668 \\
6\end{array}$ & 5638 & $\begin{array}{c}678 \\
8\end{array}$ & 4960 & & \\
\hline 75 & 6639 & $\begin{array}{l}\text { National Food } \\
\text { Technology } \\
\text { Research Centre } \\
\text { Botswana }\end{array}$ & Kenya & $\begin{array}{c}527 \\
4\end{array}$ & 7141 & $\begin{array}{c}602 \\
0\end{array}$ & 4173 & $\begin{array}{l}\text { Plot } 1840 \text { Mpuutsane Industrial } \\
\text { Area } \\
\text { Lobatse Road } \\
\text { Kanye } \\
\text { Telephone: (00267) } 5440441 \\
\text { Fax: (00267) 5440713 }\end{array}$ & mail@naftec.org \\
\hline 76 & 6756 & $\begin{array}{l}\text { Centre } \\
\text { International de } \\
\text { Recherches } \\
\text { Medicales de } \\
\text { Franceville }\end{array}$ & Gabon & $\begin{array}{c}613 \\
8\end{array}$ & 6411 & $\begin{array}{c}678 \\
8\end{array}$ & 4960 & & \\
\hline 77 & 6762 & $\begin{array}{l}\frac{\text { National }}{\text { Veterinary }} \\
\text { Research } \\
\underline{\text { Institute Vom }}\end{array}$ & Nigeria & $\begin{array}{c}683 \\
0\end{array}$ & 7451 & $\begin{array}{c}602 \\
0\end{array}$ & 1331 & $\begin{array}{c}\text { National Veterinary Research } \\
\text { Institute } \\
\text { P.M.B } 01 \text { Vom, Plateau State } \\
\text { Nigeria } \\
07055578876 \\
\text { edvr@nvri.gov.ng }\end{array}$ & enquiries@nvri.gov.ng \\
\hline 78 & 6823 & $\begin{array}{l}\text { National } \\
\text { Hospital Abuja }\end{array}$ & Nigeria & $\begin{array}{c}710 \\
2\end{array}$ & 6861 & $\begin{array}{c}581 \\
6\end{array}$ & 4960 & $\begin{array}{c}\text { Dr. Tony Okam } \\
\text { Chairman } \\
\text { tonyokam@yahoo.com }\end{array}$ & $\begin{array}{c}\text { info@nationalhospitalabuja.n } \\
\text { et }\end{array}$ \\
\hline 79 & 6824 & $\begin{array}{l}\frac{\text { Tea Research }}{\text { Foundation of }} \\
\underline{\text { Kenya }}\end{array}$ & Kenya & $\begin{array}{c}562 \\
2\end{array}$ & 6636 & $\begin{array}{c}694 \\
5\end{array}$ & 4960 & $\begin{array}{c}\text { The Director, } \\
\text { Tea Research Foundation of } \\
\text { Kenya, } \\
\text { Off Kericho-Nakuru Road, } \\
\text { P.O Box 820 - 20200, Kericho, } \\
\text { Kenya. } \\
\text { Tel.: +254-52-20598, 20599, } \\
\text { +254-722-209915 } \\
\text { Fax: }+254-52-20575\end{array}$ & info@tearesearch.or.ke \\
\hline 80 & 6841 & $\begin{array}{l}\text { Joint Clinical } \\
\underline{\text { Research Center }} \\
\underline{\text { Uganda }}\end{array}$ & Uganda & $\begin{array}{c}686 \\
3\end{array}$ & 6895 & $\begin{array}{c}610 \\
6\end{array}$ & 4960 & $\begin{array}{l}\text { Plot } 101 \text { Upper Lubowa Estates } \\
\text { P O Box } \\
\text { Tel: }\end{array}$ & jcrc@ @crc.org.ug \\
\hline$\overline{81}$ & 6843 & $\begin{array}{l}\text { Chris Hani } \\
\text { Baragwanath } \\
\underline{\text { Hospital }}\end{array}$ & $\begin{array}{l}\text { South } \\
\text { Africa }\end{array}$ & $\begin{array}{c}712 \\
2\end{array}$ & 5679 & $\begin{array}{c}718 \\
3\end{array}$ & 4960 & $\begin{array}{l}\text { R68 Old Potchefstroom Road } \\
\text { PO Bertsham } \\
\text { Johannesburg } \\
\qquad 2013 \\
\text { South Africa } \\
\text { line / Switchboard: } \\
\text { Tel: }+27(0) 11 \text { 933-8000 } \\
\text { Public Relations Department: } \\
\text { Tel: }+27(0) 11 \text { 933-9111 } \\
\text { Fax: }+27(0) 11938-1005\end{array}$ & \\
\hline 82 & 6929 & $\begin{array}{l}\frac{\text { Kintampo }}{\text { Health Research }} \\
\underline{\text { Centre }}\end{array}$ & Ghana & $\begin{array}{c}625 \\
7\end{array}$ & 7240 & $\begin{array}{c}581 \\
6\end{array}$ & 4960 & $\begin{array}{c}\text { KHRC \|Kintampo Health Research } \\
\text { Centre } \\
\text { Kintampo, P.O.Box } 200 \\
\text { Ghana } \\
\text { Phone: }+233(0) 352092037-8\end{array}$ & enquiries@kintampo-hrc.org \\
\hline 83 & 7061 & Institut du Sahel & Mali & $\begin{array}{c}754 \\
0\end{array}$ & 5155 & $\begin{array}{c}718 \\
3\end{array}$ & 4960 & $\begin{array}{l}\text { Quartier Hamdallaye ACI } 2000 \\
\text { Rue } 453 \text {, porte } 538 \\
\text { Bamako - Mali } \\
\text { Tél.: (+223) } 20.22 .21 .48 \text { / } \\
\text { 20.22.30.43 / 20.22.47.06 } \\
\text { Fax: (+223) 20.22.78.31 }\end{array}$ & dginsah@insah.org \\
\hline$\overline{84}$ & 7102 & $\begin{array}{l}\text { Council for } \\
\text { Scientific and } \\
\text { Industrial } \\
\text { Research Ghana }\end{array}$ & Ghana & $\begin{array}{c}754 \\
0\end{array}$ & 5363 & $\begin{array}{c}718 \\
3\end{array}$ & 4960 & & \\
\hline 85 & 7118 & $\begin{array}{l}\text { Inkosi Albert } \\
\underline{\text { Luthuli Central }} \\
\underline{\text { Hospital }}\end{array}$ & $\begin{array}{l}\text { South } \\
\text { Africa }\end{array}$ & $\begin{array}{c}677 \\
9\end{array}$ & 7312 & $\begin{array}{c}610 \\
6\end{array}$ & 4960 & & \\
\hline 86 & 7218 & $\begin{array}{l}\frac{\text { Centre Africain }}{\text { de Recherches }} \\
\underline{\text { sur Bananiers et }} \\
\underline{\text { Plantains }}\end{array}$ & $\begin{array}{c}\text { Cameroo } \\
\mathrm{n}\end{array}$ & $\begin{array}{c}635 \\
8\end{array}$ & 7288 & $\begin{array}{c}678 \\
8\end{array}$ & 4960 & $\begin{array}{l}\text { Tel : (+237) } 33228639 \\
\text { CARBAP Bureau de liaison } \\
\text { BP } 832 \text { Douala Bonanjo }\end{array}$ & carbap@carbapafrica.org \\
\hline
\end{tabular}




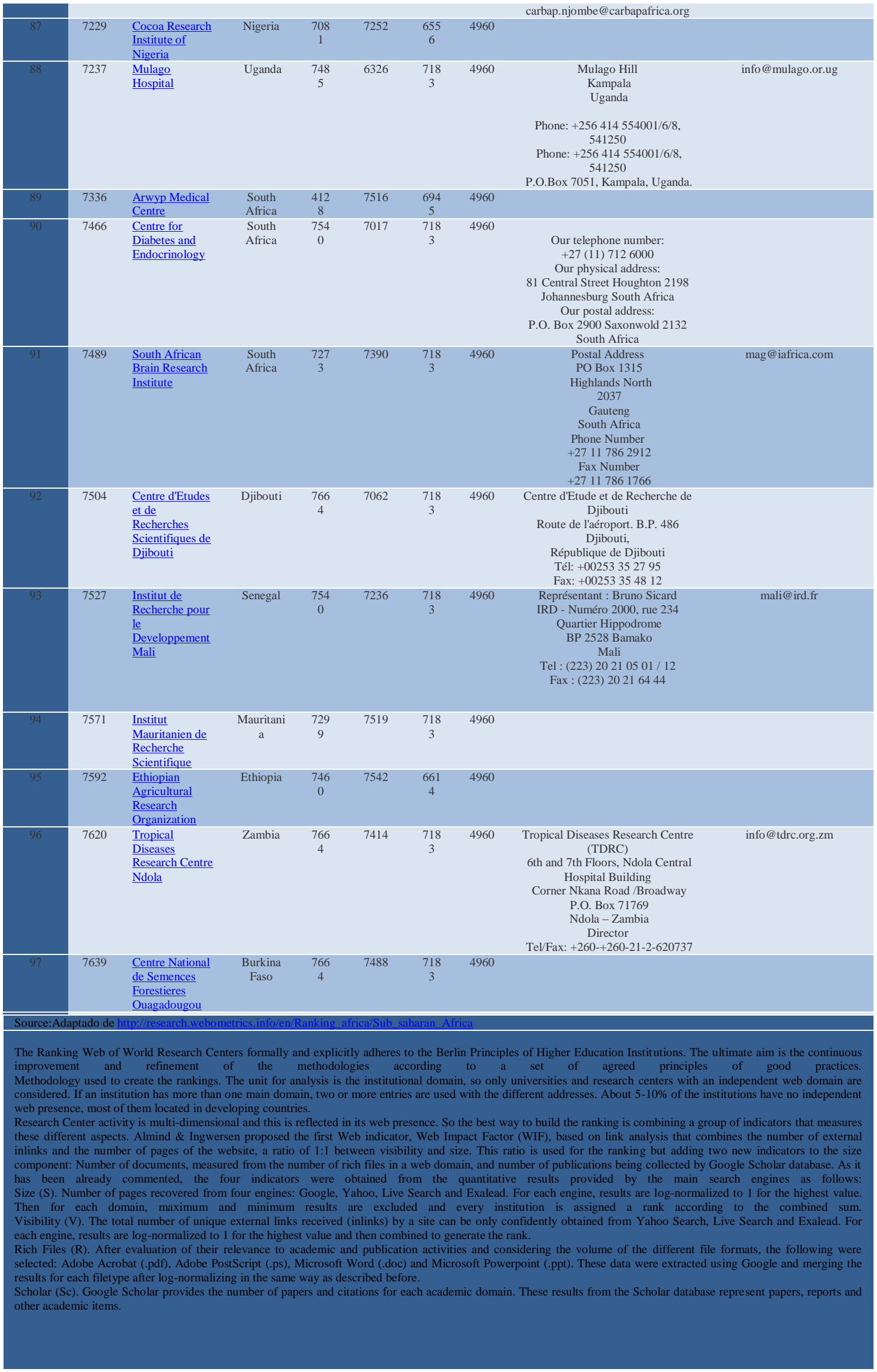


VNIVERSIDAD

DSALAMANCA

Fonte: adaptado de http://research.webometrics.info/en/Ranking_africa/Sub_saharan_Africa 


\section{N 5 T I T U T \\ :}

Anexo 11 - Despesa corrente como \% do total da despesa em instituições públicas de ensino superior (\%), por país - ASS - 1999-2013

\begin{tabular}{|c|c|c|c|c|c|c|c|c|c|c|c|c|c|c|c|c|}
\hline & 1999 & 2000 & 2001 & 2002 & 2003 & 2004 & 2005 & 2006 & 2007 & 2008 & 2009 & 2010 & 2011 & 2012 & $\begin{array}{c}201 \\
3\end{array}$ & Total \\
\hline Angola & .. & .. & .. & .. & .. & .. &.. & $\begin{array}{r}71.1 \\
1404\end{array}$ &.. & .. & .. &.. &.. & .. & .. & $\begin{array}{r}71.11 \\
404\end{array}$ \\
\hline Benin & & .. & & .. & .. & .. & .. & $\begin{array}{r}68.6 \\
4675\end{array}$ & $\begin{array}{r}91.0 \\
386\end{array}$ & $\begin{array}{r}91.5 \\
5543\end{array}$ & $\begin{array}{r}84.0 \\
0254\end{array}$ & $\begin{array}{r}97.8 \\
5216\end{array}$ &.. & .. & .. & $\begin{array}{r}433.0 \\
9548\end{array}$ \\
\hline $\begin{array}{l}\text { Botswa } \\
\text { na }\end{array}$ & .. & .. & .. & .. & .. & .. &.. & .. & .. & .. & $\begin{array}{r}92.2 \\
5156\end{array}$ &.. &.. & .. & .. & $\begin{array}{l}92.25 \\
156\end{array}$ \\
\hline $\begin{array}{l}\text { Burkin } \\
\text { a Faso }\end{array}$ & .. & .. & .. & .. & .. & .. &.. & .. & $\begin{array}{r}71.7 \\
5048\end{array}$ & .. & .. &.. & $\begin{array}{r}80.2 \\
432\end{array}$ & $\begin{array}{r}70.2 \\
7864\end{array}$ & .. & $\begin{array}{r}222.2 \\
7232\end{array}$ \\
\hline $\begin{array}{l}\text { Burund } \\
\mathrm{i}\end{array}$ & $\begin{array}{r}94.0 \\
5137\end{array}$ & .. & $\begin{array}{r}90.1 \\
9214\end{array}$ & $\begin{array}{r}94.0 \\
2787\end{array}$ & .. & $\begin{array}{r}95.9 \\
1013\end{array}$ & .. & .. & .. & $\begin{array}{r}97.4 \\
6039\end{array}$ & $\begin{array}{r}92.9 \\
851\end{array}$ & $\begin{array}{r}97.1 \\
1986\end{array}$ & $\begin{array}{r}96.7 \\
1269\end{array}$ & $\begin{array}{r}98.7 \\
2617\end{array}$ & .. & $\begin{array}{l}857.1 \\
8572\end{array}$ \\
\hline $\begin{array}{l}\text { Camer } \\
\text { oon }\end{array}$ &.. & .. & .. & .. & .. & .. & .. & .. & .. & $\begin{array}{r}76.4 \\
3399\end{array}$ & 100 & $\begin{array}{r}69.7 \\
2983\end{array}$ & $\begin{array}{r}86.3 \\
1687\end{array}$ & 100 & .. & $\begin{array}{r}432.4 \\
8069\end{array}$ \\
\hline $\begin{array}{l}\text { Cabo } \\
\text { Verde }\end{array}$ & .. & .. & .. & .. & .. & $\begin{array}{r}81.4 \\
7573\end{array}$ & .. & $\begin{array}{r}53.9 \\
6558\end{array}$ & .. & $\begin{array}{r}87.8 \\
031\end{array}$ & $\begin{array}{r}74.8 \\
2291\end{array}$ & .. &.. &.. & .. & $\begin{array}{r}298.0 \\
6732\end{array}$ \\
\hline $\begin{array}{l}\text { Central } \\
\text { African } \\
\text { Republ } \\
\text { ic }\end{array}$ & .. & .. & .. & .. & .. & .. & $\begin{array}{r}98.6 \\
7668\end{array}$ & .. & $\begin{array}{r}98.7 \\
5869\end{array}$ & $\begin{array}{r}96.7 \\
1091\end{array}$ & .. & $\begin{array}{r}95.8 \\
3298\end{array}$ &.. &.. & .. & $\begin{array}{r}389.9 \\
7926\end{array}$ \\
\hline Chad & .. & .. & .. &.. & .. & .. & .. & .. & .. & .. & .. & .. & $\begin{array}{r}67.7 \\
2494\end{array}$ &.. & .. & $\begin{array}{r}67.72 \\
494\end{array}$ \\
\hline $\begin{array}{l}\text { Comor } \\
\text { os }\end{array}$ & .. & .. &.. & .. & .. & .. &.. & .. & .. &.. & .. &.. &.. & .. & .. & 0 \\
\hline Congo & .. & .. & .. & .. & .. & .. & .. & .. & .. & .. & .. & $\begin{array}{r}65.3 \\
003\end{array}$ &.. & .. & .. & $\begin{array}{r}65.30 \\
03\end{array}$ \\
\hline $\begin{array}{l}\text { Côte } \\
\text { d'Ivoire }\end{array}$ & $\begin{array}{r}85.1 \\
2358\end{array}$ & .. & .. & .. & .. & .. &.. & .. & .. & .. & .. &.. &.. & .. & .. & $\begin{array}{r}85.12 \\
358\end{array}$ \\
\hline $\begin{array}{l}\text { Democ } \\
\text { ratic } \\
\text { Republ } \\
\text { ic of } \\
\text { the } \\
\text { Congo }\end{array}$ & .. & .. & .. & .. & .. & .. &.. & .. & .. & .. & .. & $\begin{array}{r}94.6 \\
812\end{array}$ &.. & .. & .. & $\begin{array}{r}94.68 \\
12\end{array}$ \\
\hline $\begin{array}{l}\text { Djibout } \\
\mathrm{i}\end{array}$ & .. & .. &.. & .. & .. & .. & .. & .. & .. & .. & .. &.. &.. &.. & .. & 0 \\
\hline $\begin{array}{l}\text { Equato } \\
\text { rial } \\
\text { Guinea }\end{array}$ & .. & .. &.. & .. & .. & .. & .. & .. & .. & .. & .. &.. &.. & .. & .. & 0 \\
\hline Eritrea & .. & $\begin{array}{r}47.1 \\
3958\end{array}$ &.. & $\begin{array}{r}24.0 \\
2364\end{array}$ & .. & $\begin{array}{r}63.7 \\
4329\end{array}$ & .. & .. & .. & .. & .. &.. &.. & .. & .. & $\begin{array}{r}134.9 \\
0651\end{array}$ \\
\hline $\begin{array}{l}\text { Ethiopi } \\
\text { a }\end{array}$ & .. & .. & .. & .. & .. & .. & .. & .. & .. & .. & .. & .. &.. &.. & .. & (1) \\
\hline Gabon & .. & .. & .. & .. & .. & .. & .. & .. & .. &.. &.. &.. &.. & .. & .. & 0 \\
\hline $\begin{array}{l}\text { Gambi } \\
\text { a }\end{array}$ & .. & .. & .. & .. & .. & .. & .. & .. & .. & $\begin{array}{r}94.7 \\
0768\end{array}$ & 100 & $\begin{array}{r}85.0 \\
2701\end{array}$ & $\begin{array}{r}85.8 \\
5737\end{array}$ & $\begin{array}{r}77.5 \\
9349\end{array}$ & .. & $\begin{array}{l}443.1 \\
8555\end{array}$ \\
\hline Ghana & .. & .. & $\begin{array}{r}99.6 \\
7169\end{array}$ & .. & .. & $\begin{array}{r}86.0 \\
137\end{array}$ & $\begin{array}{r}77.3 \\
5287\end{array}$ & $\begin{array}{r}81.6 \\
4539\end{array}$ & $\begin{array}{r}69.4 \\
9396\end{array}$ & $\begin{array}{r}71.4 \\
0145\end{array}$ & $\begin{array}{r}76.6 \\
8693\end{array}$ & $\begin{array}{r}67.1 \\
2807\end{array}$ & .. & .. & .. & $\begin{array}{r}629.3 \\
9406\end{array}$ \\
\hline Guinea & .. & .. & .. & .. & .. & .. & .. & .. & .. & $\begin{array}{r}96.6 \\
9542\end{array}$ & $\begin{array}{r}87.1 \\
8879\end{array}$ & $\begin{array}{r}68.6 \\
2309\end{array}$ & $\begin{array}{r}93.6 \\
7362\end{array}$ & $\begin{array}{r}98.4 \\
1378\end{array}$ & .. & $\begin{array}{r}444.5 \\
947\end{array}$ \\
\hline $\begin{array}{l}\text { Guinea } \\
\text {-Bissau }\end{array}$ & .. & .. & .. & .. & .. & .. & .. & .. & .. & .. & .. & .. &. & .. & .. & 0 \\
\hline Quénia & .. & .. & .. & .. & .. & .. & .. & .. & .. & .. & .. & .. &.. & .. & .. & 0 \\
\hline $\begin{array}{l}\text { Lesoth } \\
0\end{array}$ & $\begin{array}{r}90.8 \\
9237\end{array}$ & .. & $\begin{array}{r}96.4 \\
6914\end{array}$ & .. & .. & .. & .. & .. & .. & $\begin{array}{r}96.1 \\
8173\end{array}$ & .. &.. &.. & .. & .. & $\begin{array}{r}283.5 \\
4324\end{array}$ \\
\hline Liberia & .. & .. & .. & .. &.. & .. & .. & .. & .. & .. &.. &.. &.. &.. & .. & \\
\hline $\begin{array}{l}\text { Madag } \\
\text { ascar }\end{array}$ & .. & .. & .. & .. & .. & .. & $\begin{array}{r}78.2 \\
46\end{array}$ & $\begin{array}{r}97.7 \\
4982\end{array}$ & $\begin{array}{r}89.3 \\
914\end{array}$ & $\begin{array}{r}88.1 \\
0766\end{array}$ & .. & .. & $\begin{array}{r}86.1 \\
5735\end{array}$ & $\begin{array}{r}99.5 \\
5763\end{array}$ & .. & $\begin{array}{r}539.2 \\
0986\end{array}$ \\
\hline Malawi & .. & .. &.. &.. & .. & .. & .. & .. & .. & .. & .. & $\begin{array}{r}97.9 \\
3111\end{array}$ & $\begin{array}{r}99.2 \\
4443\end{array}$ &.. & .. & $\begin{array}{l}197.1 \\
7554\end{array}$ \\
\hline$\overline{\text { Mali }}$ & .. & .. & .. & .. & .. & .. &.. & .. & .. & $\begin{array}{r}88.3 \\
5821\end{array}$ & $\begin{array}{r}85.5 \\
6865\end{array}$ & $\begin{array}{r}81.3 \\
3519\end{array}$ & $\begin{array}{r}72.1 \\
8476\end{array}$ & .. & .. & $\begin{array}{r}327.4 \\
4681\end{array}$ \\
\hline $\begin{array}{l}\text { Maurit } \\
\text { ania }\end{array}$ & .. & .. & & .. & .. & .. & .. & .. & .. &.. & ... & .. &.. & .. & .. & \\
\hline
\end{tabular}


VNiVERSiDAD

DSALAMANCA

\begin{tabular}{|c|c|c|c|c|c|c|c|c|c|c|c|c|c|c|c|c|}
\hline $\begin{array}{l}\text { Mauriti } \\
\text { us }\end{array}$ & & .. & .. & .. & .. & .. & IL & MAN & .. & .. & .. & $\begin{array}{r}98.6 \\
367\end{array}$ & .. &.. &.. & $\begin{array}{r}98.63 \\
67\end{array}$ \\
\hline $\begin{array}{l}\text { Mozam } \\
\text { bique }\end{array}$ & .. & .. &.. &. & .. & .. &.. & $\begin{array}{r}86.2 \\
7505\end{array}$ & .. & .. &.. &.. & .. &.. & .. & $\begin{array}{r}86.27 \\
505\end{array}$ \\
\hline $\begin{array}{l}\text { Namibi } \\
\text { a }\end{array}$ & .. & $\begin{array}{r}86.6 \\
9787\end{array}$ &.. & .. & .. & .. &.. & .. & .. & .. & .. &.. & .. &.. & .. & $\begin{array}{r}86.69 \\
787\end{array}$ \\
\hline Niger & .. &.. &.. & .. & .. & .. &.. & $\begin{array}{r}98.9 \\
2601\end{array}$ & .. & $\begin{array}{r}95.5 \\
4555\end{array}$ & $\begin{array}{r}92.6 \\
5615\end{array}$ & $\begin{array}{r}89.7 \\
9716\end{array}$ & $\begin{array}{r}78.6 \\
5381\end{array}$ & $\begin{array}{r}80.7 \\
9873\end{array}$ & .. & $\begin{array}{l}536.3 \\
7741\end{array}$ \\
\hline Nigeria & .. &.. &.. & .. & .. & .. &.. &.. & .. & .. & .. &.. & .. &.. & .. & 0 \\
\hline $\begin{array}{l}\text { Rwand } \\
\text { a }\end{array}$ & .. & .. &.. & .. & .. & .. & .. & & .. & .. & .. & $\begin{array}{l}93.4 \\
0428\end{array}$ & $\begin{array}{r}90.8 \\
0785\end{array}$ & $\begin{array}{r}83.7 \\
1098\end{array}$ & $\begin{array}{r}82.2 \\
215\end{array}$ & $\begin{array}{l}350.1 \\
4461\end{array}$ \\
\hline $\begin{array}{l}\text { Sao } \\
\text { Tome } \\
\text { and } \\
\text { Princip } \\
\text { e }\end{array}$ & .. &.. &.. &. & .. & .. &.. & .. & .. & .. & .. &.. & .. &.. & .. & 0 \\
\hline $\begin{array}{l}\text { Senega } \\
1\end{array}$ & .. &.. &.. &. & .. & .. &.. &.. &.. & .. &.. & $\begin{array}{r}94.4 \\
4648\end{array}$ & .. &.. & .. & 94.44 \\
\hline $\begin{array}{l}\text { Seyche } \\
\text { lles }\end{array}$ & .. & .. & .. & .. & .. & .. &.. & .. & .. & .. & .. &.. & $\begin{array}{r}99.1 \\
935\end{array}$ &.. & .. & $\begin{array}{r}99.19 \\
35\end{array}$ \\
\hline $\begin{array}{l}\text { Sierra } \\
\text { Leone }\end{array}$ & .. &.. & .. &. & .. & .. &.. & .. & 100 & $\begin{array}{r}89.8 \\
115\end{array}$ & $\begin{array}{r}99.4 \\
9133\end{array}$ & $\begin{array}{r}93.6 \\
2943\end{array}$ & $\begin{array}{r}97.1 \\
1554\end{array}$ & 100 & .. & $\begin{array}{r}580.0 \\
478\end{array}$ \\
\hline $\begin{array}{l}\text { Somali } \\
\text { a }\end{array}$ & .. & .. &.. & .. & .. & .. &.. & .. & .. & .. &. &.. & .. &.. & .. & 0 \\
\hline $\begin{array}{l}\text { South } \\
\text { Africa }\end{array}$ & .. &.. & $\begin{array}{r}98.4 \\
4756\end{array}$ & .. & $\begin{array}{r}99.9 \\
5521\end{array}$ & .. & $\begin{array}{r}99.8 \\
5194\end{array}$ & $\begin{array}{r}95.8 \\
9718\end{array}$ & $\begin{array}{r}99.9 \\
5444\end{array}$ & $\begin{array}{r}99.9 \\
4076\end{array}$ & $\begin{array}{r}99.9 \\
0632\end{array}$ & $\begin{array}{l}99.7 \\
6998\end{array}$ & 100 & 100 & .. & $\begin{array}{l}9993.7 \\
2339\end{array}$ \\
\hline $\begin{array}{l}\text { South } \\
\text { Sudan }\end{array}$ & .. & .. & .. & .. & .. & .. & .. &.. & .. & .. & .. &.. & .. &.. & .. & 0 \\
\hline Sudan & .. &.. & .. &. & .. & .. & .. & .. & .. & .. &.. &.. & .. &.. & .. & 0 \\
\hline $\begin{array}{l}\text { Swazil } \\
\text { and }\end{array}$ & .. &.. & .. & .. & .. & .. & .. & .. & .. & .. &.. &.. & .. &.. & .. & 0 \\
\hline Togo & .. & $\begin{array}{r}99.7 \\
2315\end{array}$ & .. &.. & .. & .. & .. & .. & .. & .. & .. & $\begin{array}{r}97.5 \\
9243\end{array}$ & $\begin{array}{r}92.7 \\
7778\end{array}$ &.. & .. & $\begin{array}{l}290.0 \\
9336\end{array}$ \\
\hline $\begin{array}{l}\text { Ugand } \\
\text { a }\end{array}$ & .. & .. & .. & .. & .. & $\begin{array}{r}75.4 \\
5992\end{array}$ & .. & .. & .. & .. & $\begin{array}{l}83.2 \\
7785\end{array}$ & $\begin{array}{r}94.4 \\
4457\end{array}$ & .. &.. & .. & $\begin{array}{r}253.1 \\
8234\end{array}$ \\
\hline $\begin{array}{l}\text { United } \\
\text { Republ } \\
\text { ic of } \\
\text { Tanzan } \\
\text { ia }\end{array}$ & .. & .. & .. & .. & .. & .. & .. & .. & .. & .. &.. &.. & .. &.. & .. & 0 \\
\hline Zambia & .. & 100 & .. & .. & .. & $\begin{array}{r}95.2 \\
4235\end{array}$ & .. & .. &.. & .. & .. &.. & .. &.. & .. & $\begin{array}{r}195.2 \\
4235\end{array}$ \\
\hline $\begin{array}{l}\text { Zimba } \\
\text { bwe }\end{array}$ & .. & .. & .. & .. & .. & .. & .. & .. & .. & .. & $\begin{array}{l}94.7 \\
7414\end{array}$ &.. & .. &.. & .. & $\begin{array}{l}94.77 \\
414\end{array}$ \\
\hline Total & $\begin{array}{r}270 . \\
0673\end{array}$ & $\begin{array}{r}333 . \\
5606\end{array}$ & $\begin{array}{l}384 . \\
7805\end{array}$ & $\begin{array}{r}118 . \\
0515\end{array}$ & $\begin{array}{r}99.9 \\
5521\end{array}$ & $\begin{array}{l}497 . \\
8451\end{array}$ & $\begin{array}{r}354 . \\
1275\end{array}$ & $\begin{array}{r}654 . \\
2198\end{array}$ & $\begin{array}{r}620 . \\
3876\end{array}$ & $\begin{array}{r}1270 \\
.714\end{array}$ & $\begin{array}{l}1263 \\
.612\end{array}$ & $\begin{array}{l}1682 \\
.282\end{array}$ & $\begin{array}{r}1326 \\
.664\end{array}$ & $\begin{array}{l}909 . \\
0794\end{array}$ & $\begin{array}{r}82.2 \\
215\end{array}$ & \\
\hline \multicolumn{17}{|c|}{ data extracted on 04 Aug 2014 10:42 UTC (GMT) from UIS/ISU } \\
\hline \multicolumn{17}{|l|}{$\begin{array}{l}\text { Legend } \\
:\end{array}$} \\
\hline$+:$ & National E & mation & & & & & & & & & & & & & & \\
\hline a: & $\begin{array}{l}\text { Category } n \\
\text { applicable }\end{array}$ & & & & & & & & & & & & & & & \\
\hline \$: & UIS Estim & & & & & & & & & & & & & & & \\
\hline
\end{tabular}

Fonte: Dados Adaptados de UIS/ISU 


\section{N 5 T I T U T D \\ :}

Anexo 12 - Despesa do Governo com IES como \% do PIB (\%), por país, ASS

\begin{tabular}{|c|c|c|c|c|c|c|c|c|c|c|c|c|c|c|c|c|}
\hline & & & & & Despes & 0 Gove & $10 \mathrm{com} \mathrm{I}$ & 5 como & do PI & $(\%)$, por & aís, $\mathrm{AS}$ & & & & & \\
\hline & 1999 & 2000 & 2001 & 2002 & 2003 & 2004 & 2005 & 2006 & 2007 & 2008 & 2009 & 2010 & 2011 & 2012 & $\begin{array}{c}201 \\
3\end{array}$ & \\
\hline Angola & .. & .. & .. & .. & .. & .. & $\begin{array}{r}0.229 \\
97\end{array}$ & $\begin{array}{r}0.24 \\
883\end{array}$ & .. & & & .. & .. & .. & .. & $\begin{array}{r}0.478 \\
8\end{array}$ \\
\hline Benim & .. & .. & .. & .. & .. & .. & .. & $\begin{array}{r}0.52 \\
252\end{array}$ & $\begin{array}{r}0.51 \\
622\end{array}$ & $\begin{array}{r}0.512 \\
47\end{array}$ & $\begin{array}{r}0.63 \\
225\end{array}$ & $\begin{array}{r}0.582 \\
58\end{array}$ & .. & .. & .. & $\begin{array}{r}2.766 \\
0104\end{array}$ \\
\hline $\begin{array}{l}\text { Botswa } \\
\text { na }\end{array}$ & .. & .. & .. & .. & .. & .. & $\begin{array}{r}1.144 \\
56\end{array}$ & .. & $\begin{array}{r}1.10 \\
429\end{array}$ & .. & $\begin{array}{r}1.13 \\
981\end{array}$ & .. & .. & .. & .. & $\begin{array}{r}3.388 \\
66\end{array}$ \\
\hline $\begin{array}{l}\text { Burkina } \\
\text { Faso }\end{array}$ & .. & .. & .. & .. & .. & .. & $\begin{array}{r}0.330 \\
97\end{array}$ & $\begin{array}{r}0.49 \\
563\end{array}$ & $\begin{array}{r}0.50 \\
497\end{array}$ & .. & .. & $\begin{array}{r}0.632 \\
83\end{array}$ & $\begin{array}{r}0.626 \\
52\end{array}$ & $\begin{array}{r}0.71 \\
476\end{array}$ & .. & $\begin{array}{r}3.305 \\
68\end{array}$ \\
\hline Burundi & .. & .. & $\begin{array}{r}0.59 \\
239\end{array}$ & $\begin{array}{r}0.58 \\
631\end{array}$ & .. & .. & $\begin{array}{r}0.555 \\
93\end{array}$ & .. & .. & $\begin{array}{r}0.655 \\
72\end{array}$ & $\begin{array}{r}0.72 \\
582\end{array}$ & $\begin{array}{r}0.734 \\
56\end{array}$ & $\begin{array}{r}0.583 \\
55\end{array}$ & $\begin{array}{r}0.80 \\
874\end{array}$ & .. & $\begin{array}{r}5.243 \\
02\end{array}$ \\
\hline $\begin{array}{l}\text { Camero } \\
\mathrm{n}\end{array}$ & .. & .. & .. & .. & .. & .. & $\begin{array}{r}0.394 \\
88\end{array}$ & .. & .. & $\begin{array}{r}0.252 \\
38\end{array}$ & $\begin{array}{r}0.31 \\
04\end{array}$ & $\begin{array}{r}0.308 \\
49\end{array}$ & $\begin{array}{r}0.447 \\
04\end{array}$ & $\begin{array}{r}0.21 \\
666\end{array}$ & .. & $\begin{array}{r}1.929 \\
85\end{array}$ \\
\hline $\begin{array}{l}\text { Cabo } \\
\text { Verde }\end{array}$ & .. &.. & .. & $\begin{array}{r}0.38 \\
152\end{array}$ & .. & .. & $\begin{array}{r}0.226 \\
74\end{array}$ & $\begin{array}{r}0.20 \\
616\end{array}$ & .. & $\begin{array}{r}0.250 \\
9\end{array}$ & $\begin{array}{r}0.45 \\
566\end{array}$ & .. & $\begin{array}{r}0.482 \\
46\end{array}$ & .. & .. & $\begin{array}{r}2.003 \\
44\end{array}$ \\
\hline $\begin{array}{l}\text { Central } \\
\text { Africa } \\
\text { Republi } \\
\text { ca }\end{array}$ & .. & .. & .. & .. & .. & .. & .. & .. & $\begin{array}{r}0.27 \\
941\end{array}$ & $\begin{array}{r}0.225 \\
52\end{array}$ & $\begin{array}{r}0.21 \\
8\end{array}$ & $\begin{array}{r}0.183 \\
41\end{array}$ & .. & .. & .. & $\begin{array}{r}0.906 \\
34\end{array}$ \\
\hline Chade & .. & .. & .. & .. & .. & $\begin{array}{r}0.28 \\
015\end{array}$ & $\begin{array}{r}0.317 \\
44\end{array}$ & .. & .. & & $\begin{array}{r}0.21 \\
826\end{array}$ & .. & $\begin{array}{r}0.194 \\
79\end{array}$ & .. & .. & $\begin{array}{r}1.010 \\
64\end{array}$ \\
\hline $\begin{array}{l}\text { Cômoro } \\
\mathrm{s}\end{array}$ & .. & .. & .. & $\begin{array}{r}0.29 \\
236\end{array}$ & .. & .. & .. & .. & .. & $\begin{array}{r}1.111 \\
39\end{array}$ & .. & .. & .. & .. & .. & $\begin{array}{r}1.403 \\
75\end{array}$ \\
\hline Congo & .. & .. & .. & $\begin{array}{r}0.45 \\
147\end{array}$ & .. & .. & $\begin{array}{r}0.475 \\
69\end{array}$ & .. & .. & .. & .. & $\begin{array}{r}0.317 \\
77\end{array}$ & .. & .. & .. & $\begin{array}{r}1.244 \\
93\end{array}$ \\
\hline $\begin{array}{l}\text { Côte } \\
\text { d'Ivoire }\end{array}$ & .. & .. & .. & .. & .. & .. & .. & .. & .. & .. & .. & .. & .. & .. & .. & (1) \\
\hline $\begin{array}{l}\text { Republi } \\
\text { ca } \\
\text { Democr } \\
\text { atica do } \\
\text { Congo }\end{array}$ & .. & .. & .. & .. & .. & .. & .. & .. & .. & .. & .. & $\begin{array}{r}0.600 \\
68\end{array}$ & .. & .. & .. & $\begin{array}{r}0.600 \\
68\end{array}$ \\
\hline Djibouti & .. & .. & .. & .. & .. & .. & .. & .. & .. & .. & .. & .. & .. & .. &.. & 0 \\
\hline $\begin{array}{l}\text { Equator } \\
\text { ial } \\
\text { Guine } \\
\end{array}$ & .. & .. & $\begin{array}{r}0.18 \\
921\end{array}$ & $\begin{array}{r}0.17 \\
611\end{array}$ & .. & .. & .. & .. & .. & .. & .. & .. & .. & .. & .. & $\begin{array}{r}0.365 \\
32\end{array}$ \\
\hline Eritreia & .. & $\begin{array}{r}0.22 \\
823\end{array}$ & .. & $\begin{array}{r}0.52 \\
467\end{array}$ & .. & $\begin{array}{r}1.00 \\
444\end{array}$ & .. & .. & .. & .. & .. & .. & .. & .. & .. & $\begin{array}{r}1.757 \\
34\end{array}$ \\
\hline Etiópia & .. & .. & .. & .. & .. & .. & .. & .. & .. & .. & .. & $\begin{array}{r}0.167 \\
74\end{array}$ & .. & .. & .. & $\begin{array}{r}0.167 \\
74\end{array}$ \\
\hline Gabon & .. & .. & .. & .. & .. & .. & .. & .. & .. & .. & .. & .. & .. & .. & .. & (1) \\
\hline Gambia & .. & .. & $\begin{array}{r}0.30 \\
749\end{array}$ & $\begin{array}{r}0.39 \\
844\end{array}$ & $\begin{array}{r}0.35 \\
458\end{array}$ & $\begin{array}{r}0.16 \\
006\end{array}$ & $\begin{array}{r}0.162 \\
55\end{array}$ & $\begin{array}{r}0.16 \\
654\end{array}$ & $\begin{array}{r}0.19 \\
636\end{array}$ & $\begin{array}{r}0.318 \\
6\end{array}$ & $\begin{array}{r}0.26 \\
834\end{array}$ & $\begin{array}{r}0.410 \\
7\end{array}$ & $\begin{array}{r}0.299 \\
52\end{array}$ & $\begin{array}{r}0.30 \\
274\end{array}$ & .. & $\begin{array}{r}3.345 \\
92\end{array}$ \\
\hline Gana & .. & .. & $\begin{array}{r}0.76 \\
007\end{array}$ & .. & .. & $\begin{array}{r}1.47 \\
226\end{array}$ & $\begin{array}{r}1.638 \\
25\end{array}$ & $\begin{array}{r}1.06 \\
787\end{array}$ & $\begin{array}{r}1.43 \\
614\end{array}$ & $\begin{array}{r}1.488 \\
62\end{array}$ & $\begin{array}{r}1.26 \\
942\end{array}$ & $\begin{array}{r}1.437 \\
7\end{array}$ & $\begin{array}{r}1.068 \\
61\end{array}$ & .. & .. & $\begin{array}{r}11.63 \\
894\end{array}$ \\
\hline Guine & .. & .. & .. & .. & .. & $\begin{array}{r}0.56 \\
966\end{array}$ & $\begin{array}{r}0.565 \\
11\end{array}$ & .. & .. & $\begin{array}{r}0.573 \\
1\end{array}$ & $\begin{array}{r}0.61 \\
447\end{array}$ & $\begin{array}{r}0.840 \\
9\end{array}$ & $\begin{array}{r}0.656 \\
99\end{array}$ & $\begin{array}{r}0.42 \\
628\end{array}$ & .. & $\begin{array}{r}4.246 \\
51\end{array}$ \\
\hline $\begin{array}{l}\text { Guiné- } \\
\text { Bissau }\end{array}$ & .. & .. & .. & .. & .. & .. & .. & .. & .. & .. & .. & .. & .. & .. & .. & 0 \\
\hline Quénia & .. & .. & .. & .. & $\begin{array}{r}0.78 \\
893\end{array}$ & $\begin{array}{r}0.87 \\
747\end{array}$ & .. & $\begin{array}{r}1.08 \\
691\end{array}$ & .. & .. & .. & .. & .. & .. & .. & $\begin{array}{r}2.753 \\
31\end{array}$ \\
\hline Lesotho & .. & $\begin{array}{r}0.06 \\
984\end{array}$ & $\begin{array}{r}2.00 \\
824\end{array}$ & .. & .. & .. & $\begin{array}{r}2.003 \\
78\end{array}$ & $\begin{array}{r}1.88 \\
435\end{array}$ & .. & $\begin{array}{r}1.522 \\
66\end{array}$ & .. & .. & .. & .. & .. & $\begin{array}{r}7.488 \\
87\end{array}$ \\
\hline Liberia & .. & .. & .. & .. & .. & .. & .. & .. & $\begin{array}{r}0.49 \\
323\end{array}$ & & & .. &.. & $\begin{array}{r}0.01 \\
202\end{array}$ & .. & $\begin{array}{r}0.505 \\
25\end{array}$ \\
\hline $\begin{array}{l}\text { Madagá } \\
\text { scar }\end{array}$ &.. & .. & .. & .. & .. & .. & .. & .. & $\begin{array}{r}0.32 \\
227\end{array}$ & $\begin{array}{r}0.328 \\
36\end{array}$ & $\begin{array}{r}0.38 \\
889\end{array}$ & .. & $\begin{array}{r}0.226 \\
74\end{array}$ & $\begin{array}{r}0.16 \\
286\end{array}$ & .. & $\begin{array}{r}1.429 \\
12\end{array}$ \\
\hline Malawi & .. & .. & .. & .. & $\begin{array}{r}0.72 \\
015\end{array}$ & .. & .. & .. & .. & .. & .. & $\begin{array}{r}1.162 \\
04\end{array}$ & $\begin{array}{r}1.365 \\
06\end{array}$ & .. & .. & $\begin{array}{r}3.247 \\
25\end{array}$ \\
\hline $\begin{array}{l}\text { Mauritâ } \\
\text { nia }\end{array}$ &.. & .. & .. & .. & .. & .. & .. & .. & .. & $\begin{array}{r}0.631 \\
67\end{array}$ & & $\begin{array}{r}0.800 \\
27\end{array}$ & $\begin{array}{r}0.473 \\
33\end{array}$ & .. & .. & $\begin{array}{r}1.905 \\
27\end{array}$ \\
\hline $\begin{array}{l}\text { Mauríci } \\
\text { as }\end{array}$ & .. & $\begin{array}{r}0.41 \\
267\end{array}$ & $\begin{array}{r}0.40 \\
228\end{array}$ & $\begin{array}{r}0.48 \\
409\end{array}$ & .. & .. & $\begin{array}{r}0.476 \\
77\end{array}$ & $\begin{array}{r}0.39 \\
439\end{array}$ & .. & .. & $\begin{array}{r}0.28 \\
489\end{array}$ & $\begin{array}{r}0.299 \\
19\end{array}$ & $\begin{array}{r}0.237 \\
28\end{array}$ & $\begin{array}{r}0.21 \\
54\end{array}$ & .. & $\begin{array}{r}3.206 \\
96\end{array}$ \\
\hline $\begin{array}{l}\text { Moçam } \\
\text { bique }\end{array}$ & .. & .. & .. & .. & .. & .. & .. & $\begin{array}{r}0.60 \\
782\end{array}$ & .. & .. & .. & .. & .. & .. & .. & 0.607 82 \\
\hline $\begin{array}{l}\text { Namibi } \\
\text { a }\end{array}$ & .. & $\begin{array}{r}0.94 \\
328\end{array}$ & .. & .. & $\begin{array}{r}0.53 \\
912\end{array}$ & .. & .. & .. & .. & $\begin{array}{r}0.546 \\
77\end{array}$ & .. & $\begin{array}{r}1.327 \\
79\end{array}$ & .. & .. & .. & $\begin{array}{r}3.356 \\
96\end{array}$ \\
\hline Niger & .. & .. & .. & .. & .. & .. & .. & $\begin{array}{r}0.21 \\
426\end{array}$ & $\begin{array}{r}0.34 \\
804\end{array}$ & $\begin{array}{r}0.272 \\
89\end{array}$ & $\begin{array}{r}0.35 \\
031\end{array}$ & $\begin{array}{r}0.319 \\
39\end{array}$ & $\begin{array}{r}0.397 \\
47\end{array}$ & $\begin{array}{r}0.78 \\
131\end{array}$ & .. & $\begin{array}{r}2.683 \\
67\end{array}$ \\
\hline Nigeria & .. & .. & .. & .. & $\begin{array}{r}0.50 \\
335\end{array}$ & .. & .. & .. & .. & .. & .. & .. & .. & .. & .. & $\begin{array}{r}0.503 \\
35\end{array}$ \\
\hline
\end{tabular}




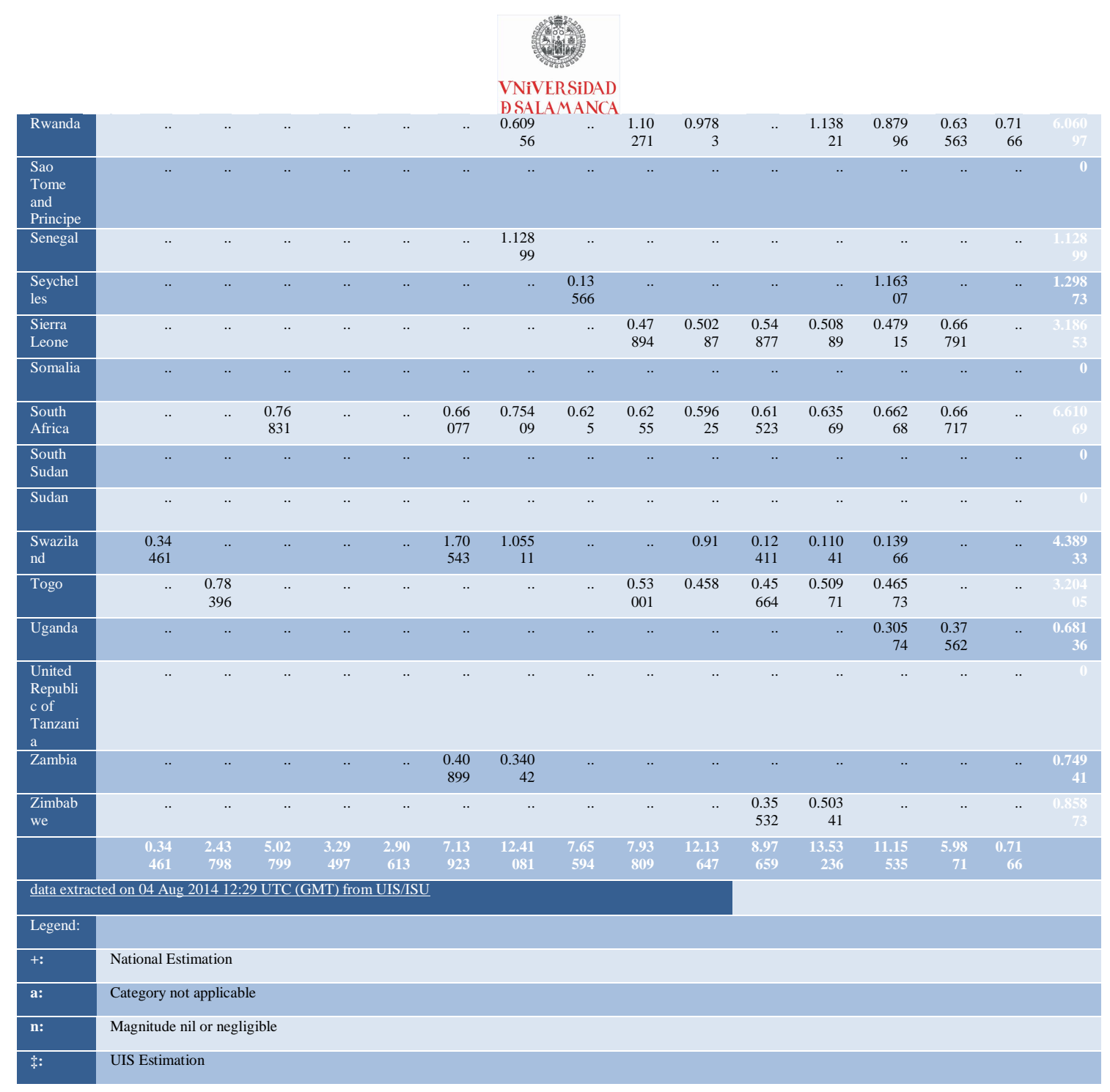

Public expenditure per pupil as a \% of GDP per capita. Tertiary is the total public expenditure per student in tertiary education as a percentage of GDP per capita. Public expenditure (current and capital) includes government spending on educational institutions (both public and private), education administration as well as subsidies for private entities (students/households and other privates entities).

Fonte: http://www.heritage.org/research/features/index/chapters/pdf/index2008_execsum.pdf

Anexo 13 - Liberdade Económica, por país da ASS, 2014 


\begin{tabular}{|c|c|c|c|c|c|c|c|c|c|c|c|c|}
\hline País & $\begin{array}{c}\text { A } \\
\text { no }\end{array}$ & $\begin{array}{l}\text { To } \\
\text { tal }\end{array}$ & $\begin{array}{c}\text { Direito } \\
\text { de } \\
\text { proprie } \\
\text { dade }\end{array}$ & $\begin{array}{l}\text { liberd } \\
\text { ade de } \\
\text { corru } \\
\text { pção }\end{array}$ & $\begin{array}{l}\text { Liber } \\
\text { dade } \\
\text { Fiscal }\end{array}$ & $\begin{array}{c}\text { Desp } \\
\text { esa } \\
\text { do } \\
\text { Gove } \\
\text { rno } \\
\end{array}$ & $\begin{array}{l}\text { Liber } \\
\text { dade } \\
\text { de } \\
\text { negóci } \\
\text { o }\end{array}$ & 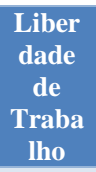 & $\begin{array}{c}\text { Liber } \\
\text { dade } \\
\text { monet } \\
\text { ária }\end{array}$ & $\begin{array}{l}\text { Liber } \\
\text { dade } \\
\text { de } \\
\text { comér } \\
\text { cio } \\
\end{array}$ & $\begin{array}{l}\text { Liberda } \\
\text { de de } \\
\text { Investi } \\
\text { mento }\end{array}$ & $\begin{array}{c}\text { Liber } \\
\text { dade } \\
\text { Finan } \\
\text { ceira }\end{array}$ \\
\hline Angola & $\begin{array}{l}20 \\
14\end{array}$ & $\begin{array}{c}47 . \\
7\end{array}$ & 15 & 17.7 & 87.7 & 55.3 & 47.5 & 40.1 & 63.6 & 70.1 & 40 & 40 \\
\hline$\underline{\text { Benin }}$ & $\begin{array}{l}20 \\
14\end{array}$ & $\begin{array}{c}57 . \\
1\end{array}$ & 30 & 29.5 & 68.3 & 86.1 & 51 & 50.5 & 75.4 & 60 & 70 & 50 \\
\hline$\frac{\text { Botswa }}{\underline{\text { na }}}$ & $\begin{array}{l}20 \\
14\end{array}$ & 72 & 70 & 61.2 & 81 & 69.8 & 68.5 & 69.7 & 72.4 & 82.7 & 75 & 70 \\
\hline $\begin{array}{l}\overline{\text { Burkina }} \\
\text { Faso }\end{array}$ & $\begin{array}{l}20 \\
14\end{array}$ & $\begin{array}{c}58 . \\
9\end{array}$ & 30 & 31.3 & 83 & 82.3 & 60.7 & 55 & 78.8 & 67.8 & 60 & 40 \\
\hline Burundi & $\begin{array}{l}20 \\
14\end{array}$ & $\begin{array}{c}51 . \\
4\end{array}$ & 20 & 15.9 & 73.5 & 51.9 & 59.8 & 63.1 & 68.2 & 71.8 & 60 & 30 \\
\hline$\frac{\text { Camero }}{\underline{\text { on }}}$ & $\begin{array}{l}20 \\
14\end{array}$ & $\begin{array}{c}52 . \\
6\end{array}$ & 30 & 21.9 & 71.7 & 86 & 45 & 56.1 & 69.4 & 61.2 & 35 & 50 \\
\hline $\begin{array}{l}\overline{\text { Cape }} \\
\text { Verde }\end{array}$ & $\begin{array}{l}20 \\
14\end{array}$ & $\begin{array}{c}66 . \\
1\end{array}$ & 70 & 54.9 & 77.4 & 68.6 & 63.8 & 48 & 79.1 & 69.6 & 70 & 60 \\
\hline $\begin{array}{l}\overline{\text { Central }} \\
\frac{\text { African }}{\text { Republi }} \\
\underline{\underline{c}}\end{array}$ & $\begin{array}{l}20 \\
14\end{array}$ & $\begin{array}{c}46 . \\
7\end{array}$ & 10 & 20.6 & 65.1 & 92.6 & 33.9 & 40.4 & 72.5 & 51.8 & 50 & 30 \\
\hline Chad & $\begin{array}{l}20 \\
14\end{array}$ & $\begin{array}{c}44 . \\
5\end{array}$ & 20 & 15.9 & 46.2 & 80 & 24.9 & 43.3 & 69.8 & 55.2 & 50 & 40 \\
\hline$\underline{\text { Comoro }}$ & $\begin{array}{l}20 \\
14\end{array}$ & $\begin{array}{c}51 . \\
4\end{array}$ & 30 & 22.1 & 64.5 & 85.3 & 49.4 & 50.1 & 74.5 & 72.7 & 35 & 30 \\
\hline $\begin{array}{l}\text { Côte } \\
\text { d'Ivoire }\end{array}$ & $\begin{array}{l}20 \\
14\end{array}$ & $\begin{array}{c}57 . \\
7\end{array}$ & 30 & 22.1 & 79.1 & 79.8 & 55.1 & 59 & 80.6 & 71.4 & 50 & 50 \\
\hline 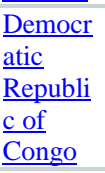 & $\begin{array}{l}20 \\
14\end{array}$ & $\begin{array}{c}40 . \\
6\end{array}$ & 10 & 17.6 & 69.4 & 74.6 & 30 & 38.5 & 63 & 63 & 20 & 20 \\
\hline$\overline{\text { Djibouti }}$ & $\begin{array}{l}20 \\
14\end{array}$ & $\begin{array}{c}55 . \\
9\end{array}$ & 30 & 30.9 & 80.6 & 62.8 & 42.7 & 65.1 & 77.2 & 54.8 & 65 & 50 \\
\hline $\begin{array}{l}\text { Equator } \\
\frac{\text { ial }}{\text { Guinea }}\end{array}$ & $\begin{array}{l}20 \\
14\end{array}$ & $\begin{array}{c}44 . \\
4\end{array}$ & 10 & 16.6 & 75.5 & 62.6 & 43.4 & 41.5 & 75.4 & 53.8 & 35 & 30 \\
\hline Eritrea & $\begin{array}{l}20 \\
14\end{array}$ & $\begin{array}{c}38 . \\
5\end{array}$ & 10 & 22.9 & 57 & 66.1 & 18.6 & 63.6 & 57.6 & 69.1 & 0 & 20 \\
\hline $\begin{array}{l}\text { Ethiopi } \\
\underline{\mathrm{a}}\end{array}$ & $\begin{array}{l}20 \\
14\end{array}$ & 50 & 30 & 27 & 77.5 & 89.9 & 57.8 & 54.7 & 59 & 64.2 & 20 & 20 \\
\hline Gabon & $\begin{array}{l}20 \\
14\end{array}$ & $\begin{array}{c}57 . \\
8\end{array}$ & 40 & 29.1 & 74.5 & 81.7 & 58.9 & 63 & 75.1 & 61 & 55 & 40 \\
\hline Ghana & $\begin{array}{l}20 \\
14\end{array}$ & $\begin{array}{c}64 . \\
2\end{array}$ & 50 & 40.4 & 85.4 & 83.3 & 62.6 & 60.2 & 65.8 & 64.8 & 70 & 60 \\
\hline$\underline{\text { Guinea }}$ & $\begin{array}{l}20 \\
14\end{array}$ & $\begin{array}{c}53 . \\
5\end{array}$ & 20 & 19.2 & 69.3 & 86.2 & 51.8 & 73.4 & 64.1 & 61.2 & 50 & 40 \\
\hline$\frac{\text { Guinea- }}{\underline{\text { Bissau }}}$ & $\begin{array}{l}20 \\
14\end{array}$ & $\begin{array}{c}51 . \\
3\end{array}$ & 20 & 20.2 & 89 & 86.6 & 40.5 & 61.4 & 74.4 & 61.4 & 30 & 30 \\
\hline Kenya & $\begin{array}{l}20 \\
14\end{array}$ & $\begin{array}{c}57 . \\
1\end{array}$ & 30 & 21 & 78 & 74.6 & 55.8 & 64 & 74.9 & 72.8 & 50 & 50 \\
\hline Lesotho & $\begin{array}{l}20 \\
14\end{array}$ & $\begin{array}{c}49 . \\
5\end{array}$ & 40 & 37.1 & 67.4 & 0 & 54 & 62.4 & 75.5 & 68.6 & 50 & 40 \\
\hline Liberia & $\begin{array}{l}20 \\
14\end{array}$ & $\begin{array}{c}52 . \\
4\end{array}$ & 30 & 33.8 & 83.6 & 70.5 & 62.3 & 47 & 72.9 & 64.1 & 40 & 20 \\
\hline $\begin{array}{l}\text { Madaga } \\
\text { scar }\end{array}$ & $\begin{array}{l}20 \\
14\end{array}$ & $\begin{array}{c}61 . \\
7\end{array}$ & 40 & 27.3 & 90.8 & 92.3 & 62.8 & 43.9 & 77.6 & 77.8 & 55 & 50 \\
\hline Malawi & $\begin{array}{l}20 \\
14\end{array}$ & $\begin{array}{c}55 . \\
4\end{array}$ & 45 & 31.9 & 78 & 63 & 38.9 & 60.3 & 64.1 & 72.7 & 50 & 50 \\
\hline Mali & $\begin{array}{l}20 \\
14\end{array}$ & $\begin{array}{c}55 . \\
5\end{array}$ & 20 & 27.7 & 69.8 & 81.7 & 48 & 63.2 & 76.7 & 73.2 & 55 & 40 \\
\hline$\frac{\text { Maurita }}{\underline{\text { nia }}}$ & $\begin{array}{l}20 \\
14\end{array}$ & $\begin{array}{c}53 . \\
2\end{array}$ & 25 & 23.9 & 81.7 & 75.8 & 38 & 53.1 & 75.5 & 69 & 50 & 40 \\
\hline $\begin{array}{l}\overline{\text { Mauriti }} \\
\underline{\text { us }}\end{array}$ & $\begin{array}{l}20 \\
14\end{array}$ & $\begin{array}{c}76 . \\
5\end{array}$ & 65 & 53.4 & 92.2 & 81.8 & 74.4 & 78 & 76.7 & 88.6 & 85 & 70 \\
\hline
\end{tabular}


VNIVERSIDAD

\begin{tabular}{|c|c|c|c|c|c|c|c|c|c|c|c|c|}
\hline \multicolumn{13}{|c|}{$\begin{array}{l}\text { VNIVERSIDAD } \\
\text { DSALAMANCA }\end{array}$} \\
\hline$\frac{\text { Mozam }}{\underline{\text { bique }}}$ & $\begin{array}{l}20 \\
14\end{array}$ & 55 & 30 & 26.2 & 75.7 & 64.6 & 65.2 & 36.7 & 80.8 & 75.5 & 45 & 50 \\
\hline$\frac{\text { Namibi }}{\underline{\mathrm{a}}}$ & $\begin{array}{l}20 \\
14\end{array}$ & $\begin{array}{c}59 . \\
4\end{array}$ & 30 & 44.2 & 66.9 & 58.8 & 64.4 & 81.9 & 75 & 82.9 & 50 & 40 \\
\hline Niger & $\begin{array}{l}20 \\
14\end{array}$ & $\begin{array}{c}55 . \\
1\end{array}$ & 30 & 26 & 76.8 & 88.4 & 35.2 & 45.4 & 88.3 & 65.6 & 55 & 40 \\
\hline$\underline{\text { Nigeria }}$ & $\begin{array}{l}20 \\
14\end{array}$ & $\begin{array}{c}54 . \\
3\end{array}$ & 30 & 22.7 & 85 & 74.5 & 48 & 66.4 & 73.1 & 63.8 & 40 & 40 \\
\hline $\begin{array}{l}\text { Republi } \\
\frac{\text { c of }}{\text { Congo }}\end{array}$ & $\begin{array}{l}20 \\
14\end{array}$ & $\begin{array}{c}43 . \\
7\end{array}$ & 10 & 20.6 & 67.5 & 79.6 & 35.1 & 47 & 72 & 55.6 & 20 & 30 \\
\hline$\underline{\text { Rwanda }}$ & $\begin{array}{l}20 \\
14\end{array}$ & $\begin{array}{c}64 . \\
7\end{array}$ & 30 & 46.9 & 80.3 & 78.2 & 69.6 & 84.1 & 74.8 & 77.7 & 65 & 40 \\
\hline $\begin{array}{l}\frac{\text { São }}{\text { Tomé }} \\
\text { and } \\
\text { Príncipe }\end{array}$ & $\begin{array}{l}20 \\
14\end{array}$ & $\begin{array}{c}48 . \\
8\end{array}$ & 20 & 32.5 & 86.9 & 27.9 & 52.6 & 44.7 & 68.3 & 75.3 & 50 & 30 \\
\hline Senegal & $\begin{array}{l}20 \\
14\end{array}$ & $\begin{array}{c}55 . \\
4\end{array}$ & 40 & 29.5 & 65.1 & 75.4 & 47.5 & 41.5 & 81.8 & 73.2 & 60 & 40 \\
\hline $\begin{array}{l}\text { Seychel } \\
\underline{\text { les }}\end{array}$ & $\begin{array}{l}20 \\
14\end{array}$ & $\begin{array}{c}56 . \\
2\end{array}$ & 50 & 48.5 & 76.8 & 61.8 & 67.6 & 68.5 & 75.1 & 33.4 & 50 & 30 \\
\hline$\underline{\text { Sierra }}$ & $\begin{array}{l}20 \\
14\end{array}$ & $\begin{array}{c}50 . \\
5\end{array}$ & 15 & 24.6 & 80.7 & 85.7 & 55.3 & 28.7 & 70.2 & 70.2 & 55 & 20 \\
\hline$\underline{\text { Somalia }}$ & $\begin{array}{l}20 \\
14\end{array}$ & $\begin{array}{c}\text { N/ } \\
\text { A }\end{array}$ & N/A & 5 & N/A & N/A & N/A & N/A & N/A & N/A & N/A & N/A \\
\hline $\begin{array}{l}\text { South } \\
\text { Africa }\end{array}$ & $\begin{array}{l}20 \\
14\end{array}$ & $\begin{array}{c}62 . \\
5\end{array}$ & 50 & 41.6 & 68.7 & 69.1 & 74.5 & 54.4 & 75.3 & 76.1 & 55 & 60 \\
\hline$\underline{\text { Sudan }}$ & $\begin{array}{l}20 \\
14\end{array}$ & $\begin{array}{c}\text { N/ } \\
\text { A }\end{array}$ & N/A & 9.8 & 85.1 & 90.3 & 54.5 & 49.1 & 55.8 & 55.6 & 15 & N/A \\
\hline$\underline{\text { Swazila }}$ & $\begin{array}{l}20 \\
14\end{array}$ & $\begin{array}{c}61 . \\
2\end{array}$ & 40 & 31.6 & 74.7 & 70.9 & 64.2 & 71.7 & 72.3 & 81.5 & 65 & 40 \\
\hline$\frac{\text { Tanzani }}{\underline{\mathrm{a}}}$ & $\begin{array}{l}20 \\
14\end{array}$ & $\begin{array}{c}57 . \\
8\end{array}$ & 30 & 28.8 & 79.7 & 78.3 & 47 & 61.1 & 66 & 76.8 & 60 & 50 \\
\hline $\begin{array}{l}\text { The } \\
\text { Gambia }\end{array}$ & $\begin{array}{l}20 \\
14\end{array}$ & $\begin{array}{c}59 . \\
5\end{array}$ & 30 & 31.7 & 79 & 79.8 & 57.4 & 65.8 & 71.3 & 65 & 65 & 50 \\
\hline Togo & $\begin{array}{l}20 \\
14\end{array}$ & $\begin{array}{c}49 . \\
9\end{array}$ & 30 & 23.8 & 69.7 & 82.4 & 43.3 & 42.8 & 79.3 & 62.8 & 35 & 30 \\
\hline$\underline{\text { Uganda }}$ & $\begin{array}{l}20 \\
14\end{array}$ & $\begin{array}{c}59 . \\
9\end{array}$ & 30 & 23.8 & 79.1 & 87.3 & 45.1 & 87.4 & 71 & 75.4 & 60 & 40 \\
\hline Zambia & $\begin{array}{l}20 \\
14\end{array}$ & $\begin{array}{c}60 . \\
4\end{array}$ & 30 & 31.3 & 71.8 & 82.9 & 74.9 & 50.1 & 68 & 84.6 & 60 & 50 \\
\hline$\frac{\text { Zimbab }}{\underline{\text { we }}}$ & $\begin{array}{l}20 \\
14\end{array}$ & $\begin{array}{c}35 . \\
5\end{array}$ & 10 & 19.3 & 63.3 & 64 & 34.5 & 22.2 & 73 & 54.2 & 5 & 10 \\
\hline
\end{tabular}

Fonte: $\quad$ http://www.heritage.org/index/explore.aspx?nomobile\&view=by-region-country-year 


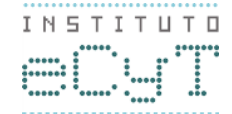

Anexo 14 - Lista de países Recetores da APD - DAC, 2008, 2009, 2010

DAC List of ODA Recipients

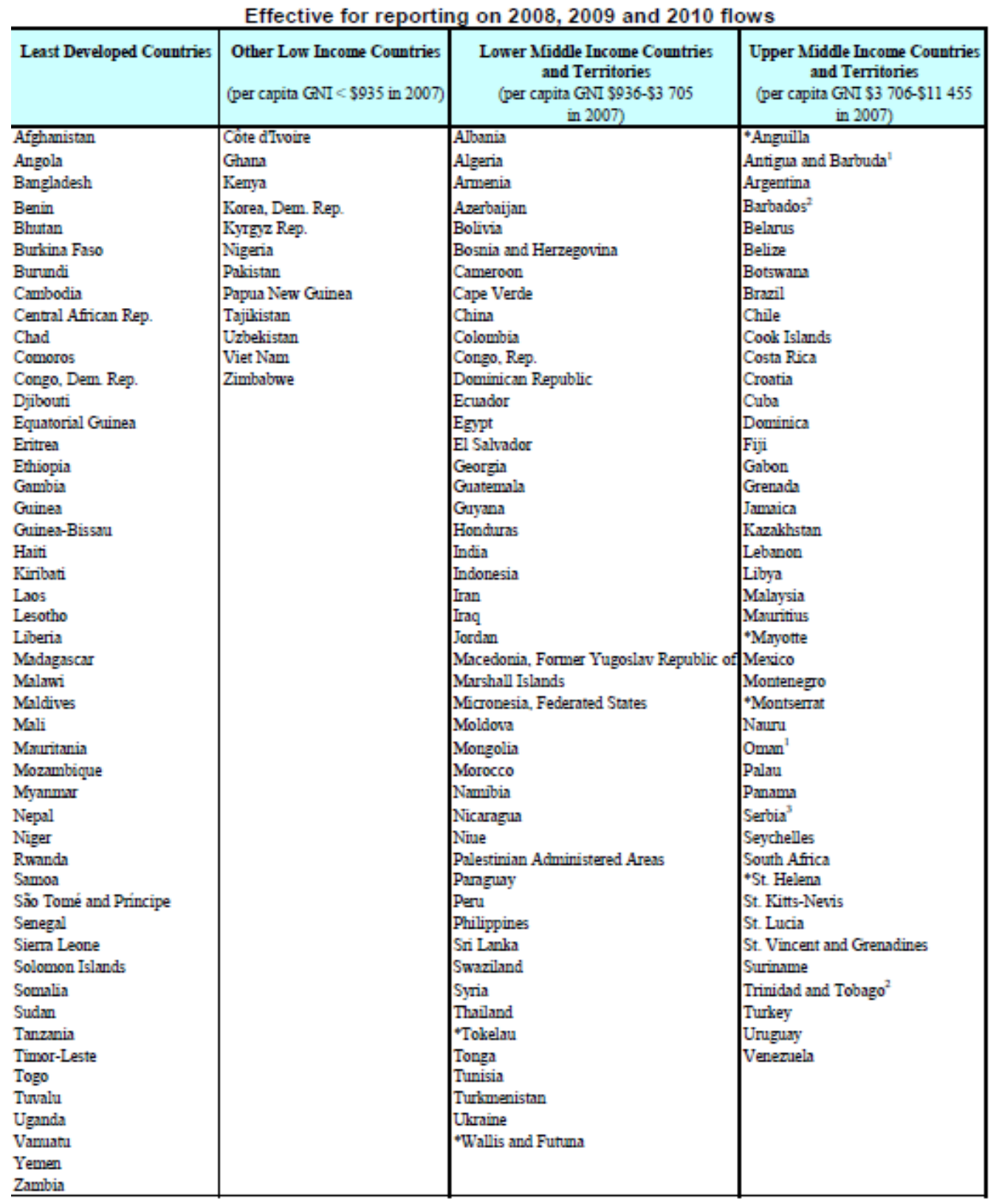

"Territory.

(1) Antigun \& Barbuda and Oman exceeded the high income country threshold in 2007. In accordance with the DAC nules for revision of this List both will graduate from the List in 2011 if they remsin high income countries until 2010.

(2) Barbados and Trinidad \& Tobago exceeded the high income coumtry threshold in 2006 and 2007 . In accordance with the DAC rules for revisio of this List, both will graduate from the List in 2011 if they remain high income countries until 2010.

(3) At present aid to Kosovo is recorded under aid to Serbia. Kosovo will be listed separately if and when it is recognised by the UN.

As of Apni 2008, the Heavily Indebted Poor Countries (HIPCs) are : Afghanistan, Benin, Bolivin, Burkina Faso, Burundi, Cameeroon, Central African Republic, Chad, Comoros, Congo (Dem Rep.). Congo (Rep.). Côte d'Troire, Eritrea Ethiopia, Gambia, Ghana, Guinea, Guinea-Bissan, Guyana, Haiti, Honduras, Kyrgyz Republic, Liberia, Madagascar, Malawi, Mali, Mauritania, Mozambique, Nepal, Nicaragua, Niger, Rwanda, São Tomé and Principe, Senegal, Sierra Leone, Somalia, Sudan, Tanzania, Togo, Uganda and Zambia.

Fonte: http://www.oecdilibrary.org/docserver/download/4305012ec003.pdf?expires=1412694344\&id=id\&accname=guest\&checksum=0374505DF E6B5A2801EB1EF75B44ED92 
Anexo 15 - Mobilização de Alunos Africanos por local de destino, 1999-2012

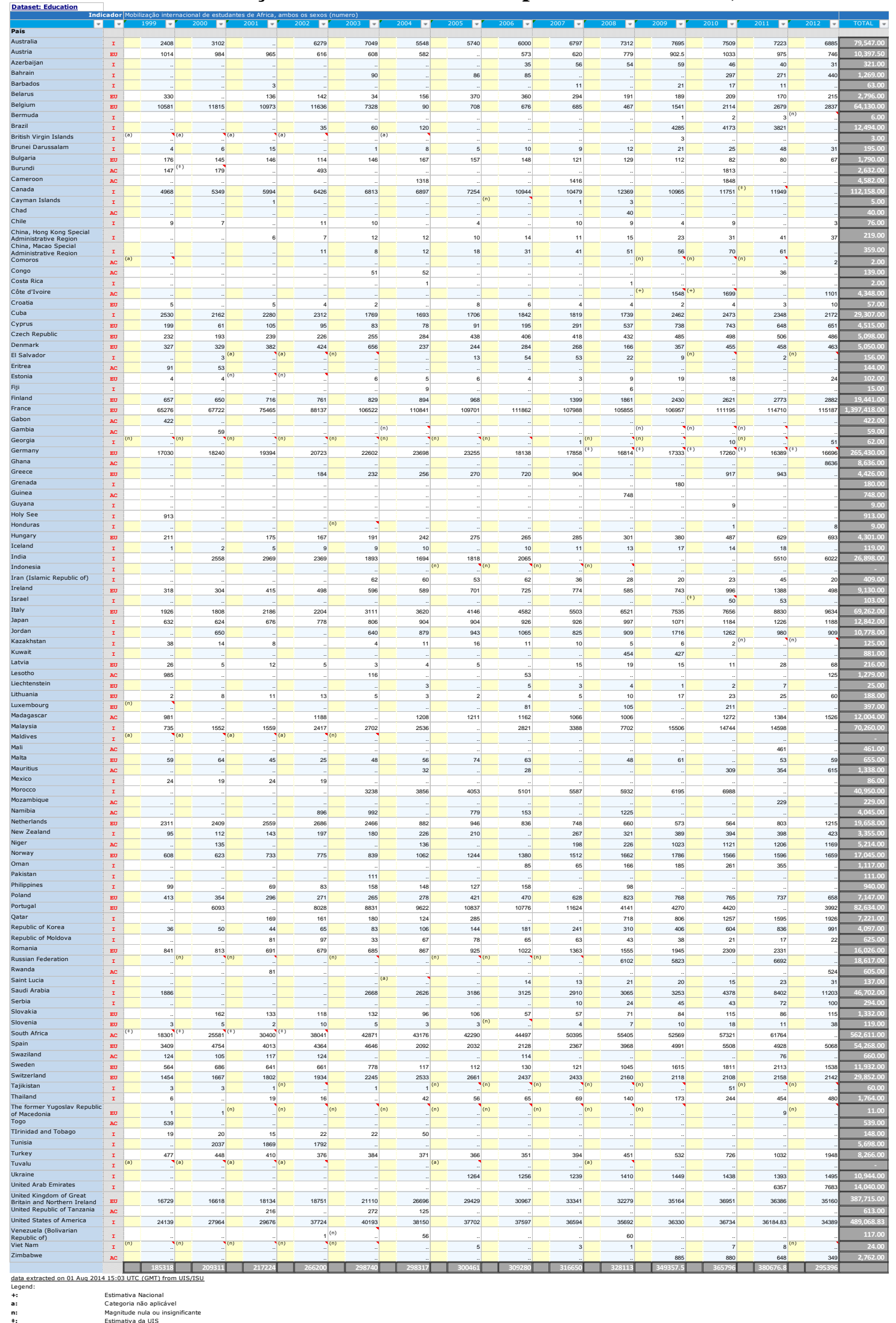

Fonte: dados extraidos e adaptados de UIS/ISU (2013) 


\title{
Anexo 16 - Inquérito
}

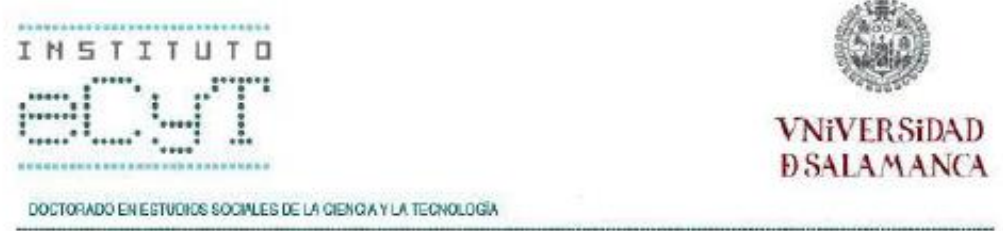

Universidad de Salamanca

Instituto de Estudios para la Ciencia y la Tecnología (ECYT)

$\underline{\text { Lúcia Susana Peixoto dos Santos Oliveira }}$

Ph.D.

The role of partnerships between European and African universities in development in the context of twenty-first century: an application of the model CATWOE

\author{
Thesis Director \\ Santiago Lopez \\ (University of Salamanca) \\ Spain \\ Tutor \\ Carlos Sangreman \\ (University of Aveiro) \\ Portugal
}

$1)$ 


\section{Introduction}

The African Higher Education, at the beginning of the new Millennium, faces new challenges as it becomes recognized as a key factor for economic and social development. On the other hand, it is important to mention that this type of education has a central role in an increasingly globalized and internationalized world, where knowledge and innovation are among the most developed and competitive societies in the world. However, generalize about such a vast and diverse continent like Africa is not an easy task, given that trends in higher education in North Africa are considerably different from sub-Saharan Africa. Nevertheless, it is possible to find common elements; we have chosen to analyse the sub-Saharan Africa, in order to delimit the field of analysis, and consequently, these same differences. Although, sub-Saharan African countries also differ greatly among themselves, the comparative study is possible considering that the subject in question allows this same analysis. This diversity occurs chiefly in the operation, guidance, financial support level, but also in what regards to national and local circumstances. There are various challenges that African universities face in order to become more effective and efficient institutions. For this it is necessary to evolve with regard to its economic management, and manage the cultural and political legacies. Thus, it becomes imperative for greater investment in post-secondary sector and the real recognition, by the various actors, that tertiary education is crucial for development in Africa. 
IN 5 T I T U T Q

:

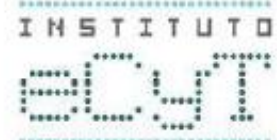

VNIVERSIDAD

DSALAMANCA

DOCTORADO ENEGTUCIOS SOCNLES DELA GIENGKY LA TECNOLOGA

\section{Survey}

Name

Title

Organisation

Job Description

How many years are you working in the area of international cooperation?

Male $\square$ Female $\square$

3 


\section{Part I}

\section{Public Educational Politics}

1. Do you considerer education as a public good ${ }^{1}$ that should be given to everybody? Can you please explain your answer?

$\square$ Yes

No

1.1. In which level of education do you think that the States should provide to the people for free? Can you please underline the main reasons?

$\square$ Primary

$\square$ secondary

$\square$ Tertiary

${ }^{1}$ A public good should be in the public domain, meaning that is available for everyone to consume it, fairly and equitably. 


\section{N 5 T I T U T D \\ :}

IH 5 T I T $\sqcup T$ T

:.............

VNIVERSIDAD

ESALAMANCA

DOCTORADO ENEGTUOHOS SOCNLES DELA GIENGAY YLA TECNOLOGIA

1.2. At what level should International actors for development interfere?

2. Having in mind the mission of education, and in your opinion, what kind of institutions do you think that the countries in development should create/support: private or public? Can you please explain the main reasons?

2.1. What kind of support should the international actors give to each one of them?

2.2. In your opinion do you think that education contributes to the development of the local economies as well for the national ones?

2.2.1. If yes, can you please identify the areas where it might have a bigger impact? 
VNIVERSIDAD

PSAIAMANCA

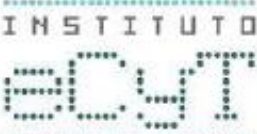

VNIVERSIDAD

DSALAMANCA

DOCTORNDOENEGTUDHOS SOCNLES OE LA GESGRY LA TECHOLOGIS

2.2.2. Which level of education is more important for this development? Can you please explain your opinion?

3. In your opinion, does a higher level of education guarantee better conditions of life? Can you please explain your point of view?

$\square$ Yes

$\square$ No

6 
Part II

\section{Higher Education in Africa}

1. Considering the particularity of the African continent, and in particular, the countries of Sub-Saharan Africa, do you think that higher education plays an important role in the development of these countries? Can you please explain your opinion?

2. What areas do you think that higher education should provide courses in order to face regional and national socio-economic problems?

2.1. Considering the fact that the new development agenda is the successor of the Millennium Development Goals, do you think that higher education should be one of the preoccupations of this new development agenda post 2015? Can you explain the main reasons? 
VNIVERSIDAD

F) SALAMANCA

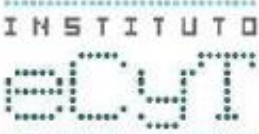

DOCTORADOENEGTUDUOS SOCNLES OELA GESTEKYLA TECNOLOGA

3. What challenges do universities face in countries in development?

8 
Part III

Financial System in Africa Higher Education Institutions

1. What kind of financial support do you believe that would fit better the needs of higher institutions, in development countries? Can you please explain your choice?

$\square$ Regional

$\square$ National

$\square$ international

2. What kind of financial contribution do the international agencies for development should give to these institutions? 
VNIVERSIDAD

PSAIAMANCA

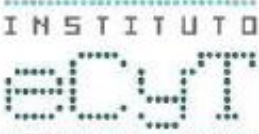

VNIVERSIDAD

DSALAMANCA

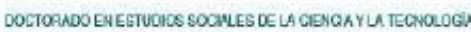

3. In your opinion is it sufficient? Can you please explain your opinion?

$\square$ Yes

$\square$ No

4. What kind of support do you think that the agencies could give to universities?

5. Do you have an idea of how much your institution has been given to support Africa subSaharan higher institutions?

6. This financial support comprises some measures to assess how it is spent by the countries in development? If yes, do you believe that the donors consider it efficient?

$\square$ Yes

$\square$ No

10 
I N 5 T I T U T D

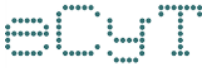

I H 5 T I T U T D

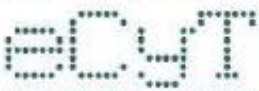

VNiVERSIDAD

DSALAMANCA

DOCTORNDOENEGTUDOCS SOCNLES OELA GESGKY Y TECNOLOGA

7. Does this kind of support have in count the student's needs?

7.1. And what about inequalities and financial difficulties of the students?

$11)$ 
Academic Cooperation EU - Africa

1. In your opinion the academic cooperation between EU and Africa is important for the development of qualified human resources?

2. Do you think that universities have a strategic role on the progress of economies in development?

3. In your opinion the technological development in Africa is dependent of the academic cooperation? Can you please explain your opinion?

$\square$ Yes

$\square$ No

12 


\section{N 5 T I T U T D \\ :}

I H 5 T I T U T D

:

VNIVERSIDAD

BSALAMANCA

DOCTOANDO EY EGTUDIOS SOCNLES OE LA GIENGKY YLA TECNOLOGH

4. Do you consider that government policies of the developing countries are supporting technological development? In what level: regional, national or international? Can you please explain your answer?

5. In your opinion the academic cooperation between EU and Africa has been promoting better conditions for students?

Yes

No

5.1. And for the population in general? Can you please explain your point of view?

6. Do you think that this cooperation might have increased the number of students in the universities in Africa?

7. In your opinion the academic cooperation favours the migration of students?

8. What kind of consequences / advantages you think are most prevalent? 
9. In your opinion the new development agenda should have a special focus in higher education?

10. Do you agree that the education in development countries might have a positive impact in the following areas? Can you explain your choices? Can you please explain your opinion?

Poverty reduction

Better Quality of life

Promotes fair societies

11. Can you please indicate the name of persons that might have some interest to give his/her contribute to this research (name and email):

Thanks for your contribution to this research.

Lucia Olluectra 
INSTITUTC

ㄴ. 